Andrews University

Digital Commons @ Andrews University

2005

\title{
The Heavenly Sanctuary/Temple Motif in the Hebrew Bible : Function and Relationship to the Earthly Counterparts
}

Elias Brasil de Souza

Andrews University, ebsouza@andrews.edu

Follow this and additional works at: https://digitalcommons.andrews.edu/dissertations

Part of the Biblical Studies Commons, and the Reading and Language Commons

\section{Recommended Citation}

de Souza, Elias Brasil, "The Heavenly Sanctuary/Temple Motif in the Hebrew Bible : Function and Relationship to the Earthly Counterparts" (2005). Dissertations. 33.

https://digitalcommons.andrews.edu/dissertations/33

https://dx.doi.org/10.32597/dissertations/33

This Dissertation is brought to you for free and open access by the Graduate Research at Digital Commons @ Andrews University. It has been accepted for inclusion in Dissertations by an authorized administrator of Digital Commons@ Andrews University. For more information, please contact repository@andrews.edu. 


\section{Andrews \$university}

Seek Knowledge. Affirm Faith. Change the World.

Thank you for your interest in the

\section{Andrews University Digital Library of Dissertations and Theses.}

Please honor the copyright of this document by not duplicating or distributing additional copies in any form without the author's express written permission. Thanks for your cooperation. 
Andrews University

Seventh-day Adventist Theological Seminary

THE HEAVENLY SANCTUARY/TEMPLE MOTIF IN THE HEBREW BIBLE: FUNCTION AND RELATIONSHIP TO THE EARTHLY COUNTERPARTS

\author{
A Dissertation \\ Presented in Partial Fulfillment \\ of the Requirements for the Degree \\ Doctor of Philosophy
}

by

Elias Brasil de Souza

April 2005 
UMI Number: 3164586

Copyright 2005 by

de Souza, Elias Brasil

All rights reserved.

\title{
INFORMATION TO USERS
}

The quality of this reproduction is dependent upon the quality of the copy submitted. Broken or indistinct print, colored or poor quality illustrations and photographs, print bleed-through, substandard margins, and improper alignment can adversely affect reproduction.

In the unlikely event that the author did not send a complete manuscript and there are missing pages, these will be noted. Also, if unauthorized copyright material had to be removed, a note will indicate the deletion.

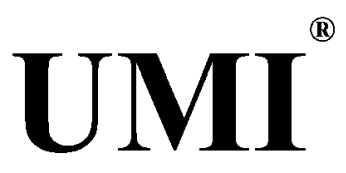

\section{UMI Microform 3164586}

Copyright 2005 by ProQuest Information and Learning Company.

All rights reserved. This microform edition is protected against unauthorized copying under Title 17, United States Code.

\author{
ProQuest Information and Learning Company \\ 300 North Zeeb Road \\ P.O. Box 1346 \\ Ann Arbor, Ml 48106-1346
}


(C) Copyright by Elias Brasil de Souza 2005 All Rights Reserved 


\title{
THE HEAVENLY SANCTUARY/TEMPLE MOTIF IN THE HEBREW BIBLE: FUNCTION AND RELATIONSHIP TO THE EARTHLY COUNTERPARTS
}

\author{
A dissertation \\ presented in partial fulfillment \\ of the requirements for the degree \\ Doctor of Philosophy
}

by

Elias Brasil de Souza

APPROVAL BY THE COMMTTTEE:

Richoulm. Nueidsans

Faculty Adviser,

Richard M. Davidson

J. N. Andrews Professor of Old Testament

Interpretation

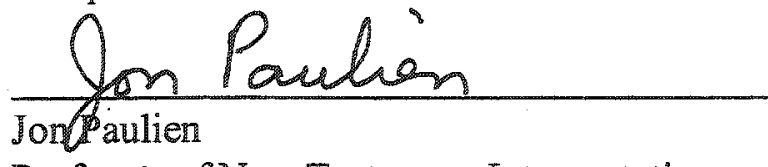

Professor of New Testament Interpretation

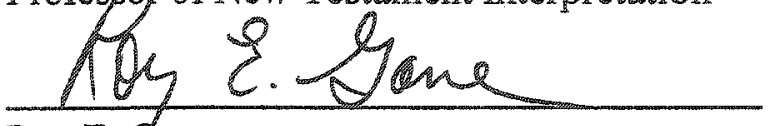

Roy E. Cane

Professor of Hebrew Bible and Ancient Near

Eastentanguages

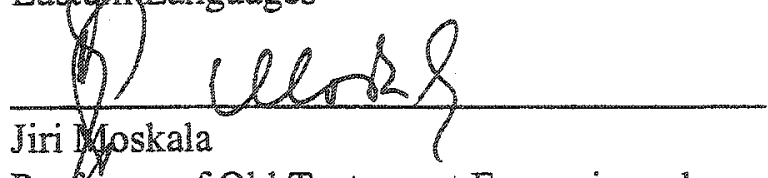

Processor of Old Testament Exegesis and

Whelogyn henere

William H. Shea

Retired, Associate Director of Biblical

Research Institute

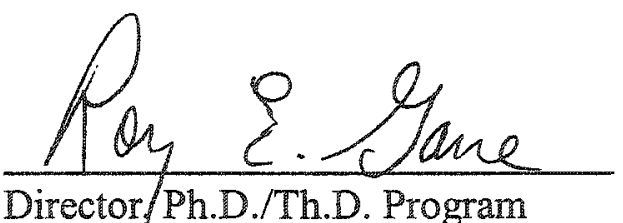

Director/Ph.D./Th.D. Program

Roy E. Gane

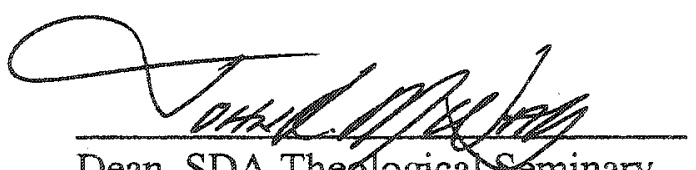

Dean, SDA Theologicarseminary John K. McVay 


\begin{abstract}
THE HEAVENLY SANCTUARY/TEMPLE MOTIF IN THE HEBREW BIBLE: FUNCTION AND RELATIONSHIP TO THE EARTHLY COUNTERPARTS
\end{abstract}

by

Elias Brasil de Souza

Adviser: Richard M. Davidson 


\title{
ABSTRACT OF GRADUATE STUDENT RESEARCH
}

Dissertation

\author{
Andrews University \\ Seventh-day Adventist Theological Seminary
}

\section{Title: THE HEAVENLY SANCTUARY/TEMPLE MOTIF IN THE HEBREW BIBLE: FUNCTION AND RELATIONSHIP TO THE EARTHLY COUNTERPARTS}

Name of researcher: Elias Brasil de Souza

Name and degree of faculty adviser: Richard M. Davidson, Ph.D.

Date completed: April 2005

The present dissertation investigates the function of the heavenly sanctuary/temple and its relationship to the earthly counterparts, as reflected in forty-three passages of Hebrew Bible. Following an introductory chapter, the second chapter of this dissertation is devoted to a survey of the heavenly sanctuary/temple motif in the ANE literature, as represented by Sumerian, Akkadian, Hittite, Ugaritic, and Egyptian texts. The investigation of these texts reveals that the heavenly sanctuary/temple motif was part of the worldview of the ANE, where the heavenly sanctuary was not only assumed as existing in heaven, but also as functioning in close relationship to the earthly counterparts.

Chapters 3,4 , and 5 are devoted to the exegesis of heavenly sanctuary/temple passages in the Hebrew Scriptures, according to the canonical divisions of the Hebrew 
Bible (namely Torah, Prophets, and Writings). This investigation reveals the pervasive presence of the heavenly sanctuary/temple motif in the Hebrew Bible and provides a broad delineation of its function and relationship to the earthly counterparts. It has been found that the heavenly sanctuary temple functions as a place of divine activities where YHWH supervises the cosmos, performs acts of judgment (sometimes conceived as a two-stage activity in which the execution of the sentence was preceded by an investigative phase), hears the prayers of the needy, and bestows atonement and forgiveness upon the sinners. The perception also emerged of the heavenly sanctuary/temple as a place of worship, a meeting place for the heavenly council, and an object of attack by anti-YHWH forces, thus playing a pivotal role in the cosmic battle between good and evil.

In terms of its relationship to the earthly counterparts, it becomes apparent that the heavenly sanctuary/temple was understood to operate in structural and functional correspondence to the earthly counterparts. Moreover, some texts reveal a dynamic interaction between heavenly and earthly sanctuaries/temples, inasmuch as the activities of one could affect the other.

Chapter 6 presents a theological synthesis of the heavenly sanctuary/temple motif based on the previous chapters. Some consideration is given to the similarities and differences between the heavenly sanctuary/temple motif as found in the Hebrew Bible and in its ANE background. Next, attention is devoted to some theological implications of the heavenly sanctuary/temple motif for the notions of judgment, cosmic battle, and covenant. To conclude, the Hebrew Bible conceives of the heavenly sanctuary/temple in functional and structural correspondence with its earthly counterpart with both sanctuaries/temples operating in dynamic interaction. 
To Mágela

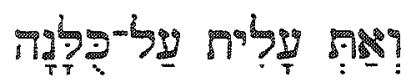

Prov 31:29

To Guilherme and Gustavo

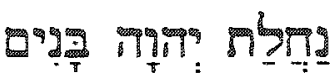

Ps 127:3 


\section{TABLE OF CONTENTS}

LIST OF FIGURES $\ldots \ldots \ldots \ldots \ldots \ldots \ldots \ldots \ldots \ldots \ldots \ldots \ldots \ldots \ldots$

LIST OF TABLES $\ldots \ldots \ldots \ldots \ldots \ldots \ldots \ldots \ldots \ldots \ldots \ldots \ldots \ldots \ldots$

LIST OF ABBREVIATIONS $\ldots \ldots \ldots \ldots \ldots \ldots \ldots \ldots \ldots \ldots \ldots \ldots \ldots \ldots$

ACKNOWLEDGMENTS ....................................

Chapter

1. INTRODUCTION $\ldots \ldots \ldots \ldots \ldots \ldots \ldots \ldots \ldots \ldots \ldots \ldots$

Problem $\ldots \ldots \ldots \ldots \ldots \ldots \ldots \ldots \ldots \ldots \ldots \ldots \ldots \ldots \ldots$

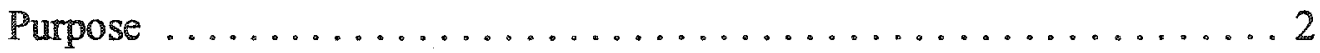

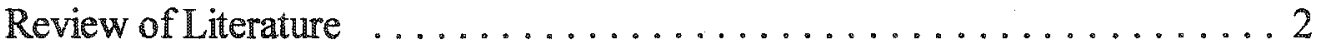

G. B. Gray . . . . . . . . . . . . . . . . . . . . 4

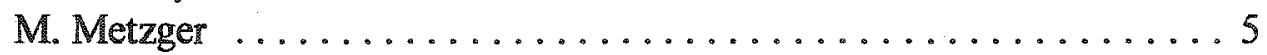

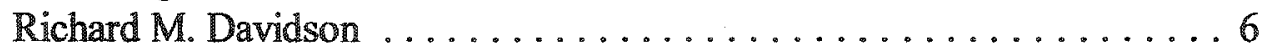

N. E. Andreasen . . . . . . . . . . . . . . . . . . . 8

William H. Shea ............................ 10

F. Hartenstein . . . . . . . . . . . . . . . . . . . . . 11

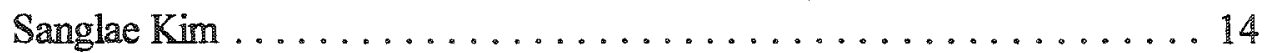

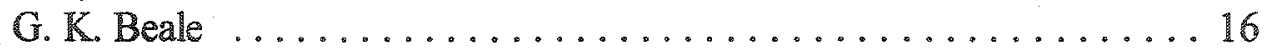

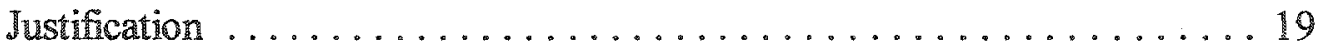

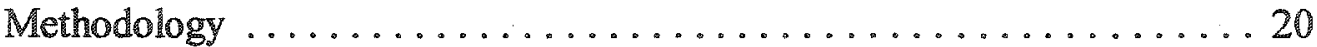

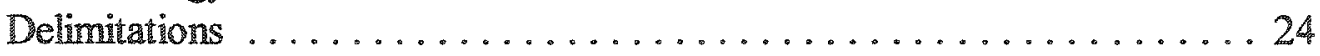

2. ANCIENT NEAR-EASTERN BACKGROUND ............. 26

Sumerian Literature . . . . . . . . . . . . . . . . . . . . . 28

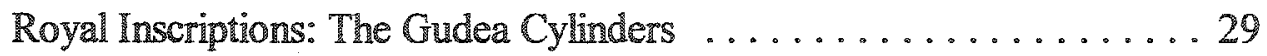

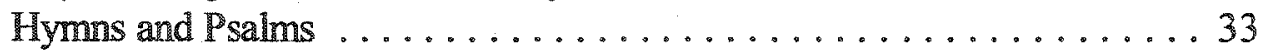

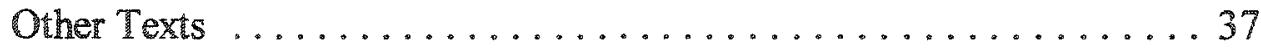

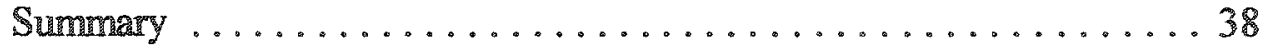

Akkadian Literature . . . . . . . . . . . . . . . . . . . . . . 39

iil 


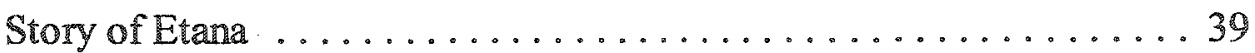

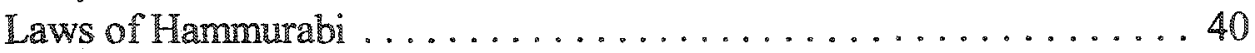

Epic of Gilgamesh $\ldots \ldots \ldots \ldots \ldots \ldots \ldots \ldots \ldots \ldots \ldots \ldots$

Enuma Elish ............................ 44

Excursus: Nabuapaliddina's Relief ................. 47

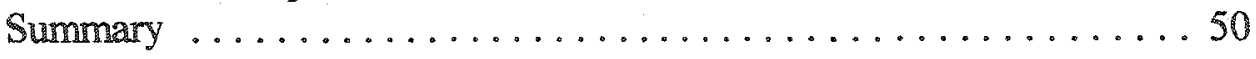

Hittite Literature $\ldots \ldots \ldots \ldots \ldots \ldots \ldots \ldots \ldots \ldots \ldots \ldots \ldots$

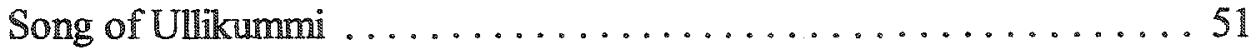

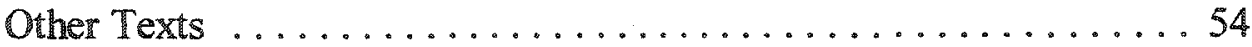

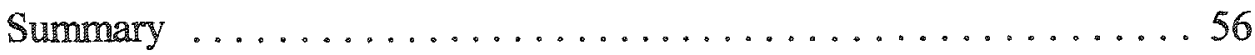

Ugaritic Literature $\ldots \ldots \ldots \ldots \ldots \ldots \ldots \ldots \ldots \ldots \ldots \ldots \ldots$

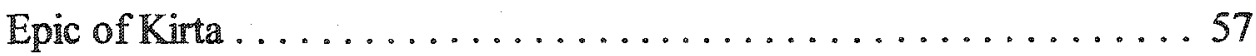

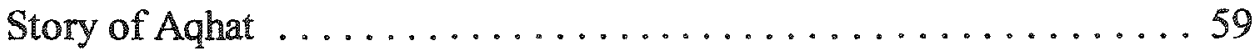

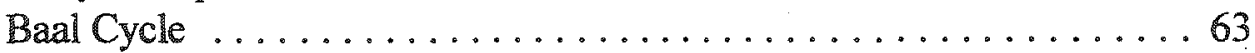

Summary . . . . . . . . . . . . . . . . . . . . . . . .

Egyptian Literature $\ldots \ldots \ldots \ldots \ldots \ldots \ldots \ldots \ldots \ldots \ldots \ldots \ldots$

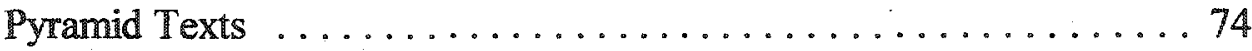

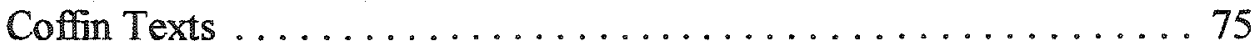

Book of the Dead $\ldots \ldots \ldots \ldots \ldots \ldots \ldots \ldots \ldots \ldots 77$

Other Texts $\ldots \ldots \ldots \ldots \ldots \ldots \ldots \ldots \ldots \ldots \ldots \ldots . \ldots \ldots$

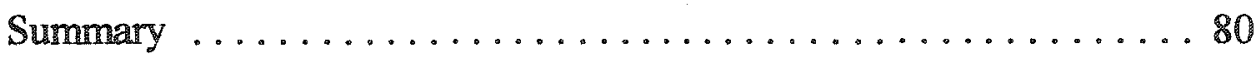

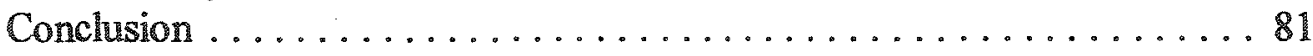

3. THE HEAVENLY SANCTUARY/TEMPLE MOTIF IN THE TORAH ... . 83

Gen $11: 1-9 \ldots \ldots \ldots \ldots \ldots \ldots \ldots \ldots \ldots \ldots \ldots . \ldots \ldots$

Preliminary Observations $\ldots \ldots \ldots \ldots \ldots \ldots \ldots \ldots \ldots$

Semantic and Other Exegetical Considerations ............86

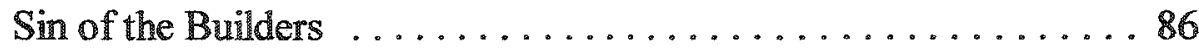

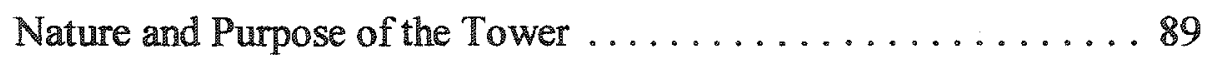

Tower as a Defensive Structure . . . . . . . . . . . . . 90

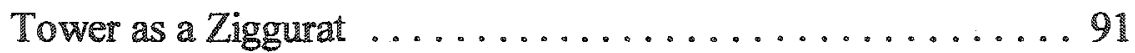

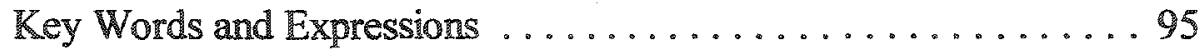

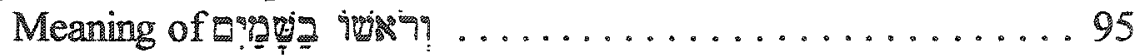

Meaning of 777 7 $\ldots$. .

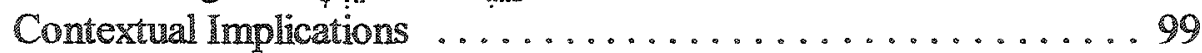

Heavenly Sanctuary/Temple Motif .................. 100

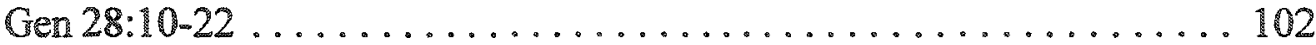

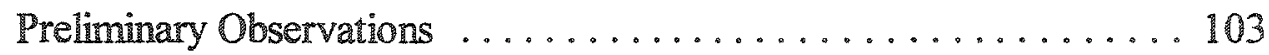

Semantic and Other Exegetical Considerations ............ 109

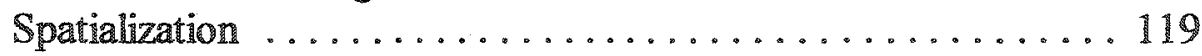

Key Words and Expressions .................... 110

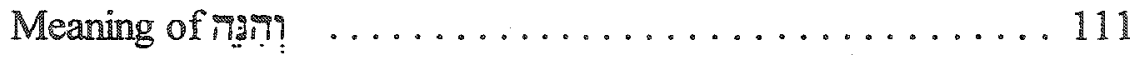

iv 


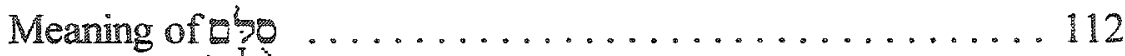

Syntax of

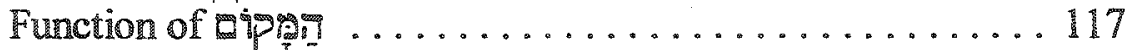

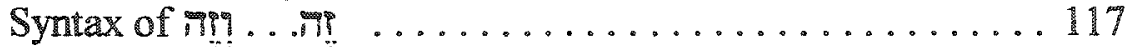

Referent of

Heavenly Sanctuary/Temple Motif . . . . . . . . . . . . . . . 122

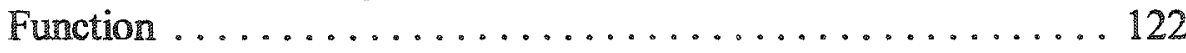

Relationship to Earthly Counterpart ............... 122

Exod 15:1-18 ................................ 124

Preliminary Observations ...................... 125

Semantic and Other Exegetical Considerations . ........... 133

Syntax and Meaning of $\square$. $\ldots \ldots \ldots \ldots \ldots \ldots \ldots \ldots . \ldots \ldots$

Syntax and Meaning of wipa. . . . . . . . . . . . . . . . 134

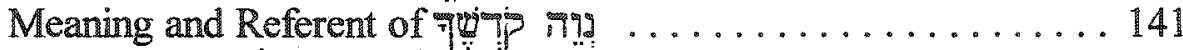

Referent of

Meaning of

Referent of

Heavenly Sanctuary/Temple Motif ................... 148

Function ................................. 152

Relationship to Earthly Counterpart ............... 153

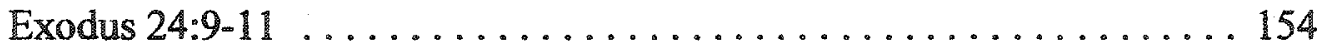

Preliminary Observations ...................... 154

Semantic and Other Exegetical Considerations ............. 159

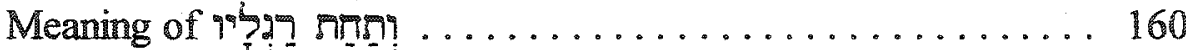

Meaning כִ.

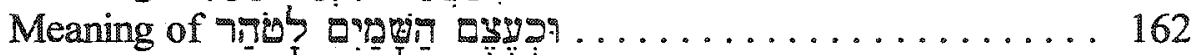

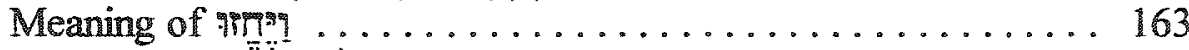

Meaning of

Heavenly Sanctuary/Temple Motif . . . . . . . . . . . . . . . . 164

Function ............................. 164

Relationship to Earthly Counterpart . . . . . . . . . . . . . 164

Exod 25:9,40 .............................. 164

Semantic and Other Exegetical Considerations ............. 165

Meaning of

Semantic analysis .......................... 165

Contextual analysis . . . . . . . . . . . . . . . . . . 169

Meaning of

Heavenly Sanctuary/Temple Motif .................. 173

Function .............................. 173

Relationship to Earthly Counterpart .............. 173

Exodus 32:1-34:34 ........................... 173

Preliminary Considerations ....................... 174

Heavenly Sanctuary/Temple Motif . . . . . . . . . . . . . . . 177 
Function ............................. 177

Relationship to Earthly Counterpart ............... 177

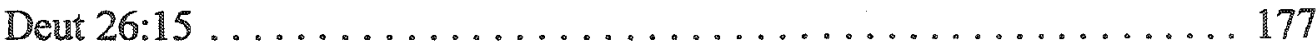

Preliminary Observations ....................... 178

Semantic and Other Exegetical Considerations ............ 178

The Meaning of

The Meaning of $\ldots \ldots \ldots \ldots \ldots \ldots \ldots \ldots \ldots$

The Meaning of 7 ?

Heavenly Sanctuary/Temple Motif ................... 183

Function ............................. 183

Relationship to Earthly Counterpart $\ldots \ldots \ldots \ldots \ldots \ldots \ldots \ldots \ldots \ldots \ldots \ldots \ldots \ldots \ldots \ldots \ldots \ldots \ldots \ldots \ldots$
Summary $\ldots \ldots \ldots \ldots \ldots \ldots \ldots$

\section{THE HEAVENLY SANCTUARY/TEMPLE MOTIF}

IN THE PROPHETS . . . . . . . . . . . . . . . . . . . . . . 187

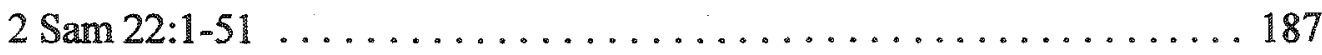

Preliminary Observations ...................... 188

Semantic and Other Exegetical Considerations . . . . . . . . . . . . 190

The Meaning of

The Meaning of

The Meaning of

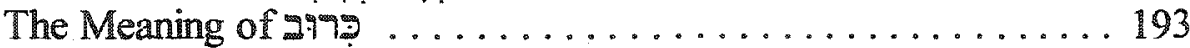

The Meaning of

Heavenly Sanctuary/Temple Motif . . . . . . . . . . . . . . . 194

Function ... . . . . . . . . . . . . . . . . . . . . . . . . . 194

Relationship to Earthly Counterpart . . . . . . . . . . . . . 197

$1 \mathrm{Kgs} 8: 12-66$................................ 197

Preliminary Observations ........................ 199

Excursus: The Function of the Earthly Temple

and the "Name" Theology ....................... 202

Prayer versus Sacrifice . . . . . . . . . . . . . . . . . . . 203

Transcendence versus Immanence ................. 206

Semantic and Other Exegetical Considerations ............ 211

The Meaning of

The Meaning of a.

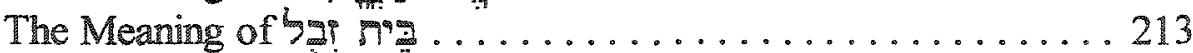

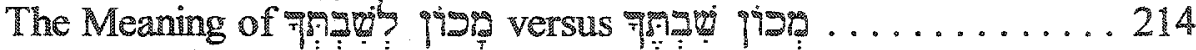

The Meaning of

Heavenly Sanctuary/Temple Motif . . . . . . . . . . . . . 216

Function ............................... 217

Relationship to Earthly Counterpart ............... 220

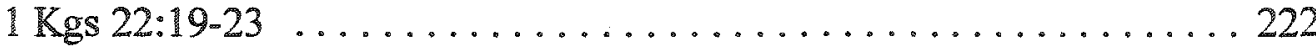




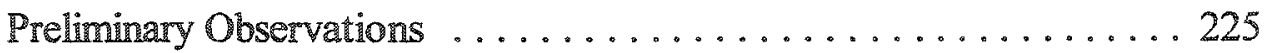

Semantic and Other Exegetical Considerations ............ 227

The Meaning of

The Meaning of a

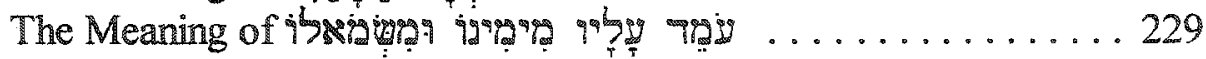

Heavenly Sanctuary/Temple Motif . . . . . . . . . . . . . . . 229

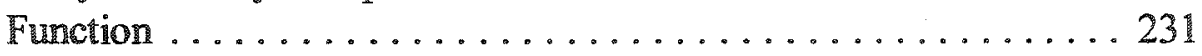

Relationship to Earthly Counterpart .............. 232

Excursus: Effect of the Heavenly Sanctuary/Temple

on Earthly Affairs .......................... 231

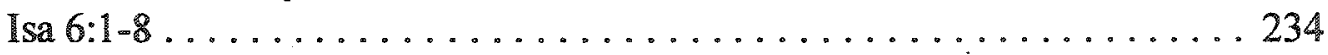

Preliminary Observations ......................... 235

Semantic and Other Exegetical Considerations ............ 237

Meaning of

Meaning of

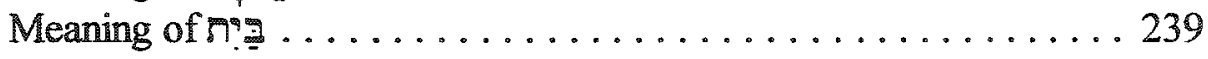

Meaning of

Heavenly Sanctuary/Temple Motif .................. 241

Function ............................. 241

Relationship to the Earthly Counterpart ............. 244

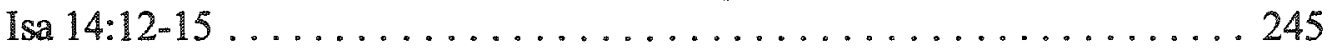

Preliminary Observations ..................... 246

Excursus:

Excursus: Identity of the King of Babylon ............ 253

Excursus: Alleged Mythological Background of 14:12-15

and the Referent of Helel ben Shahar ............... 255

Semantic and Other Exegetical Considerations . . . . . . . . . . 257

Meaning of

Meaning of

Meaning of

Heavenly Sanctuary/Temple Motif . . . . . . . . . . . . . . . 264

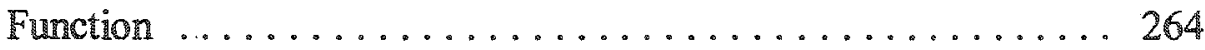

Relationship to the Earthly Counterpart ............. 265

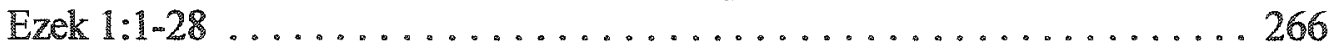

Preliminary Observations ..................... 267

Semantic and Other Exegetical Considerations . . . . . . . . . 270

Heavenly Sanctuary/Temple Motif ................... 273

Function ............................. 273

Relationship to the Earthly Counterpart ... . . . . . . . 273

Ezek 10:1-22 ............................. 273

Preliminary Observations ....................... 274

Heavenly Sanctuary/Temple Motif . . . . . . . . . . . . . . 276

Function ................................ 276

vii 


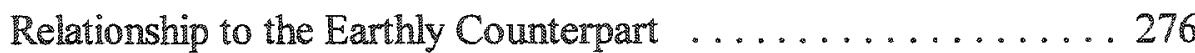

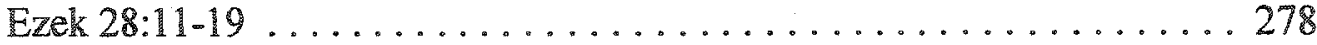

Preliminary Observations ...................... 280

Semantic and Other Exegetical Considerations ............... 285

Garden of Eden ......................... 285

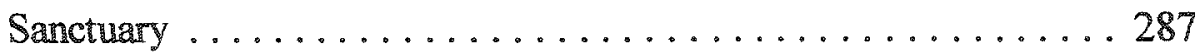

Heavenly Sanctuary/Temple Motif . . . . . . . . . . . . . . 290

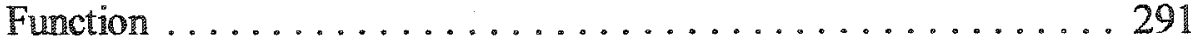

Relationship to the Earthly Counterpart ............ 292

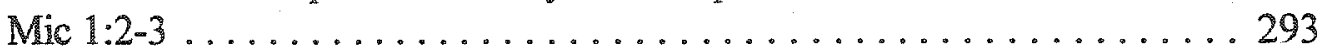

Preliminary Observations $\ldots \ldots \ldots \ldots \ldots \ldots \ldots \ldots . \ldots \ldots 4$

Excursus: Two Objections against the Heavenly

Sanctuary/Temple Motif . . . . . . . . . . . . . . . . . . . . . . . . . . 299

Semantic and Other Exegetical Considerations ............ 301

Meaning of ang. . . . . . . . . . . . . . . . . . . 301

Meaning of

Meaning of

Meaning of

Heavenly Sanctuary/Temple Motif . . . . . . . . . . . . . 304

Function ............................. 304

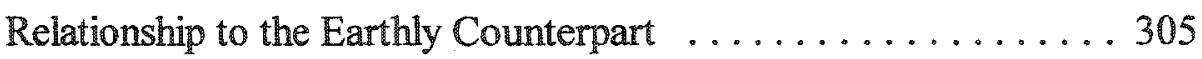

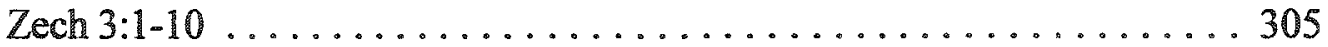

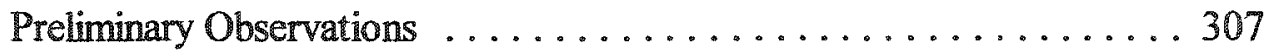

Semantic and Other Exegetical Considerations ................. 311

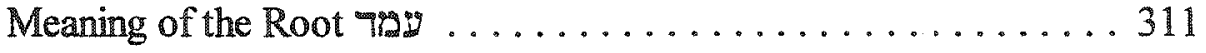

Role of the Angel of YHWH . . . . . . . . . . . . 312

Analysis of

Implications of Changing Clothes $\ldots \ldots \ldots \ldots \ldots . \ldots . \ldots 316$

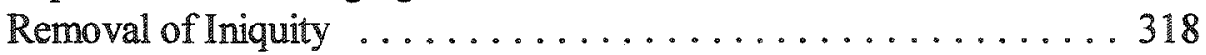

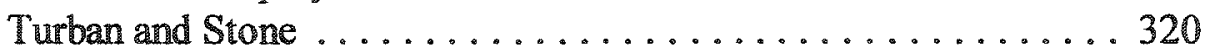

Excursus on Zech 3:7: The Purpose of the Vision

and the Privileges of Joshua $\ldots \ldots \ldots \ldots \ldots . \ldots \ldots . \ldots \ldots 22$

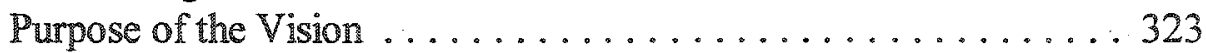

Joshua and the Privilege of Judgment . . . . . . . . . . . . 323

Joshua and the Privilege of Access to the Heavenly Council . . . . 326

Heavenly Sanctuary/Temple Motif . . . . . . . . . . . . . 328

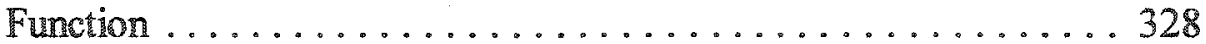

Relationship to Earthly Counterpart ............... 330

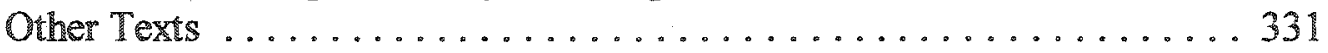

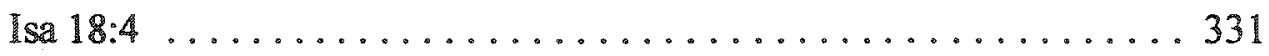

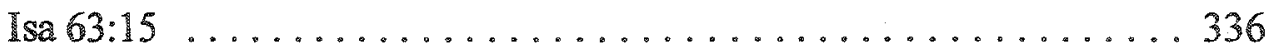

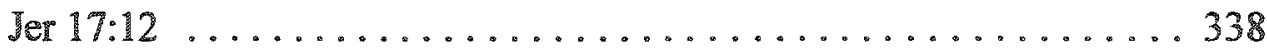

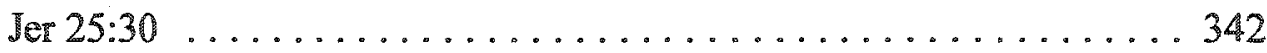

viii 


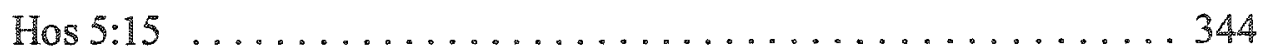

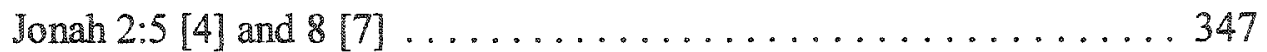

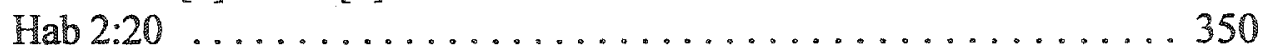

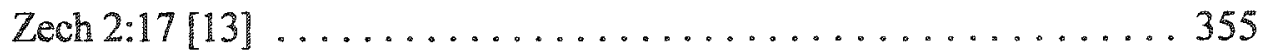

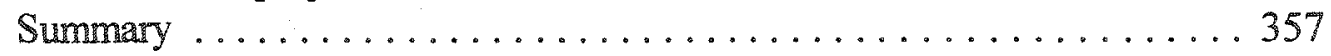

\section{THE HEAVENLY SANCTUARY/TEMPLE MOTIF}

N THE WRITINGS . . . . . . . . . . . . . . . . . . . . . 362

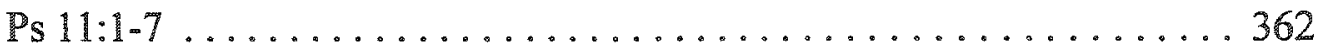

Preliminary Observations ........................ 363

Semantic and Other Exegetical Considerations ............ 365

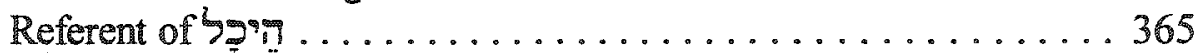

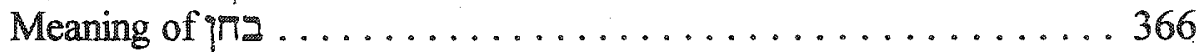

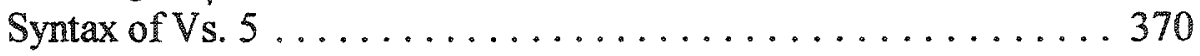

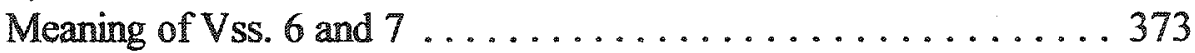

Heavenly Sanctuary/Temple Motif . . . . . . . . . . . . . . 375

Function .............................. 375

Relationship to Earthly Counterpart ................ 376

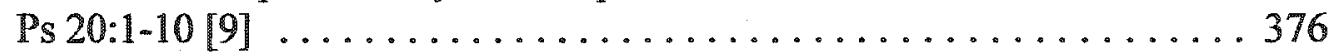

Preliminary Observations ......................... 376

Semantic and Other Exegetical Considerations ............ 378

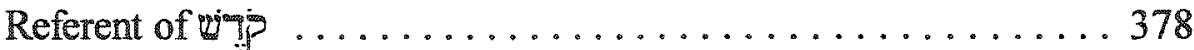

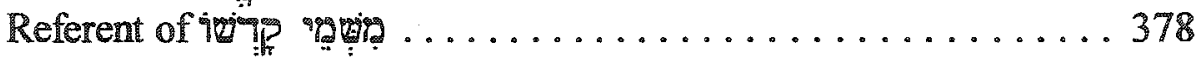

Heavenly Sanctuary/Temple Motif . . . . . . . . . . . . . . . . 379

Function ................................. 379

Relationship to Earthly Counterpart $\ldots \ldots \ldots \ldots \ldots \ldots \ldots 379$

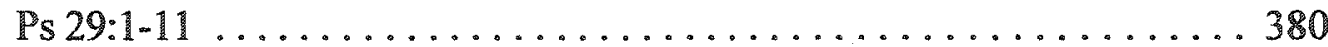

Preliminary Observations ..................... 380

Semantic and Other Exegetical Considerations . . . . . . . . . 384

Meaning of

Meaning and Referent of

Storm Imagery . . . . . . . . . . . . . . . . . . . 387

Referent of

Meaning of

Heavenly Sanctuary/Temple Motif . . . . . . . . . . . . . . . . 393

Function . . . . . . . . . . . . . . . . . . . . . . . . . 394

Relationship to Earthily Counterpart . . . . . . . . . . . . . . . . . . 394

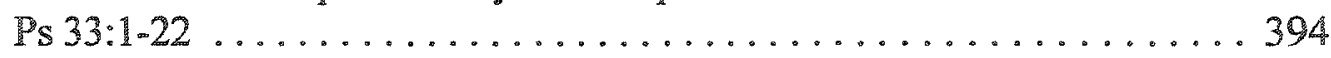

Preliminary Observations ........................ . 394

Semantic and Other Exegetical Considerations ............. 395

Semantic Connotation and Referent of

Idea of YHWH Looking Down . . . . . . . . . . . . . . . . 397

ix 
Heavenly Sanctuary/Temple Motif . . . . . . . . . . . . . . . 398

Function . . . . . . . . . . . . . . . . . . . . . . . . . 398

Relationship to Earthly Counterpart . . . . . . . . . . . . . 399

Ps 60:1-14 [12] ............................... 399

Preliminary Observations ...................... 400

Semantic and Other Exegetical Considerations ............ 401

Heavenly Sanctuary/Temple Motif . . . . . . . . . . . . . . 406

Function .......................... 406

Relationship to Earthly Counterpart ............ 406

Ps 68:1-36 [35] .............................. . 407

Preliminary Observations ................... 407

Semantic and Other Exegetical Considerations ........... 409

Referent of

Meaning and Referent of wyp in vs. $18[17] \ldots \ldots \ldots \ldots .411$

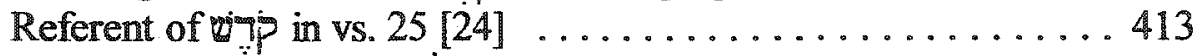

Meaning and Referent of $\ldots$. . . . . . . . . . . . . . . 413

Referent of

Heavenly Sanctuary/Temple Motif . . . . . . . . . . . . 417

Function ........................... 417

Relationship to Earthly Counterparts . . . . . . . . . . . 418

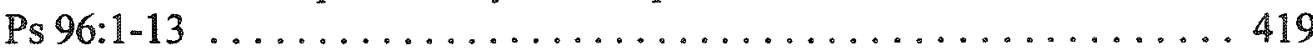

Preliminary Observations .................... 420

Semantic and Other Exegetical Considerations . . . . . . . . . 421

Referent of $\ldots$. . . . . . . . . . . . . . . . . . . . 421

Referent and Meaning of

Heavenly Sanctuary/Temple Motif . . . . . . . . . . . . . . 425

Function ........................... 425

Relationship to Earthly Counterpart $\ldots \ldots \ldots \ldots \ldots \ldots \ldots 426$

Ps $102: 20-21[19-20] \ldots \ldots \ldots \ldots \ldots \ldots \ldots \ldots \ldots \ldots . \ldots . \ldots 427$

Preliminary Observations $\ldots \ldots \ldots \ldots \ldots \ldots \ldots \ldots \ldots . \ldots 427$

Semantic and Other Exegetical Considerations ............ 429

Meaning of

Meaning of

Heavenly Sanctuary/Temple Motif . . . . . . . . . . . . . . . . . . 432

Function ......................... . 432

Relationship to Earthly Counterpart .............. 433

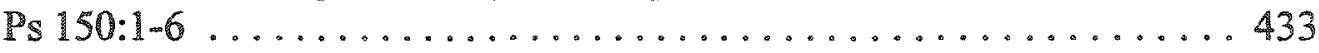

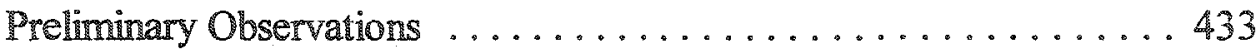

Semantic and Other Exegetical Considerations ............ 435

Heavenly Sanctuary/Temple Motif . . . . . . . . . . . . . . . 437

Function ............................. 437

Relationship to the Earthly Counterpart ............ 438

Daniel 7:9-14 ............................. 440 
Preliminary Observations ...................... 441

Semantic and Other Exegetical Considerations ............. 444

Vertical Dimension ........................ 445

Judicial and Cultic Language and Imagery . . . . . . . . . . 445

Identity of

Implications of 79 and

Implications of

Meaning of $\ldots \ldots \ldots \ldots \ldots \ldots \ldots \ldots \ldots . \ldots . \ldots . \ldots 48$

Referent of

Heavenly Sanctuary/Temple Motif . . . . . . . . . . . . . . . . 449

Function ................................. 449

Relationship to the Earthly Counterpart ............. 450

Daniel 8:9-14 ................................ 450

Preliminary Observations $\ldots \ldots \ldots \ldots \ldots \ldots \ldots \ldots \ldots . \ldots 451$

Semantic and Other Exegetical Considerations ........... 452

Vertical Dimension ........................ 452

Interpretation of צִ 8 in $8: 13 \ldots \ldots \ldots \ldots \ldots \ldots \ldots 454$

Cultic Language ........................... 456

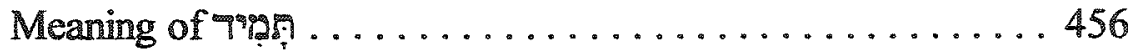

Meaning of

Meaning of

Referent and function of

Heavenly Sanctuary/Temple Motif . . . . . . . . . . . . . . . 464

Function ......................... 464

Relationship to the Earthly Counterpart ............ 465

Daniel 9:24 ............................... 466

Other Passages .......................... 470

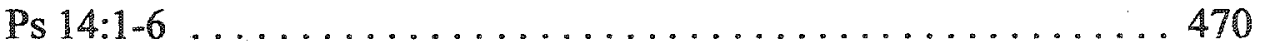

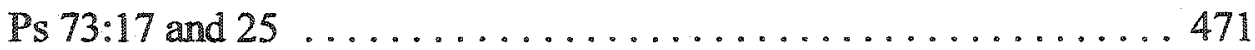

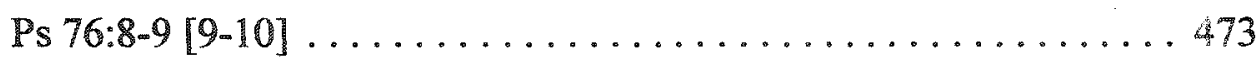

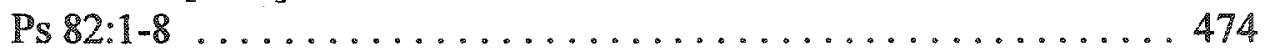

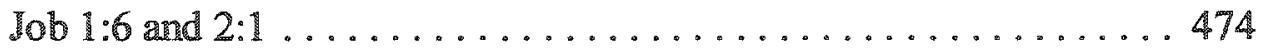

2 Chr 30:27 ...............................476

Summary ................................ 478

6. THEOLOGICAL SYNTHESIS ................... 483

Hebrew Bible and ANE Background: Similarities and Differences .... 484

Heavenly Sanctuary/Temple and Judgment . . . . . . . . . . . . 486

Heavenly Sanctuary/Temple the Cosmic Battle . . . . . . . . . . . 487

Heavenly Sanctuary/Temple and Covenant ................ 489

Relationship to Earthly Counterpart. . . . . . . . . . . . . . . . 491

Dynamic Interaction . . . . . . . . . . . . . . . . . . 491 
Structural Correspondence ....................493

Functional Correspondence ................... 495

Summary and Conclusions ..................... 498

Suggestions for Further Study . . . . . . . . . . . . . . . . . 499

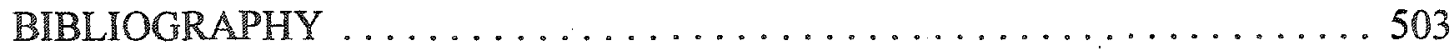

xii 


\section{LIST OF FIGURES}

1. Nabuapaliddina's Relief. $\ldots \ldots \ldots \ldots \ldots \ldots \ldots \ldots \ldots . \ldots \ldots$

2. Semiotic Structure of Gen $28: 10-22 \ldots \ldots \ldots \ldots \ldots \ldots \ldots \ldots$

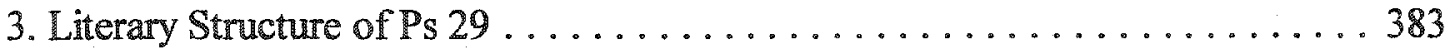

4. Vertical Movement of the Little Horn ................. 453

\section{LIST OF TABLES}

1. Key Words in Genesis $28: 10-22 \ldots \ldots \ldots \ldots \ldots \ldots . \ldots \ldots$

2. The Heavenly Sanctuary/Temple Motif in the Torah $\ldots . \ldots \ldots \ldots$

3. The Heavenly Sanctuary/Temple Motif in the Prophets ........... 360

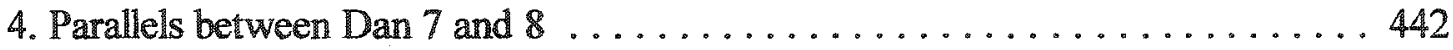

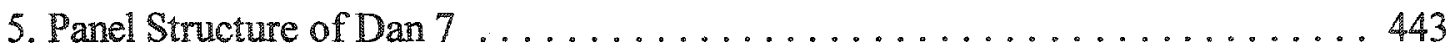

6. Literary Structure of Daniel $9: 24 \ldots \ldots \ldots \ldots \ldots \ldots \ldots$

7. The Heavenly Sanctuary/Temple Motif in the Writings $\ldots \ldots \ldots \ldots$.... 467

8. The Heavenly Sanctuary/Temple Motif in the Hebrew Bible ...........499 


\section{LIST OF ABBREVIATIONS}

\begin{tabular}{|c|c|}
\hline AAL & Arbeitsheft zur Altorientalischen Literatur \\
\hline $\mathrm{AB}$ & Anchor Bible \\
\hline$A B D$ & Anchor Bible Dictionary \\
\hline$A B R$ & Australian Biblical Review \\
\hline AcOr & Acta Orientalia \\
\hline$A J B I$ & Anmual of the Japanese Biblical Institute \\
\hline$A J S L$ & The American Journal of Semitic Languages and Literature \\
\hline$A N E T$ & Ancient Near Eastern Texts Relating to the Old Testament \\
\hline ATD & Alte Testament Deutsch \\
\hline AOAT & Alter Orient und Altes Testament \\
\hline ASTI & Anmual of the Swedish Theological Institute \\
\hline ATANT & Abhandlungen zur Theologie des Alten und Neuen Testaments \\
\hline AUSDDS & Andrews University Seminary Doctoral Dissertation Series \\
\hline AUSS & Andrews University Seminary Studies \\
\hline BASOR & Bulletin of the American Schools of Oriental Research \\
\hline$B R R$ & Bulletin of Biblical Research \\
\hline BBS & Biblical and Judaic Studies \\
\hline$B D B$ & The Brown Driver Briggs Hebrew and English Lexicon \\
\hline BHS & Biblia Hebraica Stuttgartensia \\
\hline$B i b$ & Biblica \\
\hline
\end{tabular}

$$
x^{*}
$$




\begin{tabular}{|c|c|}
\hline Biblnt & Biblical Interpretation \\
\hline BibOr & Biblica et Orientalia \\
\hline BIS & Biblical Interpretation Series \\
\hline BKAT & Biblischer Kornmentar Altes Testament \\
\hline$B N$ & Biblische Notizen \\
\hline BSCS & Bible Study Commentary Series \\
\hline$B T$ & The Bible Translator \\
\hline$B T B$ & Biblical Theology Bulletin \\
\hline BWANT & Beiträge zur Wissenschaft vom Alten und Neuen Testament. \\
\hline$B Z$ & Biblische Zeitschrift \\
\hline BZAW & Beiheft zur Zeitschrift für die alttestamentliche Wissenschaft \\
\hline CahRB & Cahiers de la Revue Biblique \\
\hline CBOTS & Coniectanea Biblica, Old Testament Series \\
\hline CBET & Contributions to Biblical Exegesis and Theology \\
\hline$C B Q$ & Catholic Biblical Quarterly \\
\hline $\mathrm{CBC}$ & The Cambridge Bible Commentary \\
\hline $\mathrm{CC}$ & Continental Commentaries \\
\hline CCSOT & Communicator's Commentary Series: Old Testament \\
\hline ConBOT & Coniectanea biblica: Old Testament Series \\
\hline $\cos$ & The Context of Scripture \\
\hline$C Q R$ & Church Quarterly Review \\
\hline DARCOM & Daniel and Revelation Committee Series \\
\hline
\end{tabular}

XV 


$\begin{array}{ll}\text { DSB } & \text { The Daily Study Bible } \\ \text { EC } & \text { Epworth Commentaries } \\ \text { ECC } & \text { The Eerdmans Critical Commentary } \\ \text { ETL } & \text { Ephemerides Theologicae Lovanienses } \\ \text { EstBib } & \text { Estudios biblicos } \\ \text { Exp } & \text { The Expositor } \\ \text { ExpTim } & \text { Expository Times } \\ \text { ETR } & \text { Etudes Théologiques et Religieuses } \\ \text { FOTL } & \text { Forms of the Old Testament Literature } \\ \text { GSEAT } & \begin{array}{l}\text { Geistliche Schriflesung: Erläuterungen zum Alten Testament für die } \\ \text { geistliche Schriflesung }\end{array} \\ \text { HAR } & \text { Hebrew Annul Review } \\ \text { HAT } & \text { Handbuch zum Alten Testament } \\ \text { HALOT } & \text { The Hebrew and Aramaic Lexicon of the Old Testament } \\ \text { HCOT } & \text { Historical Commentary on the Old Testament } \\ \text { Hermeneia } & \text { Hermeneia-A Critical and Historical Commentary on the Bible } \\ \text { HTKAT } & \text { Herders Theologischer Kommentar zum Alten Testament } \\ \text { HTR } & \text { Harvard Theological Review } \\ \text { HSM } & \text { Harvard Semitic Monographs } \\ \text { HSS } & \text { Harvard Semitic Studies } \\ \text { IBC } & \text { Interpretation: A Bible Commentary for Teaching and Preaching } \\ \text { ICC } & \text { The International Critical Commentary } \\ \end{array}$

XVi 


\begin{tabular}{|c|c|}
\hline Int & Interpretation \\
\hline ITC & International Theological Commentary \\
\hline JANES & Journal of the Ancient Near Eastern Society \\
\hline JANESCU & Journal of the Ancient Near Eastern Society of Columbia University \\
\hline$J B L$ & Journal of Biblical Literature \\
\hline JBLang & Journal of Biblical Language \\
\hline JATS & Journal of the Adventist Theological Society \\
\hline$J E A$ & Journal of Egyptian Archaeology \\
\hline JETS & Journal of the Evangelical Theological Society \\
\hline JNES & Journal of Near Eastern Studies \\
\hline JNSL & Journal of Northwest Semitic Languages \\
\hline$J Q R$ & Jewish Quarterly Review \\
\hline$J R$ & Journal of Religion \\
\hline$J R S$ & Journal of Religious Studies \\
\hline JSOT & Journal for the Study of the Old Testament \\
\hline JSOTSup & Joumal for the Study of the Old Testament Supplement Series \\
\hline JSS & Journal of Semitic Studies \\
\hline $\operatorname{ITS}$ & Journat of Theological Studies \\
\hline KAT & Kommentar zum Alten Testament \\
\hline KTU & $\begin{array}{l}\text { The Cuneiform Alphabetic Texts from Ugarit, Ras Ibn Hani and Other } \\
\text { Places (KTU: second, enlarged edition) }\end{array}$ \\
\hline$L B$ & Linguistica Biblica \\
\hline
\end{tabular}

xvii 
LTQ Lexington Theological Quarterly

NABC The New American Bible Commentary

NAC The New American Commentary

NCBC New Century Bible Commentary

NEBKTAE Die Neue Echter Bibel: Kommentar zum Altes Testament mit der Einheitsübersetzung

NIBC New International Biblical Commentary

NICOT The New International Commentary on the Old Testament

NIDOTTE New International Dictionary of Old Testament Theology and Exegesis

NSBT New Studies in Biblical Theology

NSKAT Neuer Stuttgarter Kommentar: Altes Testament 24.1

Numen International Review for the History of Religions

OBO Orbis Biblicus et Orientalis

Or Orientalia

OTE Old Testament Essays

OTL The Old Testament Library

OTMBTC Old Testament Message: A Biblical-Theological Commentary

$R B \quad$ Revue biblique

RevExp Review and Expositor

RHR Revie de l'histoire des religions

RNS Recherches: Nouvelle Série

RSMS Religious Studies Monograph Series 


$\begin{array}{ll}\text { SBLMS } & \text { Society of Biblical Literature Monograph Series } \\ \text { SDABC } & \text { Seventh-day Adventist Bible Commentary } \\ \text { SEA } & \text { Svensk Exegetisk Arsbok } \\ \text { STJ } & \text { Stulos Theological Journal } \\ \text { TBC } & \text { Torch Bible Commentaries } \\ \text { TDOT } & \text { Theological Dictionary of the Old Testament } \\ \text { THBW } & \text { Theologish-homiletish Bibel Werk } \\ \text { TOTC } & \text { The Tyndale Old Testament Commentary } \\ \text { TWAT } & \text { Theologisches Wörterbuch zum Alten Testament } \\ \text { TWOT } & \text { Theological Wordbook of the Old Testament } \\ \text { SSN } & \text { Studia Semitica Neerlandica } \\ \text { TZ } & \text { Theologische Zeitschrift } \\ \text { UBL } & \text { Ugaritisch-Biblische Literatur } \\ \text { UF } & \text { Ugarit-Forschungen } \\ \text { WT } & \text { Vetus Testamentum } \\ \text { VTSup } & \text { Vetus Testamentum Supplement } \\ \text { WAW } & \text { Writings from the Ancient World } \\ \text { WBC } & \text { Word Biblical Commentary } \\ \text { WMANT } & \text { Wissenschaftliche Monographien zum Alten und Neuen Testament } \\ \text { WSRAT } & \text { Wuppertaler Studienbibel, Reihe Altes Testament } \\ \text { WTJ } & \text { Westminster Theological Journal } \\ \text { WUNT } & \text { Wissenschaftliche Untersuchungen zum Neuen Testament } \\ \end{array}$


Kerux Kerux: The Journal of Northwest Theological Seminary

ZASS Zeitschrift für Aguptische Sprache and Alterumskunde

ZAW Zeitschrift für die alttestamentliche Wissenschaft

ZB Zürcher Bibelkommentare

ZDPV Zeitschrift des Deutschen Palästina Vereins

ZS Zeitschrift für Semitisk und verwandte Gebiete 


\section{ACKNOWLEDGMENTS}

It is impossible to mention by name each person who has been a contributor to this doctoral dissertation. Because of that I would like mention those who were more directly involved in the process of bringing forth this study.

Particular thanks go to the members of my advisory committee: to Dr. Richard M. Davidson who supervised this dissertation and manifested sustained enthusiasm for the topic. I also express my thanks to the other members of my dissertation committee: Dr. Jon Paulien, Dr. Roy E. Gane, and Dr. Jiri Moskala, whose comments and criticisms helped me sharpen my views in several important aspects of this work. As the external examiner, Dr. William H. Shea also provided valuable comments and suggestions that helped improve the final presentation of this work.

I also express appreciation to the administration of Northeast Brazil College for financial support during the entire doctoral program, from the course work to the completion of this dissertation. My thanks also go to Dr. Leona Running for meticulous editorial work that saved my manuscript from many blunders; those that remain are, of course, my own responsibility.

Finally, I am most grateful to my wife Mágela, for her support and encouragement, and for my children Guilherme and Gustavo who had to endure my absence in those many hours in which my research claimed my presence in the library.

$x x i$ 


\section{CHAPTER 1}

\section{INTRODUCTION}

\section{Problem}

Though the picture of a heavenly sanctuary/temple in the Hebrew Bible is generally recognized, its full implications are far from clear. Usually critical scholarship tends to view the biblical concept of a heavenly sanctuary/temple as borrowed from ancient $\mathrm{Near}$ Eastern mythology in which a correspondence between heavenly and earthly realities is assumed. ${ }^{1}$ On the other hand, some Adventist conservative scholars have studied the heavenly sanctuary/temple from a historical-theological perspective without detailed exegesis of the heavenly sanctuary/temple biblical passages. ${ }^{2}$ A few studies scattered among chapters of books and journal articles have advanced the understanding of this subject, as noted in the review of literature below.

${ }^{1}$ Cf. e.g., Eric Burrows, "Some Cosmological Patterns in Babylonian Religion," in The Labyrinth: Further Studies in the Relation between Myth and Ritual in the Ancient World (London: Macmillan, 1935), 4570; R. E. Clements, God and Temple (Ox ford: Basil Blackwell, 1965), 1-16; Hugh W. Nibley, "What Is a Temple?," in The Temple in Antiquity: Ancient Records and Ancient Perspectives, ed. Truman G. Madsen, The Religious Studies Monograph Series 9 (Provo, UT: Brigham Young University, 1984), 19-37.

${ }^{2}$ E.g., Frank Holbrook, "The Israelite Sanctuary," in The Sanctuary and the Atonement: Biblical, Theological, and Historical Studies, ed. Frank Holbrook (Silver Spring, MD: Biblical Research Institute, 1989), 3-36. See the chapter on "The Heavenly Sanctuary," in M. L. Andreasen, The Sanctuary Service (Washington, DC: Review and Herald, 1937), 224-40; Alberto R. Treiyer, The Day of Atonement and the Heavenly Judgement from Pentateuch to Revelation (Siloam Springs, AR: Enterprises International, 1992), 269-366. 


\section{翼踏pose}

This dissertation presents an investigation of OT passages containing the heavenly sanctuary/temple motif in order to achieve a threefold purpose: (1) to ascertain the function of the heavenly sanctuary/temple; (2) to determine the relationship of the heavenly sanctuary/temple with its carthly counterpart, and (3) to provide a comprehensive picture of the heavenly sanctuary/temple motif in the Hebrew Bible.

\section{Review of Literature}

A substantial review of literature has been provided by Sanglae $\mathrm{Kim}^{1}{ }^{1}$ so a detailed restatement is unnecessary. At the outset, it should be noted that some studies on the heavenly sanctuary/temple motif have focused on extrabiblical apocalyptic literature, ${ }^{2}$ others have been concerned with the idea of a heavenly temple in the context of a background for the temple or New Jerusalem in the New Testament. ${ }^{3}$ A few studies have dealt with the heavenly sanctuary/temple motif in the Dead Sea Scrolls ${ }^{4}$ and rabbinic

${ }^{1}$ Cf. Sanglae Kim, "The Heavenly Sanctuary/Temple in the Hebrew Bible" (Ph.D. diss., University of Sheffield, 2002), 27-44.

${ }^{2}$ R. G. Hamerton-Kelly, "The Temple and the Origins of Jewish Apocaliptic," Vetus Testamentum 20 (1970): 1-15; Allan James McNicol, "The Relationship of the Image of the Highest Angel to the High Priest Concept in Hebrews" (Ph.D. diss., Vanderbilt University, 1974); 53-146; Allan James McNicol, "The Heavenly Sanctuary in Judaism: A Model for Tracing the Origin of an Apocalypse," JRS 13, no. 2 (1987): 66-94.

${ }^{3}$ Pilchan Lee, The New Jerusalem in the Book of Revelation: A Study of Revelation 21-22 in the Light of Its Background in Jewish Tradition, WUNT 2/129 (Tübingen: Mohr Siebeck, 2001); Sarah Ann Sharkey, "The Background of the Imagery of the Heavenly Jerusalem in the New Testament" (Ph.D. diss., Catholic University of America, 1986), 232-93; James Valentine, "Theological Aspects of the Temple Motif in the Old Testament and Revelation" (Ph.D. diss., Boston University, 1987), 75-128.

${ }^{4}$ Carol Newsom, Songs of the Sabbath Sacrifice: A Critical Edition, HSS 27 (Atlanta, 
literature ${ }^{1}$ including early Christianity. ${ }^{2}$ For the purpose of this research, attention is given to those works that have focused on the heavenly sanctuary/temple motif in the Hebrew

Bible. An examination of the scholarly literature reveals that although several works touch upon this topic, ${ }^{3}$ only a few scholarly studies have been devoted to the idea of a heavenly sanctuary/temple in the Hebrew Bible. To these latter works, attention is now devoted according to a chronological order.

GA: Scholars Press, 1985), 1-21. Cf. William H. Shea, "Sabbath Hymns for the Heavenly Sanctuary," in Symposium on Revelation-Book I, ed. Frank B. Holbrook, Daniel and Revelation Committee Series 7 (Silver Spring, MD: Biblical Research Institute, 1992), 391-407.

${ }^{1}$ Victor Aptowitzer, The Celestial Temple as Viewed in the Aggadah, adapted by Aryeh Rubinstein (Jerusalem: International Center for University Teaching of Jewish Civilization, 1931), 1-47; Beate Ego, Im Himmel wie auf Erden: Studien zum Verhältnis von himmlischer und irdischer Welt im rabbinischen Judentum (Tübingen: J.C.B. Mohr, 1989), 27-61.

${ }^{2}$ Hans Bietenhard, Die himmlische Welt im Urchristentum und Spätjudentum, WUNT 2 (Tübingen: Mohr, 1951), 123-42. Cf. Robert A. Briggs, Jewish Temple Imagery in the Book of Revelation, ed. Hemchand Gossai, Studies in Biblical Literature 10 (New York: Peter Lang, 1999), 96-103.

${ }^{3}$ E.g., Clements, God and Temple, 65-68; Richard J. Clifford, The Cosmic Mountain in Canaan and the Old Testament, Harvard Semitic Monographs 4 (Cambridge, MA: Harvard University Press, 1972), 178; Jon D. Levenson, "The Temple and the World," The Journal of Religion 64 (1984): 275-97; David Lemoine Eiler, "The Origin of Zion as a Theological Symbol in Ancient Israel" (Ph.D. diss., Princeton Theological Seminary, 1968), 146, 174; John M. Lundquist, "The Common Temple Ideology of the Ancient Near East," in The Temple in Antiquity: Ancient Records and Ancient Perspectives, ed. Truman G. Madsen, The Religious Studies Monograph Series 9 (Provo, UT: Brigham Young University, 1984), 53-76; idem, "Temple, Covenant, and Law in the Ancient Near East and in the Old Testament," in Israel's Apostasy and Restoration: Essays in Honor of Roland K. Horrpison, ed. Avraham Gileadi (Grand Rapids, MI: Baker, 1988), 293-305; idem, "What Is a Temple? A Preliminary Typology," in Quest for the Kingdom of God: Studies in Honor of George E. Mendenhall, ed. E. A. Spina, H. B. Huffmon, and A. R. W. Green (Winona Lake, $\mathbb{N}$ : Eisenbrauns, 1983), 205-19. 
G. B. Gray

The first scholarly work that was devoted to the heavenly sanctuary/temple motif in the Hebrew Bible was conducted by G. B. Gray. In a thirty-five-page article, Gray discusses the origins of the heavenly sanctuary/temple idea and its relationship to other ideas. After discussing the possible origins of this idea in Babylonian literature, he concluded that the idea of a heavenly temple had no antecedent in the ANE literature; rather, it developed among the Jewish people between about 500 and 100 B.C. ${ }^{2}$ Consequently, in his discussion of 1 sa $6: 1$ he argued that the temple referred to therein is the Jerusalem temple, ${ }^{3}$ since, according to him, "there is no direct evidence for the existence of the belief [in the heavenly temple] earlier than the Testament of the Patriarchs at the end of the second century B.C." With this sweeping generalization, Gray totally denies the presence of the heavenly sanctuary/temple motif in the Hebrew Bible. He also argued that the "failure of the belief to appear in three writers, Ezekiel, $\mathrm{P}$, and the Chronicler, all of whom had good reason for betraying it if they held it, should receive due weight." Interestingly enough, however, Gray allows for the presence of a "heavenlypalace" motif in certain passages (Pss 11:4, 18:7, Mic 1:2, Isa 63:15) due to the distinction he makes between the idea of temple, on the one hand, and palace, on the other. $531-46$.

"G. B. Gray, "The Heavenly Temple and the Heavenly Altar," Exp 5 (1908): 385-402;

\footnotetext{
2ibid., 546 .

${ }^{3}$ Tbid., $539-40$

${ }^{4}$ Tbid., 541.

${ }^{5}$ Ibid., 544.
} 
A few comments about Gray's view are in order. At the outset, it must be pointed out that his efforts to treat the biblical concept of a heavenly sanctuary/temple independently from Babylonian ideas is a step in the right direction. However, Gray's critical approach prevents him from perceiving the heavenly sanctuary/temple motif as clearly expressed in Isa 6 . Furthermore, Gray's contention that the belief in a heavenly temple fails "to appear in three writers, Ezekiel, $P$, and the Chronicler" cannot be sustained in the light of passages such as Ezek 1, 10; Exod 25:9, 40; and 2 Chr 30:27.' Finally, it should be noted that Gray's distinction between the idea of temple and that of palace imposes a foreign analytical idea on the synthetic Hebraic concept of temple/sanctuary/palace.

\section{Metzger}

In 1970, M. Metzger published an interesting article dealing with the heavenly and earthly dwelling place of $Y H W H .^{2}$ Apparently his main concern was to demonstrate that there is a continuum between the earthly and heavenly sanctuaries so that it is almost impossible to draw a line of separation between the two. For Metzger, "heavenly and earthly sanctuary are only two aspects of the same idea. ${ }^{83}$ Thus, he argued that "the sanctuary is the place where heavenly and earthly worlds meet and interpenetrate each

\footnotetext{
These passages will be discussed later in this dissertation.

${ }^{2}$ M. Metzger, "Himmliche und Irdische Wohnstatt Jahwes," UF 2 (1970): 139-58.

3"Himmlisches und irdisches Heiligtum sind hier nur zwei Aspekte desselben Vorstellungskomplexes" (ibid.).
} 
other." In other words, "in the sanctuary the border between the earthly and heavenly world is relativized." Among other examples of this idea, Metzger mentions Isa 6 as portraying such a merger inasmuch as the throne of $Y H W H$, according to his view, is jutting from earth to heaven so that YHWH is understood as dwelling in both the heavenly and earthly temples at the same time. ${ }^{3}$

Metzger's article contributed interesting insights about the close relationship between heavenly and earthly sanctuaries. However, his view of an indistinct merge between heavenly and earthly sanctuaries seems overdrawn. Metzger's literalistic interpretation of YHWH's throne jutting up between heaven and earth is not corroborated by a close scrutiny of the passage. ${ }^{4}$ Furthermore, it must be pointed out that although the Hebrew Bible conceives of the heavenly and earthly sanctuaries as working in close relationship, the distinction between them is kept.

\section{Richard M. Davidson}

A significant study on the heavenly sanctuary/temple motif has been produced by Richard M. Davidson. In an unpublished paper dated to 1976,5 Davidson undertakes an

\footnotetext{
"Das Heigtum der Ort ist, an dem die 'himmlische' und 'irdische' Welt einander begegnen, ja geradezu ainander durchdringem" (ibid., 144).

2"Im Heligtum die Grenzen zwischen der irdischen und der himmlischen Welt relativiert sind" (ibid., 145).

3rbid., $144-45$.

${ }^{4}$ See the exegesis of Isa 6 in chapter 3 of this dissertation.

${ }^{5}$ Richard M. Davidson, "The Heavenly Sanctuary in the Old Testament, "TMs, 1981, Adventist Heritage Center, Berrien Springs, MI, 1-29.
} 
examination of several passages dealing with the heavenly sanctuary/temple motif in the Hebrew Bible. Taking a lead from Exod 25:9, 40, he devotes special attention to the vertical typology, that is, the correspondence between the heavenly sanctuary and its earthly counterpart. Davidson investigated ten passages ${ }^{1}$ which were found to contain the heavenly sanctuary/temple motif, and pointed to some others ${ }^{2}$ where this idea may be potentially present. As a result of his study, the perceptions emerged that the sanctuary/temple would function in close relationship to its earthly counterpart, and that the presence of this motif in the Hebrew Bible is much more widespread than previous scholarship had realized. Another contribution by Davidson to the concept of vertical typology was developed in his published dissertation, ${ }^{3}$ where he dealt with the characteristics and structures of biblical types and antitypes. Particularly relevant for the present study is his detailed study of tynlb. T; ("model") in Exod 25:9, 40, and its implications for a vertical (earth-heaven) sanctuary correspondence. ${ }^{4}$

Finally, it should be pointed out that Davidson's study on the area of heavenly sanctuary and biblical typology contributed to demonstrate the need and viability of future research on this topic. ${ }^{5}$ Thus, the present dissertation takes Davidson's study as a point of

'Pss 11:4, 18:7 [6] (par. 2 Sam 2:7); 60:8 [6], 63:3 [2]; 68:36 (35), 96:6 (par. 2 Chr $16: 27), 102: 20$ [19], Isa 6, Jonah 2:8 [7], Mic 1:2.

${ }^{2}$ E.g., Deut 26:5; Jer 25:30; Zech 2:17; 6:12, 13; Pss 29:9; 68:6 [5]; 2 Chr 30:27.

${ }^{3}$ Richard M. Davidson, Typology in Scripture: A Study of Hermeneutical tútoc Structures. AUSDDS 2 (Berrien Springs, MI: Andrews University Press, 1981), 367-88. This is discussed further in chapter 2 .

${ }^{4}$ See ibid., 367-88, for a detailed discussion of "vertical rumoc structures in Exod 25:40."

${ }^{5}$ See the insightful excursus on vertical "rutoc structures," and a discussion of tynlb.T; in 
departure for a more detailed and comprehensive delineation of the vertical typology of the heavenly sanctuary/temple in the Hebrew Bible.

\section{N. E. Andreasen}

In 1981, N. E. Andreasen contributed a paper ${ }^{1}$ in which he discusses the heavenly sanctuary in the Hebrew Bible according to three areas of concern: "the relationship between heaven and earth in the Ancient Near East; God's heavenly and earthly residence in the OT; and prophetic visionary descriptions of the heavenly sanctuary through the earthly." ${ }^{2}$ Concerning the first area, Andreasen pointed to ANE materials where the idea of a relationship between heaven and earth is effected by means of the Weltberg (cosmic mountain), or Weltbaum (cosmic tree), ${ }^{3}$ which was understood to be the meeting point between heaven and earth. This ANE background of the heavenly sanctuary/temple motif, so Andreasen implies, was shared to a certain extent by the writers of the Hebrew Bible. ${ }^{4}$ In his second area of concern, Andreasen discusses the divine residences on earth and in heaven. ${ }^{5}$ He then proceeds to survey several passages containing the idea of YHWH

Richard M. Davidson, Typology in Scripture: A Study of Hermeneutical tútros Structures. AUSDDS 2 (Berrien Springs, MI: Andrews University Press, 1981), 367-88. This is discussed further in chapter 2.

"Niels-Erik Andreasen, "The Heavenly Sanctuary in the Old Testament," in The Sanctuary and the Atonement, ad. Arnold Wallenkampf and Richard Lesher (Washington, DC: Biblical Research Institute, 1981), 67-86.

21bid., 67.

${ }^{3}$ Ibid.

4Ihird. 60 
residing in heaven and on earth, especially in cases where the idea is expressed by means of terms such as que ("tabernacle"), geg" ("dwell"),

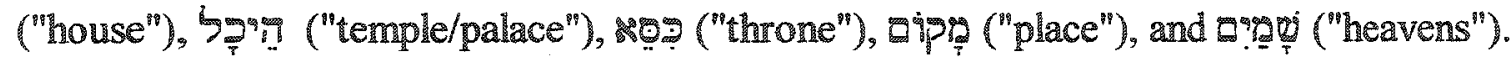
According to Andreasen, the heavenly sanctuary and its earthly counterpart are so closely connected that, although being "cosmographically distinct, their functions are conceptually inseparable in the OT." In his third area of concern, Andreasen turns to visionary accounts of the heavenly throne room (Isa 6; Ezek 1, 40-48; and Zech 3). These visions throw light on the close relationship between the heavenly sanctuary and its earthly counterpart inasmuch as the heavenly sanctuary/temple experiences attested in these visions occur in the context of the earthly temple.

Andreasen's investigation provided a glimpse into the ANE background of the heavenly sanctuary/temple motif, and a general view of the heavenly sanctuary/temple in the Hebrew Bible. In the narrow limits of his study, however, he was not able to engage in detailed exegetical investigation of specific heavenly sanctuary/temple passages.

Therefore, detailed work remains to be done with specific passages in order to delineate a broader picture of the heavenly sanctuary in the Hebrew Bible and produce an exegetical delineation of the function of the heavenly sanctuary/temple along with its relationship to the earthly counterpart.

Ibid., 73. 
William $H$. Shea

In 1982 , William $H$. Shea touched upon the heavenly sanctuary/temple motif in his study on the biblical parallels for the investigative judgment, published as part of a larger study dealing with prophetic interpretation. 'Shea surveyed the passages of Pss 11, 14//53, $29,53,76,102,103$, Mic 1 , and $1 \mathrm{Kgs} 22$ which, according to him; depict the concept of judgment issuing from the heavenly temple. Although Shea offered a cursory treatment of these passages, his observation that the heavenly sanctuary/temple functions as a place of judgment needs further consideration.

In a discussion of the term yigr in Dan 8:12, Shea observed that this word, which designates either the heavenly or earthly sanctuary, "refers to the sanctuary as the place of God's dwelling, the location of His throne, and the place from which He acts. God's activities described in this manner are specifically those of answering prayer and administering justice and righteousness through the giving of judgment." ${ }^{\text {Shea's }}$ observation that the heavenly sanctuary/temple is a place of divine activities provides motivation for further research on this aspect of the heavenly sanctuary/temple motif.

'William H. Shea, Selected Studies on Prophetic Interpretation, 7 vols., DARCOM 1 (Washington, DC: General Conference of Seventh-day Adventists, 1982), 5-8.

In his discussion of the term Yise in Dan 8:12, Shea observed that this word, which is used to refer to either the heavenly or carthly sanctuary, is used in the Hebrew Bible as a sanctuary word. "It refers to the sanctuary as the place of God's dwelling, the location of His throne, and the place from which He acts. God's activities described in this manner are specifically those of answering prayer and administering justice and righteousness through the giving of judgment" (idem, "Unity of Daniel," in Symposium on Daniel, ed. Frank B. Holbrook, DARCOM (Washington, DC: Biblical Research Institute, 1986), 213-14). 
Furthermore, the connection between heavenly temple and its earthly counterpart briefly mentioned by Shea in his discussion of Ps 76 needs further probing in other passages of the Hebrew Bible. ${ }^{1}$ Other works by Shea dealing especially with the sanctuary in the book of Daniel ${ }^{2}$ also provided a significant contribution to the understanding of the heavenly sanctuary/temple motif, as noted in chapter 5.

\section{F. Hartenstein}

In $2001, F$. Hartenstein ${ }^{3}$ contributed an article devoted to the topic of the heavenly sanctuary/temple motif in the Hebrew Bible. In an attempt to delineate the origin and cosmology of the heavenly sanctuary, Hartenstein focuses on $1 \mathrm{Kgs} 8$, Ps $18 / / 2$ Sam 22, Exod 24:9-11, Ezek 1 and 10, Amos 9:5-4, and Ps 104. Methodologically, the author follows the tradition-criticism approach, and evaluates the biblical material in the light of Mesopotamian ideas. In his view, during preexilic times there is no attestation of the heavenly sanctuary idea in the Hebrew Bible. In this context, the Jerusalem temple itself was understood along the lines of ANE mythology according to which the temple

'Shea, Selected Studies on Prophetic Interpretation, 6.

"William H. Shea, "The Prophecy of Daniel 9:24-27," in The Seventy Weeks, Leviticus, and the Nature of Prophecy, ed. Frank B. Holbrook, DARCOM (Washington, DC: Biblical Research Institute, General Conference of Seventh-day Adventists, 1986), 75-118; idem, "Spatial Dimensions in the Vision of Daniel $8, "$ in Symposium on Daniel, ed. Frank B. Holbrook, DARCOM (Washington, DC: Biblical Research Institute, 1986), 497-526; idem, "Unity of Daniel," 165-255; idem, Daniel 7-12: Prophecies of the End Time, The Abundant Life Bible Amplifier (Boise, ID: Pacific Press, 1996), 85-154.

${ }^{3}$ Friedhelm Hartenstein, "Wolkendunkel und Himmelfeste: Zur Genese und Kosmologie der Vorstellung des himmlischen Heiligtums JHWHs," in Das biblische Weltbild und seine altorientalischen Kontexte, ed. Bernd Janowski and Beate Ego (Tubingen: Mohr Siebeck, 2001), 125-79. 
functioned as the navel of the earth, and as the place where communication with the deity was established. ${ }^{1}$

According to Hartenstein, it is only during the Babylonian exile that some early Jewish texts speak explicitly of a "heavenly sanctuary" (himmlischen Heiligtum). ${ }^{2}$ A passage such as Isa 6 that would undermine Hartenstein's view is considered to be a reference to the Jerusalem temple. According to him the passage does not refer to heaven as the abode of YHWH, but only betrays the mythical concept of the Jerusalem temple as the place above which YHWH was enthroned. ${ }^{3}$ In Hartenstein's words, "YHWH's mythical dwelling towers in a vertical plane above Mount Zion. It reaches heaven, without being located 'in' it." In the same vein, Ps 18:8-16 and $1 \mathrm{Kgs} \mathrm{8:12-13}$ are said to express a cosmic understanding of the earthly temple. ${ }^{5}$ When it comes to 2 Sam 22 , Harteinstein concedes that the idea of a heavenly "Palace" (Palast) of YHWH is present in that text, but it is a redactional insertion. ${ }^{6}$

In his discussion of Exod 24:9-11 and Ezek 1 and 10, Hartenstein focuses on the cosmological background of these passages. Regarding Exod 24:9-11, Hartenstein

Ibid., 126.

${ }^{2}$ Ibid., 127.

3Ibid., $127-26$.

${ }_{413 H W H}$ mythischer Wohnsitz ragt in der verticale Ebene bergeshoch vom Zion auf. Er reicht hinauf an den Himmel, ohne jedoch 'in' diesem lokalisiert zu sein" (ibid., 128-29).

${ }^{5}$ Ibid., 131.

${ }^{6}$ Ibid. 
contends that this pericope, which "is certainly not originally linked with Sinai,"1 displays Mesopotamian connections. ${ }^{2}$ Ezek 1 and 10 are deemed to be a combination of Jerusalemtemple tradition in interaction with Mesopotamian concepts. ${ }^{3}$ In Amos 9:5-6 and Ps 104, Hartenstein claims to discern the tradition of a connection between heaven and earth along the lines of Mesopotamian cosmic imagery, namely the idea of a vertical linkage between heaven and earth. Such imagery, Hartenstein contends, is also reflected in Gen 28:11-13, 16-19.

Space considerations prevent a more detailed delineation of Hartenstein's views; however, for the purpose of this research the following comments are in order. First, it should be noted that Hartenstein's concern in analyzing the biblical text from the perspective of ANE cosmology prevents him from understanding the Hebrew Bible on its own terms. Second, his contention that the heavenly sanctuary/temple motif is a late development does not take into account the testimony of early passages. Thus, passages that could undermine his view are deemed to be late, or redactional insertions, which betrays some circularity in his argumentation. Third, Hartenstein does not define his idea of heavenly sanctuary. He deals with the general idea of heaven as the dwelling place of YHWH, with the heavenly throne, but hardly focuses specifically on the idea of a sanctuary/temple located in heaven. As a matter of fact, Hartenstein gives the impression that he is more concerned with the cosmological/mythical understanding of the earthly

\footnotetext{
"Mit Sicherheit nicht ursprünglich mit dem Sinai verbunden" (ibid., 137).

${ }^{2}$ Ibid., 139.

${ }^{3}$ Ibid., 141.
} 
temple, and the implications of that concept for the heavenly-temple idea, than with a focused attention on the heavenly temple per se.

\section{Sanglae Kim}

In 2002, a major study on the heavenly sanctuary/temple motif was produced by Sanglae Kim. ${ }^{1}$ The major focus of that study was to "examine whether or not a concept of the heavenly sanctuary/temple motif exists in the Hebrew Bible." In order to accomplish that goal, Kim undertook a detailed investigation of eighteen passages (Gen $11: 1-9 ; 28: 10$ -

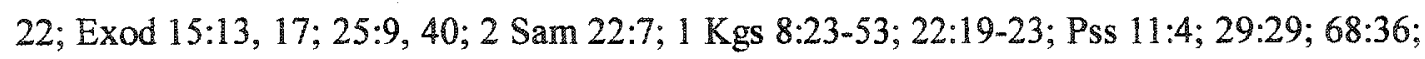
150:1; Isa 6:1-8; Ezek 40-48; Jonah 2:5, 8; Mic 1:2; Hab 2:20; Zech 2:17;3:1-10) usually understood by scholars as referring to the heavenly sanctuary/temple motif, and concludes that the idea of a heavenly sanctuary/temple is present in only eight of them (Gen 28:11-22; Exod 25:8-9, 40; 2 Sam 22:7=Pss 18:7 (6); 29:29; 150:1; Isa 6:1-8; Zech $2: 17 ; 3: 1-10)$.

Two important terminological distinctions are worthy of note in this work. First, Kim draws a very detailed semantic distinction between the notion of "temple/sanctuary" and that of "palace." According to his definition, "sanctuary/temple refers to a place in relation to sacred elements, i.e. 'deity, 'worship' or 'holy.' On the other hand, 'palace' designates a place in connection with kingly elements, i.e. "king, "rulership' or sovereign." Thus, consistent with his terminological definition, Kim argued that $1 \mathrm{Kgs} 22: 19-26$ and

'Sanglae Kim, "The Heavenly Sanctuary/Temple in the Hebrew Bible" (Ph.D. diss., University of Sheffield, 2002).

2lbid, 1 .

${ }^{3}$ bid., 26. 
Ps 11:4 contain the idea of a heavenly palace rather than that of a heavenly sanctuary/temple.' Second, Kim noted that scholars have used the idea of a heavenly sanctuary/temple in a rather imprecise way to refer to "sanctuary in heaven," "heaven as a sanctuary," or a "sanctuary like heaven," the latter in reference to the earthly temple. He then makes clear at the outset that his notion of "heavenly sanctuary/temple" is that of a "sanctuary in heaven."

In the subsequent investigation of the eighteen selected biblical passages, Kim successfully accomplished the main goal of his investigation by demonstrating that the Hebrew Bible in fact contains the heavenly sanctuary/temple motif. A few observations about his terminological definitions are in order at this juncture. Kim's semantic distinction between the concept of "palace" and that of "sanctuary/temple," however useful it may be from a literary/semantic point of view, seems difficult to apply from a theological perspective. The Hebrew Bible does not make a clear-cut differentiation between "palace" and "sanctuary/temple," using the same word for both. In other words, YHWH does not have a heavenly "sanctuary/temple" apart from His heavenly "palace." As a matter of fact, both temple and palace coalesce in one unified entity. On the other hand, Kim's criticism of the imprecise usage of the idea of "heavenly sanctuary/temple" is to the point, and his decision to investigate the heavenly sanctuary temple motif as the idea of a "sanctuary in heaven" was very appropriate.

'Cf. ibid., $129-30 ; 140$.

${ }^{2}$ Ibid., 26. 
This dissertation builds upon the foundation laid by Kim's work; however, it departs from the latter in four important ways. First, assuming the validity of previous scholarship, now put on fimer ground by Kim's study, that the Hebrew Bible does contain the idea of a heavenly sanctuary/temple, this dissertation investigates the function of the heavenly sanctuary/temple. Second, attention is given to the relationship between the heavenly sanctuary/temple and its earthly counterpart. Third, in some passages this dissertation takes issue with Kim's negative verdict about the presence in them of the heavenly sanctuary/temple motif. Fourth, it attempts to be more comprehensive. While Kim demonstrated the presence of the heavenly sanctuary/temple motif in eight passages, the present research will base its investigation on forty-three passages.

\section{G. K. Beale}

A most recent contribution to the sanctuary/temple theme has been made by $G$. $K$. Beale. In a comprehensive study of the theology of the temple and its implications for the church's mission, Beale advanced the thesis that "the Old Testament tabernacle and temples were symbolically designed to point to the cosmic eschatological reality that God's tabernacing presence, formerly limited to the holy of holies, was to be extended throughout the whole earth." Thus, Beale is not concerned with a vertical correspondence between the earthly sanctuary/temple and its heavenly counterpart, but rather with a

${ }^{1} \mathrm{G} . \mathrm{K}$. Beale, The Temple and the Church's Mission: A Biblical Theology of the Dwelling Place of God, New Studies in Biblical Theology (Downers Grove, IL: Inter-Varsity Press, 2004), 25. Part of this book appeared as idem, "Garden Temple," Xerux 18, no. 2 (2003): 3-50. 
horizontal relationship in which the earthly temple/sanctuary foreshadows the future eschatological reality of YHWH's presence among His people. ${ }^{1}$

Although not dealing specifically with the heavenly sanctuary/temple motif, Beale touches upon this topic in a few places during his discussion. Although he provides no clear definition of heavenly sanctuary or temple, it appears that the heavenly sanctuary/temple is understood in the sense of a cosmic temple, or heaven itself rather than a place located in heaven. ${ }^{2}$ Beale also conceives of the entire cosmos (heaven and earth) as a sanctuary/temple, ${ }^{3}$ as noted in the assertion that "God created the cosmos to be his great temple in which he rested after his creative work." ${ }^{14}$ That being the case, it appears that Beale understands the heavenly sanctuary as a nonstructural entity of cosmic proportions encompassing heaven and earth. For example, in his treatment of Isa 57 , Beale has suggested that this passage refers to YHWH's heavenly temple as a nonstructural entity descending upon the earth to encompass the saints. ${ }^{5}$ An inspection of the larger context of Beale's assertion indicates that he has in mind a nonstructural entity which

'For example, in his treatment of Isa 57, Beale has suggested that this passage refers to YHWH's heavenly temple as a nonstructural entity descending upon the earth to encompass the saints (Beale, The Temple and the Church's Mission, 135, 152). An inspection of the larger context of Beale's assertion indicates that he has in mind a nonstructural entity which basically equates YHWH's presence with the "eschatological sanctuary" (ibid., 154).

\footnotetext{
${ }^{2}{ }^{T}$ bid., $31,32,38$.

3Ibid., 135.

${ }^{4}$ Ibid., 138.

5ibid., 135, 152.
} 
basically equates the "eschatological sanctuary" with YHWH's presence. This is made explicit in the section on Ezek $40-48,{ }^{2}$ where Beale contends that the heavenly temple depicted in these chapters would "be established on earth in non-structural form in the latter days." ${ }^{13}$

To conclude, one should recognize that Beale has performed a comprehensive study and provided a significant contribution to the understanding of some aspects of the sanctuary/temple motif. A few observations, however, are in order. First, since Beale has focused primarily on the earthly sanctuary/temple as a symbol of YHWH's eschatological presence, other significant aspects of the sanctuary/temple were overlooked, such as its function as the place where YHWH performs activities of judgment and redemption. Second, Beale's understanding of the heavenly sanctuary/temple as mainly a cosmic nonstructural entity appears to be at odds with several biblical passages depicting the heavenly sanctuary/temple as an entity located in heaven. ${ }^{4}$ Third, as a consequence of the latter, one notices that since Beale focused on the horizontal dimension of the sanctuary/temple, namely its function as a symbol of YHWH's eschatological presence, the vertical dimension has been almost completely overlooked. Therefore, no significant attention has

'Ibid., 154.

2Tbid., 335-64.

${ }^{3}$ Ibid., 353.

${ }^{4}$ See chapters 3,4 , and 5 of this dissertation. 
been given to the correspondence and connection between the heavenly sanctuary/temple and its earthly counterpart. ${ }^{1}$

\section{Justification}

There are major reasons that justify an investigation of the heavenly sanctuary/temple motif in the Hebrew Bible. First, as noted, there is currently no comprehensive study available that investigates the function of the heavenly sanctuary/temple motif in the Hebrew Bible and its relationship to earthly counterparts. Second, since the sanctuary/temple is the core of Israelite cult and religion, the study of the heavenly sanctuary/temple motif in the Hebrew Scriptures may advance the understanding of the theology of the Hebrew Bible. Third, this study may also have implications for the field of New Testament studies. The existence of the heavenly sanctuary/temple is assumed by the New Testament writers. The books of Hebrews ${ }^{2}$ and Revelation ${ }^{3}$ frame vital arguments by presupposing the reality of the heavenly sanctuary/temple as it was spelled out in the Hebrew Scriptures. Hence, this study may contribute to a better understanding of the relationship between the Testaments in the field of vertical typology.

\footnotetext{
In this regard one should note Beale's suggestion that the tripartite division of the earthly sanctuary/temple into outer court, holy place, and holy of holies, represented respectively the habitable world, the visible heavens, and the invisible dimension of the cosmos where YHWH and His hosts dwelt (Beale, The Temple and the Church's Mission, 32-33).

${ }^{2}$ See Richard M. Davidson, "Typology in the Book of Hebrews," in Issues in the Book of Hebrews, $121-86$.

3Richard M. Davidson, "Sanctuary Typology," in Symposium on Revelation - Book I, ed. Frank B. Holbrook, DARCOM 6 (Silver Spring, MD: Biblical Research Institute, 1992), 99-131; Valentine, 207-348.
} 


\section{Methodology}

In order to situate the topic of this research against the broader backdrop of its Ancient Near Eastem context, chapter 2 is devoted to an exposition of the concept of a heavenly sanctuary/temple in Egyptian, Sumerian, Akkadian, Hittite, and Ugaritic texts. This chapter is important for two basic reasons. First, although some scholars have denied the presence of the heavenly sanctuary/temple motif in the ANE literature, ${ }^{1}$ the textual evidence from the ANE seems to demonstrate otherwise. In spite of most scholars' admission of the presence of this motif in the ANE literature, there is no specific study of this motif covering a reasonable variety of texts. In most cases, there are only assumptions based on isolated passages.

Second, the survey of the ANE background of the heavenly sanctuary/temple motif is important because the Hebrew Bible did not emerge in isolation from its environment, but in interaction with it, and sometimes in reaction to it. In dealing with these extrabiblical texts, special attention is given to function and relationship to the earthly counterparts. Furthermore, this analysis may expose similarities and differences between Israel and its neighbors in their respective conceptions of a heavenly sanctuary/temple, thus contributing to a better understanding of the biblical data.

Chapters $3-5$ of this study are devoted to an exegetical and theological investigation of selected heavenly sanctuary/temple passages found in the Torah, Prophets,

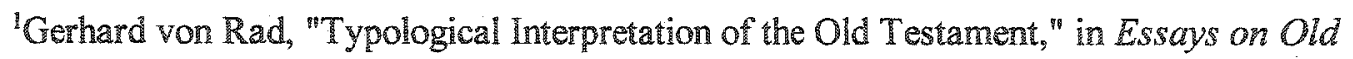
Testament Interpretation, ed. Claus Westerman (London: SCM Press, 1963), 17; Gray, "The Heavenly Temple and the Heavenly Altar," 394-402; 530-38; idem, Sacrifice in the Old Testament (Oxford, Clarendon: 1925), 155-56. 
and Writings, respectively. At the outset it must be established that by sanctuary/temple is meant an association of symbols and practices which evoke the presence of the deity in a piece of sacred space. ${ }^{1}$ This notion is usually, although not exclusively, expressed by the concept of an architectural building. ${ }^{2}$ There are cases, however, in which the idea of a temple/sanctuary may be evoked by related concepts such as holy mountain or altar, and also references to worship and cultic allusions. ${ }^{3}$ By heaven/heavenly is meant the extraterrestrial sphere of the deity. Although scholars sometimes apply the qualification "heavenly" to the earthly sanctuary/temple in the sense of a heaven-like entity, this dissertation employs the concept heaven/heavenly in contrast to earth/earthly. Thus the term "heavenly sanctuary/temple" is used in this dissertation to signify an entity located outside the earthly realm, that is, in heaven.

As for the function of the heavenly sanctuary/temple and its relationship to the earthly counterpart, the following clarifications are in order. By function is meant the kinds of activities YHWH performs in the heavenly sanctuary/temple, as well as those

${ }^{1}$ As Davidson pointed out, "since God is naturally the object of worship in the temple, it seems to follow that whenever God is mentioned in a temple context, then the sanctuary/temple is in view" ("The Heavenly Sanctuary in the Old Testament, 4-5").

${ }^{2}$ As Beale convincingly argued, "a holy piece of geography or a sacred area can be considered a true 'sanctuary' or 'temple' even when no architectural building is constructed there" (The Temple and the Church's Mission, 97). In this connection, Beale pointed out that the worship areas built by the patriarchs featured five elements: God appears to them, they pitch a tent, build an altar, worship God, and make sacrificial offerings (ibid., 96). The combination of these five elements, "occurs only elsewhere in the Old Testament in describing Israel's tabernacle or temple" (ibid., 96).

${ }^{3}$ Aelred Cody, Heavenly Sanctuary and Liturgy in the Epistle to the Hebrews (St. Meinrad, IN: Grail Publications, St. Meinrad Archabbey, 1960), 15. 
activities implied in the atitude of human beings as they reflect on the heavenly sanctuary/temple.

As for the relationship between the heavenly sanctuary/temple and the earthly counterpart, this dissertation seeks to identify functional and structural correspondences between the heavenly and the earthly sanctuaries/temples. In this regard one needs to investigate whether the functions of the heavenly temple/sanctuary correspond with, or parallel, those of the earthly counterpart, in which case the claim may be made that there is a functional correspondence between the heavenly and earthly sanctuaries/temples. ${ }^{1}$

Furthermore, the possibility of structural correspondences must also be investigated. Some scholars tend to see the heavenly sanctuary as nonstructural entity, heaven itself, or just a metaphor for YHWH's presence. ${ }^{2}$ An investigation of the biblical text must be undertaken in order to determine whether such a nonstructural understanding of the heavenly sanctuary/temple can be substantiated. Thus special attention is given to the vocabulary used to designate the heavenly sanctuary/temple in order to ascertain whether such a vocabulary connotes a structural entity in the lines of the earthly counterpart. Moreover, since previous studies have suggested a close connection between

${ }^{1}$ For example, the earthly sanctuary/temple is portrayed in the Hebrew Bible not only as mere place of dwelling for YHWH, but also as a place where YHWH is enthroned as king (see, e.g., Amos 1:2; Ps 99:1-2) and executes judgment (see, e.g. 50:2ff.;). The earthly sanctuary/temple is also portrayed as a place of atonement (see, e.g., Lev 16), worship (Isa 62:9; Ps 99:9; Ezra $3: 10$ ), source of help (see, e.g., Ps 20:2). Furthermore the sanctuary/temple is also related to the covenant (Exod 19-26; Ezek 37:26;1 Kgs 6:19) and may be an object of attack by the enemies (see, e.g. Dan 1:1-2).

${ }^{2}$ So, e.g., Beale, The Temple and the Church's Mission, 135, 152. 
heavenly and earthly temples in a few passages, ${ }_{9}$ it is instructive to investigate a large number of texts to delineate the contours of this relationship, which seems to consist of a dynamic interaction between the heavenly sanctuary/temple and the earthly counterparts. Forty-three passages were selected for this investigation, the majority of which contains explicit references to a sanctuary/temple related to heaven. Nonetheless, some passages are also included which, although not containing a specific term for sanctuary/temple, depict a heavenly setting and therefore contribute to illuminate certain activities and roles of the heavenly sanctuary/temple. It must be pointed out, in this connection, that the forty-three passages investigated in this dissertation are by no means an exhaustive inventory of heavenly sanctuary/temple passages. Other passages claimed by scholars to contain the sanctuary motif were not included in this investigation, ${ }^{2}$ both because some texts do not seem to contain this motif, and the addition of other passages would exceed a manageable amount of material to be dealt with within the limitations of space and time available for this research.

Due to the large concentration of heavenly sanctuary/temple passages in the Prophets (chapter 4) and Writings (chapter 5), some texts receive more detailed treatment in these chapters, while others, usually short ones, are treated more briefly at the end of their respective chapter. In the exegesis of the passages, wherever appropriate, the

'E.g. Davidson, on PS 150 ("The Heavenly Sanctuary in the Old Testament," 15); Kim on Gen 28:10-22; Is 6:1-9; (181-87); Shea, on Ps 76 (Selected Studies on Prophetic Interpretation, 6).

${ }^{2}$ E,g. Ezek 40-48; Amos 9:6; Zeph 1:7; Zech 4; Ps 23:6; 27:4; 36:9; 47:9 [8]; 63:3 [2]; $65: 5[4] ; 78: 69 ; 104: 2 ; 134: 2 ;$ Dan $11: 45$. 
boundaries of the literary subunits in which the sanctuary/temple motif occurs are identified and analyzed according to their literary form and genre. Attention is paid to rhetorical devices, repetitions, parallelisms, chiastic structures, etc., and their possible contribution to the interpretation of the text. This is especially relevant in the poetic units where rhetorical devices such as parcllelismus membrorum, strophe, and repetition play a significant role in the communicative act. Consequently, this dissertation adopts a synchronic approach based on the Massoretic text. Such methodology has been demonstrated as valid by studies in rhetorical criticism ${ }^{1}$ and canonical approaches. ${ }^{2}$ In chapter 6 , the final chapter, a theological synthesis of this investigation is presented. This contains a summary of the results of this research in terms of exegetical conclusions and theological insights. It is hoped that a deeper understanding of the function of the heavenly sanctuary/temple, and the relationship between the heavenly sanctuary/temple and its earthly counterpart in the context of the Hebrew Bible may emerge as a result of this investigation.

\section{Deliminitations}

The chapter on ANE background will cover sample texts from Egyptian, Sumerian, Akkadian, Ugaritic, and Hittite sources. Geographic, chronological and thematic connections with the biblical material are most evident in these sources. As for

${ }^{1}$ Cf. Phyllis Trible, Rhetorical Criticism: Context, Method, and the Book of Jonah (Minneapolis: Fortress, 1994), 5-52.

${ }^{2} \mathrm{Cf}$. Brevard Childs, Old Testament Theology in a Canonical Context (Philadelphia: Fortress, 1986), 1-19; John H. Sailhamer, Introduction to Old Testament Theology: A Canonical Approach (Grand Rapids: Zondervan, 1995), 184-311. 
the biblical texts, no exhaustive exegesis of the passages is intended. The exegetical process is restricted to issues immediately relevant for the topic under study. Considerations of introductory matters such as authorship, historical context, and even text-critical issues are omitted unless they are capable of affecting the interpretation of the passage under study. Furthermore, no attempt is made to uncover hypothetical sources which allegedly lie behind the present text in its final canonical form. Finally, it should be added that although this research covers a vast range of texts, it does not claim to be exhaustive. Future investigation may detect the heavenly sanctuary/temple motif in passages not included in this study. Nevertheless, one may be cautiously confident that due to the comprehensiveness of this research, further investigation of overlooked passages would not alter the picture of the heavenly sanctuary/temple provided by this research. 


\section{CHAPTER 2}

\section{ANCIENT NEAR EASTERN BACKGROUND OF THE HEAVENLY SANCTUARY/TEMPLE MOTIF}

This chapter is designed to examine the use of the heavenly sanctuary/temple motif in the ANE literature in order to understand the larger context in which the Hebrew Bible was formed. However, this investigation is not undertaken because of an alleged literary or theological dependence between the Hebrew Bible and the ANE texts, but because it is expected that some points of contact may emerge. In this process, either similarities or contrasts can contribute to the understanding of this motif in the biblical literature, a task to be undertaken in the ensuing chapters of this dissertation.

Although the idea of a heavenly sanctuary/temple in the ANE has been recognized by several scholars, ${ }^{1}$ no attempt has been made to undertake a detailed investigation of the function of the heavenly temple/sanctuary and its relationship to the earthly counterpart. Therefore, the ensuing discussion undertakes a survey of Sumerian, Akkadian, Hittite,

'Andreasen, "The Heavenly Sanctuary in the Old Testament," 67-86; Margaret Barker, On Earth as It Is in Heaven: Temple Symbolism in the New Testament (Edinburgh: T\&T Clark, 1995), 24; Clements, God and Temple, 68; Clifford, The Cosmic Mountain in Canaan and the Old Testament, 177; David Lemoine Eiler, "The Origin of Zion as a Theological Symbol in Ancient Israel" (Ph.D. diss., Princeton Theological Seminary, 1968), 139-40; Alfred Jeremias, The Babylonian Conception of Heaven and Hell (London: D. Nutt, 1902), 40-41; Arvid S. Kapelrud, "Temple Building, a Task for Gods and Kings," Or 32 (1963): 56-58; Geo Widengren, "Aspetti Simbolici dei Templi e Luoghi di Culto del Vicino Oriente Antico," Numen 7 (1960): 3-4. 
Ugaritic, and Egyptian texts in order to grasp the ANE perception of the heavenly sanctuary/temple, with special attention to its function and relationship to the earthly counterpart.

Each section is subdivided according to the individual compositions belonging to each literary corpus; and, with due allowance for the uncertainties regarding their date of composition, the texts are presented in chronological sequence. Furthermore, this investigation of $\mathrm{ANE}$ texts by no means claims to be exhaustive, since only a sampling of the available evidence is investigated. It is hoped, however, that the data herein investigated is representative of the overall ANE idea of the heavenly-sanctuary/temple motif, especially regarding the function of the heavenly temple and its relationship to the earthly counterpart.

Prior to the investigation that follows, two observations are in order. First, when faced with texts alluding to a heavenly sanctuary/temple, one has to ascertain whether such a sanctuary/temple is located in heaven, in some unspecified mythical realm, or on earth. Furthermore, some texts may portray an earthly/historical sanctuary/temple as heavenly entity because of its heaven-like quality. Thus, in the survey that follows, priority is given to texts referring to a sanctuary/temple located in heaven. Second, the concept of "heavens" turns out to be more complex and elusive than one might have supposed at first glance. Sumerian incantation texts, for example, reveal a tradition of seven heavens and

'Due to my lack of expertise in extra-biblical ANE languages, with the exception of Ugaritic, use is made of the standard translations available, with attention to key terms for heavenly sanctuary/temple in the original where possible. 
seven earths. ${ }^{1}$ In addition, a three-storied universe with netherworld, dry land, and heaven-each with its deities and sanctuaries/temples-seems to be presupposed. ${ }^{2}$ Priority is given to texts related to deities associated with the heavenly realm, since, most probably, a celestial deity would have his/her sanctuary/temple in heaven. In a few cases, however, it seems very difficult ascertain whether the sanctuary/temple referred to in the text lies in heaven or some unspecified mythic realm. Nonetheless, even in the latter case, the text under study may be useful for the purposes of this study, since a mythic sanctuary/temple may be functionally equivalent to a heavenly sanctuary/temple.

\section{Sumerian Literature}

S. N. Kraemer's claim that "thirty-nine firsts" of human recorded history are found in Sumer ${ }^{3}$ justify starting this chapter with Sumerian texts. These written records endorse the contention that the temple was the most important building in the Sumerian city ${ }^{4}-a$ city understood by the Sumerian theologians as belonging to its principal tutelary deity

\footnotetext{
'Wayne Horowitz, Mesopotamian Cosmic Geography, Mesopotamian Civilizations 8 (Winona Lake, IN: Eisenbrauns, 1998), 208.

2Ibid., $223-362$.

${ }^{3}$ Samuel Noah Kramer, History Begins ot Sumer: Thinty-Nine Firsts in Mon's Recorded History, 3rd rev. ed. (Philadelphia: University of Pennsylvania Press, 1981).

${ }^{4}$ According to Kramer, there were at least forty major temples in Sumer (Samuel Noah Kramer, "Poets and Psalmists: Goddesses and Theologians," in The Legacy of Surner: Invited Lectures on the Middle East at the University of Texas at Austin, ed. Denise Schmandt-Besserat [Malibu: Undena Publications, 1976], 8). For a comprehensive list of Mesopotamian temples, see A. R. George, House Most High: The Temples of Ancient Mesopotomia, Mesopotamian Civilizations 5 (Winona Lake, IN: Eisenbrauns, 1993), $1-171$.
} 
since the creation of the world. The centrality of the temple is confirmed by the vast amount of material devoted to temples in the Sumerian written records, which points to the importance of that institution in the religious and social life of that ancient civilization. Hymns, poetry, literary and historical texts, in addition to the archaeological excavations, display the centrality of the temple and its ubiquitous influence on the Sumerian society. ${ }^{2}$ For the purpose of this investigation, it is instructive to note whether the Sumerians had the notion of a sanctuary/temple located in heaven. If so, it becomes instructive to inquire what was the function and relationship, if any, of the heavenly sanctuary/temple with its earthly counterpart. A cross-section investigation is undertaken in the following pages in order to probe the heavenly-temple motif in a sampling of texts belonging to different genres and historical periods. ${ }^{3}$

\section{Royal Inscriptions: Gudea Cylinders}

One of the most important Sumerian texts dealing with the temple is contained in the Gudea Cylinders ${ }^{4}$ which report a dream in which King Gudea of Lagash is shown a

"Samuel Noah Kramer, "The Temple in the Sumerian Literature," in Temple in Society, ed. Michael V. Fox (Winona Lake: Eisenbrauns, 1988), 1-16.

${ }^{2}$ Kramer, "Poets and Psalmists: Goddesses and Theologians," 3:21.

${ }^{3}$ For summary of Sumerian literary history and a brief classification by genre, see William W. Hallo, "Toward a History of Sumerian Literature," in Sumerological Studies in Honor of Thorkild Jacobsen on His Seventieth Birthday, June 7, 1974, Assyriological Studies 20 (Chicago: University of Chicago Press, 1976), 181-203.

${ }^{4}$ The Gudea Cylinders, a royal inscription belonging to the genre of temple hymns, were written about 2125 B.C. to commemorate the building of a temple to the god Ningirsu by Gudea, king of Lagash. This document has been the subject of several studies. E.g., Diane M. Sharon, "A Biblical Parallel to a Sumerian Temple Hymn? Ezekiel 40-48 and Gudea," JANES 24 (1996), 99 109; Richard E. Averbeck, "Ritual Formula, Textual Frame, and Thematic Echoes in the Cylinders 
plan of a temple he is supposed to build for the god Ningirsu. In Gudea's dream "there was a warrior who bent (his) arm holding a lapis lazuli plate on which he was setting the ground-plan of a house. "Although this "ground-plan" reminds one of the "model" (กาำ ) of the sanctuary Moses was shown on Mount Sinai (Exod $25: 9,40),{ }^{2}$ there is a significant difference between the two accounts. Gudea saw a "ground-plan" in the process of being prepared, ${ }^{3}$ while the biblical text says that Moses was shown a "model" (กำ received general guidelines from the deity; the "plan" most probably consisted of a "blueprint" or "ground plan," while the portrayal of the "model" (ก9รภ) shown to Moses implies a tridimensional entity. ${ }^{4}$

It is difficult to determine whether the "plan" shown to Gudea was understood to be based on some archetypical temple (i.e. a heavenly temple), or was simply an ideal

of Gudea," in Crossing Boundaries and Linking Horizons: Studies in Honor of Michael C. Astour on His 80th Birthdoy, ed. Mark W. Chavalas, Gordon D. Young, and Richard E. Averbeck (Bethesda, MD: CDL Press, 1997), 39-93.

'Dietz Otto Edzard, Gudea and Dynasty, The Royal Inscriptions of Mesopotamia Early Periods, vol. 3/1 (Toronto: University of Toronto, 1997), 71-72 (v 2-4).

${ }^{2}$ See Victor A. Hurowitz, "The Priestly Account of Building the Tabernacle," 21-30; idem, "I Hove Bullt You an Exalded House": Temple Building in the Bible in Light of Mesopotamian and Northwest Semitic Writings, JSOTSup 115 (Sheffield: JSOT Press, 1992).

${ }^{3}$ Edzard, $71-72$ ( $\vee 2-4$ ). This is corroborated by other translations as well: "He had a bent arm (and held) a tablet of lapis lazuli in his hand, (and) was drawing the plans for a temple (or 'house')" (E. Jan Wilson, The Cylinders of Gudea: Transliteration, Translation and Index, Alter Orient und Altes Testament 244 [Neukirchen-Vluyn: Neukirchener Verlag, 1996], 28 [v 3-4].); He "hatte die Arme gebeugt, hielt eine Platte aus Lapislazuli in der hand, setzte darauf den Grundriss des Hauses" (Adam Falkenstein and Wolfram von Soden, Sumerische und Akkadische Hymnen und Gebete [Zürich: Artemis-Verlag, 1953], 142 [v 3-4]).

${ }^{4}$ See chapter 3 for a detailed discussion of n99? 
temple conceived in the deity's mind. This latter possibility seems to be endorsed by the following statement: "Ningirsu had conceived (the House) in his (heart) as a sanctuary from which the seed sprouted." Also the several references to heaven in the text do not indicate a temple in heaven, but are used in relation to the earthly temple, either to emphasize its heaven-like appearance, ${ }^{2}$ or as a backdrop to express its cosmic dimensions; or, as J. Wilson has suggested, ${ }^{3}$ its function as a link between heaven and earth. ${ }^{4}$ It is

${ }^{1}$ Edzard, 95 (B xiii 6).

${ }^{2}$ George Barton's transiation of the Cylinders of Gudea, which is no longer deemed reliable by scholars, contain several allusions to a heavenly temple which have vanished in more recent translations. Cf., e.g.:

Barton:

(A xxvii 11-13) the façade of the temple was a great mountain rising from the earth; its interior was as the setting forth of a united feast; its side as the lofty temple of heaven filled with abundance (George A. Barton, The Royal Inscriptions of Sumer and Akkad, vol. 1 [New Haven: Yale University Press, 1929], 233).

Wilson:

"(A xxvii 11-13) A temple whose face is like a great mountain rising from the earth. Inside (were) incantations, and harmonious singing (?) (p. 118). Its sides (like) heaven, a mighty wind, risen in abundance (118)."

Edzard:

"(A xxvii 11-13) House whose front is an enormous mountain set on the earth, whose interior (resounds with) incantations and harmonious hymns, whose exterior is the sky (86)."

Falkenstein and von Soden:

"(A xxvii 11-13) Des Hauses Front ist ein großer Berg, der bis zer Erde reicht, sein Inneres eine Beschwôrung, ein Fest für alle, sein Äußeres ist An, der das hohe Haus in Überfluß sich erheben läßt" (164).

${ }^{3}$ Wilson, The Cylinders of Gudea, 49-51, n. 4.

${ }^{4} \mathrm{C}$. the following excerpts:

"(A i 11) I will render Eninnu most influential in heaven and on earth (Edzard, 69)."

"(A ix 11-15) The heavens tremble before my House, the Eninnu, founded in heaven, whose powers are the greatest, surpassing all others, before the House whose owner looks out over a great distance, (tremble) as before the roaring Thunderbird (ibid., 74)."

"(A ix 16) the fierce halo (of the house) reaches up to heaven (ibid., 75)."

"(A xvii 18-19) To the house whose halo reaches to heaven, whose powers embrace heaven and earth (ibid., 80)."

"(A xxi 15-16) He sat down beside the door frames: "Huge house embracing heavens" (ibid., 
possible, nonetheless, that the idea of Gudea's temple as a heavenly realm may point to some kind of connection with a heavenly archetype. This seems to be corroborated by the observation that "Gudea had painted it [i.e., the temple] (to recall) the splendour of heaven," which might also suggest that the earthly temple was supposed to mirror some reality beyond itself, which might be either a temple located in heaven (though this is never made explicit), or heaven itself.

To summarize, although the Gudea Cylinders are primarily focused on the building of an earthly temple ${ }^{2}$ - which is described with cosmic/heavenly connotations - the function of this temple as a link between heaven and earth, and its description with heaven-like features, may well be an echo of the underlying idea that it was related to a heavenly counterpart. ${ }^{3}$

82)."

"(A xxi 23-25) The house looked up like a mountain range between heaven and earth (ibid.)." (B xxiv 14) Eninnu is joined both to heaven and earth (ibid., 101).

(B xxiv 9-10) "O House that reaches to heaven like a great mountain, whose awe and aura are shed over the land" (ibid.).

${ }^{1}$ Edzard, 86 (A xxvii 1-2).

${ }^{2}$ According to Snyder, the key elements of temple theology in the Gudea cylinders are as follows: (1) The temple is to be built by a king; (2) the king is shown the plan of the temple by a deity; (3) the temple displays significant cosmic connotations; (4) the temple grows up between heaven and earth; (5) the construction of the temple would bring about fertility. Barbara Wootten Snyder, "Combat Myth in the Apocalypse: The Liturgy of the Day of the Lord and the Dedication of the Heavenly Temple (Revelation)" (Ph.D. diss, University of Califomia Berkeley, 1991), 19.

3in the description of the Ekur, the temple is thus praised: "Its awesome glow reaches unto heavens .... Its roof reaches unto the heart of heavens" (Daniel David Reisman, "Two NeoSumerian Royal Hymns" [Ph.D. diss., University of Pennsylvania, 1969], 63 [lines 78, 80]). The connection of the earthly sanctuary with the heavens might well have been triggered by the conception of a sanctuary/temple located in heaven as a counterpart to the earthly sanctuary. 
Hymns and Psalms

In a hymn to Nisaba, the goddess is described as the one "(104) who restores the fallen heaven to its place, the stewardess of heaven." That this composition may contain the idea of a heavenly sanctuary/temple can be perceived in the following, unfortunately fragmented, line: "(107) [.. . . . for you (?) in heaven, you (?) .. for him."2 In the sequence of the text, it is stated that "(109) in the house of the great gods they praise you as one."

A hymn to Inana displays the following significant statement: ${ }^{: 3}(126)$ The good lady, the joy of An, a heroine, she surely comes from heaven. (127) In the .. of heaven she bears the ormament, (128) She consults with An in his lofty place. ${ }^{14}$ It seems that the reference to "An in his lofy place" refers to the heavenly abode, which is portrayed as the place whence his decrees/decisions are issued..$^{5}$ An important text for the purpose of this research is an eršemmat in which the goddess Inanna laments the destruction of her temple

Ibid., 59.

${ }^{2}$ Ibid., 120. "The context sems to suggest that this line may indicate that the King IsbiErra is summoned to exercise leadership of the people on the basis of a decision of the gods" (ibid., 33).

${ }^{3}$ Tbid.

${ }^{4}$ ibid., 172.

${ }^{5}$ According to Sjoberg, however, the expression "lofty place" (ki-mah) refers to the sanctuary of Eninnu (E. Sjöberg, Der Mondgott Nama-Suen in der Sumerischen Uberlieferung, vol. 1 [Stockholm: Almquist \& Wiksell, 1960], 59).

${ }^{6}$ The texts known as Eršemma consist of lament compositions addressed to the gods. These texts derive from tablets dating to the Old Babylonian period (ca. 2000-1600 B.C.), though they might have been composed much earlier. See Mark E. Cohen, ed., Sumerian Hymnology: The Eršemma, Hebrew Union College Annual Supplements 2 (Cincinnati: Hebrew Union College 
in Uruk and goes to present her case before Enlil. The relevant portions of the text read as follows:

(10) the genie (?) (of) my house! My house which stands from the very heavens upon the earth! ... (15) I am the hierodule of heaven ... my house! My shrine Eanna! (16) I am the lady of the Eanna. My brickwork of Uruk and of Kulaba! . . (19). I am the hierodule of heaven. [My] great gate of the Enamtar! (20) I am the lady of the Eanna [My] holy "eyebrow" which is raised above the house! (21) I am the hierodule of heaven. My seat in heaven and (my) seat upon earth! (22) I am the lady of the Eanna. My ... the nation!

This text seems to suggest the concept of a correspondence between heavenly and earthly sanctuaries. The hyperbolic language of lines 10 and 15 probably refers to Inama's shrine-Eanna-in the city of Uruk. One should note, however, her claim to have a seat in heaven, as stated: "I am the hierodule of heaven. My seat in heaven and (my) seat upon earth!" If the "seat upon earth" is understood as the deity's throne in the temple of Uruk, it is reasonable to suppose that the "seat in heaven" would be understood as being located in her heavenly temple. Granting that this inference is correct, the text seems to convey the idea of a correspondence between heavenly and earthly sanctuaries.

The next eršemma explicitly reveals the function of the temple. Though it is difficult to determine the meaning or nuance of several words and expressions, the overall thrust of the passage can be perceived. It depicts the goddess Ninisina's visit to Enlil in order to remove a misfortune that had befallen her. Her entrance into the house of Enlil is thus described:

Press, 1981), 1.

'Mark E. Cohen, 68. 
(25) When I Ninisina do not rejoice, (26) so I enter unto my? father, into the house where the fates are determined. (27) So I enter unto Enlil, into the house where the fates are determined. (28) So I enter unto the house of judgments, the house of decisions. (29) So I enter . . of mankind. ${ }^{1}$

The text clarifies that the "house of Enliil" was a "house of judgments," a judgment which seems to be related to the process of determining the fates. A few lines below, the text mentions the "tablets of fate," as noted in the following excerpt: "(39) After he removed the (tablets of) fate, [he looked at me]. (40) After he closed shut the housing for the (tablets of) fate, [he spoke to me]: (41) (Your) fate is placed in this ... place, my lap."2 Thus, the judgment consisted in determining the fate which, it seems, was recorded in the tablets stored in the temple. ${ }^{3}$

A question that needs to be addressed at this point concerns the location of the "house of Enlil." According to Sumerian mythology, Enlil was the god of the wind, son of An, the god of heaven. Enlil's weapon is the storm-flood, and he is also called "King of lands." ${ }^{\text {Th }}$ Therefore, since Enlil was not defined as a god of heaven, one cannot say that his temple was understood to be located in heaven. Nonetheless, since the interactions described in the text happen between the deities, Enlil's temple most probably would lie in

'Mark E. Cohen, 100.

${ }^{2}$ Ibid., 101.

${ }^{3}$ It is instructive to note that a hymn extolling King Sulgi of Ur (ca. 2094-2047 B.C. [57] seems to locate the tablets of destiny in heaven, as can be deduced from the following excerpt: In regard to the temple of Enlil at Nippur, it is remarked that it is a "(25)...[....]......, shrine where destiny is determined" and "(33) your base serves' heaven and earth" ( $\AA$ ke W. Bergmann and $E$. Sjöberg, The Collection of the Sumerian Temple Hymns, Texts from Cuneiform Sources, vol. 3 [Locust Valley, NY: J. J. Augustin, 1969], 18).

${ }^{4}$ Manfred Lurker, Dictionary of Gods and Goddesses, Devils and Demons (London: Routledge and K. Paul, 1988), 110. 
some mythical place and, therefore, may be regarded as a functional equivalent to a heavenly temple.

An eršemma over the destruction of Sumer and Ur conveys the idea of a judgment in the heavenly temple: "(364) The judgment of the assembly cannot be tumed back, (365) The word of An and Enlil knows no overturning." As the text unfolds, it is stated: "(493) May An not change the decrees of heaven, the plans to treat the people with justice." 2 The "judgment of the assembly" in connection with the "decrees of heaven" probably indicates a work effected in a heavenly temple setting, whence the gods issued decisions affecting the fate of Sumer and Ur. ${ }^{3}$

'Piotr Michalowski, The Lamentation over the Destruction of Sumer and Ur (Winona Lake, IN: Eisenbrauns, 1989), 59.

${ }^{2}$ Ibid., 69.

${ }^{3}$ However, we must note that the concept of judgment is also related to temples clearly located on earth. The temple of Ninurta is claimed to be the "(61) House with the gathered me's of heaven standing on a great place," and "(65) founded by the primeval lord, (temple which makes) a decision through' the princely's me's" (Bergmann and Sjöberg, 3:113). Your foundations (are like those of) the Abzu, fifty in number, 'seven' occeans (are) within you, (114) Shrine, which looks into the 'heart' of the gods, (115) Your prince, the prince who makes decisions, the crown of the wide heaven, (116) The Lord of heaven Ašmbabbar" (ibid., 23). As for the temple of Eninnu, it is qualified as "(251) ... . 'furious face,' house (full of) splendor, (251) The place of judgment, lord Ningirsu (252) Has filled with radiance and awe." In the same vein, of the temple of Bau in Uruku(g), it is stated that "(264) within you (is) the river of ordeal which vindicates the just man" (ibid., 31-32). The temple of Ninurta is claimed to be the "(61) House with the gathered me's of heaver standing on a great place," and "(65) founded by the primeval lord, (temple which makes) a decision through' the princely's me's" (ibid., 22). The same statement is also made about the temple of Ninursaga in Hiza-" (496) On the place where destiny is determined you determine destiny." The temple of Ninhursag in Adab is called "(367) Lofty house, 'House of the Universe', suited for its queen." The temple of Utu in Sippar is called "(480) Sanctuary? of heaven, star of heaven, crown, borne by Ningal, (481) House of Utu, your prince ... . [ . . ], he fills heaven and earth" (ibid., 46). Also the temple of Nininsina in Isin is regarded as the "(383) Place where An and Enlil determine destiny, (384) Place where the great gods dine" (385) Filled with radiance and awe (ibid., 39). 
The heavenly temple is depicted as a place of judgment, where the fates are determined. That these functions are ascribed to both heavenly and earthly temples may well indicate that they were understood to function in mutual correspondence. Furthermore, the extolling of the earthly temple as a heaven-like entity ${ }^{1}$ may also corroborate this view of an earthly temple in close relationship with its heavenly counterpart.

\section{Other Texts}

In the myth of Inanna's descent to the netherworld there are some significant allusions to the heavenly temple/sanctuary motif. As Inanna decides to come to the netherworld, she thus instructs her messenger Ninshubur: "(33) When I shall have come to the netherworld, (34) Fill heaven with complaints for me, (35) In the assembly shrine cry out for me, (36) In the house of the gods rush about for me."2 The parallelism observed in lines 33-35 between "heaven," "assembly shrine," and "house of the gods" suggests a place in heaven where the assembly of the gods convenes and makes decisions capable of helping Inanna in her adventure in the netherworld. ${ }^{3}$

"Cf., e.g., the literary work "Angim" which relates the return of the god Ninurta to Nippur after his conquering the foreign lands. Ninurta is depicted as returning from the mountains to Nippur and Ekkur. In this context, his temple should "raise its head (as high as) heaven!" (Jerrold S. Cooper and E. Bergmann, The Retum of Nimurta to Nippur, Analecta Orientalia 52 [Rome: Pontificium Institutum Biblicum, 1978], 170).

${ }^{2}$ ANET, 53. These words are repeated almost verbatim in lines 172-75 and 302-04.

${ }^{3}$ S. N. Kramer, the translator, opens the possibility that "perhaps, however, the two lines refer to Ninshubur's making the rounds of the gods in Nippur, Ur, and Eridu; if so, 'shrine' and 'house' (lines 35, 36) should read 'shrines,' and 'houses,' and 'rush about' might perhaps be read 'make the rounds" (ANET, 53, n. 14). 
The poetic composition "Enki and Sumer" deals with the activities of Enki, the god of subterranean fresh water. The first part of the poem, approximately one hundred lines, is too fragmentary to be read. Its intelligible parts display Enki decreeing the fate of Sumer and the organization of the earth by establishing law and order upon it. The following excerpt is the most relevant for this research:

The king, begotten, adorns himself with lasting jewel, The lord, begotten, sets crown on head, Thy lord is an honored lord; with An, the king, he sits in the shrine of heaven, Thy king is the great mountain, the father Enill, Like... the father of all the lands. ${ }^{\prime}$

Though it is possible that the shrine referred to in this text is an earthly shrine in the land of Sumer, a heavenly setting is more likely since Enki is depicted as sitting with An, the god of heaven. This is further corroborated by the large spectrum of activities performed from the "shrine" wherein Enki decrees the fate of Ur and appoints a god and a goddess to take care of the sea and the winds, respectively. The heavenly "shrine" thus functions as command center whence the deity makes decisions and performs activities related to the administration of his domain.

\section{Summary}

The investigation undertaken above allows the following delineation of the heavenly sanctuary in Sumerian texts. The heavenly sanctuary is depicted as a place of divine activities of judgment, and where determination of fates is performed. (In relation to

'Samuel Noah Kramer, Sumerian Mythology: A Study of Spiritual and Literary Achievement in the Third Millennium B.C. (Philadelphia: American Philosophical Society, 1944), 59. 
this, it was noted that the so-called tablets of fate/destiny are stored in the heavenly temple.) The heavenly sanctuary/temple is understood as a kind of command center whence the deity would issue decrees and make decisions affecting the earthly/cosmic order. It should also be noted that these texts suggest that the heavenly temple is the meeting place of the assembly of the gods. Furthermore, the implication may also be drawn that the heavenly temple was understood as existing in relationship to its earthly counterpart.

\section{Akkadian Literature}

The Akkadian literature is largely dependent upon Sumerian themes and motifs. Actually some of its myths and stories go back to Sumerian mythographers. Therefore, this new section on Akkadian texts is separated from the previous one only on the basis of the language employed and ultimately does not represent a major break from its Sumerian predecessor.

\section{Story of Etana}

The story of Etana, ${ }^{1}$ available in Old Babylonian, Middle Assyrian, and New Assyrian versions, is a myth of the rise of King Etana of Kish to heaven on the wings of an eagle. The trip seems to have had the purpose of consulting the goddess Istar about the plant of birth needed by the childless king. The New Assyrian version contains the portion

\footnotetext{
${ }^{1} \mathrm{COS}, 1: 453-57$. Cf. Michael Haul, Das Etana-Epos: Ein Mythos von der Himmelfahrt des Königs von Kiss, Göttinger AAL (Göttingen: Seminar für Keilschriftforschung, 2000).
} 
of text most relevant for this research. It reports that Etana and the eagle traversed the gates of Sin, Šmaš, Adad, and Ištar:

Etana opened his mouth and spoke to the eagle, My friend, that god showed me [another dream?]

We were going through the entrance of the gate of Anu, Ellil, and Ea

We bowed down together, you and I.

We were going through the entrance of the gate of

Sin, Shamash, Adad and Ishtar

I saw a house with a window that was not sealed.

I pushed it open and went inside.

Sitting there was a girl

(10) adorned with a crown, fair of face

A throne was set in place, and [...]

Beneath the throne crouched snarling lions. ${ }^{1}$

The heavenly-sanctuary/temple motif emerges from this text in the report of a dream in which Etana sees the "house," probably the house of Ishtar and her throne. That Etana goes through the gates of Anu, Elli, Ea, Sin, Shamash, Adad, and Ishtar, to finally be able to see the splendorous house, indicates that the "house" must be the heavenly temple of Ishtar. ${ }^{2}$ That being the case, the imagery portrayed by the text evokes the idea of a heavenly temple/sanctuary functioning as a royal palace of the deity-a suggestion corroborated by the reference to the "throne."

\section{Laws of Hammurabi}

The prologue to the laws of Hammurabi (c. 1792-1750 B.C.) contains interesting allusions to the heavenly-sanctuary/temple motif. The king claims himself to be the one

${ }^{1}$ COS, $1: 457$ (Tablet IV).

${ }^{2}$ See Horowitz, Mesopotamian Cosmic Geography, 208, for a geography of heavens in the story of Etana. 
"who made famous the temple of Ebabbar which is akin to the abode of heaven [subat šamâ" 1$]. " 1$ The word "abode," šubat, derives from the noun šubu, and has the meaning of dwelling place, residence of a king, god's residence in temple, in heaven, etc. ${ }^{2}$ Thus, the abode of heaven seems to refer to a specific place located in heaven where the deity dwells, and to which the earthly temple of Ebabbar was compared.

The analogy between heavenly and earthly temples seems to connote the idea of a relationship or correspondence between the heavenly temple and its earthly counterpart. This seems to be corroborated by the qualification of the temple of Ebbabar as "band" of heaven and earth, ${ }^{3}$ which seems to depict the connection and cooperation between heavenly and earthly spheres (i.e. between heavenly and earthly temples). The main idea inferred from this text is that of heavenly and earthly temples functioning in close connection.

\section{Epic of Gilgamesh}

Although the Epic of Gilgamesh does not yield direct references to the heavenly sanctuary/temple motif, it seems to contain some allusions to that motif. The gods are

${ }^{1}$ Martha T. Roth, Low Collections from Mesopotamia and Asia Minor (Atlanta: Scholars Press, 1997), 77 (ii 22-31).

${ }^{2} \mathrm{Cf}$. Jeremy Black, Andrew George, and J. N. Postgate, eds., A Concise Dictionary of Akkadian, 2nd (corrected) printing (Wiesbaden: Harrassowitz, 2000), 379.

${ }^{3}$ It must be borne in mind that the city of Nippur is called the "band [markasu] of heaven and earth" (Roth, 77 [i 50-62]) because it hosted the Ekur temple, as the context makes clear. Thus, the concept that the earthly temple is the point of connection, markasu, between heaven and earth might well be based on the assumption that the earthly temple functioned as a counterpart to the heavenly one. 
understood to dwell in heaven ${ }^{2}$ and on the top of the Cedar Mountain. ${ }^{2}$ There are also several references to the assembly of the gods, seemingly to be located in heaven or in some mythic realm. In the first reference, the gods decide to punish Enkidu for having killed the Bull of Heaven. The relevant portion of text reads as follows: "My friend, why are the Great Gods in conference? (In my dream) Anu, Enili, and Shamash held a council, and Anu spoke to Enlil: 'Because they killed the Bull of of Heaven and have also slain Humbaba, the one of them who pulled up the Cedar of the Mountain must die!"3 As the conference proceeds it turns out that Enkidu must die since he bore the major responsibility for the facts he is accused of. In the sequence, references are made to "the Assembly," "the temple of the gods," and "the temple of the holy gods." Unfortunately these phrases are located in a very damaged section of the tablet, and therefore it is difficult to ascertain what the "the assembly" does, or where it is located. Nevertheless, the overall context of the passage may give some indication of the location of this temple. In the previous sections, Gilgamesh is searching for Utnapishtim, the only human being to whom the gods granted eternal life. When Gilgamesh eventually found him they started a conversation. The damaged portion is a speech of Utnapishtim to Gilgamesh

'Maureen Gallery Kovacs, The Epic of Gilgamesh (Stanford, CA: Stanford University Press, 1989), 19 (Tablet II, lines 228-29).

\footnotetext{
${ }^{2}$ Ibid., 41 (Tablet V, line 5).

${ }^{3}$ Ibid., 59 (Tablet VII, lines 1-5).

${ }^{4}$ Tbid., 92 (Tablet X line 61).

5bid. (Tablet X line 77).

Tbid. (Tablet X line 78).
} 
in which the former deals with issues related to creation, suffering, the inevitability of death, and the role played by the gods in them. This becomes very clear in the subsequent lines of the tablet. Granting the plausibility of the previous analysis, it is reasonable to suppose that "the temple of the gods" is located in the transcendent realm, probably in heaven itself, where issues of life and death are decided by the gods. It is also likely that the assembly referred to in line 61 is the assembly of the gods.

The final lines of this tablet seem to reinforce this interpretation. They read as follows: "After Enlil had pronounced the blessing, the Anunnaki, the Great Gods, assembled. They established death and life, but they did not make known the days of death." Additional references to the assembly of the gods occur in tablet XI which narrates the flood story. In line 7, Gilgamesh asks Utnapishtim: "How is it that you stand in the assembly of the gods, and have found life?"2 Utnapishtim does not answer the question but starts to tell the story of the flood. Lines 119 and 120 refer again to the "Assembly of the Gods." The words now are spoken by Ishtar, who blames herself for having said evil things in the "assembly of the gods," thus ordering a catastrophe to destroy her people. As for the location of this assembly, though it is not specified by the context, it seems to be in the transcendent realm of the gods, in the heavenly sanctuary/temple, or heaven itself, where the gods make decisions affecting humankind.

Ibid., 93-94 (lines 305-09).

${ }^{2}$ Ibid., 97.

3ribid., 101. 
Thus, if the above interpretation of tablet $X$ is correct, a synchronic reading of the epic would suggest that the heavenly sanctuary/temple functions as a place of decision, since it is portrayed as the meeting place of the assembly of the gods.

\section{Enuma Elish}

The so-called Epic of Creation, the Babylonian myth Enuma Elish, provides some interesting references and allusions to the concept of a heavenly sanctuary as an entity located in heaven, and also as a reference to the earthly temple as a heaven-like entity. ${ }^{1}$ In the following discussion, attention is focused upon the first aspect which depicts the temple as being located in heaven.

1Y is interesting to note how the text portrays the construction of the historical temple of Marduk. The context runs as follows: After the creation of mankind by Marduk, the Anumnaki were liberated from their compulsory work, which was now set upon the recently created human beings (cf. also the Epic of Atrahasis [complete in a Late Old Babylonian recension] which explains the creation of man as intended to free the Igigi-gods from work. Cf. COS, 1:450-52). To express their gratitude for what the high god had done, they undertook the construction of the sanctuary of Esagila in honor of Marduk. In the sequence, the sanctuary is identified with the historical temple of Marduk in Babylon. This text shows how closely bound together the heavenly and the earthly temples could be. Although the sanctuary was described as something built by the gods, it is identified as a historical temple located in Babylon, as can be perceived in the excerpt quoted below.

"The Anunnaki opened their mouth(s)

And said to Marduk their Lord:

"Now, O Lord, who hast established our freedom from compulsory service,

What shall be the sign of our gratitude before thee?

Come, let us make something whose name shall be called 'sancuary.'

It shall be a dwelling for our rest at night; come let us repose therein!

There lef us erect a throne dais, a seat with a back support!

On the day we arrive, we will repose in it."

When Marduk heard this,

His countenance shone exceedingly, [lik] the day, (and he said)

So(?) shall Babylon be, whose construction ye have desired;

Let its brick work be fashioned, and call it a sanctuary."

Alexander Heidel, The Babylonian Genesis, 2nd ed. (Chicago: University of Chicago Press, 1951), 4 (Tablet VI, lines 47-58). 
The following allusion is significant for the purpose of this research. After

Marduk's defeating Tiamat and splitting her into halves, the following statement is found:

(143) The Lord measured the construction of Apsu,

(144) He founded the Great Sanctuary, the likeness of Esharra,

(145) (In) the Great Sanctuary, (in) Esharra, which he built, (and in) heaven,

(146) He made Ea, Enlil, and Anu dwell in their holy places. ${ }^{1}$

This text suggests that the Apsu was conceived as a Great Sanctuary in the likeness of which the Esharra (the earthly temple) was created. But it is interesting to note that in the same text, it is stated that the great sanctuary was also built in heaven. ${ }^{2}$ Thus it seems that, at least in the case of Esharra, the earthly temple was conceived as being in correspondence with heaven above and with the Apsu below. ${ }^{3}$ Thus the idea of a correspondence between heavenly and earthly temples seems to emerge in this text.

Another important quotation for this research reads, in reference to Marduk, as follows:

He shall establish for his fathers great food offerings, He shall provide for them, he shall take care of their sanctuaries.

${ }^{1} C_{\text {COS, } 1: 398-99}$ (Tablet IV, lines 143-46).

${ }^{2}$ Landsberger and Wilson propose the following translation for line 145: "The large abode, Esharra, which he had created, the heavens, He made Anu, Enlil and Ea occupy (as) their holy districts" (B. Landsberger, and J.V. Kinnier Wilson, "The Fifth Tablet of Enuma Eliš," JANES 20 (1961): 176, n. 120). If this suggestion is correct, then "heaven" would be understood as syntactically in apposition to Esharra, and not as a reference to the locus of a sanctuary. Nevertheless, when the passage is examined against its immediate grammatical context, one notes that the ancient worldview of a threefold division of the cosmos in the underworld (Apsu), earth, and heaven seems to form the conceptual background of the passage. Since the text speaks of a sanctuary in the Apsu, or the Apsu as a sanctuary, and also the sanctuary of Esharra, the earthly one, it is reasonable to suppose that a third one would be located in heaven, or heaven itself could be in view.

${ }^{3}$ It must be noted at this juncture that Apsu was the name of the primeval monster killed by Ea (Enki) which was fashioned into a place of sanctuaries. COS, 1:391-392 (lines 69-79). 
He shall cause incense bumers to be savored, he shall make their chambers rejoice. He shall make on earth the counterpart of what he brought to pass in heaven."

Another translation reads the last line thus: "May he make a likeness on earth of what he has wrought in heaven." $\mathrm{A}$ close look at the context suggests that the notion of a "counterpart" implies the idea of a correspondence between heavenly and earthly spheres that goes beyond a mere spatial/geographical correspondence and seems to refer to the cultic activities that are performed in both heavenly and earthly sanctuaries. This can be deduced from the references to "food offerings," "sanctuaries," and "incense burners" found in the passage.

At this juncture the views of two eminent orientalists are in order. According to Jeremias, "all the great cities and temples of Babylonia [had] corresponding cosmic originals." 3 Geo Widengren observed that "the room of destiny of Esagila is then a symbol and a copy of the celestial room of Upsukkinnaku, and the earthly king, who is installed upon the former, and from whom comes the decision of the destiny, is an image, tam. šll.ili of Marduk, the king of the gods. ${ }^{\text {id }}$

Summing up, the major contribution of the text surveyed above for this study on the heavenly-sanctuary/temple motif is the idea of a relationship or correspondence

${ }^{1} \operatorname{COS}, 1: 402(\mathrm{~V} 109-13)$

${ }^{2}$ ANET, 69 .

${ }^{3} J$ remias, The Babylonian Conception of Heaven and Hell, $40-41$.

${ }^{4}$ The Italian text reads: "La sala dei destini di Esagila è quindi in simbolo e una cópia della sala celeste Upšukkinnaku, e il re terrestre, che qui in essa viene installato e di cui viene deciso il destino, è un'immagine, un tam.šil-illi di Marduk, re degli dèi" (Geo Widengren, "Aspetti Simbolici dei Templi e Luoghi di Culto del Vicino Oriente Antico," Numen 7 [1960]: 3-4). Interestingly enough, this text reminds one of the "image of the beast" referred to in Rev 13:14, 15 . 
between the heavenly temple and its early counterpart. This correspondence seems to have been understood, more than in mere structural terms, to involve the idea of a functional correspondence as deduced from the references to "food offerings," "sanctuaries," and "incense burners" in the last-quoted passage.

\section{Excursus: Nabuapaliddina's Relief}

Although this research deals with written sources, this excursus exceptionally discusses an important sculptured scene, which may shed additional light on the topic under study, since it apparently depicts the relationship between the heavenly and earthly temples. ${ }^{1}$ See fig. 1 . This sculptured scene is ascribed to King Nabuapaliddina ( 870 B.C.) of Babylon, and was found in the temple of the Sun god in Sippar.

In the right part of the relief, there is a throne scene in which the solar deity Shamash is depicted as sitting on a throne under a tent-like sanctuary. Underneath the canopy are pictured the symbols of the three heavenly deities: Sin, Šamaš, and Ištar. Under the throne are a number of wavy lines, which both Metzger and Mettinger interpret as the celestial ocean. The left part of the relief contains a presentation scene which shows the priest Nabunadinshum leading King Nabuapaliddina into the presence of Shamash; the king and the priest are followed by a goddess. The deity is not approached directly; rather, the procession approaches a cultic table with a representation of the sun's disc. Metzger,

\footnotetext{
${ }^{1}$ The following discussion is largely based on the studies of M. Metzger ("Himmliche und Irdische Wohnstatt Jahwes," Ugarit-Forschungen 2 [1970]: 139-58) and Tryggve N. D. Mettinger ("YHWH SABAOTH - The Heavenly King on the Cherubim Throne," in Studies in the Period of David and Solomon and Other Essays, ed. Tomoo Ishida [Winona Lake: Eisenbrauns, 1982], 10938), who have devoted considerable attention to the implications of this document for the sanctuary/temple motic.
} 


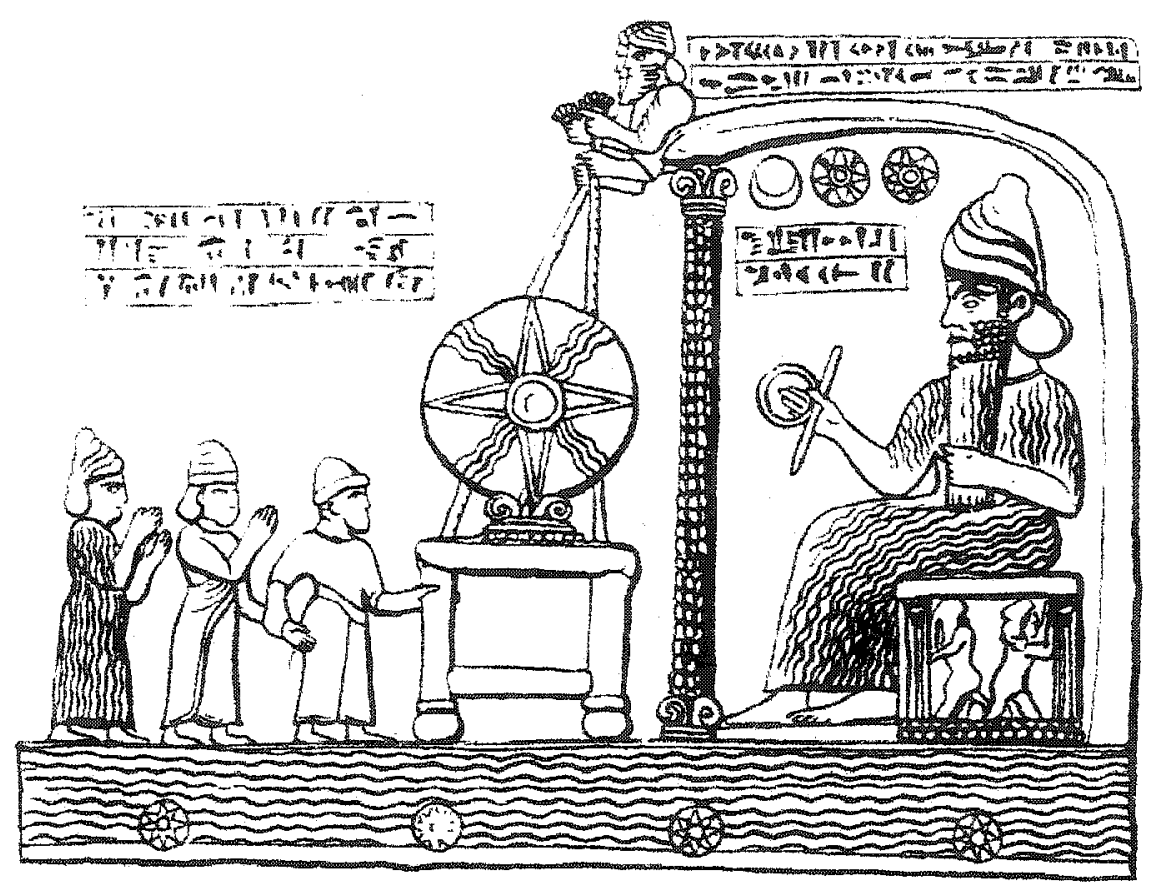

Fig. 1. Nabuapaliddina's relief. Presentation scene and throne scene on Nabuapaliddina's stone tablet in the temple of Shamash at Sippar. Scene $18 \times 10 \mathrm{~m}$. Abu Habba. Nabuapaliddina c. 885-850. London, British Museum. Drawing by Andrzej Szlagor for Tryggve N. D. Mettinger, "YHWH SABAOTH-The Heavenly King on the Cherubim Throne," in Studies in the Period of David and Solomon and Other Essays, ed. Tomoo Ishida (Winona Lake: Eisenbrauns, 1982), 120. 
followed by Mettinger, pointed out that since the wavy lines extend over the entire breadth of the picture, the meaning of the scene would be to indicate "the heavenly associations of the temple," or "the place where heaven and earth meet, or heaven on earth." Metzger expressed the same idea by saying that the sanctuary/temple is "the place in which the distinction between heaven and earth, between 'this world' and 'the world beyond' is abolished."

Thus, Metzger and Mettinger tend to view the relationship between the heavenly and earthly sanctuary/temple as a continuum, where any distinction between heaven and earth collapses. Although this may be true, it seems more likely that the scene reflects the idea of a dynamic relationship between the heavenly sanctuary/temple and its earthly counterpart. If the throne scene at the right side of the relief depicts Shamash enthroned in his "Heavenly Sanctuary,"4 as Metzger explicitly recognizes, and the left scene depicts an earthly-temple setting, then the theological thrust of the picture may be simply that of representing a connection-not the abolition of any distinction-between heavenly sanctuary and its earthly counterpart. That is, the relief probably depicts a relationship between heavenly and earthly sanctuary/temples, as suggested.

That being the case, it may be hypothesized that what takes place on earth-that is, Nabuapaliddina's presentation in the earthly temple of Shamash-is legitimized by the

"Mettinger, "YHWH SABAOTH-The Heavenly King on the Cherubim Throne," 121.

${ }^{2} \mathrm{Ibid}$.

${ }^{3 "}$ Der Ort, an dem der Untershied zwischen Himmel und Erde, zwischen 'Diesseits' und 'Jenseits' aufgehoben ist" (Metzger, 144).

"Himmlischen Heiligtum" (Ibid., 142). 
deity in the heavenly sanctuary/temple. The earthly temple thus derives significance and legitimation from its connection with the heavenly counterpart, and idea that possibly lies behind the ANE concept of the earthly temple as "heaven on earth." At this juncture, the following statement by Lindquist, though from a different context, provides an apt summary of the concept of the interconnection of heavenly/earthly temples conveyed by this relief, and suggests a rationale for this interconnectedness.

The basic idea is that there exists in the sky a perfect place, the 'city' of the gods. The goal of human life is both to establish contact with this place, and to return to it after death, thus to share in the life of the gods. The primary way by which the gods share with humans the knowledge of this place, and information on how to get there, it [sic] through the temple. The earthly temple is an exact replica of the heavenly temple. ${ }^{2}$

\section{Summary}

The foregoing survey of Akkadian texts (including the excursus on Nabuapaliddina's Relief) yielded some additional insights into the ANE understanding of the heavenly sanctuary/temple motif. In terms of function, it was noted that in addition to its serving as a dwelling place of the deity, or royal palace, the heavenly sanctuary/temple was understood as the meeting place of the assembly of the gods, a place where decisions and judgments were pronounced, and wherein cultic activities took place. There is also some evidence of a relationship between the heavenly sanctuary/temple and the earthly counterparts.

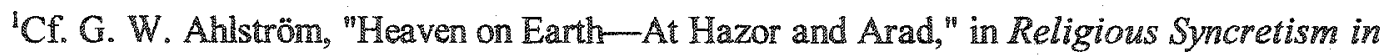
Antiquity: Essays in Conversation with Geo Widengren, ed. Birger A. Pearson (Missoula, MT: Scholars Press, 1975), 66-83.

${ }^{2} J o h n$ M. Lundquist, The Temple: Meeting Place of Heaven and Earth (London: Thames and Hudson, 1993), 11. 


\section{耳itutite Listerature}

Although most of the references to temples/sanctuaries in the Hittite literature have in view the earthly/historical temples of the deities, there are several indications that the Hittites conceived of a temple/sanctuary in heaven. Since the gods were understood to live and engage in activities in heaven (as well as upon the earth and on mountains), it is natural that a concept of a heavenly temple/sanctuary would emerge from this literature.

\section{Song of Ullikummi}

The text known as "The Song of Ullikummi" displays several references to a heavenly sanctuary/temple. As a strategy to dethrone Tessub, ${ }^{1}$ Kumarbi impregnates a rock in order to have a son strong enough to overcome his opponent "and go up to heaven to kingship."2 The success of Kumarbi resulted in a son named Ullikummi who grows so tall that he "reaches up to the temples (karimnus) and the kuntarra house in heaven." Later, it is reported that "it has blocked heaven, the holy temples (karimmi), ${ }^{5}$ and Hebat." Another significant reference to the heavenly-sanctuary/temple motif emerges in a

${ }^{1}$ Tessub was the "supreme Storm God" and "reigning king of the gods according to Hurrian theology" (Harry A. Hoffner, Jr., Hittite Myths [Atlanta: Scholars Press, 1998], 113).

2Ibid., 58 .

${ }^{3}$ Cf. Hans G. Gutterbock, "Hittite Mythology," in Mythologies of the Ancient World, ed. Samuel Noah Krammer (Garden City, NY: Doubleday, 1961), 25.

${ }^{4} A N E T, 123$. Hoffiner translates it as, "In the sky above it meets temples and (their) kuntarra-shrines" (Hoffner, Hittite Myths, 59).

${ }^{5}$ Gütterbock, 45 .

${ }^{6}$ Hofner, Hittite Myths, 64. 
confrontation between Tessub and Ullikummi. The latter assures the former that "I will go up to heaven to kingship. I will take myself Kummiya, [the gods'] holy temples (karimmi), ${ }^{1}$ and the kuntarra-shrines. I will scatter the gods down from the sky like meal":2

Some considerations regarding this text are in order. First, the text clearly attests the concept of a heavenly temple. As Hoffner puts it, the kuntarra-shrine is "the holiest of holies of the chief god Tessub located in heaven." It is worthy of note that the "kuntarra of Tessub" is mentioned in a treaty text as a building in the Anatolian city of Tarhüuntašša. ${ }^{4}$ This raises the possibility that the Hittites also conceived of a correspondence between the earthly and heavenly sanctuaries along the lines of their Semitic neighbors.

Second, it is possible that, along with the concept of a heavenly temple, the text under consideration points to a heavenly city. ${ }^{5}$ Although Kummiya is identified with "the home of the storm god Tessub, located in Northern Syria, "6 it seems that in the aforementioned text, Kummiya is located in heaven. Two arguments reinforce this possibility:

'Hans Gustav Guterbock, ed., The Song of Ullikummi: Revised Text of the Hittite Version of a Hurrian Myth (New Haven, CT: The American Schools of Oriental Research, 1952), 49.

${ }^{2}$ Hoffner, Hittite Myths, 65.

${ }^{3}$ Ibid., 111.

${ }^{4} \mathrm{Cf}$ " The Treaty of Tudhalia IV with Kurunta of Tarhuntašša on the Bronze Tablet Found in Hattussa $(2: 18)^{n} \$ 10(1.91-101,11.1-3)$ in COS, $2: 102$.

5Gütterbock supplies the word "town" (Gütterbock, 49).

"Hoffner, Hittite Myths, 111. 
1. Since the purpose of Ullikummi's ascension to heaven was to attain kingship by taking over "Kummiya, [the god's] holy temples (karimmi), and the kuntarra-shrines," it seems reasonable to suppose that Kummiya was located in heaven.

2. In addition, it must be noted that the taking over of Kummiya and the "god's holy temples" will result in his scattering "the gods down from the sky like meal." Therefore, Kummiya and the gods' temples must be located in heaven. Thus, in addition to the concept of a heavenly sanctuary/temple, the text seems to point to the idea of a heavenly city.

Third, the text under consideration also displays a significant indication about the function of this heavenly temple. Since the context displays a struggle for kingship in which Ullikummi wants to take over the kuntarra-shrines of Tessub, it seems reasonable to postulate that the heavenly temple was a token of kingship. By taking over the heavenly temples, Ullikummi would establish his kingship. Although the extant text does disclose the result of this confrontation, Hoffner conjectured that Tessub "apparently will win." In addition to the concept of a heavenly temple, the song of Ulikummi displays two references to the assembly of the gods. In a short and fragmented section of the myth which describes Tessub meeting Ea, mention is made of the "assembly." Although this text does not indicate where this assembly would be located, another section apparently refers to the "place of assembly" as being located in heaven. The relevant portion of the text reads as follows: "Tasmisu heard and rejoiced. He clapped (?) three times, and up in

Ibid., 56.

${ }^{2}$ Ibid., 63. 
the sky the gods heard. He clapped (?) a second time, and Tessub, the valiant King of Kummiya, heard. Then they came to the place of the assembly, and all the gods began to bellow like cattle at Ullikummi." Along with pointing to heaven as the locus for the assembly, the larger context suggests that this assembly could well take place in one of the heavenly sanctuaries mentioned in the story, or even in the kuntarra-house of the gods.

\section{Other Texts}

Volkert Haas refers to a text in which the gods are depicted as bringing iron to build the heavenly palace. ${ }^{2}$ The composition known as the "Mursilis Hymn and Prayer to the Sun-goddess of Arinna" displays some allusions to the heavenly sanctuary/temple motif. The relevant portion reads as follows:

O Sun-goddess of Arinna, are the source of light. Throughout the lands you are a favored deity, and you are father and mother to all the lands. You are the divine guided lord [sic] of judgment, and in the place of judgment there is no tiring of you. Also among the primeval gods you are favored. O Sun-goddess of Arinna, allot the sacrifices to the gods, and the share of the primeval gods you allot as well. They open up the door of heaven for you, and you cross the gate of heaven, $O$ favored [Sungoddess of Arinna]. The gods of heaven [and earth bow down to you], O Sun-goddess of Arinna. Whatever you say, O Sun-goddess of Arinna, [the gods] fall down before you, O Sun-goddes of Arinna. ${ }^{3}$

The portrayal of the Sun-goddess of Arina's performance in the "place of judgment" and her crossing the gate of heaven point to a heavenly setting. Although no

${ }^{1}$ IIbid., $64-65$.

${ }^{2}$ Volkert Haas, Geschichte der Hethitischen Religion (Leiden: E. J. Brill, 1994), 126. The text mentioned by Haas is in Hugo Heinrich Figulla and others, Keilschrifttexte aus Boghazköi (Leipzig: J. C. Hinrichs, 1916), 4:1, vs. 39.

${ }^{3}$ Itamar Singer, Hittite Proyers, Writings from the Ancient World 11 (Atlanta: Society of Biblical Literature, 2002), 51 (A I 29'-ii 2'). 
specific word for temple/sanctuary (e.g., karimmi-/karimna-, kuntarra) is used, the reference to the "place of judgment" may well convey a temple setting. Additionally, the "door of heaven" may also reinforce the notion of the heavenly sphere as an enclosed space where the deities perform their activities. In sum, the main idea in this text seems to be that of a judgment, which is executed by the deity in a heavenly setting.

In the "Prayer to be Spoken in an Emergency" in which Muwatallis invokes the gods for help, reference is made to heavenly and earthly temples. The Sun-god of Heaven is urged to call on the other gods as follows: "Those gods, O Sun-god of Heaven, summon from heaven (and) from earth, from the mountains (and) from the rivers, from their temples (and) their thrones!"1 Apart from the concept of heavenly and earthly temples, this passage also points to the assembly of the gods as a major motif. ${ }^{2}$ Although the text does not make it explicit, it is possible that both ideas are somehow intertwined inasmuch as the heavenly temple(s) might have functioned as the locus for the divine assembly.

'ANET, 398.

${ }^{2}$ Houwink ten Cate, "The Sun God of Heaven and the Hittite King," in Effigies Dei: Essays on the History of Religions, Studies in the History of Religion 51 (Leiden: E. J. Brill, $1987), 23$. The assembly of the gods conveys a notion of judgment, and consequently may be related to the heavenly-sanctuary/temple motif. Furthermore, although one cannot be certain about the specific spot where this assembly would convene, the overall ANE evidence allows the possibility that the heavenly temple might be one of its loci.

Hittite literature contains several references to the assembly of the gods, as the following sampling demonstrates. In the bilingual edict of Hattusili I, the monarch pleads for the gods to "take a stand on my side and judge the [legal case] on my side" (COS, 2:88). In a treaty document between Suppiluliuma and Aziru, the assembly of the gods is called to witness (ibid., 95). The same motif occurs in the blessings and curses of the treaty between Suppiluliumas and Kurtiwaza. The text says that "at the conclusion of this treaty we have called the gods to be assembled and the gods of the contracting parties to be present, to listen and to serve as witnesses" (ANET, 205). In a prayer by Mursillis II, all the gods are "summoned to assemble for witnessing an oath" (COS, 2:156). In the Telepinus myth, it is reported that "the gods [were gathered] in assembly under the hatalkešnaš tree " (ANET, 128), assumed to be the hawthorn according to ten Cate (16). 
The basic assumption behind the idea of a divine assembly would be that humans can appeal to the gods and win their support. As ten Cate has stated, "the gods were supposed to transmit to their equals complaints which had reached them from human beings." At this juncture, it is worth noting that the assembly of the gods seemed to have its counterpart among humans in the Hittite assembly, which gathered as a judicial body under the will of the king. ${ }^{2}$ Thus, the idea developed that as the Hittite king used to convoke his assembly, in like manner his divine counterpart, understood as the sun god, would convoke the other deities to gather in assembly. ${ }^{3}$ Therefore, if the Hittites developed the idea of an earthly counterpart for the assembly of the gods, it is reasonable to infer that they might also have entertained the notion of the heavenly sanctuary/temple in correspondence to an earthly counterpart. ${ }^{4}$

\section{Summary}

Hittite texts portray the heavenly sanctuary as a token of kingship, which functions as a place of judgment and, possibly, as the locus for the divine assembly of the gods. The

'ten Cate, 21.

${ }^{2}$ Gary Beckman, "The Hittite Assembly," Joumal of the American Oriental Society 102 (1982): $102-442$.

$3_{\text {ten Cate, } 19 .}$

The connection between heavenly and earthly assemblies suggests a correspondence between the heavenly sanctuary/temple of the deity and the earthly sanctuary/temple (or the palace of the king, for that matter). It is interesting to note that the Sumerian logogram E (from E.GAL: ii. "large house," i.e. "temple/palace") is also used in Hittite, as noted in the Hittite terms

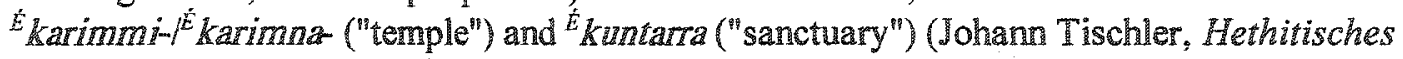
Etymologisches Glossar [Innsbruck, Institut für Sprachwissenschaft der Universität Innsbruck, 1983], 407 and 635-36, respectively). 
possibility may also be raised that Hittites also conceived of a correspondence between the earthly and heavenly sanctuaries along the lines of their Semitic neighbors.

\section{Ugaritic Literature}

The discovery of the ancient city of Ugarit provided a major venue for the understanding of the religion of Canaan, and consequently opened new vistas to the religious context of the Hebrew Bible. ${ }^{1}$ Among the most important finds brought to light by the archaeological excavations of Ugarit are three major works of narrative poetry written in a cuneiform alphabet providing significant insights into the religion of Ugaritthe Epic of Kirta, the story of Aqhat, and the Baal Cycle. These works are the major sources for the following survey of Ugaritic texts.

\section{Epic of Kirta}

The Epic of Kirta is a story of a royal hero who has to fight against the near extinction of his dynasty. A significant feature of this story is the role played by the gods in the plot. They are deeply involved as the actions of the hero unfold. They feast with him, help him, and are involved in the major decisions regarding Kirta's fortune. Of special interest for the purposes of this research are the references to the dwellings of the gods.

"Peter C. Craigie, "Ugarit and the Bible: Progress and Regress in 50 Years", in Ugarit in Retrospect: 50 Years of Ugarit and Ugaritic, ad. Gordon Douglas Young (Winona Lake, $\mathbb{N}$ : Eisenbrauns, 1981), 99-111; idem, Ugarit and the Old Testament (Grand Rapids: Eerdmans, 1983), 3-6; John Day, "Ugarit and the Bible: Do They Presuppose the Same Canaanite Mythology and Religion?" in Ugarit and the Bible: Proceedings of the International Symposium on Ugarit and the Bible, ed. Adrian H. W. Curtis, John F. Healey, and George J. Brooke, UgaritischBiblische Literatur 11 (Muinster: Ugarit-Verlag, 1994), 35-52; J. A. Emerton, "What Light Has Ugaritic Shed on Hebrew?" in Ugarit and the Bible, 53-69. 
The gods are depicted as living in tents, as the following quotation demonstrates:

tbrk'ilm? tity

tity ilm lahlhm

dr il.lmšknthm
The gods offer blessing, they go

The gods go home to their tents

The circle of El to their dwellings. ${ }^{1}$

Although the text does not specify where these houses/tents are located, it may reasonably be surmised that they were understood to be located in heaven or in some mythical place, such as the underworld. ${ }^{2}$ The text also alludes to Baal's dwelling located on the mythical Mount Saphon. ${ }^{3}$ Although, strictly speaking, this is not a heavenly sanctuary (i.e., a sanctuary located in heaven) its importance lies in the fact that it was probably regarded as the counterpart to the earthly/historical temple of Baal in the city of Ugarit, ${ }^{4}$ and therefore plays a role functionally equivalent to that of a heavenly temple.

${ }^{1}$ Ibid., 26 (KTU 1:15 III 17-19).

${ }^{2}$ Marjo Christina Annete Korpel, $A$ Rift in the Clouds: Ugaritic and Hebrew Descriptions of the Divine (Münster: Ugarit-Verlag, 1990), 375.

${ }^{3} \mathrm{Cf}$. the following passages:

tbkyk. $a b \cdot g r \cdot b r l$

$s p n \cdot h l m \cdot q d s$

$n ! n y \cdot h l m \cdot a d r$

hl rhb mknpt
Baal's mountain will weep for you, fatherMount Saphon, the holy domain, Mount Nani, the mighty domain A domain stretched as wide as a wingspan.

Simon B. Parker, ed, Ugaritic Narrative Poetry, WAW 9 (Atlanta: Society of Biblical Literature, 1997), 31 (KTU 1.16 1 6-9). This text is repeated verbatim by Kirta's daughter Thitmanit in Parker, 35 (KTU 1.16 II 44-47).

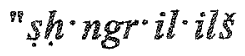

$$
\begin{aligned}
& \text { ills }[s] \cdot<n g r \cdot b t \cdot b C l> \\
& \text { wath } n g r t \cdot \text { illt } \\
& y \text { sh.ngr il.ils } \\
& \text { ils } n g r \cdot b t \cdot b r t \\
& \text { wath } \cdot \text { ngrt illht } \\
& \text { Summon the herald-god, Illish- } \\
& \text { Ilish, the herald of Baal's house } \\
& \text { And his wives, herald-godesses, too? } \\
& \text { He summons the herald-god, Ilish, } \\
& \text { Ilish, the herald of Baal's house, } \\
& \text { And his wives, herald-goddesses, } 100 " \\
& \text { (Parker, } 36 \text { [KTU 1.16 IV 3-4]). Cf. Parker, } 37 \text { (KTU 1.16 IV 10-12). }
\end{aligned}
$$

${ }^{4}$ This idea will be elaborated below. 
Summing up, from the few allusions to the heavenly/mythical sanctuary/temple motif found in the Epic of Kirta one gets the impression that the heavenly/mythical sanctuary functions primarily as a dwelling for the deities. Its location is left unspecified except for Baal, whose abode is located on Mount Saphon.

\section{Story of Aqhat}

The story of Aqhat reports about the childless king Danel in whose favor Baal intercedes before $\mathrm{El}$ to bless him with a son. After Baal's intercession, a son, named Aqhat, was born to Danel. Actually, the major concern of the story is with Danel's son, and not with Danel himself. So in the following survey of the story of Aqhat focuses mainly on the references to the gods' dwellings located both in Ugarit and in heaven or some mythical place. ${ }^{1}$ It is instructive to note that El's abode is described as being located at a mythical place, "at the springs of the rivers," as can be seen in the text transcribed below, in which Anat marches towards El's dwelling:

'David P. Wright has identified twenty ritual scenes in the Aghat narrative, the majority of which are "sorted out in (a) feasts, (b) blessings, (c) mourning rites, and (d) retaliation rites" (David P. Wright, Ritual in Narrative: The Dynamics of Feasting, Mourning, and Retaliation Rites in the Ugaritic Tale of Aqhat [Winona Lake: Eisenbrauns, 2001], 13). Although Wright has performed a detailed analysis of this story, with a meticulous identification of the ritual scenes contained therein, unfortunately he paid no attention to the heavenly-temple motif. 
$i d k$ [ltm p]nm

$\tau_{m} \cdot i l \cdot m b k \cdot n h r m$

[qrb ap]q.thmtm

tgly.dd il

[wtbu q]rš'mlk:ab šm
Then [she sets her fa]ce

Toward El at the springs of the rivers, [Among the strea]ms of the deeps. She proceeds to the precinct of El, [Comes to the c]amp of the King, the Father of Years $^{1}$

It is instructive to note that, along with his mythical tent "at the springs of the rivers," El had a house or sanctuary in the city of Ugarit, as the text below seems to demonstrate. The context of the passage depicts Baal interceding before El so that a son would be given to Kirta. The requested offspring was expected

$s p u \cdot k s m h \cdot b t \cdot b e l$

$[w]$ mnth. br il
To eat his portion in Baal's house

His share in the house of $\mathrm{El}^{2}$

For the purpose of this study, it suffices to note that Baal's and El's houses as mentioned in this text most probably refer to the earthly sanctuaries of these deities, since the text is referring to ritual actions to be performed by Kirta's future son. At this juncture three remarks are in order. First, it is clear that the Ugaritic culture understood the abode of the deities in two spheres: El had a "house" (bt) physically located at Ugarit, ${ }^{3}$ and a "precinct" $(d d)^{4}$ at the cosmic waters. This is in line with ANE theology and cosmology

1Parker, 62 (KTU 1.17 VI 46-49). The locution "Father of Years" reminds one of the expression "Ancient of Days" in Dan 7:9-10. This passage will receive attention in chapter 3 of this dissertation.

${ }^{2}$ Ibid., 53 (KTU 1.17 I $31-32$ ).

${ }^{3}$ Although archaeological excavations have not yet identified a sanctuary/temple belonging to $\mathrm{El}$, several ritual texts have attested the existence of a sanctuary to this deity in the ancient city Ugarit. Cf., e.g., Dennis Pardee, Ritual and Cult at Ugarit (Atlanta: Society of Biblical Literature, 2002), 51 (RS24.266, lines 6, 14 [Obv.]).

${ }^{4}$ Clifford translates $d d$ as "tent" on the basis of the parallelism of Ugaritic poetry. According to him "the word is probably plural, as frequently in housing terms in Ugaritic. The usual translation is 'area' or 'mountain.' While there is no extra-Ugaritic evidence for $d d$ as "tent," 
according to which the god's earthly "sanctuary" was understood to be a copy or counterpart of the heavenly/cosmic one. ${ }^{1}$

Second, earthly and heavenly sanctuaries seem to have been understood as operating in dynamic relationship. The following text seems to point to this aspect. After Danel's weeping over the death of his son Aqhat for seven years, the text reports that
wyq[ry] dbh ilm $y s^{\check{c} l y \cdot d \dot{g} t[h l] m(?)}$
He pres[ents] a meal for the gods, dğt hrnmy. [bk] bkbm Into the heavens sends incense, [to the ] stars the Harnemite's incense. ${ }^{2}$

The picture here seems to be that of Danel entering a sacred precinct in Ugarit and performing some ritual action. ${ }^{3}$ The clause "into the heavens he sends incense" seems to express the connection between the earthly and heavenly dwellings of the deities (i.e., Danel presents a meal in the earthly temple or sacred precinct and, at the same, time sends incense up into the heavenly sanctuary of the deities). The implication is that both sanctuaries are connected in the same ritual action. Thus the term "heavens" is probably a metonymic expression for the heavenly sanctuary of the deities.

the intra-Ugaritic evidence is strong. $d d$ appears five times in the cliche for El's dwelling, reprinted in the text. A rigid parallelism is the rule in the cliché: mabbikur [source]// apiqui [pool]; maharami ["two rivers"] // thiham(a) tami [double-deep]; 'ilu [El] //millü abu sanima [king, father of years]; tagliyu [roll back] // tabu' $u$ [enter]. $d d$ should therefore be parallel to qarasü, "tent frame, tent" (Richard J. Clifford, "The Tent of El and the Israelite Tent of Meeting, CBQ 33 [1971]: 222, $\mathrm{n}$. 4). Clifford notes another proof of this parallelism in lines 51-52 of the the story of Aqhat: $a g r m \cdot b a t . b d d k$ [pgtt] $b a t \cdot b<a>h l m$. "The woman we hired is come to our camp, [ ] is come to our tents" (ibid.). Cf. Parker, 77 (KTU 1.19 IV 51-52).

I"Among the Canaanites, the high god was thought to dwell in a temple or tent on the holy mountain. The earthly temple of the deity was considered a copy of the heavenly temple on the mountain" (Clifford, The Cosmic Mountain in Canaan and the Old Testament, 177).

${ }^{2}$ Parker, 76 (KTU 1.19 IV 22-25).

${ }^{3}$ Cf. David P. Wright, 200-03. 
There is also the possibility that the term "heavens" may point to the earthly sanctuary itself which, because of its relationship with the heavenly sanctuary, could be called "heaven." ${ }^{\text {"1 }}$ Nevertheless, the reference to the "stars" renders the heavenly abode of the deities the most probable referent for the passage and, consequently, suggests a dynamic relationship between earthly and heavenly sanctuaries.

II is instructive to note that an Ugaritic hymn to Anat refers to the sanctuary of the goddess, located on the mythical mount Inbub, as "high heavens" ( $5 \mathrm{~mm} \mathrm{rm}$ ). The relevant part of the text reads as follows:

\begin{tabular}{|c|c|}
\hline 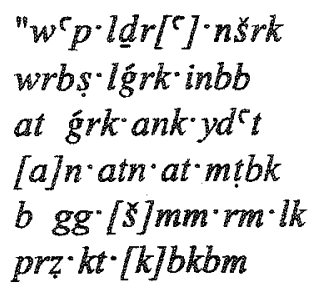 & $\begin{array}{l}\text { And fly with your falcons } \\
\text { and settle on your mountain Inbub, } \\
\text { come to your mountain (which) I know! } \\
\text { Lo! Come yourself to your dwelling; } \\
\text { to the ro[of] of the high [hea]vens go, } \\
\text { and run towards the stars" }\end{array}$ \\
\hline
\end{tabular}

(N. Wyatt, trans., Religious Texts from Ugarit, 2nd ed., Biblical Seminar 53 [London: Sheffield, 2002], 170-71 [KTU 1.13 8-13]).

The Phoenician inscriptions of 'Ešmunazar and Bod'aštart, both from the fifth century B.C., seemingly refer to the precincts of a temple in Sidon as "mighty heavens" " $(\mathrm{smm}$ ' $\mathrm{drm})$ and "high heavens"(vmm rmm) respectively. The relevant parts of lines 15-17 of the "Ešmunazar inscription read: (15). . . bnn 'yt bt (16) 'Inn 'yt bt 'strt bșdm 'rs ym wyšrn 'yt bt 'aštrt $\Im m^{2} d r m$ w'nhn (17) 's bnn bt l' 'smn [s]d/r qdక 'nydll bhr wyšbny šmmedrm . . "(15) ... we built the house of (16) the gods: the temple of Ashtarot in Sidom, land of the sea, and have made Ashtarot dwell in the mighty heavens; and we (17) built a house to Eshmun, the holy prince (?) NYDLL, on the mountain and made him dwell in the mighty heavens" (H. Donner and $W$. Röllig, Kanaonöische und Aramäische Inschriften [Wiesbaden: Otto Harrassowitz, 1966], 1:3, inscription number 14). For the English translation I followed with some minor changes the German translation in Donner, 2:19-20. The Bod astart inscription, a short text inscribed in the foundations of the Eshmun temple, contains the following words: mlk bdr $\$$ trt mlk sdnm bn bn mlk hsmn'zr mlk șdnm bsdn ym šmm rmm 'rș ršpm șdn mšl 's bn sdn šdr 'yt hbyt z bn $l$ ly $l: \$ m n s d / r$ qds. "King BDASTRT, King of the Sidonians, grandson of ASMNZR, king of the Sidonians, in 'Sidon of the sea, "high heavens, 'land of RŠPM, "Sidon rules,' which he built. And Sidon of the hall which he built to his god, to 'ESMN, the holy prince." Donner, 1:3, inscription number 15. My English translation follows closely the German translation in Donner, 2:23-24. "Sidon of the sea," "high heavens," "land of RŠPM," "Sidon rules," correspond to four quarters of the Sidon according to J. T. Milik, "Le Papyrus Araméens dHermopolis et les Cultes Syro-Phéniciens," Bib 48 (1967): 597-98. For something similar in Ebla, cf. Mitchell J. Dahood, "The Temple and Other Sacred Places in the Ebla Tablets," in The Temple in Antiquity: Ancient Records and Ancient Perspectives, ed. Truman G. Madsen, RSMS 9 (Provo, UT: Brigham Young University, 1984), 84 . 


\section{Baal Cycle}

Dated to about 1400-1359 B.C., the so-called Baal cycle is composed of six tablets and various fragments of about 1,830 lines, though estimates for the original text go as high as 5,000 lines. ${ }^{1}$ The research on these tablets has generated considerable debate. Scholars have discussed the order of the tablets, also whether the six tablets should be read as a single story or a group of separate narratives about Baal, ${ }^{2}$ and the function of this cycle in the Ugaritic religion. ${ }^{3}$ Nonetheless, in spite of this discussion, no consensus has emerged, and for the purposes of this research no absolute decision regarding these matters is required.

The text narrates "the story of Baal's rise to kingship over the gods by his defeat of the forces of chaos, Sea and Death." ${ }^{114}$ As the composition unfolds, several themes become prominent such as a council in heaven, battle between the deities, creation, temple

${ }^{3}$ Mark Smith, "The Baal Cycle," in Ugaritic Narrative Poetry, ed. Simon B. Parker (Atlanta: Society of Biblical Literature, 1997), 81.

${ }^{2}$ Smith seems to imply that the cycle is a single story when he says that despite the difficulties "the outline of the narrative is clear. "Ibid. Clifford has suggested that the six tablets of Baal texts "contain two variants of the same basic myth of the victory of the god rather than, as is often assumed, of a single connected story of a conflict with Sea followed by a conflict with Death." Richard J. Clifford, "The Temple in the Ugaritic Myth of Baal," in Symposia, ed. F. M. Cross (Boston: American Schools of Oriental Research, 1975), 138.

JJohanes C. De Moor, The Seasonal Patterns in the Ugaritic Myth of $B a^{\prime} a l u$, ed. Manfred Dietrich, Kurt Berghof, and Oswald Loretz, AOAT 16 (Vluyn: Verlag Butzon \& Bercker Kevalaer, 1971); Dirk Kinet, "Theologische Reflexion im Ugaritischen Ba'al-Zyklus," BZ 22 (1978).

${ }^{4}$ Michael David Coogan, ed., Stories from Ancient Canacn (Philadelphia: Westminster, 1978), 75. 
building, sacral meal, and others. ${ }^{1}$ For the purposes of this research, special attention is devoted to the theme of El's tent and Baal's palace-the most prominent theme in the Baal texts. $^{2}$

An interesting reference to El's abode occurs in a text in which Anat comes to the mountain of $\mathrm{El}$ to request that a palace be built for Baal.
$\operatorname{tgl} d[d] i l[\cdot] w t b u$
[She comes to] the mountain of $\mathrm{El}$ and enters.
$[a r] s \cdot m[l] k \cdot a b l \cdot s n m$
[The te]nt of the king, the father of years.
$\left[\operatorname{lr}\left[\int[\mathrm{t}] \mathrm{bu} \cdot \mathrm{d} d \mathrm{~m}\right.\right.$
[She] enters the mountain.
$[n] n[] n[\Pi]$
qlh:ysmr $\operatorname{tr}[\cdot i] l \cdot a b h$
Her voice Bull [E]l her Father, hears;
$y\left[r_{n} \cdot\right] / b s b^{r} \cdot h[d] r m$.
$[b t] m n\left[t^{\circ} a p\right] s g r t$.
EI1] an[sw]ers from the seven $r[00] \mathrm{ms}$, [from the] eigh[t en]closures. ${ }^{3}$

Some significant features regarding El's abode deserve discussion. At first, it seems clear that the text refers to El's heavenly/mythical abode. The description of El's sanctuary as a seven-room palace points to grandeur and majesty that exceed an earthly sanctuary. In fact, that EI is depicted as being located at the innermost chamber of his abode ${ }^{4}$ recalls the

"John M. Lundquist, "What Is a Temple? A Preliminary Typology," in Quest for the Kingdom of God: Studies in Honor of George E. Mendenhall, ed. E. A. Spina, H. B. Huffmon, and A. R. W. Green (Winona Lake, IN: Eisembrauns, 1983), 214.

${ }^{2}$ Cf. F. Løkkegaard, "The House of Baal," AcOr 22 (1955).

${ }^{3}$ Parker, 116 (KTU 1.3 V 7.12).

${ }^{4}$ It has been further suggested that "this idiom of seven concentric boundaries surrounding a god's shrine appears to establish its central location; it corresponds to the notion of seven barriers in the underworld of both Egyptian and Mesopotamian tradition. It may also be compared to the seven boundaries represented architecturally in Egyptian temples, most clearly at Edfu. The image of the god here resided in the innermost chamber (the shrine-box) of the building. $A$ similar symbolism, though perhaps not so explicitly developed, probably lies behind the construction of the temples at Ugarit" (Nicholas Wyatt, "The Religion of Ugarit: An Overview," in Handbook of Ugaritic Studies, ed. Wilfried G. E. Watson and Nicolas Wyatt [Leiden: Brill, 1999], 533). Cf. also Margerite Yon, "Sanctuaires d'Ougarit," in Temples et Sanctuaires: Séminaire de Recherche sous la Direction de $G$. Roux, Travaux de la Maison de l'Orient 7 (Lyon: GIS-Maison de l'Orient, 
layouts of $\mathrm{ANE}$ temples in which an image of the deity was housed in the imnemost sanctuary."

Another aspect of El's temple that deserves comment relates to its function. Since the context portrays the goddess Anat coming to $\mathrm{El}$ in order to request that a temple be built for Baal, the tent of El functions as the place where the deity would make decisions and whence he would issue his decrees. This is reinforced by another text that reads as follows:

$i d k \cdot l t$ tripnm $\quad$ Now she heads out ' $m \cdot i l \cdot m b k \cdot n h m \quad$ For El at the springs of the Rivers qrb. apq thmtm Amid the streams of the deeps. $\operatorname{tgly} \cdot d d \cdot i l \cdot w t b u \quad$ She comes to the mountain of El and enters $q r \xi m l k \cdot a b \cdot s n m$ The tent of the King, the Father of Years. ${ }^{2}$

El's dwelling is depicted as being located "at the springs of the Rivers" (mbknhrm). Some scholars have advanced the view that the "springs of the Rivers" could be reminiscent of the subterranean waters, and therefore El's abode would be located

1984), 37-50.

'Several studies on the layout of ANE temples have revealed an inner sanctuary where the image of the deity was located. Cf., e.g., John M. Monson, "The Temple of Jerusalem: A Case Study in the Integration of Text and Artifact" (Ph.D. diss., Harvard University, 1998); Lawrence T. Geraty, "The Jerusalem Temple and its Near Eastern Context," in The Sanctuary and the Atonement: Biblical, Theological, and Historical Studies, ed. Arnold Valentin Wallenkampf, W. Richard Lesher, and Frank B. Holbrook (Silver Spring, MD: Biblical Research Institute, 1989), 37-62; G. R. H. Wright, "Pre-Israelite Temples in the Land of Canaan," Polestine Explorotion Quarterly 103 (1971): 17-32; Volkmar Fritz, "Temple Architecture: What Can Archaeology Tell Us About Solomon's Temple?," Biblical Archaeology Review 13, no. 4 (1987): 39-49; John M. Lundquist, "The Common Temple Ideology of the Ancient Near East," in The Temple in Antiquity: Ancient Records and Ancient Perspectives, ed. Truman G. Madsen, The Religious Studies Monograph Series 9 (Provo, UT: Brigham Young University, 1984), 53-76 (cf. esp. pp. 62-63, for a brief discussion of the holy of holies in Mesopotamian and Egyptian temples).

2Parker, 127 (KTU 1.4 IV 20-24). 
somewhere in the netherworid. 'Such a view, nonetheless, cannot be sustained upon closer examination. More likely, the phrase "springs of the Rivers" refers to the waters of paradise, the source of life-giving waters. ${ }^{2}$ Besides, it seems reasonable to suppose that since El was understood as the chief deity of the Ugaritic pantheon, ${ }^{3}$ he would be conceived of as living in some other place than the netherworld. As a matter of fact, Ugaritic literature discloses indications that El was located in heaven. ${ }^{4}$ From this place, "the center of the universe ... El exercises that vital restraining, but essentially benevolent providence (...) without which everything would collapse in chaos. ${ }^{15}$ El's dwelling place functions as the headquarters from where the chief god of the pantheon rules the universe. As noted by Clifford, the tent of El is always described in contexts of messengers or deities asking El's decision or taking orders from him. ${ }^{6}$ 104.

${ }^{1}$ Cf., e.g., Marvin H. Pope, El in the Ugaritic Texts, VTSup 2 (Leiden: Brill, 1955), 92-

${ }^{2}$ Clifford, The Cosmic Mountain in Canaan and the Old Testament, 50-51. Cf. Conrad E. l'Heureux, Rank among the Gods El, Ba'al, and the Repha'im, ed. Frank M. Cross, Harvard Semitic Monographs 21 (Missoula, MT: Scholars Press, 1979), 26-28.

${ }^{3}$ El also held a prominent position in the ancient South Arabic religion, as noted by Ulf Oldenburg, "Above the Stars of El: El in Ancient South Arabic Religion," ZAW 82, no. 2 (1970): 187-208.

${ }^{4} \mathrm{Cf}$., e.g., the following from Kirta epic: $20, s a \cdot y d k \cdot s m m \cdot d b h \cdot l \underline{s}$ abk il ["Lift your hands to heaven, sacrifice to Bull your father, El"] (KTU 1.14 il 20). The biblical expressions "EI

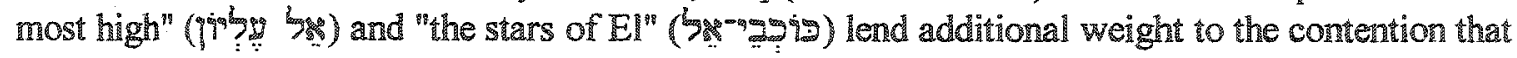
Ugaritic mythology most probably conceived of El's dwelling as located in heaven (or in some mythical place functionally equivalent to heaven).

5. L. Gibson, "The Theology of the Ugaritic Baal Cycle," Or 53 (1984): 210.

${ }^{6} \mathrm{Clifford}$, "The Tent of El and the Israelite Tent of Meeting," 223. 
Now, attention is turned to some of the references to the building of Baal's house, a major theme in the Baal cycle. After Baal's fighting and defeating Yam (Tablets 1-2), El granted the request of Athirat that a house be built for Baal. In gratitude for El's permission, Athirat extolls him and spells out her expectations of what Baal would accomplish from the termple as follows:

wnap. ${ }^{\circ}$ nn mith brl

$y^{c} d n \cdot{ }^{\top} d n n^{\top} t r(!) t \cdot b g l t$

wtn $q$ lh $\cdot b^{r} r p t$

šn-larș brqm
So now may Baal enrich with his rain, May he enrich with rich water in a downpour. And may he give his voice in the clouds, May he flash to the earth lightning.'

The words of Athirat seem to imply that Baal temple would be a source of fertility inasmuch as this temple would be the place from which Baal's royal self-disclosure would emanate in the form of rain, thunder, and lightning. Clifford has noted that "apparently, the cosmic function of Baal's temple is the subject. Baal's temple and kingship will bring fertility and cosmic harmony. If this is the function of the heavenly temple, it may also be the function of the earthly shrine which represents the heavenly sphere."2

Another text that deserves consideration is the section that describes the actual building of Baal's mythical palace as follows:

$[h \mathrm{~s} \cdot]$ bhth $t b r n$

Ihs.Jmmm helh

y[tl]k.llbrn'w'sh

I[sr]yn'mhmd arzh

h[n $\cdot l l b n n \cdot w^{\top} s h$

sryn'mhmd:arzh

tst[?]ist.bbhtm

$n b$ llat bhkm
[Quickly] he builds his house,

[Quickly] he erects his palace.

He [se]nds to Lebanon for its wood,

To [Sir]yon for its choicest cedar In[deed (?) to Le]banon for its wood, To Siryon for its choicest cedar.

A fire is set in the house,

A IIIJame in the palace.

'Parker, 129 (KTU 1.4 V 6-9).

${ }^{2}$ Clifford, The Cosmic Mountain in Canaan and the Old Testament, 106. 


\begin{tabular}{|c|c|}
\hline$h n[\cdot] y m \cdot w t m$ & There! for a day and a second, \\
\hline sikl istr.lohtm & A fire burns in the house, \\
\hline nble bhklm & A flame in the palace. \\
\hline tlt $r(!) b^{r} y m$ & For a third and a fourth, \\
\hline tikl[· i]st·bhtm & [A f]ire burns in the house, \\
\hline nbla[t-jbhklm & A flame in the palace. \\
\hline$h m x^{*} t[d] \underline{t} \cdot y m$ & For a fifth and a si[x]th, \\
\hline tikl ist. [b] htm & A fire burns [in] the house, \\
\hline nblt b[qrb-hk]lm & A flame a[mid the pa]lace. \\
\hline$m k b s ̌ b[c \cdot y[m m]$ & Then on the seventh-d[ay,] \\
\hline$t d \cdot i s t b b h t m$ & The fire leaves the house, \\
\hline$n[b l] t \cdot b h k l m$ & The flam]e, the palace. \\
\hline$s b \cdot k s p \cdot l r q m$ & The silver had turned to plates, \\
\hline hrss nsb.llbnt & The gold had turned to bricks. \\
\hline$\$ m h$ aliyn $b r l$ & Mightiest Baal rejoices: \\
\hline$<b>h t y \cdot b n t d t k s p$ & "My house I have built of silver, \\
\hline$h k l y[\cdot] \mathrm{dtm} h r s$ & My palace of gold." \\
\hline
\end{tabular}

The above-quoted text yields significant information about the nature and function of Baal's mythical abode. As for its nature, it must be noted that the work is described in very human terms. Earthly materials are used in its construction: wood from Lebanon, gold, and silver. A heavenly temple seems to be constructed with the same materials as if it were a palace of a human king. ${ }^{2}$ However, at the same time a supernatural tone is struck when it is stated that fire contributed to the completion of the work. Elsewhere it is also stated that the house had gigantic dimensions, ${ }^{3}$ was made of clouds, ${ }^{4}$ and had a window described as a rif in the clouds (bdqt 'rpt). ${ }^{5}$ An additional detail indicates that Baal's

"Parker, 133-34 (KTU 1.4 VI 16-38).

${ }^{2}$ Korpel, 375.

${ }^{3}$ Parker, 132 (KTU 1.4 V 56-57).

${ }^{4}$ Ibid., 136 (KTU 1.4 VII 17-20).

5Ibid. 
temple is far beyond any human king's mansion. This temple contains eight rooms in which Baal does not store ordinary earthly treasures, but thunder, lightning and snow.'

Therefore, it may be concluded that although the description of Baal's heavenly ${ }^{2}$ palace is made against the backdrop of his earthly temple located in the city of Ugarit, ultimately, it seems that the earthly language intends to convey the idea of the deity's heavenly/mythical abode. Another possibility is that the myth refers to both earthly and heavenly/mythical temples at the same time, as Stoltz has suggested. ${ }^{3}$ Thus, the mixing of earthly and heavenly elements seems to operate as a kind of connection between the earthly temple and its heavenly archetype.

At this juncture, one should note that the correspondence between earthly and heavenly temples seems to be substantiated by the correlation of the literary description of Baal's temple with the archaeological data. The literary description attests that one of the interesting features of Baal's palace was a window. Although rejecting it at first, Baal eventually reverses his decision and allows Kothar to make the window in the house.

'KTU 1.101:3ff; KTU 1:4 VI 59f. (restored on the basis of KTU 1.8: Il.13). Cf. Korpel, 375, n. 76.

${ }^{2}$ The fact that Baal is a storm-god indicates that he is a celestial deity, and therefore his mythical temple is located in heaven.

${ }^{3}$ Fritz Stoltz, ed., Funktionen und Bedeutungsbereiche des ugaritischen Ba' alsmythus, Funktionen und Leistungen des Mythos (Göttingen: Vandenhoeck \& Ruprecht, 1982).

${ }^{4}$ Wyatt, Religious Texts from Ugarit, 106, n. 147.

${ }^{5}$ This has been understood as the opening of the clouds through which the rain would fall (Norman Habel, Yahweh versus Baal: A Conflict of Religious Cultures INew York: Bookman Associates, 1964], 77). $\mathbb{T}$. Gaster has made the interesting suggestion that this incident reflects an actual rain-making ceremony at the Baal temple of Ugarit in which the windows of the temple roof were opened "to simulate the opening of the windows of heaven" (Theodor H. Gaster, Thespis: 
Now, it is worth noting that the temple of Baal uncovered during the excavations at Ras

Shamra had a window in the roof, as had Baal's mythical temple on Mount Zaphon.

Therefore, it seems reasonable to assume that Ugaritic religion understood the earthly

temple to be "the counterpart of Baal's heavenly abode."2

In the sequence of the narrative, the royal functions of Baal's temple become apparent, as can be perceived from the following passage:
$b \mathrm{~km} \cdot y+b \cdot b \mathrm{l} \cdot \mathrm{lbhth}$
So Baal is enthroned in his house:
$u m l k \cdot u b m l k /$
Will either king or commoner
arṣ. drkt yškn
Establish a land of dominion?

In this connection Lokkegaard expressed the view that "the house is meant as a step towards absolute power, as a token of supremacy, ${ }^{n 4}$ and Clifford argued that "the palace is central. It is a concrete symbol of kingship." That kingship is a major function of Baal's

Ritual, Myth, and Drama in the Ancient Near East, rev. ed. [New York: Harper and Row, 1965], 195. It must be noted that Gaster's view is based on a ritual interpretation of the Baal cycle that has been criticized by several scholars. For a summary of these criticisms, cf. Mark Smith, "Interpreting the Baal Cycle," UF 18 [1986]: 317). A brief sampling of suggestions may be instructive: U. Cassuto argued that Baal refused the window because he feared Mot would enter. through it (Biblical and Oriental Studies, 2:135). De Moor suggested that the window represented the coming of the rains (The Seasonal Pattern in the Ugaritic Myth of Ba'lu, 162-63). For $\mathrm{L}$. Fisher, the building of Baal's house and window represented the creation of the universe (L. Fisher, "Creation al Ugarit and in the Old Testament," VT 15 [1965]: 313-24). For a summary of these and some other views, c1. Mark Smith, "Interpreting the Baal Cycle," UT 18 (1986): 313-39.

${ }^{3}$ Cf. Claude F. A. Schaefer, The Curneiform Texts of Ras Shampa-Ugarit (London: Oxford University Press, 1939), 66f?.

2F. Lokkegaard, "The House of Baal," AcOr 22 (1955): 17.

3Parker, 137 (KTU 1.4 VII 42-44).

${ }^{4}$ Lokkegaard, 17.

${ }^{5}$ Richard J. Clifford, "Cosmogonies in Ugaritic Texts and in the Bible," Or 53 (1984): 197. 
palace is made explicit by the following statement in which Baal himself claims that "I myself am the one who reigns over the gods" (ahdy dymlk. $₹ \mathrm{l} \cdot \mathrm{ilm}) .^{1}$ After the construction of his palace, Baal offers a banquet to all the gods. Subsequently, he marches through numerous cities and, in thunder, proclaims his kingship from his palace.

\section{Summary}

From the survey of Ugaritic texts undertaken above, the following picture of the heavenly/mythical sanctuary emerges: Although there are allusions to dwellings of the deities located in heaven, the texts dealing with El's dwelling and Baal's temple locate the abode of these deities in mythological places - the "springs of the rivers," and Mount Saphon, respectively. The following functions of the heavenly/mythical temple can be perceived from this study: A place of divine activities of decision whence the deity issues decrees and judgments affecting the earthly and cosmic sphere. The heavenly/mythical temple also seems to function as a source of fertility and a token of kingship, which is made especially clear in the report about the construction of Baal's temple.

Ugaritic texts also attest the idea of a relationship between the heavenly/mythical temple and its earthly counterpart. As the correlation between the literary and archaeological data indicates, a structural correspondence emerges in connection with the "window" of Baal's temple. The textual data also seems to indicate a dynamic relationship, inasmuch as incense offered in an earthly sanctuary goes up to heaven, which suggest

${ }^{1}$ Parker, 137 (KTU 1.4 VII 40-50). 
some kind of dynamic relationship between the heavenly temple/sanctuary and its earthly counterpart.

\section{Egyptian Literature}

Egyptian texts display a variety of notions regarding the sanctuary/temple motif. Apart from the obvious concept of the earthly/historical temples, Egyptian texts portray concepts such as a sanctuary/temple in heaven, in the underworld, 'or in some undetermined mythical realm. The idea also emerges of a primeval sanctuary ${ }^{2}$ which was

\footnotetext{
'The Book of the Dead contains several references to the judgment hall (Thomas George Allen, The Book of the Dead or Going Forth by Day: Ideas of the Ancient Egyptians Concerning the Hereafter as Expressed in Their Own Terms, Studies in Ancient Oriental Civilization 37 [Chicago: Oriental Institute of the University of Chicago, 1974], 22 [Spell 15B3]), double sanctuary (ibid., 175), broad hall of Geb (ibid., 204, Spell 185a.), and underworld offerings (ibid., 217, Spell Pleyte 167) which possibly refer to the underworld shrine(s) where the council of the gods would undertake the judgment of the dead. A major motif in the Egyptian texts is that of an underworld tribunal where a council of gods presided over by Osiris would decide whether the person was worthy of eternal life (Stephen Quirke, "Iudgment of the Dead," in The Oxford Encyclopedia of Ancient Egypt, ed. Donald B. Redford [Oxford: Oxford University Press, 2001], 2:211-14). Worthy of attention at this juncture is the "hall of the two truths" (ibid., 97, 101, Spell 125a). This refers to the netherworld shrine at one end of which Osiris sits upon a throne to perform the judgment of the dead (Alan W. Shorter, The Egyptian Gods: A Handbook [London: K. Paul, Trench, Trubner and Co., 1937], 52). An assembly of gods was supposed to be present in the course of this judgment. Special reference is made to the forty-two gods in whose presence the deceased person had to deny having commitsed forty-two specified sins (for a list of the forty-two gods and the corresponding list of sins to be denied by the deceased person, cf. Thomas George Allen, 98-99, Spell 125b) in order to be acquitted. Thus, a major function of the netherworld sanctuary was one of judgment. In this connection, it should be noted that Egyptian religious texts are similar to their ANE counterparts, except that the Egyptians placed greater emphasis on a judgment located in the netherworld (this is not to deny that the other ANE texts postulated the existence of the netherworld. My contention is that Egyptian religious texts seem to give more weight to this concept of judgment performed in the netherworld realm than the other ANE literature).
}

${ }^{2}$ Some texts allude to the concept of a primeval or cosmic temple. In these texts, the prototypical temple is not depicted as an entity located in heaven, but projected back into the mythical past. This archetypical temple is identified with the first spot to emerge from the waters when the world was created. In a study about the Egyptian temple, Reymond notes that "in some Pyramid texts of the $V$ dynasty, the Earth in its earliest shape was pictured as a mound which 
founded upon the first mound when the world began. In latter times even the world came

to be conceived as a sanctuary. In the ensuing discussion, the major focus is on the first of

emerged from the primeval water. This mound was considered a divine being and as the original terrestrial configuration on which the creator, Atum, dwelt and from which he created the four tangible divine beings" (E. A. E. Reymond, The Mythical Origin of the Egyptian Temple [Manchester: Manchester University Press, 1969], 59). Additionally, the Edfu texts refer to the houses of the gods in the primeval age as prototypes of the historical temples (ibid., 44). These temples are deemed to be the work of the gods and appear to be conceived as actual, physical entities (ibid., 45). As Reymond further notes, "This short record seems to indicate a belief in a historical temple that was a direct continuation, projection, and reflection of a mythical temple that came into existence at the beginning of the world" (ibid., 4).

'It has been pointed out that in later Ptolemaic times the Egyptians began to see the temple as a microcosm of the world (Harold Nelson, "The Egyptian Temple," in The Biblical

Archaeologist Reader, ed. G. Ernest Wright and David Noel Freedman [Boston: American Schools of Oriental Research and Scholars Press, 1975], 150). The holy of holies was seen as the mound which arose from the primeval waters, the floor was conceived as the earth, its ceiling is painted blue for the sky (ibid., 151.4). These developments noted by Nelson are further corroborated by the inscriptions of the pious pilgrim later carved on the temples of the $18^{\text {th }}$ dynasty. One of these inscriptions reads as follows: "The scribe N. came in order to see the beautiful temple of King Snefru. He found it like a heaven in its interior, in which Rê would come out and say: The heaven showers fresh myrrh, it drips frankincense on the roof of the temple of King Snefru" "Der Schreiber N. kam, um den schönen Tempel des Königs Snefru zu sehen. Er fand ihn (d.h. den Temple) wie einen Himmel in seinem Inneren, indem Rê darin ausging, und sagte: Es regnet der Himmel frische Myrrhen, er tröpfelt Weihrauch auf das Dach(?) des Tempels des Königs Snefru" (W. Spiegelberg, "Die Auffassung des Temples als Himmel," ZÄS 53 [1917]: 99).

Furthermore, it is worthy of note that this concept left its mark in the Egyptian language itself, since the Egyptian word for "shrine" ( $3 w y-p t)$ has the meaning of "doors of heaven" (cf. Jaroslav Cemy, "Note on (3wy-pt," JEA 34 (1948): 120; Edward Brovarski, "The Doors of Heaven," Or 46 [1977]: 107-115. As Morenz observed, "In particular the shrine of the deity is simply called 'heaven', or with an eye to its doors 'the doors of heaven'" (Siegfried Morenz, Egyptian Religion [thaca, NY: Comell University Press, 1973], 88). Probably this is the meaning of the following passage from the daily ritual of the temple of Amun in Karnak: "The doors of heaven are open. The doors of the earth are opened. Hail to Geb, as the gods have said, established on their thrones. The doors of heaven are opened so that the Ennead might shine" (COS, 1:56). These qualifications of the earthly temples as "heaven" might well stem from the belief that the earthly temple was considered to be "a replica of a pattern in heaven" (N. Wyatt, Space and Time in the Religious Life of the Near East, The Biblical Seminar 85 [Sheffield: Sheffield Academic Press, 2001], 185). 
these ideas--the heavenly-sanctuary/temple motif-the notion of sanctuary/temple located in heaven. ${ }^{1}$

\section{Pyramid Texts}

The following passage comes from a so-called "ascension" text. The relevant portion reads as follows: ${ }^{1}$

As for any god who will take me to the sky, may he live and endure; bulls shall be slaughtered for him, forelegs shall be cut off for him, and he shall ascend to the mansion ${ }^{2}$ of Horus which is in the sky; but as for any god who will not take me to the sky, he shall not have honour, he shall not possess a leopard-skin, he shall not taste $p 3 k$-bread, and he shall not ascend to the Mansion of Horus which is in the sky on that day when judgment is made $[\ldots]_{0}^{3}$

It is interesting to note that the "mansion of Horus" is related to the activity of judgment. This is close to other ANE literature where the heavenly temple is portrayed as a place of judgment. The following text seems to portray a correspondence between heavenly and earthly realities: "My house in the sky will not perish, my throne on earth will

${ }^{1}$ It is generally assumed by scholars that the earliest home of the gods in Egyptian thought is the sky, where is also located the home of the blessed. Cf. Raymond Oliver Faulkner, The Ancient Egyptian Pyramid Texts (Oxford: Clarendon Press, 1969), 243-24, Utterance 106; Erik Hornung, Conceptions of God in Ancient Egypt: The One and the Many, trans. John Baines (Ithaca: Cornell University Press, 1982), 227; Samuel A. B. Mercer, "Heaven, and How to Get There in the Pyramid Texts," in The Pyramid Texts, ed. Samuel A. B. Mercer (New York: Longmans Green, 1952), 1-6.

${ }^{2}$ Egyptian texts use a variety of words to convey the concept of a sanctuary/temple, as can be perceived by the translations. Terms such as mansion, shrine, broad hall, castle, and house are used in the texts to convey the heavenly-sanctuary/temple motif, a phenomenon also noted by Nam in his study of the throne motif in the Egyptian texts. Cf. Daegeuk Nam, "The 'Throne of God" Motif in the Hebrew Bible" (Th.D. diss., Andrews University, 1989), 104, n. 1.

${ }^{3}$ Faulkner, 172 , Utterance 485. 
not be destroyed." In this spell, the deified king claims to have a house in the sky and a corresponding throne on earth, which probably should be identified with the living king on the throne of Egypt. ${ }^{2}$

Another interesting feature of the heavenly-temple motif is portrayed by the following text: "I am the $d h 3 i$ of the gods who is behind the Mansion of $\operatorname{Re}($, born of 'prayer-of-the gods' who is in the bow of the bark of Re'. I sit before him, I open his boxes, I break open his edicts, I seal his dispatches, I send out his messengers who do not grow weary, and 1 do what he says to me..$^{13}$ The "Mansion of $\mathrm{Re}^{(")}$ is depicted as a royal palace whence the god performs his administrative duties and governs his realm. A related text also seems to refer to some cultic activity when it states of the King that "His bread offering is up above with $\operatorname{Re}^{(114}$

\section{Coffin Texts}

The coffin texts provide several references to a heavenly or mythical sanctuary of the god(s). The following passage displays an interesting allusion to the heavenly sanctuary/temple motif: "O my soul, my spirit, my magic and my shade, open the doors of the sky, throw open the gates of heaven, may your ornament be secured on yourself so

Ubid., $91-92$, Utterance 302.

${ }^{2} \mathrm{C}$. Vincent Arieh Tobin, Theological Principles of Egyptian Religion (New York: $\mathbb{P}$. Lang, 1989), 89-124.

${ }^{3}$ Faulkner, 96, Utterance 309.

${ }^{4}$ Ibid., 68, Utterance 258. 
that you may enter to the great god who is in his shrine and see $\operatorname{Re}^{(}$in his true shape." Another text alludes to the heavenly shrine of $\operatorname{Re}^{\prime}$ as the place where divine beings praise him:

O Re', great in your shrine, exalted on your pedestal, may you fare southward to the Great Place, may you moor at the very great plain to the south of the horizon of the sky, may you take your seat on it, may praise be given to you by all the gods who are in the sky, the lords of the horizon of the sky, who are upon the upper sky, may these please you every day. ${ }^{2}$

The mythical sanctuary of Thoth is depicted as the place where the deity receives praises and offerings, as the following passage makes clear: "Thoth goes forth in his brightness with his ritual-book in his hands, and praise is given to him, offerings are presented to him by those who are in the great castle [. . . .".3

The heavenly or mythical temple is also depicted as a source of help, as can be perceived in the following quotation: "O Atum who are in the Great Mansion. Sovereign of the Ennead, save me from that god who lives by slaughter, whose face is that of a hound and whose skin is that of a man." ${ }^{4}$

Some passages reveal that the most important activity occurring in the heavenly or mythical temple is related to judgment, as perceived in the references to the "Great

1Raymond Oliver Faulkner, The Ancient Egyptian Coffin Texts (Warminster, England: Aris and Phillips, 1973), 2:134, Spell 492.

${ }^{2}$ bid., 2:137, Spell 498 .

3bid., 3:96, Spell 985.

${ }^{4}$ Ibid., 1:265, Spell 335, Part II. 
Tribunal of the Sky"1 and to "tribunals which are in the sky and upon the waters." The following passages further illuminates this aspect. One text states that the "(soul of the deceased) may go up and see the great god $\operatorname{Re}^{(}$within his shrine on the day of reckoning up all souls, all spirits, all shades and all [magic(?)]. ${ }^{13}$ The text seems to imply the belief in a day of judgment to be performed in the heavenly shrine of $\operatorname{Re}^{l}$. The concept occurs in other passages: "As for him who knows this word of God, he shall be in the sky with $\operatorname{Re}^{(}$ among the gods who are in the sky, and vindication shall be given to him in every tribunal into which he goes down." "I will speak of the requirements of this Great One of yours who is in his shrine, and he will speak and induct himself into the tribunal in company with the Ennead which is about his shrine. ${ }^{\circ 5}$ Thus, the heavenly or mythical sanctuary/temple is depicted in these texts mostly as a place where the activity of judgment is performed.

\section{Book of the Dead}

Along with the ideas noted above, the Book of the Dead seems to be aware of an earthly/heavenly correspondence, as the following passage from the Book of the Dead shows: "Osiris triumphs against his enemies, and Osiris N. triumphs before the great Council in the sky and before the great Council in the earth." Although no explicit

IIbid., 2:208, Spell 625.

2Tbid., 3:11, Spell 820 .

${ }^{3}$ Ibid., 2:138, Spell 499.

${ }^{4}$ Ibid., 2:225, Spell 651 .

5ibid., 3:9, Spell 818 .

${ }^{6}$ Thomas George Allen, 103, Spell 127:1. 
reference is made to a heavenly temple/sanctuary, the text seems to presuppose some kind of correspondence between an earthly council and a heavenly one that might have obtained for the sanctuary as well.

\section{Other Texts}

A hymn to Amon depicts the deity as "Har-akhti who is in the heaven." In some monumental inscriptions the deity is referred to as "Lord of heaven." "Lady of Asheru, Lady of heaven, is probably a reference to the Asherah of Canaanite mythology, since this is found on a stela that commemorates Sethos I's campaign to Yenoan and Lebanon. ${ }^{3}$ In the same inscription mention is made of "Neferhotep, the great god, Lord of Heaven."

Heaven is also depicted as the place of residence of the Ennead, which, in some texts, is portrayed as a judgment council..$^{5}$ In a text probably inspired by Canaanite mythology, Astarte decides "to go to the Ennead to the place where they were gathered." Although this text does not specify where this place is located, another text, which

Tbid., 369.

${ }^{2} \cos , 2: 25$.

${ }^{3}$ Ibid., 27.

${ }^{4}$ bid.

${ }^{5}$ The Emnead consisted of the sun-god creator and his descendants. In the Pyramid texts, however, the two Enneads represent all the gods of Egypt. The Ennead is also portrayed as a judgment council in both mythology and historical inseriptions. Cf. George Hart, A Dictionary of Egyptian Gods and Goddesses (London: Roulledge and Kegan Paul, 1986), 65-66; B. van de Walle, "L'Ennéade d'Héliopolis dans les Textes des Pyramids-Excursus II," in The Pyramid Texts, ed. Samuel A. B. Mercer (New York: Longmans Green, 1952), 4:6-18.

${ }^{6} \mathrm{C}$. $\cos , 1: 35$.

7ibid. 
expresses the reaction about the victory of Horus over Seth, seems to locate the Ennead in heaven-"The Ennead is in Jubilee, and heaven is in joy."1 The Ennead, or council, in heaven is reminiscent of the heavenly council motif found in other ANE texts.

It is instructive to note that one Egyptian text seems to imply that the statues of the Ennead of gods dwelling in the temple of Abydos were counterparts of those in heaven, as the following quotation seems to convey: "The standards thereof were of electrum, more excellent than their predecessors; more splendid were they than that which is in heaven;, more secret were they than the fashion of the nether world; more-were they than the dwellers in Nun."3

Possible allusions to the heavenly-sanctuary/temple motif are found in the hymn to Amun-Re. In this poetic work the deity is referred to as "Lord of heaven," and also as the one "whose shrine is hidden" and "grand of appearances in the Mansion of Benben." In a probable reference to Amon-Re's activity as judge in the contest between Seth and Horus,

'ANET, 17. It should be noted, however, that in "The Great Hymn to Osiris," the Ennead gathers in the hall of Geb, a chthonic deity. Cf. COS, 1:42.

${ }^{2}$ The expression "that which is in heaven" by itself is ambiguous and may refer to either the gods, or images thereof, located in heaven. However, the last clause of the text which likens these statues to the "dwellers of Nun" suggests that those statues in Abydos were counterparts of the deities who dwelled in heaven.

${ }^{3}$ James Henry Breasted, Ancient Records of Egypt: Historical Documents from the Earliest Times to the Persian Conquest, 5 vols. (Chicago: University of Chicago Press, 1906), 2:39, par. 95 (emphasis supplied).

${ }^{4} \mathrm{COS}, 1: 38$.

5rbid.

IIbid., 39. 
the hymn refers to Amon as the one "who judges the two contestants in the great broad hall." The reference to the "broad hall" as place of judgment recalls Osiris's activities of judgment in the underworld shrine. Additionally it must be noted that the phrase used to qualify Amun-Re as the one "whose shrine is hidden" followed by "the mansion of Benben" points to an extramundane sphere as the place where the deity carries out his activities. That "mansion of Benben," understood as the primordial mound first risen from the Abyss, ${ }^{2}$ may further reinforce the possibility that what is in view in these references is a heavenly/mythical sanctuary.

\section{Summary}

Although in a few cases it was difficult to determine whether the sanctuary/temple referred to in the Egyptian texts was conceived as being located in heaven or in some mythical place, the following considerations attempt a synthesis of the main ideas. The heavenly sanctuary emerged from these texts as a place of divine activities, that of judgment being the most prominent one. Egyptian texts also depict the heavenly temple as a place of cultic activities (like praises and offerings), possibly as the locus for the judgment council; and interestingly enough, it was also portrayed as a source of help, a motif virtually absent from other ANE texts. Finally, it should be noted that the texts surveyed above also convey the notion of a vertical correspondence between the heavenly temple and its earthly counterpart.

'Ibid., 40 .

${ }^{2}$ Ibid., 39, n. 12. 


\section{Conclusion}

The sampling of Sumerian, Akkadian, Hittite, Ugaritic, and Egyptian texts surveyed above allows the following synthesis of the heavenly-sanctuary/temple motif in the ANE. As for the function of the heavenly sanctuary/temple, we noted that in addition to serving as the dwelling of the deities, it is conceived as a place for the following divine activities:

1. Judgment and administration of the world/cosmos-from the heavenly temple the deity issues decrees and makes decision affecting the world/cosmic order. It thus functions as a kind of command center or headquarters for the administration of the earth/cosmos.

2. Meeting place for the divine assembly - the heavenly sanctuary is also conceived as the meeting place for the divine assembly, where the council of the gods would make decisions affecting the earthly/cosmic realm.

3. Cultic activities-some texts also suggest the heavenly temple as a place where cultic activities could take place. At least one text alludes to prayers being directed towards the heavenly temple.

4. Token of kingship-the heavenly temple also emerges as a token of kingship and a sign of power.

As for the relationship between the heavenly temple and its earthly counterpart(s), the following picture emerged. Overall, ANE texts seem to entertain the notion of a functional and structural correspondence between the earthly and heavenly sanctuaries. The textual indications seem to be corroborated by the graphic depiction, as observed 
above in the excursus on Nabuapaliddina's Relief, which conveys the notions of heavenly and earthly sanctuaries functioning in dynamic interaction. 


\title{
CHAPTER 3
}

\section{THE HEAVENLY SANCTUARY/TEMPLE MOTIF}

\author{
IN THE TORAH
}

This chapter investigates the following passages which were found to contain the heavenly sanctuary/temple motif in the Torah: Gen 11:1-9; 28:10-22; Exod 15:1-18;24:9$11 ; 25: 9,40 ; 32-34$; and Deut 26:15. Although, it is hoped that these texts represent a comprehensive inventory of this motif in the Torah, they are not intended to be exhaustive. Future study may well uncover the heavenly sanctuary/temple motif in other texts. Since this study is mainly concerned with the heavenly sanctuary/temple motif, the exegetical procedures to be followed are aimed at this goal. Other themes and motifs contained in the passages under investigation will receive attention only to the extent that they contribute to clarifying the main topic of this research.

\section{Gen $11: 1-9^{1}$}

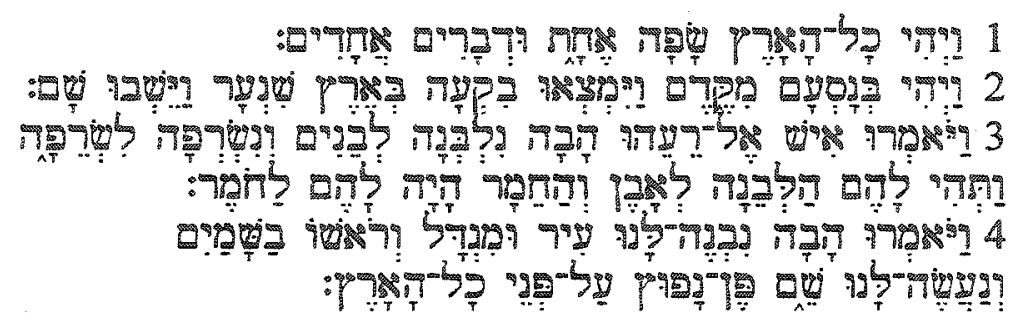

${ }^{1}$ Translation of biblical texts follows closely the wording of the NASB, which is sometimes modified to reflect a more literal translation of the Hebrew text. 


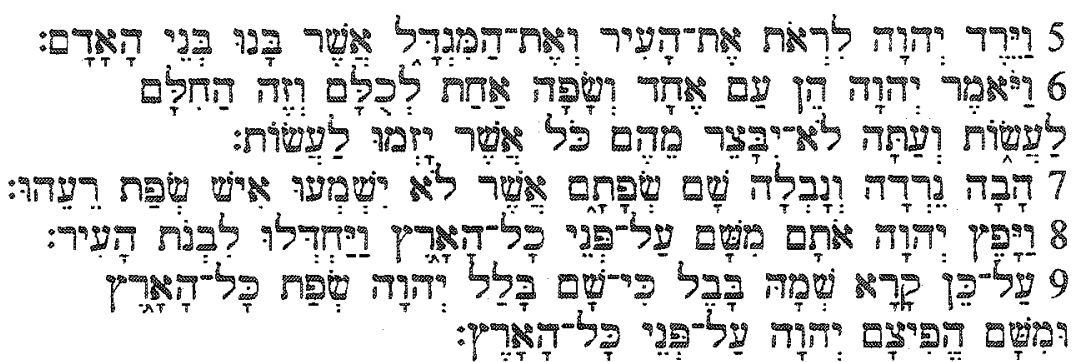

1 Now the whole earth used the same language and the same words.

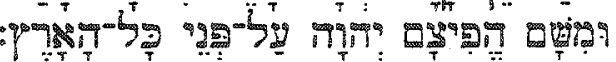

2 It came about as they journeyed east, that they found a plain in the land of Shinar and settled there.

3 They said to one another, "Come, let us make bricks and burn them thoroughly." And they used brick for stone, and they used tar for mortar.

4 They said, "Come, let us build for ourselves a city, and a tower with its top into heaven, and let us make for ourselves a name, otherwise we will be scattered abroad over the face of the whole earth."

5 YHWH came down to see the city and the tower which the sons of men had built. 6 YHWH said, "Behold, they are one people, and they all have the same language. And this is what they began to do, and now nothing which they purpose to do will be impossible for them.

7 "Come, let us go down and there confuse their language, so that they will not understand one another's speech."

8 So YHWH scattered them abroad from there over the face of the whole earth; and they stopped building the city.

9 Therefore its name was called Babel, because there YHWH confused the language of the whole earth; and from there YHWH scattered them abroad over the face of the whole earth.

\section{Preliminary Observations}

The story of Babel comes almost at the end of the prepatriarchal history (Gen 1-11), with its description of how/why the multiplicity of languages upon the earth came into being. Since Gen 10 had already described the diversity of peoples and their distinct languages (vss. $5,20,31$ ), it is reasonable to suppose that this is a case of "deliberate dischronologization," since this pericope describes events belonging within the beginning

'Victor P. Hamilton, The Book of Genesis: Chapters 1-17 (Grand Rapids, MI: Eerdmans, 1990), 350. 
of chap. 10. This "chronological displacement" should probably be explained on the grounds of the "literary artistry" of the primeval history, in which blocks of narrative materials are bracketed by genealogies, as has been suggested by Victor P. Hamilton. ${ }^{2}$

The boundaries of the pericope are clearly established by the expression which occurs at the beginning and at the end of the narrative, thus forming an inclusio. As for its structure, the text may be divided into two parts: Vss. $2-4$, deliberations of men; vss. 5-8, deliberations and actions of YHWH; vss. 1 and 9 are introduction and conclusion, respectively. A more complex structure arranged as a palistrophe with its center at vs. 5 has been perceived by some scholars. ${ }^{3}$ According to this structure, the clause "YHWH came down" (vs. 5) marks the turning point of the narrative as displayed below.

${ }^{1}$ For a study on the phenomenon of chronological displacement in Mesopotamian, biblical, and postbiblical literature, cf. David A. Glatt, Chronological Displacement in Biblical and Related Literatures (Atlanta, GA: Scholars Press, 1993).

${ }^{2}$ Hamilion argues that the opening chapters of Genesis are characterized by narrative blocks bracketed by genealogies:

(1) (a) 5:32 genealogy (Noah's sons)

(b) 6:1-8 narrative (the son's of God)

(a') 6:9-10 genealogy (Noah's sons)

(2) (a) 6:9-10 genealogy (Noah's sons)

(b) 6:11-9:17 narrative (the Flood)

(a') 9:18-19 genealogy (Noah's sons)

(3) (a) 10:21-31 genealogies (Shemites)

(b) 11:1-9 narrative (Tower of Babel)

(a) 11:10-32 genealogy (Shemites)

Hamilton, The Book of Genesis: Chapters 1-17, 350.

3J. P. Fokkelman, Narrative Art in Genesis: Specimens of Stylistic and Structural Analysis, 2nd ed. (Sheffield, England: JSOT Press, 1991), 22; Isaak M. Kikawada, "The Shape of Genesis 11:1-9," in Rhetorical Criticism: Essays in Honor of James Muilenburg, ed. Jared J. Jackson and Martin Kessler (Pittsburgh: Pickwick Press, 1974); Gordon J. Wenham, Genesis 1-15 (Waco, TX: Word Books, 1987), 235. 
A "The whole earth had one language" (vs. 1)

B "there" (vs. 2)

C "each other" (vs. 3)

D "Come let us make bricks" (vs. 3)

$\mathrm{E}$ "let us build for ourselves" (vs. 4)

F "a city and a tower"

G "VHWH came dow ..." (vs s

$F^{1}$ "the city and the tower"

$\mathrm{E}^{1}$ "which mankind had built"

$\mathrm{D}^{1}$ "come... let us mix up" (vs. 7)

$C^{1}$ "each other's language"

$\mathrm{B}^{1}$ "from there" (vs. 8)

$A^{1}$ "the language of the whole earth" (vs. 9).

\section{Semantic and Other Exegetical Considerations}

Gen $11: 1-9$ contains a few interpretative issues that call for investigation in order to provide the backdrop against which the heavenly sanctuary/temple motif may be perceived. The following points will receive attention in the ensuing discussion: First, the nature of the sin of the builders; second, the nature and purpose of the tower; third, the meaning of several words and expressions; fourth, the relationship of the text under scrutiny to the broad context of the book of Genesis. A clarification of these issues is called for in order to ascertain the presence of the heavenly sanctuary/temple motif in the pericope under study.

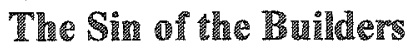

Upon closer examination the text provides verbal and conceptual clues that point to the nature of the sin of the builders. The text says they wanted to make a "name" (avi) for themselves, as 11:4a makes clear: "Come, let us build for ourselves a city, and a tower 
whose top will reach into heaven, ${ }^{1}$ and let us make for ourselves a name ("שvi)." The lexeme voj connotes the idea of "fame," "reputation," in 11:4. In the primeval history, wet also appears in Gen $6: 4,{ }^{2}$ where the progeny of the mixed marriages between the "sons of

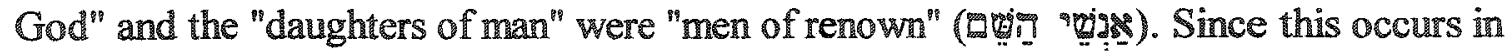
the preface to the flood and depicts a situation that prompts YHWH to send the judgment of the flood upon humankind, it is reasonable to suppose that con in this passage conveys a negative connotation which by virtue of the context is associated with arrogance and desire to avoid accountability to $\mathrm{YHWH}^{3}$

The injunctive clause a $11: 4$ requires some investigation. The noun 6 is used in the Hebrew Bible in syntagmatic relationship with several verbs. ${ }^{4}$ It has been noted that when 200 is used with "rigreg, "it is confined to the king, and to YHWH, working wonders in Egypt." The expression as

${ }^{1}$ This reminds one of the temple of Esagila which means, in Sumerian, "the structure with upraised head" (Ephraim Avigdor Speiser, Genesis [Garden City, NY: Doubleday, 1964], 75). See more on this below.

20.6 ("name") occurs about 14 times in the "primeval history" (Gen 1-11). Twelve occurrences carry the "normal" lexical denotation of a word or phrase by which a person, thing, or class of things is known, called, or spoken to or of, while the other two occurrences carry the connotation of "reputation" (11:4) and "renown" (6:4). See Ludwig Köhler and others, The Hebrew and Aramaic Lexicon of the Old Testament (HALOT), trans. and edited under the supervision of M. E. J. Richardson, 5 vols. (1994), S.v. "ge."."

${ }^{3}$ Frank Anthony Spina, "Babell," Anchor Bible Dictionary (ABD), ed. David Noel Freedman (New York: Doubleday, 1992), 1:562.

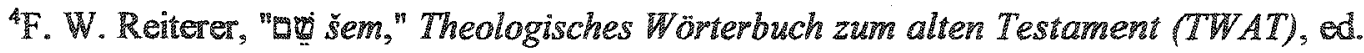
G. Johannes Botterweck und Helmer Ringgren (Stuttgart: W. Kohlhammer, 1973-97), 10:152-74.

${ }^{5}$ Claus Westermann, Genesis 1-11: A Commentary (Minneapolis: Augsburg, 1984), 548. Cf. 2 Sam 7:9; 8:13; Jer 32:20; Isa 63:12, 14; Dan 9:15; Neh 9:10; also Josh 7:9 with modification. 
applied to the builders of the tower of Babel (11:4) thus connotes rebellion against, or usurpation of, YHWH's prerogatives. Therefore, that the builders of the tower were eager to make a "name" attests to their defiant attitude and their willingness to challenge

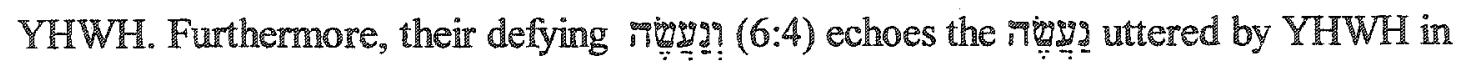

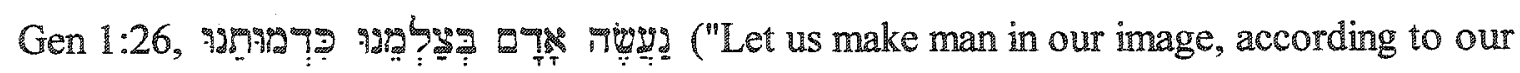
likeness"). It seems clear, on the basis of verbal connections and allusions, that the builders of the "city and tower" were usurping YHWH's prerogatives. "To make a name" is YHWH's own prerogative to be conferred on those whom he chooses, as demonstrated by Gen 12:3 - And I will make you a great nation, and I will bless you, and make your name (ๆ?: great; and so you shall be a blessing." The reader thus learns that what the builders of Babel wanted to achieve by their own efforts, YHWH bestowed freely on his servant Abram.

One should also note that the negative purpose clause in 11:4 Pansi the attitude and motives behind the whole enterprise. The "preventive conjunction" q ("lest") which introduces the clause expresses tear or precaution, ${ }^{2}$ and indicates a negative wish of the speaker or speakers. ${ }^{3}$ It indicates that the building project, in addition to contributing to their reputation, was intended to prevent their being scattered upon the

"HALOT, s.v." "Y."."

${ }^{2}$ Ronald James Williarns, Hebrew Syntax: An Outline, 2nd ed. (Toronto: University of Toronto Press, 1976), 75.

${ }^{3}$ Paul Joilon and T. Muraoka, A Grammar of Biblical Hebrew, 2 vols., Subsidia Biblica 14/1-14/2. (Rome: Editrice Pontificio Istituto Biblico, 1996), 2:635. 
face of the earth. Although no explicit reason is given for this fear inside the narrative, ${ }^{1}$ it is probable that the scattering to be avoided was related to YHWH's command reported to post-flood humanity, ${ }^{2}$ or a fear of another flood or some such disaster. ${ }^{3}$ If this is so, the building project also represented a deliberate and willful act of disobedience against YHWH, and lack of trust in YHWH's promise that there would not be another Flood.

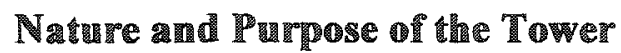

Two suggestions have been advanced by scholarship regarding the nature and purpose of the tower. On the one hand, the vast majority of scholars suggests that the tower was a ziggurat; on the other hand, there are some who argue that the tower was meant to be only a fortification. ${ }^{4}$ The implication of these views for the present study can be stated at the outset. If the tower was intended to be simply a fortification, it is improbable that the passage would contain any allusion to the heavenly sanctuary/temple motif. However, if a ziggurat is intended, it is highly possible that the narrative of Gen 11:1-9 alludes to the heavenly sanctuary/temple motif. ${ }^{5}$ Since this aspect relates directly to

"Paul Borgman refers to the "fear of being 'scattered over all the earth" and likens Babel to a neighbourhood full of Cains, Lamechs, Eves and Adams--a grouping together of anxious individuals" (Genesis: The Story We Hoven' Heard [Downers Grove, IL: Inter Varsity Press, 2001], 36-37).

"Be fruitful and multiply, and fill the earth" (Gen 9:1). Cf. Umberto Cassuto, $A$ Commentary on the Book of Genesis (Jerusalem: Magnes, 1989), 242.

${ }^{3}$ Cf. "Let Us Build a City" [Gen 11:4], Seventh-day Adventist Bible Commentary (SDABC), rev. ed., ed. Francis D. Nichol (Washington, DC: Review and Herald, 1976-80), 1:284.

${ }^{4} \mathrm{Kim}, 49-52$.

${ }^{5}$ Although taking the opposing view, Kim admits that "if the Babel story in Gen. 11.1-9 adopts this idea [i.e., Ziggurat, Weltberg, 'cosmic mountain '] in any real sense, it is likely to 
the purpose of this investigation, a detailed description and evaluation of the arguments from both sides is undertaken.

Tower as a defensive structure

It has been argued that the Hebrew word bagl (tower") does not refer to a ziggurat, but to a defensive structure "set inside the city as a final place of refuge." 2 One of his arguments runs as follows: "The word 'tower', ל.7? is not used to designate a temple tower, because v. 4 does not specify that they are building the 'city and tower' for religious purposes. ${ }^{13}$ This argument is problematic, since it is based on silence: vs. 4 does not specify that they are building the "city and tower" as a fortification structure.

It must be noted at this juncture that the Hebrew language does not contain a word for ziggurat due to the obvious fact that ziggurats were not part of the architectural world of the biblical writers. The closest word the Hebrew lexicon could provide to convey the

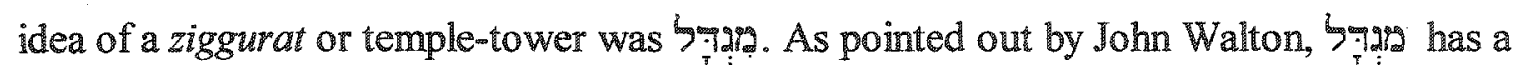
similar etymology to ziggurat, being derived from לาa ("to be large"), while ziggurat is derived from the Akkadian word Zagäu ("to be high"). Seeley has additionally observed that "when Herodotus $(1: 18-183)$ needed a word to describe the cight levels of the

understand that this narrative conveys the idea of the heavenly temple" (ibid., 48 ).

Ibid., $50-51$.

${ }^{2}$ Ibid., 51 .

${ }^{3}$ Ibid., 49 .

4John H. Walton, "The Mesopotamian Background of the Tower of Babel Account and Its Implications," BBR 5 (1995): 156. 
ziggurat he saw in Babylon, he chose túpyos, which is the Greek word most commonly used for defensive towers."

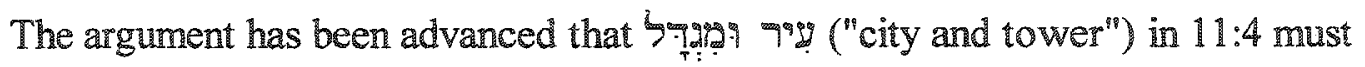
be understood as a hendiadys. The focus of the story thus understood is not simply upon a tower, but upon a city with a tower. ${ }^{2}$ Although this is probably true, it must be kept in mind that could also evoke cultic connotations: The main building of an ancient city was the temple, and life in the city revolved around the temple. ${ }^{3}$

\section{Tower as a ziggurat}

The vast majority of scholars support the view that Gen $1: 1-9$ should be understood against the background of Sumerian-Babylonian urban culture which featured the ziggurat as a major architectural achievement. The Hebrew narrative of the story provides several indications that point in this direction. The most significant pointers are the mention of Shinar, the overall geographic location where the story unfolds, and Babel, the name of the city. Other elements included in the narrative, such as the building techniques and the overall ideology behind the ciry/tower builders, also contribute to

\footnotetext{
"Paul H. Seely, "The Date of the Tower of Babel and Some Theological Implications," WTJ 63 (2001): 19.

${ }^{2} \mathrm{Kim}, 49 . \mathrm{Cf}$. Margaret Barker who, in an incidental comment on Hab 2:1-3, suggested that "the tower was a common description of the sanctuary" (The Gate of Heaven: The History and Symbolism of the Temple in Jerusalem [London: SPCK, 1991], 128, italics hers). Although she provides no evidence to support this affirmation, it may be true at least regarding the templetowers of Mesopotamia, as will be argued below.

${ }^{3}$ See L. R. Fisher, "The Temple Quarter," JSS 8 (1963): 34-41; Adam Falkenstein, The Sumerian Temple City (Los Angeles: Undena Publications, 1974), 7-14; James Valentine, "Theological Aspects of the Temple Motif in the Old Testament and Revelation" (Ph.D. dissertation, Boston University, 1987).
} 
locate the events reported in Gen 1 1:1-9 in ancient Mesopotamia. In the discussion below, the main arguments for understanding bTgra as a "temple-tower" or ziggurat are presented.

First, the setting of the story should be noted. Everything happens in Shinar ( (90960), which refers to the area known to the Mesopotamians as the "land of Sumer and Akkad." Additionally, the reference to Babel ( narrative is ancient Mesopotamia. Since the ziggurat was the most prominent structure in a Mesopotamian city, it is reasonable to infer that the "tower" referred to in Gen 11 was some kind of ziggurat. Once the story is placed against a Mesopotamian backdrop, "one of the immediate results of that perspective is the firm conviction that the tower that figures predominantly in the narrative is to be identified as a ziggurat."

Second, the builders" desire to "make a name" for themselves-"and let us make for ourselves a name" (a was carried out by gods and kings. ${ }^{3}$ Seely has argued that "Mesopotamian kings often took pride in building ziggurats, but no such pride was taken in defensive towers which

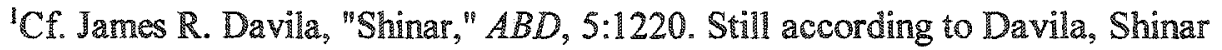
"corresponds to the portion of modern Iraq $S$ of Baghdad [i.e., Sumer]. This meaning is confirmed by the LXX, Targum Onkelos, and the Genesis Apocryphon. All three sometimes translate 'Shinar' as Babylon(ia)" (ibid., 1220).

Walton, 155 .

3Victor A. Hurowitz, I Hove Built You an Exalted House: Temple Building in the Bible in Light of Mesopotamicn and Northwest Semitic Writings, JSOT Supp. 115 (Sheffield: ISOT Press, 1992), 17-128; Arvid S. Kapelrud, "Temple Building, a Task for Gods and Kings," Or 32 (1963): 56-62; Richard E. Averbeck, "Sumer, the Bible, and Comparative Method: Historiography and Temple Building," in Mesopotamia and the Bible: Comporative Explorations, ed. K. Lawson Younger and Mark W. Chavalas (Grand Rapids: Baker, 2002), 88-125. 
were simply parts of the city wall." As a matter of fact, kings also prided themselves in city walls, but they did not single out towers for special mention apart from the walls.

Third, the baked brick and the bitumen corroborate the evidence that the "tower" referred to in the narrative was a ziggurat. $^{2}$ Baked brick and bitumen were very expensive in Mesopotamia ${ }^{3}$ and consequently were most probably used to build palaces and temples rather than defensive towers. ${ }^{4}$

Fourth, the sequence of the actions described in the narrative recalls Mesopotamian temple-building accounts. In these accounts, baked bricks are mentioned first (vs. 3), and after that, the building of the city and tower with its top in the heavens (vs. 4). Speiser has noted that this is the pattern described in the construction of Esagila: "The first year they molded its bricks. And when the second year arrived they raised the head of Esagila towards Apsu." If the Mesopotamian context has any bearing upon the interpretation of Gen $11: 1-9$, then it is reasonable to suppose that the tower referred to in the narrative must be a cultic building like a temple or ziggurat.

${ }^{1}$ Seely, 18.

2"The tower of Babel (Gen 11:4-5) probably represents another case where migdal refers to a temple. There is little doubt that the account recalls the ziggurat temples of Mesopotamia" $(\mathbb{E}$. B. Banning, "Towers," $A B D, 6: 623-24$ ).

${ }^{3}$ R. I. Forbes, "Chemical, Culinary, and Cosmetic Arts," in A History of Technology from Early Times to the Fall of Ancient Empires, ed. Charles Joseph Singer, E. J. Holmyard, and A. R. Hall (Oxford: Clarendon Press, 1954), 254.

${ }^{4}$ Seely, 18.

${ }^{5}$ Speiser, $75-76$. 
Fifth, the builders intended the tower to reach the heavens. This language also recalls the Mesopotamian temple. The Gudea Cylinders provide an instructive example of the Mesopotamian understanding of the temple and its connection with heaven. The temple built by King Gudea is designated as a "house whose halo reaches to heaven."1 Another passage reads: " $O$ house that reaches to heaven like a great mountain, whose awe and aura are shed over the Land."2

Sixth, by examining the narrative from a perspective of its "spatialization," one perceives that the narrator placed the city and tower in the very center of the narrative space. The spatial references noted in the narrative can be categorized in concentric circles that move from the broadest circle ("all the earth") to the very hub where the tower is located ("there"). This spatial organization can be thus represented: "All the earth" $\rightarrow$ "land of Shinar" $\rightarrow$ "plain" $\rightarrow$ "there" - the place where the city and tower were built.

In the space conceived by the narrator, the city/tower occupies the center (or "navel") of the world, a concept later applied to the Jerusalem temple. ${ }^{4}$ This spatial organization is also working in a vertical direction as the tower is built towards heaven, a

'Dietz Otto Edzard, Gudea and Dynasty, The Royal Inscriptions of Mesopotamia; Early Periods, vol. 3/1 (Toronto: University of Toronto, 1997), 80 (A xvii 18).

2Tbid., 101 (B xxiv 9-10).

"The concept of "spatialization" comes from discourse semiotics. It undertakes to explain how discourse organizes space to convey meaning. "Spatialization is one of the components of "discursivization," i.e., the putting into discourse of deeper semiotic structures. Cf. "Space" and "Spatialization" in Algirdas Julien Greimas and Joseph Courtés, Semiotics and Language: An Analytical Dictionary (Bloomington; Indiana University Press, 1982), 305-07.

${ }^{4}$ Cf. Pss 48:1-2 [2-3]; 74:12; Isa 2:1-4 (= Mic 4:1-3); 45:22; Zech 14:8-10. Cf. Steven S. Tuell, "7ามต ," New International Dictionary of Old Testament Theology and Exegesis (NIDOTTE), ed. Willem A. VanGemeren (Grand Rapids: Eerdmans, 1997), 2:333-34. 
movement that is opposed by YHWH as he comes down to investigate the matter. This is discussed more fully below. For now, it suffices to note that the spatial organization of the narrative portrays the "lower" as the center of the world, thus evoking the idea of a temple or ziggurat.

\section{Key Words and Cxpressions}

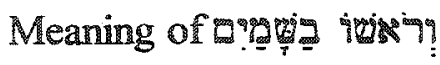

The phrase a"อ

Scholarship has been divided about the exact meaning of this expression. Von Rad, along with other scholars, argues that "it is only an expression for the special height of the

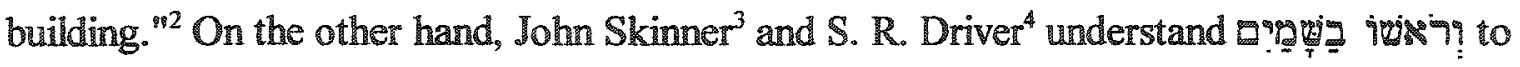
be literal and to express the real intention of the builders of reaching to heaven, a view that has been adopted by several scholars. ${ }^{5}$ At this juncture, an exegetical investigation of this

'E.g. Hubert Bost, Babel: Du texte au symbole, Le Monde de la Bible (Genève: Labor et Fides, 1985), 55; Frank S. Frick, The City in Ancient Israel (Missoula, MT: Scholars Press, 1977), 207-09; Benno Jacob, The First Book of the Bible: Genesis (New York: KTAV, 1974), 78; Nahum M. Sama, Genesis, The JPS Torah Commentary (Philadelphia: Jewish Publication Society, 1989), 83.

${ }^{2}$ Von Rad, Genesis: A Commentary, 149.

3"The expression is not hyperbolical (as Dt. 1:28) but represents the serious purpose of the builders to raise their work to the height of the dwelling-places of the gods ( $w b$ X. 19, etc.)." John Skinner, A Critical and Exegetical Commentary on Genesis, 2nd ed., ICC (Edinburgh: T. and T. Clark, 1930), 226.

4"The expression is probably meant here, not hyperbolically (Dt. i 28 ), but literally, 'heaven' ( $c$ f. on $\mathrm{i.}$ 6) being regarded as an actual vault, which might be reached (Is. xiv 130) at least by a bold effor" (S.R. Driver, The Book of Genesis, Westminster Commentaries [London: Methuen, 1943], 135).

${ }^{5}$ E.g., Ronald F. Youngblood, The Book of Genesis: An Introductory Commentary, 2nd 
expression is required in order to ascertain its meaning in the context of the passage under study.

As noted, the narrative of the tower of Babel has its focal point in vs. 5 where it is reported that YHWH came down to see the city and the tower that the sons of men had built. This focal point marks the intersection between the horizontal and vertical movements. On a horizontal level, everything that happens before that point moves towards the center, the place where the city and tower are built. Thus, vss. 1-4 portray the centripetal movement of the people to the spatial center of the narrative, the place where the city and tower were located. In vss. $6-9$, one perceives a reversal as if a centrifugal force caused the people to be scattered upon the face of the earth. In other words, the first movement, centripetal, is caused by the intentions and actions of men; the second movement, centrifugal, is caused by YHWH as a reaction against the previous centripetal movement.

At the same time, the narrative portrays a vertical action and reaction. As the protagonists of the story move toward heaven, YHWH descends to investigate their accomplishments. Although the text does not specify the place whence he descended, the implication is that he descended from his heavenly abode (i.e., from his heavenly

ed. (Grand Rapids, MI: Baker, 1991), 127; J. P. Fokkelman, Narrotive Art in Genesis: Specimens of Stylistic and Structural Amalysis, 2nd ed. (Sheffield, England: JSOT Press, 1991), 19-20; Alfred Gottschalk, "The Image of Man in Genesis and in the Ancient Near East," MAARAV7 (1991): 140; Westermann, Genesis 1-11, 548; Jack M. Sasson, "The 'Tower of Babel' as a Clue to the Redactional Structuring of the Primeval History (Genesis 1:1-11:9), "in The Bible World: Essays in Honor of Cyrus Gordon, ed. Gary A. Rendsburg et al. (New York: KTAV and the Institute of Hebrew Culture and Education of New York University, 1980), 219; Frank Michaeli, Le Livre de la Genèse (Neuchâtel, Paris: Delachaux and Niestlé, 1957), 104. 
sanctuary/temple). ${ }^{1}$ As the symmetry of the narrative seems to imply, as people attempt a movement upwards, from earth to heaven, YHWH undertakes a reverse action moving downwards, from heaven to earth. The symmetry of the story, which portrays YHWH as descending from heaven, requires that the builders be understood as moving upwards to heaven. Worthy of note is the alliteration to convey the idea of a vertical relationship between the "there" where the city and tower were located, and "heavens," towards which the tower was rising up, the place whence YHWH comes down. In this connection, N. Sarna has pointed out that Eש⿱宀 ("there") "repeated five times, directs our attention to the central importance of the particular site chosen; at the same time, it should evoke an association with shamaym, 'heavens,' with which the site is supposed to be physically connected, as well as with shem [םi]], 'a name,' in vs. $4 . .^{12}$

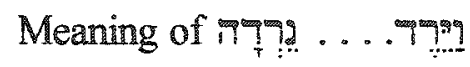

The text seems to imply that YHWH descended twice. The first reference in 11:5a, לด tower"), marks the central point of the narrative, thus initiating a reversal in the story. The

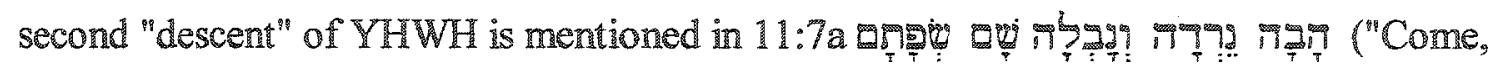
let us go down and there confuse their language"). In spite of some scholarly conjectures

\footnotetext{
"The implication is that YHWH dwells in heaven," as Julian Morgenstern put it. "The Book of the Covenant," HUCA 5 (1928): 41-42.

${ }^{2}$ Sama, Genesis, 81.
} 
that these two "descents" are vestiges of two different traditions or redactional levels, ${ }^{3}$ an interpretation that respects the integrity of the story and accounts for this "superfluous repetition" is suggested below.

As the narrative makes clear, YHWH first descended in order to investigate the situation. Umberto Cassuto pointed out that "the expression came down [11:5] is only one of the corporeal phrases commonly found in the Pentateuch, and it means that YHWH, as a righteous judge, wished to investigate the matter thoroughly." Jacob likewise, commenting on $11: 3$, speaks of a "formal investigation of the facts." 1 thould be noted as well that YHWH "came down to see (T) the city and the tower which the sons of men had built" (11:5). No reference to punishment is made; the purpose of YHWH is "to see" the accomplishments of the "sons of men." The best description for this kind of action is that of an "investigation" or, put differently, an "investigative judgment." It has been observed that according to the Hebrew Bible, YHWH's intervention in history in order to save the righteous or punish the rebels is usually preceded by an investigative phase. ${ }^{4}$

'See Bost, 68-69; Claus Westermann, Genesis: A Practical Commentary, trans. David Green (Grand Rapids, MI: Eerdmans, 1987), 82.

${ }^{2}$ Umberto Cassuto, A Commentary on the Book of Genesis (Jerusalem: Magnes, 1989), 244.

Jacob, 78 .

${ }^{4} \mathrm{Cf}$. Davidson, "Cosmic Metanarrative for the Coming Millemium," 116-17; William H. Shea, Selected Studies on Prophetic Interpretation, 1-23. According to Moshe Weinfeld, "God accordingly descends to see what the men have built, and returns to his heavenly abode to report to the heavenly council the nature of men's activity and the threat it entails" (Deuteronomy and the Deuteronomic School [Oxford: Clarendon, 1972], 200). 
In the second descent, however, YHWH has the purpose of executing judgment. The chain of volitive verbal forms in 11:7a נרק ("Come, let us go down and there confuse their language") clearly demonstrates that a verdict had been achieved, and now it was necessary to execute the judgment, which is conveyed by the

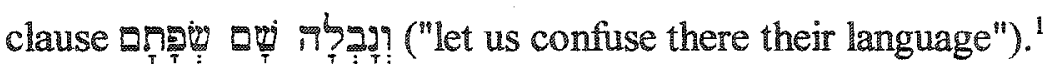

\section{Contextual Implications}

A look at Gen 11:1-9 against the backdrop of its larger context contributes new insights to its understanding. The call of Abram (Gen 12) and Jacob's dream (Gen 28) reverberate motifs already portrayed in the Babel narrative, thus contributing to its understanding. In Gen 12, the reader learns that the "name" which the builders of Babel wanted to achieve by their own efforts was graciously bestowed upon to Abram. ${ }^{2}$ In Gen

1The "us" implied in the plural verbs הדุ be better interpreted as a "plural of plenitude" which implies a distinction of personalities inside the deity. For a discussion of several suggestions and an able defense of the "plural of plenitude," cf. Gerhard Hasel, "The Meaning of 'Let Us' in Gn 1:26," AUSS 13 (1975): 58-66. See also H. C. Leupold, Exposition of Genesis (Columbus, OH: Wartburg Press, 1942), 390; "Let Us Go Down" [Gen 11:7], SDABC, 1:285.

${ }^{2}$ Bost has noted the following parallels between Gen 11:1-9 and 12:1-3:

"11,1-9: le récit de Babel

v. $3-4$ les hommes se parlent

deux monologues parallèles

v. 2 Les hommes sont un peuple anonyme

v. 2 Les hommes ont linitiative de la parole et de la action v. 4 Les hommes, qui se déplaçaient, s'artêtent et sinstallent: sedentarité v. 4 les hommes veulent se faire un nom
12;1-3: la vocacion d'Abraham

v. 6-7 YHWH se parle;

v. 1 YHWH parle à Abraham; linstauration dun dialogue

v. 1 Abraham esi nommé

v. 1 YHWH a linitiative de la parole e de l'action v. 1 Abraham, installé dans son pays reçoit l'ordre de partir: nomadisme

v. 2 YHWH rendra grand le nom d'Abraham 
28 the connection with heaven purported by the tower was freely given to Jacob when, in a dream, he saw a ladder linking heaven and earth. The contribution of the latter to Gen 11:1-9 seems almost self-evident: If Gen 28 portrays a connection between heaven and earth, as will be argued below, the Babel story most probably portrays a failed project to achieve such a connection. Furthermore, the name "Bethel" ("house of God") given to the place evokes "Babel" (Akk. "gate of the god[s]/Heb. confusion [pejorative etymology])." As the observations just made indicate, what happened in the Babel narrative was reversed in Jacob's dream.

\section{Heavenly Sanctuary/Temple Motif}

As argued above, several lines of evidence attest the presence of the heavenly sanctuary/temple motif in the Babel narrative. A historical and theological reading of the passage yields several indications that the builders of the city and tower intended the construction to function as a point of connection with the heavenly realm. The material they used, the language employed to describe their intentions, the structure of the narrative, and its organization of space having the building at the center, all corroborate

\footnotetext{
v. \&-9 YHWH sanctionne l'entreprise humaine. "Toute la terre" est éclatée géographiquement et linguistiquement.
}

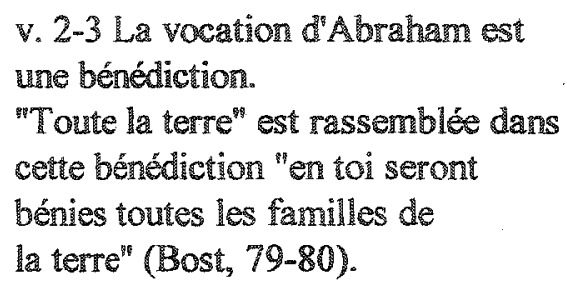
une bénédiction.

"Toute la terre" est rassemblée dans cette bénédiction "en toi seront bénies toutes les familles de la terre" (Bost, 79-80).

'Walther Zimmerli, 1. Mose 1:1-11:32: Die Urgeschichte, 3rd ed. (Zürich: Zwingli Verlag, 1967), 405-07. 
the view that the structure was supposed to achieve some kind of linkage with the heavenly realm.

Two aspects of the heavenly sanctuary/temple motif can be detected in the text. First, a negative aspect is attested by the builders in their endeavor to establish a linkage with the heavenly realm, as the tower was raised towards heaven. As this human effort was forestalled by YHWH, a positive aspect emerges, which can be perceived from YHWH's double descent to investigate the works of humanity and to execute judgment, respectively. This double descent of YHWH seems to imply the heavenly sanctuary/temple motif. According to Rashi, "He [YHWH] speaks to his heavenly court after having returned to heaven." Thus, one notes that between the first and second descents, YHWH may have held a heavenly assembly session to examine the situation (investigative judgment) and eventually intervene (executive judgment). Summarizing, the heavenly sanctuary/temple as reflected in Gen 11:1-9 seems to have functioned as a place of judgment, the latter apparently being performed in two phases, thamely, an investigative and executive phase.

Gen 28: 10-22

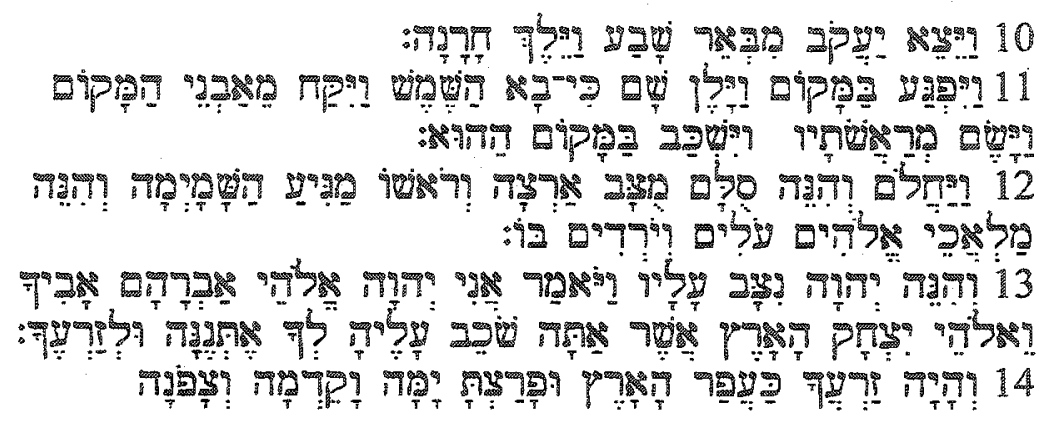

'Jacob, 78. Cf. Weinfeld, Deuteronomy and the Deuteronomic School, 200. 


\section{2}

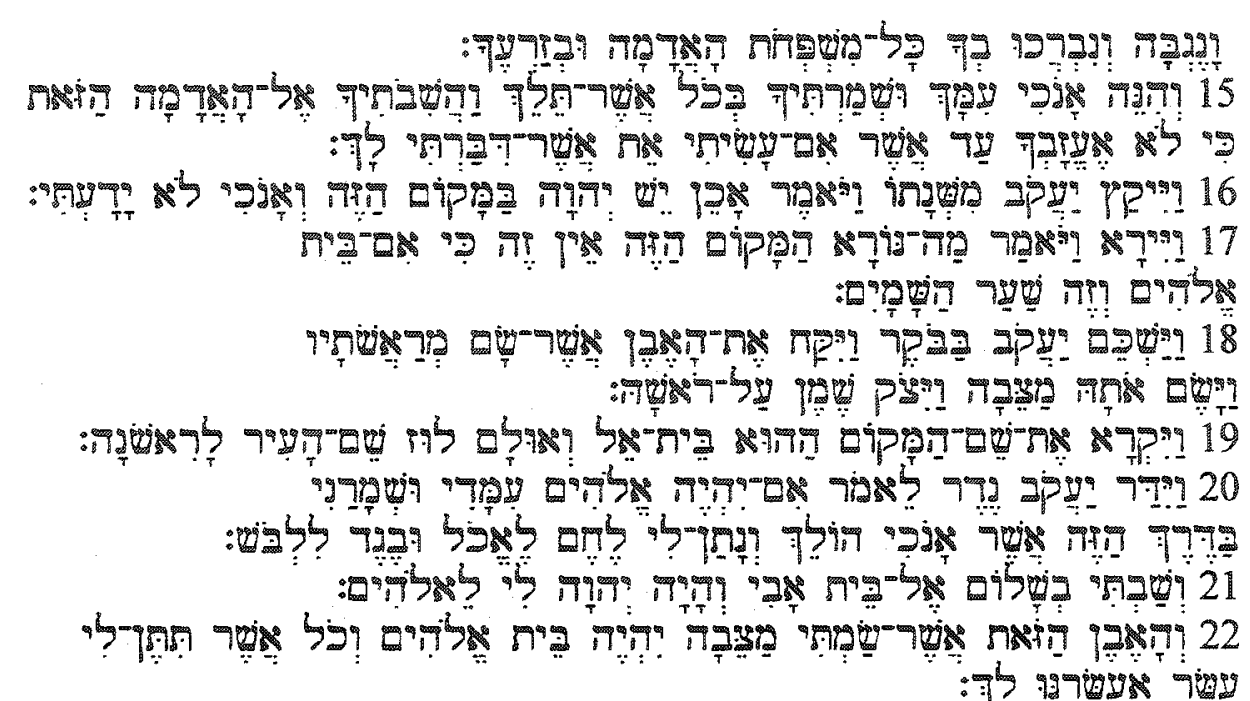

10 Then Jacob departed from Beersheba and went toward Haran.

ㄱำ

11 He came to a certain place and spent the night there, because the sun had set; and he took one of the stones of the place and put it under his head, and lay down in that place.

$12 \mathrm{He}$ had a dream, and behold, a ladder was set on the earth with its top reaching to heaven; and behold, the angels of God were ascending and descending on it.

13 And behold, YHWH stood above it and said, "I am YHWH, the God of your father Abraham and the God of Isaac; the land on which you lie, I will give it to you and to your descendants.

14 "Your descendants will be like the dust of the earth, and you will spread out to the west and to the east and to the north and to the south; and in you and in your descendants shall all the families of the earth be blessed.

15 "Behold, I am with you and will keep you wherever you go, and will bring you back to this land; for I will not leave you until I have done what I have promised you."

16 Then Jacob awoke from his sleep and said, "Surely YHWH is in this place, and I did not know it."

17 He was afraid and said, "How awesome is this place! This is none other than the house of God, and that is the gate of heaven."

18. So Jacob rose early in the morning, and took the stone that he had put under his head and set it up as a pillar and poured oil on its top.

19 He called the name of that place Bethel; however, previously the name of the ciry had been Luz.

20 Then Jacob made a vow, saying, "If God will be with me and will keep me on this journey that I take, and will give me food to eat and garments to wear, 21 and I return to my father's house in safety, then YHWH will be my God.

22 "This stone, which I have set up as a pillar, will be God's house, and of all that you give me I will surely give a tenth to you." 
Preliminary Observations

The narrative of Gen 28:10-22 forms a text unit clearly delimited by conceptual and verbal markers. It starts by reporting that Jacob stopped in a certain place while journeying to Haran (28:10), and ends at $28: 22$, since $29: 1$ clearly marks the beginning of another episode by revealing that "then Jacob went on his journey, and came to the land of the sons of the east." This short narrative belongs to the larger context of the Patriarchal History (Gen 12-50) and stands in the flow of promises and blessings YHWH bequeathed to the patriarchs. The pericope contains conspicuous stylistic features that, once identified, can contribute to its interpretation. Repetition of key words and motifs contributes to its unity and provides clues for meaning. This "dance of key words," ${ }^{11}$ as Fokkelman puts it, can be observed in table 1, where it becomes apparent that several words occurring in vss. 11-12 reappear in 16-18. This quasisymmetry on the lexical level may well indicate that the narrator intended both sections to correspond thematically and theologically. For the purposes of this study, it is instructive to note the correspondence between vss. 12 and 16 17 , the implications of which will be discussed in due course. Thus, although this study does not aim at a detailed investigation of the various themes and motifs contained in the text, an outline of the pericope is provided below in order to set the discussion of the heavenly sanctuary/temple motif against the backdrop of the entire passage.

'J. P. Fokkelman, Narrative Art in Genesis: Specimens of Stylistic and Structural Analysis. 2nd ed. (Sheffield, England: JSOT Press, 1991), 71. 
TABLE 1

KEY WORDS IN GENESIS 28:10-22

\begin{tabular}{|c|c|c|c|c|c|c|c|c|c|}
\hline Verse & 1 & 2 & 3 & 4 & 5 & 6 & 7 & 8 & 9 \\
\hline $\begin{array}{l}11 \\
12 \\
12\end{array}$ & 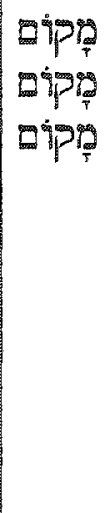 & לק? & 928 & Q & ภำ & $\begin{array}{l}2989 \\
2999\end{array}$ & 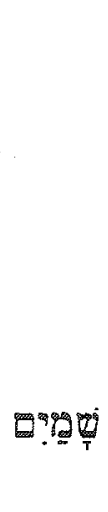 & gority & กิบ? \\
\hline $\begin{array}{l}16 \\
17\end{array}$ & $\begin{array}{l}\text { Expps } \\
\text { Eip? }\end{array}$ & & & & & & g9990 & gamidgs: & mit? \\
\hline 18 & Exipgs & $\pi p_{?}$ & 978 & $\begin{array}{l}\text { Eq6e } \\
\text { Eqce }\end{array}$ & 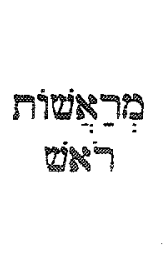 & 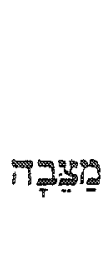 & & & \\
\hline
\end{tabular}

Source: J. P. Fokkelman, Narrative Art in Genesis: Specimens of Stylistic and

Structural Analysis, 2nd ed. (Sheffield, England: JSOT Press, 1991), 71. 
10-11 Jacob's Arrival at "the Place"

12-15 Jacob's Dream

12-13a Vision

13b-15 Audition

16-19 Jacob's Response to the Vision

16-17 Jacob's First Reaction to the Vision

18-19 Jacob's Second Reaction to the Vision

20-22 Jacob's Response to the Audition

After discussing the structure of the narrative, attention must now be given to its genre and purpose in the theological-literary context in which it belongs. Scholars tend to ascertain the function of this text in terms of "cult etiology" and "oracle of salvation."2

Since most of these scholarly discussions are based on the supposition that the text reflects a conflation of sources and/or traditions, ${ }^{3}$ it is necessary to assess this issue from the perspective of the final canonical form of the text.

Although the pericope portrays cultic elements and depicts YHWH accepting Jacob and making promises to him, thus providing the young man with comfort, neither of these concepts explains the text as a whole. The contention of this research is that a major

${ }^{1}$ Hermann Gunkel, Genesis, trans. Mark E. Biddle, Mercer Library of Biblical Studies (Macon, GA: Mercer University Press, 1997), 313; Claus Westermann, Genesis 12-36: A Commentary (Minneapolis: Augsburg, 1985), 452.

${ }^{2}$ Hyacinthe M. Dion, "Patriarchal Traditions and the Literary Form of the Oracle of Salvation," CBQ29(1967).

${ }^{3}$ See Erhard Blum, "Noch einmal: Jakobs Traum in Bethel-Genesis 28, 10-22," in Rethinking the Foundations: Historiography in the Ancient World and in the Bible, Essays in Honour of John Ian Seters, ed. Steven L. McKenzie and Thomas Römer, BZAW 294 (Berin: Walter de Gruyter, 2000); Sean McEvenue, "A Return to Sources in Genesis 28,10-22," ZAW 106 (1994): 375-89; Manuel Oliva, "Visión y voto de Jacob en Bethel," Estudios Bíblicos 33 (1974): 117-55; John Van Seters, Prologue to History: The Yahwist as Historian in Genesis (Louisville, KY: Westminster/John Knox, 1992), 288-306. 
purpose of the narrative is to portray the "reiteration of the covenant, "which had been given to Abraham and Isaac, to Jacob. It should be noted that prior to Gen 28, YHWH had become the God of Abraham and Isaac. Now, as the narrative unfolds, YHWH becomes the God of Jacob. This is accomplished by means of a covenant-ratification process made evident by several allusions to the covenant motif found in the text.

Alusions to the covenant are present in the auditory part of the dream. The words of YHWH as he presents himself to Jacob as "the God of Abraham "and "the God of Isaac" recall the covenant promises given to them. ${ }^{2}$ Now the same promises are reaffirmed to Jacob. More precisely, the following promises made to the patriarchs are reapplied to Jacob: (1) Blessing-Gen 12:3//28:14b; (2) Seed-Gen 13:16//28:14; (3) Land-Gen $13: 15 / / 28: 13 b ;$ (4) Communion-Gen $17: 17 ; 26: 3 / / 28: 15$.

Jacob's response to the dream also evinces covenant overtones. The use of the

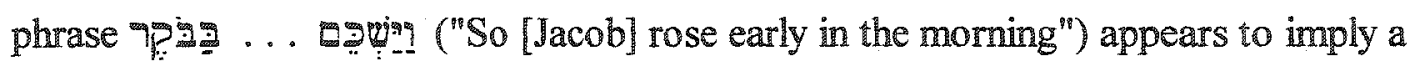
continuation of activity that began in the nocturnal theophany. Several examples in Genesis of the sequence 79 ... night, which eventually culminates in the ratification of the covenant. ${ }^{3}$ Jacob's response to 1987), 240 .

1D. Stuart Briscoe, Genesis, ed. Lloyd G. Ogilvie, CCSOT 4 (Waco, TX: Word Books,

2Livingston has pointed out that "common to visitations of God to man in a covenant context is an opening statement which identifies the One who first speaks." George Herbert Livingston, "Genesis," in Beacon Bible Commentary (Kansas City: Beacon Hill Press, 1969), 111.

${ }^{3}$ It has been pointed out that in Gen 19:27, Abraham rose early in the moming at the place where he had stood before YHWH. In Gen 20:8 Abimelech rises early in the morning, after a nocturnal vision, and proceeds to make a covenant with Abraham. Gen $21: 14$ and 22:3 report Abraham rising early in the morning after a night vision. In $22: 3$, he performs a sacrifice. In $26: 31$, Isaac, Abimelech, and Phicol rise early in the morning after a communal feast in the night and 
the dream by means of the vow and the Tygme ("pillar") further reinforces the view that the text reflects a ritual of covenant-making. The TI of "commemorating the conclusion of a covenant." Monuments of stone are mentioned in the Hebrew Scriptures and ancient Near Eastern texts as regular symbols of memorial and consecration, and sometimes are used to signal the ratification of a covenant. ${ }^{2}$ In addition, the anointing of the Tร్g provides additional evidence as regards the covenant overtones of the pericope, as noted in the following observation:

The anointing of the witness stone with oil was a symbolic act establishing a contractual bond between Jacob and YHWH. There is widespread evidence from the ancient Near East for the use of oil in intemational treaty relationships and in effectuating business contracts. It seems to have been a token of peace, friendship, and assuming obligation. In Jacob's case, the anointing is connected with the making of a vow that binds him to a certain commitment. The special connection between the pouring of oil and the vow is explicit in $31: 13 .^{3}$

exchange oaths with one another. In 32:1 [31:55], Laban rises early in the morning after spending the night in covenant-making with Jacob. Exod 24:4 and 34:4 should also be mentioned in this connection, where Moses rises early in the morning to perform ritual acts in the context of covenant-making. See Francisco O. Garcia-Treto, "Jacob's 'Oath-Covenant' in Genesis 28 ," in Trinity University Studies in Religion (San Antonio, TX: Trinity University Dept. of Religion 1975), 4.

"The German text reads: "Einen Bundesschluss zu errinem" (J. Alberto Soggin, Das Buch Genesis: Kommentar [Darmstadt, Germany: Wissenschaftiche Buchgesellschaft, 1997], 366).

${ }^{2} \mathrm{Cf}$. , e.g. Gen $31.45-54$ where the igagng "serves as a mute witness of the treaty between Jacob and Laban" (Sarna, Genesis, 199). In Exod 24:4, "ITas9 also functions in a covenant context. Also, in extrabiblical sources pillars are attested in the context of a covenant, as demonstrated by the eighth-century Inscriptions of Sephire where pillars are used to seal a treaty. Interestingly, the pillar or stone stela was called Bty ihy '[bethels] (Joseph A. Fitzmyer, The Aramaic Inscriptions of Sefire, BibOr 19 [Rome: Pontificial Biblical Institute, 1967], 82-83 [Sf II, Face C, lines 7, 910]. See Garcia-Treto, 5; Gordon J. Wenham, Genesis 16-50, WBC [Waco: Word Books, 1994], 2:224).

\footnotetext{
${ }^{3}$ Sama, Genesis, 200.
} 
Covenant overtones can also be perceived in Jacob's allusion to the promise of

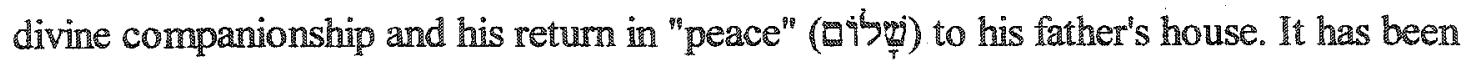
pointed out that "shalom" is a key word at the conclusion of successful negotiations or treaties. ${ }^{1}$ Therefore, the use of "peace" (aib incidental. Rather it most likely implies a careful diplomatic procedure that presupposes a covenant relationship. Furthermore, Jacob's promise to give YHWH a tenth of all his possessions further alludes to the concept of a covenant relationship between the patriarch and $\mathrm{YHWH}^{2}$

Therefore, as seen above, the covenant motif functions as the overarching theme of the pericope. Other motifs and themes such as "salvation," and all the evident cultic allusions such as "house of God," the anointing of the pillar, the reference to the tithe-later to become the main source of income to the temple-function within the sphere of covenant relationship between YHWH and Jacob.

'Donald J. Wiseman, "Is If Peace?: Covenant and Diplomacy," VT 32, no. 3 (1982): 311 26. Wiseman notes about Gen 28:21 that the expression to "'return in peace to my father's house' primarily denoted the successful conclusion of the marriage covenant for which he [Jacob] had set out with the blessing and commission of his father" (Wiseman, 325). It is not clear, however, that Jacob is primarily referring to the marriage covenant. It seems more likely that the "return in peace" was connected to Jacob's covenantal relationship with YHWH. Jacob's marriage covenant is better placed under the larger umbrella of his covenant with YHWH, as implied in one of the elements of the covenant-the promise of numerous "seed."

2It should be noted that the presenting of gifts upon concluding a treaty is mentioned in the pact between Abraham and Abimelech (Gen 21:27). For further arguments about the use of the "tithe" as an element of a covenant, cf. D. Elgavish, "The Encounter of Abram and Melchizedek King of Salem: A Covenant Establishing Ceremony," in Studies in the Book of Genesis: Literature, Redaction and History, ed. André Wénin, Bibliotheca Ephemeridum theologicarum Lovaniensium 155 (Leuven: Uitgeverij Peeters, 2001), 500-02. 


\section{Spatialization?}

The assumption behind this discussion is that space markers in a text are not peripheral devices, but are employed by narrators to add meaning. Semiotic analysis provides a theoretical framework to analyze and explain the contribution of these features for the meaning of texts. ${ }^{2}$ Spatialization can be perceived by such space markers as place names, locative adverbs, and other deictic particles, and verbs of movement. In the discussion undertaken below, it is noted how the text handles space in its horizontal and vertical dimensions.

The text may be conceptualized as a horizontal line: "Jacob departed from Beersheba and went toward Haran" (28:10). On his way along this line, Jacob "came to the place (cipges) and spent the night there" (vs. 11). The implication of this latter information, from a semiotic point of view, is that "the place" was located in the middle of the narrative horizontal line. ${ }^{3}$ The use of the article in this first occurrence of $a$ ipis, when an indefinite expression would be more appropriate, may well point to the distinctiveness of this place in

\footnotetext{
${ }^{1}$ The semiotic analysis undertaken in this section takes the article of Hans Jensen as its starting point (Hans Jorgen Lundager Jensen, "Reden, Zeit und Raum in Genesis 28, 10-15, $L B$ 49 [1981]: 54-70). The implications of this analysis for the heavenly sanctuary/temple motif, however, are not mentioned in the article just cited. Besides, Jensen deals only with Gen 28:10-15, while the discussion undertaken in this study endeayors to take into consideration the entire pericope of Gen $28: 10-22$.

${ }^{2}$ Greimas and Courtés, 306-07.

${ }^{3}$ That Bethel is not in the geographic middle of the line is not relevant. What matters is that Bethel, in the narrative, lies in the middle, i.e., in between Jacob's point of departure and his destiny-Laban's place. Jensen, 68.
} 
the course of the narrative as the setting for the dream and its sequel. It is noteworthy that Eips ("place") turns out to be one of the key words in the text, occurring six times in the pericope. This may well indicate its semantic centrality in the spatial axis of the narrative.

The pericope also conceives of a vertical line which intersects the middle of the horizontal line: "A stairway was set on the earth with its top reaching to heaven; and behold, the angels of God were ascending and descending on it" $(28: 12)$. The stairway thus, from a semiotic point of view, functions as a vertical axis between heaven and "the place" where Jacob was lying down, as ig. 2 illustrates.

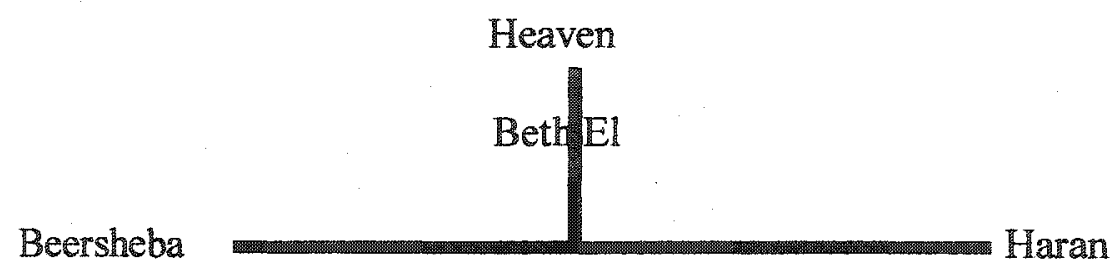

Fig. 2. Semiotic structure of Gen 28:10-22.

\section{Key Words and Expression}

This section narrows down on vss. 12-13a and 16-17, since most of the verbal and conceptual indicators of a heavenly sanctuary/temple motif are concentrated on these verses. Furthermore, they provide a description and evaluation of "the place," where the horizontal and vertical axes intersect. For the reader's convenience the text is displayed below. 
Gen $28: 12-13 a$

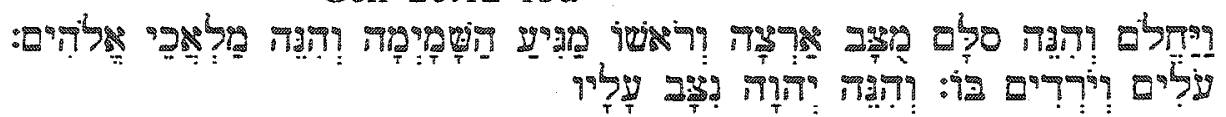

He had a dream, and behold, a ladder was set on the earth with its top reaching to heaven; and behold, the angels of God were ascending and descending on it. And behold, YHWH stood above it.

Gen $28: 16-17$

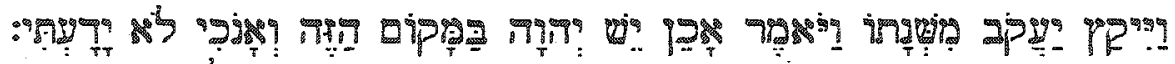
: Then Jacob awoke from his sleep and said, "Surely YHWH is in this place, and I did not know it." He was afraid and said, "How awesome is this place! This is none other than the house of God, and that is the gate of heaven."

The meaning of 797 ?

Attention is now given to the semantic and syntactic contribution of the deictic particle 7gm?. It has been observed that the "Hebrew particle hinne performs a deictic function with emphasis, situates the object in a present field, and claims upon the object the attention of the interlocutor." It "emphasizes the immediacy, the here-and-now-ness, of the situation. ${ }^{\prime 2}$ Hence, it is no wonder that dream and vision reports are often introduced by 7997? followed by participial clauses. ${ }^{3}$ In the text under study, the participial clauses have great consequences for the experiencing of time in the narration, since they signal a shift from the past to the present, since "the narrator withdraws behind the protagonist and in a

\footnotetext{
"The Spanish text reads: "La particula hebrea hinne ejerce con énfasis una función deíctica; sitúa un objecto en un campo presente, y reclama sobre el objeto la atención del interlocutor" (Luis Alonso-Schökel, "Nota estilistica sobre la particula rạn," Bib 37 [1956]: 74). See also D. J. McCarthy, D. J. "The Uses of whinneh in Biblical Hebrew," Bib 61 (1980): 33042; Yishak Sadka, "Hinne in Biblical Hebrew," UF 33 (2001): 479-93. 168.

'Thomas Oden Lambdin, Introduction to Biblical Hebrew (New York: Scribner, 1971),

${ }^{3}$ See, e.g., Gen $41: 1 ;$ Jer $4: 24$; Dan 8:15; Amos 7:1, 4.
} 
subordinate position he records what his, Jacob's, eyes see. "Hence, "there is no longer a narrator who looks back to a past; there is only the present as Jacob experiences it."

Meaning of 9

The precise meaning of 59 has been debated. Most scholars interpret it as a ladder, ${ }^{3}$ ramp, or stairway/staircase. ${ }^{4}$ More recently, Oblath has suggested that 9 should be interpreted as a gate-like structure through which the divine beings traverse vertically or obliquely between heaven and earth. In short, the main argument adduced in favor of this view comes from the context. Oblath argues that the expression a?. refers back to the excursus at the end of his article, Oblath still conjectures that 59 might be a corruption of D? (vestibule) in which case the could have been mistakenly transcribed as an $0 .{ }^{6}$ Oblath's suggestion would be the solution for this crux, if it were not for a crucial detail.

'Fokkelman, Narrative Art in Genesis, 51.

${ }^{2}$ Tbid.

${ }^{3}$ Robert Couffignal, "Le Songe de Jacob: Approches nouvelles de Genèse 28, 10-22," $B i b$ 58 (1977): 342-60; J. G. Griffiths, "The Celestial Ladder and the Gate of Heaven (Gen 28:12 and 17)," ExpTim 76 (1964-65): 229; W. Sibley Towner, Genesis, Westminster Bible Companion (Louisville, KY: Westminster John Knox Press, 2001), 216.

${ }^{4}$ Terence E. Fretheim, "The Book of Genesis: Introduction, Commentary, and Reflections," in The New Interpreter's Bible, ed. Leander E. Keck (Nashville: Abingdon Press, 1994), 541; Speiser, 219-20; Von Rad, Genesis, 279; Youngblood, 219; A. R. Millard, "The Celestial Ladder and the Gate of Heaven (Gen xxvii. 12, 17), "ExpTim 78 (1966-67): 87-89.

${ }^{5}$ Michael Oblath, "'To Sleep, Perchance to Dream . . .: What Jacob Saw at Bethel (Genesis 28.10-22)," JSOT 95 (2001): 117-26.

${ }^{6}$ Ibid., 126. 
The text reports about a by "set on the earth with its top reaching to heaven" (gespe

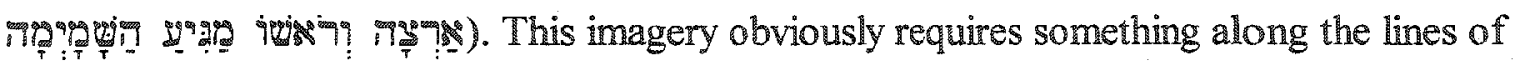
a ladder or a stairway, rather than a gate-like structure.

At this juncture a semantic and etymological analysis of $E^{2} y g^{1}$ is in order. Since the word is a hapax legomenon, it is necessary to resort to its etymology and possible occurrences in cognate languages in order to clarify its meaning. The root of this word, 36, which is attested several times in biblical Hebrew, has the meaning "to lift up, cast up." Biblical Hebrew attests three other words derived from this root: it?

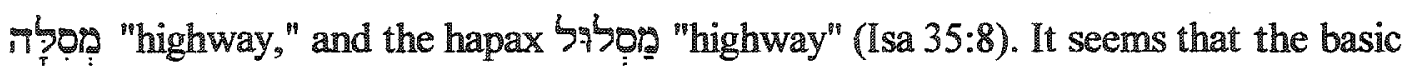
denotation of the root is that of something "lifted up," hence "way" or "highway." As for the precise meaning of $\square$, however, its Akkadian cognate simmiltư may contribute to a more precise interpretation. This word has been attested with the meaning of "staircase," "siege ladders," "ladders to heaven." If there is an etymological and semantic relationship between the Akkadian simmiltu and the meaning of the latter is considerably narrowed down. Nonetheless, the precise visual image behind the word, whether a ladder or a stairway, remains elusive. Fortunately, this detail is immaterial for this investigation.

'The in a is probably an afformative, although some grammarians would consider it a residue of mimation. Cf. Paul Joüon and T. Muraoka, A Grammar of Biblical Hebrew, 2 vols., Subsidia Biblica 14/1-14/2 (Rome: Editrice Pontificio Istituto Biblico, 1996), 1:266.

${ }^{2}$ Francis Brown, with S. R. Driver and Charles A. Briggs, The Brown-Driver-Brigs Hebrew and English Lexicon of the Old Testament, with an Appendix Containing the Biblical Aramaic (BDB), based on the Lexicon of William Gesenius (1906), s.v. I לSo.

${ }^{3}$ Cf. HALOT, s.v.

${ }^{4}$ Jeremy Black, Andrew George, and J. N. Postgate, eds., A Concise Dictionary of Akkadian (2000), s.v. simmiltu(m). Cf. Millard, 86-87. 
What matters is that the 5 So "links heaven and earth and has been placed on the earth presumably near where Jacob was lying."

As for the symbolic connotations of 5 , some scholars have advanced the view that the "stairway"/"ladder" evokes the stairway to heaven from Egyptian sources; ${ }^{2}$ others suggest that the inspirational stimulus for the vision comes from the Mesopotamian temple towers or ziggurats. ${ }^{3}$ The Egyptian connection-although, like Gen 28 , uniting two cosmic realms -is improbable, since contrary to the stairway of Egyptian texts which functioned as a pathway for the deceased to travel from the netherworld to heaven, the stairway of Jacob's dream is a pathway for the angels of God traversing between heaven and earth. ${ }^{4}$ In like manner, the Mesopotamian background also presents difficulties, for as Hoffner has demonstrated, the ziggurat stairways were used by priests, not by deities ${ }^{5}$ or, as in Jacob's dream, heavenly beings.

${ }^{1}$ Wenham, Genesis 16-50, 221-22.

${ }^{2}$ Griffiths, 229-30.

${ }^{3}$ Millard, 86-87; Speiser, 218; Von Rad, Genesis, 284.

${ }^{4}$ C. Houtman, "What Did Jacob See in His Dream at Bethel?" VT 27 (1977): 340. 398.

"Harry A. Hoffner, "Second Millennium Antecedents to the Hebrew 'ôb," JBL 86 (1967):

'Some have tried to establish the Mesopotamian link by means of the Babel narrative which is regarded as being connected with Jacob's dream. Nonetheless, despite the obvious thematic connections between both narratives, it must be noted that there is also a strong opposition between the two entities. The tower of Babel is a product of human fabrication; the stairway of Jacob's dream comes without any human intervention as a way by which YHWH revealed himself to Jacob. Furthermore, had the narrator wanted to evoke a ziggur at, he/she would have probably used the word bivas (tower), the most appropriate Hebrew word to convey the idea of a ziggurat. Cf. Victor P. Hamilton, The Book of Genesis: Chapters 18-50 (Grand Rapids, MI: Eerdmans, 1995), 240. 
Thus, instead of defining the connotation or symbolical function of the stairway in the light of alleged ancient Near Eastern parallels, a more likely solution can be found in the pericope itself. Those scholars who see the stairway as a symbol of the real "fellowship between God in heaven and his people upon the earth," or a "symbolical expression of the intercourse which, though invisible to the natural eye, is nevertheless ever taking place between heaven and earth," ${ }^{12}$ are probably on the right track. If the covenant is a major motif in the pericope, as argued above, then it may be suggested that the stairway with angels going up and down, thereby linking heaven and earth, revealed to Jacob that the promises he received on earth were legitimated by YHWH standing "on the top of the stairway," at "the gate of heaven."(see below for the exegesis of these expressions). In like manner, the earthly spot was the "house of God" because of its connection with the "gate of heaven." In sum, the stairway functions as a graphic illustration of the vertical relationship between heavenly and earthly realities, thus pointing to a mutual correspondence and interaction between both domains.

\section{Syntax of 9 ?}

The main concern of this discussion is to determine the antecedent of the pronominal suffix in 19 לִ or "over him" (i.e., Jacob), or that the Lord was "upon it" (i.e., the stairway). Although

\footnotetext{
"He dreamed" [Gen 28:12], SDABC, 1:382.

${ }^{2}$ Driver, The Book of Genesis, 265.
} 
most scholars prefer "at his side" or "over him," it should be noted that this view is largely, though not always, motivated by regarding $28: 13$ as the beginning of a new source that was ignorant of the ladder. If one takes the passage as a unified composition, the traditional understanding "over it," (i.e., the Lord on top of the stairway) ${ }^{2}$ seems preferable for the following reasons: ${ }^{3}$

First, it must be noted that 9 g the reader to "enter" the dream and see the events from the perspective of Jacob. Thus it is much more likely that 9 describes what Jacob sees in the visual part of his dream (i.e., YHWH over the stairway). Second, from a text-linguistic point of view, it must be noted that 6 is the topical base of $12-13 \mathrm{a}$ (i.e., the clauses and sentences are saying something about it). That is why it is introduced explicitly in the first clause, and subsequently referred back to by means of pronominal suffixes. Third, as Wenham pointed out, "the image of YHWH at the top of the ladder forms a fitting climax to the whole and fits in with the idea that angels report back to him after patrolling the earth (1 Kings $22: 19-22 ;$ Job $1: 6-8 ; 2: 1-3 ;$ Zech 1:10)."14

'Driver, The Book of Genesis, 265; Hamilton, The Book of Genesis: Chapters 18-50, 24041; Skinner, 377; Speiser, 218; Westermann, Genesis 12-36, 455; Saadiah quoted in Sarna, Genesis, 364, n. 6.); NJB, NSRV, JPS.

${ }^{2}$ Blum, 33-54; Wenham, Genesis 16-50, 22; J. Alberto Soggin, Das Buch Genesis: Kommentar (Darmstadt, Germany: Wissenschaftliche Buchgesellschaft, 1997), 363-63; "He dreamed," SDABC, 1:382; Vulgate; Septuagint; Peshitta; Rashi; Ibn Ezra; Ramban; NASB; RSV; NIV. The references to Jewish commentators are from Sarna, Genesis, 364, chap. 28, n. 6.

${ }^{3}$ Gunkel, as noted by Wenham, though admitting that "over him" was how I understood the phrase, "in the current context in JE, one is inclined to translate 'on it," that is, on the ladder." (Gunkel, 310). Cf. Wenham, Genesis 16-50, 222.

${ }^{4}$ Wenham, Genesis 16-50, 222. 
Function of aipip

As shown in the diagram above, gipsi is a key word in the pericope, occurring six times, being thus the most frequent word in this short narrative. By carrying the article in its very first occurrence, its significance is established at the outset. The spatialization noted above has indicated the centrality of aipers as the point of intersection between the horizontal and vertical axes of the narrative. As the story unfolds, what is at first gip? becomes represented by the stairway with angels going up and down upon it.

Syntax of it? ... I?

The expression $7 ! ?$. . . T? is found in 9 .9. ("This is none other than the house of God, and that is the gate of heaven"). The use of the demonstrative pronouns II! . . . TI has elicited some debate. Some scholars argue that the pair should be translated "this ... and this" in reference to the same place. ${ }^{1}$ Others would translate as "this ... and that" in a distributive sense, referring thus to both ends of the stairway, and hence to earthly and heavenly realms, respectively. ${ }^{2}$ An examination of the occurrence of this pair in the Hebrew Bible corroborates Waltke and O'Connor's

\footnotetext{
'Von Rad, Genesis, 283, 285; Wenham, Genesis, 218; Claus Westermann, Genesis 1236: A Commentary (Minneapolis: Augsburg, 1985), 451, 456-57.

${ }^{2}$ Arnold Bogumil Ehrich, Randglossen zur hebräischen Bible: Texthritisches, Sprachliches und Sachliches, 7 vols. (Hildesheim: G. Olms, 1968), 1:136; Hamilton, The Book of Genesis: Chapters 18-50, 244; Kim, 62-65; Niels-Erik Andreasen, "The Heavenly Sanctuary in the Old Testament," 68; Speiser, 218-20; Diana Lipton, Revisions of the Night: Politics and Promises in the Patriarchal Dreams of Genesis, ISOTSup 288 (Sheffield: Sheffield, 1999), 91.
} 
observation that "is? is used for both the 'near' object and the 'far' when a pair is juxtaposed." A few examples will suffice to clarify this point. ${ }^{2}$

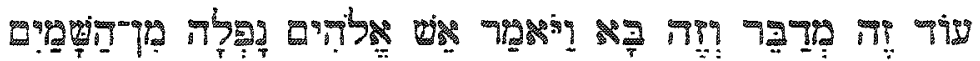
While this one was still speaking, that one came and said, "The fire of God fell from heaven..." (Job 1:16)

\section{กระ}

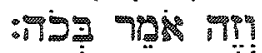
And YHWH said, "Who will entice Ahab to go up and fall at Ramoth-gilead?" And this one said this while that one said that. (1 Kgs 22:20)

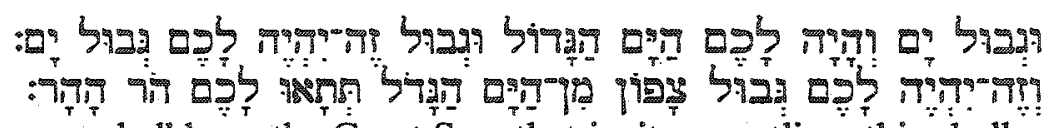

As for the western border, you shall have the Great Sea, that is, its coastline; this shall be your west border. And that shall be your north border: you shall draw your border line from the Great Sea to Mount Hor. (Num 34:6-7)

If Jacob wanted both expressions to refer to the same entity, he would have used the pair

: Jacob said when he saw them, "This is God's camp." So he named that place Mahanaim. (Gen 32:3)

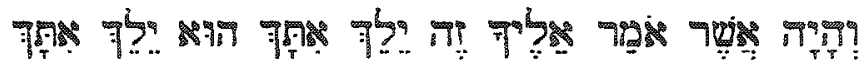
Therefore it shall be that he of whom I say to you, "This one shall go with you," he shall go with you. (Judg $7: 4$ )

Had Jacob intended to identify "this place" with "gate of heaven," he would have said, $^{4}$

${ }^{1}$ Bruce K. Waltke and M. O'Connor, An Introduction to Biblical Hebrew Syntax (Winona Lake, $\mathbb{N}$ : Eisenbrauns, 1990), 309.

${ }^{2} \mathrm{Cf}$ also Exod $3: 15 ;$ Isa $44: 5 ;$ Ps $75: 8 ; 2$ Chr 18:19.

${ }^{3}$ Oblath, 122; cf. Willelm Gesenius, E. Kautzsch, and A. E. Cowley, Gesenius' Hebrew Grammar, 2nd English ed. (Oxford: Clarendon, 1910), 442. Cf. also BDB, s.v. Ty?.

${ }^{4}$ This countertext was suggested by Oblath, 122. 
פด

"This is none other than the house of God, and this is the gate of heaven."

Therefore, on grammatical, syntactical, and stylistic grounds, the statement "This is none other than the house of God, and that is the gate of heaven" refers to two different, albeit interconnected entities. One, "the house of God" (פיר ת refers to "the place" (घiparis) where Jacob stood, the earthly spot occupied by Jacob at that moment, and touched by the stairway. The other, "the gate of heaven" (" end of the stairway, the point where it touches heaven. This analysis, therefore, agrees with Ehrlich's observation that

the repetition of $\mathrm{nI}$ in the second half of the verse would be completely obscure, if Jacob referred only to one place, as generally agreed. In fact, however, two distinct places are referred to here; namely, the place upon the earth where the ladder stood, and the point in heaven which, according to v. 12, its top reached. The place upon the earth Jacob named House of God; and the spot in heaven, Gate of Heaven. ${ }^{1}$

\section{Referent of}

This is the only place in the entire Hebrew Bible where the phrase "gate of heaven" occurs. Some related expressions such as "windows of heaven" and "doors of heaven" appear in a few places in the Hebrew Bible, ${ }^{2}$ but they relate to meteorological phenomena, being thus of little help to clarify the phrase under study, which is placed in the context of a

'The German text reads: "Die Wiederholung von unerklärlich, wenn Jakob nur auf eine Stätte hinwiese, wie allgemein angenommen wird. Tatsächlich aber wird hier auf zwei verschiedene Stätten hingewiesen, nämlich auf die Stelle auf der Erde, wo die Leiter stand, und dam auf den Punkt am Himmel, an den sie nach V. 12 mit ihrer spitze reichte. Die Stätte auf Erde nennt Jakob Haus Gottes und die Stelle am Himmel Himmelspforte" (Ehrlich, 1:136).

$$
{ }^{2} \text { E.g., Gen 7:11; PS 78:23. }
$$


theophany. A close examination of the context in which the phrase occurs probably holds the key to its meaning.

As noted above, the earthly spot, called "house of God" ("9.7\% 792 ), corresponds to its counterpart on the top of the stairway, "gate of heaven" (ำ. latter expression is related to the former as heavenly and earthly counterparts of two interconnected sacred spheres, as the analysis of the distributive pair $7 ?$ ? . . . T! demonstrated, then further investigation is required in order to establish the precise connotation of רgeg ("gate").

At this juncture it is interesting to note that the parallel expressions "house of God" and "gate of heaven" in reference to earthly and heavenly realms, ${ }^{1}$ respectively, are used as a formulaic word pair in Hebrew and Ugaritic. ${ }^{2}$ It should be noted that word pairs were a common stylistic device by means of which poets could achieve different kinds of parallelism. ${ }^{3}$ Thus after using "house" in the first line, Jacob naturally spoke "gate" in the

"The argument might be advanced that the "gate of heaven" refers to the earthly place itself, since ancient temples might be considered as gates to the heavenly realm (see, e.g., Margaret Barker, The Gate of Heaven: The History and Symbolism of the Temple in Jerusalem [London: SPCK, 1991]). It must pointed out, however, that such an argument does not seem to apply to the present text due to the grammatical structure passage, as argued above.

${ }^{2}$ See, e.g., Deut $6: 9 ; 11: 20 ;$ Jer $26: 16 ; 36: 10 ;$ Neh $2: 3 ; 1$ Chr 9:23; 26:13; see also M. Dahood and T. Penar, "Ugaritic-Hebrew Parallel Pairs," in Ras Shampa Parallels: The texts from Ugarit and the Hebrew Bible, ed. Loren R. Fisher et al. (Rome: Pontifical Biblical Institute, 1972). 1:137, n. 137.

${ }^{3}$ For a discussion of word pairs from a linguistic perspective, see Adele Berlin, "Parallel Word Pairs: A Linguistics Explanation," UF 15 (1983): 7-16; idem, The Dynamics of Biblical Parallelism (Bloomington: Indiana University Press, 1985), 64-102. 
second line for the sake of parallelism.' Therefore, his choice of 7906 in the second line of this short poetic utterance is explained along the lines of ancient literary conventions.

Now, since the word "quge parallels $\Omega^{4}$, it is reasonable to suppose that the expression abode/temple/sanctuary. Skinner seems to have had in mind something along this line when he stated that "the earthly sanctuary became as it were the entrance to the true heavenly temple, with which it communicated by means of a ladder." In a similar vein, Von Rad has observed that "in the ancient Orient a rather general distinction was made between the earthly place of a god's appearing and its actual (heavenly) dwelling place. ${ }^{103}$ Commenting upon this passage, Jeremias suggested that Jacob saw "the 'high gate, the heavenly temple, whose earthly counterpart and entrance was formed by the holy site whereupon he stood. ${ }^{104}$

\footnotetext{
${ }^{1}$ Kselman has suggested that Gen $28: 17$ contains a tricolon of poetry which can be perceived in the metric arrangement below:

$m h$ nwr' hmqwm hzh

yn zh ky' $m$ byt 'thym wzh s'r hsmym

"The parallelism of the verse, and specifically the presence of the pair תיa/79u, formulaic in Hebrew and Ugaritic, points to the poetic nature of this tricolon" (John S. Kselman, "Recovery of Poetic Fragments from the Pentateuchal Priestly Source," JBL 97 [1978]: 161-62).

${ }^{2}$ Skinner, 377.

${ }^{3}$ Von Rad, Genesis, 279.

4"die 'Hohe Pforte', den himmlischen Tempel, dessen irdisches Gegenbild und Zugang die heilige Stätte bildet, auf der er liegt" (Alfred Jeremias, Das Alte Testament im Lichte des Alten Orient [Leipzig: J. C. Hinrichs, 1930], 361).
} 
Heavenly Sanctuary/Temple Motif

The discussion undertaken above made apparent that Gen $28: 10-22$ contains the heavenly sanctuary temple motif. This investigation agrees with Kim's study concerning the presence of the heavenly sanctuary/temple motif in the text; nevertheless it attempts to go beyond his study in order to ascertain the function of the heavenly sanctuary/temple as portrayed in the passage, as well as its relationship to the earthly counterpart.

\section{Function}

YHWH is depicted in the text as being on the top of the stairway, implying that he is located at the gate of the heavenly temple. Although it has been argued that the connotation of the heavenly sanctuary/temple in this text is that of "heavenly house of God," since there is "no evidence that reveals the kingship of God," the text seems to indicate otherwise. If one accepts the presence of the covenant motif in the pericope, it gives a conspicuous picture of a heavenly temple from which YHWH, the Suzerain King, ratifies the covenant with his vassal-servant Jacob. The heavenly temple/sanctuary thus seems to be portrayed not merely as the place where YHWH dwells, but also as the place of divine activities, namely, the place whence YHWH issues his promises of help and prosperity for Jacob in comnection with the ratification of the covenant.

\section{Relations:}

The functional correspondence and the dynamic interaction between earthly and heavenly realities and is indicated by verbal connections, spatialization of the text, and the

$$
{ }^{1} \mathrm{Kim}, 68 .
$$


grammatical structure of Jacob's statement. The following verbal connections, for example,

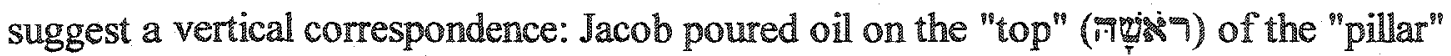

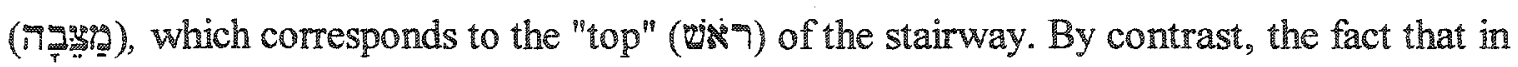
Gen 35:14 the narrator simply says that Jacob anointed a "pillar" by simply pouring oil

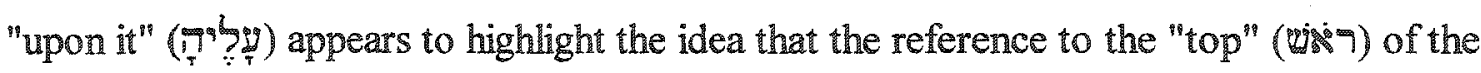

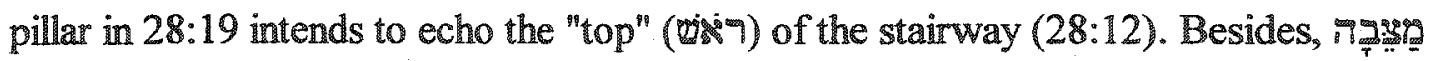

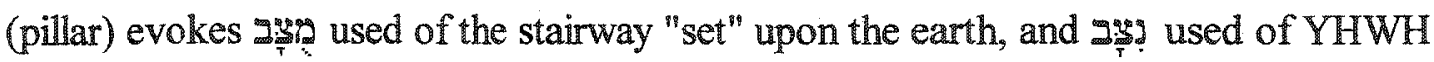
"standing" upon it (i.e., the stairway).

In the spatialization of the text, one perceives that the vertical axis of the narrative, as conveyed by the image of the ladder with angels going up and down, suggests a dynamic interaction between the heavenly temple and its earthly counterpart. Additional support, however, for a vertical correspondence between earthly and heavenly sanctuary is provided by Jacob's poetic utterance: "This is none other than the house of God, and that is the gate of heaven." Thus what is implied in allusions and verbal connections now becomes explicit. The earthly site, "the house of God," alludes to a heavenly counterpart-"the gate of heaven," which, as argued above, is a poetic reference to the heavenly sanctuary/temple itself. Furthermore, the statements and cultic acts performed by Jacob in response to the dream imply a vertical correspondence between the earthly sanctuary and its heavenly counterpart. Besides, the ladder with angels going up and down indicate a dynamic interaction between both spheres in the context of the dream. 


\section{Exod 15:1-18}

หู่ 11 "Who is like you among the heavenly beings, $\mathrm{O}$ YHWH? Who is like you, majestic in the sanctuary, Awesome in praises, working wonders?

A number of scholars have dealt with Exod $15: 1-18$ from a variety of

methodological principles, and with distinct motivations. These have yielded contributions

which advanced the understanding of the metric structure, poetic imagery, theological

underpinnings, linguistic characteristics, date, and Sitz im Leben of the hymn. ${ }^{1}$ The

following discussion does not intend to review all these studies, but is limited to the pursuit

of the theme of the heavenly sanctuary/temple motif in this poetic unit. ${ }^{2}$

'Martin Leon Bremer, The Song of the Sea: Ex. 15:1-21 (Berlin: W. de Gruyter, 1991); Trent Craver Butler, "The Song of the Sea': Exodus 15:1-18: A Study in the Exegesis of Hebrew Poetry" (Ph.D. diss., Vanderbilt University, 1971); Peter Campbell Craigie, "Earliest Israelite Religion: A Study of the Song of the Sea (Exodus 15:1-18)" (Ph.D. diss., McMaster University, 1971); Frank Moore Cross, Canaanite Myth and Hebrew Epic: Essays in the History of the Religion of Israel (Cambridge, MA: Harvard University Press, 1973), 112-44; Thomas B. Dozeman, "The Song of the Sea and Salvation History," in On the Way to Nineveh: Studies in Honor of George M. Landes, ed. Stephen L. Cook and S. C. Winter, ASOR Books 4 (Atlanta, GA: Scholars Press, 1999), 94-113; Paul Lee Engstrom, "Deliverance at the Sea: A Reading of Exodus 15 in Light of Ancient Near Eastern Literature and Its Implications for the Assemblies of God" (Th.D. diss., Luther Seminary, 1996); David Noel Freedman, "Strophe and Meter in Exodus $15, "$ in A Light unto My Path: Old Testament Studies in Honor of Jacob M. Myers, ed. Howard N. Bream, Ralph Daniel Heim, and Carey A. Moore (Philadelphia: Temple University Press, 1974), 163-203; Maribeth Howell, "Exodus 15:1b-18: A Poetic Analysis," ETL 65, no. 1 (1989): 542; Brian Douglas Russell, "The Song of the Sea: The Date and Theological Significance of Exodus 15:1-21" (Ph.D. diss., Union Theological Seminary and Presbyterian School of Christian Education, 2002); James Muilenburg, "A Liturgy on the Triumphs of Yahweh," in Studia Biblica et Semitica; Theodoro Christiono Vriezen qui mumere professoris theologiae per XXV amnos functus est, ab amicis, collegis, discipulis dedicata (Wageningen: H. Veenman, 1966), 233-51; Richard D. Patterson, "Victory at Sea: Prose and Poetry in Exodus 14-15," BibSac 161, no. 641 (2004): 42-54; Philip Matthew Schafran, "The Form and Function of Exodus 15:1-18" (Th.D diss., Dallas Theological Seminary, 1988); John D. W. Watts, "Song of the Sea-Ex. XV," VT 7, no. 4 (1957): 371-80; George Wesley Coats, "Song of the Sea," CBQ 31 (1969): 1-17.

${ }^{2}$ It has been a common procedure to describe the units of Hebrew poetry in terms of poetic lines or cola, and thus a sequence of cola has been labeled as bicolon, tricolon, etc., according to the number of cola in a given poetic strophe. Efforts have also been made to establish criteria to 


\section{Preliminary Observations}

The range of suggestions advanced by scholars regarding the genre of this text leads one to conclude that this passage cannot be made to fit a single form. ${ }^{1}$ John I. Durham has pointed out that this poetic composition "is not comparable to any one psalm, or song or hymn, or liturgy known to us anywhere else in the Hebrew Bible or in ANE literature."2 Fortunately, a decision on this issue is not indispensable for this study, and in the course of the following discussion, for variety's sake, the pericope will be referred to as "hymn," "song," "Song of the Sea," etc. On a macrostructural level, it has been argued that the socalled Song of the Sea (Exod 15:1-21) stands in the middle of the book of Exodus, serving as the "pivoting center" of the book. It provides the appropriate climax for the narrative of the deliverance from Egypt (Exod 1-14) with a proleptic overview of the joumey to Sinai

define a poetic line and the various types of parallelism according to devices such as word count, syllable count, and vowel count (see P. J. Nel, "Parallelism and Recurrence in Biblical Hebrew Poetry: A Theoretical Proposal," JNSL 18 [1992]: 136). However effective and profitable these procedures may be, they need to be complemented by a linguistic approach to the text. And from a linguistic point of view, as Eep Talstra has pointed out, "the basic syntactic unit of analysis is not the poetic line or (colon), but the syntactic clause" (Eep Talstra, "Reading Biblical Hebrew Poetry: Linguistic Structure or Rhetorical Device?," JNSL 25 [1999]: 101-26). Without being oblivious to the rhetorical dimensions of the text, the discussion of Exod 15:1-18 in the present chapter, and other poetic texts in chapters 4 and 5 of this dissertation, gives special attention to syntactic issues.

1E.g., "hymn" (Norbert Lohfink, The Christian Meaning of the Old Testament, trans. $\mathbb{R}$. A. Wilson Milwaukee: Bruce, 1968], 72-81; John D. W. Watts, "Song of the Sea-Ex. XV,"VT 7 [1957]: 371-80), "victory song, (Cross, Cancanite Myth and Hebrew Epic, 121-23), "liturgy (James Muilenburg, "A Liturgy on the Triumphs of Yahweh," in Studia Biblica et Semitica [Wageningen: $\mathbb{H}$. Veenman, 1966], 233-51), "poem of mixed type (John I. Durham, Exodus, WBC 3 [Waco: Word Books, 1987], 203)."

${ }^{2}$ Ibid.

${ }^{3}$ Mark S. Smith, The Pilgrimage Pattern in Exodus, with Contributions of Elizabeth $M$. Bloch Smith, JSOTSup 239 (Sheffield: Sheffield Academic Press, 1997), 183. 
(Exod 15:22-40), ${ }^{\prime}$ and ultimately to the promised land (rest of the Pentateuch, and Joshua).

Studies on strophic and metric structure of this song have revealed an artful composition formed by an intricate relationship of strophes and verses. ${ }^{2}$ Although no two analyses agree in respect to the details, most scholars recognize the important structural function of vss. $6,{ }^{3} 11,16 \mathrm{~b},{ }^{4}$ and that the poem is divided into two major structural sections: The first (1-11 [or 12]) focuses on the saving experience at the Red Sea; the second $(12$ [or 13$]-18),{ }^{5}$ deals with the subsequent experience of Israel in its journey to the promised land.

The composition contains three major structural junctures marked by vss. 6,11 , and 16b. Vs. 11, for reasons soon to be explained, plays a more prominent role than vss. 6 and 16. Whereas vss. 6 and 16 are thematically connected with their respective sections, vs. 11 is thematically and verbally disconnected from the events being celebrated by the song.

'Brian Douglas Russell, "The Song of the Sea: The Date and Theological Significance of Exodus 15:1-21" (Ph.D. diss., Union Theological Seminary and Presbyterian School of Christian Education, 2002), 87.

2For the purposes of this research, however, it suffices to outline the broad structure of the poem, especially the identification of its center, for reasons that will become clear in due course.

IIt has been demonstrated that the poetic unit of vs. 6 includes vs. 7 a, a view adopted in the following discussion. Cf. Jon Paulien, "The Sing of Miriam: A Poetic Analysis," TMs, 1981, 8; Russell, 120.

${ }^{4} \mathrm{C}$. William Henry Propp, Exodus 1-18: A New Translation with Introduction and Commentary, AB 2 (New York: Doubleday, 1999), 505.

${ }^{5}$ There is no consensus among scholars about where to start the second major section of the song. Most of them opt for either 12 or 13 . For reasons to be explained in due course, vs. 12 is the suggestion of this study. 
Thus, vs. 6 proclaims YHWH's power by shattering the enemy, which clearly links it thematically with the first section. In like manner, vs. 16 contains the theme of guidance and therefore stands in the thematic flow of the second section. Vs. 11, in contrast, by being placed at the "center and apex of the poem ... relates equally to both strophes: The God described in vs 11 is equally responsible for the victory at the sea and for the triumphant march to the Holy Land."1

An important feature of vs. 11 is the repetition of the rhetorical question ("Who is like you") which provides the verse with a staircase parallelism in which YHWH's incomparability is emphasized. Labuschagne has demonstrated that rhetorical questions are frequently used in the Hebrew Bible to express the absolute power, uniqueness, and incomparability of YHWH. ${ }^{2}$ Thus vs. 11 by means of this rhetorical device underscores the absolute power and majesty of YHWH "in the sanctuary"13 and among the "heavenly beings."

Freedman further states that "by being less specific than the other refrains, which relate directly to the theme of their respective strophes ... vs. 11 serves them both as center and fulcrum." Interestingly enough, vs. 11 is the only segment of the hymn containing no finite verb. It contains only nominal and participial clauses, thus portraying

Freedman, "Strophe and Meter in Exodus 15," 185.

${ }^{2}$ C. J. Labuschagne, The Incomparability of Yahweh in the Old Testament (Leiden: Brill, 1966), $16 \mathrm{ff}$.

${ }^{3}$ The translation of the prepositional phrase due course.

${ }^{4}$ Freedman, "Strophe and Meter in Exodus 15," 185. 
distinct time perspective as if the poet, at this point, not only breaks the thematic flow of the hymn, but also steps outside the time frame of the hymn while addressing YHWH who, surrounded by heavenly beings, is present "in the sanctuary."

Other scholars have noted the special structural role of vs. 11 as well. Fokkelman argues that "the hymnal center does not link any of the terms celebrating God to the concrete situation, as if to indicate that God cannot be contained and that his perfections utterly transcend the horizon of human knowing. "In the same vein, Propp recognized that "Exod $15: 11$ is difficult to relate to its context. It seems an ecstatic interjection into the historical résumé of vv 10 and $12 . " 2$ Georg Fischer added his agreement to the above opinions by saying that vs. 11 "stands in the center of the song, ${ }^{103}$ and Jasper Burden argued that "the staircase parallelism of verse 11 serves as a pivot point of the hymn proper emphasizing the most important point the poet wishes to make: Who is like thee, 0 LORD? ${ }^{\text {n4 }}$

Therefore, the hymn may be regarded as broadly divided into two major sections (1-10 and 12-18) having vs. 11 in the center. Some verbal and thematic features reinforce this outline. For example, a closer inspection of the composition reveals that the first

1J. P. Fokkelman, Major Poems of the Hebrew Bible: At the Interface of Hermeneutics and Structural Analysis, 2 vols., SSN 37 (Assen, The Netherlands: Van Gorcum, 1998), 1:46.

${ }^{2}$ Propp, 528.

"The German text reads: "im Zentrum des Lieds steht" (Georg Fischer, "Das Schilfmeerlied Exodus 15 in seinem Kontext," Bib 77, no. 1 [1996]: 35).

"Jasper J. Burden, "A Stylistic Anaysis of Exodus 15:1-21: Theory and Practice," in Exodus 1-15: Text and Context: Proceedings of the 29th Annual Congress of the Old Testament Society of South Africa, ed. J. J. Burden, P. J. Botha, and H. F. Van Rooy, OTWSA/OTSSA 29 (1986) (Pretoria: Univ. of South Africa, 1987), 51. 


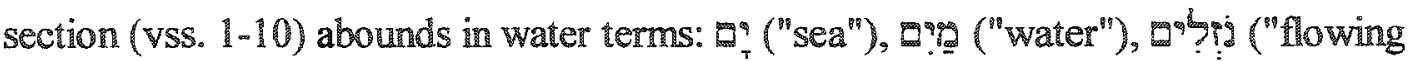

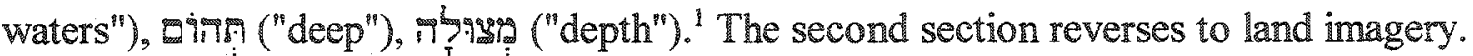
Vs. 12 mentions pos (earth/land) ${ }^{2}$ and after that, all the events transpire upon dry land. YHWH is mainly depicted as a shepherd, guiding his people to their goal. At the end of this second section, after references to the mountain and the sanctuary, a "concluding antiphon"3 (vs. 18) provides a fitting closure to the entire composition by proclaiming

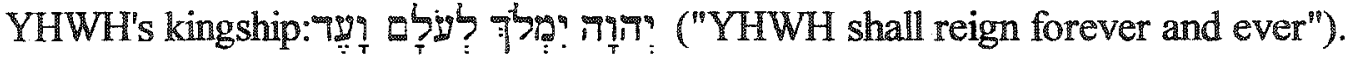
Additionally, we should note that the second section presents several motifs and allusions pointing forward to the subsequent history of the people. ${ }^{4}$ Turning to the center of the hymn, one notes that vs. 11 contains heaven imagery as implied by the reference to YHWH

${ }^{1}$ It should be added that these do not depict personal forces, but are only instruments used by YHWH, the divine warrior, to defeat Israel's enemies.

${ }^{2}$ Vs. 12 seems to be problematic for the suggested outline, since it apparently refers back to the experience at the Sea: ץר earth swallowed them"). This can be explained as follows: vs. 12 does not refer to the destruction of the Egyptian army at the Red Sea, but to the judgment of Korah, Dathan, and Abiram. If so, the expression pros ("The earth swallowed them") may well be a prophetic allusion to Num 16:32: ם up"). Notice that 1 's is used six times in the Hebrew Bible in reference to the judgment upon Korah, Dathan, and Abiram. On the other hand, 2 hy in its 40 occurrences in the Hebrew Bible never refers to the destruction of the Egyptians at the Red Sea, unless Exod 15:12 is thus understood. If this suggestion is accepted, there is a perfect coincidence between the thematic flow of the narrative and the structural suggestion made above, since vs. 12 would in fact refer to Israel's experience on the way to the promised land (cf. Fischer, "Das Schilfmeerlied Exodus 15 in seinem Kontext," 36, n. 14; John D. W. Watts, "Song of the Sea-Ex. XV," VT 7, no. 4 [1957]: 374).

${ }^{3}$ Thomas W. Mann, Divine Presence and Guidance in Israelite Traditions: The Typology of Exaltation (Baltimore: Johns Hopkins University Press, 1977), 125.

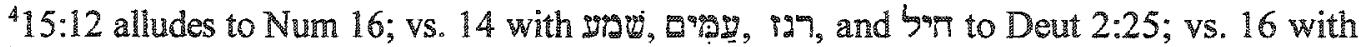
กภำ to $1 \mathrm{Kgs} 8: 13$. 
among the "heavenly beings" (E) in the "sanctuary" (vip). The hym, therefore, portrays three interrelated environments: vss. 1-10: sea; vs. 11: heaven; vss. 12-18: earth/land. Thus, as noted by Propp, the song "begins in the Sea's depths" and "ends on a mountaintop sanctum, from which YHWH reigns for ever."1

In view of the foregoing discussion, it may be suggested that the song is formed by two major sections, divided by vs. 11 at the center, as the "pivot point" for the entire song. A simplified structure of the hymn may be thus outlined: ${ }^{2}$ Retrospective experience of Israel-salvation at the Red Sea (15:1-10); pivot point: YHWH surrounded by heavenly beings in the [heavenly] sanctuary (15:11); prospective experience of Israel-guidance through the wilderness to the promised land/sanctuary $(15: 12-18)$.

After this overview of the structure of the song, a closer examination of the structure of $15: 11$ is in order. This verse is organized in a staircase parallelism, ${ }^{3}$ a literary device quite common in Ugaritic ${ }^{4}$ and Hebrew poetry. ${ }^{5}$ Exod 15:6-7a and 15:11 follow the three-line variety. In this type of poetic structure, as noted above, the second line

\section{Propp, 571.}

${ }^{2}$ For a detailed study of the metric structure of this song, cf. Cross, Canaanite Myth and Hebrew Epic, 112-44; Fokkelman, Major Poems of the Hebrew Bible, 1:24-53; Freedman, "Strophe and Meter in Exodus 15," 163-203.

${ }^{3}$ For a discussion of staircase parallelism, cf. Wilfred G. E. Watson, Classical Hebrew Poetry: A Guide to Its Techniques, ISOTSup 26 (Sheffield: JSOT Press, 1984), 150-56.

${ }^{4}$ A classical example is the following excerpt from KTU 1:2 IV 8-9:

ht ibh brm Now your foe, Baal,

ht ibk tmins N Now your foe you must smite;

ht tsmt srth Now you must destroy your adversary?

Wyatt, Religious Texts from Ugarit, 65.

${ }^{5}$ Cf., e.g., Judg 5; Pss 29; 77:17; 89:52; 92:10; Isa 26:15. 


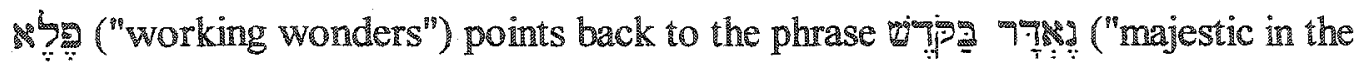
sanctuary"), a probable allusion to YHWH's activities in the heavenly sanctuary.

Following this discussion about the overall structure of the hymn and the specific structure of 15:11, one should examine the structure of the second major division of the text. Therein are found several occurrences of words related to the sanctuary motif. Therefore, an identification of the major structural elements in this section may be useful in the process of ascertaining the contribution of these words to the investigation of the heavenly sanctuary motif.

A study by Howell, ${ }^{1}$ further refined by Russell, ${ }^{2}$ has proposed that Exod 15:12-17 displays the following chiastic structure:

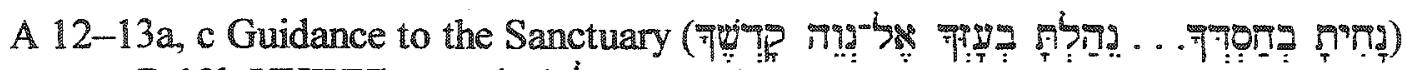

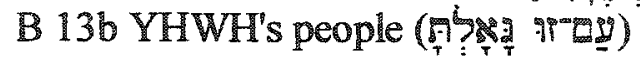

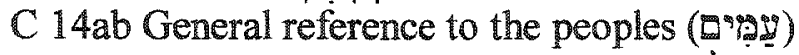

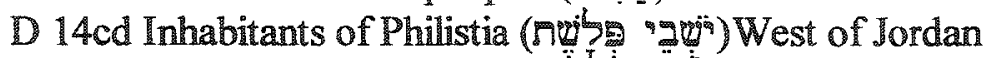
E 15ab Chiefs of Edom (4) East of Jordan

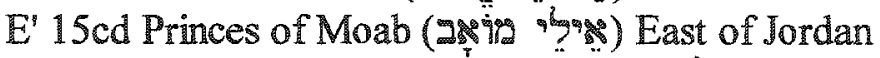

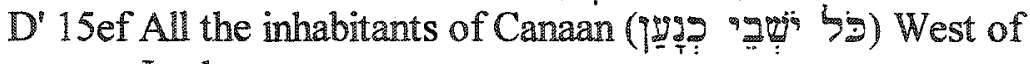
Jordan

$C^{\prime} 16 \mathrm{abcd}$ General reference to the peoples

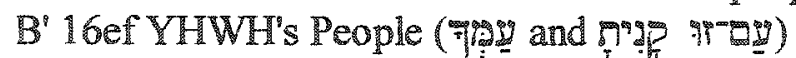

$A^{\prime}$ Guidance to the Sanctuary (all of vs. 17)

Worthy of note is that the sanctuary motif frames the entire section, since both $\mathrm{A}$ and $A^{\prime}$ are related to the concept of guidance to the sanctuary. This observation, along with

${ }^{1}$ Howell, 38. Howell notes that the kemel of her structure $C: D: D ': C^{\prime}$ (i.e., $D: E:: E^{\prime}: D$ ' in the rearrangement by Russell; pp. 55-56) was proposed by Norman K. Gotwald, The Tribes of Yahweh: A Sociology of the Religion of Liberated Israel, 1250-1050 B.C.E. (Maryknoll, NY: Orbis, 1979), 512.

${ }^{2}$ Russell, 55-56. 
the perception that vs. 11 is the pivot point of the hymn, will be relevant for the ensuing discussion.

\section{Semantic and Other Exegetical Considerations}

The song contains several words and expressions evocative of the heavenly sanctuary/temple motif. These terms are now investigated in order to ascertain their contribution to the theme under study.

\section{Syntax and Meaning of abse}

The expression 6 is formed by combining with the preposition may be translated as "among the gods," since the noun ts is a general Semitic word for "God/god." In view of the context, the translation "heavenly beings" is suggested, since "gods" might imply a polytheistic idea contrary to the theological outlook of the Hebrew Bible. ${ }^{2}$ The imagery evoked by the text seems to be that of YHWH surrounded by heavenly beings "in the sanctuary," as will be argued below. But regarding a are in order. Among four other occurrences of $t$ s in the Hebrew Bible, ${ }^{3}$ the most relevant for this study is PS 89:7-8 [6-7] because it displays the same syntactic structure (i.e., preposition + noun phrase) and seems to evoke the same imagery as the Exodus text.

\section{"HALOT, S.v. "Mls.".}

2Some Jewish scholars opted to render it as "angels." Thus Ibn Ezra, Ramban (mentioned by Hyatt, 165); Benno Jacob, The Second Book of the Bible: Exodus (Hoboken, NJ: Ktav, 1992), 430. The IPS Tanakh (1985) seems to imply a similar understanding by translating g"bas as "celestials."

3Pss 89:7-8 [6-7]; 29:1; Job 41:17; Dan $11: 36$ 


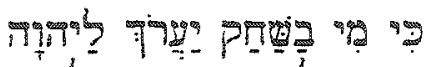

שים

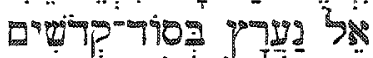

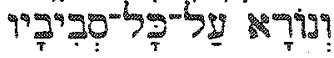

For who in the skies is comparable to YHWH? Who among the sons of the mighty is like YHWH, A God greatly feared in the council of the holy ones, And awesome above all those who are around him?

It should be noted in the text above that the syntagm "among the mighty" ('9.

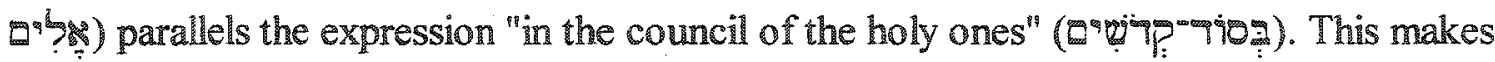
clear that Ps 89:7-8 [6-7] portrays heavenly council imagery. That being the case, it is reasonable to argue that Exod 15:11 expresses the same concept.

Although it is outside the scope of this study to present a detailed analysis of the heavenly council motif, two observations are in order. First, as Gregory A. Boyd put it, "the Old Testament exhibits no reservation in acknowledging the existence of gods [sic $]^{1}$ outside Yahweh and of the gods who form his heavenly council. But even here Yahweh's supremacy is always at the forefront of their thoughts."2 Second, the imagery of the council of YHWH evokes a temple/sanctuary associative field, since the temple/sanctuary is sometimes portrayed as the locale wherein the divine assembly convenes. ${ }^{3}$

\section{Symtax and Meaming of wipg}

The lexeme occurs in 382 verses the Hebrew Bible; it often has an adjectival function in genitival constructions. Sometimes it is used as a noun meaning "holiness," or

"By "gods," Boyd means divine beings created by, and under the authority of, YHWH (Gregory A. Boyd, God at War: The Bible \& Spiritual Conflict [Downers Grove, IL: Inter Varsity Press, 1997], 117).

${ }^{2}$ Ibid.

${ }^{3}$ See the first chapter of this dissertation for an overview of the function of the heavenly sanctuary/temple in ANE literature. See also Mullen, Jr., $128 \mathrm{ff}$. 
"sanctuary," but when govemed by the preposition meaning in almost all of its occurrences. Therefore, it is suggested that waj in $15: 11$ can be translated as "in the sanctuary."

Most versions and scholars prefer to translate it either as an abstract "in holiness," or as a concrete noun "among the holy ones," the latter being understood either as a collective, or plural, according to the $\mathrm{LXX}{ }^{3}$ These translations, however, are problematic for the following reasons: First, it is difficult to relate ofpas as abstract expression "in holiness" with the root "7m (as in Exod 15:11), since the latter, as Cohen pointed out, always refers to physical strength in ancient Hebrew poetry. ${ }^{4}$ Second, the collective meaning of ojem is not attested elsewhere in the Hebrew Bible. Third, as for the emendation of is to read a

${ }^{1} \mathrm{~K}$. Kornfeld, "שู่าp qdšs," TWAT, 6:1186.

${ }^{2}$ Cf., e.g., ASV, KJV, JPS, NASB, NIV, NKJV, RSV.

${ }^{3}$ Suggestion advanced by $\mathrm{G}$. Quell in the apparatus of $B H S, 111$.

${ }^{4}$ Chaim Cohen, "Studies in Early Israelite Poetry 1: An Unrecognized Case of Three-Line Staircase Parallelism in the Song of the Sea, ${ }^{\prime} J A N E S 7$ (1975): 16, n. 22.

${ }^{5}$ This interpretation is favored by scholars who often refer to Deut $33: 3$ (Cross, Canaanite Myth and Hebrew Epic, 129, n. 61; Trent Craver Butler, "The Song of the Sea: Exodus 15:1-18: A Study in the Exegesis of Hebrew Poetry" [Ph.D. diss., Vanderbilt University, 1971], 72; Patrick D. Miller, Jr., "Two Critical Notes on Psalm 68 and Deuteronomy 33," HTR 57 [1964]: 241; Muilenburg, "A Liturgy on the Triumphs of Yahweh," 244) and/or Ps 77:14 (cf. Mitchell J. Dahood, Psalms 11: 51-100: Introduction, Translation, and Notes, AB (Garden City, NY: Doubleday, 1968), 230; Brian Douglas Russell, "The Song of the Sea: The Date and Theological Significance of Exodus 15:1-21" [Ph.D. diss., Union Theological Seminary and Presbyterian School of Christian Education, 2002], 21-22)-passages which allegedly employ wo in a collective sense. The major problem with the appeal to Deut $33: 33$ is that, despite the textual problems that beset the passage, "revp is clearly in the plural as shown by the connecting " before the pronominal suffix 9. It should, therefore, be translated as "holy ones." As for Ps 77:14 [13], it must be pointed out that a collective sense of eripg does not fit the context. 
in the other textual witness apart from the LXX.' Therefore, due to the difficulties with the "abstract" and "collective" interpretations of may be adequately translated as a locative "in the sanctuary" for reasons delineated below.

First, although the lexeme wisplays a wide range of meanings varying from concrete to abstract denotations, it is perceived that when it is governed by the preposition it conveys a spatial/locative idea. Out of twenty-eight occurrences of wype in the Hebrew Bible, twenty-five ${ }^{2}$ can be safely translated spatially as "in the sanctuary" or "holy

'There are scholars, however, who prefer to read wip' as a plural according to the LXX. Whether the LXX translators found the plural in the Vorlage, or simply imposed their interpretation upon the text is a moot point; what is clear, however, is that all the other textual witnesses corroborate a singular reading.

${ }^{2}$ Exod $15: 11 ; 26: 34 ; 28: 43 ; 29: 30 ; 35: 19 ; 39: 1,41 ;$ Lev $6: 23 ; 10: 18 ; 16: 17,27$; Num $4: 12,16 ; 18: 10 ; 28: 7 ; 2$ Chr 29:7; 35:5; Pss 60:8 [6]; 63:3 [2]; 68:18 [17], 25 [24]; 74:3; 108:8 [7]; 150:1; Ezek 44:27. Among these passages, Num 18:10 requires additional comment: The verse reads as follows: "משר

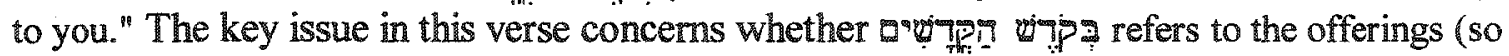
R. Dennis Cole, Numbers, NAC 3b [Nashville, TN: Broadman and Holman, 2000], 284; cf, e.g., also the following versions: NIV, NASB, TNK, ASV, BBE, NJB, NRSV), or to the place wherein the offerings were supposed to be consumed by the priests (so George Buchanan Gray, A Critical and Exegetical Commentary on Numbers, NICC [Edinburgh: T. and T. Clark, 1956], 223; "In the Most Holy Place," SDABC, 1:883; cf., e.g., the following versions: DRA, ESV, GNV, JPS, KJV, NKJ, ELB). A reference to the offerings is complicated by the use of the preposition which

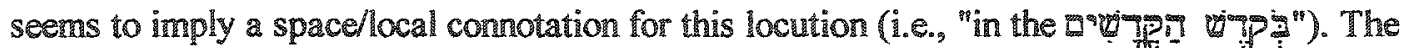
translation "in the most holy place" is also problematic since only the high priest could have access to it, and exclusively in the day of atonement (cf. Timothy R. Ashley, The Book of Numbers, NICOT [Grand Rapids, MI: Eerdmans, 1993], 348). A probable solution would run as follows:

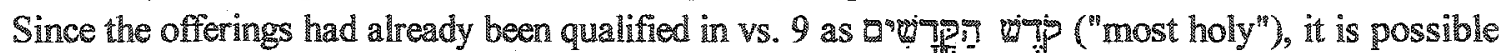
that vs. 11 would now refer to the sacred place where these offerings could be consumed.

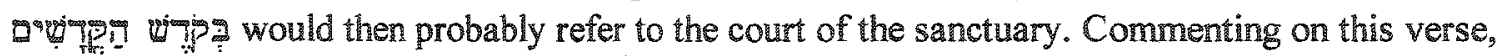
Milgrom observed that the offering should be "eaten in the Tabernacle courtyard on the same day by male priests, in accordance with Lev 6,9,19 and 7:6" (Numbers: The Traditional Hebrew Text with the New JPS Translation, The IPS Torah Commentary [Philadelphia: Jewish Publication Society, 1990], 150). Thus on the basis of the previous observations, the expression areqping most probably has a local/spatial meaning. Whether this refers to the "court" (see above, Milgrom), or to some other compartment of the sanctuary should not concern us here, since the major task 
place" (in reference to the sacrificial court), ${ }^{1}$ as attested by versions and commentators.

Three cases are left, which require further comment. In Ps 89:35 and Amos 4:2 the phrase w9. as part of an oath formula, is justifiably translated "by my/his holiness," as translations and commentators usually do. ${ }^{2}$ The other seeming exception is wipg in $\mathrm{Ps}$ 77:14 [13], read by versions and commentators as "in holiness." This passage is relevant for this discussion due to its conceptual and verbal connections with Exod 15:11, as noted in the ensuing discussion. For the reader's convenience both passages are displayed below.

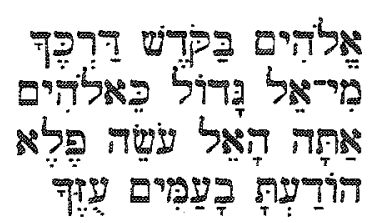

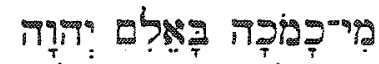

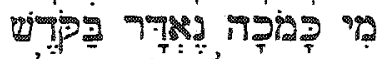
ม
Ps 77:14-15 [13-14] $]^{3}$

Your way, $\mathrm{O}$ God, is in the sanctuary;

What god is great like our God? You are the God who works wonders; You have made known your strength among the peoples.

\section{Exod 15:11}

Who is like you among the heavenly beings, O YHWH? Who is like you, majestic in the sanctuary, Awesome in praises, working wonders?

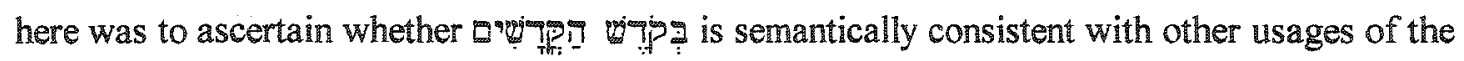
phrase vomp in the Hebrew Bible. In summary, for the purpose of this research it shall suffice to note that Num 18:10 is also to be understood spatially, i.e., in reference to a holy place.

'According to Jacob Milgrom vipa in Lev 10:18, 2 Chr 29:7, Ps 63.3 [2], and Ezek 44:27 refers to the sacrificial court of the Tabemacle/Temple. Jacob Milgrom, Leviticus 1-16: A New Translation with Introduction and Commentary, AB 3 (New York: Doubleday, 1991), 605, 62526.

"These two references contain the oath formula you "swear by" which appears in expressions like "The Lord has sworn by the pride of Jacob, His right hand, by himself," etc. Cf. Deut $6: 13$; Josh $2: 12 ;$ Isa 62:8; Jer $51: 14 ;$ Amos 4:2; 6:8; 8:7. Interestingly enough, in Mishnaic times oaths could also be taken in the name of the temple. See Shalom M. Paul and Frank Moore Cross, Amos: A Commentary on the Book of Amos, Hermeneia-A Critical and Historical Commentary on the Bible (Minneapolis: Fortress Press, 1991), 129, n. 15.

${ }^{3}$ The translation of ${ }^{2}$, by "in the sanctuary" is supported by Vulgate, LXX, ASV, DBY, GNV, NKJ, RWB, ELB, ELO, ARC. 
The intertextual conneetions between both passages being evident, it suffices to demonstrate that therefore the first line may be thus translated: "Your way, ${ }^{1} \mathrm{O}$ God, is in the sanctuary," a reading adopted by several ancient and modern versions. ${ }^{2}$ Thus, out of twenty-eight occurrences of pin in the Hebrew Bible, twenty-six can be translated as "in the sanctuary."

Second, the parallelism between שִ should be understood in a locative sense, like the of others. ${ }^{4}$ Furthermore, as noted above, that evokes the concept of the "heavenly council" which would be located in the sanctuary lends further support to this suggestion.

Third, the occurrence several words and expressions for sanctuary/temple, occurring in the second section of the hymn, strengthens the probability that the structural

\footnotetext{
"The word "way" (797) is frequently found in the Psalms in the sense of "law," "ordinance" (Pss 18:22 [21], 31 [30]; 25:4; 25:8; 27:11; 37:34; 51:15; 67:2; 81:14; 86:11; 103:7; $119: 14,27,30,32,33$ ), hence that YHWH's "way ... is in the sanctuary" is a fitting concept in view of the tablets of the ten commandments being stored therein. In addition, it should be kept in mind that the sanctuary/temple, with its priests, rituals, ceremonies, and all the instructions regarding YHWH's purposes for his people, was the most concrete locus for YHWH's ways to be manifested and taught to the people.

${ }^{2} \mathrm{LXX}$, Vulgate, ASV, NKJ, DBY, DRA, GNV, KJV, DRB, ARC, ACF. Cf. also Albert Barnes, Book of the Psolms (New York: Harper, 1868), 371.

${ }^{3}$ The German text reads: "wopg ist Ortsangabe wie why und heisst im Rate der Heiligen, eigentlich im Heilgtum, doi.o, im Himmel" (Ehrlich, 1:321).

${ }^{4}$ Brenner, 113; Propp, Exodus 1-18, 527.
} 
center of the composition (i.e., 15:11) alludes to the heavenly sanctuary/temple, thus anticipating the major theme of the second section. ${ }^{1}$

Fourth, if extrabiblical parallels can shed any light upon the text, then it may be argued that ANE understanding of the warrior-deity being enthroned in the sanctuary after a major battle resonates with the overall thematic pattern of Exod 15:1-18. ${ }^{2}$ For example, Marduk following his victory over Tiamat is proclaimed supreme in the sanctuary. ${ }^{3}$ Also Baal, after defeating Yam, is enthroned in his heavenly temple. ${ }^{4}$ If the Hebrew poet intended a similar pattern in this composition, as several scholars would agree, ${ }^{5}$ then it may discussed below.

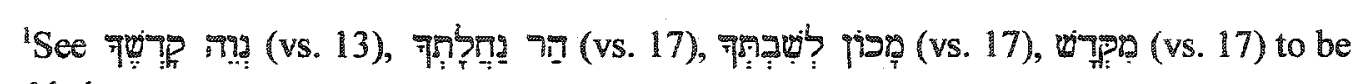

${ }^{2} \mathrm{P}$. Schafram argues that Exod 15:1-18 follows the thematic pattern of "WarriorBattle/Victory-Kingship" as present in ANE literature, namely, the Baal Epic and Enuma Elish. The author intentionally used formulaic language of the myths to capture their function and thereby exalt YHWH and his new creation, the nation of Israel. Philip Matthew Schafran, "The Form and Function of Exodus 15:1-18" (Th.D diss., Dallas Theological Seminary, 1988).

${ }^{3} \mathrm{Cf}$. Alexander Heidel, The Babylonian Genesis: The Story of the Creation, $2 \mathrm{~d}$ ed. (Chicago: University of Chicago Press, 1951); L. W. King, The Seven Tablets of Creation or the Babylonion and Assyrian Legends Concerning the Creation of the World and of Mankind, vol. 1 (London: Luzac and Co., 1902).

${ }^{4} \mathrm{Cf}$. "The Baal Cycle of Myths," in N. Wyatt, Religious Texts from Ugarit, $34 \mathrm{ff}$.

${ }^{5}$ Some scholars maintain a connection between Exod 15:1-18 and ANE mythological texts. See, e.g., Bernard Frank Batto, Slaying the Dragon: Mythmaking in the Biblical Tradition (Louisville, KY: Westminster/John Knox Press, 1992), 128-52; idem, "Paradise Reexamined," in The Biblical Canon in Comparative Perspective: Scripture in Context IV, ed. K. Lawsson, William W. Hallo, and Bernard F. Batto, Ancient Near Eastern Texts and Studies 11 (Lewiston, NY: Mellen, 1991), 33-66.

Although some scholars see mythological overtones in Exod 15:1-18, the differences should not be overlooked. E.g. in the biblical account, the enemy is an historical entity, and the sea is a mere instrument in the hands of YHWH to execute his judgment. In a sense one might say that Mลงก is nothing more than a passive instrument in the hands of YHWH, as recognized by Cross in the following statement: "[The] sea is not personified or hostile, but a passive instrument in YHWH's control. There is no question here of a mythological combat between two gods. YHWH defeats historical, human enemies" (Cross, Canaanite Myth and Hebrew Epic, 131-32). 
be suggested that receives further support. The thematic pattern that emerges from the song seems clear-YHWH, the divine Warrior, defeats the Egyptian army, and is immediately portrayed "in the sanctuary."

Fifth, as noted above, the hymn seems to exhibit a threefold spatial structure: sea (15:1-10), heaven (15:11), earth (15:12-18). Therefore, if wip in $15: 11$ means "in the sanctuary," then it becomes apparent that this is the "heavenly sanctuary." A similar understanding of the passage was espoused by Ibn Ezra, who translated this expression as "in the holy place-i.e. on His throne of Glory."

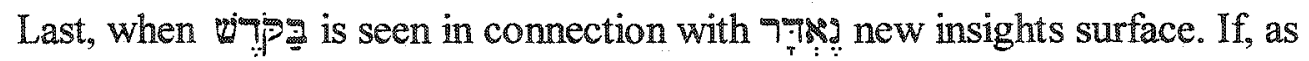
already noted, the root $77 \mathfrak{M}$ in ancient Hebrew poetry always refers to physical strength, it is difficult to understand its relationship to "holiness."2 An interesting use of the root 975 is found in Ps 93:4. The intertextual linkages of this passage with Exod 15:11 may contribute to our understanding of the latter.

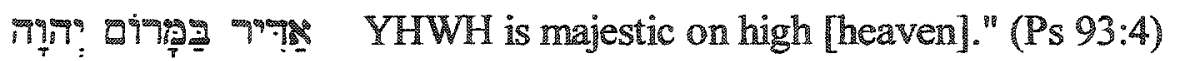

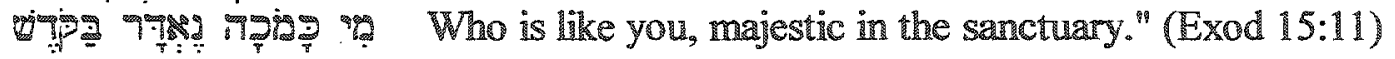
Ps 93:4 seems to be the only place in the Hebrew Bible, apart from Exod 15:11, where the root $97 x$ is followed by the preposition 3 in a locative expression (ㄴา

1'A. J. Rosenberg, Shemoth: A New English Translation, 2 vols., Judaica Press Books of the Bible (New York: Judaica Press, 1995), 1:217.

${ }^{2}$ Chaim Cohen suggested that 07 be read as a collective in the sense of "holy ones" ("Studies in Early Israelite Poetry I: An Unrecognized Case of Three-Line Staircase Parallelism in the Song of the Sea," JANES 7 [1975]: 16, n. 22). This interpretation is favored by other scholars, who often refer to Deut $33: 3$ and/or Ps $77: 14$, as noted above. 
construction identical to prom in Exod 15:11. Interestingly enough, this expression in $\mathrm{PS}$ 93:4 occurs in the context of YHWH's exaltation above the waters/sea/rivers (Ps 93:3-4). Moreover, the word goccurs in the immediate context (PS 93:5). To sum up, this intertextual connection is noted here, because it demonstrates that the construction is followed by a locative noun as the object of the preposition.

The foregoing discussion is intended to demonstrate that 2yig? in Exod 15:11 is better translated as "in the sanctuary," namely, the "heavenly sanctuary," as indicated by the structure and context of the passage. Apart from being supported by the grammatical and thematic context of the song, this interpretation seems to agree in general lines with a wellknown ANE pattern where the victorious deity, after defeating the enemy, is enthroned in the temple. Intertextual connections with other Hebrew Bible passages contribute to further reinforce the plausibility of this suggestion.

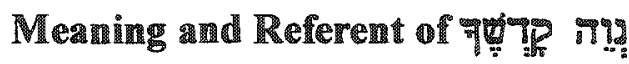

The exact phrase Bible, and has mostly been translated as "your holy habitation/dwelling/abode." Two versions, however, have translated it as "the dwelling of your sanctuary. "While the latter translation seems to have understood wip in a concrete sense of sanctuary, the former understood it as an abstract noun used to qualify mig. This word has the lexical meaning of

\footnotetext{
'Both verses contain basically the same syntactic structure $77 x+2+\mathrm{N}(\mathrm{loc})$.

2"Wohnung deines Heiligtums" by the The German Schlachter Version, Genfer Bibelgesellschaft (Geneva Bible Society, 1951); "habitación de tu santuario" by The Spanish Reina-Valera Bible, 1909.
} 
"stopping place, settlement," hence "dwelling/habitation." Although nị can be used in reference to the land of Israel, or Jerusalem, ${ }^{2}$ there are indications that in Exod 15:13 it evokes temple imagery, as can be noted by the use of vigp in connection with ก!g which echoes temple and cult mentality, ${ }^{3}$ and by the structural correspondence between vss. 13 and 17 as well.

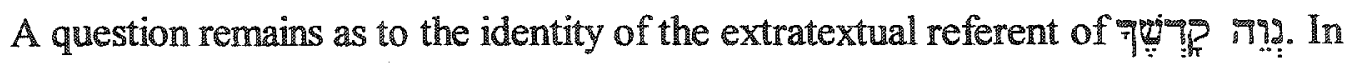
order to ascertain the meaning of this expression, attention must be given to the structural position of between ${ }^{2}$ two aspects are pursued in connection with $15: 17$, below). For now, it suffices to note that the chiastic structure of the second part of the poem (Exod 15:12-18) displayed above reveals that vs. 13 corresponds to vs. 17 , the implication being that the referent of TI9 in 15:13 most probably coincides with the referent of the temple/sanctuary terms in 15:17. The investigation of vs. 17 in the ensuing discussion intends to clarify vs. 11. It should noted again that the second section of the song prospectively depicts YHWH guiding the people to their ultimate goal, a goal described in four expressions (vs. 13 is included for the sake of comparison):

"HALOT, s.v. "הְִּ:"

${ }^{2} 2$ Sam 15:25; Jer 50:19; Ps 79:7; Lam 2:2.

${ }^{3}$ The intertextual connection with Jer 31:23 seems to demonstrate this: "YHWH bless you,

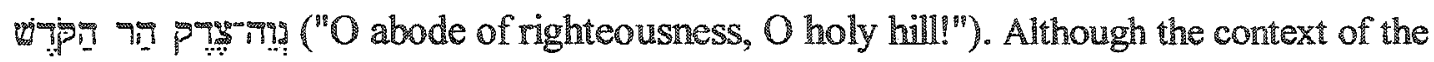
passage seems to have the whole land in view, since it speaks of all of Judah dwelling on the holy mountain, commentators usually agree that the author has Jerusalem and the temple in mind. Cf. Brenner, 136-37. 


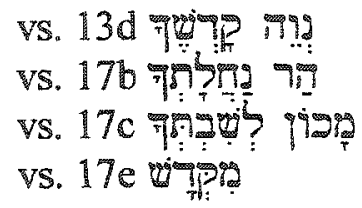

As noted, the parallelism between Fשg? T!? in Exod 15:13 and its parallel expressions in 15:17bce stress the possibility that all of them point to the same referent. "This referent has been understood as Mount Sinai, ${ }^{2}$ cosmic mountain, ${ }^{3}$ the sanctuary at Gilgal, ${ }^{4}$ the land of Canaan as a whole, Jerusalem temple. ${ }^{6}$ Some scholars have opted for a mixture of two or more options $^{7}$ or remained undecided.

The idea that Gilgal was the immediate goal of the joumey has no exegetical basis and therefore does not require further consideration. ${ }^{9}$ Simai might be a reasonable option in view of Israel's experience in comection with this mountain, namely the reception of the

${ }^{1}$ Watts, 377.

2David Noel Freedman, "Temple Without Hands," in Temples and High Places in Biblical Times (Jerusalem: Nelson Glueck School of Biblical Archaeology of Hebrew Union College, 1977), 21-30; Russell, 161-82.

${ }^{3}$ Clifford, The Cosmic Mountain in Canaan and the Old Testament, 7-8.

${ }^{4}$ Cross, Canaanite Myth and Hebrew Epic, 142.

${ }^{5}$ Terence E. Fretheim, Exodus, Interpretation: A Bible Commentary for Teaching and Preaching (Lousville: John Knox Press, 1991), 162; Schafran, 93.

${ }^{6}$ Bremner, 136-52; Burden, 34-72.

7E.g., Cassuto argues that 15:13 refers to Sinai, and 15:17 to the temple to be built in the "mountain" in Canaan. Umberto Cassuto, A Commentary on the Book of Exodus (Jerusalem: Magnes, 1967).

PPropp states that "the most we can do is explore the manifold possibilities, acknowledging that several or all may be simultaneously correct" (Propp, 564). He then proceeds to spell out "the manifold possibilities" as Sinai, Zion, Shiloh, Gilgal, Canaan, and Northern Israel (564-68).

${ }^{9}$ For a concise criticism of this idea, cf. Russell, $153-56$. 
law, and the instructions culminating in the building of the tabernacle. Nevertheless, it must be noted that Sinai was not the ultimate goal of the journey, as implied in the thematic movement of the text. Furthermore, the hymn alludes to a progression of events and destination that goes beyond Sinai, reaching the land of promise. Another option is the land of Canaan as a whole. It should be noted, however, that although the land of Canaan was part of the larger picture of the destination of the people, the textual evidence points to Mount Zion/Jerusalem temple, as the ultimate goal of the journey. ${ }^{2}$

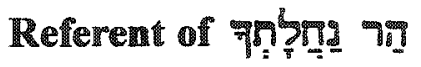

Although this phrase is used only here in the entire Hebrew Bible, ${ }^{3}$ the parallelism with the next phrases seems to point to Mount Zion and Jerusalem as its immediate historical referent. At this juncture, it must be noted that most important cultic motifs in the Hebrew Bible and ANE. ${ }^{4}$ may sometimes refer to

\footnotetext{
"Sinai is not the final goal of the Exodus, but lying between Egypt and Canaan, it does represent YHWH's mastery over both" (Jon D. Levenson, Sinai and Zion [New York: Harper and Row, 1985], 23).

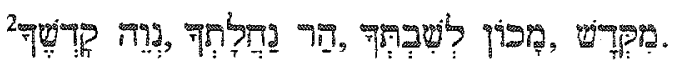

${ }^{3}$ This expression occurs in Ugaritic where it parallels Saphon and Sanctuary, thus probably having Baal's heavenly abode as its referent. See the text below.

$b$ tk' $\mathrm{g} r \cdot$ il spn In the midst of my divine mountain Saphon,

$b$ qds $b$ gr il nhlty In the sanctuary, in the mountain of my inheritance,

$b n^{r} m \cdot b \mathrm{gb}$ tliyt In paradise, on the height of victory.

Wyat, Religious Texss from Ugarit, 78 (KTU 1.3 iii 29-31).

${ }^{4}$ See Richard J. Clifford, "The Temple and the Holy Mountain," in The Temple in Antiquity: Ancient Records and Ancient Perspectives, ed. Truman G. Madsen, The Religious Studies Monograph Series 9 (Provo, UT: Brigham Young University, 1984), 107-24; R. E. Clements, God and Temple (Oxford: Basil Blackwell, 1965), 2-11; Lundquist, "What Is a Temple? A Preliminary Typology," 205-19; Winfried Vogel, "The Cultic Motif in Space and Time in the Book of Daniel" (Th.D. diss., Andrews University, 1999), 29-68.
} 
Sinai, though in most cases it alludes to the locale of the Jerusalem temple, and in a few instances it can even point to the heavenly Zion, or YHWH's heavenly abode.

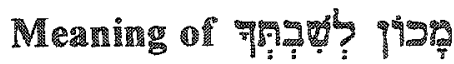

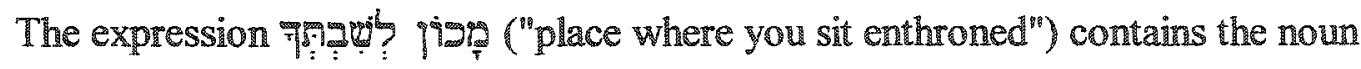

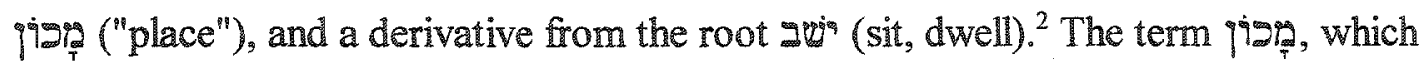
means "site," "fixed or established place, foundation," occurs seventeen times, ${ }^{5}$ all but

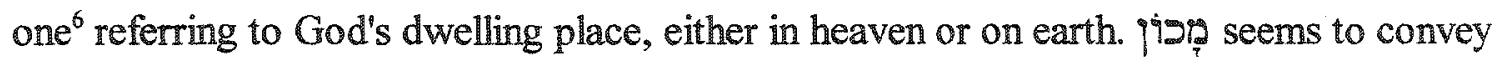
the special nuance of "firmness," as noted in the root 919 (be established, be permanent, endure), ${ }^{7}$ and is sometimes used to designate the sanctuary/temple. As for the derivative of gerg" ("dwell") in the prepositional phrase Fratert? it should be noted that it contains the sense-component "to sit (enthroned), to be throned," thus comnoting the idea of YHWH's

${ }^{1}$ E.g., Isa 14:13; Ezek 28:14, 16; Dan 11:45. Cf. Jacques Doukhan, Le Soupir de la Terre: Etude Prophétique du Livre de Daniel (Dammarie les Lys, France: Editions Vie et Santé, 1993), 299f.; Martin Selman, "gig," NIDOTTE, 1:1051-55.

${ }^{2}$ HALOT, s.v. "gwe's"."

${ }^{3}$ HALOT, S.V. PISPS.

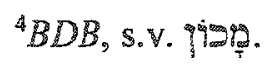

${ }^{5}$ Exod 15:17; 1 Kgs $8: 13 ; 39 ; 43 ; 49 ; 2$ Chr 6:2, 30, 33, 39; Ezra 2:68; Pss 33:14; $89: 15 ; 97: 2 ; 104: 5 ;$ Isa $4: 5 ; 18: 4 ;$ Dan $8: 11$.

${ }^{6}$ Ps 104:5.

7HALOT, S. V. Y9.

${ }^{8}$ Tryggve N. D. Mettinger, The Dethronement of Sabaoth, ConBOT 18 (Uppsala, Sweden: CWK Gleerup, 1982), 92. See M. Görg, "gự:? yäsab," Theological Dictionary of the Old Testament (TDOT), ed. G. Johannes Botterweck and Helmer Ringgren (Grand Rapids: Eerdmans, $1974-2004), 6: 422$. 
"enthronement" in the temple. The combination of ๆị from Exod 15:17. In two references it points to the temple on Mount Zion, ${ }^{1}$ whereas in seven other occurrences it refers to the heavenly sanctuary. ${ }^{2}$ In seven other places wherein only pisio occurs, it refers once to the site of the Jerusalem temple, ${ }^{3}$ one time to the site of Zion ${ }^{4}$ two times it is used metaphorically in connection with YHWH's throne in heaven, ${ }^{5}$ two times in reference to YHWH's dwelling in heaven, ${ }^{6}$ and in one occurrence it appears outside of a cultic context. ${ }^{7}$ In sum, out of sixteen occurrences of apart from Exod 15:17, eleven are related either to YHWH's heavenly dwelling ( $9 x$ ) or heavenly throne (2x). Therefore, as Friedbert Ninow pointed out, the occurrence of pi⿱宀㠯十 in Exod 15:17, especially in the phrase Tึ: goes beyond the earthly sanctuary." ${ }^{18}$

If the presence of pispr points to something beyond the earthly temple/sanctuary, a closer inspection of the phrase 隹

${ }^{1} 1 \mathrm{Kgs} 8: 13,2$ Chr 6:2.

${ }^{2} 1 \mathrm{Kgs} 8: 39,43,49,2 \mathrm{Chr} 6: 30,33,39$, Ps 33:14 [13].

${ }^{3}$ Ezra 2:68.

4 Isa 4:5.

${ }^{5}$ Pss 89:15 [14]; $97: 2$.

Isa 18:4; Dan 8:11 (these passages are investigated in chapters 4 and 5 of this dissertation, respectively).

${ }^{7}$ See the reference to the foundations of the earth in Ps 104:5.

${ }^{8}$ Friedbert Ninow, "Indicators of Typology within the Old Testament: The Exodus Motif" (Ph.D. diss., Andrews University, 1999), 158. 


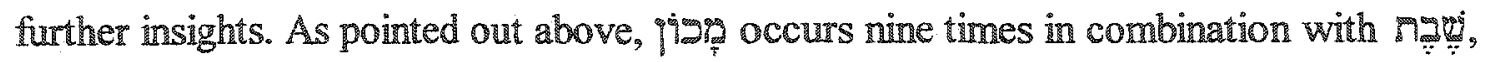
two times in reference to the earthly temple, and seven times in reference to the heavenly temple/sanctuary. Now the possibility may be raised that the Hebrew Bible employs two subtly distinct syntactical constructions with piva to indicate different connotations of

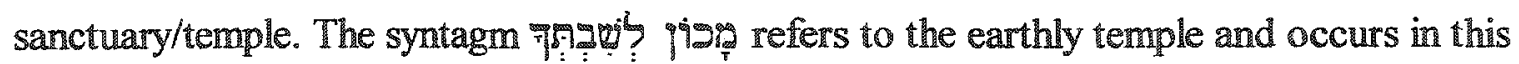

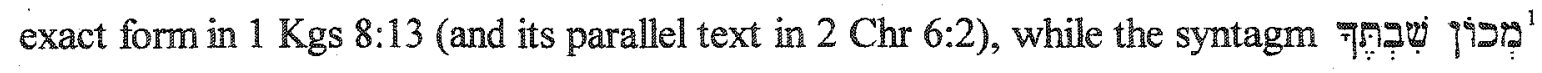
refers to the heavenly sanctuary/temple. The semantic nuance of each construction is subtle, but nonetheless significant. The locution for your dwelling" (i.e., another place in addition to the "Place" in heaven where YHWH dwells). On the other hand the construction "the palace of your dwelling" (i.e., "the Place" located in heaven where YHWH dwells). Although it may be argued that this syntactic distinction is semantically irrelevant, the fact

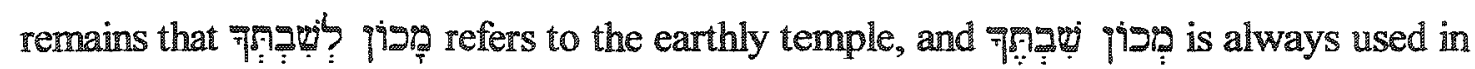
reference to the heavenly sanctuary/temple. Such consistency suggests that the syntactic distinction was intended to communicate distinct semantic connotations.

To conclude, the expression 7 กา temple in view; nonetheless it should be noted that when Fnבw $15: 17$, it is understood to be in connection with the heavenly counterpart. ${ }^{2}$ Furthermore, that the sanctuary (F⿻日禸

${ }^{1} \mathrm{Kgs} 8: 39,43,49,2 \mathrm{Chr} 6: 30,33,39, \mathrm{P}_{\mathrm{S}} 33: 14$ [13]. The latter passage has the $3 \mathrm{~ms}$

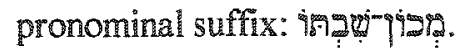

${ }^{2} 1 \mathrm{Kgs} 8: 13 ; 2$ Chr $6: 2$. 


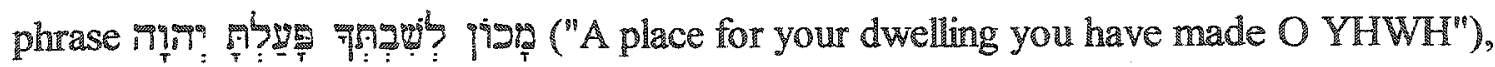
seems to point beyond human reality to the heavenly sanctuary.

\section{Referent of}

The word op? ("sanctuary") is found seventy-five times in the Hebrew Bible and can refer to local sanctuaries, ${ }^{1}$ the tabernacle of the wilderness, ${ }^{2}$ the temple in Jerusalem, ${ }^{3}$ and the heavenly sanctuary. In the present text, Jerusalem temple. Nevertheless, as pointed out by Ninow, 999\% in only two passages: in Exod 15:17 and Dan 8:11, where these words appear in the context of the heavenly sanctuary. ${ }^{5}$ This is significant, for it indicates that the song not only evokes a yearly gathering at the temple in Jerusalem, but anticipated a fulfilment on a larger, cosmic level.

\section{Heavenly Sanctuary/Temple Motif}

The presence of the heavenly sanctuary/temple motif in the Song of the Sea also becomes apparent against the backdrop of the typology of history within the composition. N. Lohfink has noted the typological dimension of the song by asserting that "the narrative

Isa 16:12; Amos 7:9, 13.

${ }^{2}$ Exod 25:8; Lev 12:4; 16:33 et al.

${ }^{3}$ E.g., 1 Chr 22:19; 28:10; 20:8; Ps 74:7.

${ }^{4}$ Ezek 28:18; Dan 8:11.

${ }^{5}$ Ninow, 159.

${ }^{6} \mathrm{Ibid}$. 
contained in the hymn is incomplete and open-ended" so that "coming generations would be able to see their own experience contained in this song. "Lohfink's basic insights were confirmed by Ninow, who noted that the song "has not only a prophetical element but also an eschatological one. ${ }^{.13}$ Ninow further observed that the terminology used to designate the sanctuary in Exod 15:17 indicates that the author anticipated a fulfillment on a larger cosmic level, a Steigerung. ${ }^{4}$

The Song of the Sea was phrased in such a way as to leave room for a projection to the future, and a vertical movement up into the heavenly realm. The text seems to be open, pointing both horizontally to future events in the history of YHWH's people, and vertically to the heavenly realm. For example, the enemy portrayed in the first part of the song is Pharaoh and his army; however, at the same time the portrayal of their defeat is framed with cosmic overtones so that, at the same time, the victory at the Red Sea may point forward to YHWH's final victory over the forces of evil. The victory is achieved by YHWH alone as he employs the forces of nature to judge the enemy. Furthermore, the second part of the song predicts YHWH's victory upon the future enemies, followed by YHWH's bringing his people to his own dwelling.

'Lohfink, 81.

2 lbid., 84.

${ }^{3} \mathrm{Ninow}, 155$.

4bid., 159. Steigerung in Typology studies refers to the intensification or escalation in the historical progression from the type to the antitype. The antitype constitutes the climactic and eschatological reality towards which the type points. Cf. Davioson, Typology in Scripture, $280-81$. 
The "openness" of the hymn may also be perceived in the use of verbal tenses. All across the composition yiqtol and qatal verbal forms altermate so that the identification of past, present, and future is challenging at best.' Engstrom has suggested that the Hebrew tenses were intended to support the "supra-historical element" of the song. ${ }^{2}$ It seems clear that later biblical authors understood this aspect of the song as they portrayed new actions of MHWH in favor of his people as a new exodus. ${ }^{3}$

As the tense of verbal forms is indeterminate, so is the identification of YHWH's people. Though some of the enemies are identified by their ethnic designations, YHWH's people remain generic. In Exod 15:13 and 16, they are referred to by their relationship to

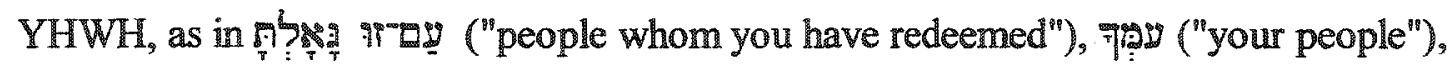
กำ 97 ("people whom you have purchased"). In 15:17 YHWH's people are referred to

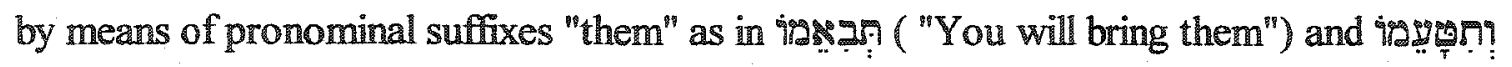
("and you will plant them"). The people of YHWH consisted in those who were the object of his care. Therefore, as the indeterminate language suggests, the identity of YHWH's people could not be restricted to those Israelites who took part in the foundational experience at the Red Sea, but would transcend ethnic boundaries so as to include a

${ }^{1}$ Cross and Freedman suggested that the tenses of this song resemble Ugaritic Poetry. See Frank M. Cross and David Noel Freedman, "The Song of Miriam," JNES 14 (1955): 237-50. Also Gevirtz suggested that the mix of verbal forms may be a characteristic feature of Old Canaanite style. Stanley Gevirtz, "Evidence of Conjugational Variation in the Parallelization of Selfsame Verbs in the Amama Letters," JNES 23 (1973): 99-104.

2Paul Lee Engstrom, "Deliverance at the Sea: A Reading of Exodus 15 in Light of Ancient Near Eastern Literature and Its Implications for the Assemblies of God" (Th.D. diss., Luther Seminary, 1996), 161.

${ }^{3}$ See Ninow, 186ff. 
multiethnic community who in the eschatological times will experience the new exodus. Thus, the movement towards the promised land implies a reality that goes beyond the first exodus and points to another even more significant event which will encompass a larger community.

The foregoing discussion, which focused on the horizontal typology of the song, its "openness" to the future, and Steigerung, has set the stage for the main concern of this research. It is argued that in regard to the sanctuary motif the language of the composition also expresses a similar "openness" and projection to the vertical dimension. The first indication of this "vertical dimension" is found in the phrase wipg in Exod 15:11, which occurs in the middle of the song. That the focus of the hymn switches up to the heavenly sanctuary and the council of YHWH at the structural center of the composition bespeaks the interconnection between earthly events and heavenly activities.

Besides, the temple/sanctuary terminology is presented in such a way that Exod 15:17 may suggest a covert allusion to the heavenly temple. The association of ${ }^{\prime}$ iso and טיפ seems to indicate heavenly sanctuary overtones. As already noted, apart from Exod 15:17,

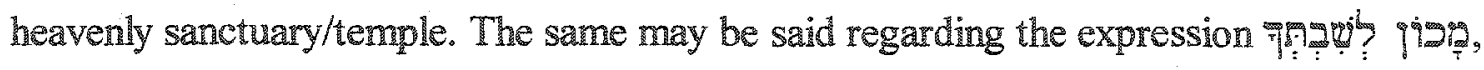
which, though used to indicate the earthly temple, also may evoke heavenly sanctuary/temple imagery.

'As already noted, Dan $8: 14$ receives a detailed treatment in chapter 5 of this dissertation. 


\section{Function}

That the heavenly sanctuary/temple is first identified in the structural center of the composition may signify more than a mere rhetorical device. It may point to the centrality of the heavenly sanctuary/temple in the context of the struggle between YHWH and the forces of evil, and also its role in relation to the guidance of the people to their ultimate goal - "the sanctuary which thy hands have made" (Exod 15:17). A close reading of the passage suggests that the heavenly sanctuary performs the following functions:

First, as already noted, the parallel between wing ("sanctuary") and ghs ("heavenly beings") evokes heavenly council imagery. Thus it may be said that the heavenly sanctuary is the locale wherein the council of YHWH convenes.

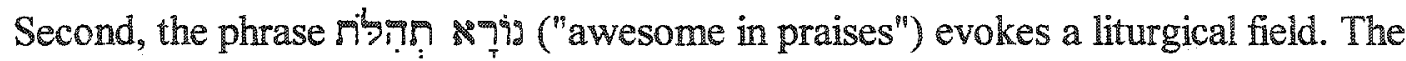
imagery suggested by the context is that of YHWH being worshiped by the "gods," that is, celestial beings ( $\square$ ? wherein YHWH receives adoration from the gods (i.e., heavenly beings).

Third, the phrase orgeng ("working wonders") seems to be related to YHWH's mighty works in the heavenly sanctuary. ${ }^{2}$ This receives support from a significant expression in the previous linebe translated as "powerful." Hence the phrase "powertul in the sanctuary" would be an

${ }^{1}$ Cf. Pss 86:8; 89:6 [5]; 150:1; Isa 6:1-4.

${ }^{2}$ These mighty works could by a reference to the plagues, as cautiously suggested by William Shea in a personal communication.

${ }^{3}$ HALOT, s.v. "has." 
indication of YHWH's activities in the heavenly sanctuary. In short, the heavenly sanctuary functions as a place of divine activity.

Last, since gip in Exod 15:11 anticipates vprat and its synonyms in vss. 13 and 17 as argued above, then the sanctuary functions as a seat of kingship, as explicitly indicated in

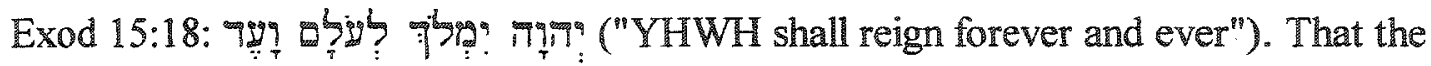
primary referent of vss. 13 and 17 is the Jerusalem temple does not invalidate this suggestion, since the sanctuary referred to in vss. 13 and 17 exists in relationship with the heavenly counterpart. Therefore, Exod 15:18 may not refer exclusively to the earthly sanctuary, but also to the ultimate sanctuary, the heavenly one.

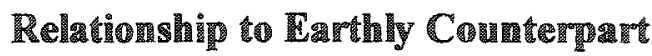

The occurrence of eyplon at the structural center of the hymn and the terminology employed by the poet in reference to the earthly sanctuary/temple indicates a vertical correspondence to the heavenly counterpart. These points are further elaborated below.

First, as already noted, wp ("[heavenly] sanctuary") in Exod 15:11 anticipates by

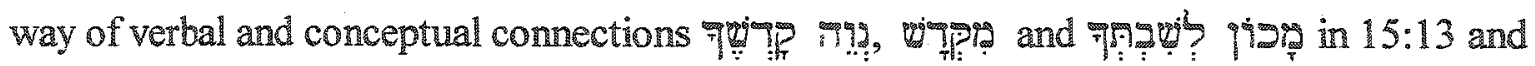
$15: 17$, respectively. If these terms refer primarily to the Jerusalem temple, as noted above, it seems plausible that the earthly sanctuary/temple was undeterstood to exist in vertical

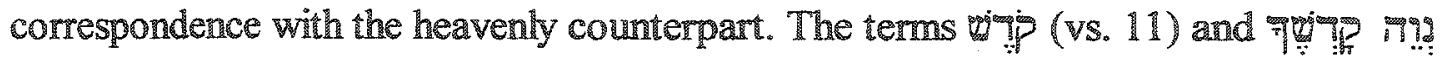
(vs.13) suggests a structural correspondence.

Second, that the heavenly and earthly temples are related is further supported by the

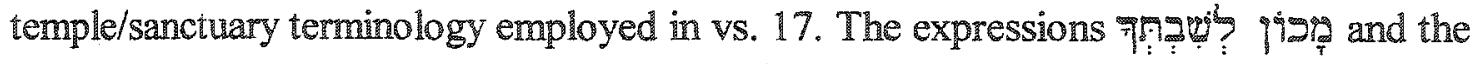




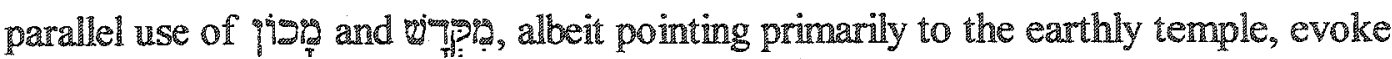
heavenly sanctuary imagery as well.

Third, the portrayal of YHWH in the heavenly sanctuary (and surrounded by the heavenly court) in Exod 15:11 anticipates, in the flow of the song, the depiction of YHWH ruling from the earthly temple in $15: 18$. The implication is that the heavenly and earthly temples function in close connection and possibly performing interrelated functions.

Last, that the sanctuary was established by YHWH's hands (Exod 15:17) suggests that this sanctuary contains a quality that transcends the earthly temple, pointing to the ultimate sanctuary located in heaven.

\section{Exod 24:9-11}

9 10 11

9 Then Moses went up with Aaron, Nadab and Abihu, and seventy of the elders of Israel,

10 And they saw the God of Israel; and under his feet was something like a pavement of lapis lazuli, and like the very heavens for clearness.

11 Yet he did not stretch out his hand against the nobles of the sons of Israel; and they saw God, and they ate and drank.

\section{Preliminary Observations}

Exod 24:9-11 belongs to the text unit comprising chaps. 19-24, which has the covenant at Sinai as the major focus. The internal organization of this section has baffled

II should be noted that the three following passages (Exod 24:9-11;25:9, 40, and Exod 32-34) belong to the larger section of Exod 19-32. These blocks of material are interconnected by a skilled interweaving of narrative and instructional materials. Although each pericope receives individual treatment in its respective section, there may be some overlap, since issues discussed in relation to one passage may have a bearing upon the others. 
scholars because of many literary difficulties, such as, for example, the repetition of the theophany in 20:18 (parallel to 19:16-19), Moses' frequent trips up and down the mountain, the awkward placement of the Decalogue and the Book of the Covenant within the narrative, and so on. Some critical have sought to explain these phenomena by appealing to different sources or traditions. ${ }^{1}$ More recently, however, the text has been under the scrutiny of scholars who assume the final form of the text as the main parameter for the exegetical task. For example, Chirichigno, ${ }^{2}$ Sprinkle, ${ }^{3}$ followed by Kim, ${ }^{4}$ have found the text to be a homogenous literary work. The apparent awkward and dischronologized redundancies, especially Moses' trips up and down the mountain, are deemed to be intended by the narrator, who crafted the pericope according to the literary device of "resumptive repetition." It should be kept in mind that the intertwining of narrative and

${ }^{1} \mathrm{Cf}$. Joseph Blenkinsopp, "Structure and Meaning in the Sinai-Horeb Narrative (Exodus 19-34)," in A Biblical Itinerary: In Search of Method, Form and Content: Essays in Honor of George W. Coats, ed. Eugene E. Carpenter, JSOTSup 240 (Sheffield: Sheffield Academic Press, 1997), 109-25; Thomas B. Dozeman, God on the Mountain: A Study of Redaction, Theology, and Canon in Exodus 19-24 (Atlanta, GA: Scholars Press, 1989), 1-17; Wolfgang Oswald, Israel am Gottesberg: Eine Untersuchung zur Literargeschichte der vorderen Sinaiperikope Ex 19-24 und deren historischen Hintergrumd, OBO 159 (Freiburg, Switzerland: Universitätsverlag; Göttingen: Vandenhoeck and Ruprecht, 1998), 80-113; B. Renaud, La Théophanie du Sinaï: Ex 19-24: Exégèse et Théologie, CahRB 30 (Paris: J. Gabalda, 1991), 17-192; John Van Seters, "Comparing Scripture with Scripture': Some Observations on the Sinai Pericope of Exodus 1924," in Canon, Theology, and Old Testament Interpretation: Essays in Honor of Brevard S. Childs, ed. Gene M. T. Tucker, David L. Petersen, and Robert R. Wilson (Philadelphia: Fortress, 1988), 111-30. $457-79$.

${ }^{2}$ Gregory C. Chirichigno, "The Narrative Structure of Exod 19-24," Bib 68, no. 4 (1987):

${ }^{3}$ Joe M. Sprinkle, The Book of the Covenant: A Literary Approach, JSOTSup 174 (Sheffield: ISOT Press, 1994), 11-34.

${ }^{4} \mathrm{Kim}, 85-101$. 
regulations is a stylistic device not restricted to Exod 19-24, but is common to the entire book of Exodus, and extending through Numbers. ${ }^{1}$ For the purpose of this research, it suffices to note the intertwining of narrative and regulations in Exod 19-24, as follows: Exod 19:1-25 (Narrative); 20:1-17 (Law: Decalogue); 20:18-21 (Narrative); Exod 20:2323:33 (Law: Covenant Book); 24:1-18 (Narrative).

Since the major concern of this discussion is to understand Exod 24:10-11, a narrative segment in the larger context of the Sinai pericope, attention is now focused on the narrative sections of Exod 19-24, so that the structural position of Exod 24:9-11 may shed light upon its interpretation. Exod 19:1-25;20:18-21; and 24:1-8 contain some overlap and repetition due to the literary technique of "resumptive repetition" thus explained by Sprinkle: "The essence of this technique is that the narrator tells a story once, then picks up the story again somewhere in the chronological sequence and retells it, often expanding the story or telling it from a different point of view."

When the narrative is read from the perspective of "resumptive repetition," the following picture emerges. Exod 19:1-25 contains an overall report of YHWH's offer of the covenant and Moses trips up and down the mountain that seems to be presented in

'See G. J. Wenham, Numbers (Downers Grove: InterVarsity, 1981), 14-18; Terence E. Fretheim, "Because the Whole Earth Is Mine": Theme and Narrative in Exodus," Int 50, no. 3 (1996): 229-39; James W. Watts, Reading Law: The Rhetorical Shaping to the Pentateuch, The Biblical Seminar 59 (Sheffield: Sheffield Academic, 1999); Calum Carmichael, "Law and Narrative in the Pentateuch, in The Blackwell Companion to the Hebrew Bible, ed. Leo G. Perdue, Blackwell Companions to Religion 1 ( Oxford: Blackwell Publishers, 2001), 321-34; Martin Ravndal Hauge, The Descent from the Mountain: Narrative Patterns in Exodus 19-40, JSOTSup 323 (Sheffield: Sheffield Academic, 2001), 190-246.

${ }^{2}$ Sprinkle, 19. 
roughly chronological sequence. Resumptive repetition is noted in the following parallels: Exod 19:16-19 is repeated almost verbatim in 20:18-21. The latter passage presents the same theophanic features reported by the former, except that it focuses on the reaction of the people. Another occurrence of this stylistic device occurs in 19:21-25, which is picked up again in 24:1-3a. After 24:3b the narrative advances chronologically. The subsection $24: 3 c-8$ moves the story forward by reporting the covenant ceremony performed between YHWH and the people.

The narrative moves forward again in 24:9ff, as Moses, Aaron, Nadab and Abihu, and seventy of the elders ascend the mountain. Although the command to ascend the mountain had been spelled out previously (i.e., Exod $19: 24 ; 24: 1$ ), it is only in $24: 9 \mathrm{ff}$. that Moses actually ascends the mountain with the leaders of the nation.

When the stylistic repetitions are taken into consideration, it becomes apparent that the narrative sequence of Exod 19-24 portrays four trips of Moses up and down the mountain, ${ }^{1}$ as shown below.

First trip: 19:3-8b

Second Trip: 19:8c-19;20:18-21

Third Trip: 19:20-25; $24: 1-8$

Fourth Trip: $24: 9-18$

${ }^{1}$ Another way of analyzing this structure would yield a total of six trips. In this case the six trips in Exod 19-24 could be added to another trip in 32-34 to make up the meaningful total of seven trips. As for 19-24, this can be thus illustrated:

\begin{tabular}{|c|c|c|c|c|c|}
\hline First Trip & Second Trip & Third Trip & Fourth Trip & Fifth Trip & Sixth \\
\hline $19: 3-8 b$ & $18: 8 \mathrm{c}-19$ & $19: 20-25$ & $20: 18-21$ & $24: 1-11$ & $24: 12-18$ \\
\hline
\end{tabular}

There is also the suggestion advanced by Daniel $C$. Arichea, who sees a possibility of seven trips thus outlined: Exod $9: 3 ; 19: 8 ; 19: 10 ; 19: 18 ; 20: 1 ; 24: 1 ; 24: 12$. He sees three more trips in 32:31 and 33:1. Daniel C. Arichea, Jr., "The Ups and Downs of Moses: Locating Moses in Exodus 19-33," BT 40, no. 2(1989): 144-46. 
In the first trip, YHWH offers the covenant, and the people accept; in the second trip Moses takes the people's response to YHWH and is instructed to establish boundaries around the mountain, culminating with the theophanic manifestation of thunder and lightning. In the third trip, Moses is instructed to ascend the mountain with Aaron, Nadab, Abihu, and the priests. Back at the mountain's foot Moses performs the covenant ceremony by sprinkling blood upon the people and the altar. This is a preparation for the last and climactic trip reported in 24:9-18, which includes the covenant meal celebrated by the leaders and a vision of the heavenly sanctuary, as argued below. Additionally, it should be noted that the fourth trip contains several significant characteristics which are aptly summarized by K.im:

(1) Up to now, only Moses had been called up the mountain, but this time he is told to come up with Aaron, and his two sons, who are destined to become high priests, and the elders as representatives of the people. (2) Until now the people had only experienced the phenomena that accompany God's presence such as the thundering, the lightning flashes, the sound of the trumpet and the smoking $(20: 18,22)$, but this time the leaders of Israel see God's presence itself (24:9-11a). (3) Until now Moses had gone up the mountain alone. This time, accompanied by the others, he and Joshua climb up the higher slope than the other leaders of Israel, and then Moses leaves Joshua and continues even higher by himself. (4) Up to now, Moses has spoken to God and heard his voice (19.9), but only here for the first time does he go into the midst of the cloud of glory $(24: 16-18)$. $^{1}$

The special features of this last and climactic trip, being especially relevant for the interpretation of $24: 9-11$, and also for $25: 9,40$, need further elaboration here. It must be noted that sanctuary imagery pervades the report of this fourth trip. For example, it is during this trip that the categorization of sacred space up and around the mountain more clearly resembles that of the tabemacle. Access to the mountain was imited to Moses,

$$
{ }^{1} \mathrm{Kim}, 95 .
$$


Aaron, Nadab, Abihu, and seventy elders of Israel, who could go up a certain distance; however, only Moses could ascend to the place where YHWH was standing. Besides, boundaries were set around the mountain and an altar was built at its foot. It is not difficult to see how strikingly this arrangement resembles that of the subsequent tabernacle.

The reference to Aaron and his sons, who would soon become priests provides a further link to the sanctuary. Furthermore, if the text of the book of Exodus is taken in its canonical form, it becomes apparent that it was in this fourth trip that Moses was shown the ngagn, model of the sanctuary. Therefore, on contextual and structural grounds it becomes apparent that the visio dei depicted in 24:9-11 must be related to sanctuary imagery. At this juncture, semantic and other exegetical considerations are required in order to further ascertain the plausibility of this suggestion.

\section{Semantic and Other Exegetical Considerations}

Several words and phrases occurring in Exod 24:9-11 require closer inspection, since they may provide a clearer delineation of the heavenly sanctuary motif in this passage. At the outset, it must be noted that Exod 19-24 contains several words belonging to the associative field of the sanctuary motif. ${ }^{2}$ The mentioning of Aaron and his sons, together

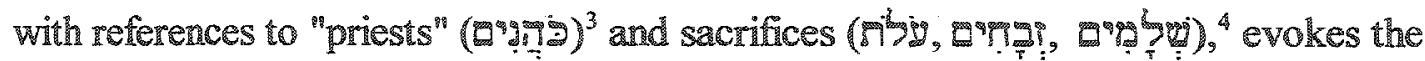

"See Angel Manuel Rodríguez, "Sanctuary Theology in the Book of Exodus," AUSS 24 (1986): $127-45$.

${ }^{2} \operatorname{Exod} 24: 5$

${ }^{3}$ Exod 19:6, 24.

${ }^{4}$ Exod 24:5. 


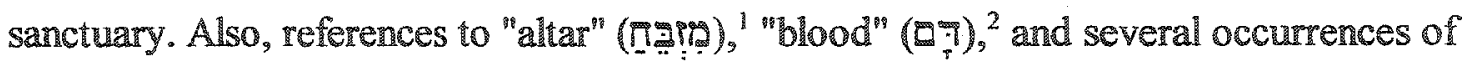
derivatives of romp ${ }^{3}$ further reverberate sanctuary concepts.

\section{Meaming of ๆ}

Although it is reported that Moses and the others "saw the God of Israel," there is no attempt whatsoever to describe his appearance; they can only see what was "under his

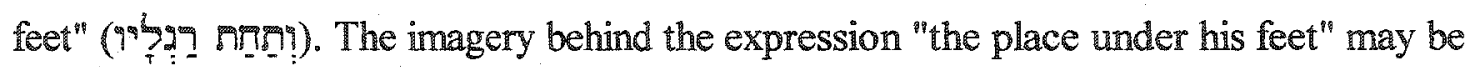
that of YHWH seated as king on his throne, as suggested by Houtman. ${ }^{4}$ Furthermore, the language used to describe the pavement, which evokes heavenly realities, implies that the representatives of Israel saw "the heavenly palace, ${ }^{15}$ or something YHWH let down, ${ }^{6}$ possibly in a visionary encounter, as suggested by the verb TiT, to be discussed below, used to describe that theophanic experience.

\section{Meaning of 7 ำ}

There is some consensus that 790 refers to lapis lazuli, a blue stone often associated with heaven. ${ }^{7}$ More important, however, than the identification and translation

${ }^{1}$ Exod 24:4.

${ }^{2} \operatorname{Exod~24:6,8.~}$

${ }^{3}$ Exod 19:6, 10, 14, 22, 23.

${ }^{4}$ Comelis Houtman, Exodus, trans. Sierd Woudstra, HCOT (Leuven, Belgium: Peeters, 2000), 3:292.

sibid.

${ }^{6} \mathrm{Cf}$, e.g., Ezek 1.

${ }^{7}$ Horowitz, Mesopotamian Cosmic Geography, 9; Othmar Keel, Jahwe-Visionen und Siegelkunst: eine neue Deutung der Majesiötsschilderungen in Jes 6, Ez 1 und 10 und Sach 4 
of ape is to ascertain its connotation and contribution to the present text. A brief survey of this word in the Hebrew Bible and other ANE literature may contribute to uncover its comotations, as the ensuing considerations intend to demonstrate.

First, it should be noted that lapis lazuli in Ezek $1: 26 ; 10: 1$ is related to YHWH's heavenly throne. In this connection, it is significant to note that Ezek 1:16 and 10:1 are also set in the context of a theophanic vision like Exod 24:9-11. Another reference to lapis lazuli occurs in Ezek 28:13 as a stone in the covering of the King of Tyre who is in Eden, the mountain of God. Interestingly enough, the New Jerusalem is also laid with lapis lazuli.'

Second, similar connotations are found in ANE texts where lapis lazuli is mentioned in connection with temples. In Egypt and Mesopotamia lapis lazuli was associated with the blue sky; therefore, it comes as no surprise that in a culture where temples were understood to be connected to the heavenly realm, lapis lazuli came to be related to temple building and cultic mobiliary. ${ }^{2}$ From Ugarit one learns that lapis lazuli was used in the construction of Baal's palace on Mount Saphon. ${ }^{3}$ Thus, in the Hebrew Bible and ANE literature lapis

(Stuttgart: Verlag Katholisches Bibelwerk, 1977), 256.

'See Isa 54:11; Rev 21:19.

${ }^{2}$ R. E. Clements, Exodus (Cambridge: Cambridge University Press, 1972), 159; Friedhelm Hartenstein, "Wolkendunkel und Himmelfeste: Zur Genese und Kosmologie der Vorstellung des himmlischen Heiligums JHWHs," in Das biblische Weltbild und seine altorientalischen Kontexte, ed. Bernd Janowski and Beate Ego (Tübingen: Mohr Siebeck, 2001), 140. It is worthy of note that blue was a prominent color in sanctuaries and temples in early Mesopotamia (Pauline Albenda, "Mesopotamian Art and Architecture," $A B D, 1: 420$ ) and blue-glazed bricks were used to decorate the structure of the throne room in a palace found in Babylon (Jean-Claude Margueron, "Babylon," ABD, 1:564).

${ }^{3}$ According to KTU 1.4, v 18, the palace was to be built of silver, gold, and "pure lapis lazuli" (thr iqnim) (Manfred Dietrich, Oswald Loretz, and Joaquin Sanmartin, The Cuneiform Alphabetic Texts from Ugarit, Ras Ibn Honi and Other Places [KTU: second, enlarged edition] 
lazuli seems to evoke the heavenly realm, or heavenly temple imagery. This is reinforced by the next expression to be discussed below.

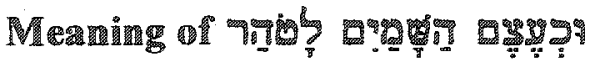

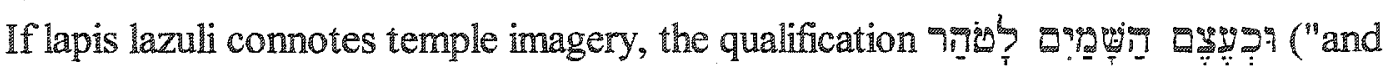
like the very heavens for clearness") increases the probability that the imagery behind the passage is that of the heavenly sanctuary/temple. Its description however is vague. The narrator just mentions what is under the feet of YHWH. If the humblest spot in YHWH's dwelling, namely, the spot where he lays his feet, is so splendid, it goes without saying that the rest of his abode is indescribably glorious and pure. The preposition ? in רing is is better understood as ? of specification ${ }^{1}$ which conveys the meaning of "with respect to purity" in the phrase under study. The noun 7nit is a derivative of 7 Tre and conveys the idea of "purity, clearness" or "ceremonial purifying."12 In the present context it possibly underscores the "brilliancy" of the heavenly pavement under YHWH's feet.

[Münster: Ugarit-Verlag, 1995], 19). The association of $t h r(" p u r e ")$ with lapis lazuli recalls Exod 24:10-11, where this precious stone is associated with the Hebrew cognate mones.

'Watke and O'Connor, 206-07.

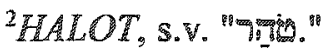

${ }^{3} \mathrm{C}$. C. F. Keil and F. Delitzsch, Biblical Commentary on the Old Testament: The Pentateuch, vol. 2 of 3, trans. James Martin (from the German), Biblical Commentary on the Old Testament (Grand Rapids: Eerdmans, 1952), 226. 
Meaning of Mrring?

The verb הin ("see") is a technical term for a specific divine revelation to the prophets. ${ }^{1}$ Its use in Exod 24:10 probably conveys the idea that Moses and the other representatives of Israel had a visionary experience of the heavenly sanctuary/temple. Nonetheless, since Moses was the only one to have access to the top of the mountain, he most probably had a deeper perception of the heavenly temple/sanctuary, as implied in Exod $25: 9,40 .^{2}$

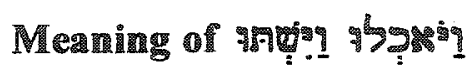

Although the exact meaning and function of this act has been debated, a contextual interpretation suggests it was a covenant meal. ${ }^{3}$ The ritual manipulation of blood performed by Moses (Exod 24:3-8) qualified the people for the final encounter with YHWH and the conclusion of the covenant. Since it would be impracticable for the whole people to ascend

"Cf. A. Jepsen, "T⿱宀ฺฺ, hุāzâ," TDOT, 4:280-90.

${ }^{2}$ Although Dozeman argued that "the leaders of Israel have a direct and immediate vision of God enthroned in the heavenly temple" (Dozeman, God on the Mountain, 114), the text suggests that they had only a glimpse of the heavenly sanctuary. The text reports that they saw the pavement, adding no further detail. Besides, they had to stop halfway, since only Moses was allowed to ascend further to the very place where YHWH was standing, the implication being that Moses saw more of the heavenly temple/sanctuary, as implied in Exod 25:9, 40.

${ }^{3}$ Cf. E. W. Nichoison, "The Interpretation of Exodus XXIV 9-11," VT 24 (1974): 77-97; B. Renaud, La Théophanie du Sinai: Ex 19-24: Exégèse et Théologie, CahRB 30 (Paris: J. Gabalda, 1991): 98-99; Bernhard W. Anderson and Steven Bishop, Contours of Old Testament Theology (Minneapolis, MN: Fortress Press, 1999), 141; Hallvard Hagelia, "Meal on Mount Zion-Does Isa 25:6-8 Describe a Covenant Meal?," SEA 68 (2003): 79-80. 
the mountain, the nation in the persons of its representatives shares the covenant meal in the presence of YHWH, the Suzerain King."

\section{Heavenly Sanctuary/Temple Motif}

\section{Funtion}

As noted in the discussion above, the heavenly sanctuary/temple motif emerges as a place of ratification of the covenant, as indicated by the the covenant establishing ceremony reported by the pericope.

\section{Relationship to Earthly Counterpart}

From the above discussion the impression emerges that the heavenly temple as glimpsed by the elders and more fully experienced by Moses was in a dynamic interaction with its earthly counterpart, as the latter was functionally represented by the mountain. The delimitation of sacred space around Sinai, and and the comotion of the mountain seems to conveys the notion that the heavenly temple was in a dynamic interaction with its earthly counterpart.

\section{2: $25: 9,40$}

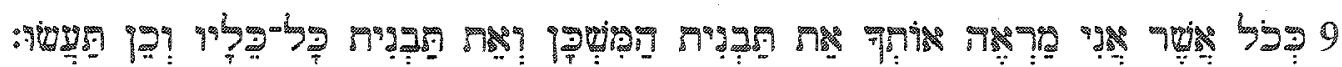
9 According to all that $I$ am showing you, the pattern of the tabemacle and the pattern of all its fumiture, just so you shall construct it.

$\therefore$ ำ 40 See that you make them after the pattern for them, which is shown to you on the mountain. 59.

${ }^{1}$ Keil and Delitzsch, Biblical Commentary on the Old Testament: The Pentateuch, 2:158- 
Exod $25: 9,40$ contains a significant allusion to the heavenly sanctuary/temple motif

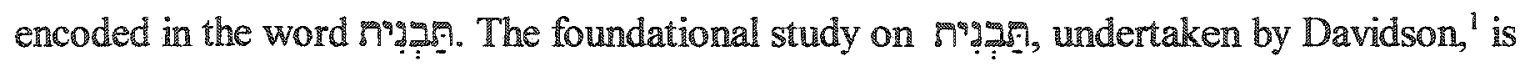
summarized in order to provide an overview of the main issues related to the meaning of תח This is followed by a suggested reading of Exod 25:9, 40 in the light of its narrative context. $^{2}$

\section{Semantic and Other Exegetical Considerations}

\section{Meaning of בגבְבִִית}

Semantic analysis

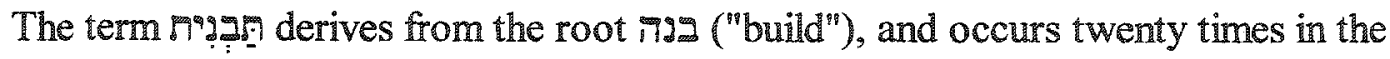
Hebrew Bible. It is categorized by $B D B$ as construction, structure, pattern, figure, and image. ${ }^{3}$ HALOT defines it as pattern, model, copy, reproduction, image, representation, something like, and architectural plan. ${ }^{4}$ Davidson organized this variety of definitions under three German terms: ${ }^{5}$ Urbild, Vorbild, and Nachbild. That is to say, חיר may refer to an original entity (Urbild), a model to be copied (Vorbild), or a copy of another entity (Nachbild). It can also do double duty and function as a Nachbild/Vorbild, that is, be patterned after an original (Urbilch), in order to serve as a model (Vorbild) to be copied. ${ }^{6}$

\footnotetext{
'Davidson, Typology in Scripture, 367-88.

${ }^{2}$ Especially Exod 24:9-18.

${ }^{3} B D B$, s.У. กุด จุ.

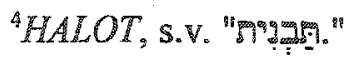

${ }^{5}$ Davidson, Typology in Scripture, 372-73.

${ }^{6}$ Ibid.
} 
Davidson summarized the several scholarly views on ת9 six different positions: (1) Vorbild of the earthly sanctuary (in the form of a miniature model; (2) a Vorbild of the earthly sanctuary in the form of an architect's plan; (3) a Nachbild of the heavenly sanctuary which functions as a Vorbild of the earthly sanctuary (in the form of a miniature model); (4) a Nachbild of the heavenly sanctuary which functions as a Vorbild of the earthly sanctuary (in the form of an architect's plan); (5) the heavenly sanctuary itself (the original or Urbild) as the Vorbild for the earthly sanctuary; (6) a subjective inspiration (with no communication of propositional facts) as the Vorbild for the earthly sanctuary. ${ }^{1}$

Position (1) has been more recently defended by Hurowitz. He contends that Moses "was shown an exact model of the Tabernacle, which he was to make. If so, he was not shown the divine heavenly dwelling." His argument contains a non sequitur, since the contention that "Moses was shown an exact model of the heavenly sanctuary" does not necessarily preclude Moses' having seen the heavenly sanctuary itself as well.

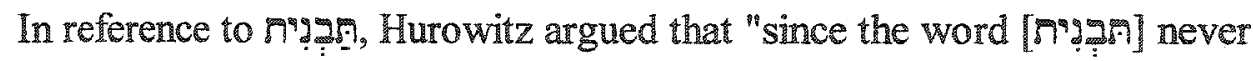
designates the 'real thing,' but only a representation of it, it cannot be taken to refer to the heavenly abode of God." ${ }^{\text {*3 }}$ Taking into consideration ANE comparative evidence, he further argues that "even when the object to be manufactured is to be a copy of a previously

'Davidson, Typology in Scripture, 372-74.

${ }^{2}$ Hurowitz, 168 , italics his.

${ }^{3}$ Ibid., 169. 
existing object, it is not the preexisting object itself which is revealed to the builder, but a model."1

Regarding Hurowitz's view, a few observations are in order:

1. To say that "הבְְנִית "never designates the 'real thing"' is not quite accurate since Ps 144:12 seems to refer to

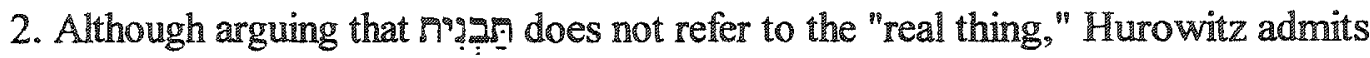
that it refers to a "representation of it." Therefore one must conclude that חפיפ evokes the Urbild, and only makes sense if the existence of an Urbild is assumed. ${ }^{2}$ As Davidson noted,

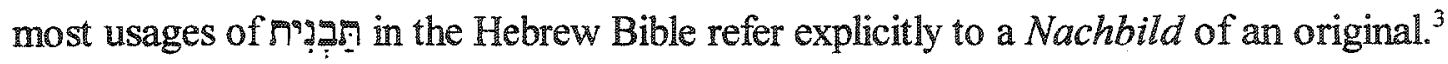
Seven times it has the character of a Vorbild, that is, a pattern after which something

'Tbid., 170.

${ }^{2}$ For example, Hittite texts refer to a dreamer who sees a god in a dream and is commanded to make an exact earthly replica of what he has seen and dedicate it to the deity.

"As to the god Iarri who in the dream was standing on a lion, his form being, however, like that of the Weather-god, and as to (the fact that somebody) said in the dream to His Majesty: 'This is (the god Iarri of) the father of His Majesty! - - the (priestess) Hepa-SUM said (concerning this dream): 'This statue one should make exactly as (seen) and give it to the Great Deity (i.e. the deity of the sanctuary to which the priestess belonged)!"' (KUB XV 5 II: 39-45, quoted in A. Leo Oppenheim, The Interpretation of Dreams in the Ancient Near East, With a Translation of an Assyrian Dream-Book, Transactions of the American Philosophical Society, New Series-Volume 46, Part 3 [Philadelphia: American Philosophical Society, 1956], 193).

It should be noted that the text quoted above does not make clear that the dreamer merely saw a copy of what he should make. As a matter of fact, it seems that the dream depicts a vision of the god Iarri himself (the Urbild), whose statue was supposed to be made and placed in the sanctuary. At any event, even if the dream only depicted a "model" of what should be made, what matters is that the "model" ultimately was understood to reflect a heavenly original. As Oppenheim stated: "The creativeness of the Near Eastern artist can derive its authenticity from the fact that his opus reflects faithfully its prototype in heaven which was revealed to him either in a dream or through a specific and special divine intervention" (Oppenheim, 193).

Josh 22:28; Deut 4:16;17, 18, Ps 106:20, Isa 44:13; Ezek 8:3, 8, 10. Cf. Davidson, Typology in Scripture, 371. 
should be made, ${ }^{3}$ and in at least one occurrence, as reported in $2 \mathrm{Kgs} 16: 10-11$, ת999: signifies both Vorbild and Nachbild. ${ }^{2}$ As for the text under study, it should be noted that the narrative context of Exod 25:9, 40 suggests that Moses and the elders had a vision of the heavenly sanctuary/temple. Therefore, it seems reasonable to suppose that תִגבר was somehow related to this visible reality shown to them. That being the case, position (1) becomes unlikely.

Positions (2), (4), and (6) are highly improbable for two main reasons: First, Exod 25:9, 40 makes clear that the תִ architect's plan, it would have been "given" to him to be brought down to the Israelite camp. As regards position (6), it should be observed that it is difficult to understand how a "subjective inspiration" would have been "shown" to Moses. Second, an examination of the usages of this word reveals that by far most of its occurrences refer to tridimensional entities. $^{3}$

After these considerations, one is left with positions (3) and (5), which will be evaluated below in connection with the contextual reading of Exod 25:9, 40 and the

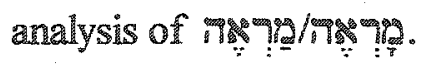

"Patterns/Models" of the sanctuary and utensils (Exod 25:9, 9, 40), the Solomonic temple and its furnishings ( $1 \mathrm{Chr} 28: 11,12,19)$; golden chariot of the cherubim (1 Chr 28:18; ibid., 371 72).

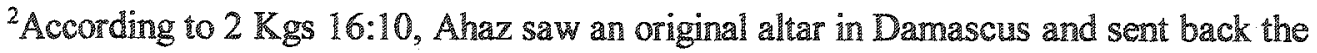
mag The following diagram illustrated: Altar in Damascus (Vorbild) $\rightarrow$ ก Altar in Jerusalem (Nachbild).

${ }^{3}$ Cf. Deut $4: 16 ; 17,18 ;$ Josh 22:28; 2 Kgs 16:10; Pss 106:20; 144:12; Isa 44:13; Ezek 8:3, $10 ; 10: 8$. 
Contextual analysis

As convincingly demonstrated by Kim, the context provides a decisive clue for the understanding of 7999.1 .3 . Thus, as already mentioned in the discussion regarding the context structure of Exod 19-24, chaps. 25-31 contain the instructions YHWH gave Moses during his fourth ascent of the mountain. It is reasonable to infer, therefore, that the m99. was shown to Moses on this occasion. The narrative of Exod 24:9-18 suggests that other representatives of Israel did not have more than a glimpse of the heavenly temple, of which only the pavement is mentioned. Onily Moses was allowed to ascend to the very place where YHWH was standing, which implies that he was shown many more details not available to the others, and it was during that time that Moses received instructions for the construction of the tabernacle.

As noted by Kim, the fourth ascent of Moses has distinctive features that set it apart from the previous ascent narrative. ${ }^{2}$ Aaron is presented in the spotlight, possibly to demonstrate that the present narrative will focus on the sanctuary. It is in this narrative that the representatives of the people had a glimpse of the heavenly sanctuary. Besides, this fourth ascent contains more salient sanctuary overtones than the previous ones. The arrangement of the sacred space in which a limited group of people could go up to a certain point on the mountain, and only Moses could go up to the top, recalls the sanctuary.

\footnotetext{
${ }^{1} \mathrm{Kim}, 78-100$.

${ }^{2}$ Ibid., 95.
} 


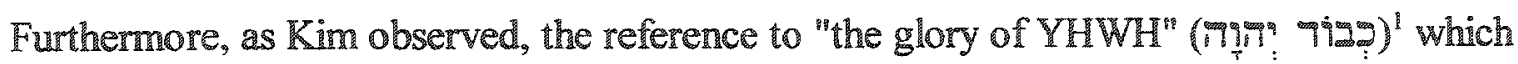

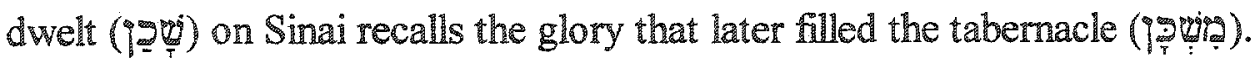

Exod 24:16a

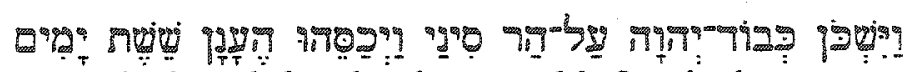
The glory of YHWH rested on Mount Sinai, and the cloud covered it for six days. Exod 40:34

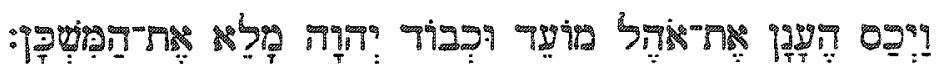
Then the cloud covered the tent of meeting, and the glory of YHWH filled the tabernacle.

These paralleis evoking sanctuary/temple imagery were Moses had entered probably intended to show that, by ascending the mountain this fourth time, the sanctuary, or a functional equivalent of the earthly sanctuary. Freedman has argued that Moses was invited to the heavenly sanctuary, "the true tabnit, the sanctuary which served as a model for all replicas." ${ }^{2}$ Although Freedman is most probably right in that Moses saw the heavenly

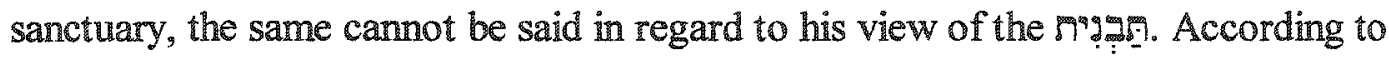
Freedman, ת ת ת refers exclusively to the heavenly sanctuary itself (i.e., position [5]). This is difficult to sustain when other references about the heavenly temple are taken into consideration. As Davidson observed, "Elsewhere in Scripture, the heavenly sanctuary is described as a vast, majestic temple, accommodating countless angels, ${ }^{n 3}$ an observation corroborated by texts such as Isa 6:1, Ps 11:4, and Dan 7:9-14. ${ }^{4}$ Besides, one should hold

"As Kim pointed out, the "glory of YHWH" appears in Exod 24:16 for the first time (98).

2Freedman, "Temple Without Hands," 28.

${ }^{3}$ Davidson, Typology in Scripture, 385.

${ }^{4}$ See the discussion of Dan 7:9-14 in the fith chapter of this dissertation. 
in mind that since the earthly temple should be built according to the magas, it is reasonable to suppose that a miniature model would be much closer to the entity that should be built on earth and, therefore, would be more effective from an instructional point of view.

If so, it seems more reasonable to understand the n99: as a miniature model of the heavenly sanctuary intended to function as a model for the construction of the earthy sanctuary, as suggested by position (3) described above. This model was presented in the context of Moses' experience on the top of the mountain, which included a vision of the heavenly sanctuary, as implied in Exod 24:9-11. If this is the case, it may be argued that 9999 bespeaks a structural correspondence between the heavenly original and its earthly counterpart.

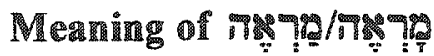

The causative participial forms 7 พ the ת"g. was not something YHWH "gave" to Moses, but something YHWH "showed" him, implying "that Moses beheld a visible reality." Thus when Moses came down from the mountaintop, he was not carrying the n999.9, but only the tablets of the law. The 999997 was

${ }^{1}$ That is, a Nachbild of the heavenly sanctuary which functions as a Vorbild of the earthly sanctuary (in the form of a miniature model).

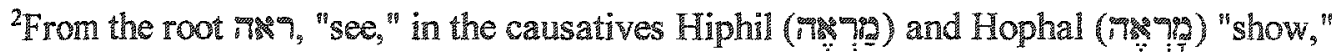
and "be shown" respectively.

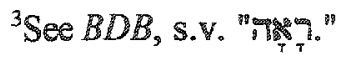

${ }^{4}$ Davidson, Typology in Scripture, 376.

5Davidson has aptly said: "If Moses had boen shown merely architect's plans, it would seem likely that these plans would have been made available to take down from the mountain so that the builder would follow then" (ibid., 376). 
shown during his stay there, which, according to the narrative context, lasted "forty days and forty nights" (Exod 24:18).

Num $8: 4$ adds weight to this suggestion by reporting that Moses made everything

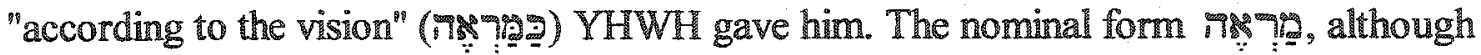
translated as "pattern" by most English versions, ${ }^{1}$ is better translated as "appearance" or "vision." "Tx" also occurs in Exod 24:17 to report that "the appearance [or vision] (ตพา?

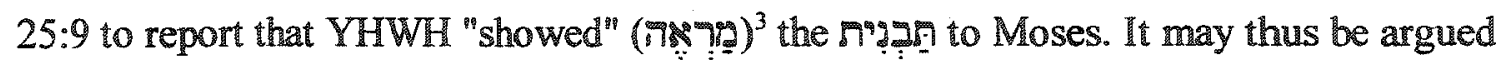
that the term $7 x$ ? in Num $8: 4$ and Exod $24: 17$ most probably indicates that the n'? was was "shown" (inger interpretation accords better with the semantic comotations of the participial forms Tรา

${ }^{1}$ E.g., NASB, NIV, NJB, NKJ, RSV, NRSV.

${ }^{2}$ Cf. $B D B$, s.v. $\pi$. It is worthy of note that the prepositional phrase twenty places outside Num 8:4, and almost always refers to "appearance" vision contexts. Cf. Lev $13: 43$; Num 8:4; 9:15; Judg 13:6; Ezek 1:13, 26;8:2, 4; 10:1; 40:3; $41: 21 ; 42: 11 ; 43: 3 ;$ Dan 8:15; $10: 6,18 ;$ Joel $2: 4$. The only exception seems to be Lev $13: 43$, which refers to the "appearance" of leprosy.

${ }^{3}$ In vs. 40 , a passive form of the root ing" is used to report that the ngas? was "shown" (\%)

${ }^{4} \mathrm{Cf}$. Davidson, Typology in Scripture, 375-76. 
Heavenly Sanctuary/Temple Motif

\section{Fienction}

The picture of the heavenly sanctuary/temple which emerged the above discussion is that of a model for the construction of the earthly counterpart. This idea is conveyed mainly by the concept of 9997 in Exod $25: 9,40$, which reveals that the heavenly sanctuary/temple functions as the archetype for the earthly temple. In this context n9y functions as the Vorbild/Nachbild of the sanctuary Moses was to build upon the earth.

\section{Relationship to Earthly Counterpart}

The usage of nagr in the above discussion as its connection to the larger context of the book of Exodus suggests a structural correspondence between the heavenly sanctuary/temple and its earthly counterpart. Moses was probably shown the heavenly sanctuary and a "model" of what he should build upon the earth. The ngags thus presupposes an original reality (Urbild) and, at the same time, also suggests a structural correspondence between the heavenly sanctuary and its earthly counterpart.

\section{Exod 32:1-34:34}

Exod $32: 1-34: 34^{1}$ has significant interconnections with the sanctuary material displayed in other parts of the Torah. Fretheim, for example, has pointed out that the "sacrificial system in Lev $1-9$ must be seen as part of God's response to Israel's sin and

${ }^{1}$ Edward G. Newing regards Exod 32-34 as the "central pivot of the whole of the Hexateuch [sic]" ("Up and Down-In and Out: Moses on Mount Sinai: The Literary Unity of Exodus 32-34," ABR 41 [1993]: 18). It should be kept in mind however that other suggestions have also been advanced, like Rolf Rendtorff, e.g., who regards Lev 16 as the center of the Torah. See Rendtorff, "Leviticus 16 als Mitte der Torah," BibInt 11 (2003): 252-58. 
God's interaction with Moses, narrated in Exodus 32-34." Interestingly enough, this is the first time in the Torah narrative that forgiveness comes into view. ${ }^{2}$

\section{Preliminary Considerations}

For the purpose of this research, it must be noted that the unit of Exod 32-34 presupposes and continues the narrative of Exod $19-24,{ }^{3}$ which portrays Moses trips up and down the mountain. As a matter of fact, Moses' interactions with YHWH, interceding for the people, occur on the top of the mountain, in the context of the vision experience of the heavenly sanctuary. That being the case, this section of the Torah seems to contain a few perceptions on the heavenly sanctuary/temple motif which may indicate a functional correspondence between heavenly and earthly sanctuary/temple.

The following observations further develop this concept: First, Exod 32:30 reports that Moses intended to ascend the mountain with a very specific purpose in mind: To atone for the people's sin, as the passage makes clear:

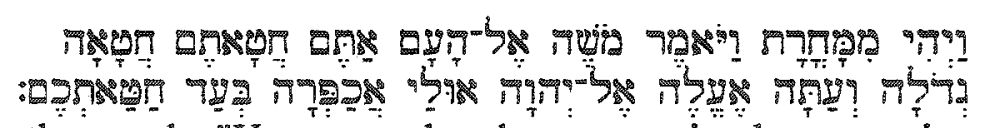

On the next day Moses said to the people, "You yourselves have committed a great sin; and now I am going up to YHWH; perhaps I can make atonement for your sin."

Because of the "great sin" ("It) ascended the mountain to make atonement (75a) for them. It must be noted that one of the

'Fretheim, "Because the Whole Earth Is Mine:' Theme and Narrative in Exodus," 230.

${ }^{2}$ Fretheim, Exodus, 305-07; idem, "Because the Whole Earth Is Mine': Theme and Narrative in Exodus, ${ }^{2} 230$.

${ }^{3}$ R. W. L.Moberly, At the Mountain of God: Story and Theology in Exodus 32-34, JSOTSup 22 (Sheffield: ISOT Press, 1983), 44ff. 
most basic functions of the earthly sanctuary was to be the place of atonement for the sins of the people, the verb 792 being a common term to describe this process. In this regard, the suggestion may be advanced that the atonement perfomed by Moses on the top of the mountain occurs in sanctuary/temple context. ${ }^{1}$ Thus, one may note that soon after being shown a structural correspondence between heavenly and earthly sanctuaries, ${ }^{2}$ Moses was shown a functional correspondence. It is most significant to note that Moses is performing a function soon to be taken over by the priests in the earthly sanctuary. Additionally, that Moses is on the mountain interacting with YHWH and pleading for forgiveness implies that YHWH is acting from his heavenly sanctuary, as already suggested. Therefore, it may be garnered from the above considerations that Moses is shown a functional correspondence between the heavenly sanctuary and its earthly counterpart, soon to be built.

Second, if the narrative context of Exod 32-34 bespeaks heavenly sanctuary imagery, as argued above, then the allusion to YHWH's "book" (7פe) may add weight to this contention. When interceding on behalf of the people, Moses implores YHWH to forgive them. Moses was even willing to have his own name blotted out "from your book (Tๆ? "Whoever has sinned against me, I will blot him out of my book ("9pop)" (Exod 32:33).

'It has been observed that Moses' intercession functions as a cohesive motif which binds all three chapters together, as noted in the following segments: $32: 9-14,30-34 ; 32: 12-17,18-23 ; 34: 5-$ 10a. Cf. Dale R. Davis, "Rebellion, Presence, and Covenant: A Study in Exadus 32-34," WTJ 44 (1982): $71-87$.

${ }^{2}$ See the previous discussion on .9999. 
This "book" has been identified as the book of life, which contains the names of those who belong to YHWH. It should be noted that in the Hebrew Bible and other ANE literature, "books" can belong to the associative field of the heavenly sanctuary/temple motif. For example, Dan 7:10 refers to books in a heavenly sanctuary setting. ${ }^{2}$ In Sumerian literature reference is made to the "tablets of destiny" which were stored in the heavenly temple of the deity. ${ }^{3}$ This does not imply that the biblical motif was borrowed from the ANE literature; they may well go back to a common tradition, or be independent. ${ }^{4}$ At any event, the idea of "books/tablets" related to the heavenly temple both in the Hebrew Scriptures and ANE literature adds weight to the probability that Exod 32-34 contains heavenly sanctuary/temple imagery.

In sum, since Moses' intercession before YHWH is understood as happening in the context of the heavenly sanctuary/temple, one can assert with Rodriguez that YHWH

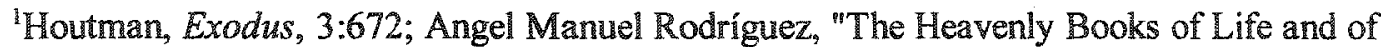
Human Deeds," JATS 13, no. 1 (2002): 12.

${ }^{2}$ See the discussion of this passage in chapter 5 of this dissertation.

${ }^{3}$ See chapter 2 of this dissertation.

"Additionally, it should be noted that the "tablets of destiny" functioned different from the book of life mentioned in the Hebrew Scriptures. While the former were supposed to decide the fate of individuals, the latter was understood as a book of records containing the names of those who were faithful to YHWH. Cf. Shalom M. Paul, "Heavenly Tablets and the Book of Life," JANESCU 5 (1973): 345-53; Rodriguez, "The Heavenly Books of Life and of Human Deeds," 10 26. 
proclaimed "from his most holy place" his willingness to forgive his people for their iniquity, and rebellion, and $\sin .{ }^{.2}$

Heavenly Sanctuary/Temple Motif

\section{Funnction}

The narrative section of Exod $32-34$ indicates that the heavenly sanctuary/temple functions as a place of atonement where YHWH deals with the sin problem, judging the sinners, accepting intercession, and bestowing forgiveness on the basis of his grace. In short, the heavenly sanctuary/temple functions as a place of atonement.

\section{Relationship to Earthly Counterpart}

Considering that Exod 32-34 depicts the heavenly sanctuary/temple as place of atonement-a function also ascribed to the earthly sanctuary/temple-the conclusion may be advanced that there was functional correspondence between the heavenly temple/sanctuary and its earthly counterpart.

\section{Deut 26:15}

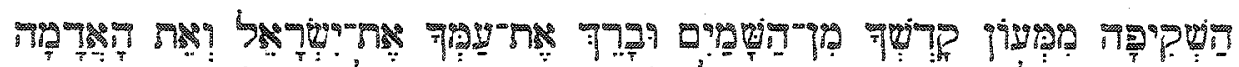

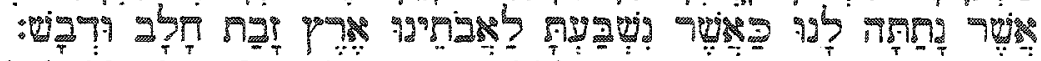
Look down from your holy habitation, from heaven, and bless your people Israel, and the ground which you have given us, a land flowing with milk and honey, as you swore to our fathers.

Notice that it was a "most holy place" because YHWH was there.

2Rodríguez, "Sanctuary Theology in the Book of Exodus," 141. 


\section{Preliminary Observations}

Deut 26 belongs to the larger unit of chaps. $26-28$ which contains the concluding appeals of Moses' to Israel. Chaps. 26 presents Moses' instructions regarding prayer at the presentations of the first fruits and tithes. This chapter divides itself into three rhetorical units: the presentation of offerings with an appropriate verbal affirmation (vss. 1-11), an oath of innocence (vss. 12-15), and a declaration of covenant commitments (vss. 16-19). The unit of vss. $12-15$ deals with the tithe of the third year and an affirmation of obedience to YHWH's commands; vs. 15 then concludes the unit with an address to YHWH in his heavenly habitation.

\section{Semantic and Other Exegetical Considerations}

The presence of the heavenly sanctuary/temple motil is made explicit by the term "heaven" in apposition to "holy habitation." Crucial for this investigation about the function of the heavenly sanctuary and its relationship to earthly counterparts are the semantic and

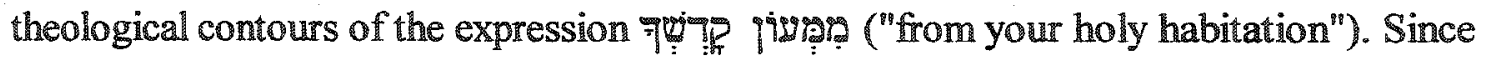
the lexeme wip has already been discussed in comection to Exod 15:11, the following investigation deals mainly with gigys ("habitation"). The verb "qug is also discussed, since it expresses the divine activity performed in connection with the heavenly sanctuary/temple.

'Walter Brueggemann, Deuteronomy, Abingdon Old Testament Commentaries (Nashville: Abingdon, 2001), 246. 


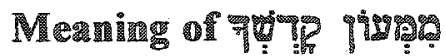

The word 9 ipy occurs sixteen other times ${ }^{2}$ in the Hebrew Bible in reference to the dwelling of YHWH (eight times), ${ }^{3}$ of humans (three times), ${ }^{4}$ and of animals (five times). Worthy of note is the application of 9isin to the temple/sanctuary as YHWH's dwelling. For example, ๆigris ("habitation") in 2 Chr 36:15 and Trng give ("habitation of thy house") in Ps 26:8 indicate

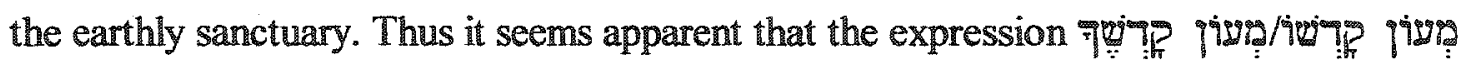
carries the connotation of sanctuary/temple, which is reinforced by means of the genitival qualifier wig.

It is interesting to note that when jigr $_{T}$ occurs in construct relationship with usually refers to the heavenly sanctuary/temple, as indicated by the other four occurrences

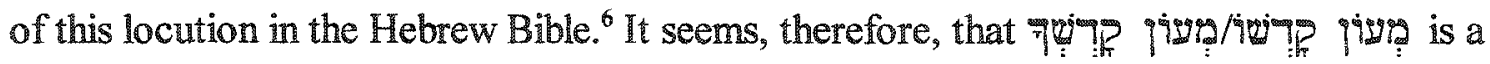
technical term for the heavenly sanctuary/temple. In Deut $26: 15$, this is made clear, as

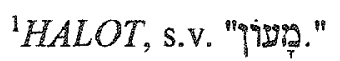

${ }^{2}$ This number may vary from 12 to 19 depending on one's view of some disputed passages.

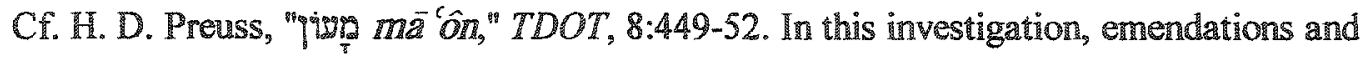
conjectures are not taken into consideration.

${ }^{3} 1 \operatorname{Sam} 2: 29 ; 32 ; 2$ Chr $30: 27 ; 36: 15 ;$ Dss $26: 8 ; 68: 6 ;$ Jer $25: 30 ;$ Zech $2: 17$.

${ }^{4}$ Pss $71: 3 ; 91: 9 ;$ Zeph $3: \%$. The first two passages refer metaphorically to YHWH as the "dwelling" of the righteous.

5Jer $9: 10 ; 10: 22 ; 49: 33 ; 51: 37$; Nah $2: 12$ [11].

6Jer 25:30; Zech 2:17 [13]; Ps 68:6 [5]; 2 Chr 30:27. These passages are discussed subsequent chapters of this dissertation. 


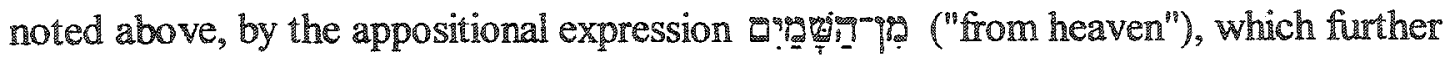

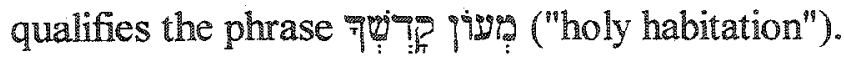

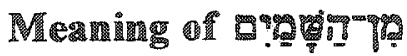

Tigay claims that "the word 'heaven' [in Deut 26:15] emphasizes the Deuteronomic idea that his abode is heaven, not the temple." Payne also asserts that "the sanctuary was, so to say, the sky above."2 This trend to downplay the reality of a heavenly sanctuary/temple and to make heaven itself a sanctuary has been pursued by some scholars who see the so-called Deuteronomistic name-theology, understood to be an abstract conception of the deity, at odds with the alleged anthropomorphic Priestly conception of YHWH's glory dwelling in the tabernacle. ${ }^{3} \mathrm{It}$ is argued that as a response to the destruction of the Jerusalem temple, the putative Deuteronomists conceived of YHWH as dwelling in heaven; only his name dwelt in the earthly temple. ${ }^{4}$ The implication of this view is that the

\footnotetext{
${ }^{1}$ Jeffrey H. Tigay, Deuteronomy, The JPS Torah Commentary (Philadelphia: Jewish Publication Society, 1996), 244; emphasis supplied.

2David F. Payne, Deuteronomy (Philadelphia: Westminster, 1985).

${ }^{3}$ A classical exposition of this view is found in Gerhard von Rad, Studies in Deuteronomy (London: SCM Press, 1953), 37-44. Cf. R. E. Clements, The Book of Deuteronomy: A Preacher's Commentary (Peterborough: Epworth, 2001), 117; Mettinger, The Dethronement of Sabaoth, 11634; Moshe Weinfeld, Deuteronomy and the Deuteronomic School (Oxford: Clarendon, 1972), 191-209. A more detailed study of the name-theology and its implications for the heavenly sanctuary/temple motif is undertaken in chapter 4 of this dissertation in connection with the exegesis of $1 \mathrm{Kgs} 8$.

${ }^{4}$ The fact that YHWH dwells in the heavenly temple/sanctuary does not rule out his presence from the earthly sanctuary/temple. As already observed, some scholars have drawn a wedge between the so-called Deuteronomistic theology of the "name" and the priestly theology of the "glory." The Deuteronomistic theology, so it is argued, stresses YHWH's transcendence by emphasizing that YHWH dwells in heaven, while only his "name" dwells in the earthly sanctuary/temple. The biblical evidence indicates that transcendence and immanence are kept in
} 
references to YHWH's heavenly dwelling express YHWH's transcendence, with no intention to convey the heavenly sanctuary/temple motif.

This view seems to be justified, at first glance, by the syntactic structure of the text. Since Fơ to in the passage is heaven itself. Nonetheless it should be noted that E.? syntactic apposition to the expression Fซgre? giga, is not a synonym of the latter. Due to the clear semantic contours of 707 p 999 , as seen above, it is more appropriate to understand the appositional "heaven" as a specification of ๆש़ that the temple/sanctuary referred to in the passage is the heavenly one. "Two examples of syntactic apposition in which the appositional elements are not synonyms add weight to this

tension in both the so-called $\mathrm{P}$ and $\mathrm{D}$ materials. As a matter of fact, the putative $\mathrm{D}$ materials are also concerned with YHWH's immanence. Texts depicting YHWH's dwelling in heaven also understand YHWH to be able to "look down" (กอบ? the prayers and bestowing his blessing ( $\mathrm{Cf}$., e.g., Deut $1: 17 ; 4: 36)$. Hence, the theology underlying these passages keeps in tension transcendence and immanence and should not be pressed to incline to one side or the other. In sum, the emphasis on YHWH dwelling in heaven does not preclude his presence in the earthly temple/sanctuary. In fact, if the narrative context of the Pentateuch is taken seriously, it must be admitted that YHWH is present in both earthly and heavenly temples/sanctuaries. Furthermore, both heavenly and earthly sanctuaries function in vertical correspondence, as discerned in other passages of the Hebrew Bible (see, e.g., the discussion of 1 Kgs 8, Isa 6:1-6, and PSS 20 and 76 in chapter 4). As for Deut 26:15, it seems appropriate that in the context of a prayer for blessings for people and land, with its attendant implications of rain and fertility for the crops, the Israelites would direct their petitions to the ultimate source of these blessings- $\mathrm{YHWH}$ in his heavenly temple.

'Craigie's observation that "heaven is a theological manner of referring to the 'residence' of the transcendent God." is correct, except for its implicit identification of the sanctuary with heaven itself (Peter C. Craigie, The Book of Deuteronomy, The New International Commentary on the Old Testament [Grand Rapids: Eerdmans, 1976], 323). Also Merril in his comment on Deut 26:15 tends to overlook the reality of the heavenly temple by simply saying that "Israel's God reigned from heaven above." Eugene H. Merril, Deateronomy, The New American Bible Commentary, vol. 4 (Dallas: Broadman \& Holman, 1994), 336. 
contention. In Exod 14:2, the Israelites are told to camp "in front of Pi-ha-hirot ... in front of Zaphon." These names, of course, are not synonyms; they are, so to say, coordinates that help to locate more precisely the spot where the Israelites should camp. The same can be said of Exod 30:6, in which the golden altar is to be put "before the veil that is by the ark of the testimony, before the mercy seat that is over the testimony. It is obviously clear that the two appositional elements are distinct items of the tabernacle

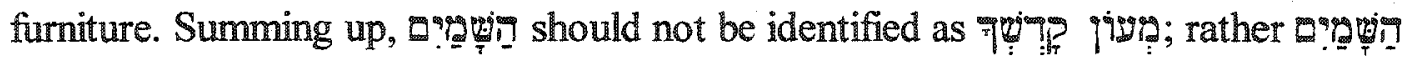

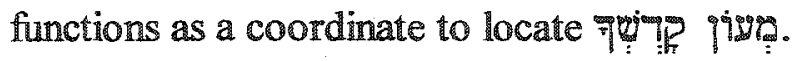

\section{Meaning of}

The verbal form 7? is the imperative piel of q9a ("bless"). When YHWH is the subject of this verb, as in Deut 26:15, it means "to endue someone with special power."2 For the purposes of this study it will suffice to note that this verb governs two objects: "the people" (Taps"

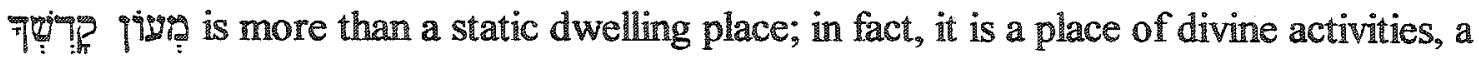
place wherein YHWH interacts with his people, hears their prayers, and blesses them and their land. ${ }^{3}$

\footnotetext{
'These examples are noted by Ian Wilson (Out of the Midst of the Fire: Divine Presence in Deuteronomy [Atlanta, GA: Scholars Press, 1995], 175-76), although in a different context.

${ }^{2}$ HALOT, s.v. "Tาב."

${ }^{3}$ For the temple as a source of fertility in ANE temple theology, see chapter 1.
} 
Heavenly Sanctuary/Temple Motif

The heavenly sanctuary/temple motif is clearly portrayed in Deut $26: 15$. The

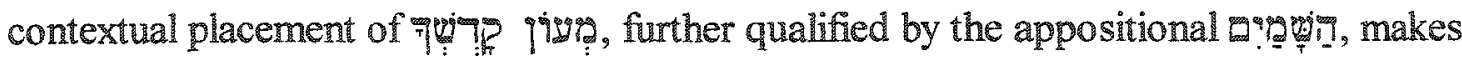
clear that it is the heavenly sanctuary which is in view in this passage. ${ }^{1}$ Furthermore, from the semantical and exegetical survey of the expression

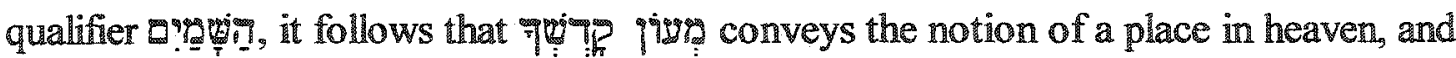
therefore should not be confused with heaven itself. The appositional a

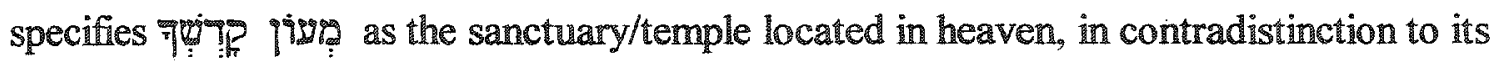
counterpart located on earth.

\section{Function}

In the discussion undertaken above, it has become apparent that the heavenly sanctuary as portrayed in Deut 26:15 is not a mere place of dwelling, but also a place of divine activities: hearing prayers, and blessing people and land. The fact that the prayer is directed to YHWH in his heavenly temple/sanctuary indicates that the heavenly sanctuary/temple functions as YHWH's headquarters (i.e., as the command center from which he exerts his rulership). Although YHWH can be and act at any other place, the text implies that there is a specific location in heaven where he undertakes his divine activities.

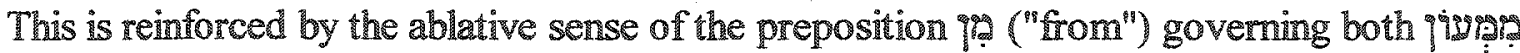

'The suggestion has been advanced that "the words 'from heaven' seem to be an explanatory appendage intended to prevent misconstruing the expression 'holy habitation' as referring to the sanctuary" (Moshe Weinfeld, Deuteronomy and the Deuteronomic School [Oxford: Clarendon, 1972], 198). Cf. Duane L. Christensen, Deuteronomy, WBC 6b (Waco, TX: Word Books, 2002), 642 . 


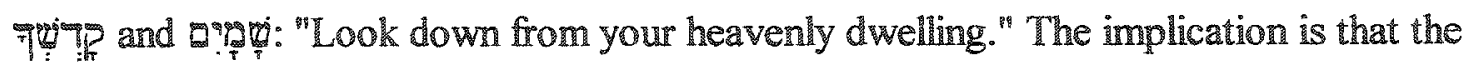
"heavenly dwelling" is the place "from" where YHWH interacts with the human situation, by "looking down" and bestowing "blessings." If p? is allowed to play its full role in the

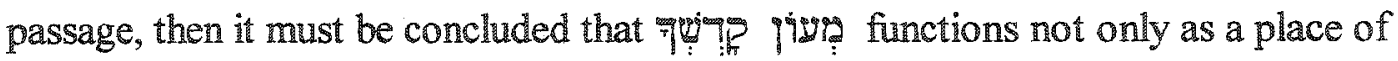
dwelling, but as place of divine activities, whence YHWH blesses his people and bestows fertility upon the land.

\section{Relationship to Earthly Counterpart}

As noted above, the term بִ ("habitation") is also applied to the earthly temple/sanctuary as YHWH's dwelling, as noted in $2 \mathrm{Chr} 36: 15$ and Ps 26:8. Thus, the implication emerges that the heavenly sanctuary/temple exists in a structural relationship to the earthly counterpart.

\section{Summary}

This chapter has discussed several passages containing the heavenly sanctuary/ temple motif in the Torah, and reached a number of insights concerning its function and relationship to earthly counterparts. It has become apparent that the heavenly sanctuary/temple as depicted in the Torah functions as the locus of divine activities, such as judgment, ratification of the covenant, worship, atonement, and source of blessings and fertility. The perception also emerged of the heavenly sanctuary/temple as the meeting place of the heavenly council and model for the construction of the earthly sanctuary. As for its relationship with the earthly counterparts, the heavenly sanctuary/temple seems to have been understood in functional and structural correspondence to the earthly 
counterpart. Such a relationship has also emerged as a dynamic interaction since the heavenly temple may be portrayed as affecting, or interacting with, its earthly counterpart. These findings are summarized as shown in table 2: 
TABLE 2

THE HEAVENLY SANCTUARY/TEMPLE MOTIF

IN THE TORAH

\begin{tabular}{|c|c|c|c|c|c|}
\hline \multirow[t]{3}{*}{ Passage } & \multirow[t]{3}{*}{ Vocabulary } & \multirow[t]{3}{*}{ Function } & \multicolumn{3}{|c|}{ Relationship to Earthly Counterpart } \\
\hline & & & \multicolumn{2}{|c|}{$\begin{array}{c}\text { Vertical } \\
\text { Correspondence }\end{array}$} & \multirow[t]{2}{*}{$\begin{array}{l}\text { Dynamic } \\
\text { Interaction }\end{array}$} \\
\hline & & & Functional & Structural & \\
\hline Gen 11:1-9 & $\begin{array}{l}\text { [yrd, } \\
\text { šămayim] }\end{array}$ & $\begin{array}{l}\text { Judgment (investigative } \\
+ \text { executive) }\end{array}$ & & & \\
\hline Gen $28: 10-22$ & $\begin{array}{l}\text { ša'ar } \\
\text { haššamayim }\end{array}$ & Ratification of covenant & 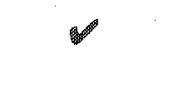 & & 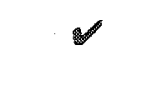 \\
\hline Exod 15:1-18 & gödes & $\begin{array}{l}\text { Heavenly assembly, } \\
\text { worship, kingship }\end{array}$ & 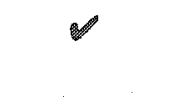 & $\infty$ & \\
\hline $\operatorname{Exod} 24: 9-11$ & $\begin{array}{l}\text { [libnat } \\
\text { hassappir, } \\
\text { hašsamayim }\end{array}$ & Kingship, covenant & 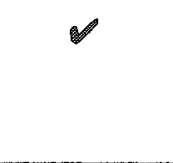 & & $\mathscr{P}$ \\
\hline Exod 25:9, 40 & tabnit & $\begin{array}{l}\text { Model for the } \\
\text { construction the earthly } \\
\text { sanctuary }\end{array}$ & & 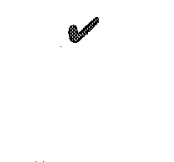 & . \\
\hline Exod $32-34$ & Iimplied & Place of atonement & $\infty$ & & \\
\hline Deut 26:15 & $\begin{array}{l}\text { mé ôn } \\
\text { godšè }\end{array}$ & $\begin{array}{l}\text { Prayers, blessings, } \\
\text { fertility }\end{array}$ & 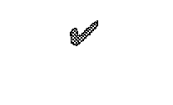 & 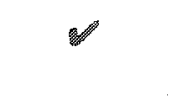 & \\
\hline
\end{tabular}




\section{CHAPTER 4}

\section{THE HEAVENLY SANCTUARY/TEMPLE MOTIF}

\section{IN THE PROPHETS}

The present chapter provides an investigation of the following passages of the prophetic corpus containing the heavenly sanctuary/temple motif: 2 Sam $22: 1-51 ; 1 \mathrm{Kgs}$ $8: 12-66 ; 22: 19-23$; Isa $6: 1-8 ; 14: 12-15 ;$ Ezek $1: 1-28 ; 10: 1-22 ; 28: 11-19 ;$ Mic $1: 2-3 ; 3: 1-$ 10; Zech 3:1-10. In order to provide a broader data base for this investigation, a more cursory treatment is reserved for shorter passages at the end of this chapter: Isa 18:4; $63: 15 ;$ Jer 17:12; 25:30; Hos 5:15; Jonah 2:5 [4] and 8 [7]; Hab 2:20; Zech 2:17.

Although these texts are not claimed to be an exhaustive inventory of heavenly sanctuary/temple passages in the Prophets, they do claim to represent a fairly comprehensive overview of the theme under study in this section of the Hebrew Bible. Consequently, it is hoped that even if future research claims that other passages contain the heavenly sanctuary/temple motif, their investigation will not change the basic picture suggested by this study.

\section{Sam 22:1-51}

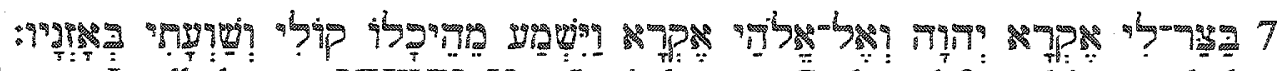
7 In my distress 1 called upon YHWH, Yes, I cried to my God; and from his temple he heard my voice, and my cry for help came into his ears. 
The presence of the heavenly sanctuary/temple motif in 2 Sam $22: 7$ has been recognized by several scholars and further investigated and endorsed by Kim in his recent dissertation. ${ }^{1}$ Nevertheless, further study remains to be done to ascertain the function of the heavenly sanctuary/temple and its possibie relationship to the earthly counterpart. In the ensuing discussion, after some preliminary observations on the text unit and genre of 2 Sam 22:1-51 are provided, a semantic analysis of some key words and expressions in vs. 7 and its immediate context contribute to a delineation of the function of the heavenly sanctuary/temple and its relationship to the earthly counterpart.

\section{Preliminary Observations}

2 Sam 22 , usually referred to as a "royal song of thanksgiving, ${ }^{2}$ is claimed by the text itself to have been composed by David when YHWH delivered him from the hands of his enemies. ${ }^{3}$ The song is naturally divided into two parts (vss. $1-30$ and vss. $\left.31-50\right) .{ }^{4}$ The first part contains expressions of praises to YHWH and a description of David's mortal perils, followed by a theophany which concludes with an affirmation of YHWH's justice.

${ }^{1} \mathrm{Kim}, 102-12$.

${ }^{2}$ Frank Moore Cross and David Noel Freedman, "A Royal Song of Thanksgiving: II Samuel 22=Psalm 18," JBL 72 (1953): 15-34.

${ }^{3}$ As a matter of consistency with the canonical/narrative approach adopted in this study, the superscription of the song which ascribes it to David is taken at face value. Regardless of one's opinion regarding the authorship, it seems clear that the song as it stands in the Hebrew Scriptures was intended to be understood in the context of David's personal experience of deliverance by YHWH.

${ }^{4}$ Alberto R. W. Green, The Storm-God in the Ancient Near East, BBS \& (Winnona Lake, NN: Eisenbrauns, 2003), 269. 
The second part praises YHWH for granting victory over the enemies and dominion over foreign peoples, and concludes with an expression of thanksgiving.

Although some scholars view this composition as an amalgam of two different poems, ${ }^{1}$ there are compelling reasons to take this song as a unity, as demonstrated by several scholars. ${ }^{2}$ Among these, one should mention Kuntz, who, by means of rhetorical analysis of the parallel text in PS 18, demonstrated that the song should be regarded as a unified composition. ${ }^{3}$

The date of the song has also been a matter of discussion. Although there are scholars who date the text to the postexilic period, ${ }^{4}$ the broader consensus is that it displays several archaic features which might reach back to a time as early as the tenth century B.C. ${ }^{5}$ This consensus being accepted, there is nothing in the composition that

'H. Schimdt, Die Psalmen (Tübingen: Mohr, 1934), 15; E. Baumann, "StructurUntersuchungen im Psalter I," ZAW 61 (1945-48): 114-76; D. Michel, Tempora und Satzstellung in den Psalmen (Bonn: Bouvier, 1960), 49ff; A. A. Anderson, 2 Samuel (Dallas, TX: Word Books, 1989), 262.

${ }^{2} J$. Kenneth Kuntz, "Psalm 18: A Rhetorical Analysis," JSOT 26 (1983): 3-31; Artur Weiser, The Psalms: A Commentary. The Old Testament Library (Philadelphia: Westminster, 1962), 186-87; Marc Girard, Les Psaumes: Analyse Stracturelle et Interpretation: 1-50, Recherches Nouvelle Série-2 (Montréal: Éditions Bellarmin, 1984), 157-68.

${ }^{3} K_{\text {untzZ, }}$ 3-31.

${ }^{4}$ Bernhard Duhm, Die Psalmen (Freiburg: Mohr, 1899), 59; Hans H. Spoer, "Versuch einer Erklärung von Psalm 18," ZAW 27 (1907): 155; $\mathbb{R}$. Tournay, "En Marge d'une Traduction des Psaumes," RB 63 (1956): 167.

${ }^{5}$ Cross and Freedman, "A Royal Song of Thanksgiving. I Samuel 22=Psalm 18," 15-16; Louis Jacquet, Les Psames et le cour de l'homme: Étude texuelle, littéraire et doctrinale (Gembloux, Belgien: Duculot, 1975), 434; Mitchell J. Dahood, Psalms I (1-50): Introduction, Translation, and Notes, AB 16 (Garden City, NY: Doubleday, 1966), 104-19; P. Kyle McCarter, II Samuel: A New Translation with Introduction, Notes, and Commentary (Garden City, N.Y.: Doubleday, 1984), 473-75. 
precludes its ascription to David himself. After all, its placement alongside the last words of David seems to indicate that its association with David goes back to an old tradition.

\section{Semantic and Other Exegetical Considerations}

\section{Veraning or}

The word לఫ9", usually translated as "temple/palace," comes from Sumerian $\dot{E}$ gal, "great house," via Akkadian, êkall $\hat{u}$, hence "palace" or "temple." In the Hebrew Bible, ל⿻ গฺ may connote a royal palace or residence, ${ }^{3}$ and also a cultic center of worship (i.e., a temple for the deity). ${ }^{4}$ Thus, on the basis of the definition of temple/sanctuary already spelled out, ${ }^{5}$ one can safely affirm that 395 has the connotation of "temple/sanctuary" since it clearly refers to YHWH's dwelling and contains cultic allusions and temple imagery, as pointed out later in this discussion.

As for the location of the 599, it should be noted that despite some scholars affirming that the 5 "I referred to in this passage is the earthly temple, ${ }^{6}$ the following reasons may be adduced in favor of its referring to the heavenly temple of YHWH. First,

${ }^{1}$ Palace of deity, with deity regarded as royalty.

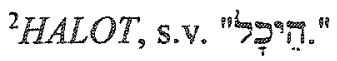

${ }^{3}$ E.g., 1 Kgs $21: 21 ; 2$ Kgs 20:18; 2 Chr 36:7; Prov 30:28; Isa 13:22; 39:7; Dan 1:4.

${ }^{4}$ E.g., 1 Sam 1:9; 2 Kgs 18:16;23:4; 2 Chr $3: 17 ;$ Ezra $3: 6 ;$ Neh $6: 11 ;$ Pss 5:8; 11:4.

see chapter 1.

${ }^{6} \mathrm{Cf}$., e.g., M. Ottosson, "hoss hêkāl," TDOT, 3:386; Hans-Joachim Kraus, Psalmen, 2nd ed., 2 vols., BKAT (NeukirchenKreis Moers: Neukirchener Verlag der Buchhandlung des Erziehungsvereins, 1961), 1:143. 
from a narrative perspective one should not ignore that the song is composed by David; and that by itself would exclude the Jerusalem temple as the referent of the 5 \$T.

Second, the subsequent actions of $Y$ HWH, undertaken in response to David's cry for help, are issued fom the heavenly realm, as clearly expressed by several words and expressions. Two subsequent prepositional phrases in the paradigmatic field of ${ }_{\tau}$ T? will

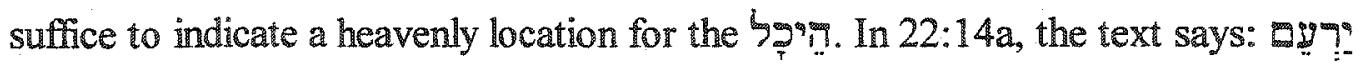

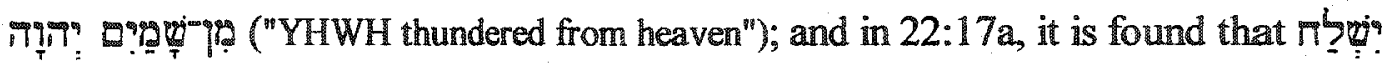

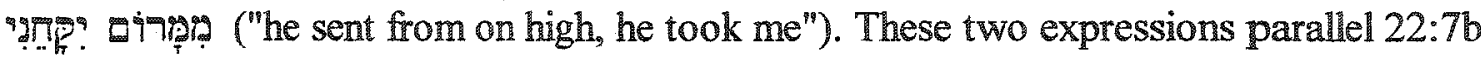
which reads: "? Since the actions of YHWH, as described in the song, issued "from heaven"/ from on high," it is reasonable to understand that

Third, the rhetorical-spatial imagery adds further weight to heaven as the location of the temple. For example, the psalmist describes his distress as a "Sheol" experience in the sense of exposure to despair and death. From a rhetorical-spatial perspective Sheol is understood as the lowest place to which someone could descend. Therefore it is natural to suppose that help would come from the highest realm one could imagine-heaven itself. ${ }^{1}$ Furthermore, vss. 11 and 12 expressed in verbs such as "bowed," "came down," "rode," "flew" more naturally point to the heavenly realm as the location of the by9m. ${ }^{2}$

\footnotetext{
${ }^{1}$ The same concept also appears in Jonah $2: 5[4], 8[7]$, as noted later in this chapter. ${ }^{2} \mathrm{Kim}, 110$.
} 


\section{Meaming of a}

The reference to the larger picture of the manifestation of YHWH in response to David's prayer, not only stresses the splendor of the theophany, but also contains a subtle allusion to temple/sanctuary imagery. The expression "coals of fire" occurs only in three other places in the Hebrew Bible (apart from Ps 18), and always in contexts where activities of judgment from the sanctuary/temple are in view. ${ }^{1}$ In Lev 16:12, it is used in connection with the day of atonement in the earthly sanctuary; and in Ezek 1:13 and Ezek 10:2 in a context of judgment from the temple. Such references to fire in connection with sanctuary/temple imagery reinforce the probability that the reference to "coals of fire" in 2 Sam 22:13 also connotes temple imagery.

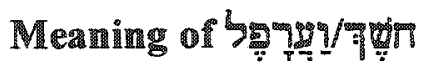

The imagery of "darkness," frequently associated with the day of YHWH, also had its counterpart in the temple, as seen in $1 \mathrm{Kgs} 8: 12$ :

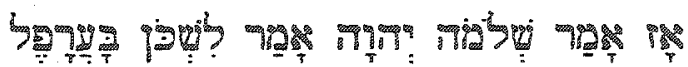

Then Solomon said, "YHWH has said that he would dwell in the thick cloud."

Therefore, in addition to the other terms and expressions, the motif of "darkness" also contributes to reinforce the temple imagery reflected in the passage. ${ }^{2}$

${ }^{1}$ See Lev 16:12; Ezek 1:13; 10:2.

${ }^{2} \mathrm{Cf}$. Friedhelm Hartenstein, "Wolkendunkel und Himmelfeste: Zur Genese und Kosmologie der Vorstellung des himmlischen Heiligtums NHWHs," in Das biblische Weltbild und seine altorientalischen Kontexte, ed. Bernd Janowski and Beate Ego (Tübingen: Mohr Siebeck, 2001), 130; Craig C. Broyles, Psalms, NIBC, Old Testament Series 11 (Peabody, MA: Hendrickson; Carlisle, U.K.: Paternoster Press, 1999), 104-05. 


\section{Meaning of}

The reference to 37 ("cherub") in 2 Sam $22: 11$ further reinforces the sanctuary/temple imagery present in the text. If the plural reading of the $\mathrm{LXX}$ is accepted, as suggested by Cross and Freedman, ${ }^{1}$ temple connotations become even more obvious, in view of the even more obvious allusion to the two overlaid images of cherubim that covered the ark in the most holy place of the tabernacle (and later Solomon's temple). Additionally, one may argue that this reference to cherub/cherubim points more specifically to most-holy-place imagery, ${ }^{2}$ a connection reinforced by the cherubim related to God's throne, as one can deduce from Ezek 1:5-28 and 28:14, passages also pervaded by other aspects of temple imagery. ${ }^{3}$

\section{Meaning of กi๋อ}

This word should probably be read 990 or 1 ing being the case, this reference to "his tent" would be a further allusion to the sanctuary motif. This lexeme, together with Sirk ("tent"), is frequently used in the Psalms as a metaphor for the "protective throne-room" or YHWH.

"Cross and Freedman, "A Royal Song of Thanksgiving: II Samuel 22=Psaim 18," 15-34.

${ }^{2}$ C. F. Keil and F. Delitzsch, Biblical Commentary on the Books of Samuel, trans. James Martin (Grand Rapids: Eerdmans, 1950), 473-75.

${ }^{3}$ See the study of these passages later in this chapter.

${ }^{4}$ See the critical apparatus of BHS on 2 Sam $22: 12$.

"Schutzenden Thronraum" (Hartenstein, 130).

${ }^{6}$ Cf. Pss 15:1; 27:5f:; $31: 21 ; 61: 5$. 


\section{Heavenly Sanctuary/Temple Motif}

As seen above, the term gor refers to the heavenly temple, rather than to the earthly counterpart. Furthermore, the text displays several references and allusions to the temple motif. The mentioning of "coals of fire," "cherub," and "darkness" indicates that temple imagery permeates the song. It should also be noted that temple imagery and theophanic representation are interconnected in the text. After all, it is from the heavenly temple that YHWH "came down" to intervene in favor of the petitioner."

\section{Function}

Several scholars avoid translating Sפד as "temple," preferring instead to translate it as "palace" or some other term connoting "dwelling." It seems that behind these translations lies the unstated assumption that place of dwelling for the deity, by analogy with the palace of earthly kings. ${ }^{3} \mathrm{~A}$ closer inspection of the passage, however, yields further insights. First, as noted above, temple

\footnotetext{
"In diesem Abschnitt finden sich neben der Gewittermetaphorik auch Elemente der Tempelsymbolik" (Hartenstein, 130).

${ }^{2}$ Cf., e.g., Cross and Freedman, "A Royal Song of Thanksgiving: II Samuel 22=Psalm 18," 23, n. 11; Kuntz, 25; McCarter, 465; Charles Briggs, and Emilie G. Briggs, $A$ Critical and Exegetical Commentary on the Book of Psalms, 2 vols., ICC (Edinburgh: T. and T. Clark, 19061907), 138; Mitchell J. Dahood, Psalms I (1--50): Introduction, Translation, and Notes, AB 16 (Garden City, NY: Doubleday, 1966), 101, 106; Hermann Hupfeld and Wihelm Nowack, Die Psalmen, 3rd ed. (Gotha: F.A. Perthes, 1888), 7; Hans Schmid, Die Psalmen, HAT, vol. 15 (Tübingen: J.C.B. Mohr, 1934), 28; Klaus Seybold, Die Psalmen, Handbuch zum Alten Testament 15 (Tübingen: J.C.B. Mohr- Paul Siebeck, 1996), 81.

${ }^{3} \mathrm{Cf} .$, e.g., Briggs and Briggs who argue that although Sor" is "sometimes conceived as a heavenly temple, where He is worshipped (sic) .. . by heavenly beings"; in the present context it should be understood "as a palace because royal help is given, rather than response to worship" (Briggs and Briggs, 142).
} 
imagery pervades the pericope. This seems to suggest that the ל⿻丷木 as depicted in this text functions as temple/sanctuary with its attendant implications. It should be noted that the cry of the psalmist to the Sפ్ implies cultic connotations. As pointed out by Davidson, "prayer, even in the form of a cry for help, is a form of worship." In the same vein, Kim observed that "the place in which human crisis is resolved is the "temple." The fact that YHWH heard David "from his [i.e. YHWH's] temple" seems to imply that the temple had a special function, otherwise, the psalmist could have simply said "YHWH had heard me" without any reference to the temple. The connection of YHWH with the temple as the specific place whence he hears/answers prayers and intervenes in favor of David points to the significance of the temple in the context of YHWH's actions.

The heavenly temple, as depicted in this pericope, functions as the place whence "royal help" is granted to the king. Also, on the basis of the subsequent verses, this function is expanded. The other two expressions parallel to 159 Tif yield complementary perceptions of the heavenly temple. In $22: 14$ and 15 one learns that YHWH thundered

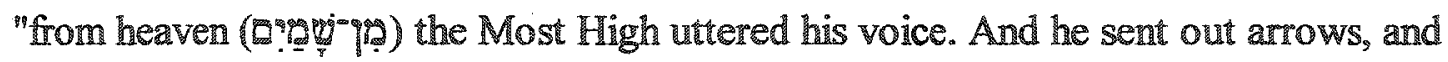
scattered them, lightning, and routed them." This suggests that the heavenly temple is the place whence THWH sends judgments to punish the enemies of the peitioner.

In 2 Sam 22:17, again, the concept of help from the sanctuary is implied in the

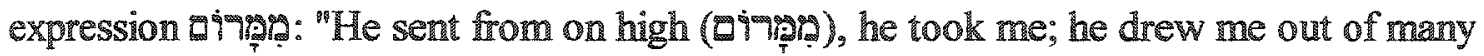

'Davidson, "The Heavenly Sanctuary in the Old Testament," 7.

${ }^{2} \mathrm{Kim}, 111$. 
waters." In the sequence of the text it is stated that YHWH "has rewarded me ("gh? according to my righteousness (nperge), according to the cleanness (79) of my hands he

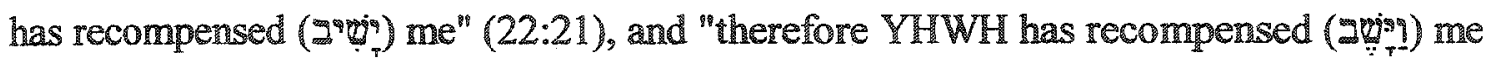
according to my righteousness (97) eyes" (2 Sam 22:25). It should be noted that these actions of YHWH in favor of his

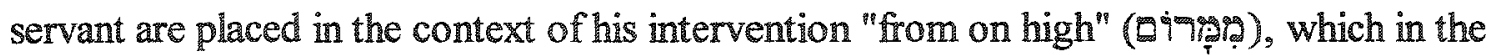
light of $22: 7$ should be understood as "from the [heavenly] temple." The heavenly temple thus emerges in 2 Sam 22 as the place whence YHWH vindicates the psalmist. This

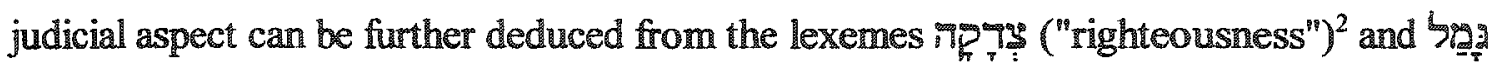
("recompense"), which in connection with givi statements connote divine judgment. Also the word 79 in David's claim to "cleanness ( 9 ) of hands 15 connotes cultic imagery, thus contributing to reinforce the temple connotations of the text. ${ }^{6}$

Summing up, the heavenly sanctuary/temple as portrayed in this composition emerges with the following functions: the place whence YHWH answers prayer, thus

${ }^{1} \mathrm{Cf}$. Jonah $2: 4[3]$.

${ }^{2} \mathrm{Cf}$. Jerome P. Justesen, "On the Meaning of SADAQ, AUSS 2 (1964): 53-61.

${ }^{3}$ Cf., e.g. Joel 4:4, 7 [3:4, 7]; Obad 15; Jer 51:6, 56; Isa 59:18b; Ps 7:5 [4]; Prov 3:30.

${ }^{4}$ Cf., K. Seybold, "Sgà gämal," TDOT, 3:29.

${ }^{5}$ However odd David's "cleamess of hands " may be, such claim should be understood in the light of Ps 51. If this prayer song was uttered by David towards the end of his life, as the canonical placement of the text seems to suggest, then it may be argued that David could claim what he claimed, not on the basis of self-justification, but rather on the premise that YHWH had forgiven and purified him.

${ }^{6}$ Wilfried Paschen, Rein und unrein: Untersuchung zur biblischen Wortgeschichte (Munich: Kösel-Verlag, 1970). 
granting "royal help" to the king; the place whence YHWH issues judgments to punish the enemies of the petitioner; and the place where YHWH vindicates the righteousness and cleanness of his servant. Thus the heavenly sanctuary/temple is not a mere place of dwelling, but a place where divine activities of answering prayers, judgment of the wicked, and vindication of the righteous take place.

\section{Relationship to Earthly Counterpart}

Although the primary referent of the passage is the heavenly sanctuary/temple, several elements seem to point to a vertical correspondence. Davidson has noted an earthheaven correspondence in the allusion to the cherub-chariot. ${ }^{1}$ Thus, the reference to "darkness under his feet" and the term Yq $_{T} \%$, as noted above, suggest a structural correspondence with the earthly sanctuary/temple as portrayed in the Hebrew Scriptures. The functions of the heavenly temple as discemed in the text also had their parallels in the earthly temple, thus indicating a functional correspondence between the heavenly sanctuary/temple and its earthly counterpart. At this point, Stuhlmueller's statement is an apt conclusion for these considerations: "Not only did the Jerusalem sanctuary reflect God's heavenly abode, but its magnificent liturgy also mirrored God's celestial wonder." 2

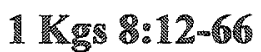



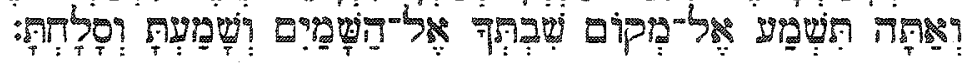

"Davidson, "The Heavenly Sanctuary in the Old Testament," 7.

${ }^{2}$ Carroll Stuhlmueller, Psalms I (Psalms 1-72), OTMBTC 21 (Wilmington, DE: Michael Glazier, 1983), 129. 
Hear the supplication of your servant and of your people Israel when they pray toward this place. Hear from heaven, your dwelling place, and when you hear, forgive.

It has been argued that there is no evidence of heavenly sanctuary/temple in this text. According to him "although 'heaven' and 'heavenly dwelling place' are expressed in connection with the Jerusalem temple, they are not used to deliver a notion of the temple itself. Rather, they are used to represent the transcendence of Yahweh."1 He further concludes his study by saying that "the phrase, 'heaven' and 'heaven God's dwelling place' is irrelevant to my [i.e., his] concerns about the heavenly sanctuary. It is used in this narrative as a technical term to designate God's transcendence." 2 Regarding the earthly temple he also expressed the view that "the earthly temple in 1 Kings 8 is neither the locus of offering sacrifices nor a place of divine manifestation. It is not a place of Yahweh's hearing prayer, but a place of prayer. ${ }^{.33}$ However, despite Kim's affirmation to the contrary, it is argued below that $1 \mathrm{Kgs} 8$ does contain allusions to the heavenly sanctuary/temple motif, ${ }^{4}$ as well as indications of a relationship between the heavenly temple and its earthly counterpart.

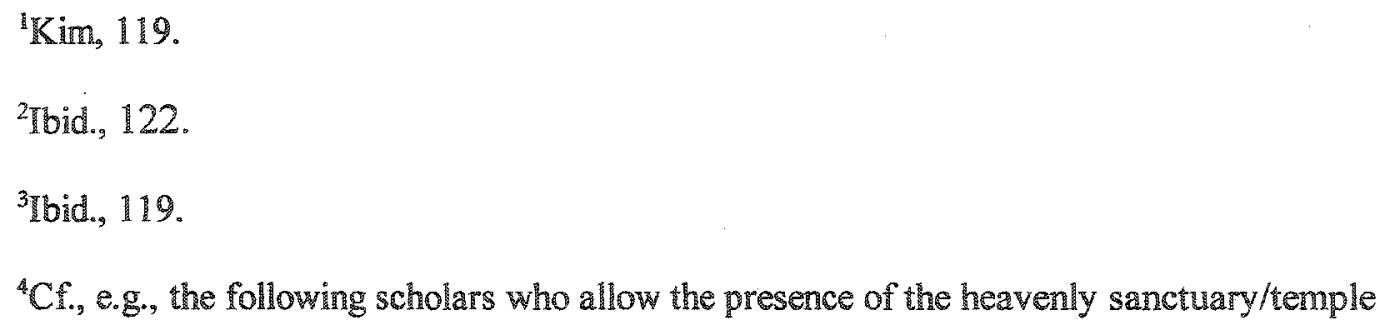
motif in $1 \mathrm{Kgs} \mathrm{8:} \mathrm{Francis} \mathrm{I.} \mathrm{Andersen,} \mathrm{Habakkuk:} \mathrm{A} \mathrm{New} \mathrm{Tronslation} \mathrm{with} \mathrm{Introduction} \mathrm{and}$ Commentary, AB 25 (New York: Doubleday, 2001), 256; James Montgomery, A Critical and Exegetical Commentary on the Book of Kings, ICC (Edinburgh: T. and T. Clark, 1951), 193; Winfried Vogel, "Cultic Motifs and Themes in the Book of Daniel," JATS 7, no. 1 (1996): 200. Angel Rodriguez, "Significance of the Cultic Language in Daniel 8:9-14," in Symposium on Daniel, ed. Frank B. Holbrook, DARCOM (Washington, DC: Biblical Research Institute, 1986), 530-31. 
The ensuing investigation dwells on the assumption that $1 \mathrm{Kgs} 8$ is a unified composition. Therefore, the narrative framework is also taken into consideration in the course of this study. The cogent arguments in favor of the literary unity of this chapter, as argued below, make this approach methodologically justified. Some preliminary observations on the unity and structure of the pericope are provided below, followed by an excursus about two theological aspects related to the passage. This theological discussion tackles the issues of transcendence versus immanence and prayer versus sacrifice, which are relevant for this study. Thereafter semantic and exegetical considerations pave the way for further ascertaining the presence of the heavenly sanctuary/temple motif in the passage as well as its function and relationship to the earthly counterpart.

\section{Preliminary Observations}

Although from the perspective of critical scholarship, $1 \mathrm{Kgs} 8$ displays a complex process of composition and revision through the hands of several authors/editors, ${ }^{1}$ there is

${ }^{1}$ There are four major views regarding the composition of $2 \mathrm{Kgs} 8$ : (1) Noth and his followers view most of $1 \mathrm{Kgs} 8$ as a unified pericope composed mainly, if not totally, by the (exilic) Deuteronomist. Cf. Martin Noth, The Deuteronomistic History, ed. David J. A. Clines et al., trans. Jane Doull, JSOTSup 15 (Sheffield: Sheffield Academic, 1981); O. Plöger, "Reden und Gebete im Deuteronomistis und chronistichen Geschichtswerk, in Festchrift fur Günther Dehn zum 75. Geburtstag, ed. W. Schneemelcher (Neukirchen: Buchhandlung des Erziehungsvereins, 1957), 35-49; Moshe Weinfeld, Deuteronomy and the Deuteronomic School (Oxford: Clarendon, 1983), 35-36, 195-98; H.-D. Hofmann, Reform umd Reformen: Untersuchungen zu einen Grundthema der deuteronomistichen Geschichtsschreibung, ATANT 66 (Zürich: Theologischer Verlag, 1980); John Van Seters, In Search of History: Historiography in the Ancient World and the Origins of Biblical History (New Haven: Yale University Press, 1983), 310-11.

(2) Cross contended that Solomon's prayer stems from a preexilic Deuteronomist (Drr), later supplemented by an exilic editor (Dtr $\left.{ }^{2}\right)$. Cf. Frank Moore Cross, Conacnite Myth and Hebrew Epic: Essoys in the History of the Religion of Israel (Cambridge, MA: Harvard University Press, 1973), 274-89; Richard Ellot Friedman, The Exile and Biblical Narrative: The Formation of the Deuteronomistic and Priestly Works, Harvard Semitic Monographs 22 (Chico, CA: Scholars Press, 1981), 1-43; Steven L. McKenzie, The Chronicler's Use of the 
substantial evidence for the literary unity of this text as shown by some scholars. ${ }^{\prime}$ In an insightful article, Knoppers has convincingly demonstrated that a deliberate authorial Strategy lies behind the composition of the text. ${ }^{2}$ This strategy consists mainly of a symmetric organization of seven literary frames having Solomon's fourth petition in the center, as displayed below. ${ }^{3}$

Deuteronomistic History, Harvard Semitic Monographs 33 (Atlanta: Scholars Press, 1985), 199205; Steven L. McKenzie, The Trouble with Kings: The Composition of the Book of Kings in the Deuteronomistic History, VTSup 42 (Leiden: Brill, 1991), 137-40; Richard D. Nelson, The Double Redaction of the Deuteronomistic History, JSOTSup 18 (Sheffield: JSOT Press, 1981), 69-73.

(3) R. Smend suggests a series of exilic deuteronomistic editions and postdeuteronomistic additions. R. Smend, "Das Gesetz und die Völker: Ein Beitrag zur deuteronomistischen Redaktionsgeschichte," in Probleme biblischer Theologie: Gerhard von Rad zum 70. Geburtstag, ed. Hans Walter Wolff (Munich: C. Kaiser, 1971), 494-509; Rudolf Smend, Die Entstehung des Alten Testaments, 4th Theologische Wissenschaft 1 (Stuttgart: Kohlhammer, 1989), 111-34. Cf. also Walter Dietrich, Prophetie und Geschichte: Eine redaktionsgeschichtliche Untersuchung zum deuteronomistischen Geschichtswerk, Forschungen zur Religion und Literatur des Alten und Neuen Testaments 108 (Göttingen: Vandenhoeck and Ruprecht, 1972), 73-74; Gwilym H. Jones, 1 and 2 Kings (Grand Rapids: Eerdmans; London: Marshall Morgan and Scott, 1984), 191-209; Ernst Würthwein, Das erste Buch der Könige (Göttingen: Vandenhoeck and Ruprecht, 1977), 84103.

(4) O'Brien argues in favor of a series of preexilic, exilic, and postexilic deuteronomistic redactions of a preexilic source. Cf. Antony F. Campbell, Of Prophets and Kings: A Late Ninth Century Document (1 Samuel 1-2 Kings 10) (Washington, DC: Catholic Biblical Association of America, 1986), 207; Mark A. O'Brien and Martin Noth, The Deuteronomistic History Hypothesis: A Reassessment (Freiburg, Switzerland: Universitătsverlag; Göttingen: Vandenhoeck and Ruprecht, 1989), 151-59.

'Gary N. Knoppers, "Prayer and Propaganda: Solomon's Dedication of the Temple and the Deuteronomist's Program," CBQ 57 (1995): 229-54; Richard D. Nelson, Fipst and Second Kings, Interpretation: A Bible Commentary for Teaching and Preaching (Atlanta: John Knox, 1987), 138; Choon-Leong Seow, "The First and Second Books of Kings," in The New Interpreter's Bible, ed. Leander E. Keck (Nashville: Abingdon Press, 1994), 68; Jerome T. Walsh, I Kings, Berit Olam: Studies in Hebrew Narrative and Poetry (Collegeville, MN: Michael Glazier, 1996), 108-09.

${ }^{2}$ Knoppers, $229-54$.

${ }^{3}$ This outline follows Knoppers, although with some slight modifications in the layout in order to make some details more explicit. 


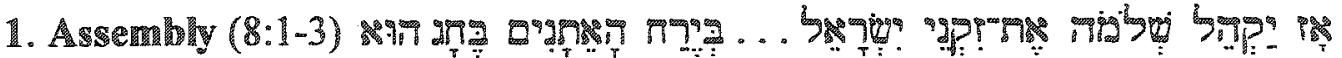

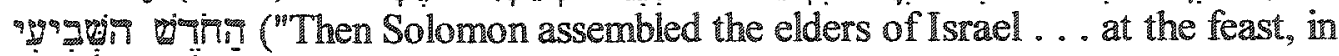
the month Ethanim, which is the seventh month.")

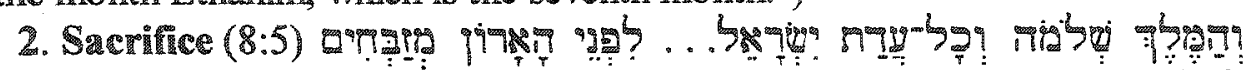

7 7xis ("And King Solomon and all the congregation of 1 srael ... before the ark sacrificing so many sheep and oxen.")

A. $(8: 6-13)$

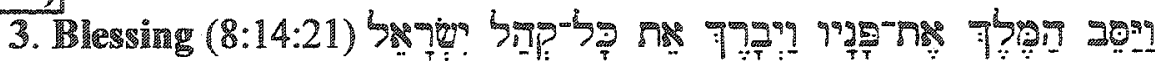

("Then the king faced about and blessed all the assembly of Israel.")

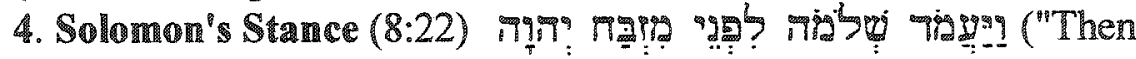
Solomon stood before the altar of YHWH ")

B. (8:23-26)

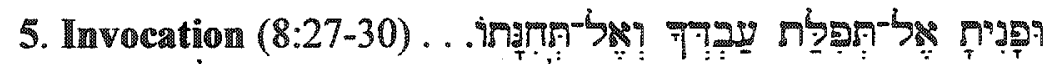

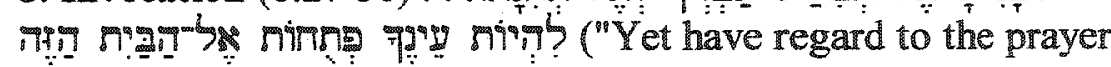
of your servant and to his supplication . . . that your eyes may be open toward this house.")

6. Three Petitions (8:31-36)

7. Generalizing Petition (8:37-40)

6. Three Petitions (8:41-51)

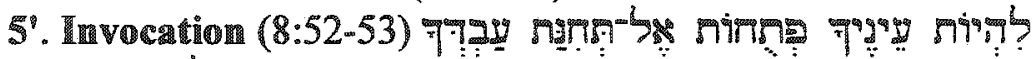

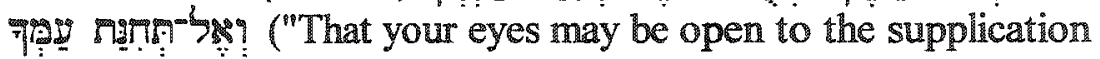
of your servant and to the supplication of your people.")

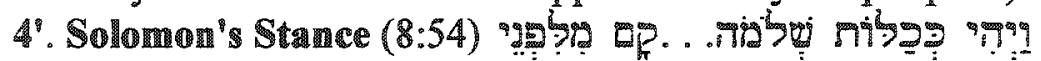

719? ngip "When Solomon had finished... he arose from before the altar of YHWH.")

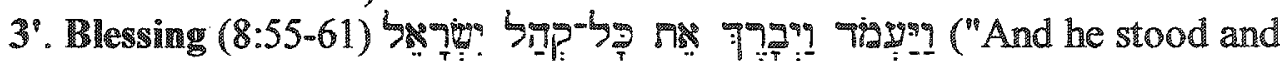
blessed all the assembly of Israel.")

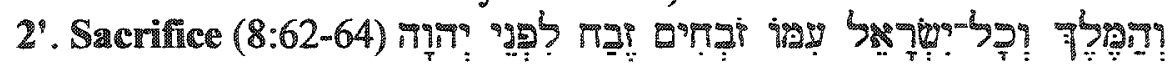

("Now the king and all Israel with him offered sacrifice before YHWH.")

C. $(8: 65)$

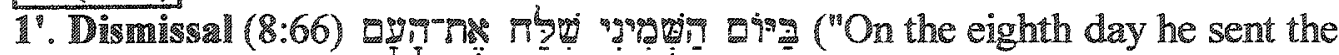
people away.")

As shown above, verbal and conceptual correspondences between both halves of

the text bespeaks its literary unity. Two additional observations regarding this structure are in order. First, the passages marked with $(A),(B)$, and $(C)$ inside blocks are material which, albeit contributing to the development of the text, do not have a counterpart in the other half of the text. Second, it might be argued that frames $(6),(7)$, and $(6)$ are rather 
artificially distributed, since it is difheult to find a clear correspondence between (6) and (6) apart from the obvious reason that they are petitions. What remains clear, however, is that the fourth petition stands out by virtue of its generalizing features, which may justify its being placed at the center of the structure. However, even if one does not accept this distribution, it remains clear that the seven petitions remain at the center, thus keeping the unity of the composition intact. ${ }^{1}$

\section{Excursus: The Function of the Earthly Temple and the "Name" Theology}

Before proceeding to probe the heavenly sanctuary/temple motif in $1 \mathrm{Kgs} 8$, it is necessary to discuss two aspects that may have implications for this study. The first relates to the function of the earthly temple and the contention that the text depicts a situation in which sacrifice was replaced by prayer. ${ }^{2}$ The second aspect relates to the view that YHWH's "name" dwelling in the temple underscores transcendence, which therefore tends to deemphasize the reality of YHWH's dwelling in the earthly temple. ${ }^{3} \mathrm{~A}$ by-product of this view is that the text does not contain the heavenly sanctuary/temple motif, since the references to heaven and heavenly dwelling are intended to connote YHWH's

\footnotetext{
That the seven petitions stand at the structural center of the composition is also acknowledged by other scholars. Cf. Richard D. Nelson, First and Second Kings, 50; Walsh, $108-$ 09.

${ }^{2} \mathrm{Cf}$. Jon D. Levenson, "From Temple to Synagogue," in Traditions in Transformation: Turning Points in Biblical Faith, ed. Baruch Halpern and Jon Douglas Levenson (Winona Lake: Eisenbrauns, 1981), 143-66.

${ }^{3} \mathrm{Cf}$., for example, Seow who asserts that "this is anti-temple theology, as it were: God is enthroned, not in the earthly temple, but in heaven. Yet, the biblical writer confesses that not even the heaven and the highest heaven can contain the deity... . Locality in not at issue in all this talk of God's realm. God's transcendence and sovereignty are" (Seow, 3:75).
} 
transcendence. These issues need to be further assessed since they affect the way one understands the heavenly sanctuary/temple motif in the pericope and the relationship between heavenly and earthly counterparts.

There are two major implications which should be stated at this point: First, if the Jerusalem temple is only a place of prayer, then this represents a major departure from, not to say contradiction to, the so-called Priestly theology of the function of the temple/sanctuary. In this case it seems that even the possibility of a relationship between earthly and heavenly sanctuary/temple evaporates, since there is neither priestly ministry nor expiatory work being performed in the earthly temple. Second, if the references to "heaven" and heavenly "dwelling place" are merely intended to denote YHWH's transcendence, then there is no heavenly sanctuary/temple motif in this pericope.

\section{Prayer versus Sacrifice}

Based on the assumption that the text, or parts thereof, evinces an exilic situation, some scholars have tended to see the emphasis on prayer in Solomon's dedication speech as a devaluation of "cultic sacrifice." Since the text would reflect a time in which the temple had been razed to the ground, so the argument goes, it portrays a worship situation in which sacrifice was replaced by prayer. Thus according to Noth, "the temple is little more than a place towards which one turns in prayer."2 Jon Levenson adds his voice to the

'Martin Noth, The Deuteronomistic History, ed. David J. A. Clines et al., trans. Jane Doull, ISOTSup 15 (Sheffield: University of Sheffield, Dept. of Biblical Studies 1981), 94.

${ }^{2}$ Ibid. Cf. also Roger Tomes, "Our Holy and Beautiful House' : When and Why Was 1 Kings 6-8 Written?," JSOT 70 (1996): 36. 
debate by arguing that although classically the temple had been the locus of "legitimate sacrifice" and of "divine revelation," Solomon's third address presents the temple as "principally a place of prayer." This, he suggests, is due to an implicit "polemic against the idea that God is literally, even physically present therein, as he was in Isaiah $6 .^{.33}$ Further discussion of this understanding of God's presence in, or rather absence from, the temple is undertaken below in the treatment of transcendence versus immanence. For the moment, this apparent dichotomy between prayer and sacrifice needs to be assessed in the light of the larger context, that is, $1 \mathrm{Kgs} 8$ as a whole.

Admittedly, Solomon's dedication speech contains a strong emphasis on prayer and conceives of the temple as a conduit of prayer. Nonetheless, to see this emphasis on prayer as a devaluation of the temple as a place of sacrifice, or as a polemic against an older theological view, which conceived of YHWH as dwelling in the temple according to other texts of the Hebrew Bible, is misleading. If one takes into account the narrative frames of the prayer, which are intrinsically connected with the prayer itself, a more nuanced picture emerges.

It should be noted, for example, that Solomon and the people offered sacrifices at the dedication of the temple. ${ }^{4}$ A closer inspection of the literary structure displayed above reveals that these sacrifices occurred at corresponding places in the literary structure, that

"Levenson, "From Temple to Synagogue," 158.

${ }^{2}$ ibid.

${ }^{3}$ Ibid., 159.

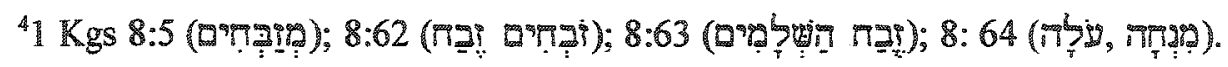


is, (B) and ( $\left(B^{\prime}\right)$. Additionally, references to the "altar"(חבp? in (4) and $\left(4^{\prime}\right)^{1}$ further reveals that the concept of sacrifice should not be excluded from the theological horizon of the text. $^{2}$

Furthermore, other Hebrew Bible passages, and also ANE texts, make a connection between prayer and sacrifice. For example: Isa $56: 7$ and 2 Chr $7: 12$ clearly connect prayer with sacrifices. Besides, Miller ${ }^{3}$ and McKenzie ${ }^{4}$ have perceived this connection in an Ugaritic text ${ }^{5}$ in which a prayer to the god Baal is framed by a ritual text. Although it is improbable that $1 \mathrm{Kgs} \&$ would have any connection with the Ugaritic text, the argument may be advanced that in the ANE religious milieu, prayer and sacrifice could stand side by side.

Summing up, Solomon's ceremony of dedication of the temple, although placing a strong emphasis on the temple as a place of prayer, does not preclude the temple from functioning as a place of sacrifice. As Knoppers aptly argued, "Prayer in an ancient context [should not] be disassociated from sacrifice." ${ }^{\text {"f }}$ Although specific references to

${ }^{1} 1 \mathrm{Kgs} 8: 22$ and 54 respectively.

${ }^{2}$ Halpern has remarked that in $1 \mathrm{Kgs} \mathrm{8:62-64,} \mathrm{"Solomon} \mathrm{demonstrates} \mathrm{how} \mathrm{to} \mathrm{make}$ petitions effective by a sacrifice" (Baruch Halpern, The First Historians: The Hebrew Bible and History [San Francisco: Harper and Row, 1988], 179, n. 48).

3Patrick D. Miller, "Prayer and Sacrifice in Ugarit and Israel," in Text and Context: Old Testament and Semitic Studies for F. C. Fensham, ed. W. Claassen, JSOTSup 48 (Sheffield: JSOT, 1988), $139-55$.

${ }^{4}$ Steven L. McKenzie, The Chronicler's Use of the Deuteronomistic History, HSM 33 (Atlanta, GA: Scholars Press, 1985), 208, n. 27.

${ }^{5} \mathrm{KTU} 1: 119$.

${ }^{6} \mathrm{Knoppers,} 231$. 
sacrifice are absent from the prayer itself, one may reasonably suggest that there is nothing in the prayer that excluded the cultic sacrifices which were performed in the temple. On the contrary, on the basis of the literary frame of the prayer, one gets the impression that the sacrifices were an integral part of the temple ritual and are simply assumed by Solomon in his prayer.

\section{Transcendence versus Immanence}

As noted in the discussion of Deut $26: 15$, undertaken in chapter 3 of this dissertation, most critical scholars would agree with the view that the so-called "name theology" was coined by the putative Deuteronomists to express the theologoumenon that God dwells in heaven, while only his name dwells in the temple. It is argued that this elaboration came into being as a corrective to the immanent theologies of the "glory" (kabod theology) championed by the priestly circles, and the concept of God dwelling in the temple current in the Zion tradition (sabaoth theology). ${ }^{1}$ According to Mettinger, this reaction was made necessary by the tragic reality of the exile and the consequent destruction of the temple. ${ }^{2}$ A reelaborated theology which asserted that only God's name dwelt in the temple (God himself dwelt in heaven) was more palatable to those who reflected on the temple theology in the light of the events of $586 \mathrm{~B}$. C. Other scholars would place the origins of the name-theology already in preexilic times simply as a

'See Tryggve N. D. Mettinger, The Dethronement of Sabaoth, CBOTS 18 (CWK Glecrup, 1982), 19-37; 80-115.

${ }^{2}$ Ibid., 116-34. 
correction of more "crude" views of God dwelling in the temple. 'At any event, the large consensus is that the concept of God's "name" abiding in the temple came to be used as a pointer to God's transcendence.

This understanding of the name-theology has not remained unchallenged. Roland de Vaux, followed by H. Seebass ${ }^{2}$ and Ernst Würthwein, ${ }^{3}$ contended that the "name" formula has its background in ANE literature where the idiom to "place a name on/to make the name dwell in" connotes possession. Therefore, in the so-called Deuteronomistic History the "name" formula did not intend to convey transcendence, since this was never in question; rather, the "name" functioned to provided assurance of God's efficacious presence in the temple where he was present by virtue of his name. ${ }^{4}$ De Vaux further

${ }^{1}$ See Gerhard von Rad, Studies in Deuteronomy (London: SCM Press, 1953), 37-44; G. Ernest Wright, "The Temple in Palestine-Syria," in The Biblical Archaeologist Reader, ed. G. Emest Wright and David Noel Freedman (Missoula, MT: American Schools of Oriental Research and Scholars Press, 1975), 181; M. Metzger, "Himmliche und Irdische Wohnstatt Jahwes," UF 2 (1970): 149-51; Moshe Weinfeld, Deuteronomy and the Deuteronomic School (Oxford: Clarendon, 1972), 191-209; Martin Rose, Der Ausschliesslichkeitsanspruch Jahwes: Deuteronomische Schultheologie und die Volksfrömmigheit in der späten Königszeit, BWA(N)T 106 (Stuttgart: W. Kohlhammer, 1975), 85-94; Victor A. Hurowitz, "I Have Built You an Exalted House": Temple Building in the Bible in Light of Mesopotamion and Northwest Semitic Writings, JSOTSupp 115 (Sheffield: ISOT Press, 1992), 290.

${ }^{2}$ H. Seebass, "quges bahnar," TDOT, 2:73-87.

${ }^{3}$ Ernst Würhwein, Das Erste Buch der Könige: Kapitel 1-16, Das Alte Testament Deứsch 11/1 (Göttingen: Vandenhoeck and Ruprecht, 1977), 102-03.

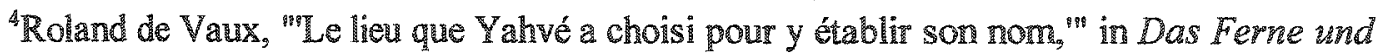
Nahe Wort, ed. Fritz Maass, BZAW 105 (Berlin: Verlag Afred Töpelmann, 1967), 226. 
remarked that "according to the Semitic and biblical mentality, the name is an extension of the personality."

In a detailed study, $\$$. Wheeler found "no indication in I Kings 8 that the 'name' is a deliberate substitution for YHWH or is designed to undermine a too crude theology of presence in the temple. It seems to be used rather as a way of enhancing the meaning of the temple's significance." 2 Along the same line, F. Kumaki examined the name-theology and found no evidence that it was formulated as a polemic against pre-Deuteronomic ideas about God's presence in the sanctuary/temple; rather the "name" functions as a theological argument that "the Solomonic temple in Jerusalem is the legitimate sanctuary for all Israel. ${ }^{n} 3$

A recent study by Sandra Richter has further investigated the meaning of the socalled name-theology. She contends that previous studies of the "name' language in the D[euteronomistic] H[istory] have been crippled by the inability to recognize and respect idiomatic boundaries, largely because of what James Barr has named 'illegitimate totality transfer. ${ }^{094}$ According to her, the "name" motif in $1 \mathrm{KgS} 8$ conveys mostly the notion of

"Tbid. Cf. also Allen Ross, "Gơ," NIDOTTE, 4:147-51; Edward L. Greenstein, "Some Developments in the Study of Language and Some Implications for Interpreting Ancient Texts and Cultures," in Semitic Linguistics: The State of the Art at the Turn of the 21 st Century, ed. Shlomo Izre'el, Israel Oriental Studies 20 (Winona Lake: Eisenbrauns, 2002), 450-51.

${ }^{2}$ Samuel Billings Wheeler, "Prayer and Temple in the Dedication Speech of Solomon, 1 Kings 8:14.61" (Ph.D. diss., Columbia University, 1977), 316. The only exception according to him is vs. 27, "which is probably later [sic]" (ibid.).

${ }^{3} \mathrm{~F}$. Kenro Kumaki, "The Deuteronomistic Theology of the Temple: As Crystallized in 2 Sam 7, $1 \mathrm{Kgs} \mathrm{8,"} A \operatorname{VB17}(1981): 40$.

${ }^{4}$ Sandra L. Richter, The Deuteronomistic History and the Name Theology: lesakken šmô sam in the Bible and the Ancient Near East, BZAW 318 (Berlin: De Gruyter, 2002), 78. 
"honor," "reputation," "fame," "commemoration," and "ownership." After probing several occurrences of the "name" imagery in $1 \mathrm{Kgs} 8$, Richter concluded that

Solomon's oration announces that the temple is both the symbol and the embodiment of the place promised to Israel, which is marked by YHWH's name. This dedicatory prayer makes clear that the bayit built by Solomon is the ultimate symbol of YHWH's past and present relationship with his people-a symbol which serves to memorialize and perpetuate YHWH acts of redemption in the midst of Israel and the nations. ${ }^{3}$

She further declared that "the majority of name idioms used in this text have nothing to do with divine presence. ${ }^{104}$

Richter's contention that the "name" imagery should not be understood in the traditional lines of the name-theology, "in which YHWH is relocated to heaven, or "dethroned"s from his earthly temple is supported by the larger context of the passage. $1 \mathrm{Kgs} 8: 10-11$, for example, asserts that "the cloud (19897) filled the house of YHWH" and the priests could not stand to minister because of the cloud (9397), for the glory of YHWH (77ฺ? :

"Illegitimate totality transfer" is "an error that arises, when the meaning of a word (understood as the total series of relations in which it is used in the literature) is read into a particular case as its sense and implication there" (James Barr, The Semantics of Biblical Language [Glasgow: Oxford University Press, 1961], 218). Or, to put it differently, "illegitimate totality transfer" is a "somewhat awkward phrase intended to express the simple fact that any one instance of a word will not bear all the meanings possible for that word" (Moisés Silva, Biblical Words and Their Meoning: An Introduction to Lexical Semontics, Rev. and expanded ed. [Grand Rapids, MI: Zondervan, 1994], 25).

${ }^{1}$ Richter, 79.

${ }^{2}$ Ibid., 84.

${ }^{3}$ Ibid., 90.

${ }^{4}$ Ibid.

${ }^{5}$ Mettinger, The Dethronement of Sabaoth, 134. 
(ก)ด and the "glory of YHWH" (Exod 40:34-35). This verbal and conceptual connection with Exod 40 implies that the same understanding of YHWH's presence in the sanctuary/temple underlies both passages. Another important reference in this connection is $1 \mathrm{Kgs} 8: 13$,

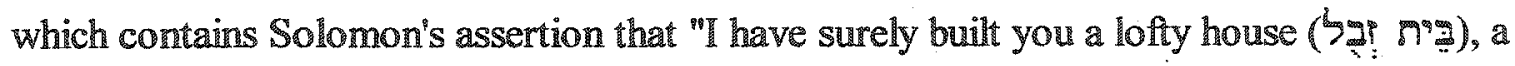

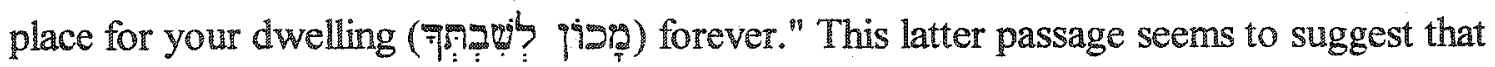
YHWH is present in the temple along the lines of the "older theological conceptions of Israel," and not only through the "name" as understood by the proponents of the nametheology.

This discussion by no means should be understood as a denial that the text evokes God's transcendence. God's transcendence is clearly reflected in $1 \mathrm{Kgs} \mathrm{8:27:} \mathrm{"But} \mathrm{will} \mathrm{God}$ indeed dwell on the earth? Behold, heaven and the highest heaven cannot contain you, how much less this house which $\mathbb{I}$ have built!" One must bear in mind, however, that God's transcendence as expressed in the above passage implies that neither the Jerusalem temple nor heaven itself can contain YHWH. It thus seems that when "transcendence" is the issue, both the earthly and heavenly temples are on the same level. Nonetheless, the fact remains that YHWH dwells in his heavenly abode as well as in his earthly temple. Therefore, to say that the references to YHWH's dwelling place in heaven are intended to connote transcendence to the exclusion of his dwelling in the earthly temple; and/or that the allusions to heaven/heavenly dwelling place intend only to denote transcendence, cannot be sustained by a close examination of the text. As F. Downing aptly put it, 
It must be noted that there appears in the theology of the Solomonic temple an element of tension between the transcendence and immanence of Yahweh. Yahweh was transcendent in the sense that the temple was his "house." The symbolism of the temple tended to indicate his cosmic domain and his immanence. An overemphasis of either would have been a distortion.'

Summing up, from what has been discussed thus far, it has become evident that $1 \mathrm{Kgs} 8$ does not display a view of the temple and God's presence in it in contradiction to earlier traditions of Israel, which allegedly favored a more concrete mode of divine presence. Although the text conceives of the temple as a place of prayer, it does not preclude other cultic activities, as noted above. The special occasion of Solomon's speech certainly called for a selection of topics to be addressed. Also, the concept of the "name" does not imply that because YHWH dwelt in heaven, only his name dwelt in the temple. The tension is kept. True, neither heaven nor earth can contain YHWH. Nonetheless he is present in the heavenly temple as well as in the earthly counterpart. Furthermore, his presence in the temple is reminiscent of his presence in the tabernacle, thus making the temple a natural successor to the desert tabermacle.

In the discussion that follows, close attention is given to some specific words related to the topic under study.

\section{Semantic and Other Exegetical Considerations}

Despite the claim that the temple depicted in $1 \mathrm{Kgs} 8$ is no more than a house of prayer, an examination of the terminology used to define this temple in the broad context of the prayer seems to demonstrate otherwise. Besides, some of these terms are used of 
both earthly and heavenly realms, which probably indicates some kind of connection between earthly and heavenly temples, apart from the obvious allusion to this relationship expressed in the prayer, as noted in the ensuing discussion.

\section{Meaning of 1 ․ํำ}

The locution 197 . 79 in $1 \mathrm{Kgs} 8: 6$ refers to the inner sanctum, and thus hints at the cultic purposes of the building, which certainly would go beyond that of a mere house of prayer. Although 99 '? has an uncertain etymology, it clearly refers to the back room of the temple, usually designated as "inner sanctuary," corresponding to the vip agen ("most holy place") of the desert tabernacle. The "inner sanctuary" in the temple was a perfect cube of 20 cubits on a side filled by two enormous cherubim made of olive wood and covered with gold. Their protective outspread wings sheltered the ark of the covenant, which was the specific representation of God's presence. ${ }^{2}$

\section{Meaning of}

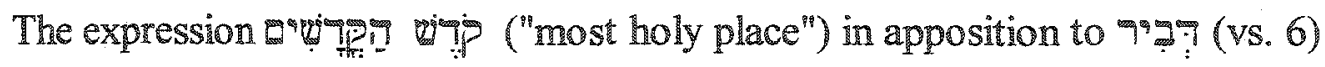
establishes a verbal and conceptual link with the tabernacle. By using this term the author

\footnotetext{
"There may be a possible connection with Arabic "dubr back," or "dabr behind" (cf. Ernest Klein, A Comprehensive Etymological Dictionary of the Hebrew Language for Readers of English [New York: Macmillan, 1987], s.v. "9g' II"). Another possibility is raised by an Egyptian text of the $21^{\text {st }}$ dynasty which refers to the $d b r$ as an object of the temple (H. Schult, "Der Debir im Salomonischen Tempel," ZDPV 80 [1964]: 45-54). Along the same line Ouellette suggested that 97 designated originally the wooden screen which separated the rooms of a given structure (Jean Ouellette, "The Solomonic D"bir according to the Hebrew Text of 1 Kings 6," JBL 89 [1970]: 22843). Ouellet also observed that in Ugaritic $d b r$ may also designate shrine. Cf. ibid., 340, n. 15.

${ }^{2}$ Carol Meyers, "Temple, Jerusalem," $A B D, 6: 358$.
} 
seems to indicate that the 797 of the temple would function similarly to the "most holy place" of the tabernacle. In other words, the temple built by Solomon is depicted as a continuation of the Mosaic tabemacle. The explicit references to the cherubim, and the ark of the covenant being brought to the temple, add further weight to the contention that the theology of the temple contained in $1 \mathrm{Kgs} 8$ does not contradict the basic view of that of the tabernacle.

\section{Meaning of}

The word by in the genitival construction 599.13$)$ has the meaning of "habitation, dwelling." This root is attested in Ugaritic with a locative meaning of "elevated place" or "lofty residence." Additionally, zbl is a common Ugaritic word for "prince," being frequently used of Baal. Therefore, it is reasonable to deduce that the distinctive semantic nuance of bg? is that of "exaltation." by? thus contributes to the expression 59 ? the Hebrew Bible never uses ל? in reference to a human habitation. ${ }^{3}$ Taking this into

'David J. A. Clines, The Dictionary of Classical Hebrew, vol. 3 (Sheffield: Sheffield Academic, 1993), s.v. "לg? I."

${ }^{2}$ HALOT, S.v. "II Ygr." Cf. Joseph Aistleitner, Wörterbuch der Ugaritischen Sprache, 2 nd ed. (Berlin: Akademie-Verlag, 1965), s.v. "zbl."

${ }^{3}$ The Hebrew Bible contains five occurrences of $y$ gi: It is used in our text and its parallel in 2 Chr 6:2 as God's earthly dwelling; in Isa 63:15 as God's heavenly dwelling; in Hab 3:11 a reference to the dwelling of the sun and the moon. Ps 49:15 [14] seems to be an exception; however, because of its many textual problems, one cannot be sure what megr means in this passage. 
consideration, the expression 59 ? 7 " house. ${ }^{\text {"II }}$

For the purpose of this research, it should be noted that this expression conveys the idea that the temple is the earthly dwelling of YHWH; hence $1 \mathrm{Kgs} 8$ should not be understood as presenting a distinct and contradictory theology of God's presence in the temple. If the semantic contours of 99 (exalted/princely house) are taken at face value, one must conclude that the temple, like the Mosaic tabernacle, was understood to be YHWH's earthly dwelling. This does not contradict the fact that YHWH is transcendent or that he dwells in heaven. As noted, both immanence and transcendence are kept in tension in $1 \mathrm{Kgs} 8$. What the text seems to communicate is that YHWH dwelt in the earthly temple and in its heavenly counterpart, and that both earthly and heavenly realms operate in relationship, as noted below.

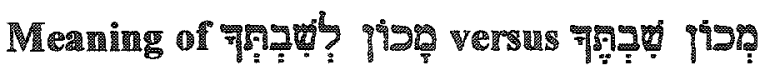

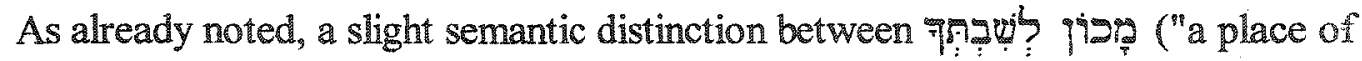
your dwelling/enthronement") and optap pige ("the place of your dwelling/enthronement") should be pointed out. The text refers to the earthly temple as Fค月 preposition 5 breaks the construct chain, making it indefinite. The earthly temple is " $a$ place for your enthronement" (that is, one place among others). On the other side, in reference to the heavenly temple, the text uses the expression Th?

"Cr. the following translations: "lofty house" (NASB), "magnificent temple" (NIV), "princely dwelling" (NJB), "exalted house" (RSV), and "stately house" (TNK). 
chain which is made definite by the pronominal suffix, which seems to connote the sense of "the place of your enthronement," that is, "the" place in heaven where YHWH sits enthroned over the Universe- that is, the heavenly sanctuary/temple. "Those expressions convey the notion that YHWH is enthroned in the earthly temple as well as in the heavenly one. On the one hand, the similarities seem to express a connection between the earthly and the heavenly places of enthronement; on the other, the slightly different syntactic constructions establish a subtle distinction between the earthly and the heavenly place of enthronement: the earthly one is a place, while the heavenly one is the place where YHWH is permanently enthroned.

\section{Meaning of ๆr:}

The expression 7 mage

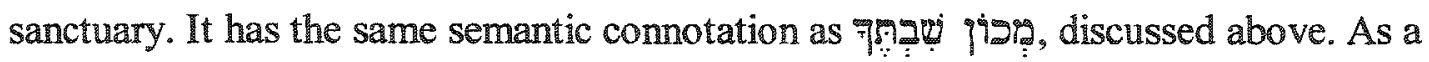
matter of fact, when in relationship to gev", both conveying basically the same meaning. ${ }^{2}$ It should be noted that aip? also refers to the earthly temple; in $8: 21$, it refers to the place of the ark in the expression 97 place for the ark"); and in $8: 29$, wipt refers to the earthly temple.

${ }^{1}$ Athough the semantic distinction between the periphrastic construction with $y$ and the construct chain may seem irrelevant, it seems that the periphrastic construction is used of the earthly temple, while the construct chain is reserved for the heavenly sanctuary/temple. For instance, the periphrastic construction is used consistently in the parallel text of $2 \mathrm{Chr} 6: 2$ and in Exod 15:17 in reference to the earthly temple.

${ }^{2}$ For ๆres? and gip? used in parallel and equivalent construction, cf. Ezek 43:7//Ps 89:15 [14]; Hos 5:15//sa 18:4; Jer 17:12//Ezra 2:68; Ps 104:8//5. H. Ringgren, "घipp mäqôm," TDOT, 8:535. 
To summarize, three major perceptions may be gained from the considerations undertaken above. First, the earthly temple was understood as a place of dwelling, and not exclusively as a place of prayer. The lexical items used to refer to this temple imply that it was understood as a place wherein YHWH would manifest himself in a concrete way. Second, the vocabulary employed in the text suggests that there was a heavenly

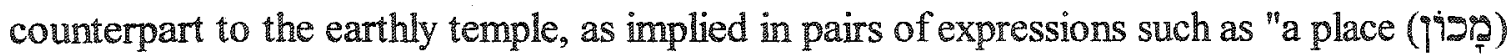
of your enthroning" (earthly temple)//"the place (פiכ) of your enthroning" (heavenly

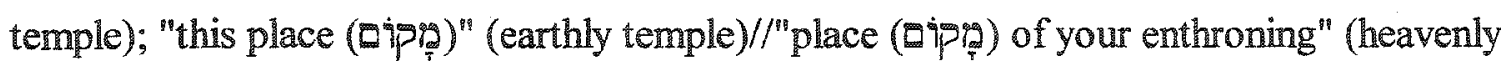
temple). Third, the lexical and semantic similarities between words used in reference to the earthly and heavenly temples indicate a vertical correspondence between the earthly temple and its heavenly counterpart in structural and functional terms.

\section{Heavenly Sanctuary/Temple Motif}

From what has been discussed thus far, it is possible to argue that $1 \mathrm{Kgs} 8$ does

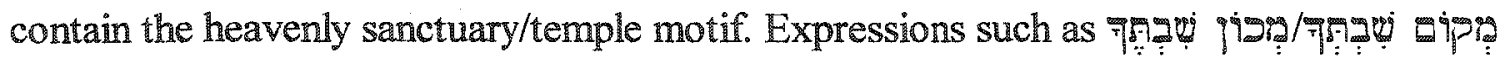
("your dwelling place") used in parallelism to ("this house") seem to convey not only the idea of a heavenly sanctuary/temple, but also imply a dynamic interaction between the heavenly temple and its earthly counterpart. As Walsh put it: "When one invokes Yahweh's name in prayer at or toward the temple, Yahweh, in his heavenly abode, will hear and heed."1 The discussion below focuses on

'Jerome T. Walsh, 1 Kings, Berit Olam: Studies in Hebrew Narrative and Poetry (Collegeville, MN: Michael Glazier, 1996), 115. 
these issues, taking into consideration the preceding discussion together with additional exegetical and theological observations.

\section{Function}

A close examination of the structural center of $1 \mathrm{Kgs} 8$, the seven-petition prayer by Solomon, allows one to discern some of the possible functions of the heavenly sanctuary/temple. It is obvious from the text that YHWH hears prayer from the heavenly temple/sanctuary, as expressed several times by Solomon's plea: "Listen to the supplication of your servant and of your people Israel, when they pray toward this place; hear in heaven your dwelling place; hear and forgive" (8:30). Nonetheless the function of "hearing prayers" expresses only a general function related to YHWH's activity in the heavenly temple/sanctuary. Although Kim has asserted that "it is almost impossible to define 'heaven' in this case as anything other than the place where God hears," we need to go further and inquire about what YHWH does or, to put it differently, is requested to do in response to prayer. As this inquiry is pursued, several interrelated functions emerge:

A first function perceived is that of forgiveness expressed in the five occurrences of the verb 1 ' 9 ("forgive") ${ }^{2}$ exemplified $1 \mathrm{Kgs} 8: 30$.

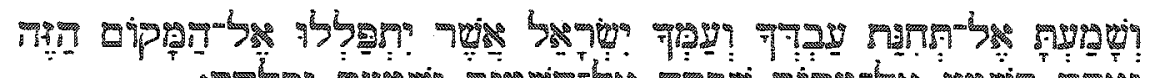
: Listen to the supplication of your servant and of your people Israel, when they pray toward this place; hear in heaven your dwelling place; hear and forgive.

\footnotetext{
${ }^{1} \mathrm{Kim}, 121$.

${ }^{2} 1 \mathrm{Kgs} 8: 30,34,36,39,50$.
} 
It is instructive that Solomon requested YHWH to "hear and forgive" in the "place of your enthronement" (i.e., the heavenly temple). That the prayer goes up to the "place of your enthronement" makes the locale where YHWH is enthroned important in the context of his activities. If the purpose of the references to heaven were simply to convey God's transcendence, there would be no need to pray towards the earthly temple and beg YHWH to respond from the place of his enthronement, in heaven. However, the repeated petition that YHWH hear from his heavenly dwelling points to the significance of "this place" in the bestowal of forgiveness and the execution of other functions to be noted below.

Another instructive reference to YHWH's activities in the heavenly temple is provided by $1 \mathrm{Kgs} 8: 32$, which is part of the first petition.

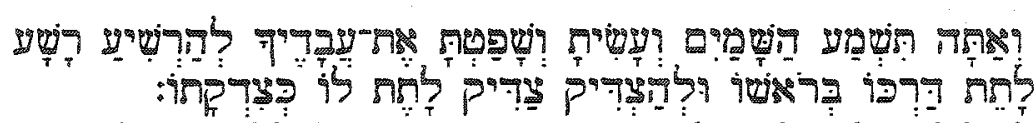
Then you will hear in heaven and act and judge your servants, condemning the wicked by bringing his way on his own head and justifying the righteous by giving him according to his righteousness.

A few points are relevant here. The text mentions activities that YHWH supposedly would perform in "heaven." As clarified by the context, this refers to an interpersonal dispute brought to the earthly temple. In this situation, the ultimate judgment belonged to YHWH

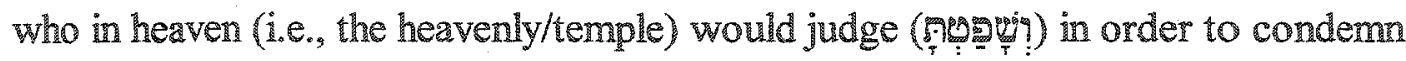

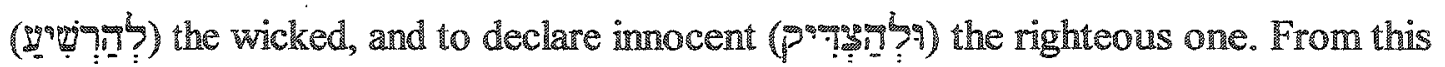
passage emerges the perception that the heavenly temple/sanctuary functions as a place of

${ }^{1}$ Cf. Deut $25: 1$. 


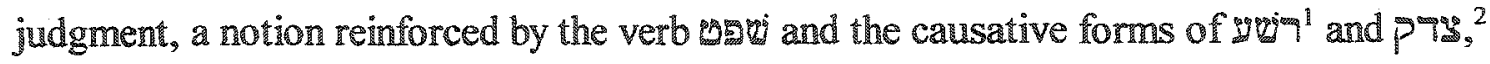
which seem to convey a forensic notion related to the courtroom. ${ }^{3}$ The same idea is suggested by $8: 39$ which reads as follows:

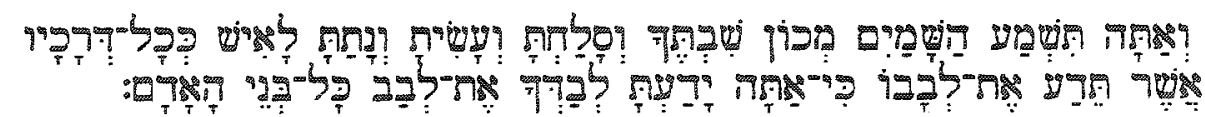

Then you will hear in heaven your dwelling place, and forgive and act and render to each according to all his ways, whose heart you know, for you alone know the hearts of all the children of men.

The concept of retributive justice seems to be implicitly included in the expression "render to each according to all his ways." Also in the situations of war against enemies (8:45) or exile (8:49), the prayer requested that YHWH in his heavenly temple/sanctuary

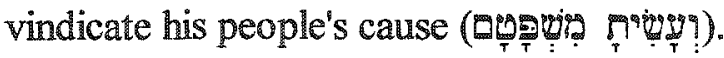

Finally, as already noted above, the term referring to the heavenly sanctuary/temple motif in our text, จ That being true, one can also assert that the heavenly sanctuary/temple has royal functions, thus connoting the idea of a place, wherein YHWH sits enthroned as heavenly king. In short, the heavenly sanctuary/temple emerges in $1 \mathrm{Kgs} 8$ as a place where YHWH hears the prayers of his people and performs activities of "forgiveness," "judgment," and other royal functions.

$$
\begin{aligned}
& { }^{1} \mathrm{Cf} \text {. HALOT, s.v. "gwom." } \\
& { }^{2} \mathrm{Cf} \text {. HALOT, s.v. "pogg." }
\end{aligned}
$$

"David Reimer, "Pryg," NIDOTTE, 3:749; Jackie A. Naudé and R. K. Harrison, "yejo," NIDOTTE, 1201; Friedrich Nötscher, Die Gerechtigkeit Gottes bei den vorexilischen Propheten: Ein Beitrog zur Alttestamentische Theologie (Münster: Aschendorff, 1915), 4-6. 


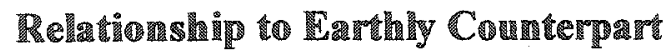

A close examination of $1 \mathrm{Kgs} 8$ and its immediate context yields two lines of evidence as regards the relationship between the heavenly temple and its earthly counterpart. A first line of evidence comes from $1 \mathrm{Kgs} 8$ itself. That the prayers were to be directed to the earthly temple, and YHWH would answer in his heavenly temple/sanctuary, seems to indicate that heavenly and earthly temples were understood to work dynamic interaction. $1 \mathrm{Kgs} 8: 30$ provides a fitting example:

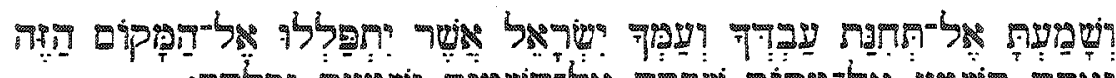

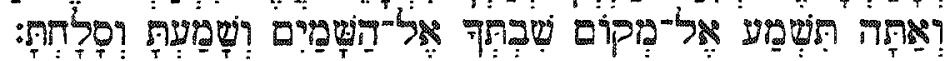

Listen to the supplication of your servant and of Your people Israel, when they pray toward this place; hear in your dwelling place, in heaven; hear and forgive.

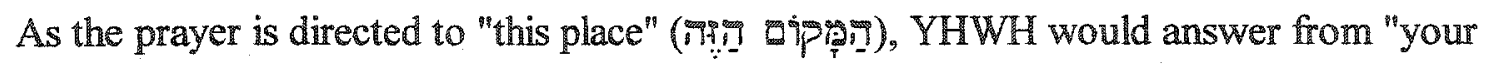

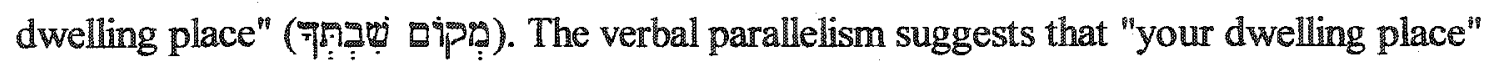
functions as the heavenly counterpart to "this place." This idea recurs several times across the text in the repeated injunction that the prayers should be directed towards the earthly

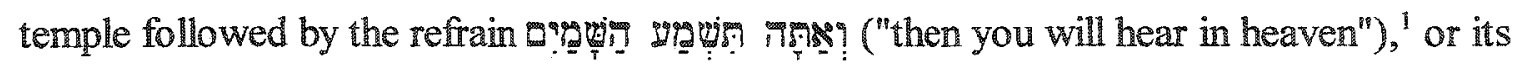

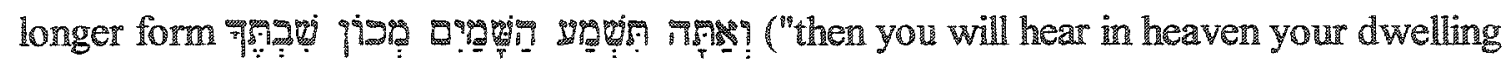
place"). ${ }^{2}$ This seems to further corroborate the existence of a dynamic interaction between heavenly and earthly temples.

A second line of evidence can be perceived in the symbolism contained in the earthly temple itself. Although it is not the purpose of this research to engage in a

${ }_{11 \mathrm{Kgs}} 8: 32,34,36,45$.

${ }^{2} 1 \operatorname{Kgs} 8: 39,43,49$. 
discussion of the symbolic meaning of the temple furniture, decoration, and architectural layout, a few remarks are in order. It is argued that the symbolism behind the temple fumiture, decoration, and layout may reveal that the earthly temple was understood to be in structural correspondence to the heavenly counterpart."

Thus, at the outset one should note that the temple, being built upon a mountain, replicates God's heavenly abode which, according to Isa $14: 13$ and Ezek $28: 14,{ }^{2}$ is also located upon a mountain. Other elements that point to a structural correspondence are the exuberant presence of lloral motifs such as palm trees and open flowers used to decorate the interior and doors of the temple, ${ }^{3}$ and lampstands which were probably stylized trees, as Carol Meyers has noted. ${ }^{4}$ The presence of vegetation motifs in the temple possibly was intended to represent "the paradise garden where Yahweh dwelt," a concept implied in Ezek 28:13, where the heavenly sanctuary/temple is depicted as a garden. ${ }^{6}$ Also, one

${ }^{1}$ For a study of temple symbolism, cf. Elizabeth Bloch-Smith, "Solomon's Temple: The Politics of Ritual Space," in Sacred Time, Sacred Place: Archaeology and the Religion of Israel, ed. Barry M. Gittlen (Winona Lake, IN: Eisenbrauns, 2002), 83-94; John M. Lundquist, "What Is a Temple? A Preliminary Typology," in Quest for the Kingdom of God: Studies in Honor of George E. Mendenhall, d. E. A. Spina, H. B. Huffmon, and A. R. W. Green (Winona Lake, N: Eisenbrauns, 1983), 205-19; Carol Meyers, "Temple, Jerusalem," ABD, 6:350-69; Jon D.

Levenson, "The Temple and the World," JR 64 (1984): 275-97.

${ }^{2}$ These two passages are discussed later in this chapter.

${ }^{3}$ Cf. 2 Kgs $7: 18,24,29,32,35$.

${ }^{4} \mathrm{Cf}$. Carol L. Meyers, The Tabernacle Menorah: A Synthetic Study of a Symbol from the Biblical Cult (Missoula, MT: Scholars Press for the American Schools of Oriental Research, 1976), 165-93.

${ }^{5} \mathrm{Clements,}$ God and Temple, 65.

${ }^{6} \mathrm{M}$. Barker asserts that "the temple interior was a garden representing the heavenly garden on the mountain of God, the original Garden of Eden. Ezekiel described it in his oracle against Tyre (Ezek 28); the jeweled trees are those of the temple" (Margaret Barker, The Gate of Hecuen: 
should note that the presence of the ark of the covenant, covered by the two cherubs in the holy of holies, was intended to represent YHWH's heavenly throne, and therefore stood as "the earthly model of Yahweh's heavenly enthronement as king and symbol of his universal power."' Finally, it should be observed that the layout of the temple may well have been conceived to portray a structural correspondence with the heavenly counterpart. In his study of the architecture of the Jerusalem temple, Monson noted that "the striking resemblance between gate design and temple layout" may suggest that the "temple was literally a gate into the cosmic realm." ${ }^{13}$ If so, it might be argued that this further corroborates the idea of a note only of a structural correspondence but of a dynamic interaction between earthly and heavenly temples.

\section{$1 \mathrm{Kgs} 22: 19-23$}

19 צ 20

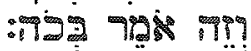
21 22 19 Micaiah said, "Therefore, hear the word of YHWH. I saw YHWH sitting on his throne, and all the host of heaven standing by him on his right and on his left. 20 "YHWH said, "Who will entice Ahab to go up and fall at Ramoth-gilead? And one said this while another said that.

The History and Symbolism of the Temple in Jerusalem [London: SPCK, 1991], 27).

'David Lemoine Eiler, "The Origin of Zion as a Theological Symbol in Ancient Israel" (Ph.D. diss., Princeton Theological Seminary, 1968), 147.

"John M. Monson, "The Temple of Jerusalem: A Case Study in the Integration of Text and Artifact" (Ph.D. diss., Harvard University, 1998), 346.

${ }^{3}$ bid., 347. 
21 'Then a spirit came forward and stood before YHWH and said, 'I will entice him.' And YHWH said to him, 'How?'

22. And he said, 'I will go out and be a deceiving spirit in the mouth of all his prophets.' Then he said, 'You are to entice him and also prevail. Go and do so."

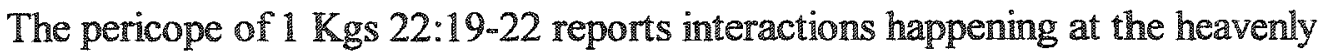
court of YHWH' ${ }^{1}$ while the kings of Israel and Judah prepare for their last battle against the king of Aram in the attempt to recapture Ramoth Gilead. After having received a favorable oracle from the court prophets concerning the battle, the king of Judah inquired

\footnotetext{
${ }^{1}$ An interesting aspect $1 \mathrm{Kgs} 22: 19-22$, although outside the scope of the present investigation, deserves some brief consideration. It concerns the nature of the lying spirit in YHWH's heavenly assembly, and the fact that this lying spirit works for the accomplishment of YHWH's purpose. Some scholars' contention that the "lying spirit" ("Pृ? TI.7) of vs. 22 was one of several evil spirits, who functioned as obedient servants in YHWH's heavenly council (cf., e.g., Neil Forsyth, The Old Enemy: Satan and the Combat Myth [Princeton, NJ: Princeton University Press, 1987], 112), or a demonic entity in rebellion against YHWH, but nonetheless being used by YHWH to accomplish his will (cf., e.g., Gregory A. Boyd, God at War: The Bible and Spiritual Conflict [Downers Grove, IL: Inter-Varsity Press, 1997], 81) seems problematic in view of the Hebrew Bible's conception of YHWH. Only if one understands the concept of "lying" (7Pש) spirit in an ontological sense does such a view that YHWH entertains evil entities in his council hold up. As a matter of fact, "lying" spirit is better interpreted as a functional attribution, that is, "lying" does not describe the nature of the "spirit," but portrays his function in accomplishing YHWH"s purpose of using the false prophets to bring judgment upon the king. In this connection, one should remember that in Isa 45:7, YHWH introduces himself as the "one forming light and creating darkness, causing well-being and creating evil." In Isa 45:7, the concept of "evil" is obviously related to the "calamities" or judgments that YHWH would bring upon impenitent sinners, not evil in its ontological sense. It may be argued, mutotis mutandis, that the same principle applies to the "lying" spirit. He is a "lying" spirit not in the ontological, or ethical sense, or because he is a demonic entity at the service of YHWH-an idea at odds with the overall portrayal of YHWH throughout the Hebrew Biblo-but in the sense that the spirit would induce the false prophets, who were already under evil influences to feed the king's own self-destructive ends by means of their delusive prophecies. Therefore, in view of the previous considerations, the view expressed by some commentators (cf. Simon J. DeVries, 1 Kings, WBC 12 [Waco: Word Books, 1985), 268; C. F. Keil and F. Delitzsch, The Books of the Kings, Biblical Commentary on the Old Testament [Grand Rapids: Eerdmans, 19521, 276f.; James Montgomery, A Critical and Exegetical Commentary on the Book of Kings, ICC [Edinburgh: T. and T. Clark, 1951], 339; Richard D. Patterson and Hermann I. Austel, "1, 2 Kings," The Expositor's Bible Commentary 4, ed. Frank E. Gaebelein [Grand Rapids: Zondervan, 1988], 165) that the "lying spirit" is the personified spirit of prophecy (cf. I Sam 10:10-12; 19:23-24; Zech 13:2; 1 John 4:6) that works in accordance with the sovereign will of YWHW accord better with the overall theology of the Hebrew Bible and its portrayal of the character of YHWH.
} 
of Ahab whether there was "not yet a prophet of YHWH here that we may inquire of him?"i The king of Israel then mentioned a certain Micaiah son of Imlah whom he hated because this prophet never prophesied good concerning him. Eventually Micaiah was brought to their presence and, as the narrative unfolds, pronounced a fateful oracle concerning the battle, an oracle that came from the heavenly "council of YHWH."

The similarities of this vision with other passages which conjoin the imagery of heavenly council and heavenly sanctuary/temple ${ }^{2}$ may well have been a significant reason for some scholars to concede the presence of the heavenly sanctuary/temple motif in this passage. ${ }^{3} \mathrm{Kim}$, however, has concluded that "it is not only illegitimate, but also misleading to use the 'heavenly temple' here to explain the meeting place of the 'heavenly council."'4 As the discussion of the pericope proceeds, this claim is evaluated in the light of the textual data.

${ }^{1} 1 \mathrm{Kgs} \mathrm{22:7.} \mathrm{A} \mathrm{crucial} \mathrm{issue} \mathrm{here} \mathrm{is} \mathrm{the} \mathrm{problem} \mathrm{of} \mathrm{true} \mathrm{and} \mathrm{false} \mathrm{prophecy} \mathrm{which} \mathrm{cannot}$ be pursued since it lies outside the scope of this investigation. A nice summary of this issue is provided by D. W. Van Winkle, "1 Kings 20-22 and True and False Prophecy," in Goldene Apfel in silbernen Schalen: collected communications to the XIIth Congress of the International Organization for the Study of the Old Testament, Leuven 1989, ed. Klaus-Dietrich Schunck and Mathias Augustin, Beiträge zur Erforschung des Alten Testaments und des antiken Judentums 20 (Frankfurt am Main: P. Lang, 1992), 9-23. Cf. Simon John De Vries, Prophet Against Prophet: The Role of the Micaiah Narrative (IKings 22) in the Development of Early Prophetic Tradition (Grand Rapids: Eerdmans, 1978), 137-51.

${ }^{2}$ E.g., Isa 6:1ff.

"Davidson, "The Heavenly Sanctuary in the Old Testament, 1976," 25; McNicol, "The Heavenly Sanctuary in Judaism," 70; H. Wheeler Robinson, "The Council of Yahveh," JTS 45 (1944): 153.

${ }^{4} \mathrm{Kim}, 130$. 


\section{Preliminary Observations}

The text unit relevant for this study is Micaiah's oracle contained in $1 \mathrm{Kgs} 22: 19$ 23. Special attention is given to vs. 19 , since it describes the "parabolic vision" ${ }^{1}$ of the heavenly court scene. Burke Long has described this pericope as a "report of dramatic word-vision, ${ }^{n 2}$, which he divided into the following segments:

a. Narrative introduction ( $19 \mathrm{a \alpha}$ )

b. Report of vision (19aß-22)

1) Summons to attention $(19 \mathrm{a} \beta)$

2) Vision (19b-22)

a) Announcement of vision (19ba)

b) Vision sequence $(19 b a-22)$

3) Interpretative conclusion: evil on Ahab (23). ${ }^{3}$

The similarities of this text with other reports of heavenly council sessions, notably those of Isa 6:1-6, Ezek 1:1-28, and 10:1-22 have been perceived by several scholars. ${ }^{4}$ Edwin C. Kingsbury, particularly, has noted five elements that are common to all three accounts: (1) Yahweh as King; (2) heavenly creatures surrounding Yahweh; (3) the prophet saw Yahweh; (4) the oracle merely communicated what the prophet saw; and (5)

'Richard D. Patterson and Hermann J. Austel, "1, 2 Kings," The Expositor's Bible Commentary 4, ed. Frank E. Gaebelein (Grand Rapids: Zondervan, 1988), 165.

${ }^{2}$ Burke O. Long, I Kings: With an Introduction to Historical Literature (Grand Rapids: Eerdmans, 1984), 232.

3rbid.

${ }^{4} \mathrm{Cf}$. Mordechai Cogan, 1 Kings: A New Translation with Introduction and Commentary, AB 10 (New York: Doubleday, 2001), 492; Volkmar Fritz, Das erste Buch der Könige, Zürcher Bibelkommentare (Zürich: Theologischer Verlag, 1996), 199; John Gray, I and II Kings: $A$ Commentary (Philadelphia: Westminster, 1963), 402; Gwilym H. Jones, I and 2 Kings (Grand Rapids: Eerdmans, 1984), 367; Walsh, 350-51. 
the vision happens at the time of Yahweh's enthronement. 'Kingsbury's arguments are compelling except for the last element, which presupposes an alleged New Year's festival that culminated in the enthronement of YHWH. This conjecture, which had Sigmund Mowinckel ${ }^{2}$ as one of its major proponents, has fallen into disfavor in recent scholarship. ${ }^{3}$ The other points, however, are well taken, and find solid support in the text. That the vision of the heavenly realm hinted at YHWH's functioning as King is implied in the passage, as indicated by the portrayal of heavenly creatures and the visionary experience of the prophet in connection with the heavenly realm. Finally, the prophet communicated what was shown to him in the vision. For the purposes of this study, the first two elements are more important because of their affinities with temple/sanctuary imagery, as noted below.

It should be remarked at this point that although the text does not refer explicitly to the heavenly sanctuary/temple, the imagery reflected therein implies that the heavenly sanctuary/temple was the locus of the heavenly council session. This idea is more clearly expressed in other passages of the Hebrew Bible where it is indicated that the heavenly council of THWH convenes in the heavenly sanctuary. ${ }^{4}$ The ensuing discussion argues 86.

${ }^{1}$ Cf. Edwin C. Kingsbury, "The Prophets and Council of Yahweh," JBL 83 (1964): 279.

${ }^{2} \mathrm{Cf}$. Sigmund Mowinckel, Religion and Cult: A Translation of Sigmund Mowinckel's Religion og Kultus, trans. John F. X. Sheehan (Milwaukee: Marquette University, 1981), 98-110.

${ }^{3} \mathrm{Cf}$. Leo G. Perdue, The Collapse of History: Reconstructing Old Testament Theology, Overtures to Biblical Theology (Minneapolis: Fortress, 1994), 116-17.

${ }^{4}$ E.g., Isa 6:1-8; Zech 3:1-10; Dan 7:9-14. 
that this passage do contain the heavenly sanctuary/temple motif, and inquires about the its function and relationship to the earthly counterpart.

\section{Semantic and Other Exegetical Considerations}

\section{Meaning of ใหนุ๋}

The root gegin stresses the stability and the duration of YHWH's residence.' As Nam pointed out: "Quite often this verb is used as a technical term to imply that the one who is sitting (yöšeb) is the ruler. ${ }^{22}$ In the text under scrutiny this concept is stressed by the lexeme 109 ("throne") which further substantiates the kingship imagery. In sum, the verbal phrase $1 \times 09+3$ YHWH in his royal functions.

The royal imagery, however, does not rule out sanctuary/temple imagery. In fact, it should be observed that the idea of "enthronement" conveyed by בשq is related to the sanctuary/temple in several places where YHWH is described as the one who 9999 ("is enthroned on the cherubim"). ${ }^{4}$ Since this clearly refers to YHWH's enthronement in the most holy place of the sanctuary/temple, one could argue that the notion of enthronement is closely connected to the idea of sanctuary/temple and not exclusively to the concept of "palace," as implied by Kim in his study of this passage. ${ }^{5}$ Other important

"Gerald H. Wilson, "avi"," NDOTTE, 2:551.

${ }^{2} \mathrm{Nam}_{s}$ "The "Throne of God Motif in the Hebrew Bible," 157.

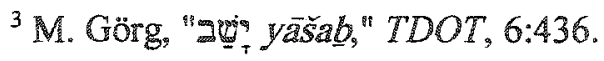

${ }^{4} 1$ Sam 4:4; 2 Sam 6:2; 2 Kgs 19:15; 1 Chr 13:6; Pss 80:2; 99:1; Isa 37:16.

${ }^{5} \mathrm{Cf} . \mathrm{Kim}, 122-30$. 
indications in this regard are found in Isa 6:1 and Ps 11:4, wherein wos? ("throne") ocurs in parallel with bs". ("temple"), thus closely linking both concepts together. ${ }^{1}$ As Nam aptly said, "the sanctuary was God's dwelling place on earth in which he sat upon his throne. Therefore, the sanctuary and the throne of God are two concepts which camot be separated from each other. ${ }^{\prime 2}$

\section{Meaning of םำ}

The expression D? the stars, usually as an object of illegitimate worship. ${ }^{3}$ In the current passage, however, this phrase refers to the celestial beings who surround YHWH at his heavenly court, a concept which may also be implied in the expression ת which appears 247 times in the Hebrew Bible. It is interesting to note that אมุร ("hosts") can also convey cultic imagery, as noted by Rodriguez. ${ }^{5}$ We should also note that

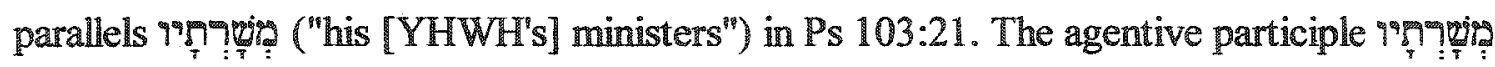

"See below further discussion on the concept of hag "temple/palace."

"Nam, "The "Throne of God Motif in the Hebrew Bible," 2.

${ }^{3}$ The following passages convey a negative connotation, since the host of heaven are referred to as the object of illegitimate worship: Deut $4: 19 ; 17: 3 ; 2 \mathrm{Kgs} 17: 16 ; 21: 3 ; 21: 5 ; 23: 4,5$; $2 \mathrm{Chr} 33: 3,5$; Jer $8: 2 ; 19: 13$; Zeph 1:5. These other passages seem to convey a more neutral connotation of stars or astral bodies: Isa $34: 4 ;$ Jer $33: 22 ;$ Neh $9: 6$. The passage of Dan $8: 10$ is dealt with in chapter 5.

${ }^{4}$ Boyd, God at War, 131.

${ }^{5}$ Rodriguez mentioned the following biblical passages, where ${ }_{\mathrm{T}}^{\mathrm{g}} \mathrm{r}_{\mathrm{r}}$ occurs in a cultic setting: Num 4:3, 23, 30; 8:24-25 ("Significance of the Cultic Language in Daniel 8:9-14," 531). 
derives from กาข , which conveys the meaning of "ritual service in the cult "1 Moreover, in Ps 148:2 the heavenly "hosts" are also depicted as standing before $\mathrm{YHWH}$ and praising

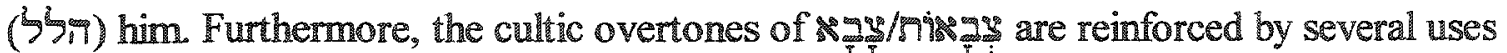
of the root 29 in connection with the tabernacle/temple service. ${ }^{2}$

\section{Meaning of}

The text adds that all the "host of heaven" was ibxista. ("standing by him on his right and on his left"). This intends to convey the idea of subordination. In an oriental court the King is usually depicted as sitting while his attendees are standing around him. ${ }^{3}$ This reinforces the royal imagery portrayed in the text.

\section{Heavenly Sanctuary/Temple Motif}

The conspicuous presence of royal imagery coupled with the seeming absence of cultic activities in our text has led Kim to conclude that the text depicts the idea of a royal palace, not that of a heavenly temple. This sharp disjunction between temple and palace is very difficult to sustain for two main reasons:

"Cf. HALOT, s.v. "mqge."

${ }^{2}$ E.g., Exod 38:8; Num 4:3, 23, 30, 35, 39, 43; 8:24; 31:6; 1 Sam 2:22.

${ }^{3}$ Albert Šanda, Die Bücher der Könige übersetzt und erklärt (Münster i. Westf.: Aschendorff, 1911), 494. For iconographic examples, cf. Othmar Keel, Die Welt der altorientalischen Bildsymbolik und das Alte Testament. Am Beispiel der Psalmen (Zürich: Beziger, 1972), 188.

${ }^{4} \mathrm{~K} \operatorname{im}, 129-30$. 
1. the Hebrew Bible seems to conceive of the temple as a unified entity with cultic and royal functions. It has been argued before that the temple/sanctuary is defined by the presence of the deity in it. Therefore, any temple/sanctuary is a palace; and conversely, every palace which hosts the deity is a temple/sanctuary. ${ }^{1}$

2. A few observations on the terminology used in the text indicates that it may bespeak sanctuary/temple overtones. For example, the root $2 w^{j}$ is used in connection with the Jerusalem temple as the dwelling place of $\mathrm{YHWH}^{2}$ A participial form of this root is used in reference to YHWH's enthronement above the cherubim, a clear reference to the earthly temple. Thus, the idea of a royal palace where YHWH dwelt and the concept of a cultic place where YHWH was worshiped cannot be separated. They seem to have always coalesced in the understanding of the temple/sanctuary. Thus, one should avoid a strict dichotomy between heavenly temple versus heavenly palace since both represent at most only different aspects of the same palace-temple entity. If the earthly temple functioned in the capacity of both palace and sanctuary, one has a compelling reason to understand the heavenly counterpart as a temple with both cultic and royal functions.

"The concept of "palace" usually conveyed by the term לָ

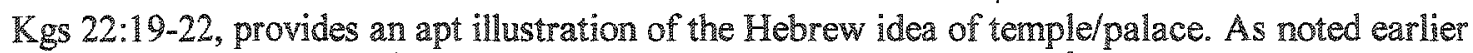
(see above, in chapter 3), b\$ָ' is etymologically related to Sumerian E.GAL ("large house") and may be used to indicate either the "palace" of earthy kings (1 Kgs $21: 1 ; 2 \mathrm{Kgs} 20: 18 ; 2 \mathrm{Chr} 36: 7$; Pss 45:9 [8], 16 [15]; 144:12; Isa 13:22; 39:7; Dan 1:4; Hos 8:14; Amos 8:3; Nah 2:7), or the temple of YHWH (1 Sam 1:9; 3:3; 2 Sam $22: 7 ; 1 \mathrm{Kgs} 6: 3,5,17,33 ; 7: 21,50 ; 2 \mathrm{Kgs} 18: 16 ; 23: 4$; $24: 13 ; 2$ Chr $3: 17 ; 4: 7 \mathrm{f}, 22 ; 26: 16 ; 27: 2 ; 29: 16$; et al.).

${ }^{2}$ See the discussion on Exod 15:1-18 in chapter 3. 
3. It is important to note that the vision reported in $1 \mathrm{Kgs} \mathrm{22:19-23} \mathrm{parallels} \mathrm{in}$ many respects Isa 6:1ff.,' as recognized by several scholars. ${ }^{2}$ Thus, assuming that Isaiah's temple vision contains the heavenly sanctuary-temple motif, as argued below, the probability increases that Micaiah's vision also contains the heavenly sanctuary/temple motif.

\section{Function}

In view of the arguments advanced above, it may be noted that $1 \mathrm{Kgs} 22: 19-23$ presupposes the following functions for the heavenly temple/sanctuary:

1. The imagery of YHWH sitting on his throne evokes royal connotations since YHWH is depicted as king exerting his royal authority. It might be said that the heavenly sanctuary/temple functions as YHWH's headquarters whence he interacts with earthly affairs and issues decrees to direct historical events according to his plans, as noted in the excursus below.

2. The portrayal of the divine council, "the host of heaven," suggests that the heavenly sanctuary/temple functions as the meeting place of the heavenly council, a function implied elsewhere in the Hebrew Scriptures. ${ }^{3}$

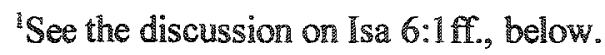

Joseph Blenkinsopp, Isaiah 1-39: A New Translation with Introduction and Commentary, AB 19A (New York: Doubleday, 2000), 224; Cogan, 492; Mordecai M. Kaplan, "Isaiah 6:1-11," JBL 45 (1926): 255-57; John D. Watts, Isaiah 1-33, WBC 24 (Waco: Word Books, 1985), 71-73; Donald D. Wiseman, 1 and 2 Kings, Tyndale Old Testament Commentaries (Leicester, England: Inter-Varsity Press, 1993), 187.

$$
{ }^{3} \text { See, e.g., Isa 6:1-3; Zech 3:1ff.; Dan 7:9-14. }
$$


3. The portrayal of YHWH surrounded by heavenly beings may also imply cultic connotations, since in other parts of the Hebrew Scriptures this imagery conveys a worship setting. ${ }^{1}$

4. Since the ultimate result of the heavenly council session was the judgment upon Ahab, the heavenly sanctuary/temple in this passage emerges as a place of judgment.

\section{Relationship to Earthy Counterpart}

The notion of judgment and the concept of YHWH sitting on his throne corresponds to the earthly temple, which was conceived not only as a place of judgment, but also as a place where YHWH dwelt among the cherubim. Thus, the suggestion may be advanced that the heavenly sanctuary/temple was understood to exist in functional correspondence to the earthly counterpart.

\section{Excursus: The Effect of the Heavenly Sanctuary/Temple on Earthly Affairs}

The heavenly scene develops in a remarkable relationship to the earthly events. It is interesting to note that the portrayal of YHWH surrounded by the "host of heaven" is matched by the kings of Israel and Judah surrounded by the host of prophets. Also, as pointed out by Nam, there is a "close relationship between the earthly thrones and the throne of God in heaven" as can be seen in two verses from the same chapter.

$1 \mathrm{Kgs} 22: 10$

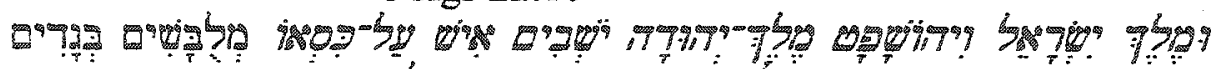

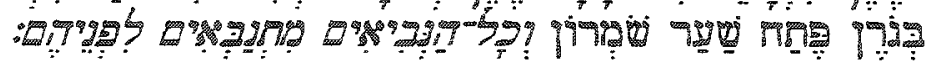

\footnotetext{
IE.g., Exod 15:11; Isa 6:1ff.; Ps 150:1.
} 
Now the king of Israel and Jehoshophot king of Judah were sitting each on his throne, arrayed in their robes, at the threshing floor at the entrance of the gate of Samaria; and all the prophets were prophesying before them.

$1 \mathrm{Kgs} 22: 19$

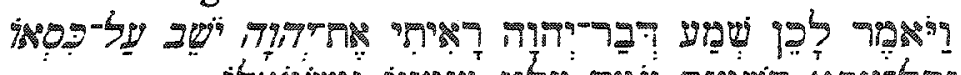

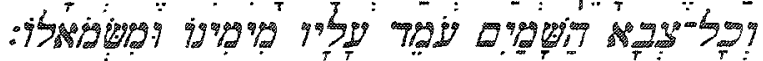

Micaiah said, "Therefore, hear the word of YHWH. I saw YHWH sitting on his

throne, and all the host of heaven standing by him on his right and on his left.

Another verbal parallel worthy of note is found in $1 \mathrm{Kgs} 22: 27$ and 22:15 which

reads Pלำ 79 ("Thus says the King [Ahab]") and

YHWH"). These parallels seem to indicate a correspondence between the scene at the

heavenly courtroom and its counterpart on earth.

However, it should be noted that this relationship is not an ideal one, ${ }^{1}$ since the earthly scene does not reflect its heavenly counterpart in some crucial aspects. The earthly kings seem to be working in opposition to their heavenly counterpart. Furthermore, it is interesting to note that the earthly counterpart is not a sanctuary/temple, but a threshing floor ${ }^{2}$ which provides the setting for the court scene where earthly kings are planning a military enterprise. ${ }^{3}$ As the story proceeds, the deliberations of the heavenly court overrule the decisions and intentions of its earthly counterpart and the ultimate intentions of YHWH are executed. In short, although there is a correspondence between the earthly

${ }^{1 C f . ~ N a m, ~ " T h e ~ " T h r o n e ~ o f ~ G o d ~ M o t i f ~ i n ~ t h e ~ H e b r e w ~ B i b l e, " ~} 155$.

${ }^{2} \mathrm{Cf} .1 \mathrm{Kgs} \mathrm{22:10.}$

${ }^{3}$ The absence of the earthly temple in the interactions between heaven and earth in this text should not come as a surprise, since the story happened in the territory of the northern kingdom of Israel, where there was no legitimate temple of YHWH. 
scene and its heavenly counterpart, the ultimate outcome depended upon the deliberation of YHWH in his heavenly sanctuary/temple. ${ }^{1}$

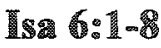

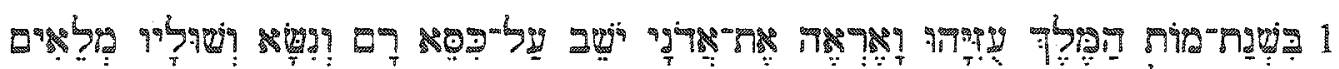

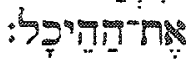

1 In the year that King Uzziah died, I saw the Lord seated on a throne, high and exalted, and the train of his robe filled the temple.

The pericope of Isa 6:1-8 contains remarkable indications not only of the heavenly sanctuary/temple, but also of a relationship between the heavenly and its earthly counterpart, as already demonstrated by Davidson, ${ }^{2}$ and more recently by $\mathrm{Kim}$ in his dissertation. ${ }^{3}$ Admittedly, the text contains several exegetical issues that have been a matter of debate among commentators, which were thus summarized by Kim:

(1) whether the chapter is Isaiah's "self report" (Selbstbericht) or an Isaian "memoir" (Denkschrift); (2) whether the vision is actually a prophetic call or Isaiah's commissioning for a specific political mission; (3) if this is a call vision, which is delayed until the sixth chapter of the book; (4) when the year that king Uzziah died was and what theological indication that has; (5) whether the words "holy, holy, holy" of $v .3$ are a trishagion or a dishagion and what its origin is; $(6)$ how this vision is related to the other visions, and (7) whether 3 \% represents the heavenly temple or the earthly temple.

Fortunately the ensuing discussion does not depend upon resolving all these issues, although some of them may need brief discussion along the way. The first task is to

1'Hartmut Schmid, Das erste Buch der Könige, WSRAT (Wuppertal: R. Brockhaus Verlag, 2000), 594.

"Davidson, "The Heavenly Sanctuary in the Old Testament," 15-20.

${ }^{3} \mathrm{Kim}, 166-91$. footnotes.

${ }^{4}$ Ibid., 168-69, with a brief explanation of each item and bibliographic information in the 
undertake some preliminary observations regarding text unit and structure. Then, specific

words and expressions, which contribute to illuminate the heavenly sanctuary/temple

motif, receive semantic and other exegetical considerations. Finally, the function of the

heavenly sanctuary its relationship to the arthly counterpart receive attention.

\section{Preliminary Observations}

The text unit of 6:1-8 can be singled out as a literary subunit of chap. 6 , which consists of a first-person account of Isaiah's temple vision. "The unit of vss. $1-8$ focuses on Isaiah's vision ${ }^{2}$ of YHWH enthroned in the temple with the accompanying liturgy of the

\footnotetext{
"The categorization of Isa 6:1-8 as "prophetic call" or "inaugural vision" has been suggested by some scholars (Norman Habel, "The Form and Significance of the Call Narratives," $Z A W 77$ [1965]: 297-323; Rolf Knierim, "The Vocation of Isaiah," VT 10 [1968]: 47-68), while others have argued that it is not a call because prophets like Moses and Jeremiah were never given a choice (e.g., H. L. Ginsberg, "Introduction [to Isaiah]," in The Book of Isaiah [Philadelphia: Jewish Publication Society of America, 19731, 15). This issue is made more acute by the location of the pericope here and not at the beginning of the book. This has led some scholars to conjecture that it was originally at the head of an independent collection of Isaianic materials (Otto Kaiser, Isaiah 1-12, trans. John Bowden [from the German], OTL [Philadelphia: Westminster, 1983], 121; John Mauchline, Isaiah 1-39: Introduction and Commentary, TBC [London: S.C.M. Press, 1962], 88-89; Hans Wildberger, Isaiah 1-12: A Commentary, trans. Thomas H. Trapp, CC Minneapolis: Fortress, 1991], 252). The problem with this view, according to Oswalt, is that it presupposes that the book of Isaiah is a patchwork of independent scrolls put together without concern for order and coherence (C. v Orelli, The Prophecies of Iscioh [Edinburgh: T. and T. Clark, 1895], 172). A reasonable option consists in understanding Is 6 functioning like a hinge, containing as it does words of judgment, but also a note of hope inasmuch as the cleansing of the prophet could be a harbinger of what YHWH could do for the whole people. Thus, this section sems to function as a suitable conclusion to chaps. 1-5 and a fitting introduction to chaps. 7-12 (cf. John Oswalt, The Book of Isaiah: Chapters 1-39 [Grand Rapids: Eerdmans, 1986], 173). From a historical perspective, one should note the contribution by Kaplan to this discussion. Noting the similarity of Isaiah's vision with Micaiah's vision (see the discussion of 1 Kgs 22:19-23, above) Kaplan cogently argues that the vision reported in Isa 6:1ff. "was experienced by Isaiah after he had been active as a prophet for some time" (Kaplan, 253).
}

2The verb is: "qu ("and I saw") implies that the prophet had a visionary experience. Actually, some other derivatives of 7 are also related to the semantic field of "vision" as

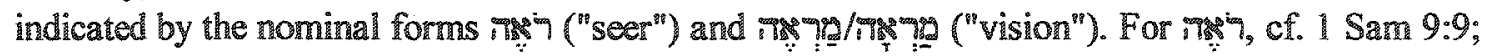

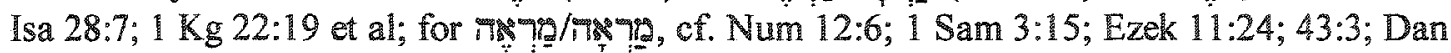


Seraphim proclaiming the trishagion and the reverberations of their voice in the temple. The vision culminates when the prophet, purified by the burning coal, volunteers for the task of being YHWH's messenger.

The unit is delimited by the repetition of "gin in vs. 1 and 8 , thus forming an inclusio. Furthermore, these two verses also display syntactic similarities: both are formed by an imperfect consecutive, followed by a participial phrase. The verbal form ing? ("and I saw") in vs. 1 corresponds to Irwing ("and I heard") in vs. 8, suggesting that the vision consisted of visual and auditory elements. Thus, in vs.1 the prophet declared: "I saw

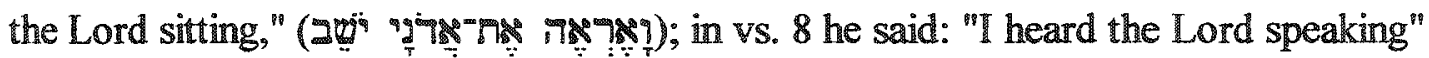
("มู่ off as a subunit inside chap. 6. At this point, a further look at $6: 1-8$ is called for in order to lay bare the structural organization of the text under study. Kim suggested the following structure: vss. 1-3 depict a scene in heaven, vss. $4-5$ portray the effects of the heavenly temple on its earthly counterpart, and vss. $6-8$ portray the intercommunication between the heavenly temple and its earthly counterpart. ${ }^{1}$ For the reader's sake, the entire pericope with the divisions just mentioned is displayed below.

1. Scene in Heaven:

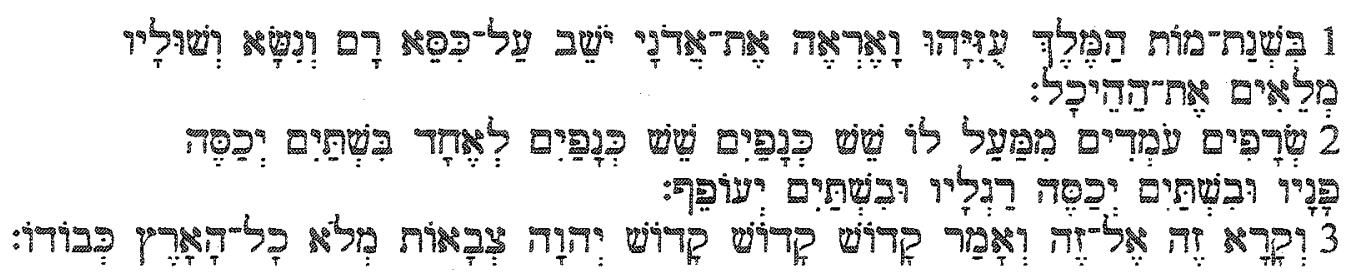

$8: 16,26 ; 9: 23 ; 10: 1$

${ }^{1} \mathrm{Kim}, 172$. 
1 In the year of King Uzziah's death I saw the Lord sitting on a throne, lofty and exalted, with the train of his robe filling the temple.

2 Seraphim stood above him, each having six wings: with two he covered his face, and with two he covered his feet, and with two he flew.

3 And one called out to another and said, "Holy, Holy, Holy, is YHWH of hosts; the whole earth is full of his glory."

2. Effects of the Heavenly Temple on Its Earthly Counterpart:

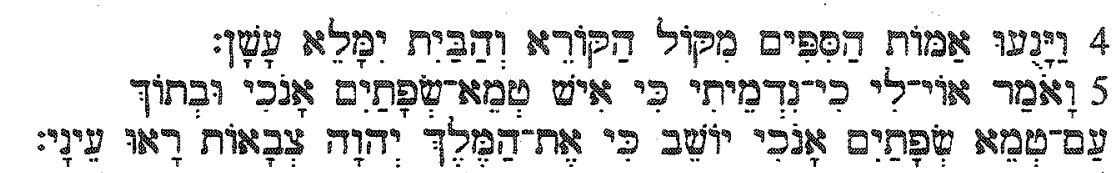

4 And the foundations of the thresholds trembled at the voice of him who called out, while the temple was filling with smoke.

5 Then I said, "Woe is me, for I am ruined! Because I am a man of unclean lips, And I live among a people of unclean lips; For my eyes have seen the King, YHWH of hosts."

3. Intercommunication between Heavenly Temple and Its Earthly Counterpart:

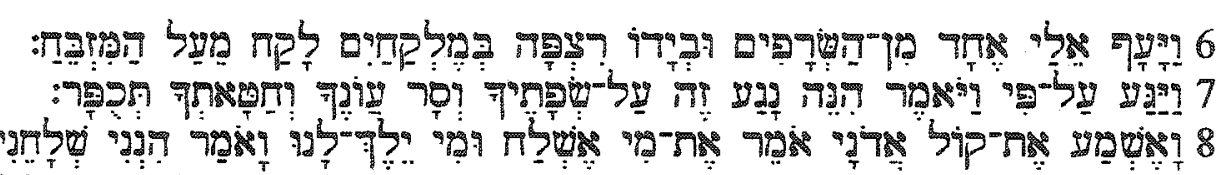

6 Then one of the seraphim flew to me with a burning coal in his hand, which he had taken from the altar with tongs.

7 He touched my mouth with it and said, "Behold, this has touched your lips; and your iniquity is taken away and your $\sin$ is forgiven."

8 Then I heard the voice of the Lord saying, "Whom shall I send, and who will go for Us?" Then I said, "Here am I. Send me!"

\section{Semantic and other Exegetical Considerations}

A closer examination of the temple/sanctuary vocabulary employed in the text can contribute insights into the picture of the heavenly sanctuary/temple portrayed in the pericope. Issues such as heavenly versus earthly temple, relationship between earthly and heavenly, and function of the earthly sanctuary can be grasped from a semantic investigation and other exegetical observations. 


\section{Mexing a}

The declaration by the prophet that he saw "the Lord sitting on a throne, lofty and exalted" sets the vision in a heavenly setting, since this expression seems to be more appropriate to indicate the heavenly throne of YHWH than the ark in the Jerusalem temple. This is supported by the similarity of this passage to $1 \mathrm{Kgs} 22: 19$, discussed above, where virtually the same expression-7ir? 9309 setting. The reference to the "throne" seems to emphasize the royal aspects of YHWH's activities, especially that of judgment.

\section{Meaning of}

The Sร". ("temple") referred to in connection with the throne has been variously interpreted. Scholars have understood as לঙ. earthly temple, or both. ${ }^{2}$ The evidence seems to point to an original Jerusalem temple

${ }^{1}$ Knierim noted the points of contact between the current text and other passages which feature YHWH's appearance in judgment: Pss 11:4-7; 12; 18:7 [6]; 45:7 [6]f; 50; 86; 95; 98:9; 122:5; Amos 1:2f.; 1 Kgs 22:19; Dan 7:9f; Mal 3:1-5 (Knierim, 54-56).

2Heavenly tempmple: see, e.g., Franz Delitzsch, Biblical Commentary on the Prophecies of Isaiah (Grand Rapids: Eerdmans, 1949), 1:190; Donald E. Gowan, "Isaiah 6:1-8," Int 45 (1991): 173; A. S. Herbert, The Book of the Prophet Isaiah: Chapters 1-39 (Cambridge: Cambridge University Press, 1973), 58; H. C. Leupold, Exposition of Isaich (Grand Rapids: Baker, 1977), 129; Orelli, 49; J. Ridderbos, Isaiah (Grand Rapids: Regency Reference Library, 1985), 76-77; W. E. Vine, Vine's Expository Commentary on Isaiah (Nashville: T. Nelson, 1997), 21; Herbert M. Wolf, Interpreting Isaiah: The Suffering and Glory of the Messiah (Grand Rapids: Academie Books and Zondervan, 1985), 87.

Earthly temple: see, e.g., E.g., Paul Auvray, Isaïe, Sources Bibliques (Paris: J. Gabalda, 1972), 86; G. B. Gray, A Critical and Exegetical Commentary on the Book of Isaiah 1-39, ICC 19, part I (Edinburgh: T. and T. Clark, 1912), 103-04; Kaiser, 125; Edward J. Kissane, The Book of Isaiah. Translated from a Critically Revised Hebrew Text with Commentary (Dublin: Browne and Nolan, 1941), 74; Knierim, 51; J. Alec Motyer, The Prophecy of Isaiah (Downers Grove, IL: Inter-Varsity, 1993), 76.

Both heavenly and earthly temple: see, e.g., E.g., Wildberger, 263; Barry G. Webb, The 
setting for the vision, as can be inferred from the opening statement, which situates the event in the year of the death of King Uzziah. ${ }^{.}$However, as far as the first three verses are concerned, the focus of the vision immediately zooms in on the heavenly sanctuary/temple. The reference to the Seraphim ( (ם) view that the תָּ referred to here is the heavenly one. Were the Jerusalem temple in view, the reference would be to Cherubim, not to Seraphim. ${ }^{2}$

\section{Meaning of n?}

Contrary to לדיף temple on earth. ${ }^{13}$ In like manner, the occurrence of $n^{9}$ in vs. 4 seems to point to an earthly sanctuary setting. That "the foundations of the thresholds trembled at the voice of him who called out" (vs. 4) seems to be much more appropriate for the Jerusalem temple than the heavenly one. Although it is not impossible that similar phenomena may happen in the heavenly temple, the context favors an earthly setting, since at this point the prophet seems to speak from the perspective of someone who is located on earth, namely, in the earthly temple. His exclamation of distress also seems to reflect an earthly environment as

Message of Isaiah: On Eagles' Wings, The Bible Speaks Today (Leicester, England: Inter-Varsity Press, 1996), 59, n. 82; ibid., 73.

"Davidson, "The Heavenly Sanctuary in the Old Testament," 16.

${ }^{2}$ Leupold, 129. Kim aptly noted that the "seraphim in this narrative are not mere images but living creatures [while] the cherubim in the Jerusalem temple were man-made images .... If Isaiah had seen Yahweh sitting on the throne located within the debir of the Jerusalem temple, he would have seen sculptured cherubim" (178, italics his).

${ }^{3}$ Knierim, 51 . This bold claim made by Knierin seems to be supported by those passages which unambiguously refer to the heavenly temple/sanctuary. 
he exclaimed: "Woe is me, for I am ruined! Because I am a man of unclean lips, and I live among a people of unclean lips" (vs. 5).

\section{Meanimg of mign}

The altar has been interpreted as either the altar of holocaust $t^{i}$ of the Jerusalem temple, or a heavenly altar, ${ }^{2}$ or more precisely the altar of incense of the heavenly temple. ${ }^{3}$ A close reading of the passage seems to favor a heavenly context for this altar.

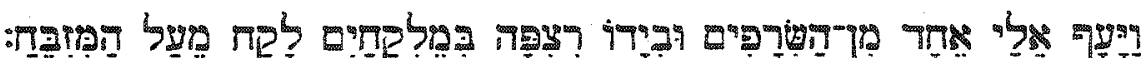

Then one of the seraphim flew to me with a burning coal in his hand, which he had taken from the altar with tongs.

Since one of the Seraphim flew to Isaiah in order to touch the prophet with the burning coal, it is much more reasonable to imagine that the divine being came flying from the heavenly temple than from the altar of holocaust or incense of the Jerusalem temple: Were the altar located in the earthly temple there would be no need for the Seraph to fly; it would be enough to walk and touch the prophet's lips. Besides, the qatal verbal form (np?) suggests a pluperfect meaning, ${ }^{4}$ indicating that the Seraph had taken the coal from

'Ross E. Price, "Isaiah," Beacon Commentary (Kansas City: Beacon Hill Press, 1966), 51.

${ }^{2}$ Delitzsch, 1:196; Orelli, 48 .

${ }^{3}$ Wolf expressed the view that "the prophet was transported into the presence of God in the heavenly temple, a scene similar to that viewed by John in Revelation 4 " (86).

${ }^{4}$ Cf. Ziony Zevit, The Anterior Construction in Classical Hebrew, SBLMS 50 (Atlanta, GA: Scholars Press, 1998), 15-32. 
the altar prior to flying (ๆ the text most probably is altar of incense ${ }^{1}$ located in the heavenly temple. ${ }^{2}$

\section{Heavenly Sanctuary/Temple Motif}

The investigation conducted above has indicated temple/sanctuary imagery in the text under study, which is conveyed by several terms and expressions employed by the author to communicate the idea of a sanctuary/temple. As already noted, the presence of the seraphic choir suggests that the לפ্ is the heavenly sanctuary. Moreover, in vs. 4 the scene shifts to the earthly temple, where n? is used instead of thas. Finally vss. 6-8 portray a close interconnection between the heavenly temple and its earthly counterpart. In view of these aspects, the function of the heavenly temple and its relationship to the earthly counterpart are investigated below.

\section{Funetion}

The picture of the heavenly sanctuary/temple conveyed by the pericope under study suggests royal and cultic functions. The heavenly sanctuary/temple is the place where $\mathrm{YHWH}$ is enthroned as King. The image of the attendant seraphim seems to echo

It is improbable that Isaiah would conceive of an altar of holocaust in heaven. Besides, the "tongs" ("TrTh) used by the Seraph to take the burning coals are mentioned elsewhere in the Hebrew Bible always in connection with activities related to the first compartment of the temple/sanctuary (see Exod 25:38; 37:23; Num 4:9; $1 \mathrm{Kgs} 7: 49 ; 2 \mathrm{Chr} 4: 21$ ). Interestingly, Ezek $10: 2$ mentions "coals of fire from between the cherubim" that should be scattered upon Jerusalem.

${ }^{2}$ The altar of incense os the heavenly sanctuary/temple seems to be related to intercession. Note that John saw prayers of repentant simners presented with incense before the throne of grace (Rev 8:3-4). See "The altar" [Isa 6:6], SDABC, 4:128-29. 
that of the "hosts of heaven," indicated by the "us" in the interrogative expression "Who will go for us?" (vs. 8). The reference to the temple in relation to the "throne," the "king," and the "seraphim" evokes a judgment session of the heavenly council. This seems to be reinforced by the context, which portrays Isaiah as the bearer of a message of judgment for the people. ${ }^{2}$

Nevertheless, it should be noted that the heavenly sanctuary/temple portrayed in the pericope is not limited to royal functions. It also displays interesting cultic dimensions noted in the verbal and conceptual affinities of the passage with the cultic language of the Hebrew Bible. Particularly interesting is that Isaiah's recognition of his sinfulness was immediately followed by expiatory actions in the heavenly temple, culminating in atonement and forgiveness. This expiatory action can be deduced from the reference to the heavenly altar from which the Seraph took the "burning coal." At this moment the expiatory procedures in the heavenly temple started:

6 6 Then one of the seraphim flew to me with a burning coal in his hand, which he had taken from the altar with tongs.

: 7 He touched my mouth with it and said, "Behold, this has touched your lips; and your iniquity is taken away and your sin is forgiven."

As noted, these verses display several verbal and conceptual affinities with the language of atonement and forgiveness. Worthy of mention are terms such as "799 ("purge") and 710 ("take away") which have as their objects กאหฺฺ

${ }^{1}$ See $1 \mathrm{Kgs} 22: 19$.

${ }^{2}$ See especially Isa 6:9ff. 
to note that the last two clauses of vs. 7 are organized chiastically in Hebrew, as shown below:

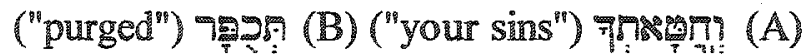

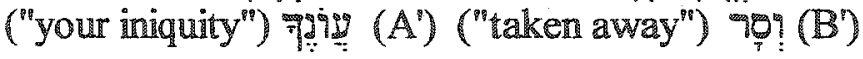

Although the prophet was possibly standing in the Jerusalem temple, the flying Seraph came with coals from the heavenly altar in order to effect forgiveness and purification. In this connection, one should note that the verb 759 ("purge") an important cultic term used in relation to the removal of sin or defilement, ${ }^{1}$ occurs in a passive form 7อบ? indicating that purging/forgiveness comes from YHWH. ${ }^{2}$ Furthermore, that the coal came from the heavenly altar probably indicates that the legitimacy of the atoning procedure stemmed from the heavenly temple, and ultimately from YHWH himself. The heavenly sanctuary thus emerges as a place wherein YHWH acts to "purge" (7פ5) the prophet, ${ }^{3}$ an act that effects the removal of the evil that disturbs a relationship, as part of a process of reconciliation ${ }^{4}$

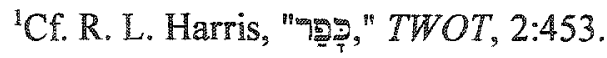

2Willem A.M. Beuken, Jesaja 1-12, HTKAT (Freiburg: Herder, 2003), 174.

${ }^{3}$ What happened to the prophet seems to be a harbinger of what YHWH was willing to do

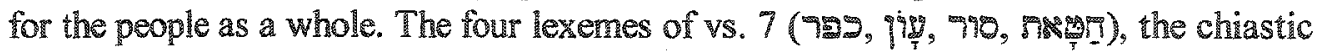
arrangement of which was displayed above, appear only one more time in the entire Hebrew Bible-in Isa 27:9, where YHWH promised to forgive his people. The implication seems to be that what was available to.Isaiah was available to the people as well.

${ }^{4}$ Cf. B. Lang, "רฐ?, kipper," TDOT, 7:288-303. 


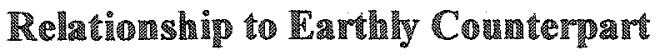

It is remarkable how the heavenly and earthly temples are interconnected in this text. The prophet receives a vision in the earthly temple, but in the course of his experience the vision expands to encompass the heavenly original. And Isaiah, who was standing either physically or only in vision in the Jerusalem temple, is allowed to have a glimpse of the throne of YHWH in the heavenly temple. This dynamic interaction is shown in the effects of the heavenly temple upon its earthly counterpart as reflected in vss. $4-5$. In this regard, vs. 4 need closer attention:

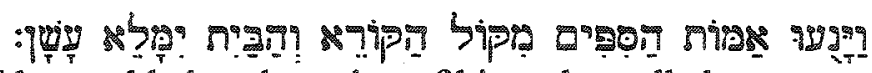
And the foundations of the thresholds trembled at the voice of him who called out, while the temple was filling with smoke.

It should be noted that the previous verses are depicting heavenly sanctuary imagery. The seraphic choir that fills the heavenly temple now reverberates into the earthly temple- - and the foundations of the thresholds trembled at the voice of him who called out, while the temple was filling with smoke." It seems obvious that

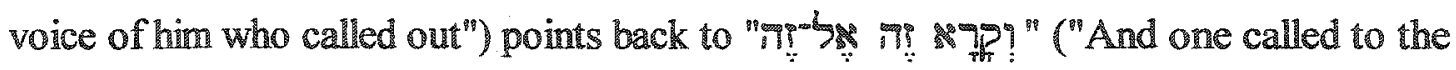
other"), a reference to the Seraphim's trishagion ("6it? temple. Therefore, what was transpiring in the heavenly temple reverberated in the earthly counterpart as if to show the effects of the heavenly temple upon the earthly counterpart. As Kim pointed out, "vv. 4-5 describe, in a vision, how the earthily temple at Jerusalem is affected by the praising of the Seraphim in the heavenly court and how the prophet himself is affected by seeing the King, YHWH of hosts." This dynamic interaction may be also

\footnotetext{
'Kim, 182.
} 
perceived in the movement of the Seraphim who flew with the coal taken from the heavenly altar and came to the earthly temple where the prophet was standing.

Finally, one should note that the text also implies structural and functional correspondences between the heavenly temple and its earthly counterpart. The mention of the "altar" of incense in the heavenly Sgr" ("temple"), and the "tongs" used to remove the "burning coals" from it, conveys a picture of a heavenly temple structurally similar to its earthly counterpart. The activity performed by the Seraph which reflected YHWH's forgiveness of the prophet points to a functional correspondence as well. In short, the heavenly temple and its earthly counterpart are portrayed in a structural and functional relationship, in addition to the dynamic interaction observed above.

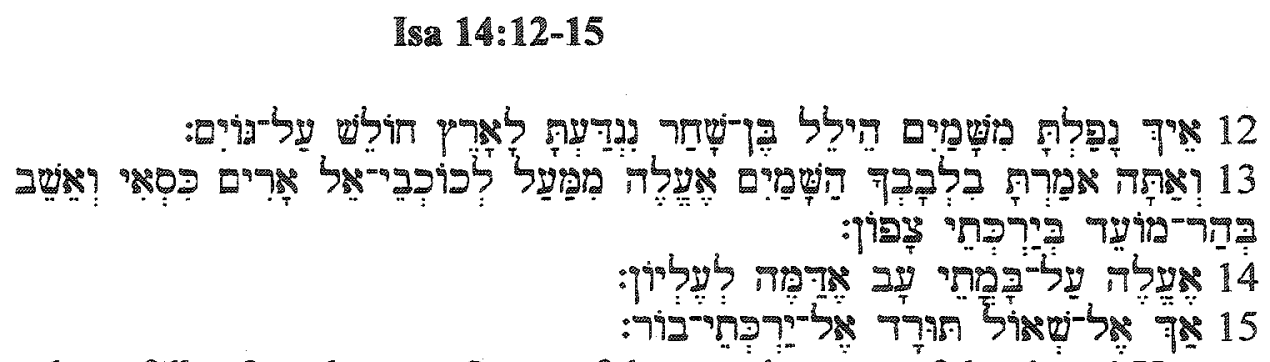

12 "How you have fallen from heaven, 0 star of the moming, son or the dawn! You have been cut down to the earth, You who have weakened the nations!

13 "But you said in your heart, 'I will ascend to heaven; I will praise my throne above the stars of God, And I will sit on the mount of assembly in the recesses of the north. 14 II will ascend above the heights of the clouds; I will make myself like the Most Tigh.'

15 "Nevertheless you will be thrust down to Sheol, to the recesses of the pit."

Although a detailed study of Isa 14:12-15 was undertaken by $J$. M. Bertolucci in the framework of the controversy between good and evill, ${ }^{1}$ some additional investigation is

${ }^{1}$ José M. Bertolucci, "The Son of the Morning and the Guardian Cherub in the Context of the Controversy between Good and Evil" (Th.D. dissertation, Andrews University, 1985), 146-219. 
needed in order to ascertain the presence of sanctuary imagery in this pericope. Davidson's observation that in this passage one has "a spotlight upon the heavenly sanctuary" further reinforces the need for an examination of the pericope in connection with the heavenly sanctuary/temple motif.

After some preliminary observations dealing with the context of the pericope, its unit and structure, three excursuses tackle some issues relevant for the exegesis of the

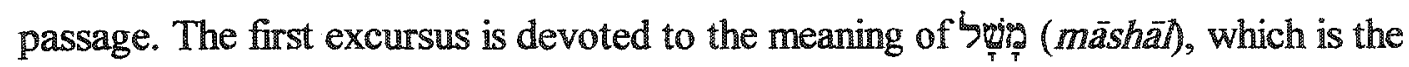
Hebrew designation for the genre of $14: 4-21$; the second discusses the identity of the King of Babylon; and the third excursus deals with the alleged mythological background of 14:12-15. Thereafter, a section on semantic and other exegetical considerations investigates the terms related to sanctuary/temple imagery. Finally, the heavenly sanctuary/temple motif which emerges in the course of the discussion is further expounded, with a special consideration of its function and relationship to the earthly counterpart.

\section{Preliminary Observations}

Although Isa $14: 12-15$ is the focus of this study, a brief analysis of Isa 13:1-14:22 is undertaken, since it constitutes the immediate context of the pericope under study and can, therefore, contribute to the understanding of Isa 14:12-15. Overall, the text can be

'Davidson makes this affirmation as he notes the comnections among Rev 12, Isa 14, and Ezek 28. See Davidson, "Cosmic Metanarrative for the Coming Millennium," 106. 
divided into two parts: the "oracle" (No city and its sins, and the mashal (

The first section (13:1-14:3), which proclaims judgment against Babylon, is pervaded by day-of-YHWH imagery (13:6). Local and universal language are interwoven throughout the text, pointing beyond the historical city to a universal/cosmic Babylon. Several expressions seem to transcend the historical city. In 13:5 "YHWH and the instruments of his wrath" come to destroy "all the earth" ( (ץ) sometimes denote "country" or "land," the lexeme ("world") in $13: 11^{2}$ favors the view that a cosmic judgment is included. ${ }^{3}$ Additionally, the upheaval of the stars, sun, moon (13:10), heaven, and earth (13:13) further points to an event of universal proportions. As Otto Kaiser aptly said: "In 13:2-22 the prophecy of the judgment of the world that is to take place on the day of Yahweh and that of the conquest and destruction of Babylon are remarkably intermingled. ${ }^{n 4}$ Therefore, it may be inferred that the judgment announced upon the historical/local city of Babylon also applies to the cosmic/eschatological city, inasmuch as Babylon is understood as an embodiment of the opposition to YHWH and his people.

${ }^{1}$ Probably the term ("oracle") refers to an entire section of Isa 13 and 14 , with the term bẹio (" $m \bar{s} s h \bar{A} \bar{A}$ ") being a more specific definition for the section 14:4-21.

${ }^{2}$ Used exclusively in poetic texts, לy "conveys the cosmic and global sense in which eres is also sometimes used; i.e., the whole earth or world considered as a single entity" (Christopher J. H. Wright, " Sgrt (tébel)," NIDOTTE, 4:272-73).

${ }^{3} \mathrm{G} . \mathrm{B}$. Gray recognizes the presence of "eschatological features" in Isa 13 , since it is not merely Babylon which will be punished, but the whole world (A Critical and Exegetical Commentary on the Book of Isaiah 1-39, 238).

${ }^{4}$ Otto Kaiser, Isaiah 13-39: A Commentary (Philadelphia: Westminster, 1974), 8. 
The second section (14:4-21) focuses on the King of Babylon. The genre employed throughout is that of lamentation (qinah) which is framed by an introduction and conclusion in prose. Although there are major disagreements about the strophic divisions of this latter part, ${ }^{1}$ J. Oswalt, ${ }^{2}$ followed by B. Webb, ${ }^{3}$ has argued for the following strophic divisions: 4b-8 Earth; 9-11 Sheol; 12-15 Heaven; 16-21 Earth. ${ }^{4}$ Bertolucci divided 16-21 into two strophes, 16-19 and 19-21, and proposed the following arrangement for the entire unit: 5

A. Earthly (4b-8)

B. Underworld $(9-11)$

C. Heavenly (12-15)

B.' Underworld (16-19a)

A.' Earthly (19b-21).

${ }^{1}$ E.g., 14:1-11; 12-21 according to Edward Young, The Book of Isaiah, 3 vols., NICOT 23 (Grand Rapids: Eerdmans, 1965), 431-46; 14:3-4a; 4b-6; 7-9; 9-15; 16-21; 22-23 according to $\mathrm{H}$. C. Leupold, Exposition of Isaiah (Grand Rapids: Baker, 1977), 254-265; 14:4b-8; 9-11; 12-15; 16-18a; 18b-22 according to Hans Wildberger, Isaiah 13-27: A Commentary, Continental Commentaries (Minneapolis: Fortress, 1991), 41-42. 16.

${ }^{2}$ John Oswalt, The Book of Isaiah: Chapters 1-39 (Grand Rapids: Eerdmans, 1986), $315-$

${ }^{3}$ Barry G. Webb, The Message of Isaiah: On Eagles'Wings, The Bible Speaks Today (Leicester, England: Inter-Varsity Press, 1996), 83.

${ }^{4} \mathrm{Cf}$. also Ewald, 162 ; Bertoluci, 151.

${ }^{5}$ Bertolucci, 208. The outline of Isa 14 suggested by Bertolucci agrees with the one suggested by R.B.Y. Scott ("The Book of Isaiah: Chapters 1-39," Interpreters Bible Commentary, ed. George Arthur Butrick (New York: Abingdon, 1956], 5:260-65), and Page H. Kelley ("Isaiah," The Broadman Bible Commentary, ed. Clifton J. Allen [Nashville: Broadman, 1969], 5:238-40). 
As noted, the apex of the poem is on the third stanza, ${ }_{1}^{1}$ which portrays what happens in the heavenly realm when Helel ben Shahar attempts to take over the "mount of assembly." This structural arrangement indicates a vertical movement. The key issue seems to be the rebel's ambition to take over the heavenly "mount of assembly" in order to establish his throne thereon. As persuasively demonstrated by Bertolucci, this should be understood in the context of the controversy between good and evil. According to him, Helel ben Shahar is to be identified with Satan, and the events portrayed in the passage are related to a rebellion which happened in the heavenly realm. ${ }^{2}$ What remains to be done is to determine the presence and role of the heavenly sanctuary/temple in the passage. In order to accomplish this, a close examination of $14: 12-15$ is required. This section is "that point in the poem where the prophet, in a clearer way, gives the impression that the implications of the poem transcend mere historical figures in the human earthly realm. Those verses seem to pertain to the heavenly realm or the sphere of the heavenly being. ${ }^{.3}$ It is in this section that are found several terms alluding to the heavenly sanctuary/temple. Thus, a close examination of its structure may yield further insights into the understanding of the heavenly sanctuary/temple motif in the passage.

'Seth Erlandsson, although suggesting different divisions for this section (i.e., vss. $4 b-8$; $9-11 ; 12-15 ; 16-21$ ), also recognizes that vss. $12-15$ "constimute the core of the song" (The Burden of Babylon: A Study of Isaiah 13:2-14:23 [Lund: Gleerup, 1970], 123).

${ }^{2}$ Bertolucci, 192.

3 bid., 192. 
A. vs. 12 mine O star of the moming, son of the dawn!")

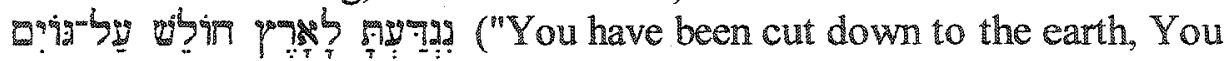
who have weakened the nations!")

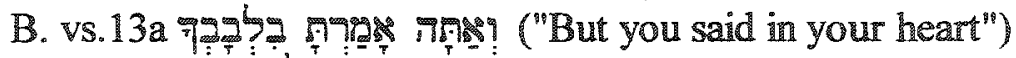

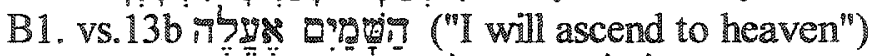

B2. v. 130 "No " the stars of God")

B2'. vs.13d 99ตัต assembly, in the recesses of the north")

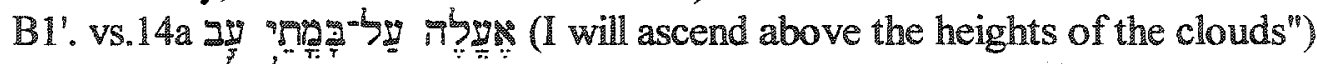

$B$ * vs.14b gig th ?

A. vs.15 9า to Sheol, to the recesses of the pit." $)^{1}$

Vss. $12(\mathrm{~A})$ and $15\left(\mathrm{~A}^{\prime}\right)$ frame the entire unit as they display verbal, syntactic, and conceptual parallels. The alliteration between $7 \mathrm{~s}($ "how") (A) and ("nevertheless") A" provides a alliterative parallel between $\mathrm{A}$ and $\mathrm{A}$; on the syntactic level one should note that both elements of the structure contain exclamatory sentences with $2 \mathrm{~ms}$ verbs; and semantically the clauses are expressions of wonderment before the fall of the tyrant. A chuster of grammatical constructions expressing the idea of "descent" further reinforces this idea: ㅁำ cut down to the earth") in vs. 12; 797. gigne ("you will be thrust down to Sheol") and

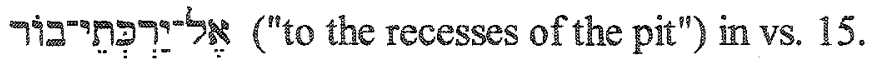

B (vss. 13 and 14) forms the center or the pericope, and is set apart from $A$ by a disjunctive vav. Its six verbal clauses are thus structured: The first clause, which contains the transitive verb "7ms ("say"), is complemented by five object clauses describing the pretensions of the tyrant. These clauses, except the last one, are also structured in a

"With some substantial modifications, this structure follows Willem S. Prinsloo, "Isaiah 14:12-15-Humiliation, Hubris, Humiliation," ZAW 93, no. 3 (1981): 432-38. 
chiastic arrangement. $\mathrm{B} 1$ (vs. $13 \mathrm{~b}$ ) parallels $\mathrm{Bl}^{\prime}$ (vs. 14a) in that both contain the verbal phrase 7 לมg ("heights of the clouds"). Finally, one notes that B2 (vs. 13c) and B2' (vs. 13d) make the apex of the structure.

At this point it should be observed that these two central members also parallel each other by containing two words which are syntagmatically related throughout the Hebrew Bible (i.e, 109 and 200 ' respectively). Thus, B2 (vs. 13c) refers to the tyrant's intention of raising his "throne (rog) above the stars," and B2' (vs. 13d) refers to his pretension of "sitting" (2שe") on the "mount of the assembly." As for $14 b\left(B^{*}\right)$, although it parallels the four previous clauses, it does not fit into their chiastic arrangement and therefore should be left out as an anacrusis. At that position, at the end of a list of five pretensions, it can appropriately function as a fitting expression of the ultimate intention of the tyrant, as implied in previous clauses-" the very apex of the entire structure is revealed the tyrant's ambition of reaching heaven ${ }^{1}$ (i.e., the "mount of assembly)." The ensuing discussion will attempt to lay bare the implications of this fact for the heavenly sanctuary/temple motif.

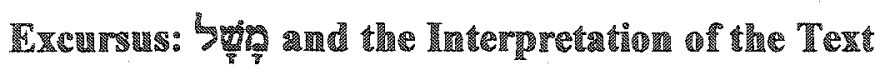

The entire section of $14: 4-21$ is classified in vs. 4 as a bogis, a word with the basic meaning of "simile," or "comparison," often employed with a negative comnotation. ${ }^{2}$ For

Interestingly, this achoes the pretensions of the builders of Babel in Gen 11:1-9. Cf. Mauchline, 140; Leupold, 260.

${ }^{2} 1$ Kgs 9:7; Jer 24:9; Ezek 14:8; Joel 2:17; Ps 44:15 [14]; 2 Chr 7:20. 
example: "You make us a bשָir among the nations, a laughingstock among the peoples" (Ps 44:15 [14]). It seems that the idea is that of someone or something being held as "a negative example in order to discourage others from following the same path. ${ }^{\text {"1 }}$ In other words, the person or situation object of the Swis becomes paradigmatic in a negative sense. $^{2}$

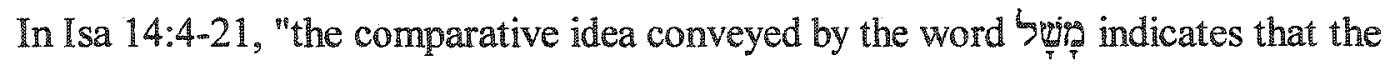
prophet was comparing the king of Babylon to a certain proverbial figure. ${ }^{103}$ The implication of this view is that Isaiah is portraying two intertwined persons and situations. The primary event, the rebellion of a supernatural being, functions as a paradigmatic negative example to the King of Babylon. To use the language of typology, Helel ben Shahar is the antitype (Urbild/Vorbild), and the historical king of Babylon is the type (Nachbild). It thus becomes apparent that, as the ל⿻ figures emerge- $-\mathrm{A}$ foolish king and a cosmic usurper." The expression "King of Babylon" thus seems to transcend its historical referent, pointing to the character and actions of another tyrant, whose rebellion against $\mathrm{YHWH}$ affected the cosmic realm.

"Gerald Wilson, "Swirg (mSL1)," NDOTTE, 2:1135.

${ }^{2}$ Besides, it should be noted that in several instances the mashal depicts an historical or factual person/situation (1 Kgs 9:7; Jer 24:9; Ezek 14:8; Joel 2:17; Pss 44:15 [14]; 69:11; 2 Chr 7:20). In fact, it seoms that for the mashal to be persuasive it must be based upon factual persons/events.

${ }^{3}$ Cf. Jeffrey Khoo, "Isaiah 14:12-14 and Satan: A Canonical Approach," STI 2 (1994): 69.

${ }^{4}$ Hugh Rowland Page, Jr., The Myth of Cosmic Rebellion: A Study of Its Reflexes in Ugaritic and Biblical Literature (Leiden: E. J. Brill, 1996), 130. 


\section{Excursus: 直entity of the ${ }^{2}$ ing of Rabylon}

Several historical figures such as Tiglathpileser III, ${ }^{1}$ Sargon II, ${ }^{2}$ Semacherib, ${ }^{3}$ Assurballit, ${ }^{4}$ Nabonidus, ${ }^{5}$ Nebuchadnezar, ${ }^{6}$ and Belshazar ${ }^{7}$ have been proposed as the tyrant referred to in the pericope. However, each of these proposals faces insurmountable difficulties. As Oswalt observed, "no single personage can be found, the events of whose life fully correspond to those of the individual in the song. None of the kings of the NeoBabylonian empire (e.g. Nebuchadrezzar or Nabonidus) fits, nor do any of the Assyrian kings of Isaiah's day (Sargon II or Semacherib)." ${ }^{18}$ Furthermore, as Wolf pointed out the

${ }^{1}$ Charles Boutflower, The Book of Lsaiah, Chapters [1-XXXIX], in the Light of the Assyrian Monuments (New York: Society for Promoting Christian Knowledge; Macmillan, 1930), 79.

${ }^{2}$ H. L. Ginsberg, "Reflexes of Sargon in Isaiah after 715 B.C.E.," in Essays in Memory of E. A. Speiser (New Haven, CT: American Oriental Society, 1968), 49-52; Herbert, 102; Hugo Winkler, Die Keilinschriften und das Alte Testament (Berlin: Reuther and Reichard, 1903), 26:28.

${ }^{3}$ W. H. Cobb, "The Ode in Isaiah XIV," JBLang 15 (1896): 27; Mauchline, 143.

${ }^{4}$ Auvray, 163.

${ }^{5}$ Emil Gottlieb Heinrich Kraeling, Commentary on the Prophets (Camden, NI: T. Nelson, $1966), 1: 86-87$.

${ }^{6}$ Hermann Eising, Das Buch Jesaja, 2nd ed. (Duisseldorf: Patmos-Verlag, 1987), 1:122; Solomon Bennett Freehof, Book of Isaiah: A Commentary (New York: Union of American Hebrew Congregations, 1972), 90-91; 1. W. Slotki, Isaiah: Hebrew Text and English Translation (London: Soncino Press, 1949), 69-70.

${ }^{7}$ Ridderbos, 144.

${ }^{8}$ Oswalt, 314. 
fact that "neither the rulers of Assyria nor Babylon claimed to be divine" makes very difficult an exclusive application of the passage to a human referent. ${ }^{1}$

Some scholars have suggested a collective or corporative application for the king of Babylon, according to which the song does not refer to a single individual, but to a class. ${ }^{2}$ According to this view, "the King of Babylon here, like Babylon itself in chapter 13 , is a representative figure, the embodiment of that worldly arrogance that defies God and tramples on others in its lust for power. ${ }^{n 3}$

However, this collective or corporative view also has its problems. $\mathrm{A}$ close reading of the passage seems to indicate that Isaiah is speaking of an individual. It is difficult to imagine how a collective entity would try to put his "throne" above the stars, or "seat" on the Mount of Assembly. It should also be noted that this entity is contrasted and compared to the other (individual) kings of the earth who had already gone down to Sheol. Furthermore, the rhetorical question "Is this the man (ving who made the earth tremble?" (14:16c) indicates that the referent is an individual, and not a collective entity. Alhough

'Herbert M. Wolf, Interpreting Isaiah: The Suffering and Glory of the Messiah [Grand Rapids: Zondervan, 1985], 113).

${ }^{2}$ Walther Eichrodt, Der Herr der Geschichte. Jesaja 13-23 und 28-39 (Stuttgart: Calwer Verlag, 1967), 23; Gray, A Critical and Exegetical Commentary on the Book of Isaiah 1-39, 261; Wolf, 112.

${ }^{3}$ Barry G. Webb, The Message of Isaiah: On Eagles' Wings, The Bible Speaks Today (Leicester, England: Inter-Varsity Press, 1996), 83.

${ }^{4}$ As noted by McCosmiskey, "connotes primarily the concept of man as an individual and thus differs in that regard from the more general concepts inherent in the words 'énós and 'ädam (mankind)" (T. E. McCosmiskey, "ras " $y s h$, "TWOT, $1: 38$, emphasis supplied). The use of vis nevertheless does not necessarily restrict the referent to an individual of the human race. It

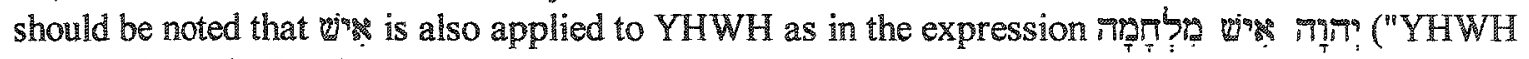
is a warrior"), in Exod 15:3. 
none of these arguments is by itself decisive, their combined effect makes a collective or corporative interpretation rather improbable.

What seems reasonable in view of the nature of the pericope and its overall context, is that the prophet intermingles historical and cosmic realities. That is, behind the local historical king of Babylon emerges the figure of the cosmic king of Babylon, the real power which stands behind the local tyrant. This possibility is reinforced by the use of the

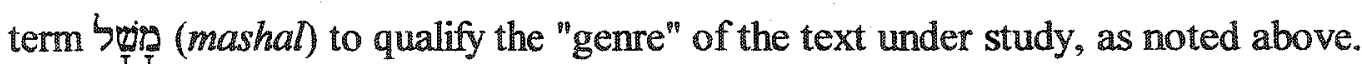

\section{Cxcursus: Alleged Mythological Background of 14:12-15 and the Referent of Helel ben Shahar}

Several suggestions have been advanced in an effort to link the pericope of Isaiah with ancient Near Eastern mythology. Connections with Sumero-Babylonian, ${ }^{1}$ Hittite, ${ }^{2}$ Egyptian, ${ }^{3}$ Greek, $^{4}$ Ugaritic, ${ }^{5}$ and South Arabic ${ }^{6}$ have been proposed. However, a major

'Hermann Gunkel, Schöpfung und Choos (Göttingen: Vandenhoeck and Ruprecht, 1895), 134; Boutflower, 77-78; Gray, A Critical and Exegetical Commentary on the Book of Isaiah 139, 225-26; Hugo Gressmann, Der Messias (Göttingen: Vandenhoeck and Ruprecht, 1929), 16570; G.W. Wade, The Book of Habakkuk, Westminster Commentaries 31 (London: Methuen, 1928), 100-101.

2Paul D. Hanson, "Rebellion in Heaven, Azazel, and Euhemeristic Heroes in 1 Enoch 611," JBL 96, no. 2 (1977): 207-09; Marvin H. Pope, E⿰ in the Ugaritic Texts, VTSup 2 (Leiden: Brill, 1955), 97.

${ }^{3} \mathrm{Cf}$. G. Keown, "A History of Interpretation of Isaiah 14:12-15" (Ph.D. diss., Southern Baptist Theological Seminary, 1979), 122-23.

${ }^{4}$ Delitzsch, 311; Bernhard Duhm, Das Buch Jesaia, 5th ed. (Göttingen: Vandenhoeck und Ruprecht, 1968), 119; Pierre Grelot, "Isaie 14:12-15 et son arrière-plan mythologique," Revue de l"Histoire des Religions 149 (1956): 18-48; J. W. McKay, "Helel and the Dawn-goddess: A Reexamination of the Myth in Isaiah 14:12-15," VT 20 (1970): 451-64.

5William Foxwell Albright, Archaeology and the Religion of Ispael (Baltimore: Johns Hopkins Press, 1942), 84; William Foxwell Albright, Yahweh and the Gods of Cancan: A 
problem remains-there is no single myth which matches the Isaiah passage in its totality. Tentative reconstructions are based on fragments from different myths which are put together in an attempt to provide a parallel to the Isaiah pericope.

After surveying the extrabiblical literature on the alleged mythological background of the pericope, Bertolucci concluded that "there is no myth of Helel ben Shahar which reflects the Isaian account in its totality." Bertolucci allows that in framing his lament against the tyrant, Isaiah may have used the imagery of Venus, the morning star, which appears early at dawn, but vanishes as the sun rises. ${ }^{3}$ Yet, the possibility of a common tradition shared by Israel and its neighbors also remains a possibility, as shown in the imagery and motifs contained in the pericope. For example, the motif of the "mount of assembly" and the "north" as the dwelling of the deity are also found in Ugaritic texts; ${ }^{4}$ and Hittite texts allude to a battle in heaven when a member of the heavenly council tried to

Historical Analysis of Two Contrasting Faiths (London: Athlone Press, 1968), 201-02; E. Theodore Mullen, Jr., The Assembly of the Gods, ed. Frank M. Cross, HSM 24 (Chico, CA: Scholars Press, 1980), 35-39; 227-45; Peter C. Craigie, "Helel, Athtar and Phaethon, Jes 14:1215 ," ZAW 85, no. 2 (1973): 223-25; D. Loretz, "Der Kanaanäische-Biblische Mythos vom Sturz des Sahar-Sohnes Helel," UF \& (1976): 133-36; Mauchline, 140; S. H. Widyapranawa, The Lord Is Savior: Faith in National Crisis: A Commentary on the Book of Isaiah 1-39 (Grand Rapids: Eerdmans, 1990), 88.

"Ulf Oldenburg, "Above the Stars of El: El in Ancient South Arabic Religion," ZAW 82, no. 2 (1970): 187-208. Cf. Keown, 131.

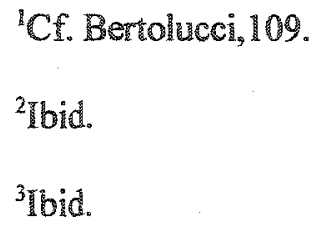

${ }^{4}$ For a survey of Ugaritic texts, see chapter 2 of this dissertation. 
overthrow the chief deity of the pantheon.' Mention is also made of an attack on the sanctuary of the deity. ${ }^{2}$ Probably the best explanation for the similarities and differences involving this and other passages of the Hebrew Bible would be that Israel and its neighbors shared some common traditions.

The question then emerges as to who is the referent of Helel ben Shahar. As noted in the previous section, attempts to identify the king of Babylon with a single human individual have been found wanting. Also, as noted above, the pericope cannot be made to fit into mythological figures known from ancient Near Eastern texts. Taking the context into consideration, It becomes apparent that Isa 14:12-15 deals with events transpiring in the heavenly realm. What emerges seems to be the attempt by one of the members of the divine council to overtake YHWH's position on the "mount of the assembly," or, in other words, to overtake the heavenly sanctuary/temple of YHWH, as noted below. The figure of Helel ben Shahar, therefore, should probably be identified with that of a superhuman rebel who turned himself against YHWH and in the process was expelled from heaven.

\section{Semantic and Other Exegetical Considerations}

The three expressions selected for investigation are potentially related to the semantic field of sanctuary/temple. Since the context of the entire pericope, as

'See Page, 120-40.

"See Roy Gane, "Hurrian Ulikummi and Daniel's 'Little Horn"," in Shalom Paul Festschrift, forthcoming. See the discussion on the "Myth of Ullikummi" in chapter 2 of this dissertation. 
demonstrated above, points to the heavenly realm, an investigation of these expressions may contribute to a better perception of the heavenly sanctuary/temple motif.

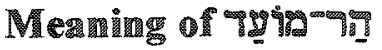

Scholars have long noted the widespread ancient Near Eastern concept of a cosmic mountain which functioned as the abode of the deity. ${ }^{1}$ Ugaritic texts refer to Mount Zaphon, on top of which Baal's temple was located, and the mount of El's abode at the source of the two rivers. Although these traditions should not be used as a hermeneutic key to unlock the meaning of "תר- ("mount of assembly") in Isa 14:13, it should be kept in mind that the concept of a mount functioning as the locus of a temple/sanctuary was a common tradition which Israel shared with its ancient Near Eastern neighbors. However, it should be noted that Israel interpreted this tradition within the framework of the Yahwistic faith. This makes it necessary that the expression רצָ ("mount of assembly") be understood in the context of the Hebrew Bible.

The exact expression פער ("mount of assembly") occurs only in Isa 14:13 in the entire Hebrew Bible. Yet its component parts, רฮี ("mount") and "มู่ ("assembly"), occur several times in connection with sanctuary imagery. The lexeme רin evokes temple/sanctuary imagery in many Hebrew Bible texts, and, as noted by Vogel, "the climax of the usage of the mountain motif as referring to a cultic location in the OT

${ }^{1}$ Cf., e.g., Richard J. Clifford, The Cosmic Mountain in Canadn and the Old Testament, Harvard Semitic Monographs 4 (Cambridge, MA: Harvard University Press, 1972); Richard J. Clifford, "The Temple and the Holy Mountain," in The Temple in Antiquity: Ancient Records and Ancient Perspectives, ed. Truman G. Madsen, The Religious Studies Monograph Series 9 (Provo, UT: Brigham Young University, 1984), 107-24. 
context undoubtedly has to be seen in the tradition of Mt. Zion." "Yet one should note that it was mainly the presence of the temple on the top of it that made Mt. Zion a cultic location par excellence. Therefore, since the sanctuary was situated on the mountain, the two are frequently used interchangeably, and as Vogel aptly pointed out, "whenever the holy mountain is being mentioned, the sanctuary is being perceived at the same time and vice versa. ${ }^{113}$ That being the case, it becomes apparent that the lexeme 7 in our text ("mount") evokes the idea of a sanctuary/temple.

As for the lexeme 7g9im, it means either place of meeting, or time of meeting. ${ }^{4}$ Koch's suggestion that in Isa 14:14 7g gods) ${ }^{* 5}$ is mistaken. In the present context, its association with "97" ("mount") conveys the idea of a specific place, which recalls the use of pygis to denote the sanctuary or temple in several biblical passages. ${ }^{6}$ Besides, the syntagmatic relationships and the parallel terms clearly show that the emphasis is on the spatial dimension. For example, the verbs convey spatial and vertical movement. Helel ben Shahar intended to "go up" (It's) above the

\footnotetext{
"Winfried Vogel, "The Cultic Motif in Space and Time in the Book of Daniel" (Th.D. diss., Andrews University, 1999$), 36$.

${ }^{2}$ Ibid., 38 ; cf. Exod $15: 17$; Isa $2: 3 ; 56: 7 ; 66: 20$; Jer $26: 18$; cf. Vogel, $38-39$.

${ }^{3}$ Vogel, 39.

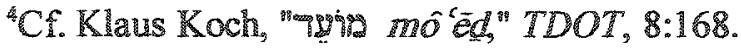

${ }^{5}$ Ibid., 171.

6For example, in Ps 74:4 7gmig ("your meeting place") is just another tem for sanctuary.

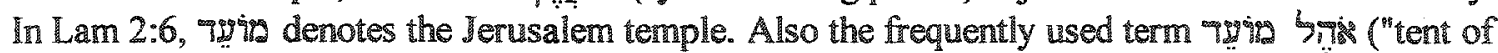
meeting") is another expression used for the "tabernacle" or "sanctuary" which occurs 146 times in the Hebrew Bible (cf. Exod 27:21; 28:43; 29:4, 10f., 30, 32, 42, 44; 30:16, 18, 20, 26, 36; $31: 7$; $33: 7 ; 35: 21 ; 38: 8,30 ; 39: 32,40 ; 40: 2,6 f, 12,22,24,26,29 f ., 32,34 f$. , et al.).
} 
Stars, "raise" (อv7) his throne, and "sit" (gw") on the mount of the assembly; and as a result of his ambition he "fell" (79") and "went down "(779) to the pit. The parallelism of the "mount of assembly" to "heaven" as demonstrated in the structural arrangement of the pericope further indicates the spatial connotation of $9 y+9$ in the passage under study.

In addition to expressing the temple/sanctuary idea, 799 î: also seems to connote some more specific aspects or function of the heavenly sanctuary/temple. If the etymology can be of any help, one should note that the idea behind 7yบหม, (7ע", "appoint, meet") may

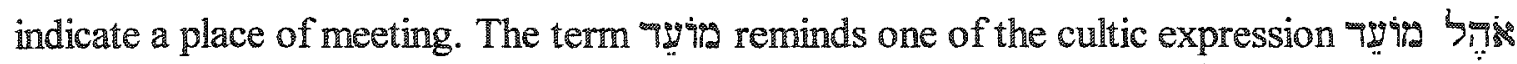
("tent of meeting"), which seems to suggest that the "mount of assembly" functioned as a place of cultic activities, among which worship may have been a prominent one. In this connection Davidson pointed out that Isa 14:13 "calls the Heavenly Sanctuary 'the mount of the congregation'-implying the original worship function of the Sanctuary before sin. $^{\text {"2 }}$ Another idea that seems conveyed by the term 79 in is that of the assembly, or council of YHWH, reflected elsewhere in the Hebrew Bible. ${ }^{3}$ That being the case, the "mount of assembly" would also be the place in heaven where the council of YHWH would convene under the leadership of YHWH himself. Therefore, on the basis of the foregoing

\footnotetext{
${ }^{1}$ See the structural arrangement above.

${ }^{2}$ Davidson, "Cosmic Metanarrative," 107.

${ }^{3}$ E.g., Isa 6:1ff., Ps 82, Job $1: 1$ ff., Dan 79ff.

${ }^{4}$ It seems difficult to determine with certainty whether the heavenly assembly of YHWH would consist of a selected group of heavenly beings or would include the entire host of unfallen creatures. Dan 7:9-14 — thousands upon thousands were attending him, and myriads upon myriads were standing before him" - seems to indicate that a great multitude of heavenly beings would form YHWH's entourage. It is not clear, however, whether Daniel depicts the full number of heavenly beings or just a selected group that stands closer to YHWH (more the discussion of Dan 7:9-14 in
} 
discussion, it has become apparent that the phrase 7y 19" "I ("mount of assembly") carries evident cultic connotations, indicating the place where YHWH receives worship and praise, ${ }^{1}$ and suggesting the idea of the heavenly sanctuary/temple as meeting place for the council of YHWH.

The task now is to ascertain the spatial location of 7giga"equ. The occurrence of "heaven" in the parallel line in vs. 13 points to heaven as the location of "มท่า" reinforced by the presence of such other terms as ב Sx-" g9y ("stars of God"). However, the "mount of assembly" should not be identified with heavens, as suggested by Watts. His contention that 72 ำ heavens ${ }^{\prime 2}$ is linguistically imprecise. It would be more correct to say that $799 \mathrm{gm}-7$ is a hyponym. Although 7g96 "7] parallels "heaven," and may overlap with it in significant ways, 7. in heaven. As a matter of fact, the very term "7gign, which is related to the root 799 ("to appoint"), carries the connotation of a specificlappointed place. In other words, the term 7 99 points to a particular place in heaven where the heavenly beings gather together to worship YHWH. Thus, on the basis of the foregoing consideration, the suggestion may be advanced that "iging indicates that heavenly sanctuary/temple of YHWH.

the next chapter).

"Davidson has observed: "Isa 14:12 calls the Heavenly Sanctuary "the mount of the congregation,' implying the original worship function of the Sanctuary before sin" "Cosmic Metanarrative," 107).

${ }^{2}$ Watts, Isaiah 1-33, 211. 


\section{Meaning of}

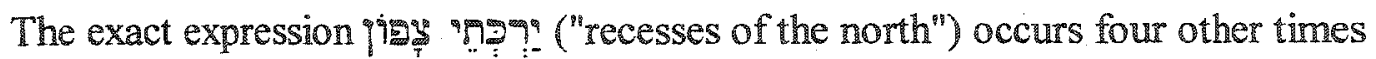
in the Hebrew Bible. In Ezek 38:6, 15; 39:2, it seems to indicate one of the cardinal points of the compass; and in Ps 48:3 [2], it refers to mount Zion. Isa 14:13, however, seems to be distinct from these other usages. It seems improbable that north") would refer either to mount Zion or one of the points of the compass. The parallel

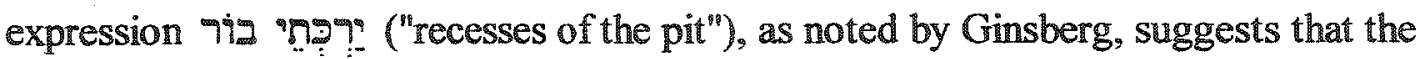
"?: "r: "recesses of the north") should be understood as the polar opposite of

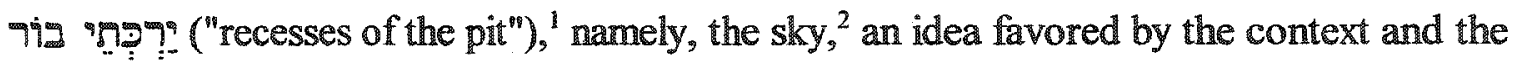
structure of the passage. Furthermore, the parallel between El") suggests that

Moreover, the concept of "north" is often associated with the dwelling of the deity both in the Hebrew Bible and other ancient Near Eastern texts. Ezek 1, for example, contains several references to the glory of YHWH coming from the north, thus locating YHWH's dwelling place in the north. Ugaritic literature also contains references to the north as the dwelling of the deity. Mt. Zaphon is mentioned in Ugaritic texts as the

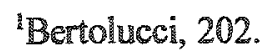

${ }^{2}$ Ginsberg pointed out that "sky' is precisely what spwn means in Job $26: 7$, where between its being governed by the verb $n t y$ (which so frequently governs smym, the commoner word for 'sky') and its standing in antithesis to 'earth' it admits no other interpretation. Our passage offers a bit of additional evidence: yarkte soppon [sic] stands in antithesis to yarktê bör, and the polar opposite of the netherworld is the sky, Amos 9:2; Ps 139:8. Nothing is gained by resisting this logic" (Ginsberg, "Reflexes of Sargon in Isaiah after 715 B.C.E," $51, n .26$ ). Cf. J. de Savignac, "Note sur le sens du terme sâphôn dans quelques passages de la Bible," VT 3 (1953): 95-96; Bertolucci, 203.

${ }^{3} \mathrm{Cf}$. Savignac, 95-96. 
dwelling of Baal. It is, however, improbable that the Isaiah text reflects any borrowing from the Ugaritic literature. A likely explanation would be that the ANE motif of the "north" as the locus for the dwelling of the deity was a common tradition used by Isaiah to fit his own theological purposes.

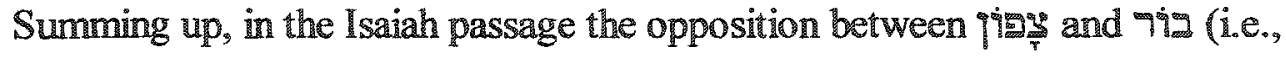

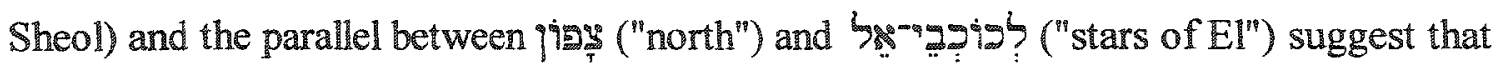
ๆต่มิ be understood as heaven.

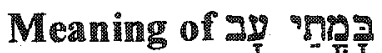

Cloud imagery, when associated with the presence of YHWH in the Hebrew Bible, ${ }^{1}$ may function either for concealment ${ }^{2}$ or transportation for the deity. ${ }^{3}$ As observed by Futato, "God's theophanic presence in or on the Q salvation (2 Sam 22:12// PS 18:13 [12]. "It has also been suggested that the association of ges ("cloud") with "Mr? ("heights of") may convey cultic connotations, since the Hebrew Bible often mentions the תirม ("high places") in connection with sacrifices

${ }^{1}$ Cf. J. Luzarraga, Las Tradiciones de la Nube en la Biblia y en el Judaismo Primitivo (Rome: Biblical Institute Press, 1973); Léopold Sabourin, "Biblical Cloud: Terminology and Traditions," BTB 4 (1974): 290-311.

${ }^{2}$ Job 22:1.

${ }^{3}$ Pss 68:5 [4], 34 [33]; 104:3; Deut 33:26.

${ }^{4}$ Mark D. Futato, "gix, 29:" NIDOTTE, 3:333. There are other passages worthy of mentioning in this connection. Exod 19:9 and Ezek 1:4 display the cloud motif in connection with the theophanic manifestation of YHWH. Another text is Dan 7:13, which mentions the "Son of man" coming "with the clouds of heaven." 
offered to the gods. Although it may be difficult to determine exactly which of these connotations the Isaiah passage intended to communicate, it seems reasonable to suppose that the cloud imagery is somehow linked to YHWH's abode. As a close look at the structural arrangement of the pericope demonstrates, the expression "heights of the clouds" (B1,' vs. 14a) matches "heaven" (B1, vs. 13b). If so, the "height of the clouds" would function in parallelism to "heaven," further defining or describing the realm of YHWH's abode.

\section{Heavenly Sanctuary/Temple Motif}

The discussion undertaken above allows the following perceptions about the heavenly sanctuary/temple motif. The expression רפר ("mount of the assembly") is to be understood as a spot located in the heavenly realm and, being suffused with sanctuary imagery, most probably connotes the idea of a heavenly sanctuary/temple.

\section{Function}

An interesting aspect that emerges from this investigation is the role of the heavenly sanctuary in the context of the controversy between good and evil. The heavenly sanctuary/temple as conveyed by the imagery of the "mount of the assembly" is the object of attack by Helel ben Shahar. This attack and the reaction to it are indicated by verbs connoting vertical movement: Tלy ("go up"), שר ("raise"), נפל (fall down), and 9aר ("go down"). Moreover, the use of 197 ("hew, hew down or off") $)^{2}$ in the expression

${ }^{1}$ Oswalt, 3222.

${ }^{2} B D B$, s.v. รั7ม. 


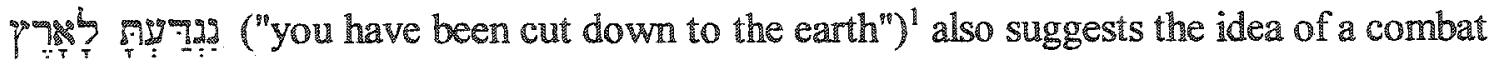
which resulted in the expulsion of the rebel. It is thus possible to affirm that at the very root of the controversy between good and evil as portrayed in Isa 14:12-15 lies the issue of who will control the mount of the assembly, that is, the heavenly sanctuary/temple. ${ }^{2}$

Summing up, the heavenly sanctuary/temple as reflected in the pericope through the imagery of the "mount of the assembly" functions in the following capacities: (1) as the dwelling place of God, (2) the meeting place of the heavenly assembly, and (3) the site of the cosmic war which resulted in the expulsion of the tyrant.

\section{Relationship to Earthly Counterpart}

The sanctuary/temple presupposed in the pericope functions in vertical correspondence to its earthly counterpart. This is indicated by the notion that the heavenly sanctuary/temple is a place of worship, a prominent function of the earthly temple, which indicates a functional correspondence between the heavenly temple and its earthly counterpart.

\section{${ }^{1}$ Isa $14: 12$.}

${ }^{2}$ The notion of a cosmic conflict between YHWH and an opponent who attacks his sanctuary/temple appears elsewhere in the Hebrew Bible, as noted in the activities of the little hom of Dan 7:8-14 and 8:9-14 (an investigation of these passages in carried out in chapter 5).

Furthermore, it should be noted that the concept of a cosmic conflict involving the sanctuary is not restricted to the Hebrew Bible. The mythology of the ancient world attests the idea of a conflict between the deities, or of an attack to the chief deity and his sanctuary/temple by a rebel god. In this connection, Roy Gane has contributed an insightful study in which he compares the HurrianHittite myth of Ullikummi (on the myth of Ulikummi, see chapter 2 of this dissertation) with the activities of the little horn in the aforementioned passages of Daniel. By means of Gane's study, it becomes apparent that the ancient world "would be familiar with many of the conceptual building blocks, which often involved cosmic and transcendent themes" (Gane, "Hurrian Ullikummi and Daniel's 'Little Horn," forthcoming). 
Eqe $1: 1-281$

The first chapter of Ezekiel is beset with textual and linguistic difficulties that have drawn the attention of several scholars. ${ }^{2}$ Fortunately it is not necessary to solve or review these issues, since they do not affect the present research. For the purpose of this study, it will suffice to make some preliminary observations on the structure and purpose of the pericope, followed by some considerations of its contribution for the understanding of the heavenly sanctuary/temple motif.

${ }^{1}$ It should be kept in mind that Ezek 1:1-28 and 10:1-22 (to be discussed below) belong to the section of Ezek 1-11. This passages, although lacking explicit references to the heavenly sanctuary/temple motif, seem to convey the idea of a heavenly counterpart to the earthly Jerusalem temple as attested in the temple imagery portrayed in these chapters. In in vision of the movable throne, which reveals a relationship between the realia of the earthly temple and their heavenly counterparts.

${ }^{2}$ Block thus summarizes the problems of this chapter: (1) morphology (inconsistent and rare spelling), (2) grammar (confusion of gender and number, infinitive absolute used as finite verb), (3) style (asyndetic constrictions, redundancies, choppy staccato sentences, abrupt insertions), and (4) substance (puzzling images incoherently conjoined). Daniel I. Block, The Book of Ezekiel: Chapters 1-24, NICOT (Grand Rapids: Eerdmans, 1997), 89. These problems have been variously explained as due to scribal lapses (Walther Eichrodt, Ezekiel: A Commentary, trans. Cosslet Quin [Philadelphia: Westminster, 1970], 55-56; Georg Fohrer, "Die Glossen im Buche Ezechiel," in Studien zzr alttestamentliche Prophetie [1949-1965] [Berlin: de Gruyter, 1967], 204-21; Kenneth S. Freedy, "Glosses in Ezekiel 1-24," VT 20 [1970]: 129-52); intrusions (Eberhard Baumam, "Die Hauptvisionen Hesekiels in ihrem zeitlichen und sachlichen Zusammenhang untersucht," ZAW 67, no. 1-2 [1955]: 57; Aclred Cody, Ezekiel, with an Excursus on Old Testament Priesthood [Wilmington, DE: M. Glazier, 1984], 25); later expansions (Walther Zimmerli, Ezekiel 1: A Commentary on the Book of the Prophet Ezekiel, trans. R. E. Clements, Hermeneia [Philadelphia: Fortress, 1979], 100-10; emotional state of the prophet (Daniel I. Block, "Text and Emotion: A Study in the 'Corruptions' in Ezekiel's Inaugural Vision [Ezekiel 1:4-28]," CBQ 50 [1988]: 418-42); diglossia (Daniel C. Fredericks, "Diglossia, Revelation, and Ezekiel's Inaugural Rite," JETS 41 [1998]: 189-99). 


\section{Preliminary Observations}

The vision reported in Ezek 1 has been generally considered as part of the call narrative, ${ }^{1}$ which includes chapters 2 and 3 . With some minor divergences several scholars would favor a fourfold subdivision of the pericope as follows: vss. 1-3 (heading), 4-14 (four living beings); vss. 15-21 (wheels), vss. $22-28$ (the glory of YHWH). ${ }^{2}$ The introduction (vss. 1-3) needs further consideration. These opening remarks introduce the call narrative and provide a chronological point of reference ${ }^{3}$ and outline what follows. By asserting that the experience of the prophet consisted of "visions of God" (1:1), "the word of YHWH" (1:3), and "the hand of YHWH" (1:3), the text establishes at the outset the main points to be developed in the first three chapters of the book. As noted by Low,

\footnotetext{
${ }^{1}$ John B. Taylor, Ezekiel: An Introduction and Commentary, Tyndale Old Testament Commentary (Downers Grove, IL: Inter-Varsity, 1969), 52-53.
}

${ }^{2}$ Alvin A. K. Low, "Interpretive Problems in Ezekiel 1" (Ph.D. diss., Dallas Theological Seminary, 1985), 7-8.

${ }^{3}$ A significant point of debate is the connection between the two chronological notes provided by the text in Ezek 1:1-3: "Now it came about in the thirtieth year, on the fifth day of the fourth month, while I was by the river Chebar among the exiles, the heavens were opened and I saw visions of God. On the fifth of the month in the fifth year of King Jehoiachin's exile, the word of YHWH came expressly to Ezekiel the priest, son of Buzi, in the land of the Chaldeans by the river Chebar; and there the hand of YHWH came upon him" (emphasis supplied). The task here is to ascertain what event this "thirtieth year" refers to. Although several explanations have been advanced to solve this problem, the most likely solution was proposed by Origen, according to whom the "thirtieth year" would refer to the age of the prophet. This has been supported by several scholars. Cf. Block, 82; Low, 58-124; Shea, Selected Studies on Prophetic Interpretation, 13; Bruce Vawter and Leslie J. Hoppe, A New Heart: A Commentary on the Book of Ezekiel, ITC (Grand Rapids: Eerdmans, 1991), 25; Christopher J. H. Wright, The Message of Ezekiel: A New Heart and a New Spirit, The Bible Speaks Today (Leicester, England: Inter-Varsity Press, 2001), 44. It should be kept in mind that at the age of thirty a priest would begin his duties in the ternple (cf. Num 4:3). Belonging to a priestly family (Ezek 1:1), Ezekiel must have felt in a special way the impact of the vision. Although exiled and therefore excluded from the temple ministry, the prophet was granted the privilege of glimpsing the "glory of YHWH" as the "heavens were opened" and he received "visions of God." Not surprisingly, throughout his book Ezekiel displays considerable interest in priestly matters. 
these three concepts are thus expanded: "visions of God:" $1: 4-28$; "word of YHWH:" $2: 1$ 3:11; "hand of YHWH:" 3:11ff.' For the purpose of this research it should be noted that the "visions of God" were received from the heavenly realm, as made clear by the following statement: "the heavens were opened and I saw visions of God" (Ezek 1:1). Therefore, the vision reported in 1:4-29 is structurally connected with events transpiring in the heavenly realm. The implication of this observation becomes clear in the ensuing discussion.

Some brief considerations about the purpose of the text are in order. Most scholars view it positively as a medium of consolation for the prophet and his people in exile, assuring them that YHWH is not circumscribed to the Jerusalem temple. ${ }^{2}$ However, some commentators have argued for a negative purpose according to which the vision should be understood as a message of judgment for YHWH's own people. ${ }^{3}$ It is beyond the scope of this study to rehearse this discussion; however, a few observations are in order.

It has been observed that the intertwined motifs of "storm theophany" and "throne theophany" reflected in the vision are frequently associated with YHWH's judgment in the

\section{${ }^{1}$ Low, 4-8.}

${ }^{2}$ Peter C. Craigie, Ezekiel, DSB (Philadelphia: Westminster, 1983), 12-14; Eichrodt, Ezekiel: A Commentory, 54; D. M. G. Stalker, Ezekiel (London: SCM Press, 1968), 45; John B. Taylor, Ezekiel: An Introduction and Commentary, The Tyndale Old Testament Commentary (Downers Grove, LL: Inter-Varsity, 1969), 41-42; Walther Zimmerli, Ezekiel 1: A Commentary on the Book of the Prophet Ezekie, trans. R. E. Clements, Hermeneia (Philadelphia: Fortress, 1979), 139-41.

${ }^{3}$ Leslie C. Allen, "The Structure and Intention of Ezekiel I," WT 43 (1993): 145-61; Richard Kraetzschmar, Das Buch Ezechiel (Göttingen: Vandenhoeck und Ruprecht: 1900), 7; William Hugh Brownlee, Ezekiel 1-19 (Waco, TX: Word Books, 1986), 18. 
Hebrew Bible." In the prophets, "the storm theophany genre is used to convey the intervention of Yahweh to bring judgment upon Israel." Furthermore, as argued by Allen on the basis of $1 \mathrm{Kgs} 22: 19-23$ and Isa 6 , the throne theophany evokes judgment. ${ }^{3}$ This seems supported by the reference to "fire" (Ezek 1:27), which may also be a subtle allusion to one of the instruments of YHWH's judgment.

The context of Ezek 1 also seems to favor the view that the vision intends to convey a message of judgment. One should keep in mind that Ezekiel was called to a "stubborn and obstinate" people (Ezek 2:4), and that eventually, the "glory of YHWH" would abandon the temple (Ezek 9-11). Therefore, Leslie C. Allen seems to be on solid grounds by emphasizing that the vision of Ezek 1 connotes judgment. However, it is not necessary to assume an either-or stance regarding this issue, as he seems to imply. ${ }^{4}$ The vision may have indeed functioned to bring both comfort and hope to the exiles and to serve as harbinger of the judgment soon to be poured out upon Jerusalem. One should not forget that judgment and salvation are two major poles of the Ezekiel message. Overali the prophetic message implies that athough YHWH would leave the temple, he would also come back to a temple built anew, as shown in Ezek 40-48. Thus in the light of the broad context of the book of Ezekiel, it could be argued that the inaugural vision might well

${ }^{1}$ Leslie C. Allen, "The Structure and Intention of Ezekiel I," 155.

2Ibid., 154. The following passages referred to by Leslie $\mathrm{C}$. Allen seem to support the connection between storm theophany and judgment: Amos 1:2; Mic 1:2-7; Isa 59:15-20; Mal 3:15.

\footnotetext{
3lbid., 155.

${ }^{4}$ Ibid., 153.
} 
have displayed this tension between judgment and salvation--a tension that appears throughout the entire book. ${ }^{1}$

\section{Semantic and Other Exegetical Considerations}

A fuller understanding of Ezek 1 must await the discussion of Ezek 10 below, where some significant themes and motifs reappear. For now, it should be noted that Ezek 1 seems to contain subtle allusions to the heavenly sanctuary/temple motif. For example, that "the heavens were opened and I saw visions of God" (1:1b) seems to imply the heavenly sanctuary. According to Zimmerli, this is the "only text in the book of Ezekiel which presupposes so clearly the heavenly dwelling place of Yahweh." ${ }^{12}$ Moreover, this is the only passage in the entire Hebrew Bible which mentions the opening of the heavens. This implies that the phenomena of the chariot and the cherubim supporting a platform with the throne of the "one like the son of man" should be understood in relation to heavenly realities. The movable throne approaching from the "north" (9ig heaven and brings down the realities of the heavenly temple of YHWH to the fray of human history.

The four living beings, later identified by the prophet as cherubim, were the living counterparts of the cherubim stationed at the holy of holies of the temple, as Ezek 10 makes clear. However, a most significant allusion to the temple/sanctuary motif is that of

"Robert R. Wilson, "Prophecy in Crisis: The Call of Ezekiel," Int 38 (1984), 117-30.

${ }^{2}$ Zimmeri, 116.

${ }^{3}$ See above, the discussion on ๆigs ("north") in connection with our study of Isa 14:12-15. 


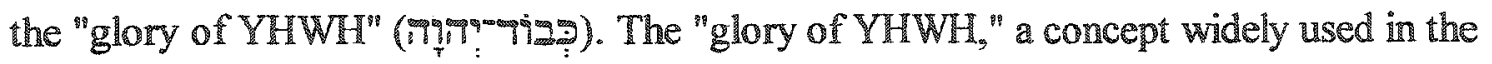
Hebrew Bible to convey the reality of YWHW's presence in the earthly sanctuary/temple, appears in the vision as coming from the heavenly realm and being carried by the heavenly beings whose earthly counterparts were located in the most holy place of the Jerusalem temple. Thus the mention that the "heavens opened" along with the reference to the "living beings," later identified with cherubim carrying the "glory of YHWH," evokes heavenly temple imagery. The implication is that the throne of YHWH leaves its location in heaven and comes to interact with the dynamics of human history.

At this juncture, it is instructive to consider the intertextual connections of Ezek 1 with other texts which convey the heavenly sanctuary/temple motif. The "glory of YHWH" and the pavement of his throne echo Exod 24:10-18; the presence of YHWH on his heavenly throne reminds one of $1 \mathrm{Kgs} \mathrm{22:19}$; the living beings carrying the "firmament" with the glory of YHWH reminds one of YHWH riding on a cherub in 2 Sam 22:11 (par. Ps 18:11 [10]). It is instructive to note that all these passages contain allusions or direct references to the heavenly sanctuary/temple and, although they should not determine the exegesis of Ezek 1, they do demonstrate that the concepts and imagery conveyed by the Ezekelian vision are those frequently conjoined with the heavenly sanctuary/temple. Nevertheless, in distinction to other references to heavenly sanctuary imagery, Ezek 1 presents a situation in which the heavenly realiries come down to interact with human affairs and, in a special way, with the earthy temple, as noted below. In this regard, one must keep in mind that the context in which these heavenly realities intersect with human affairs is that of judgment. As argued in the previous section, the imagery and motifs 
reflected in the pericope seem to suggest that YHWH comes as a judge, which is

congruent with the context, as shown by the next chapters of the book.

Thus, although the vision of Ezek 1 does not focus primarily on a sanctuary/temple located in heaven, it presupposes and evokes such an entity. The entire manifestation of YHWH has heaven as its point of departure, as implied in the statement that "the heavens were opened" and further corroborated by the reference to the "north." Furthermore, the "living beings" (i.e., cherubim) carrying the throne platform, and the majesty of the "glory of YHWH" altogether undoubtedly convey heavenly temple/sanctuary imagery. ${ }^{1}$ The major focus of the vision, however, seems to be on the interaction between the realities of the heavenly sanctuary/temple and the affairs of human history—an interaction which manifested itself in acts of judgment upon YHWH's temple and his impenitent people.

'Some scholars have tried to find the background of the imagery employed in the vision of Ezek 1 in the ancient Near Eastern iconography (e.g., Christoph Uehlinger and Susanne Müller Trufaut, "Ezckiel 1, Babylonian Cosmological Scholarship and and Iconography: Attempis at Further Refinement," TZ 57 [2001]: 140-71; Othmar Keel, Jahwe-Visionen und Siegellcunst: eine neue Deutung der Majestätsschilderungen in Jes 6, Ez 1 und 10 und Sach 4 [Stuttgart: Verlag Katholisches Bibelwerk, 1977]). In this regard the observation of Taylor is well taken: "It is tempting to search for some kind of prototype for these creatures among the composite animal figures carved on Babylonian temple and Hittite city-gates, but there is no evidence for anything more than a general influence from Egyptian and other Near Eastern art-forms with which Ezekiel must have been familiar. Almost certainly the final form is Ezekiel's own, and it reflects his passion for the symmetrical which we shall see again in the architecture of the future temple" (Taylor, 55). Craigie seems to concur with Taylor when he says that "the beings bearing the chariot are inevitably reminiscent of the cherubic figures that supported the ark of the covenant (1 Sam 4:4) which was kept in the temple in Jerusalem. And the chariot-like vehicle of the vision recalls that the ark itself was called a chariot (1 Chron. 28:18) (Craigie, Ezekiel, 11 ). 
Heavenly Sanctuary/Temple Motif

\section{Function}

From the brief discussion undertaken above, it has become apparent that the main function of the heavenly sanctuary/temple is that of judgment. The glory of YHWH and the attendant heavenly beings come to the earthly temple to undertake a work of investigative judgment against Judah.

\section{Relationship to Earthly Counterpart}

The previous discussion of Ezek 1 allows the inference that the heavenly temple exists in a functional correspondence to the earthy counterpart. This may be perceived in the notion that the glory of YHWH comes down to perform a work of judgment. Additional details regarding other aspects of this vertical correspondence are treated in the next section.

\section{Ezek 10:1-22}

Ezek 10 is closely connected with Ezek 1, inasmuch as the latter depicts the coming of the "glory of YHWH" from the east, and the former its interactions with the Jerusalem temple. When chaps. $1-11$ are taken as a whole, one perceives that the coming of the "glory of YHWH" depicted in chap. 1 is directional and eventually finds its way into the holy of holies of the Jerusalem temple. ${ }^{1}$ Therein it sits for a short while to perform a

"Shea observed that "the principal point of the vision in the first chapter of Ezekiel is that God was in transit by means of his celestial chariot to the site of his earthly residence, his temple in Jerusalem" (Selected Studies on Prophetic Interpretation, 1:44). Cf. Idem, "The Investigative Judgment of Judah," 283-91. 
work of judgment. At the end of the trial, as an ultimate expression of the doom of the temple and city, the glory of YHWH moves from the golden cherubs of the holy of holies to their living counterparts ${ }^{1}$ stationed at the entrance of the temple, thus abandoning the temple and the city.

\section{Preliminary Observations}

Ezek 10 displays a well-crafted structure, which is integrated to the larger section of chap. 8-11. Parunak has suggested the following structure for this section: ${ }^{2}$

$8: 1-4$ Convocation of the Trial

8:5 -9:11 Lawsuit of the Lord against Israel 10:2 Temple

10:3 Chariot

10:5 Chariot

10:4 Temple: The glory of YHWH moves from the cherub 10:5-7 Temple

10:8-17 Chariot

10:18 Temple

10:19a Chariot: The cherubim move from the earth 10:19b Temple

10:20-22 Chariot

11:1-21 Lawsuit of the Lord against Israel

11:22-25 Convocation of the Trial

\footnotetext{
'The correspondence between the living cherubim (i.e., the four living beings mentioned in Ezek 1), who bore the glory of YHWH, with the pair of golden cherubim statues in the most holy place of the earthly temple has been noted, e.g., by Menahem Haran, "The Ark and the Cherubim: Their Symbolic Significance in Biblical Ritual," Israel Exploration Joumal 9 (1959): 91; Shea, "The Investigative Judgment of Judah," 288-89; and Moshe Greenberg, Ezekiel 1-20, AB 22 New York: Doubleday, 1983), 192-99.

"Henry V. D. Parunak, "The Literary Architecture of Ezekiel's Mat'ôt 'Elohîm," JBL 99 (1980): 61-74. The layout of this structure was rearranged for the sake of simplicity.
} 
As can be observed in the structure displayed above, Ezek 10 is the apex of a larger chiastic arrangement focusing on the "sacral judgment." Moreover, as the structure shows, Ezek 10 consists of two parallel chiasms, the foci of which are 10:4 and 10:19a. The former shows the "glory of YHWH" moving from the "cherub" to the threshold of the temple. The latter depicts the heavenly cherubim bearing the "glory of YHWH" moving from the earth. Thus, as can be noted, vs. 4 focuses on the "cherub," namely the golden cherubim placed upon the ark of the covenant in the most holy place of the temple, while vs. 19a focuses on the heavenly cherubim stationed with the heavenly chariot at the entrance of the temple. This structure seems to demonstrate a correspondence between the heavenly cherubim and their earthly counterparts. Both the living ones and their reflex on the golden counterparts seem to have functioned in a similar fashion since both sets were supposed to work in connection with the "glory of YHWH."

It is worth noting at this juncture that the entire passage portrays a situation of judgment. William Shea has referred to it as an "investigative judgment," 2 according to which YHWH came to perform a special work of investigation in the temple before the final pouring out of divine wrath. In this "investigative judgment," two superimposed pictures emerge. One picture would be that of the earthly/historical entities who would act to judge the nation by killing the people and destroying the city and temple. These were the historical enemies embodied by the Babylonians. The other picture would be a

I'Ibid., 68.

${ }^{2}$ Shea, "The Investigative Judgment of Judah," 282-91; idem, Selected Studies on Prophetic Interpretation, 1:44. Parunak uses the terms "covenant lawsuit" and "sacral judgment," (66-69). 
"glimpse of the 'upper story' of events," which portrays YHWH himself acting in the supernatural realm that could only be perceived by the prophetic eye.

Thus when the Babylonians came, the destiny of the people had already been sealed by decisions in the supernatural realm. The movable throne bearing the glory of YHWH had come down to interact with its earthly counterpart and eventually to void the latter as an expression of the ultimate doom to fall upon the nation.

Heavenly Sanctuary/Temple Motif

\section{Function}

As noted above, the main function of the temple in Ezek 10 is that of judgment. YHWH came down from the heavenly temple to perform the investigative judgment of Judah prior to the destruction of the nation and its earthly temple.

\section{Relationship to Carthy Counterpart}

As noted above, although Ezek 10 does not portray a sanctuary/temple located in heaven, this chapter (along with Ezek 1) depicts heavenly realities coming down to interact with the earthly temple. This dynamic interaction can be observed in the heavenly chariot and its heavenly cherubim bearing the glory of YHWH. It can be inferred by the context that the heavenly chariot brought the glory of YHWH to the temple where it took residence for a few months to carry out a work of judgment.

As the vision unfolds, the correlation between the heavenly realia and the earthly temple becomes clear. First, it should be noted that the place of YHWH's enthronement

${ }^{1}$ Greenberg, Ezekiel 1-20, 202. 
above the cherubim in the most holy place corresponds to his heavenly enthronement above the heavenly chariot. Second, the living cherubim of the heavenly chariot correspond to their golden counterparts in the most holy place of the Jerusalem temple. 㨁 is instructive to note that the "living creatures" referred to in Ezek 1 are explicitly called "cherubim" in Ezek 10. By means of this terminological specification the prophet makes clear the connection between the heavenly cherubim and their earthly counterparts.

Therefore, the text implies a structural correspondence between the holy of holies of the earthly temple and the heavenly realities expressed by the heavenly chariot borne by the live cherubim. As noted above, it has been recognized that the cherubim stationed in the inner sanctum of the earthly temple were intended to represent their heavenly counterparts. That being the case, it may be argued that the heavenly chariot and its cherubim were the heavenly antitypes of the earthly temple. If so, it may be argued that the heavenly temple would exist in functional and structural correspondence to its earthly counterpart.

Besides, the text also allows one to infer a functional correspondence between heavenly realia and their earthly counterpart. As already noted, the special work performed in connection with the temple in Ezek 10 is that of judgment. As William Shea pointed out, YHWH came to the temple to perform a work of judgment. This judgment obviously involves a work executed in/from the most holy place of the Jerusalem temple, and at the same time is connected with the heavenly chariot stationed at the entrance of the temple. It is worthy of note that the fire of judgment to punish the city is taken from the midst of the living cherubim who bore the heavenly chariot. 
Summing up, although Ezek 10 does not depict a clear picture of a

sanctuary/temple located in heaven, it shows a dynamic interaction and a vertical

correspondence (functional and structural) between the heavenly realities and the earthly

counterparts.

\section{ERek 28:11-19}

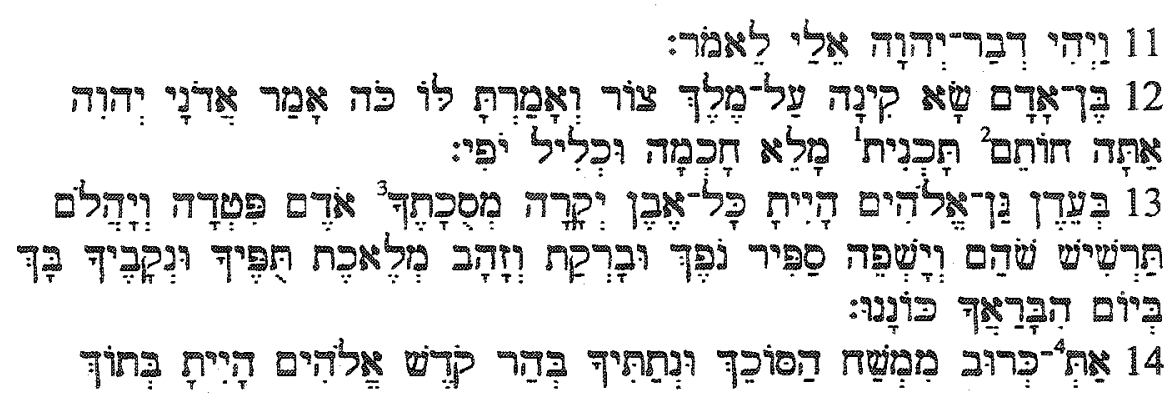

"The word חינִ has an Akkadian cognate, taknitu, and means "careful production" or

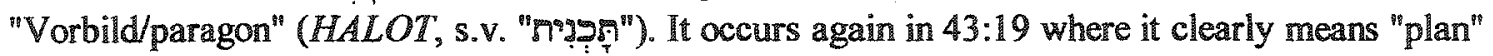
or "pattern." G. R. Driver proposed the phrase to be translated as "seal of perfection" which would qualify its referent as "a perfect work of an" (Linguistic and Texrual Problems, 159). Although, the text is admittedly difficult, Driver's suggestion seems to make sense in view of the context, which emphasizes the beauty and perfection of the cherub.

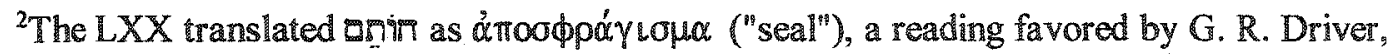
"Ezekiel: Linguistic and Textual Problems," Bib 35 (1954): 159.

3ng might be understood either in the sense of the precious stones being placed on the garments, or of their being part of the topography. If Frspos is understood to derive from the root $7 \%$, "to fence" or "hedge," the stones might belong to the topography, or be part of the wall of the sanctuary. On the other hand, if ๆกร be part of the garments of the cherub. The intertextual connections with the garments of the high priest seem to favor the latter possibility. Besides, since the context suggests that the cherub describes his beauty, it seems more plausible that the stones were part of his garments.

${ }^{4}$ This is one of the most problematic verses of this passage. The first word in the phrase 29797- according to the consonantal text could be read either as a pronoun or a preposition: (1) LXX translates nas as HeTd (with): "With the anointed cherub I placed." This reading is favored by those scholars who regard the text as a variant version of the Eden "tradition" in Gen 3 . According to this view, the cherub in Ezek 28 would not be the subject of the lamentation, but another being, "the first man" (Walther Eichrodt, Ezekiel: A Commentary, 392-93; John B. Taylor, Ezekiel: An 
政 15

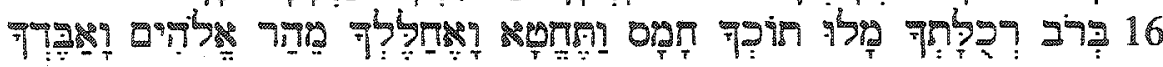

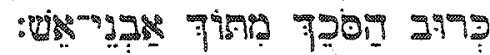
17

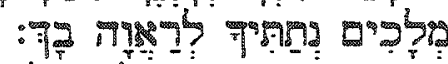

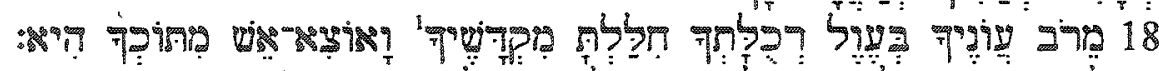

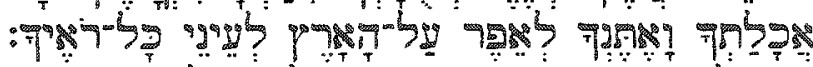
11 Again the word of YHWH came to me saying, 19 12 "Son of man, take up a lamentation over the king of Tyre and say to him, Thus says YHWH God, "You had the seal of perfection, full of wisdom and perfect in beauty. 13 "You were in Eden, the garden of God; every precious stone was your covering: The ruby, the topaz and the diamond; the beryl, the onyx and the jasper; the lapis lazuli, the turquoise and the emerald; and the gold, the workmanship of your settings and sockets, was in you. On the day that you were created they were prepared. 14 "You were the anointed cherub who covers, and I placed you there. You were on the holy mountain of God; you walked in the midst of the stones of fire.

Introduction and Commentary, TOTC [Downers Grove, IL: Inter-Varsity, 1969], 196-97; Walther Zimmerli, Ezekiel 2: A Commentary on the Book of the Prophet Ezekiel: Chapters 25-48, trans. James D. Martin, Hermeneia [Philadelphia: Fortress, 1983], 89-95). The problem with this view is that it makes a distinction-not supported by the text-between the "king" and the "cherub." Actually a look at vss. 12 and 13 reveals that (2) $\mathrm{x}$ is a pronoun: "You are the anointed cherub." The problem with this view is that the $\Omega$ is vocalized as feminine while "cherub" is masculine. However, a plausible solution was advanced by Van Dijk, who argued that "the stylistical and idiomatic similarity of vss. $12-13$ and vs. 14 suggests strongly the vocalization of 'atta [masc.] instead of 'et, 'with,' favored by many modern scholars" (H. J. van Dijk, Ezekiel's Prophecy on Tyre [Ez. 26:1-28:19]: A New Approach, BibOr 20 [Rome: Pontifical Biblical Institute, 1968], 119).

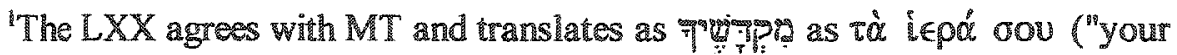
sanctuaries"). Targum and Syriac read T"tip? as singular "your sanctuary"; and the critical apparatus of BHS also suggests "my sanctuary" without pointing to any manuscript evidence. Although it is difficult to determine with certainty which is the best reading, it seems more prudent to keep the MT reading, and understand the plural to "denote a single sanctuary with its precincts," as suggested by A. S. Cooke, A Critical and Exegetical Commentary on the Book of Ezekiel, The International Critical Commentary (Edinburgh: T. and T. Clark, 1951), 324. That the plural "sanctuaries" could represent a single "sanctuary" seems to be favored by references to the Jerusalem temple in the plural. For example, in Ps 68:35 T"qup? ("sanctuaries") is used to refer to

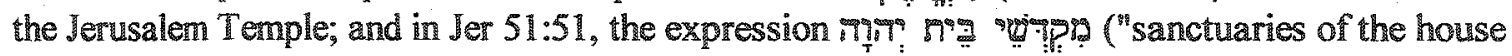
of YHWH") apparently denotes the several precincts of the Temple. Cf. also Lev $21: 23 ; 26: 31$; Ps $73: 17$. 


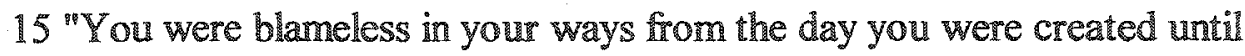
unrighteousness was found in you.

16 "By the abundance of your trade you were intemally filled with violence, and you sinned; therefore I have cast you as profane from the mountain of God. And I have destroyed you, $O$ covering cherub, from the midst of the stones of fire. 17 "Your heart was lifted up because of your beauty; you corrupted your wisdom by reason of your splendor. I cast you to the ground; I put you before kings, that they may see you.

18 "By the multitude of your iniquities, in the unrighteousness of your trade you profaned your sanctuaries. Therefore I have brought fire from the midst of you; it has consumed you, and I have tumed you to ashes on the earth in the eyes of all who see you.

19 "All who know you among the peoples are appalled at you; you have become terrified and you will cease to be forever."

\section{Preliminary Observations}

A reception formula, "the word of YHWH came to me saying" ( 9979), marks its beginning in vs. 11; and the refrain "and you will cease to be forever" (घ) for the literary structure, Davidson has demonstrated that Ezek 28:12-19 is composed in a chiastic structure:

A. Inclusio (vss. 12b-13)

$\mathrm{B}$ "The anointed cherub who covers" (vs. 14)

C "I establish you" (vs. 14)

D "on the holy (qodesh) mountain of God" (vs. 14)

$E$ "In the midst of the stones of fire" (vs. 14)

F "Perfect in your ways from the day you were created" (vs. 15a)

$F^{\prime}$ "Till iniquity was found in you, and you sinned" (vss. 15b, 16)

$E^{\prime}$ "From the midst of the stones of fire" (vS. 16)

$\mathrm{D}^{\prime}$ "From the mountain of God a profane thing (hll)" (vs. 16)

$C^{\prime}$ "I will destroy you" (vs. 16)

$\mathrm{B}^{\prime}$ "O covering cherub" (vs. 16 )

$\mathrm{A}^{\prime}$ Inclusio (vss. 17-19).

'Davidson, "The Chiastic Literary Structure of the Book of Ezekiel," 75. 
The first half of the structure $(\mathrm{A}-\mathrm{F})$ reveals the condition/origin of the cherub, while the second half $\left(\mathrm{F}^{\prime}-\mathrm{A}^{\prime}\right)$ reveals the condition/destiny of the cherub before and after his expulsion, respectively. Thus, this structure highlights the two-phase experience of the king/cherub characterized, respectively, by perfection and corruption, presence in Eden/the holy mountain of God (sanctuary), and expulsion from the holy mountain. In the first phase, the cherub acted as a coverer in the sanctuary; in the second, he defiles it. Davidson's study also revealed that Ezek 28:11-19 stands at the apex of the chiastic Structure of the entire book of Ezekiel. In this literary arrangement the first section of the chiasm reports the judgment from the sanctuary and YHWH's departure from it (Ezek 1-11). This matches the last chapters (Ezek 40-48) which portray YHWH coming back to the restored temple to establish his dwelling among his people. Thus it should not be surprising that sanctuary/temple imagery would also occur at the apex of the entire literary Structure.

Regarding its context, it must remembered that Ezek 28:11-19 is part of a larger section, comprising chaps. 25-32 with several oracles against foreign nations. In its more immediate context the pericope under study belongs to the section about the judgment of Tyre (chaps. 26:1-28:19). For the purposes of this research, it is necessary to investigate the relationship between $28: 1-10$ and $28: 11-19$. These two sections are closely connected in the literary context of the book, and display close affinities. The most obvious is the judgment on the king of Tyre designated as "gag ("prince") in the former, and "the ("king") in the latter.

${ }^{1}$ Ibid. 
Bertolucci pointed out that "the books of the Former Prophets seem to have understood the terms "ga ("prince") and Fog ("king") in the beginning of the Israelite monarchy, as comnoting rulership on lwo different levels. Several times the writers present God as saying that Saul, David, or other Israelite leaders would be the 79: over his people, while the true King of Israel was the Lord." A contextual analysis of $28: 2$ and 28:12 points to the same distinction employed by the Former Prophets. Ezek 28:1-10 suggests that the ๆ?มุ is a human being, as $28: 2$ and 9 make clear, "yet you are a man and not God." This seems to emphasize that despite all the pride and glory of the historical "prince" (999) of Tyre, he remains a mere human being. Additionally, vss. 2 and 8 locate the "prince" in "the heart of the seas," a fitting expression for the geographical location of Tyre which matches the actual location of the human ruler.

Ezek 28:11-19, however, presents a different picture. The ruler of Tyre is designated as "king" (Tל?口) and described as a "cherub" (279?). As several scholars have noted, here a distinct personage is being spoken of. ${ }^{2}$ The designation "cherub," used elsewhere in the book of Ezekiel of members of the divine entourage, ${ }^{3}$ further indicates that here another figure is in view, an idea corroborated by critical scholars. Skinner asserts that "it almost seems as if the prophet had in mind the idea of a tutelary spirit or

'Bertolucci, 249. Cf. the following passages where this distinction seems to obtain: 1 Sam $9: 16 ; 10: 1 ; 12: 12 ; 13: 14 ; 2$ Sam $5: 2 ; 6: 21 ; 7: 8 ; 1 \mathrm{Kgs} 1: 35 ; 14: 7 ; 20: 5 ; 2 \mathrm{Kgs} 20: 5 ; 1 \mathrm{Chr} 11: 2 ; 2$ Chr 32:21.

${ }^{2}$ Charles L. Feinberg, The Prophecy of Ezekiel: The Glory of the Lord (Chicago: Moody Press, 1969), 160-64; Cameron Mackay, "The King of Tyre," CQR 117 (1934): 239. Bertolucci, 253-54.

${ }^{3}$ See Ezek 1 and 10. 
genius of Tyre," while Page suggests that "Yahweh's trusted associate, who was without equal in the created order, is compared to the king of Tyre. Both are fated for destruction because of their pride and their vanity. ${ }^{12}$ These statements are instructive inasmuch as they indicate that the text refers to a supernatural being.

Besides, it is worth noting that the "king" of Tyre/cherub is described as being "in Eden, the garden of God." It has been recognized that "this phrase 'you were in Eden, the garden of God' (vs. 13) is the most difficult obstacle to the interpretation of the king of Tyre as the literal king of the city." In like manner, Ezek 28:15-"You were blameless in your ways from the day you were created ( found in you" - also poses problems for the identification of the king/cherub with any historical ruler of Tyre. It seems very unlikely that there had been a time in which the

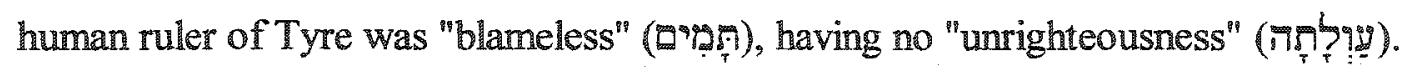

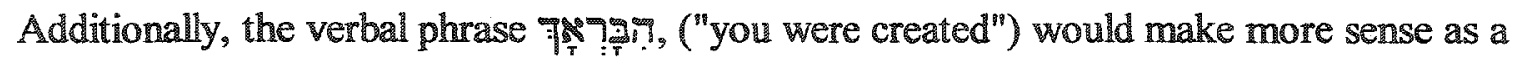
reference to a supernatural being designated as "cherub"/"king, "than to a historical ruler. When all the evidence is weighed, the probability increases that the referent of king/cherub in Ezek 28:11-19 is some supernatural figure who is acting behind the historical ruler of Tyre described in Ezek 28:1-10.

'John Skinner, The Book of Ezekiel, The Expositor's Bible, vol. 13 New York: Armstrong and Son, 1908), 253.

${ }^{2}$ Page, 157.

${ }^{3}$ Ralph H. Alexander, "Ezekiel," The Expositor's Bible Commentary, ed. Frank E. Gaebelein (Grand Rapids: Zondervan, 1976), 6:883.

${ }^{4}$ The "king" is referred to as "cherub" two times $(28: 14,16)$. 
This picture is very similar to the one presented in Isa 14:12-15, which also contains a similar vertical dynamic focusing on the fall of a supernatural figure behind the historical King of Babylon. This personage, after a failed attempt to overtake the "mount of assembly," the heavenly sanctuary/temple of YHWH, is expelled from heaven.' It seems apparent that the same event is being described by Ezekiel, though with a more varied imagery. The essentials, however, remain the same-in both texts, the sin of the rebellious creature is related to improper actions towards the sanctuary/temple. In the Isaiah pericope, the King of Babylon attacks the "mount of assembly, namely, the sanctuary; in the Ezekiel passage, the cherub defiles the "sanctuary." It thus seems reasonable to suppose that both texts portray the same event from different perspectives.

Although this vertical dimension in Ezek 28:11-19 and Isa 14:4-21 is not accepted by many scholars, some of them have proposed a mythical background ${ }^{2}$ for the language

${ }^{1}$ Although a study of Isa 14 has been provided earlier in this chapter, it may be useful to summarize here three basic arguments advanced by Bertolucci to support this view: (1) The use of the word לw్ to introduce the message against Babylon suggests a typological interpretation of the text. (2) The term Babylon has been used in the Bible with different connotations. It may point to the historical city or empire, or could also be used to refer to Babylon as an entity in opposition to God, as is the case in the narrative of the tower of Babel, and the application made by the Revelation of John. The use of bwip (mashal) to define the overall tenor of the message seems to endorse this latter possibility. (3) The passage of Isa 14 presents an interconnection of historical, underworld, and heavenly realms. Especially vss. $12-15$ display characteristics of an "apocalypiclike vertical dimension" (Bertolucci, 289-91). If this is true, then it might be argued that the prophet is speaking about a power that goes beyond the mere earhly/historical level. The following expressions are dificult to understand in reference to a human ruler; however, they seem to be better understood as reference to a supernatural power. Isa 14:12: "How you have fallen from heaven, $O$ star of the morning, son of the dawn!" Isa 14:13: "But you said in your heart, "I will ascend to heaven; I will raise my throne above the stars of God, and I will sit on the mount of assembly in the recesses of the north."

${ }^{2}$ Regarding the mythical interpretation of Ezek 28:11-19, the same observations, mutatis mutandis, already made in connection with Isa 14:12-15, apply. It is a plausible idea that Ezekiel was aware of a common tradition of a cosmic rebellion or cosmic transgression which culminated 
and imagery of these texts. 'This seems to be a tacit recognition that the realities portrayed by the text transcend the historical domain, a view that contributes to reinforce the position that the king/cherub represents a supematural being. Thus, in view of the considerations undertaken thus far, it becomes apparent that in Ezek 28:11-19, the prophet shifts the focus from the human ruler of Tyre to the supematural power behind the historical ruler of that ancient city.

\section{Semantic and Other Exegetical Considerations}

\section{Garden of Eden}

As noted below, Garden-of-Eden imagery pervades the pericope. The expression "in Eden, the garden of God" (" a garden in Eden" (१าม precious stones" ("7?? ? echo the precious stones ${ }^{2}$ in the Garden of Eden. Another possible allusion to the Garden of Eden can be perceived in the Hithpael of 7 th in $28: 14$. Referring to the cherub in vs. 14, the prophet says: "You waked (BST?

in the expulsion of a divine being from heaven to earth. This common tradition would be couched by the prophet in accordance with his Yahwistic faith.

${ }^{1}$ Cf. Walther Eichrodt, Ezekiel: A Commentary, 392-95; Walther Zimmerli, Ezekiel 2: A Commentary on the Book of the Prophet Ezekiel: Chopters 25-48, trans. James D. Martin, Hermeneia (Philadelphia: Fortress, 1983), 89-95; Leslie C. Allen, Ezekiel 20-48, WBC 29 (Dallas: Word Books, 1990), 93-96; Herbert G. May, "The King in the Garden of Eden: A Study of Ezekiel 28:12 19," in Israel's Prophetic Heritage: Essays in Honor of James Muilenburg, ed. Bernhard W. Anderson and Walter J. Harrelson (New York: Harper and Brothers, 1962), 166-76; Page, $149-58$.

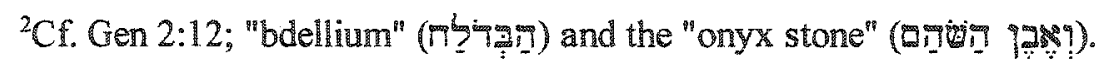


verbal stem is used in reference to YHWH walking in the garden in Gen 3:8: "and they heard the voice of YHWH God walking (THria) in the garden." The mention of the king of Tyre as a "cherub" (2979) seems to resonate with the "cherubim" (29"9 ) stationed at the east of the garden to guard the way to the tree of life (Gen 3:24). It has also been observed that the expression found in Ezek 28:18, "I will give you to the dust upon the

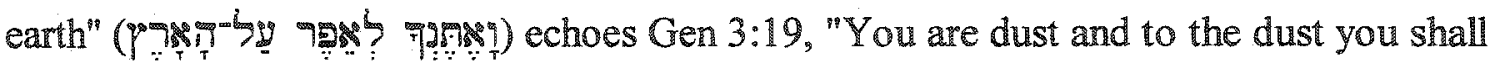

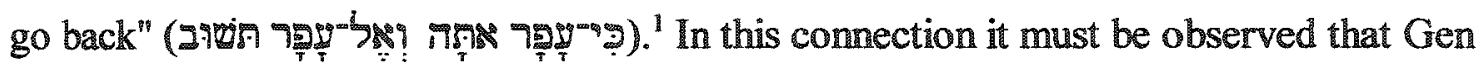
3:14 also relates the dust to the serpent: "And you shall eat dust all the days of your life"

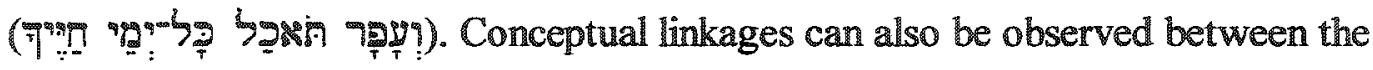
pericope of Ezekiel and the Garden narrative. For example, both the king of Tyre and serpent seemed to be extremely notable among their peers; the king was full of "wisdom" (Ti⿱ sinned. The serpent used his craftiness to lead humanity into sin, promising "knowledge" to them.

Along with the foregoing considerations, one should hold in mind that the allusions to the Garden of Eden contribute to corroborate the sanctuary setting of the passage. As several scholars have noted, the Garden of Eden is described in Gen 2 with language reminiscent of the sanctuary/temple. Davidson conveniently summarized seventeen lines of evidence for this conclusion, noting key terminological linkages ("to plant," "in the midst," YHWH "walking around," "onyx," "bdellium," "light"), thematic parallels (common

"Kalman Yaron, "The Dirge over the King of Tyre," ASTI 3 (1964): 54. 
eastward orientation, three spheres of space in ascending degrees of holiness, river,

portrayals of nature), and structural parallels (seven sections concluding with the Sabbath, and the verbal series at the conclusion: "saw the work," "made/did," "finished the work," "blessed").'

\section{Samctuary}

The nine stones mentioned in Ezek 28:13 provide a strong link with sanctuary imagery. Yaron noted that "seven of the nine stones mentioned in Ezekiel and Exodus appear only in these two places: in connection with the Garden of God and with the stones on the breast-plate of the high priest." ${ }^{2}$ Although MT and LXX diverge in the listing of

\footnotetext{
"Davidson, "Cosmic Metanarrative for the Coming Millennium," 108-11. Cf. Joaquim Azevedo, "At the Door of Paradise: A Contextual Interpretation of Gen 4:7," BN, no. 100 (1999): 45-59; Barker, The Gate of Heaven, 68-103; G. K. Beale, The Temple and the Church's Mission: A Biblical Theology of the Dwelling Place of God, NSBT 17 (Downers Grove, IL: Inter-Varsity Press, 2004), 66-80; Meredith G. Kline, Kingdom Prologue (South Hampton, MA: GordonConwell Theological Seminary, 1989), 31-32; Eric W. Bolger, "The Compositional Role of the Eden Narrative in the Pentateuch" (Ph.D. dissertation, Trinity Evangelical Divinity School, 1993); William J. Dumbrell, The End of the Beginning: Revelation 21-22 and the Old Testament (Homebush West, NSW, Australia: Lancer Books, 1985), 35-76; Michael A. Fishbane, Text and Texture: Close Readings of Selected Biblical Texts (New York: Schocken Books, 1979), 12-13; Jon D. Levenson, Sinai and Zion (New York: Harper and Row, 1985), 142-45; S. Dean McBride, Jr., "Divine Protocol: Genesis 1:1-2:3 as Prologue to the Pentateuch," in God Who Creates: Essays in Honor of W. Sibley Towner, ed. William P. Brown and S. Dean McBride (Grand Rapids, MI: Eerdmans, 2000), 11 -15; Donald W. Parry, "Garden of Eden: Prototype Sanctuary," in Temples of the Ancient World: Ritual and Symbolism, ed. Donald W. Parry (Salt Lake City, UT: Deseret, 1994), 126-151; Terje Stordalen, Echoes of Eden: Genesis 2-3 and Symbolism of the Eden Garden in Biblical Hebrew Literature, CBET 25 (Leuven, Belgium: Peeters, 2000), 111-38. Gordon J. Wenham, "Sanctuary Symbolism in the Garden of Eden Story," in Proceedings of the Ninth World Congress of Jewish Studies (Jerusalem: World Union of World Studies, 1986), 1925.
}

${ }^{2}$ Yaron, 36. 
these stones, ${ }^{1}$ it seems reasonably clear that a connection with the stones used by the high priest was intended. As noted by Bames, Ezekiel

specifies nine varieties of precious stones... They are identical with the nine varieties which formed the first, second, and fourth rows of the jewels carried on the breastplate (hoshen) of the Aaronic high priest (Exod. xxviii $17 \mathrm{fI}$; xxxix $10 \mathrm{ff}$ ). The stones of the third row are not represented in Ezekiel's list according to the M.T., though they appear in the LXX. Whichever text we adopt we cannot doubt that Ezekiel sees a connection between the protecting breastplate of Exodus and the protecting wall of the Tyrian temple. ${ }^{2}$

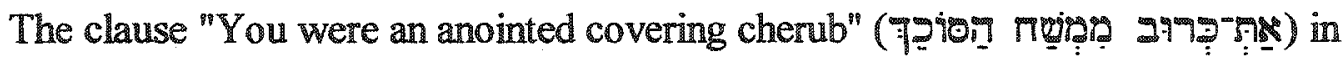
Ezek 28:14 seems to echo the cherubim over the mercy seat in the holy of holies of the tabemacle. ${ }^{3}$ The passage of Exod 25:20 seems to be the closest parallel: "And the cherubim shall have their wings spread upward, covering ("פ90) the mercy seat with their wings." The references to "holy mountain" and "mountain of God" in $28: 14$ and 16, respectively, also display sanctuary/temple connections. ${ }^{4}$ Also the clause "in the midst of the stones of fire you walked (ก:THก)" may reflect sanctuary imagery, as suggested by Lev 26:12, where the same verbal form occurs in connection with YHWH going with the people by means of the tabernacle.

Two more key expressions linking our text with sanctuary or cultic motifs deserve some considerations. The verb Shn ("profane") occurs in Ezek 28:16 and 18. In vs.16, it

${ }^{1}$ Ezek $28: 13$ (MT) provides nine of the twelve stones of Exodus in a modified sequence. Ezekiel ( $\mathrm{LXX}$ ) presents all the stones mentioned in Exodus.

${ }^{2}$ W. Emery Bames, "Ezekiel's Denunciation of Tyre," JETS 34 (1934): $51-52$.

${ }^{3} \mathrm{C}$. F. Keil, Biblical Commentaries on the Prophecies of Ezekiel, vol. 1 of 2, trans. James Martin (Grand Rapids: Eerdmans, n.d.), 413. 15 above.

${ }^{4}$ See the discussion on the "mountain" motif in connection with the discussion of Isa 14:12- 
occurs in the clause, "I have cast you as profane from the mountain of God" (avily "igt? Th? Here the verb is employed in the so-called "pregnant construction," a form in which the preposition imparts some action to the verb. ${ }^{2}$ The idea is that God expelled the cherub from the mountain/garden as a profane entity. The same verb Shm occurs again in vs. 18 where it is stated, "You [i.e., the cherub] profaned your sanctuaries" ("T "Tp? \$ㄴ. connections even more evident. The verb 5 hn is employed in the Mosaic law in the Piel stem to convey the idea of profanation or desecration. ${ }^{3}$ It can have as subject either the Israelites or the pagan nations; and as objects, Sלr can govern "the altar" (Exod 20:25), "the Sabbath" (Exod 31:14), "the name of YHWH" (Lev 18:21; 19:12); "the sanctuary" (Lev 21:12;21;23); and the "holy things" (Lev 22:15; Num 18:32), possibly those things associated with the sacrifices. Thus the verb ל 47 in Ezek 28:18 seems to evoke a cultic concept, since it has the "sanctuary" as its object" (28:18). 384.

'See E. Kautsch and E. Cowley, Gesenius' Hebrew Grammar (Oxford: Clarendon, 1910),

In this case the preposition jp, which connects לs with its adverbial modifier, implies the idea of movement "from" some place.

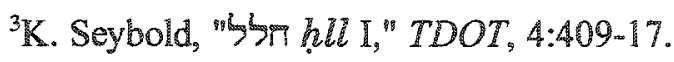

${ }^{4}$ See, e.g., Lev 21:12: "Do not profane (Shr?) the sanctuary (vorps) of his God," and Lev

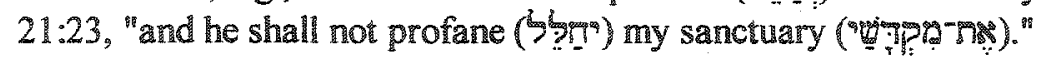




\section{Heavenly Sanctuary/Temple Motif}

Since the discussion undertaken above has revealed that sanctuary/temple imagery pervades Ezek 28:11-19, it remains to ascertain the locale of the sanctuary/temple alluded to in the pericope. The text contains four parallel expressions to denote the place where the cherub was located: "Eden, garden of God"; "holy mountain of God"; "mountain of God"; and "sanctuaries." Yaron pointed out that "the garden of Eden and the House of God are interchangeable" and "there is no clear dividing-line between the mountain of God and the House of the Lord. Indeed, we can conclude from Isa 14:13 that there is no differentiation between Heaven, Eden, the side of the North and the temple."

It must be noted that since vs. 17 reports that the cherub was cast to the earth, he must have been located in some place outside the earth. Additional, that the "cherub" was covered with "precious stones" among the "stones of fure" indicates a location at the very presence of YHWH, as implied in Ezek 1:13 and 10:2. Moreover, the connections with Isa 14:12-15 also indicate a heavenly setting for Ezek 28:11-19, which strengthens the probability that the sanctuary referred to in the latter pericope is the heavenly sanctuary. Therefore, granting that the passage refers to the heavenly sanctuary/temple, it is necessary at this juncture to investigate which aspects of the sanctuary/temple emerge from the text.

\footnotetext{
"Yaron, "The Dirge over the King of Tyre," $43-44$.
} 


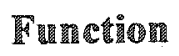

An important function of the heavenly sanctuary/temple emerges in connection

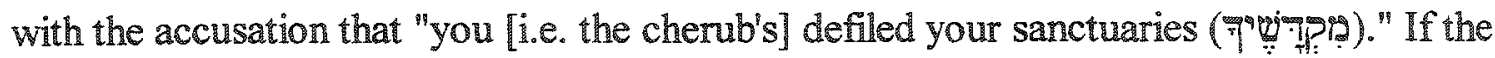
plural is understood with a singular meaning as convincingly argued by Cooke, ${ }^{1}$ it may be inferred that the heavenly "sanctuary" was the object of some improper action on the part of the cherub, as suggested by vs. $18 \mathrm{a}$ :

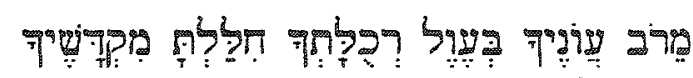

By the multitude of your iniquities in the unrighteousness of your trade you profaned your sanctuaries.

The profanation of the sanctuary was brought about by the "iniquities" of the cherub. Although the exact nature of these "iniquities" is not explained, the parallel expression "the unrighteousness of your trade" may help clarify what happened. Although the expression "your trade" (ๆกรุ? heavenly realm, Davidson's suggestion that "trade" (ำ? ) can also mean "slander"2 clarifies the meaning of that expression. If the cherub was involved in actions of "slandering," it is possible that he may have aimed his derogatory claims at YHWH himself, a sin which brought about the "profanation" of the sanctuary. Also one should not exclude the possibility that this profanation involved an attack on the sanctuary/temple similar to what is portrayed in Isa 14:12-15. The verb לS ("profane") $)^{3}$ allows this

\footnotetext{
${ }^{1}$ See the textual observation on this expression earlier in this section.

${ }^{2}$ Richard M. Davidson, "Satan's Celestial Slander," Perspective Digest 1, no. 1 (1996):

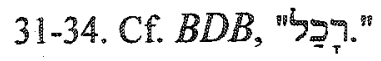

${ }^{3}$ The verb $36 \pi$ may occur in the context of a pagan military assault on the Israelite sanctuary, which results in its profanation (Ezek 7:21-24; Ps. 74:7).
} 
possibility, since it is used elsewhere in the Hebrew Bible in reference to the contamination of the Israelite sanctuary by a military assault.' Also, the observation that the cherub's heart was full with "violence" (อฌึ) may imply some violent action against YHWH and his temple/sanctuary (Ezek 28:16). The heavenly sanctuary/temple thus emerges in this passage as the setting for a cosmic war between the king/cherub and $\mathrm{YHWH}$, a picture very close to the one portrayed in Isa 14:12-15.

\section{Relationship to Earthy Conunterpart}

It seems reasonable to suppose that the reference to the sanctuary as "your sanctuaries" (20) denotes the special relation of the cherub with the sanctuary, which further emphasized by the designation "covering (729\%) cherub." As Bertolucci pointed out, it is beyond doubt that "this marvelous being seems to have his functions related to a temple or sanctuary. ${ }^{12}$ A close look at the Israelite sanctuary/temple with its cherubim "covering" the ark of the covenant in the most holy place is instructive. It may indicate that a similar structure obtains for the heavenly sanctuary, where the cherub had a special function described by the adjectival participle 72101 ("covering"). The cherubim of the earthly sanctuary were also described as e9990 ("covering") the mercy seat (Exod 25:20; 37:9). In view of the foregoing observations, that view may be advanced that the use of the lexeme wep ("sanctuary") in vs. 18 and the portrayal of "covering cherub" indicates a structural correspondence between the heavenly sanctuary and its earthly counterpart.

${ }^{1}$ Cf. Ezek 7:21-24; Ps. 74:7.

${ }^{2}$ Bertolucci, 270. 
It should also be noted that the contamination of the heavenly sanctuary/temple by the sins of the cherub in a way corresponds to the contamination of the earthly sanctuary/temple, thus pointing to a functional correspondence. ${ }^{1}$ Finally, it must be pointed out that the description of the heavenly sanctuary/temple by means of Garden-ofEden imagery may indicate that the heavenly sanctuary/temple existed in relationship not only with the Israelite sanctuary/temple, but also with the Garden of Eden, inasmuch as the latter seems to have functioned as a sanctuary.

\section{Mic 1:2-3}

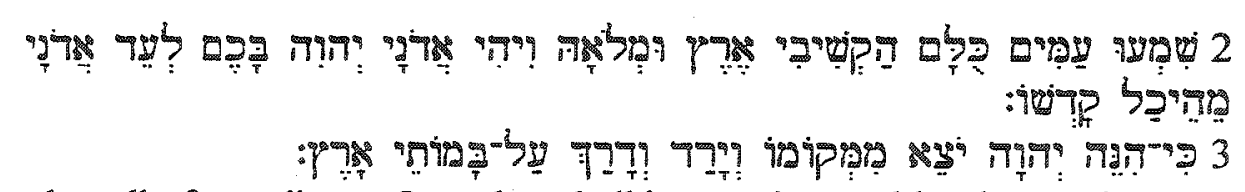

2 Hear, O peoples, all of you; listen, $\mathrm{O}$ earth and all it contains, and let the Lord YHWH be a witness against you, the Lord from his holy temple.

3 For behold, YHWH is coming forth from his place. He will come down and tread on the high places of the earth.

Perusal of commentaries and articles dealing with Mic 1:2 reveals that the vast majority of scholars regard the "temple" mentioned therein as the heavenly temple. ${ }^{2} \mathrm{Kim}$,

\footnotetext{
'Margaret Baker speculates that the "the judgement of the proud prince [i.e., the cherub] must have had its counterpart in temple rituals" (The Gate of Heaven, 27). This conjecture may contain some grain of truth, if one examines the judgment context of the activities of the earthly sanctuary in the Day of Atonement (Lev 16), when goat for Azazel was sent to the wildemess, carrying away the iniquities (migiv) of the congregation. Cf. Roy Gane, Cult and Character: Purification Offerings, Doy of Atonement, and Theodicy (Winnona Lake: Eisenbrauns, 2005), forthcoming.

${ }^{2}$ E.g., Delbert R. Hillers, Micah, Hermeneia (Philadelphia: Fortress, 1984), 19; Thomas Edward McComiskey, The Minor Prophets: An Exegetical and Expository Commentary (Grand Rapids: Baker, 1992), 2:617; Homer Hailey, A Commentary on the Minor Prophets (Grand Rapids: Baker, 1972), 193; Henry McKeating, The Books of Amos, Hosea and Micah (Cambridge: University Press, 1971), 157; Rolland E. Wolfe, "Exegesis of the Book of Micah," in The Interpreter's Bible, ed. George Arthur Buttrick (New York: Abingdon, 1956), 6:902-03.
} 
however, has concluded that the passage refers to the Jerusalem temple. ${ }^{1}$ Notwithstanding his meticulous investigation, Kim's exegesis of this passage calls for reassessment, since the text seems to point to a heavenly location for the temple referred to in the text. After some preliminary observations, a critical analysis of two objections advanced by Kim against the presence of the heavenly sanctuary/temple motif in the passage is undertaken. In the sequence, some key words and expressions are investigated in order to clarify some aspects of the text. And finally the heavenly sanctuary/temple motif is delineated with special attention to the function of the heavenly temple as portrayed by the passage.

\section{Preliminary Observations}

Mic 1:2-3 belongs to the text unit of vss. 2-7, which is usually divided by most scholars into two subsections: vss. $2-4$ containing an announcement of judgment against the gentile peoples, and vss. 5-7 describing the judgment against Israel and Judah. ${ }^{2}$ The

Elizabeth Rice Achtemeier, Minor Prophets I (Peabody, MA: Hendrickson, 1996), 295; Kenneth L. Barker and Waylon Bailey, Micah, Nahum, Habakkuk, Zephaniah., NABC 20 (Nashville: Broadman and Holman, 1998), 49, 50; John M. P. Smith, William H. Ward and Julius A. Bewer, A Critical and Exegetical Commentary on Micah, Zephaniah, Nahum, Habakkuk, Obadiah and Joel, ICC (New York: Charles Scribner's Sons, 1911), 36; Gary V. Smith, Hosea, Amos, Micah: The NIV Application Commentary from Biblical Text . . to Contemporary Life (Grand Rapids: Zondervan, 2001), 441-42; A. Cohen, The Twelve Prophets, Hebrew Text, English Translation and Commentary (Bournemouth, Hants.: Soncino Press, 1948), 156; G. Woosung Wade, The Books of the Prophets Micah, Obadiah, Joel and Jonah (London: Methuen, 1925), 3; Davidson, "The Heavenly Sanctuary in the Old Testament, 1976," 21-22; Francis I. Andersen and David Noel Freedman, Micah: A New Translation with Introduction and Commentary, AB 24 (New York: Doubleday, 2000), 139; Mitchell J. Dahood, Psalms I (1-50): Introduction, Translation, and Notes, AB 16 (Garden City, NY: Doubleday, 1966), 170; Davidson, Typology in Scriptare, 382; Shea, Selected Studies on Prophetic Interpretotion, 7.

${ }^{1} \mathrm{~K} \operatorname{im}, 238$. 372.

2John T. Willis, "Some Suggestions on the Interpretation of Micah 1:2," VT 18 (1968): 
problem with this traditional understanding of the text is that the first section announces a judgment which is not described; and the second, a judgment which is not announced.'

Some scholars have tried to explain this tension by suggesting that vss. $2-4$ were inserted by an exilic redactor. ${ }^{2}$ Nonetheless, there are compelling reasons to understand vss. 2-4 as an integral part of the text. ${ }^{3}$ A close look at the Hebrew text reveals a fine literary continuity with smooth transitions by way of connective particles and expressions ${ }^{4}$ which substantiate the integrity of the passage. The major difficulties are not related to the linguistic texture of the pericope, but to its contents.

Other scholars have tried to explain this tension by suggesting that the reference to "peoples" in vs. 2 is intended to provide a broader background and legitimation for YHWH's actions against Israel and Judah. ${ }^{5}$ Furthermore, the nations are, so to say,

${ }^{1}$ Cf. ibid.

${ }^{2} \mathrm{~T} . \mathrm{K}$. Cheyne, The Two Religions of Israel, with a Re-examination of the Prophetic Narratives and Utterances (London: A. and C. Black, 1911), 366; Robert Henry Pfeiffer, Introduction to the Old Testament (New York: Harper and Brothers, 1941), 590, 93; B. Stade, "Streiflichter auf die Entstehung der jetzigen Gestalt der alttestamentlichen Prophetenschriften," ZAW 23 (1903): 163; John Marsh, Amos and Micah (London: SCM Press, 1979), 87; Wolfe, 6:902. Interestingly enough, Hillers cautiously suggests that it is the reference to Judah and Jerusalem in ws. 5 that is a later addition. It was possibly "made already by Micah or an early collector of his sayings" (18).

${ }^{3} \mathrm{Cf}$. Willis, 372-79.

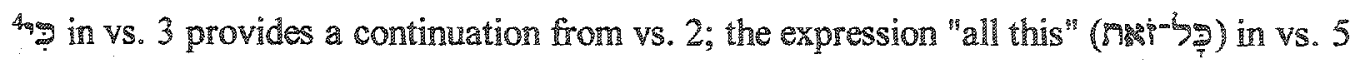
seems to refer back to the previous verse; vs. 6 starts with a weqatal verb, and vs. 7 with a conjunctive vav. The text thus flows nicely by way of these syntactic linkages, which provide smooth linguistic texture, and a coherent piece of literature.

${ }^{5}$ Cf. Peter C. Craigie, The Twelve Prophets, 2 vols., DSB (Philadelphia: The Westminster, 1984), 9-11; Hailey, 193; Gary V. Smith, Amos, rev. and expanded ed. (Fearn: Mentor, 1998), 441-42; Daniel Schibler, Der Prophet Micha, WSRAT (Wuppertal: R. Brockhaus, 1991), 36; Hans Walter Wolff, Micah the Prophet (Philadelphia: Fortress, 1981), 32-33. 
involved in transgressions similar to those of Israel and Judah. 'However, it should be noted that vs. 5, which introduces the judgment against Israel and Judah, is closely linked to the previous verses by way of the expression "all this" (Nxpm) in "All this is because of Jacob's transgression, because of the sins of the house of Israel." The text thus says that the transgressions of YHWH's people are the motivation for what transpired previously in the text. This being so, it is difficult to regard the "peoples" referred to in vs. 2 as gentile nations.

The task ahead, therefore, is to explain why vss. $2-4$ announce an oracle against "all the nations of the earth," while the oracle itself reported in vss. 5-7 addresses Israel and Judah. A solution that respects the integrity of the text and keeps the line of thought flowing smoothly across the text is to postulate that "all the peoples" and "the earth and all that is in $t^{\prime \prime}$ in vs. 2 refer to Israel and Judah, and not to the gentile nations. This view has been suggested in the past by several scholars, ${ }^{2}$ and has more recently been substantiated

\footnotetext{
${ }^{1}$ Barker and Bailey, 49.
}

2Ehrlich, 5:272; William Creighton Graham, "Some Suggestions toward the Interpretation of Micah 1:10-16," AJSL 47, no. 4 (1931): 256; Albin van Hoonacker, Les Douze Petits Prophètes (Paris: J. Gabalda, 1908), 335; P. Kleinert and Johann Peter Lange, Obadjah, Jonah, Micha, Nahum, Habakuk, Zephanjah, ed. J. P. Lange, THBW 5 (Bielefeld and Leipzig, Germany: Velhagen und Klasing, 1868), 48; McComiskey, The Minor Prophets, 2:617; C. v Orelli, The Twelve Minor Prophets, trans. J. S. Banks (Edinburgh: T. and T. Clark, 1893), 190; Carl Steuemagel, Lehrbuch der Einleitung in das alte Testament mit eimem Anhang über die Apokryphen und Pseudepigraphen (Tübingen: J.C.B. Mohr [P. Siebeck], 1912), 625. Cf. Marvin A. Sweeney, The Twelve Prophets, 2 vols., Berit Olam: Studies in Hebrew Narrative and Poetry (Collegeville, MN: Michael Glazier, 2000), 2:349. Keil, although interpreting the "peoples" as

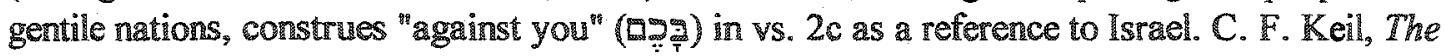
Twelve Minor Prophets, vol. 1 of 2, trans. James Martin, Biblical Commentary on the Old Testament (Grand Rapids: Eerdmans, 1949), 426. For a similar understanding, cf. B. Elmo Scoggin, "Micah," The Broadman Commentary, ed. Clifton J. Allen (Nashville: Broadman, 1972), 7:190. It is, however, very improbable that the pronominal suffix would have a referent other than the obvious and nearest antecedent "peoples." The best solution in this case is to understand 
by Kim. It has the merit of explaining the text without excisions or forced harmonizations. Besides, from a linguistic point of view, the expression "O peoples, all of you" and "O earth and all it contains" in vs. 2 can be applied to the Israelites, as shown in due course.

At this juncture, granting that the pericope is a unified composition with a coherent flow of thought, the following arrangement can be suggested: Announcement of the judicial procedure against the peoples (Israel and Judah) in the temple (vs. 2); YHWH comes forth/down from the temple in order to manifest his presence on earth and execute the judgment (vSs. 3-4); the reasons for the previous action are spelled out with a description of the execution of the judgment (vss. 5-7). ${ }^{2}$ Keeping this in mind, attention must be given to the genre of the pericope.

Scholars have identified a variety of genres in the pericope of Mic 1:2-7. In vs. 2 , as noted by several studies, the diction apparently echoes a covenantal lawsuit, ${ }^{3}$ or judicial "peoples" as the people of YHWH, both Israel and Judah, and have the pronominal suffix refer
back to it. Andersen and Freedman, after an exhaustive investigation of this expression, have
pondered that " 2 is not an unequivocal call to the (other) nations of the world to listen or
adjudicate. The plural thus matches Samaria and Jerusalem in the title. Both cities come under
attack in what rollows, but no further word is addressed to the international community, The
tantalizing ambiguity in the language of $v 2$ is not resolved until v 5 " (Andersen and Freedman,
Micah: A New Translation with Introduction and Commentary, 150).

'Kim, 237-38.

${ }^{2}$ Hillers has suggested the following outline: vs. 2 : YHWH in the divine council; vss. 34 : the theophany; vss. 5: the reason for his wrath; vss. 6-7: the resulting overthrow of Samaria (19).

${ }^{3}$ For a detailed study on the prophetic lawsuit, see Kirsten Nielsen, Yohweh as Prosecutor and Judge: An Investigation of the Prophetic Lawsuit (Rib-pattern), JSOTSup 9 (Sheffield: Dept. of Biblical Studies University of Sheffield, 1978), 74-83. Cf. Claus Westerman, Basic Forms of Prophetic Speech (Cambridge, England: Westminster, 1991), 199. 
procedure, ${ }^{1}$ as can be deduced from the use of the term "7g ("witness") and the call-toattention formula. ${ }^{2}$ Although the text does not give a description of the judicial procedures, the implication is that those procedures are about to begin in the heavenly temple, where YHWH would act as litigant against Israel and Judah because of their unfaithrulness to the covenant.

In vss. 3-4 the genre switches to that of a theophany, ${ }^{4}$ as can been seen in the two significant features of a theophany contained in these verses: The coming of YHWH from a certain place, namely, the heavenly temple; and the reaction of nature to his approach. ${ }^{5}$ This change of genre in vss. $3-4$ by no means implies textual discontinuity, as implied by Kim. $^{6}$ As a matter of fact, the theophanic language of these verses is the logical

\footnotetext{
"The term "covenantal lawsuit" has been avoided by recent scholarship on the grounds that the term "lawsuit" is a "modern technical term that has no Hebrew equivalent" (Michael DeRoche, "Yahweh's Rib against Israel: A Reassessment of the So-called 'Prophetic Lawsuit' in the Preexilic Prophets," JBL 102 [1983]: 564). Nonetheless, even those scholars who avoid using the term "covenantal lawsuit" for Mic 1:2 would agree that the pericope evokes a judicial setting. Cr. James Luther Mays, Micah: A Commentary (Philadelphia: Westminster, 1976); B. Renaud, La Formation du Livre de Michée: Tradition et Actualisation (Paris: J. Gabalda, 1977), 28; Sweeney, 2:40-41; Barker and Bailey, 48 .
}

${ }^{2 n H}$ Hear, O peoples, all of you; listen, $\mathrm{O}$ earth and all it contains, and let the Lord YHWH

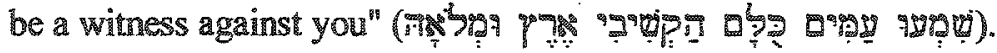

${ }^{3}$ Andersen and Freedman, Micah: A New Translation with Introduction and Commentary, 140. Hillers's suggestion that vs. 2 portrays "YHWH in the divine council" (19), although not clearly expressed by the text, can be inferred from other passages where judicial procedures are undertaken in the context of the heavenly council of YHWH. Cf., $2.9 ., 1 \mathrm{Kgs} 22: 19 ;$ Ps 82; Dan 7:9-14. The latter passage is discussed in chapter 5 .

${ }^{4}$ Rainer Kessler, Micha, Herders theologischer Kommentar zum Alten Testament (Freiburg in Breisgau: Herder, 1999), 86-87; Renaud, 28-29.

Jörg Jeremias, Theophanie: Die Geschichte einer alttestamentlichen Gatumg, 2nd ed., WMANT 10 (Neukirchen-Vluyn: Neukirchener Verlag), 11-13, 15.

${ }^{6} \mathrm{Kim}, 234,235$. 
development of vs. 2. It must be noted that after the judicial deliberations in the heavenly temple, implied in vs. 2, YHWH comes down to execute the sentence. If this is the case, the theophany is probably the most suitable genre to portray the execution of the judgment by YHWH's direct and personal intervention in the situation.

After the transitional vs. 5, which spells out the reason for the punishment, vss. 6-7 present a "judgment speech"1 of YHWH announcing the resultant overthrow of Samaria. Thus when the text is examined as a literary unit, one perceives that the variety of genres employed in the pericope of Mic 1:2-7 contributes to a dramatic and coherent portrayal of YHWH's judicial procedures. First, the covenant lawsuit genre tells of YHWH's judicial procedures in the heavenly temple; second, the theophany informs about YHWH's intervention following the deliberations in the heavenly temple; third, the "judgment speech" makes clear the eventual overthrow of Samaria.

Before proceeding to semantic and other exegetical considerations of some key words and expressions, it is necessary to address two objections advanced by Kim against the presence of the heavenly sanctuary/temple in the passage under study.

\section{Excursus: Two Objections against the Heavenly Sanctuary/Temple Motif}

It has been argued that vss. $2 \mathrm{~d}$ and $2 \mathrm{e}$ are not to be related to vs. 3 , but should be read with $2 \mathrm{a}$ and $2 \mathrm{~b}$ instead. ${ }^{2} \mathrm{He}$ implies that there is no parallelism between vs. $2 \mathrm{~d}$

\footnotetext{
${ }^{1}$ Andersen and Freedman, Micah: A New Translation with Introduction and Commentary, 135.

${ }^{2} \mathrm{Kim}, 234$.
} 
("YHWH from his holy temple") and vs. 3 ("coming forth from his place" and "he li.e., YHWH] will come down"), since vs. 2 is a "self contained unit." This being true, the argument in favor of the heavenly temple would disappear, and vs. 2 should be understood as a reference to the Jenusalem temple, rather than to the heavenly one. However, the disjunction between vss. 2 and 3 cannot be supported on exegetical grounds. The conjunction at the beginning of vs. 3 seems to link both verses together, making such a disjunction improbable.

Another argument adduced to support the view that the passage refers to the Jerusalem temple is related to the meaning of "peoples" (Q"9y) in vs. 2. According to him, since the term "peoples" ("פ Jerusalem temple. ${ }^{2}$ In this connection, approvingly mentioning A. Petrotta, Kim states that "if the addressee is Israel and Judah, it is probable to think that these lines have a provincial reference, the temple in Jerusalem." This argument, however, contains a non sequitur. The fact that vs. 2 refers to Israel and Judah does not require that the "temple" referred to in the same verse be the Jerusalem temple. As a matter of fact, Hebrew Bible also portrays the heavenly temple in connection with YHWH's people on earth." $\mathrm{At}$ this juncture, an investigation of some key words and expressions is undertaken in order to

ibid., 235.

${ }^{2}$ Ibid., 237-38.

${ }^{3}$ Tbid., 237. Cf. Anthony J. Petrotta, Lexis Ludens: Wordplay and the Book of Micah, American University Studies, Series 7, Theology and Religion 105 (New York: P. Lang, 1991), 121.

${ }^{4}$ Cf., e.g., $1 \mathrm{Kgs} 22: 19 ;$ Jer 17:12; 2 Sam 22:7, par. Ps 18:7 [6]. 
gain additional perceptions from the text, and thus obtain a more precise delineation of the heavenly sanctuary/temple motif.

\section{Semantic and other Exegetical Considerations}

\section{Meaning or op:}

Since the term "people" (oy) is used in the Hebrew Bible with different connotations and referents, its specific meaning in a given passage must be determined by the context. ${ }^{1}$ In Mic 1:2, as noted above, the expression "peoples" ("99:) has been understood by most commentators as referring to gentile nations, which gives the passage universalistic overtones. Kim rightly argues that "peoples" (ㅁ9:2) here refers to the people of Israel and Judah, an interpretation supported by the immediate context, since vss. 5-7 contain the actual description of the judgment upon these two nations. At this juncture, it is also important to note that this usage of the term "peoples" ( idiosyncrasy of Micah, but appears in other parts of the Hebrew Bible as well. An instructive example is found in Isa 3:13-14: "YHWH arises to contend, and stands to judge the peoples (ם99y) ${ }^{2}$ YHWH enters into judgment with the elders and princes of his people (ig:2), 'It is you who have devoured the vineyard; the plunder of the poor is in your houses." As can be noted in the parallelism, the peoples ( 0 "rig) referred to in the passage

$$
{ }^{1} \text { Cf. E. Lipinski, "פg 'am," TDOT, 11:163-77. }
$$

2The LXX and the Peshitta translate a'geg as singular hoòv and 'mmh respectively. Although it is difficult to determine whether the singular came from their Hebrew Vorlage or was a harmonization introduced by the translators, the latter option seems more probable on the basis of the text-critical principle of lectio dificilior preferenda est. It should be noted, however, that IQIsa ${ }^{a}$ and Targum Jonathan agree with MT here. 
are none other than YHWH's own people (198). Another interesting passage that can be adduced in this regard is Deut 33:19, which uses "peoples" (2.9p) apparently in reference to the tribes of Israel. "They will call peoples (G"ag) to the mountain; there they will offer righteous sacrifices; for they will draw out the abundance of the seas, and the hidden treasures of the sand." Thus, on the basis of this brief survey, the "peoples" most probably refers to Israel and Judah, rather than to gentile peoples.

\section{Meaning of}

Although at first glance the expression "earth and all it contains" (م⿻ฺุ seems to indicate the entire world, it can also have a restricted referent. The same expression occurs in Deut $33: 16$ in reference to "precious things" of the land of Canaan; in Ezek 19:7, to the devastation of the land of Judah; in Ezek 30:12, to the devastation of the land of Egypt. Furthermore, as noted, the context and the flow of the text seem to indicate the land of Canaan as the referent of this expression. Thus, on the basis of its immediate context, and its usage in other parts of the Hebrew Bible, the expression "earth and all it

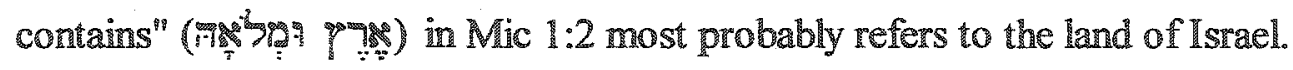

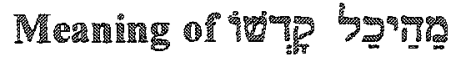

A semantic analysis of this expression has been undertaken elsewhere in this dissertation and does not need to be repeated here. 'It suffices to elucidate the referent of the locution and its function in the present context. First, it seems reasonably clear, as

\footnotetext{
'See above the discussion of $1 \mathrm{Kgs} 8$.
} 
understood by most commentators, that the expression refers to the heavenly temple of YHWH. The comection between vss. 2 and 3 effected by the conjunction makes it highly probable that what happens in vs. 3 presupposes vs. 2 . Therefore the mention of YHWH "coming down" in vs. 3 indicates a descent from the heavenly temple.

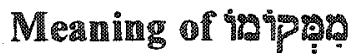

The prepositional phrase "from his place" (isgipap) adds additional support to the understanding of the "holy temple" in the previous paragraph. The word "place" (Dipis) is used in the Hebrew Bible as a technical term for the temple of YHWH. ${ }^{1}$ And, as noted by J. Gamberoni, "in its theological usage [it] rarely occurs apart from some connection with the temple theology." In Mic 1:3, the lexeme $19 \mathrm{pr}$ has the same referent as "the holy temple" mentioned in the previous verse. The verbs used in connection with "place" (घipg) suggest that the referent of the word is the heavenly temple, as can be noted in the following sequence of verbs in vs. 3: "coming forth" (sq9) ... "and will come down"

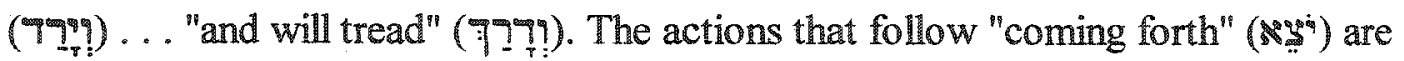
sequential, as expressed by the perfect-consecutive verbal forms. The text implies that YHWH comes down "from his place" (ip ipst), namely, from his heavenly temple, already referred to in vs. 2.

${ }^{1}$ E.g., Deut 12:5, 14; 14:23, 25; 1 Kgs 8:29, 30; Isa 18:7; Ezek 43:7. Cf. Sweeney, 1:68.

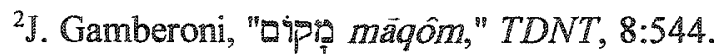




\section{Heavenly Sanctuary/Temple Motif}

The linguistic evidence suggests that the expressions "holy temple" and "his place" refer to the heavenly temple of YHWH. Vss. 2 and 3 allow one to infer that when YHWH "comes down," he does so by departing from his heavenly temple. Therefore, on exegetical grounds is seems beyond any reasonable doubt that the temple referred to in the text is the heavenly one.

\section{Function}

The function of this heavenly temple needs consideration at this point. Granting that the entire pericope $(1: 2-7)$ focuses on Israel and Judah, as argued above, a coherent picture of the heavenly temple and its function in relation to earthly events emerges. This scenario suggests a logical progression of YHWH's actions emanating from the heavenly temple. First, the covenant lawsuit genre employed in vs. 2 announces to the nation that YHWH is about to undertake a judicial process (against Israel and Judah) in the heavenly temple. Second, on the basis of what was decided therein, the theophanic language of vss. 3-4 portrays YHWH coming down and shaking the elements of nature with his awesome presence in order to execute the punishment of his people. ${ }^{1}$ Finally, after the transitional vs. 5, the judgment speech of vss. 6-7 spells out the final overthrow of Samaria, thus consummating the execution of the judgment. So, the heavenly temple emerges as the

IIt should be noted that as YHWH comes down, he does not go to the earthly temple to perform a judgment from there, as implied by Kim's view. Rather YHWH comes from the heavenly temple to execute on earth a decision already taken in the heavenly temple. 
place where YHWH undertakes a judicial process, before executing the sentence upon the condemned sinners.

\section{Relationship to Earthly Counterpart}

The heavenly temple in Mic 1:2-3 emerges in functional and structural relationship to its earthly counterpart. Thus, in its function as a place of judgment, the heavenly temple stands functional correspondence to the earthly counterpart; and in its designation as

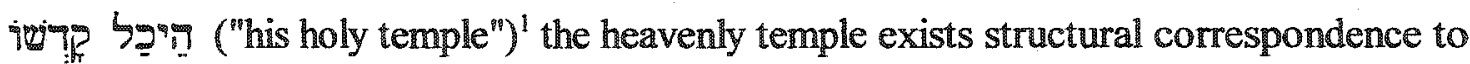
the earthly counterpart.

\section{Zech 3:1-10}

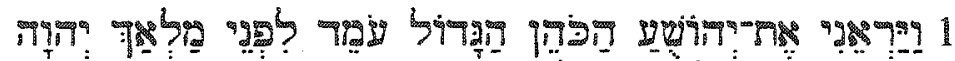

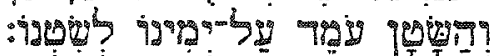

2

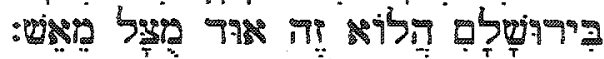
3 4

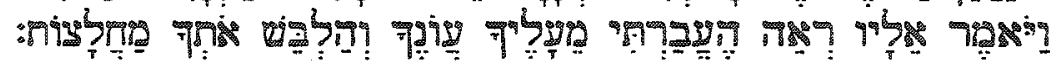
5

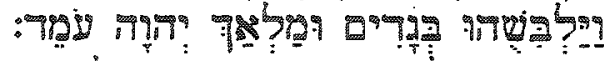
6

7 ? 8

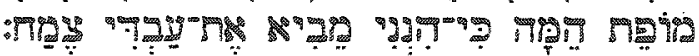
9 :

10

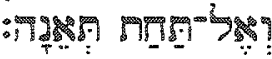

'This expression is also applied to the earthly temple in Ps 5:8 [7]; 79:1; 
1 Then he showed me Joshua the high priest standing before the angel of YHWH, and Satan' standing at his right hand to accuse him.

2 YHWH said to Satan, "YHWH rebuke you, Satan! Indeed, YHWH who has chosen Jerusalem rebuke you! Is this not a brand plucked from the fire?"

3 Now Joshua was clothed with filthy garments and standing before the angel.

4 He spoke and said to those who were standing before him, saying, "Remove the fillthy garments from him." Again he said to him, "See, I have taken your iniquity away from you and will clothe you with festal robes."

5 Then I said, "Let them put a clean turban on his head." So they put a clean turban on his head and clothed him with garments, while the angel of YHWH was standing by.

6 And the angel of YHWH admonished Joshua, saying,

7 "Thus says YHWH of hosts, If you will walk in my ways and if you will perform my service, then you will also govern my house and also have charge of my courts, and I will grant you free access among these who are standing.

8 "Now listen, Joshua the high priest, you and your friends who are sitting in front of you-indeed they are men who are a symbol, for behold, I am going to bring in my servant the Branch.

9 "For behold, the stone that I have set before Joshua; on one stone are seven eyes. Behold, I will engrave an inscription on it, declares YHWH of hosts, 'and I will remove the iniquity of that land in one day.

10 "In that day, declares YHWH of hosts, 'every one of you will invite his neighbor to sit under his vine and under his fig tree."

There is overall agreement among scholars that Zech $3: 1-10$ depicts a heavenly court scene. ${ }^{2}$ Kim has drawn attention to this matter by using the expression "heavenly court-temple, ${ }^{103}$ which aptly describes the setting and procedures depicted in the vision.

The ensuing discussion intends to survey the evidence for a heavenly court-temple setting in the passage. In order to accomplish this, some preliminary observations on the text unit,

'Although the presence of the article in the term 100 irg indicates that may function as a tille, rather than a personal name, the malicious character of this figure seems to identify him with the "Satan" of Judeo-Christian tradition.

${ }^{2}$ An exception to this is Leupold, who denies that the text portrays a trial scene. According to him "what the vision does represent is Joshua ministering to the Angel of the Lord" $(\mathrm{H}$. C. Leupold, Exposition of Zecharioh [Grand Rapids: Baker, 1971], 66). As for the setting of the vision, he seems to imply that it transpires in the Jerusalem temple (ibid., 67).

${ }^{3} \mathrm{Kim}, 266-67$. 
structure, and context are undertaken. Next, semantic and other exegetical issues will receive some consideration; and finally, an attempt is made to delineate the heavenly sanctuary/temple motif as portrayed in the passage, with a view to its function and relationship to the earthly counterpart.

\section{Preliminary Observations}

The vision of $3: 1-10$ is the fourth in the series of eight vison reports found in the first part of the book of Zechariah. As noted by Tidwell, ${ }^{1}$ three characteristics make this vision report unique among its peers:

1. The introduction does not contain the form found in the other visions. Here a Hiphil verbal form "If? ("then he showed me") is employed without the following ("behold").

2. Another interesting feature of the fourth vision is that, unlike the others, it features no.mysterious objects or figures. Its imagery is straightforward and portrays a historical figure-Joshua-as its central character.

3. Another distinctive feature of this vision is the conspicuous absence of the Interpreting Angel. In the other seven visions, this figure plays a prominent role in explaining to the prophet several aspects of the visionary experience. The fourth vision, however, portrays the Angel of YHWH, who is part of the visionary world.

"N. L. A. Tidwell, "Wāomar (Zech 3:5) and the Genre of Zechariah's Fourth Vision," JBL $94(1975): 343-55$. 
Due to its distinctive features, as noted above, some scholars suggest that the pericope was inserted later into an original seven-vision set.' Other scholars, however, have pointed out that Zech 3:1-10 fits into the book as a whole. Baldwin found two chiastic structures in each of the two major divisions of the book. ${ }^{2}$ More recently, Kline has shown that the entire book of Zechariah is built upon a three-hinge framework formed by Zech $3: 1-10,6: 9-15$, and $11: 1-17 .^{3}$ Since it is beyond the scope of this research to engage in a full evaluation of these studies, it suffices to keep in mind that they support the coherence of the canonical text.

The text divides itself into two parts: The vision (1-5), and the oracular section (610). In spite of the debate about the unity of the pericope, ${ }^{4}$ one should note that vss. $6-10$ flow naturally from the vision, which seems to support the canonical shape of the text. For

${ }^{1} \mathrm{Cf}$. David L. Petersen, Haggai and Zechariah 1-8: A Commentary (Philadelphia: Westminster, 1984), 187-88.

${ }^{2}$ Joyce G. Baldwin, Haggai, Zechariah, Malachi: An Introduction and Commentary (Downers Grove: Inter-Varsity Press, 1972), 85-86.

${ }^{3}$ Meredith G. Kline, "The Structure of the Book of Zechariah," JETS 34 (1991): 179-93.

${ }^{4}$ Although the scholarly debate about the unity of the pericope and especially the discussion on whether vss. 6-10 were originally part of the vision are outside the scope of this research, the following observations are appropriate. James C. VanderKam, "Joshua the High Priest and the Interpretation of Zechariah 3," CBQ 53 (1991): 558, presents the following summary of different proposals: Petitjean and Meyers-Meyers think that 3:8-10 form a supplementary oracle (Albert Petitjean, Les Oracles du Proto-Zacharie: Un programme de restauration pour la communauté juive après l'exil [Paris/Louvain: Lecoffre J. Gabalda et Cie, Éditeurs/Louvain Éditions Imprimerie orientaliste, 1969], 161; Carol L. Meyers and Eric M. Meyers, Haggai, Zechariah 1-8: A New Translation with Introduction and Commentary [Garden City, NY: Doubleday, 1987], 178); Beuken contends that 3:8-10 is the original oracle, while vss. 6-7 were added later (Wim Beuken, Haggai-Sacharja 1-8. Studien zur Überlieferungsgeschichte der frühnachexilischen Prophetie, Studia Semitica Neerlandica 10 [Assen: Van Gorcum, 1967], 290-300); Petersen argues that there are three oracular responses: vss. 6-7, 8 and 9 are two responses which did not belong originally with the vision; and vs. 10 is a deuteroprophetic response which builds upon the earlier two (David L. Petersen, Haggai and Zechariah 1-8, 202). 
example, the mention of the Angel of YHWH, the injunction and promise to Joshua, would not make sense apart from the vision. Therefore, the canonical form of the text is still the most objective foundation for the exegetical task ahead.

Tuming to the context of the passage, two points need attention. First, as E. Conrad ${ }^{1}$ and M. Prokurat ${ }^{2}$ have pointed out, Zech 2:17 [13])-"Be silent, all flesh, before YHWH; for he is aroused from his holy habitation" - indicates the setting, or functions as a prelude, for what is depicted in Zech 3 . This observation is significant for this study because if, as already noted, "holy habitation" refers to the "heavenly temple" of YHWH, the heavenly council setting of Zech $3: 1-10$ should be located therein.

Second, the connections between the fourth and fifth visions are contextually relevant, as perceived in the following similarities: (1) Both differ from the other vision reports by containing a different introductory formula, ${ }^{3}$ and (2) both are suffused with sanctuary/temple imagery; furthermore, (3) the main characters of each vision are related to the temple-Joshua as high priest; and Zerubbabel as temple builder, respectively. In an insightful study, William Shea has demonstrated that the fourth and fith visions form

'Edgar W. Conrad, Zecharich, Readings, a New Biblical Commentary (Sheffield: Sheffield Academic Press, 1999), 90. He implies, however, that the scene depicted in Zech 3:1-10 is set in the Jerusallem temple.

"Michael Prokurat, "llaggai and Zechariah 1-8: A Form Critical Analysis" (Ph.D. diss., Graduate Theological Union, 1988), 322.

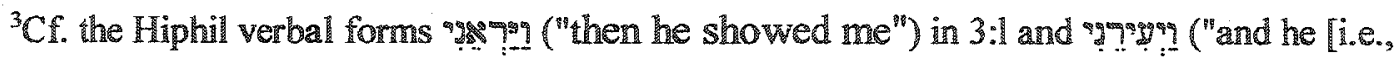
the angell roused me") in 4:1. 
the apex of a chiastic structure involving the entire set of eight visions. ${ }^{1}$ This makes apparent that the similarities just noted are part of a larger literary purpose.

Although all the eight visions emphasize that "it is time to build the temple," as pointed out by Shea, ${ }^{2}$ the fourth and fifth visions seem to be concerned with the tempie in a special way since they contain more explicit temple imagery. The fourth vision has a heavenly temple focus, it portrays the purification and forgiveness of the high priest, ${ }^{3}$ and the acceptance of his ministry in the heavenly tribunal. The fifth is focused upon the earthly temple since it refers to the building and completion of the Jerusalem temple by Zerubbabel. Thus one can perceive in this literary connection a link between the heavenly temple and its earthly counterpart.

1 "A. Vision One-Zech 7-11 Messenger horse-riders come in: The world is at peace. This peace provides an opportunity to build the temple.

B. Vision Two-Zech 1:18-21 The four homs broken. The political conditions that led to the Babylonian exile have been reversed. It is time to build the temple.

C. Vision Three-Zech 2:1-5 Man with the measuring line. The unmeasured blessing that will come with the building of the temple.

D. Vision Four-Zech 3 Message to Joshua the high priest. You are forgiven and cleansed so that you may minister in the new temple.

D'. Vision Five-Zech 4 Message to Zerubbabel the governor. You are to build the temple and I will give you the strength to do it.

$C^{\prime}$. Vision Six-Zech 5:1-4 The flying scroll. Measured curse for those who continue to violate the Ten Commandments.

B'. Vision Seven-Zech 5:5-11 The flying epha basket with the wicked woman.

Religious reasons for the Babylonian exile reversed. It is time to build the temple. A'. Vision Eight-Zech 6:1-8 War chariots and riders go out to establish peace so that the temple can be built" (William H. Shea, "The Literary Structure of Zechariah 1-6," in Creation, Life, and Hope: Essays in Honor of Jacques B. Doukhom, ed. Jiri Moscala [Berrien Springs, M: Old Testament Department, Seventh-day Adventist Theological Seminary, Andrews University, 2000], 84).

${ }^{2}$ Ibid., 83-100.

${ }^{3}$ That this act had implications for the people is noted below. 
Summing up, the reference to the heavenly temple in $2: 17$ [13] paves the way for the fourth vision. This anticipates not only the heavenly setting of the fourth vision, but also may specify that this setting is the heavenly temple itself. Interestingly enough, the fifth vision also features temple imagery and explicitly refers to the completion of the Jerusalem temple. Thus from a contextual point of view, the emphasis placed on the temple in the framing of Zech 3:1-10 further underlines the temple overtones of this passage. One should also note that when the fourth and fifth visions are read side by side, a vertical correspondence between the heavenly temple/sanctuary and its earthly counterpart seems to emerge inasmuch as both visions deal with the heavenly and earthly temples respectively.

\section{Semantic and other Exegetical Considerations}

\section{Meaning of the Root Tes}

Derivatives of the root רמפ (stand) appear six times in the pericope (vss. 1, 3, 4, 5). This is a special term to indicate the technical procedures of a judgment setting. ${ }^{1}$ It refers to Joshua who "stands" before the Angel of YHWH (vss. 1, 3); to Satan who

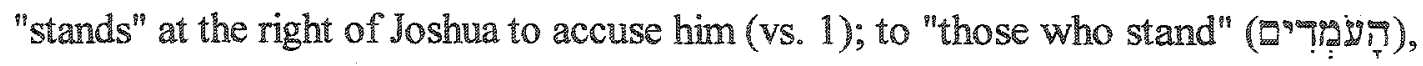
presumably the other heavenly beings who take part in the heavenly court (vss. 4,5 ); to the Angel of YHWH who "stands." Therefore, it seems reasonable to suppose that the

"Cf. H. Ringgren, "Tops 'amad" TDOT, 11:179-80. See also the occurrence of this term in Ps 109:6, which is mentioned below. 
mention of several figures "standing" ("ary), along with Satan as the accuser, points to a judgment setting.

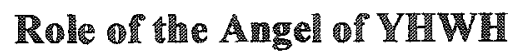

Contrary to the other seven vision reports where the Interpreting Angel plays a

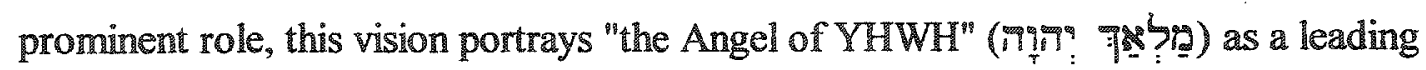
character in the visionary world. Here the Angel of YHWH does not explain elements of the vision to the prophet; rather he himself is part of the visionary world. The distinctive function of the Angel in this pericope along with the qualification " of YHWH" may raise the question whether or not the Interpreting Angel and the Angel of YHWH are the same figure. Although it is beyond the scope of this research to engage in a detailed discussion of this issue, the distinctive role played by the Angel of YHWH in this text may indicate that two different figures are in view.

Most important for the purpose of this study, however, is to understand the role of the Angel of YHWH in the judicial and cultic procedures depicted in the text. In this regard, some scholars argue that the Angel of YHWH is the one who presides over the judgment. ${ }^{2}$ Nevertheless, the reference in vs. 5 to "the Angel of YTWH standing"

"Meyers and Meyers pointed out that "ip ("stand") "is the most common word in Hebrew literature for reflecting the technical procedures of participating in the Court. Just as people appear before the king and enter his court (cf. 1 Sam 16:21-22, where David came to Saul and stood before him,' and Jer 52:12), so heavenly figures are admitted to the assembly over which Yahweh

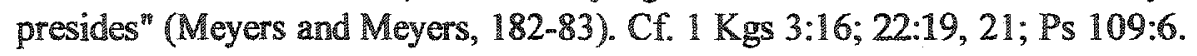

${ }^{2}$ Eugene H. Merrill, Haggai, Zechariah, Malachi: An Exegetical Commentary (Chicago: Moody, 1994), 131; David L. Petersen, Haggai and Zechariah 1-8, 190-91; Paul L. Redditt, "Zerubbabel, Joshua, and the Night Visions of Zechariah," CBQ 54 (1992): $256-57$. 
(7ตู figure, but a member-albeit the most prominent one-of the heavenly tribunal. ${ }^{2}$ The text seems to carefully avoid mentioning $Y H W H$, who is veiled by a refusal of the narrator to describe him. However, the pronominal subject implied in some of the verbs may indicate that YHWH is the one conducting the procedures. ${ }^{3}$ The Hiphil verbal form "ar?" ("and he showed $\mathrm{me}^{\prime \prime}$ ), which opens the pericope, most probably has YHWH as its subject. Likewise, the speaker in vs. 4 "he spoke and said to those who were standing before him, saying, 'Remove the filthy garments from him.' Again he said to him, 'See, I have taken your iniquity away from you and will clothe you with festal robes"-may well be YHWH. $^{5}$

Nonetheless, the Angel of YHWH seems to play a far more conspicuous role in the procedures than any other member of the heavenly council. He is the one who takes the initiative to defend Joshua from Satan's accusations, thereby acting as an advocate, as

"If the connotation of "standing" is to be understood according to the context of the pericope, the idea is not that the Angel of YHWH "was in the vicinity, standing by" (Conrad, 95, italics his), but that the Angel of YHWH was in YHWH's presence.

"The figure of the Angel of YHWH seems to evoke the "Son of Man" of Dan 7:9-14 (see the study of this passage in chapter 5 of this dissertation).

${ }^{3}$ Contrary to $1 \mathrm{Kgs} \mathrm{22:19}$ and Isa 6:1, Zech 3 does not contain a graphic depiction of the divine throne; however, YHWH's presence is certainly implied throughout the vision. See Sweeney, 2:594.

${ }^{4}$ Meyers and Meyers have pointed out that in Amos 7-8, YHWH is four times the subject of the same verb in the Hiphil (180).

${ }^{5}$ Prokurat, 333. 
proposed by Meyers and Meyers, 'and cautiously suggested by Blocher. ${ }^{2}$ As the vision develops, one gets the impression that the Angel of YHWH and YHWH himself share a mysterious identity. The Angel, though distinct from $Y H W H$, acts as $Y H W H$ himself, thus virtually blurring any distinction between them. ${ }^{3}$

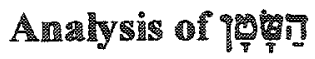

The basic meaning of ךợț is that of "adversary" or "accuser." The occurrence of this term in Ps 109:6 helps illuminate the judicial function of this figure: "Appoint a wicked man over him, and let a a of an ancient court of law, where the "satan" would stand at the right hand of the accused person. Thus it is no wonder that Satan takes his stand at the right hand of Joshua (vs. 1). Moreover, the appearance of this figure in two other places in the Hebrew Bible may cast additional light on his role and function in Zech 3:1-10. Basically, Satan appears to designate a divine being who functions as an opponent. He appears at YHWH's court to act as an adversary against Job (Job 1-2) and David (1 Chr 21:1). A detailed discussion of the nature and function of the satan, whether just a role to be filled by any member of YHWH's heavenly court, or a specific divine figure who had access to the court

'Meyers and Meyers, 185.

"Henri Blocher, "Zacharie 3: Josué et le grand jour des expiations," ETR 54 (1979): 267.

${ }^{3}$ As Merrill pointed out, the Hebrew Bible witnesses the "interchangeability of YHWH and the Angel of YHWH" (Merrill, Haggai, Zechariah, Malachi, 132, n. 7). 
proceedings to perform this exclusive task, would exceed the scope of the present research. $^{1}$

Nonetheless, it could be argued on the basis of the broad context of the Hebrew Bible that Satan does not appear in the court merely to oppose human beings, but YHWH himself. ${ }^{2}$ Although this may not be so apparent in $1 \mathrm{Chr} 21: 1$, it seems more evident in the prologue of Job, where Satan calls into question the fairness of YHWH in his relationship with the patriarch. The picture in Zech 3:1-10 is similar. Satan is rebuked by YHWH, which makes apparent that Satan ultimately acts in opposition to YHWH. That being the case, the identification of Satan with the Devil, as effected by later Jewish ${ }^{3}$ and Christian tradition, is a reasonable inference from the biblical text. ${ }^{4}$ For the purposes of this research it will suffice to note that the portrayal of Satan in Zech 3 is an additional evidence that the pericope portrays a judgment setting. Furthermore, as pointed out by Kim, "The presence

"For a detailed discussion of "satan" in the Hebrew Bible, cf. Gregory A. Boyd, Satan and the Problem of Evil: Constructing a Trinitarian Warfare Theodicy (Downers Grove, IL: InterVarsity, 2001); Peggy Day, An Adversary in Heaven: Satan in the Hebrew Bible, HSM 43 (Atlanta, GA: Scholars Press, 1988); Philip J. Nel, "The Conception of Evil and Satan in Jewish Traditions in the Pre-Christian Period," in Like a Roaring Lion (Pretoria: University of South Africa, 1987); Sydney H. T. Page, Powers of Evil: A Biblical Study of Satun and Demons (Grand Rapids: Baker, 1995); Elaine H. Pagels, The Origin of Satan (New York: Vintage Books, 1996); Marvin E. Tate, "Satan in the Old Testament," RevExp 89 (1992): 461-74.

${ }^{2 " A}$ comprehensive biblical theology deduces that he [satan] was incarnated in the serpent of the temptation account in Genesis 3 . How and why he became the adversary remains a mystery, but it is plain throughout the Scriptures that he is subservient to the sovereignty of God and his pernicious conduct as the accuser is something permitted to him by an all-wise God" (Merrill, Haggai, Zechariah, Malachi, 133).

${ }^{3} \mathrm{Nel}, 1-21$.

${ }^{4}$ Cf. Merrill, Haggai, Zechariah, Malachi, 132-33. 
of Satan makes clear that the setting of this account is heaven."1 This latter observation is endorsed by the presence of the heavenly beings as implied in the participial phrase "those who were standing" ("דis YHWH and therefore indicates a heavenly setting. ${ }^{2}$

\section{Implications of Changing Clothes}

The purpose and significance of the replacement of Joshua's filthy clothes by

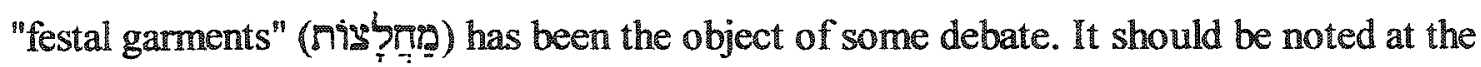
outset that in the ancient Near East, garments were deemed to have more than mere aesthetic or practical significance. It has been observed that the "garment is an extension of a person's personality." ${ }^{n 3}$ Thus a change of garments may point to symbolic connotations that easily elude Western perceptions. ${ }^{4}$ As attested in the Hebrew Bible, a change of garments may represent a change of status, as observed, for example, in marriage ceremonies, ${ }^{5}$ and the ordination of the high priest. ${ }^{6}$ Thus, in the light of its biblical use and

'Kim, 263.

${ }^{2}$ Three similarities of this scene with Job 1, 2 have been noted by Tidwell: (1) The satan's appearance before YHWH as the accuser; (2) YHWH's speech to the satan; and (3) the presence of other angels in the group (Tidwell, 346).

3Paul A. Kruger, "The Hem of the Gament in Marriage: The Meaning of the Symbolic Gesture in Ruth 3:9 and Ezek 16:8," JNSL 12 (1984): 79.

${ }^{4} \mathrm{Cf}$. A Jikk, "Zur magischen Bedeitung der Kleidung in Israel," ZAW 37 (1917/18): 109 25; Manfred Lurker, Wörterbuch biblischer Bilder und Symbole (Munich: Kösel-Verlag, 1987), s.v. "Kleid, Kleidung"; Leland Ryken, Jim Wihoit, and Tremper Longman, eds. Dictionary of Biblical Imogery (1998), S.V. "Garments."

${ }^{5} \mathrm{Cf}$., e.g., Ruth 3:9; Ezek 16:8.

${ }^{6} \mathrm{Cf}$. Exod 28; Lev 8. 
the overall ANE background, the change of Joshua's filthy garments to festal clothes most probably indicates a change of his status from that of a contaminated sinner, to that of a cleansed high priest. That was the process that qualified him to exert high priestly functions in the Jerusalem temple.

As for the specific ceremony that lies behind the description of Zech 3:1-10, at least two major options vie for acceptance: Some scholars favor an installation ceremony in which Joshua was invested as high priest; ${ }^{1}$ others prefer a Day of Atonement setting. ${ }^{2}$ Both of these ceremonies involved changing the clothes of the high priest. However, either option faces exegetical difficulties, since the cursory description of Joshua's enrobing does not provide enough information to point either to the installation ceremony of the high priest, ${ }^{3}$ or the procedures of the Day of Atonement. ${ }^{4}$ A reasonable solution is to understand that by the change of garments, Joshua is made fit for the activities he is supposed to perform in the temple. Thus instead of looking for a specific background in

\footnotetext{
'E.g., Sweeney, 2:593; Baruch Halpern, "Ritual Background of Zechariah's Temple Song," CBQ 40 (1978): 173 .

${ }^{2}$ E.g., Blocher, 264-70; Tidwell, 353.

In contrast to the account of Joshua's enrobing which mentions only "festal robes"

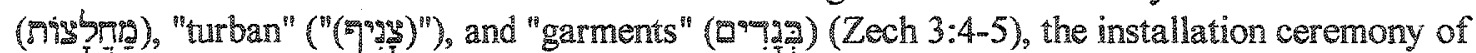

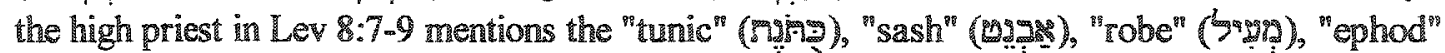

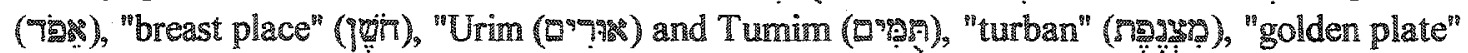

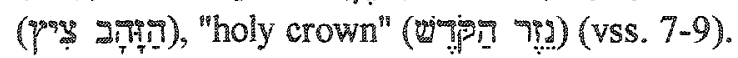

${ }^{4}$ The prescription for the enrobing of the high priest in the Day of Atonement, in Lev 16:4,

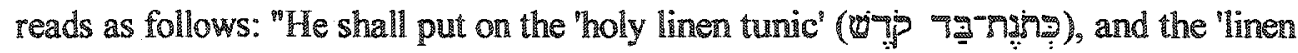

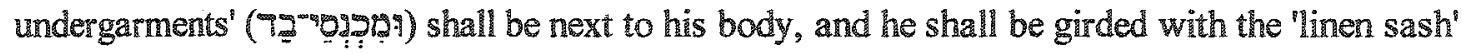
(7. Then he shall bathe his body in water and put them on" (Lev 16:4). Note that no reference is made

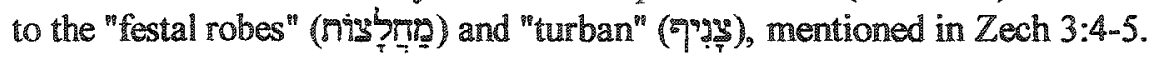


installation or Day of Atonement procedures, one can agree with the plausible suggestion that this is an "ad hoc cleansing ritual" in which YHWH vindicates Joshua from Satan's objections, ${ }^{2}$ thereby making him fit for the temple ministry. In short, the changing of clothes signaled the change of status of Joshua, and symbolized the removal of iniquity from him and from the people. These procedures were a response to a situation experienced by the high priest in the context of the temple ministry. ${ }^{3}$

\section{Removal of Iniquity}

In connection with the change of garments, and probably symbolized by it, a removal of "iniquity" (१i⿱⿴囗十丌 $)^{4}$ is effected. As noted in Zech 3:4:

ๆ4 : He spoke and said to those who were standing before him, saying: Remove the fithy garments from him. Again he said to him: See, I have taken your iniquity away from you and will clothe you with festal robes.

'Petersen, Haggai and Zechariah 1-8, 201.

${ }^{2}$ The text may contain elements which are common to the installation ceremony, and/or Day of Atonement, but there is not enough evidence of them in the text to limit the imagery to either of these settings.

${ }^{3} \mathrm{Cf} . \mathrm{Kim}, 264$.

${ }^{4}$ According to Roy Gane, "in the Hebrew Bible, 'awon ("iniquity") can refer to any part of the process of wrongful act $\Rightarrow$ blame $\Rightarrow$ punishment, whether the act is intentional or not.

However, in Leviticus 1-16 its usage is restricted to blame in the sense of 'culpability, that is, liability to punishment that the sinner must bear (Qal of $2 s^{\prime} ; 5,1,17 ; 17: 18$ ) unless/until it is transferred to an officiating priest through a purification offering, who bears $\left(n s^{\prime \prime}\right)$ it $(10: 17)$, presumably until it is borne ( $2 S^{\prime}$ ) out of the camp by the live goat on the Day of Purgation (16:2122). It is important to recognize that in Lev 1-16 'awon ("iniquity, culpability") arises from an act of hatta' ("expiable sin"), rather than from a separate wrongful act. This is clear in 5:1, 5-6, where a witness who commits a sin (verb and noun from the root ht) bears his 'awon as a consequence until he or she receives expiation (cf. 5:17; Ps 32:5)" (Roy Gane, The NIV Application

Commentary: Leviticus, Numbers [Grand Rapids: Zondervan, 2004], 280-81). 


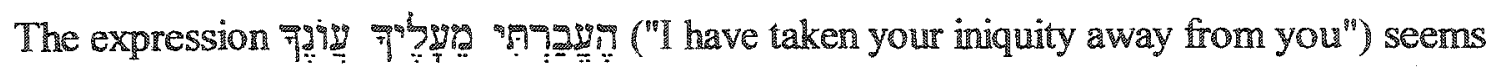

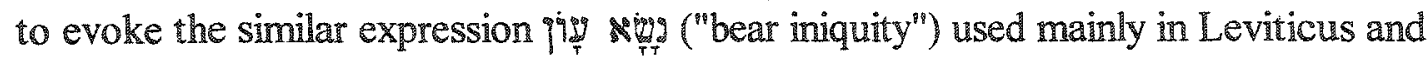

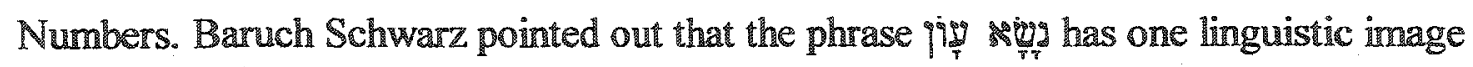
("bear $\sin ^{\prime \prime}$ ) with two uses:

When the sinner himself 'bears' his sin. He may suffer its consequences if such there be. In this usage the phrase is a metaphor for the sinner's unrelieved guilt. It is at most an oblique way of saying that the sinner deserves punishment per se. However, when and if another party-most often, but not necessarily God-'bears' the sinner's burden, it no longer rests on the shoulders of the wrongdoer; the latter is relieved of his load and of its consequences, once again if such there be. In this second usage, the "bearing" of the sin by another is a metaphor for the guilty party's release from guilt. ${ }^{1}$

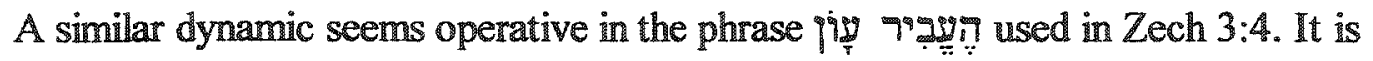

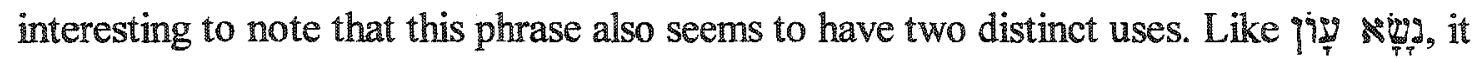
may connote the burden of the culpability over the sinner (in Qal: :

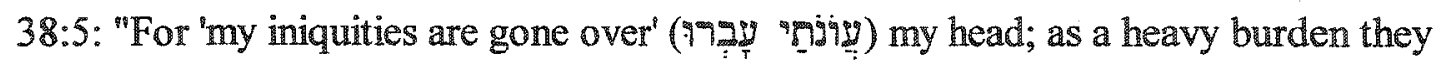

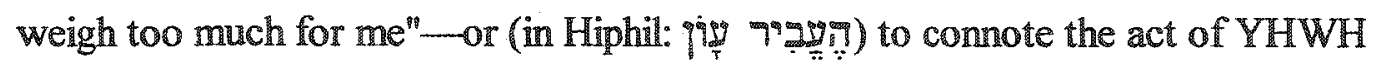
relieving the sinner by removing the guilt, as in 2 Sam 24:10 (par. 1 Chr 21:8): "And David's heart troubled him after he had numbered the people. So David said to YHWH, "I have simned greatly in what I have done. But now, O YHWH, please take away the

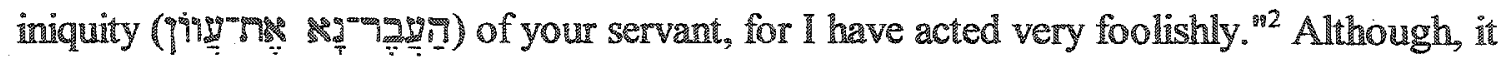
may be difficult to establish whether

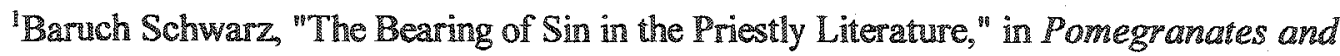
Golden Bells: Studies in Biblical, Jewish, and Near Eastern Ritual, Law, and Literature in Honor of Jacob Milgrom, ed. David P. Wright, David Noel Freedman, and Avi Hurvitz (Winona Lake, $\mathbb{N}$ : Eisenbrauns, 1995), 9, emphasis his.

${ }^{2} \mathrm{Cf}$ Job 7:21. 
979 conveys the same meaning of to connote a situation in which YHWH himself "removed the iniquity" from Joshua."

Another significant observation regarding giv a functions as a performative utterance. As suggested by Petersen, the removal of the iniquity from Joshua "is not just a performative utterance, a pure word-event. The mal'ak effects the removal of guilt by commanding and eliciting action. ${ }^{12}$ In view of the previous

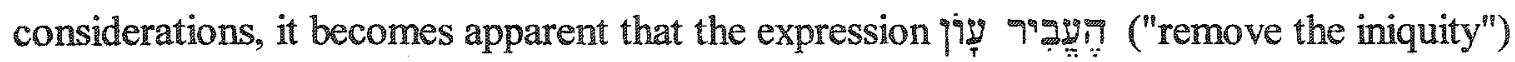
evokes temple/sanctuary activities. Therefore, since the sanctuary/temple was the locus par excellence of purification and forgiveness, it follows that the procedures of Zech 3 portray the heavenly sanctuary/temple as a place where YHWH grants purification and forgiveness to the sinner.

\section{Turban and Stone}

Two elements possibly related to the high priest's apparel echo a temple setting. Although the Hebrew word for "turban" (999

"Some scholars have suggested that the "iniquity" (otig) removed from Joshua was not

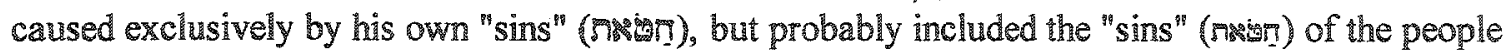
represented by him (cf. Joyce G. Baldwin, Haggai, Zechariah, Malachi: An Introduction and Commentary [Downers Grove, IL: Inter-Varsity Press, 1972], 113; Michael Prokurat, "Haggai and Zechariah 1-8: A Form Critical Analysis" [Ph.D. diss., Graduate Theological Union, 1988], 338; Robert T. Siebeneck, "Messianism of Aggeus and Proto-Zacharias," CBQ 19 [1957]: 219). Notice that the high priest was supposed to bear the iniquity of the people, as stated in Lev 10:17: "Why did you not eat the sin offering at the holy place? For it is most holy, and he gave it to you "to

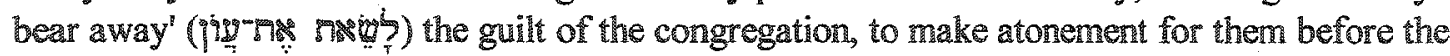
YHWH." On the other side, one should notice that the sins of the high priest could affect the whole people, as if the whole people had sinned. See Lev 4:3-12.

${ }^{2}$ David L. Petersen, Haggai and Zechariah 1-8, 194. 
Exod 28:4 (ng:?9?), it probably refers to the same item; after all, both words derive from the same root ("פgg). What is most relevant for the present research is that the mention of the turban underlines the sanctuary/temple imagery that pervades the passage.

Another item that needs some consideration here is the stone mentioned in $3: 9$. Several views have been advanced regarding the meaning of this stone.' Two of them seem to be more favored by scholarship. First, since the garments of Joshua are a major focus in the previous verses, if would be natural to understand vs. 9 as a continuation of the previous topic, which would imply that the stone is somehow related to the high priest's apparel, probably associated with the crown or turban. ${ }^{2}$ Another option would be to read Zech 3:9 with the next chapter, which mentions a stone in connection with the

'Miloš Bic, Das Buch Sacharja (Berlin: Evangelische Verlagsanstalt, 1962), 51, provided a nice summary of several possibilities: the stone as the cornerstone of the temple (Ferdinand Hitzig and Heinrich Steiner, Die Zwölf Kleinen Propheten, 4th ed. [Leipzig: S. Hirzel, 1881]; Charles H. H. Wright, Zechariah and His Prophecies, Considered in Relation to Modern Criticism: With a Critical and Grammatical Commentary and New Translation: Eight Lectures, 2nd ed. [London: Hodder and Stoughton, 1879]); the capstone of the temple (Karl Marti, Das Dodekapropheton erklärt [Tübingen: Mohr, 1902]); the rock of the temple (H. Schmidt, "Das vierte Nachtgesicht des Propheten Sacharja," ZAW 54 [1936]: 48-60); a precious stone for the royal diadem (Julius Wellhausen, Die Kleinen Propheten, 4 ed. [Berlin: De Gruyter, 1963]); the sealing stone with the name of Zerubbabel (Hugo Gressmann, Der Messias [Göttingen: Vandenhoeck and Ruprecht, 1929]); an adomment stone for the high priest (H. G. Mitchell, $A$ Critical and Exegetical Commentary on Haggai and Zechariah, The International Critical Commentary [Edinburgh: T. and T. Clark, 1912]).

${ }^{2}$ Exod 28:9-12, which contains the description of the twelve stones associated with the ephod, and 28:38-38, which mentions an omament of Aaron's turban engraved with the words "Holy to YHWH," have been suggested as possible background passages for the stone of Zech 3:9. Cf. Edgar W. Conrad, Zechariah, Readings, a New Biblical Commentary (Sheffield: Sheffield Academic Press, 1999), 95-96; Meyers and Meyers, 209; David L. Petersen, Hoggai and Zechariah 1-8, 211-12; Sweeney, 2:602. 
building of the temple. ${ }^{1}$ According to this, both passages refer to the same stone, which represents the divine sanctions for the building activities of the temple.

It is very difficult to decide which option, if any, is correct. The term "stone" by itself is ambiguous and could be used to indicate an item of priestly garb, or a part of the temple. Notwithstanding, one should keep in mind that either option contains temple/cultic connotations, and further emphasize the sanctuary/temple atmosphere that pervades the vision.

\section{Excursus on Zech 3:7: The Purpose of the Vision and the Privileges of Joshua}

Three major reasons make Zech 3:7 significant for this study: First, it reveals that the actions undertaken in favor of Joshua in the heavenly temple/sanctuary aimed at his ministry in the Jerusalem temple. This implies a dynamic interaction between the latter and the former temples. Second, the text says that one of the privileges granted to Joshua in connection with his ministry in the Jerusalem temple would be "to judge," thus implying a functional similarity between the heavenly temple and its earthly counterpart. Third, the verse says that Joshua is granted the privilege of being a member of the divine council, an assertion that further reinforces the connections between heavenly and earthly realms, and informs about the special privilege granted to the purified high priest. In the discussion that follows these issues are investigated.

In order to facilitate the explanation, the verse is displayed below, and divided into clauses which will benceforth be referred to by their respective numbers.

${ }^{1}$ Albert Petitjean, Les Oracles du Proto-Zacharie: Un programme de restauration pour la communauté juive après l'exil (Paris: J. Gabaldăa et Cie, 1969), 179-84. 
(1) Thus says YHWH of hosts

(2) If you will walk in my ways

(3) and if you will perform my service

(4) then you will also judge in my house

(5) and also have charge of my courts,

(6) And I will grant you free access

among these who are standing.

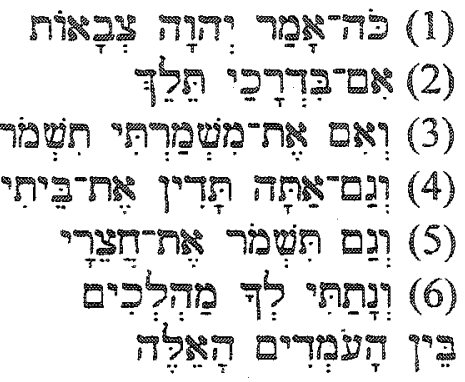

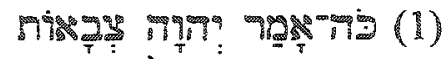

iรs

Purpose of the vision

In this verse one learns that Joshua was cleansed and forgiven in order to serve in the temple, provided that he met certain conditions, as can be deduced from the two conditional clauses (see \#2 and \#3 above). Thus it becomes apparent that the judicial and cultic procedures performed in the heavenly temple/sanctuary were intended to prepare Joshua for his ministry in the earthly temple. If this is true, it could be argued that heavenly and earthly temples were understood to work in dynamic interaction. In this case, the ministry of the heavenly temple validated the service of the earthly temple.

Joshua and the privilege of judgment

One can perceive that one of the privileges granted to Joshua, provided he met the conditions (see \#2 and \#3 above), is to "judge in my [i.e., YHWH's] house" (\#4). The significance of this privilege seems to be highlighted by the grammatically redundant

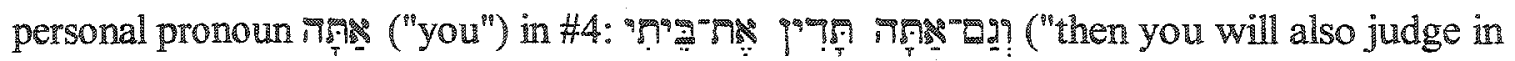
my house"). The focus on the pronoun seems to convey an idea that could be thus paraphrased: "Indeed, it is you (not somebody else), who will judge in my house." The translation of the Hebrew verb 997 as "judge" has been debated since it has the word "house" as its object, which is unusual in the Hebrew Bible. Because of this some 
scholars" and versions ${ }^{2}$ have translated this verb as "govern," or "rule," implying that the major point is that Joshua would be in charge of the administration of the temple. It must be pointed out, nonetheless, that virtually all occurrences of 99? outside Zech $3: 7,{ }^{3}$ in both its verbal or nominal forms, connote judicial overtones. p\% is most often associated with judgment by YHWH, ${ }^{4}$ occasionally of the judgment of various officials, ${ }^{5}$ but also of the judgment exercised by kings; ${ }^{6}$ it may also connote the idea of strife, contention, ${ }^{7}$ rights, or cause. $^{8}$ Therefore, in view of the consistent use of 99 in the Hebrew Bible within the semantic field of judgment, it is very unlikely that it connotes the administration of the temple in $\# 4 .^{9}$

From a contextual and grammatical point of view, 9 is better understood as conveying the idea of judgment. Joshua would have the privilege of judging "in my house [i.e., the Jerusalem temple]." As Mason noted, "the special privileges given to Joshua in

'Merrill, Haggai, Zechariah, Malachi, 138; H. G. Mitchell, A Critical and Exegetical Commentary on Haggai and Zechariah, ICC (Edinburgh: T. and T. Clark, 1912), 154; Conrad, 94; Sweeney, 2:600.

${ }^{2} \mathrm{ESV}, \mathrm{NRS}, \mathrm{RSV}, \mathrm{TNK}$. NASB, NIB, NIV, NJB.

${ }^{3}$ That is, forty-four times in thirty-eight verses.

${ }^{4}$ Gen 15:14; 30:6; Deut 32:36; 1 Sam 2:10; 24:16; Isa 3:13; PSs 7:9; 9:5, 9; 50:4; 54:3; $68: 6 ; 72: 2 ; 76: 9[8] ; 96: 10 ; 110: 6 ; 135: 14 ; 140: 13 ;$ Job $6: 31 ; 35: 14 ; 36: 17$.

5ISa 10:2.

Jer 21:12; 22:16; Prov 20:8; $31: 9$

${ }^{7} 2 \operatorname{Sam~19:10;~Job~35:14;~36:17;~Prov~20:10;~} 29: 7 ;$ Eccl 6:10.

${ }^{8}$ Prov $31: 5 ;$ Isa 10:2; Jer 5:28; 30:13; Prov $31: 8$.

${ }^{9}$ Meyers and Meyers make a strong case for "the important juridical content" of the passage (195). 
the development of the vision suggest" that he "is charged with executing judgment." $\mathrm{A}$ connection of judgment with the temple also appears in Deut 17:9-10, where the Levites are said to work as judges of the people. ${ }^{2}$ Therefore, that in $\# 4$ this idea is associated with the high priest should not come as a surprise, since the sanctuary/temple could also be understood as a place of judgment. ${ }^{3}$ Also from a grammatical point of view, the use of the locution "תִ ("my house") in syntagmatic relationship to since it functions here as an adverbial accusative to indicate the place where the action of "judging" is performed. Therefore the translation to "judge in my house" fits in both the context and syntax of the passage. In addition, the term "my house" ("ת.'9) in \#4 is most probably a reference to the Jerusalem temple, due to its parallelism with "my courts"

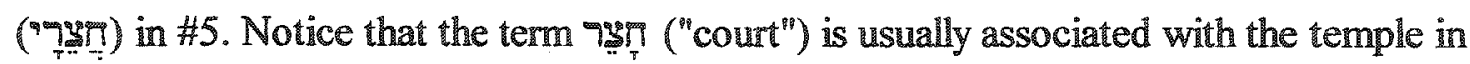
the Hebrew Bible. ${ }^{5}$

The relevance of the above observation for the present study is that it reveals a functional correspondence between the heavenly temple/sanctuary and its earthly counterpart. It should not be forgotten that since the vision describes judicial procedures

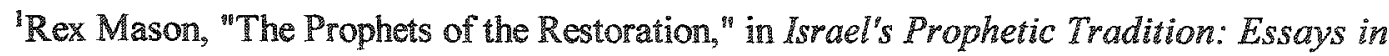
Honour of Peter R. Ackroyd, ed. R. J. Coggins, Anthony Phillips, and Michael A. Knibb (Cambridge: Cambridge University Press, 1982), 147. 32.

"Baruch Halpern, "Ritual Background of Zechariah's Temple Song," CBQ 40 (1978): 231 -

${ }^{3}$ See, e.g., Isa 6:11ff; Ezek 1: 8-11.

${ }^{4}$ That the direct object marker (ng) may be used with adverbial accusatives has been noted by Bruce K. Waltke and O'Connor, An Introduction to Biblical Hebrew Syntax (Winona Lake, $\mathbb{N}$ : Eisenbrauns, 1990), 181.

$$
{ }^{5} \text { Cf., e.g., Pss 65:5 [4]; 84:11 [10]; 92:14 [13]; 116:19;135:2. }
$$


being performed in the heavenly temple, the indication that Joshua would undertake similar actions in the earthly temple suggests a functional correspondence between the heavenly sanctuary/temple and its earthly counterpart.

Joshua and the privilege of access to the heavenly council

The last clause seems to speak of a special privilege granted to Joshua-he would have access to the heavenly council of YHWH, as implied in the statement "And I will grant you free access among these who are standing" (\#6). Access to the heavenly council was deemed to be a privilege of the prophets, as noted in Amos 3:7, "Surely the Lord YHWH does nothing unless he reveals his secret counsel (79'8) to his servants the prophets." That the high priest is granted such an honor is of major significance: Joshua would not only be a priest, but a priest-prophet. ${ }^{2}$ Since some scholars argue that \#6 does not depict Joshua's access to the assembly of YHWH in the heavenly temple/sanctuary, but to his ministration in the Jerusalem temple, ${ }^{3}$ a brief exegetical investigation of the passage is in order.

At the outset it should be noted that clauses $\# 2$ through $\# 6$ form a conditional sentence as is clearly implied by the conditional conjunction "if") at the beginning of clauses \#2 and \#3. The task ahead is to determine whether clauses \#4 and \#5 are part of

${ }^{1} \mathrm{Cf}$. e.g., $1 \mathrm{Kgs} 22: 19-23$; Amos 3:7.

${ }^{2}$ Possibly like Aaron, who, as Num 12 implies, was a prophet.

${ }^{3}$ Sweeney speculates that "the 'right of access' mahlek m apparently refers to the high priest's right of access to the Holy of Holies in the Jerusalem Temple" (2:599); McNicol claims that Joshua will be a chief cultic officer in the rebuilt temple ("The Heavenly Sanctuary in Judaism," 78). 
the protasis or belong to the apodosis, in order to better understand the last clause, which is the main goal of this analysis. The shift from to 2 in $\# 4$ seems to indicate that the apodosis starts here and culminates with Joshua's being granted access to the Heavenly Court (\#6) which, as noted above, is related to the heavenly sanctuary/temple.

The main issue in this connection is to determine the meaning of \#6: "And I will grant you free access (" determine whether the access to be granted to Joshua refers to the privilege of ministering in the Jerusalem temple and thus having access to its most holy place, or the privilege of access to the heavenly council/temple of YHWH. The reference to "these who are

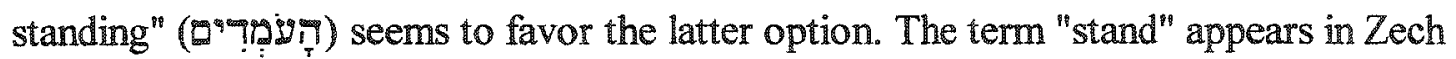

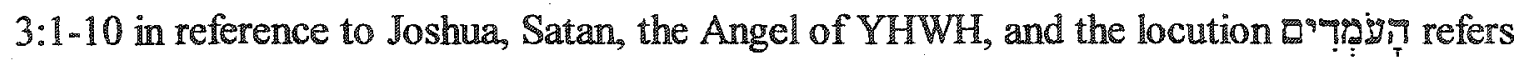
to the members of the heavenly council, since they were standing in the heavenly-court scene (Zech 3:4). Thus it seems appropriate to understand this expression in \#6 as referring to the heavenly beings, the members of the heavenly council of YHWH. That Joshua's colleagues are later referred to as those "who are sitting" (vs. 8) further reinforces the idea that "these who are standing" (ำ of YHWH. If this is so, the privilege granted to Joshua is access to the heavenly reaim. Nonetheless, how or why this access would happen is not explained. But one may surmise that this probably means that Joshua's judgments (and probably his ministry as a whole) in

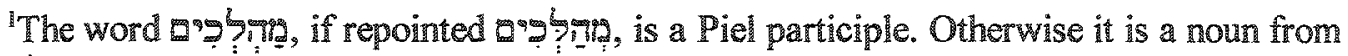
the root 7 " ("to go, walk"). Either way it conveys an intransitive meaning like "goings" or "wanderings" and would thus express the notion of free "access" or right of "access" as translated in some versions. CR. NASB, RSV, ASV, ESV, JPS, NJB.
} 
the earthly temple would have the benefit of his being privy to YHWH's judgments in the heavenly sanctuary/temple. So, the heavenly temple and earthly counterpart would work in dynamic interaction, since the latter would reflect the procedures of the former.

\section{Heavenly Sanctuary/Temple Motif}

On the basis of the previous discussion, it is reasonable to suppose that the scene portrayed in Zech 3:1-10 has its setting not only in heaven, but more specifically, in the heavenly sanctuary/temple. The presence of the high priest Joshua being accused by Satan and the presence of heavenly beings convey a graphic picture of the judicial proceedings of the heavenly tribunal. Additionally, we can also note, especially in regard to the forgiveness of Joshua as symbolized by the changing of his clothes, that the actions connote heavenly sanctuary/temple imagery. Thus, it is reasonable to say that the fourth vision of Zechariah depicts judicial and cultic procedures performed in the heavenly temple/sanctuary.

\section{Tunction}

The function of the heavenly sanctuary/temple can be delineated as follows: First, the judicial function is perceived in the court scene, where the heavenly temple functions as a court of law. The defendant, in spite of the accusations of Saran, is eventually vindicated and made clean. This imagery portrays the heavenly temple/sanctuary as a place of judgment. Second, the heavenly temple also functions as a place of cultic activity. This is revealed in the action of cleansing and forgiveness as symbolized by the changing of Joshua's clothes. 
Nonetheless, it should be kept in mind that the distinction between judicial procedures, on the one hand, and cultic, on the other, is largely artificial and is adopted only for the sake of analysis. As a matter of fact, the temple was understood as the locus not only of cultic, but also of judicial activities, which seem to have been conceived of as a unified set of procedures. In the description of the Day of Atonement (Lev 16), for example, one perceives an interconnection of cultic and judicial elements. Although the cultic aspect may seem more apparent, upon closer inspection, the judicial element can be clearly perceived.' Solomon's prayer is also worth noticing in this regard. There the temple emerges as a place where cultic and judicial questions are settled, prayers and sacrifices are offered ( $2 \mathrm{Kgs} \mathrm{8:31-32).}{ }^{2}$ Another example may be found in the parallel chapters of Dan 7 and $8{ }^{3}$ portraying the same set of activities with judicial and cultic imagery, respectively. From this it follows that it is more accurate to say that the heavenly temple functions for a complex set of procedures that can only be grasped by analogy with human institutions. Although for the purposes of analysis one may separate judicial from cultic activities, in biblical thought these are two aspects of an indissoluble set of procedures undertaken by YHWH in his heavenly sanctuary/temple.

'Roy Gane has demonstrated how cultic and judicial aspects are interconnected parts of the same system: "By treating moral evil both as relationallegal breach and as pollution, the Israelite system of skern rituals ('purification offerings'=so-called 'sin offerings') addresses both the standing and state of YHWH's people. This system shows the way not only to freedom from condemnation, but also to healing of character, which is defined in terms of loyalty to $\mathrm{YHWH}$ " (Roy Gane, Cult and Character, forthcoming).

${ }^{2}$ See the analysis of this passage above.

${ }^{3}$ See the investigation of Dan 7 and 8 below, in chapter 5 of this dissertation. 


\section{Relatiomship to rarthly Counterpart}

The relationship between the heavenly temple/sanctuary and its earthly counterpart can be perceived in two aspects. First, the judicial and cultic procedures to be performed by Joshua in the earthly temples point to a functional correspondence inasmuch as both heavenly and earthly temple are portrayed as a locus of judicial and cultic procedures.

The text also indicates a dynamic interaction with the Jerusalem temple. Joshua's purification in the heavenly temple had the purpose of making him fit for his ministry in the earthly temple. The vision apparently intended to provide heavenly sanctions for the activities soon to be performed in the earthly temple. In other words, by the procedures in the heavenly sanctuary/temple, the ministry of the earthly temple was legitimated inasmuch as the high priest was vindicated by YHWH. ${ }^{1}$ Furthermore, Joshua's right of access to the heavenly court may also imply a dynamic interaction between heavenly temple/sanctuary and its earthly counterpart, thus indicating a dynamic interaction.

As pointed out by $\mathrm{Kim}$, "the heavenly setting functions as surety and validity of Yahweh's promise. This means that in spite of the absence of a detailed description of its pattem, the heavenly temple is closely connected with the earthly temple, guaranteeing its efficient function. In other words, the former stands before or above the latter as its assurance. $^{\text {22 }}$

${ }^{1} M$ Meyers and Meyers cautiously suggested that the vision occurred in the context of a ceremony in the Jerusalem temple. Thus an "earthly investment plus prophetic vision of heavenly investment, worked in tandem to achieve the desired effect" (222). However, despite its attractiveness, this suggestion finds no support in the text.

${ }^{2} \mathrm{Kim}, 267$. 


\section{Other Tersts}

For the sake of completeness, this section undertakes a brief survey of several other passages that refer or allude to the heavenly sanctuary/temple motif.

Isa $18: 4$

$$
\text { לย }
$$
9y? 97

For thus YHWH has told me, I will look from my dwelling place quietly like dazzling heat in the sunshine, like a cloud of dew in the heat of harvest.

The "exceedingly obscure" pericope of Isa 18 contains several difficult and cryptic expressions whose historical identification has challenged the exegetes. ${ }^{3}$ A plausible

\footnotetext{
"The preposition in the prepositional phrase "gigas should be translated as "from" according to most versions. This meaning is consistent with the context of the passage which implies that YHWH looks "from" his dwelling. Besides, other Hebrew Bible passages which contain the concept of YHWH looking down from heaven or the heavenly temple use the unambiguous preposition (e.g., Deut 26:15; Pss 80:15[14]; Isa 63:15). It is also worthy of mention that a meaning "from" is commonly attested in Ugaritic texts. See Mark D. Futato, "The Preposition 'beth' in the Hebrew Psalter," WTJ 41 (1978): 68-83; S. Segert, A Basic Grammar of the Ugaritic Language with Selected Texts and Glossary (Berkeley: University of California Press, 1997), 181.

${ }^{2}$ Walter Brueggemann, Isaiah, Westminster Bible Companion (Louisville, KY: Westminster John Knox, 1998), 152.

3For example: The "people feared far and wide, a powerful and oppressive nation whose land the rivers divide" mentioned in vs. 1 has been understood as the Assyrians (R. E. Clements, Isaiah 1-39, NCBC [Grand Rapids: Eerdmans, 1980]; Watts, Isaioh 1-33, 246; W. Jansen, Mourning Cry and Woe Oracle, BZAW 125 [New York: de Gruyter, 1972], 60), the Medes (Edward J. Kissane, The Rook of Isaiah, Translated from a Critically Revised Hebrew Text with Commentary [Dublin: Browne and Nolan, 1941]), or the Ethiopians (so Kraeling, 96-97; Hans Wildberger, Isaiah 13-27: A Commentary, Continental Commentaries [Minneapolis: Fortress, 1991], 212). Also the identity of the messengers (aיs:ys) in vs. 2 has been debated. If they are the same as the "ambassadors" (ם999) referred to previously in the same verse, they may probably be Ethiopians (Wildberger, Isaioh 13-27: A Commentary, 210-11). Kaiser argues that this is an ideal scene and implies that the messengers are those sent by YHWH to deliver the message found in vs. 5 to the lands that lay south of Egypt (Otto Kaiser, Isaiah 13-39: A Commentary [Philadelphia: Westminster, 1974], 90-97). Another suggestion was put forth by Jansen according to which these a'ș Jansen, Mourning Cry and Woe Oracle, BZAW 125 [New York: de Gruyter, 1972], 60-61; John
} 
reconstruction of the historical context of Isa 18 , as suggested by several scholars, runs as follows: An Ethiopian delegation went to Jerusalem to persuade the Judeans to join an anti-Assyrian coalition. In this connection YHWH sent a message to Isaiah urging the people not to join the Ethiopians, because YHWH himself would take care of the enemy at the right time. ${ }^{1}$

For the purpose of this research it should be noted that YHWH is portrayed as exerting control from his "place" (ๆ9 "site," "fixed or established place, foundation," can refer to either the earthly or the heavenly temple. The word seems to convey the special nuance of "firmness," as noted in the root 999 (be established, be permanent, endure). ${ }^{5}$ The translation of qตร 9 as "dwelling" or "abode" followed by most versions" thus seems justified by the several uses of this word to indicate either the heavenly or earthly temple.

F. A. Sawyer, Isaiah, 2 vols. [Philadelphia: Westminster, 1984], 1:167). The difficulties of the text and its ambiguities lead one to pay closer attention to the following statement by Kaiser: "The lack of precision of the poem, together with the appeal to the inhabitants of the earth, argues against an inteprepretation in terms of contemporary history and suggests that an eschatological understanding is appropriate to the text" (Otto Kaiser, Isaioh 13-39: A Commentary [Philadelphia: Westminster, 1974], 92).

${ }^{1}$ Cf. Blenkinsopp, Isaiah 1-39, 310; Leupold, Exposition of Isaich, 1:301-08; Motyer, 135-38; Oswalt, 360.

${ }^{2}$ See the discussion of Exod 12, in chapter 3 of this dissertation.

${ }^{3}$ HALOT, S.จ. ๆig\%.

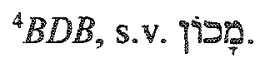

${ }^{5}$ HALOT, S.V. 999.

${ }^{6} \mathrm{C}$., e.g., NAS, RSV, NIV, TNK, ASV, DRA, ESV, JPS, KJV, NKJ, NRS.

${ }^{7}$ See the discussion of gisis in connection with the discussion of Exod 15 in chapter 3 of this dissertation. See also the section on $1 \mathrm{Kgs} 8$ above. 
Three aspects related to the "dwelling" of YHWH as referred to in this passage need further clarification: the location of this "dwelling place"; its function in the context of the passage; and the relationship between "the dwelling place" (giva) referred to in vs. 4 and the "place of the name of YHWH" (T7q?" geg apg) mentioned in vs. 7. First, although the "dwelling place" (gig/a) of YHWH in this passage coud be either the Jerusalem temple ${ }^{l}$ or his heavenly dwelling/temple, ${ }^{2}$ the latter view seems more appropriate in light of the immediate context and imagery portrayed by text. The focus of the passage on world affairs with YHWH supervising foreign nations seems to suggest that 9ig: is the heavenly dwelling place of YHWH. Moreover, the picture of YHWH looking from his "dwelling place" seems appropriate for a place in heaven. Additionally, when the Jerusalem temple is referred to in the passage, the prophet refers to it as "the place (घipis?) of the name of YHWH of hosts" (vs. 7).

Second, it is instructive to inquire about the function of YHWH's dwelling place as portrayed by the passage. Since the heavenly dwelling is the place from where YHWH

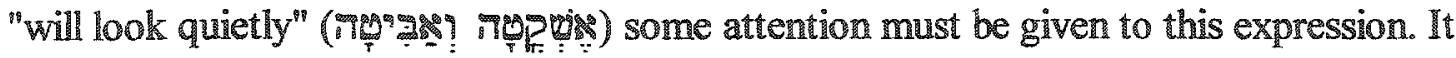
has been argued that this expression means that "the Lord will passively let things take their course," or that YHWH will remain neutral, that is, "from his heavenly dwelling

'Slotki, 86.

${ }^{2}$ Brevard S. Childs, Isaiah, The Old Testament Library (Louisville, KY: Westminster John Knox, 2001), 138; Kaiser, Isaiah 13-39: A Commentary, 95, implicitly; Dieter Schneider, Der Prophet Jesaja, WSRAT (Wuppertal: R. Brockhaus, 1988), 1:291; Widyapranawa, 106; Wildberger, Isaiah 13-27: A Commentary, 220; Edward Young, The Book of Isaiah, 3 vols., NICOT 23 (Grand Rapids: Eerdmans, 1965), 1:477.

${ }^{3}$ Kraeling, 97. 
Yahweh will neither support Egypt-Ethiopia, nor yet uphold Assyria." ${ }^{\text {"1 }}$ Nevertheless, although the root ope ("look") may refer to either "God's inactivity" or "his freedom from annoyance or care, ${ }^{12}$ the context favors the latter possibility. The use of harvest imagery (vss. 4 and 5) conveys the idea of judgment. ${ }^{3}$ As vs. 5 further clarifies, YHWH would soon create havoc amid the enemy. Eventually, foreigners would bring a gift of homage to the temple on Mount Zion (vs. 7). Thus YHWH, far from being passive or neutral, will evaluate the situation and intervene-from his heavenly dwelling/temple-at the appropriate time. It is neither passivity nor neutrality, but the control that YHWH exerts from his heavenly dwelling (१is ) that seems to be the main point. He not only watches, but actually "presides over the process." ${ }^{\text {4 }}$

In this connection, it should be remembered that the concept of YHWH "looking" (미) down from heaven, or from his heavenly temple, upon the world is used elsewhere in the Hebrew Bible. ${ }^{5}$ This imagery seemingly intends to depict YHWH's sovereignty over the created order. Nothing escapes his vigilant supervision. Thus, the explicit reference to the "place" (ןis\$) whence YHWH exerts this "looking" upon creation seems to underscore the role of the heavenly dwelling as a center of command, or headquarters of

Clements, Isaiah 1-39, 165.

${ }^{2}$ Gray, A Critical and Exegetical Commentary on the Book of Isaiah 1-39, 313.

${ }^{3}$ According to Blenkinsopp, the harvest depicted in the text is the grape harvest, "one of the more persistent images of judgment in the biblical literature" (Isaiah 1-39, 311).

${ }^{4}$ Motyer, 162.

${ }^{5} \mathrm{Cf} .$, e.g., Deut 26:15; Isa 63:15; Ps 80:15 [14]. 
YHWH. In this case, the ןior is not merely a place of dwelling, but a place from where YHWH supervises world affairs. As can be perceived in vss. 5-7, YHWH will intervene, and the nations will bring gifts "to the place of the name of YHWH of hosts, even Mount Zion" (vs. 7).

Third, it is worthy of note that both heavenly and earthly temples are referred to in the short chapter of Isa 18. While vs. 4 refers to the heavenly dwelling/temple of YHWH, vs. $7^{1}$ mentions the Jerusalem temple, here designated as "the place of the name of YHWH," thus indicating the notion of a vertical correspondence. It is instructive to note that the reference to the Jerusalem temple as "the place of the name of YHWH of hosts" displays a concept similar to $1 \mathrm{Kgs} 8$, where the dynamic relationship between the heavenly temple and its earthly counterpart is clearly affirmed. ${ }^{2}$ Therefore, the reference to YHWH's dwelling "place" in heaven (Isa 18:4), along with the mention of the "place of the name of YHWH" on earth in (Isa 18:7), indicates a vertical correspondence between the heavenly dwelling/temple and its earthly counterpart. Such a correspondence appears to be functional-inasmuch as the function of the heavenly temple parallels that of the earthly

\footnotetext{
${ }^{1}$ That this expression refers to the Jerusalem temple is made clear by the use of Zion in apposition to it (vs. 7). It should be noted that there has been some discussion among critical scholars about the authenticity of, e.g., vss. $2 b \beta, 6 b, 7$. It is argued that these verses or fragments thereof are later additions (cfo, e.g., Wildberger, Isaich 13-27: A Commentary, 209). Consistent with the canonical approach adopted in this dissertation, the text is treated as a unified composition.
}

${ }^{2}$ See the discussion on $1 \mathrm{Kgs} 8$, above. 
counterpart-and structural, since the term yigs ("place, foundation") can also designate the earthly temple. ${ }^{1}$

Isa $63: 15$

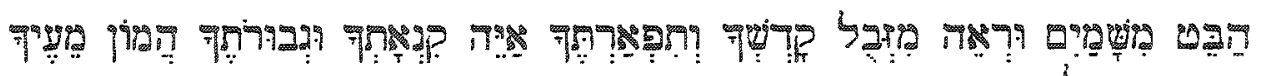 :भP}

Look down from heaven and see from Your holy and glorious habitation; where are your zeal and your mighty deeds? The stirrings of your heart and your compassion are restrained toward me.

The present pericope belongs to the text unit of Isa 63:7-64:11 [12], which according to most commentators belongs to the genre of lamentation. ${ }^{2}$ The prophet, embodying the community, laments the devastation caused by the enemy and prays for YHWH to intervene on behalf of the people. Isa 63:15 marks a change of perspective in the flow of the text. As Watts pointed out, "thus far God is seen as moving within the continuum of history. Now the perspective is vertical. He is in heaven looking down or coming down to his people. ${ }^{83}$

Commentators have usually understood the parallel expressions "heaven" and "habitation" as overlapping completely so that "Your holy and glorious habitation" would

${ }^{1}$ See the discussion of $1 \mathrm{Kgs} 8$, above.

${ }^{2}$ Childs, 519 ; Paul D. Hanson, Isaiah 40-66, IBC (Louisville: John Knox, 1995), 235; John L. McKenzie, Secord Isaiah, AB 20 (Garden City, NY: Doubleday, 1968), 188, 192; R. N. Whybray, Isaiah 40-66, New Century Bible (London: Oliphants, 1975), 255. Westerman considers this text to be "probably the most powerful lamentation in the Bible" (Claus Westermann, Isaiah 40-66: A Commentary [London: S.C.M. Press, 1969], 392). A more nuanced view is suggested by Watts, who although recognizing signs of the lamentation genre in 63:15-64:1, 9-11, contended that "the controlling genre is that of the sermon-prayer which is well known from Deuteronomy and Chronicles. This shows itself in 63:7-14, 64:3[4]-8[9]" (Isaiah 34-66, 328-29).

${ }^{3}$ Watts, Isaiah 34-66, 333. 
be identical to heaven. Nonetheless, as noted before, ${ }^{1}$ the parallelism between "heaven" and "habitation" does not require that "heaven" be understood as the "habitation"; rather it seems more logical to understand heaven as the broad area where the "habitation" is located. It instructive to hold in mind that the term "habitation" (Iבר), which is qualified

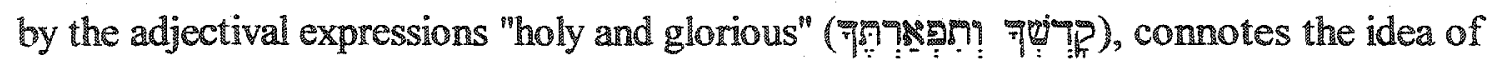
"temple/sanctuary."2 These same adjectival expressions are used in Isa 64:10 [11] to qualify the Jerusalem temple in the expression "Our holy and beautiful house"

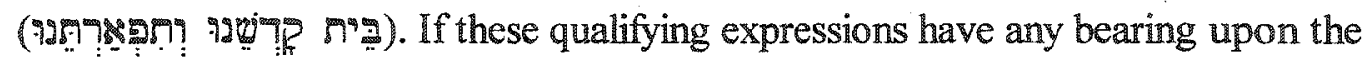
interpretation of the passage, it must be admitted that the text most probably refers to the "habitation" (Iבְֵ), not merely as "heaven," but as a place located in heaven-namely, the heavenly temple. As McKenzie noted, Isa 63:15 contains "an allusion to the heavenly temple, of which the earthly temple is the counterpart."."

Additionally, it is worth noting that the term לg? ("habitation") is also applied to the earthly temple (1 Kgs 8:13). Therefore it seems apparent that the usage of ๆภา ๆ indicates that YHWH is expected to respond from a specific place in

${ }^{1}$ See the discussion on Deut $26: 15$ in chapter 3.

"The NIV translation of byi here as "throne" seems to limit the semantic range of the word beyond evidence. The idea behind bgy is that of something high, lofty, exalted, and although this can include the throne it is by no means restricted to it. Actually, byi is never used in the Hebrew Bible in relation to the throne. As a matter of fact, apart from Isa 63.15 , this word occurs only five times in the Hebrew Bible as a common noun (1 Kgs 8:13; $2 \mathrm{Chr} 6: 2$; Ps $49: 15$; Hab 3:11). In 1 $\mathrm{Kgs} \mathrm{8:13} \mathrm{(par.} \mathrm{2} \mathrm{Chr} \mathrm{6:2)} \mathrm{it} \mathrm{refers} \mathrm{to} \mathrm{the} \mathrm{Jerusalem} \mathrm{temple;} \mathrm{in} \mathrm{Ps} \mathrm{49:15} \mathrm{it} \mathrm{seems} \mathrm{that} \mathrm{the} \mathrm{idea} \mathrm{is} \mathrm{that}$ of habitation, mansion, or princely dweling, as conveyed by most translations; and in Hab 3:11 it is used metaphorically of the dwelling place of the sun and the moon.

${ }^{3}$ McKenzie, Second Isaiah, 191. 
heaven - the heavenly temple-from where he is expected to intervene. The implication of the above considerations is that the heavenly temple is understood to exist in structural correspondence to its earthly counterpart.

As for its function, one notes that the heavenly temple emerges in this passage as a place where the prophet, in his lament, turns to YHWH for intervention. ${ }^{2}$ The basic idea seems to be that the heavenly temple works as a place of divine activities, a place from where YHWH supervises earthly affairs and hears prayer, which also indicates that the heavenly temple works in functional correspondence to the earthly counterpart.

Jer $17: 12$

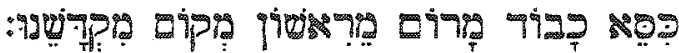

A glorious throne is on high; from the beginning is the place of our sanctuary.

'Scholars have been reluctant to note the important role of the heavenly sanctuary/temple in the context of the Hebrew Bible. This may probably be due to an unstated intention to avoid a localized idea of $\mathrm{YHWH}$, which is obviously wrong. For example, in discussing this passage Pieper refers to the "heaven as the holy and glorious dwelling place of the Lord" (August Pieper and Erwin E. Kowalke, Isaiah II: An Exposition of Isaiah 40-66 [Milwaukee, WI: Northwestern Pub. House, 1979], 645); Whybray just notes that "the idea that Yahweh dwells in heaven was an ancient one" (260); Westermann argues that the reference to YHWH's habitation here "means the far-off sovereign realm of God on high" (Westermann, Isaiah 40-66: A Commentary, 393); Muilenburg declares "that the prophet envisages God remote in his heaven" ("Exegesis of the Book of Isaiah 40-66, 736). However, the Hebrew Scriptures present YHWH as capable of being active in the most remote and improbable places (cf. Obad 4; Job 38:4; Amos 9:3) and localized in the heavenly/earthy temples.

${ }^{2}$ Some scholars see in this verse only a complaint against YHWH's indifference to the situation of his people (James Muilenburg, "Exegesis of the Book of Isaiah 40-66," in The Interpreter's Bible, ed. George Arthur Buttrick New York: Abingdon, 1956], 5:736; Whybray, 260; Young, 486; J. Ridderbos, Isaiah [Grand Rapids: Regency Reference Library, 1985]). Nonetheless, the context of the passage suggests that the suppliant expected YHWH to intervene and put an end to those troublesome circumstances. This seems implied in rhetorical questions in 64:11 [12] which imply that the suppliant expected an intervention of YHWH. 
This passage belongs to the section of Jer $17: 12-18$, which is composed in the style of a lament. ${ }^{1}$ YHWH is implored to vindicate the prophet since the latter is being despised by those who have rejected YHWH himself. ${ }^{2}$ The opening lines of this section (vs. 12) seem to contain an allusion to the heavenly sanctuary/temple motif. ${ }^{3}$ Although several scholars have seen here an allusion to the Jerusalem temple, ${ }^{4}$ a close investigation indicates the presence of the heavenly sanctuary/temple motif. In spite of its syntactic difficulties, ${ }^{5}$

'Douglas Rawlinson Jones, Jeremiah: Based on the Revised Standard Version, NCBC (Grand Rapids: Eerdmans, 1992), 243.

${ }^{2}$ Ibid.

${ }^{3} \mathrm{Cf}$. William Le Holladay and Paul D. Hanson, Jeremiah 1: A Commentary on the Book of the Prophet Jeremiah, Chapters 1-25, Hermeneia (Philadelphia: Fortress, 1986), 501; Jones, Jeremiah, 244-46.

${ }^{4}$ John M. Bracke, Jeremiah 1-29, Westminster Bible Companion (Louisville, KY: Westminister John Knox, 2000), 149; John Bright, Jeremiah, 2nd ed., AB 21 (Garden City, NY: Doubleday, 1973), 119; Ernst Haag, Das Buch Jeremia, 3rd ed., GSEAT 5 (Düsseldorf: PatmosVerlag, 1988), 1:197; F. B. Huey, Jeremiah, Bible Study Commentary, BSCS (Grand Rapids: Zondervan, 1981), 62; Henry McKeating, The Book of Jeremiah, EC (London: Epworth, 1999), 103; John Andrew Dearman, Jeremiah and Lamentations (Grand Rapids: Zondervan, 2002), 176; J. A. Thompson, The Book of Jeremiah, NICOT (Grand Rapids: Eerdmans, 1980), 423; Gunther Wanke, Jeremia, ZB (Zürich: Theologischer Verlag Zürich, 1995), 168.

${ }^{5}$ The clause divisions of the passage are complicated by a string of six morphological units without any verbal form. Thus, the versions tend to transiate the text as a single nominal clause, as can be exemplified in the NIV: "A glorious throne, exalted from the beginning, is the place of our sanctuary." However this one-clause translation entails metric problems for a poetic passage such as this. The TNK tries to bypass the syntactic complications by understanding "throne" (2) as a vocative: "O Throne of Glory exalted from of old, Our Sacred Shrine!" This translation also has its problems, since the use of "throne" in the vocative presupposes that metonymic understanding of throne where it means YHWH himself. This usage lacks any support in the other 136 occurrences of this word in the Hebrew Bible. As Nam aptly observed, the "throne of God" motif in the Hebrew Bible "is never deified or identified with God himself," and also "is never called 'God" or worshiped as a cult object" (Nam, "The "Throne of God" Motif in the Hebrew Bible," 460). All in all, the best option seems to understand the string of words in the verse as forming a bicola of two nominal clauses, which renders the verse as a parallelism of two bicolon with a syntactic chiasm, as in the translation adopted above. Cf. Holladay and Hanson, 501. 
the text becomes clear, once its poetic nature is taken into account. Such poetic nature manifests itself as a bicolon of two nominal clauses, as shown below.

A glorious throne is on high;

From the beginning is the place of our sanctuary

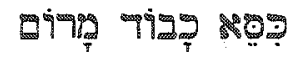

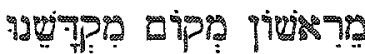

Holladay noted a chiasm in which two adverbial predicates "on high" and "from the beginning" are framed by the subjects "glorious throne" and "our sanctuary" respectively." "Throne" and "sanctuary" are parallel terms which frame the entire verse and allude to the same entity, namely, a "throne" connected with the "sanctuary." It is now necessary to determine if this "sanctuary" is located in heaven or on earth.

The words "beginning" ("ivis inquiry. A sanctuary which was since the "beginning" indicates something other than the Jerusalem temple. The latter, built by Solomon, could hardly be considered to have been "from the beginning," an expression much more appropriate to indicate the heavenly temple. Additionally, the term "high" (องา the throne of YHWH seems more fitting for a place in heaven than to the Jerusalem temple.

At this juncture, it would be useful to bring the larger context of the book of Jeremiah to bear upon our text. As noted by McKeating, Jeremiah seems to display a very

Holladay and Hanson, 501.

${ }^{2}$ Although the word gin? (height, elevation, elevated place) may point to the site of the Jerusalem temple, it is also used to indicate Drpẹ (cF., e.g., Isa 24:21; Pss 71:19; 93:4; 102:20; 148:1; Job 16:19). 
negative attitude towards the Jerusalem temple. $\mathrm{He}$ was probably not attacking the temple per se, but the kind of worship performed therein. ${ }^{2}$ In view of his overall stance towards the Jerusalem temple, it seems more reasonable to understand such lofty expressions as on "high" and "from the beginning" as qualifying the heavenly temple. It may be not far off the mark to suggest that Jeremiah was tuming the attention of his audience from the earthly temple to the true throne and the true temple of YHWH located in heaven, not in Jerusalem. ${ }^{3}$

If the above arguments for the heavenly sanctuary/temple motif in the passage under study are accepted, then two further issues deserve consideration-the function of the heavenly sanctuary, and its relationship to the earthly counterpart. As for its function, it is instructive to note that the heavenly "sanctuary" (vig?? concept of "throne" (19). This seems to evoke the basic idea of "kingship." If so, the heavenly "sanctuary" is the place whence YHWH exerts his kingly functions. Furthermore, as a place of kingship the sanctuary would naturally encompass the function of judgment. Thus vss. 12-13, which "articulate a doxology of judgment, ${ }^{\text {nf }}$ would provide further corroboration that the heavenly sanctuary functions as a place of judgment.

'McKeating, The Book of Jeremiah, 103.

${ }^{2}$ Huey, 62.

${ }^{3} \mathrm{C}$. Holladay and Hanson, 501.

${ }^{4}$ Walter Brueggemann, A Commentary on Jeremiah: Exile and Homecoming (Grand Rapids: Eerdmans, 1998), 161. 
As for the relationship to the earthly counterpart, the picture emerges of a vertical correspondence between the heavenly temple and its earthly counterpart. In the concept of judgment one perceives a functional correspondence; and the in the designation of the heavenly temple as of a structural relationship.'

Jer $25: 30$

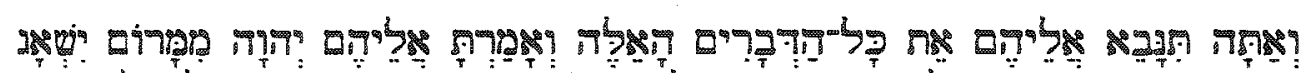

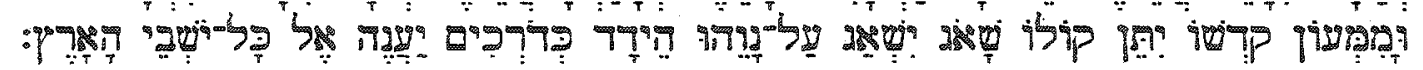
Therefore you shall prophesy against them all these words, and you shall say to them, YHWH will roar from on high and utter his voice from his holy habitation; he will roar mightily against his fold. He will shout like those who tread [the grapes], against all the inhabitants of the earth.

This passage belongs to the section of $25: 30-38$ that consists of a series of poetic sayings on the theme of universal judgment. The entire pericope is packed with images of destruction and anger, thus forming a fitting conclusion to the series of oracles against the nations in the previous section of the book of Jeremiah (i.e., 25:17-26). ${ }^{2}$ The reference to the heavenly sanctuary/temple motif in vs. 30 is thus a fitting conclusion to a section dealing with the theme of universal judgment. This verse, according to most scholars,

\footnotetext{
${ }^{1}$ it should be noted that that the text implies a tension between the earthly temple and its heavenly counterpart. If the broad context of the book of Jeremiah is taken into consideration, one gets the impression that the prophet is here turning the attention of his audience to the ultimate temple located in heaven, thus relativizing the importance of the Jerusalem temple. In a sense it seems that Jer 17:12 anticipates what the author of Hebrews would state more explicitly six centuries later when referring to "the greater and more perfect tabernacle, not made with hands, that is to say, not of this creation" (Heb 9:11).
}

${ }^{2}$ As Thompson observed, Jer 25:30-38 continues in poetic form the section on the nations (25:17-26), but without any reference to the specific countries referred to therein. Thompson, 519 . 
portrays a heavenly setting, ' a view corroborated by the parallelism and the context of the passage. For example, the two parallel lines demonstrate that "from his holy habitation" parallels "from on high," as noted below.

YHWH will roar from on high and utter his voice from his holy habitation

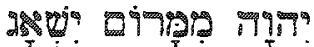

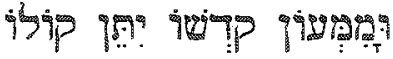

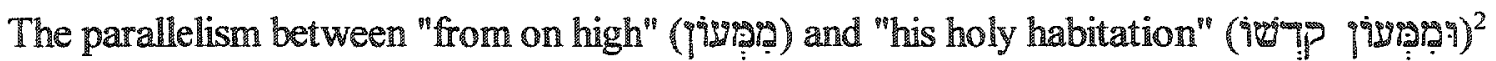
indicates that the "holy habitation," namely, the sanctuary/temple, is the heavenly one. ${ }^{3}$ This is corroborated by the term eim ("high"), which can also refer to heaven, as noted above. Furthermore, the immediate context contains a message of judgment, couched in "apocalyptic language," not only against Israel, but against "all the inhabitants of the earth." As vs. 31 makes clear, "YHWH has a controversy (29?) with the nations. He is

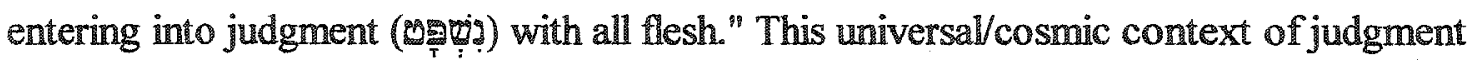
makes a temple located in heaven more appropriate than an earthly temple. sanctuary")

'Bright, 161; Holladay and Hanson, 679; Jones, 334; Thompson, 519; Wanke, 234.

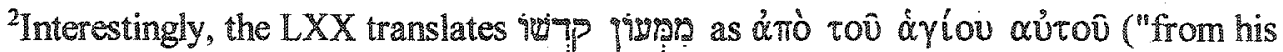

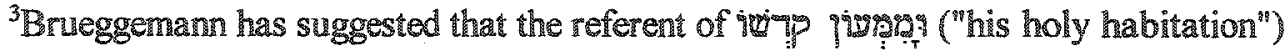
"could be either Jerusalem or heaven" (A Commentary on Jeremiah: Exile and Homecoming, 226), while Rober Carrol suggested a "dual reference to heavenly and earthly sanctuaries" (Robert P. Carroll, Jeremiah: A Commentary, OTL [Philadelphia: Westminster, 1986], 507). It is interesting to note that all the other four occurrences of $i m g$ pip gimp in the Hebrew Bible refer to the heavenly temple. See Deut 26:15; Zech 2:17; Ps 68:6;2 Chr 30:27 (all these passages are discussed elsewhere in this dissertation).

${ }^{4}$ Carroll, 507. In the expression "apocalyptic language," Carroll seems to use the term "apocalyptic" not in the sense of a literary genre, as usual in the scholarly literature, but in the sense of "diction" or "imagery" used in the apocalyptic genre. 
The above considerations indicate that the heavenly sanctuary/temple functions as a place of judgment and thus seems to be understood to exist in functional correspondence to the earthly counterpart. ${ }^{1}$ Moreover, the designation Iשฺ notion of a place in heaven and thus points to a structural correspondence between the heavenly temple and its earthly counterpart.

Hos 5:15

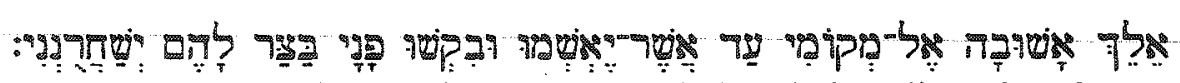
I will go away [and] return to my place until they acknowledge their guilt and seek my face; in their affliction they will earnestly seek me.

The pericope of Hos 5:15 belongs to a transitional point in the flow of the book. Placed between a message of punishment (5:10-14) and a song of penitence $(6: 1-3),{ }^{2}$ the passage of 5:15 constitutes an appropriate transition from punishment to salvation inasmuch as it depicts YHWH's strategy to bring his people back to him. The main thrust of the passage seems to be that YHWH will become absent until his people realize they need him. In this connection it should be noted that YHWH's absence is characterized by his "return to my [i.e., YHWH's] place."

For the purpose of this research we need to inquire about the referent of the expression "my place" ("פ̣ipg). Some scholars argue that, consistent with the lion

"Amos 1:2, which says that "YHWH roars from Zion" (that is, the earthly temple), further reinforces the concept of a functional correspondence between the heavenly temple and its earthly counterpart.

${ }^{2}$ Mays, Micah: A Commentory, 92. 
metaphor applied to YHWH in the previous verses, "gaps should tefer to his lair." It seems, however, that in $5: 15$ the lion metaphor gives way to cultic language. $Y H W H$ is no longer depicted as a lion ready to devour the impenitent prey, but as the personal Cod calling his people back.

At this juncture, one must undertake an examination of the lexeme gippe ("place") in order to determine its meaning in the present context. It is improbable that this word means lair, as noted above. Moreover this word is used in the Hebrew Bible as a technical term for the temple of $\mathrm{YHWH},{ }^{2}$ a usage that seems consistent with the sanctuary/temple language contained in the passage under scrutiny. ${ }^{3}$ The following terms seem to point in this direction: The verb wers (offend, be guilty) is a technical term employed in the context of the temple cult to connote ritual and moral impurity. Also the verb vip 9 ("seek") is employed to indicate the worship of YHWH or an oracular inquire of YHWH. ${ }^{5}$ Furthermore, the reference to distress ( $9 \mathrm{~g}$ ) indicates a situation of "cultic lament" in which

IFrancis I. Andersen and David Noel Freedman, Hosea: A New Translation with Introduction and Commentary (Garden City, NY: Doubleday, 1980), 414; Duane A. Garrett, Hosea, Joel, The New American Commentary 19A (Nashville, TN: Broadman and Holman, 1997), 155; Hans Walter Wolf, Hosea: A Commentary on the Book of the Prophet Hosea, Hermeneia (Philadelphia: Fortress, 1974), 116; Roy L. Honeycutt, Jr., "Hosea," The Broadman Bible Commentary, ed. Clifton Allen (Nashville, TN: Broadman, 1972), 7:31; McComiskey, The Minor Prophets, 2:86; Homer Hailey, A Commentary on the Minor Prophets (Grand Rapids: Baker, 1972), 154.

${ }^{2}$ E.g., Deut 12:5, 14; 14:23, 25; $1 \mathrm{Kgs} \mathrm{8:29,30;} \mathrm{Isa} \mathrm{18:7;} \mathrm{Ezek} \mathrm{43:7.} \mathrm{Cf.} \mathrm{Marvin} \mathrm{A.}$ Sweeney, 1:68.

${ }^{3}$ This has been aptly noted by Sweeney to whom I am indebted for the argumentation conducted in this paragraph. Cf. Sweeney, 1:68-69.

${ }^{4}$ Lev 5:6,7, 15;7:1-10. Cf. Sweeney, 1:68.

${ }^{5} 2 \operatorname{Sam} 21: 1 ;$ Pss $24: 6 ; 27: 8 ; 105: 4 ; 1$ Chr 16:11; 2 Chr 17:14; Sweeney, 1:68. 
the people seek YHWH in the temple.' Also the verb 7riv appears in cultic contexts where the people appeal to $\mathrm{YHWH} .^{2}$

Since the "place" (mipp) most probably refers to the temple, as noted, the task now is to ascertain whether the text refers to an earthly or heavenly temple. It seems that, if $\mathrm{YHWH}$ is going to be absent, this absence must be understood in reference to the place where his presence among the people was realized, namely, the Jerusalem temple. That is, YHWH's absence might be understood in terms of a departure from the earthly, namely, the Jerusalem temple, ${ }^{3}$ an idea also present in the first chapters of Ezekiel. ${ }^{4}$ Therefore, the place to which YHWH returns must be his heavenly sanctuary/temple. ${ }^{5}$ We should note that this understanding of "place" (aip/g) to indicate YHWH's heavenly temple is reflected in the Targum Jonathan, which translates "my place" ("pipp) as "my holy dwelling which

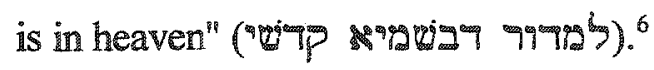

'Pss 6 and 7;. Sweeney, 1:68.

2Ps 78:34; cf. Isa 8:20; 47:11; Sweeney, 1:68-69.

${ }^{3} \mathrm{Tg}$. Jonathan thus translates the first part of our verse: "I will remove my presence

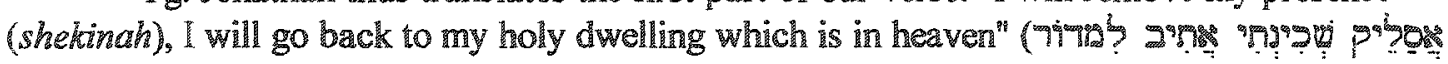

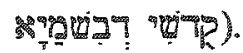

${ }^{4}$ Cf. Graham I. Davies, Hosea, NCBC (London: Marshall Pickering, 1992), 158. See the discussion on Ezek 1 and 10 above.

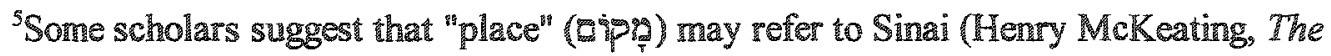
Books of Amos, Hosea and Mical [Cambridge: University Press, 1971], 108) or to Yahweh's mount (James Luther Mays, Micah: A Commentary [Philadelphia: Westminster, 1976], 92-93).

${ }^{6}$ Miqra'ot Gedolot (New York: Pardes, 1951), 9:92 (Hos 5:15). 
On the basis of the discussion undertaken above, it is highly probable that the "place" (ciple ) referred to in the passage is located in heaven, and consequently indicates YHWH's heavenly dwelling place, or in other words, his heavenly sanctuary/temple. Although the text does not elaborate the function of this heavenly "place" ( $\Xi$ ipp $)$, it seems to function as YHWH's dwelling, and the place whence he would observe and watch his people's response in order to save them, as implied in the subsequent verses.

Jonah 2:5 [4] and $8[7]$

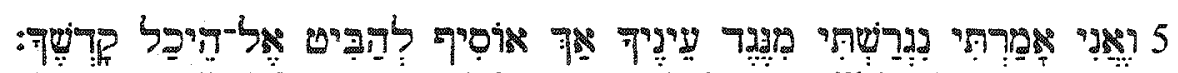
4 So I said: I have been expelled from your sight. Nevertheless I will look again toward your holy temple.

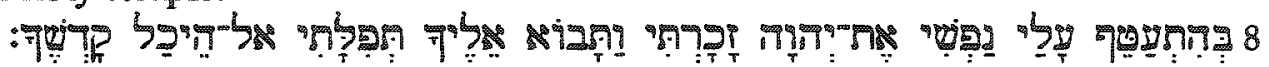
7 While I was fainting away, I remembered $\mathrm{YHWH}$, and my prayer came to you, into your holy temple.

The expression 7t? the Jerusalem temple, ${ }^{1}$ since the expression "I will look again" in vs. 5 and the mention of "sacrifices" in $2: 9$ seem to indicate an earthly setting. ${ }^{2}$ Although at first glance these arguments seem compeling, a close examination of the immediate and large context of the passage indicates that the heavenly temple may be in view. Before proceeding, it is necessary to clarify that Ty"? by ("your holy temple") in vs. 5 [4] probably indicates

${ }^{1} \mathrm{Cf}$. , e.g., Uriel Simon, Jonah: The Traditional Hebrew Text with the New JPS Translotion, trans. Lenn J. Schramm, JPS Bible Commentary (Philadelphia: Jewish Publication Society, 1999), 23; Ursula Struppe, Die Bucher Obadja, Jona, NSKAT 24/1 (Stuttgart: Katholisches Bibelwerk, 1996), 110-12; Hans Walter Wolf, Obadiah and Jonah: A Commentary (Minneapolis: Augsburg, 1986), 135.

${ }^{2} \mathrm{So} \mathrm{Kim}, 228-29$. 
the earthly temple, as implied in the expression "I will look again." Turning to vs. 8 [7], however, a different picture emerges. There seems to be some evidence to indicate that the temple mentioned there is the heavenly one, as noted in the arguments that follow.

First, that Jonah cries for help from the depth of 5 ("Sheol"), seems to imply that help will come from the polar opposite, that is, from the heavenly temple. A similar situation involving polar opposites (heavenly temple/Sheol) is reflected in 2 Sam 22:6, where the suppliant cries from the Sheol to the heavenly temple. Also worthy of note is Isa $14: 11-15$, where it is reported that although the king of Babylon wanted go up to the mount of the congregation, yet he was brought down to Sheol.

Second, in line with the previous argument, it should be observed that the cosmological language and imagery describing the distress of Jonah calls for some help beyond earthly geography: Note for example that "he was thrown into the "deep (it? 9 s?ą), into the heart of the seas (G"9)" (VS. 4 [3]), "the great deep (Gim) engulfed" him (vs. 6 [5]), and "the earth (Y situation might have been offered towards the earthly temple, the heavenly temple seems to be much more appropriate as a counterbalance to the cosmic proportions of Jonah's distress.

'Although the possibility exists that vs. $5[4]$ refers to the earthly temple in view of the expression "I will look again toward your holy temple," a brief consideration of the root 92 ("look") in eפgs? may be instructive. This verbal root appears elsewhere in the Hebrew Bible to indicate YHWH "looking" down from his heavenly sanctuary/temple. The picture in Jonah is reversed; out of distress, it is Jonah who "looks" to YHWH. The irony of this situation becomes more evident if the "holy temple" referred to in the passage is the heavenly one. 
Third, as Davidson pointed out, when YHWH addressed Jonah for the first time,

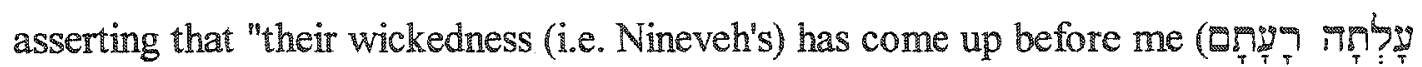

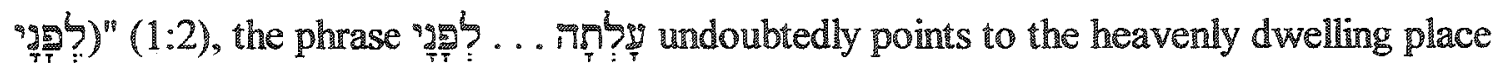
of YHWH.' Tuming to Jonah $2: 7$ [8], "it is not the wickedness of Nineveh, but Jonah's prayer that comes to God, and it would seem logical that the prayer would reach God [in] the same place as the wickedness, that is, his heavenly sanctuary. ${ }^{\prime 2}$

Fourth, a look at the large context of the Hebrew Bible reminds one of David, who in a situation of distress cries for help from the heavenly temple (1 Sam 22:7). If David's prayer can shed any light on the supplication of Jonah, one may argue that when Jonah turns toward the temple for help, it is probably the heavenly temple that is in view.

The cumulative force of the arguments advanced above reveals that those scholars who admit the presence of the heavenly temple in this pericope may be right. ${ }^{3}$ If so, one learns that the heavenly temple functions in the passage as a source of help for the suppliant in times of distress. This indicates a functional and structural correspondence between the heavenly temple and its earthly counterpart. It is functional inasmuch as the function of the heavenly temple seems to mirror that of the earthly temple. As noted elsewhere in the Hebrew Bible, the earthly temple is also portrayed as a source of help. In

"Davidson, "The Heavenly Sanctuary in the OId Testament," 20.

${ }^{2} \mathrm{Ibid}$.

${ }^{3}$ So Davidson, "The Heavenly Sanctuary in the Old Testament," 20-21; George M. Landes, "The Kerygma of the Book of Jonah: The Contextual Interpretation of the Jonah Psalm," Int 21 (1967): 21, n. 58; Jack M. Sasson, Jonah: A New Translation with Introduction, Commentary, and Interpretations AB 24B (New York: Doubleday, 1990), 181; Harold Shank, Minor Prophets, The College Press NIV Commentary, Old Testament Series (Joplin, Mo: College Press, 2001), 346. 
addition, it should be noted that the term "IT" ("temple"), which indicates both the heavenly temple (2:8 [5]) its earthly counterpart (2:5 [4]), conveys the notion of a specific place in heaven and thus indicates a structural correspondence. Finally, it should be noted that the shiff from the earthly (vs. 5 [4]) to the heavenly temple (8 [7]), and back to the earthly temple, as implied in the reference to "sacrifices" (vs. 10 [9]), may indicate a dynamic interaction between the heavenly temple and its earthly counterpart.

Hab 2:20

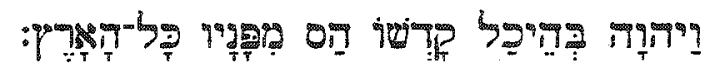

But YHWH is in his holy temple. Let all the earth be silent before him.

Different scholarly views have been expressed regarding the location of the temple (לָּ) in Hab 2:20. Some scholars understand it as the heavenly temple, ${ }^{1}$ others contend for the Jerusalem temple, ${ }^{2}$ and a third group admits the possibility that the text may refer to both. ${ }^{3}$ In support of the view that the passage refers to the Jerusalem temple, Kim adduced three lines of argument, which can be summarized as follows:

'Hailey, 288; McComiskey, 2:876; Charles L. Taylor, Ir., "Exegesis of the Book of Habbakuk," The Interpreter's Bible, ed. George Arthur Buttrick (New York: Abingdon, 1956), 6:995; Bemhard Duhm, Das Buch Hobakuk (Tübingen: Mohr, 1906), 69; D. David Garland,

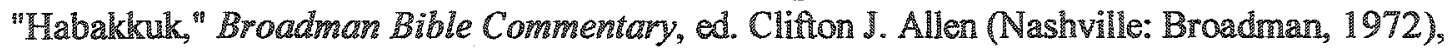
263; Cuthbert A. Simpson and Walther Russel Bowie, "Genesis," The Interpreter's Bible, ed. George Arthur Buttrick (Nashville, TN: Abingdon, 1981), 1:194; Wade, The Book of Hobakkuk, 194.

${ }^{2} \mathrm{O}$. Palmer Robertson, The Books of Nahum, Hobakkuk, and Zephaniah (Grand Rapids: Eerdmans, 1990), 210-11; Sweeney, 2:478; John D. Wats, Joel, Obadiah, Jonah, Nahum, Habakkuk and Zephaniah, CBC (Cambridge University Press, 1975), 143.

${ }^{3}$ Andersen, Habakkuk: A New Translation with Introduction and Commentary, 256; Barker and Bailey, 349; Patterson, Nahum, Habakkuk, Zephaniah, 209; "His holy temple," THab 2:201, SDABC, $4: 1055$. 
1. There is a contrast between YHWH in vs. 20 and the idols in vss. $18-19$. In other words, while the Chaldean temples contained only dead idols, the Jerusalem temple was marked by YHWH's presence. The passage is thus understood as expressing a vindication of the Jerusalem temple. ${ }^{1}$

2. "If there is a temple in heaven, why does he expect that all the earth including both the Chaldeans ${ }^{2}$ and his Judean audience or readers would need to keep silence before Yahweh?"13 Hence, it is more natural to understand "keep silence" as applied to the Jerusalem temple.

3. The final major argument is drawn from Hab 3, where YHWH's horizontal movement on earth is described. Since this movement is not a vertical one (i.e., from the heavenly temple), but from Teman, to presumably the temple in Jerusalem, it is suggested that the temple referred to in $2: 20$ is the Jerusalem temple.

Although the arguments advanced by Kim are framed by substantial exegetical analysis, the following discussion will interact with these arguments in order to probe their validity. First, the possible contrast between "idol gods in the Babylonian temples, and the

${ }^{1} \mathrm{Kim}, 247$.

${ }^{2}$ The identification of the wicked in $\mathrm{Hab} 2$ as the Chaldeans is based on a reasonable inference based on the reference to them in 1:6. It must be noted, however, that the text does not mention any specific historical references in chap. 2. As Gowan pointed out, "what is described there has occurred over and over again, and not only in antiquity" (Donald E. Gowan, The Trimph of Faith in Habakkd [Atanta: John Knox, 1976], 57). In view of this, one gets the impression that "the text has purposely been expressed in general terms so that it could be applied to tyranny in many forms" (ibid.).

${ }^{3} \mathrm{Kim}, 248$.

${ }^{4}$ lbid., 251. 
one true God Yahweh in the Jerusalem temple ${ }^{\text {11 }}$ can be seen along different lines. It seems that the contrast lies in contrast between powerless pagan gods who could be found in the pagan temples, and the almighty God YHWH who dwelled in the heavenly temple and from there ruled the world. ${ }^{2}$ Second, it is far from clear that the injunction to keep silence is more appropriate to a temple in Jerusalem than to a temple in heaven. For example, the same injunction appears in Zech 2:17 [13] and is formulated in the context of the heavenly temple. ${ }^{3}$ Third, the horizontal movement of YHWH from Teman (Hab 3:3) to, presumably, the Jerusalem temple would favor the latter as the referent for the temple mentioned in $2: 20$. However, in this regard one should ask how much weight should be placed on the highly poetic imagery of Hab $3: 3 \mathrm{ff}$. to determine whether the temple mentioned in $2: 20$ is the heavenly or the Jerusalem one.

${ }^{1}$ bid., $_{247 .}$

${ }^{2}$ According to Barker and Bailey, there is a "contrast between those who are no god and the one who is in heaven ready to respond to human need and to human questions" (349). A century prior to Barker's observation, Duhm had pointed out that when "the heathens think that the Jews do not have any god because nobody sees God in an aniconic religion; while every heathen temple houses a visible god. The Jews answer: Our God is in heaven and, therefore, can do anything he pleases. As the one who lives in heaven, he is almighty. In contrast, the images of the heathen temple are dead and nothing. And when a pious Jew trembles, he says to himself: Yahweh is in his holy palace and looks down from his heavenly throne to the earth Ps $211: 4$, comp. $2: 4$." $^{\text {" }}$ The German text reads: "die Heiden meinen, die Juden haben gar keinen Gott, weil man einem solchen in deren bilderlosen Religion niemals zu sehen bekommt, während ja jeder heidnische Tempel einen sichtbaren Gott beherbergt, die Juden antworten: unser Gott ist im IIImmel und kann darum alles tun, was ihm gefälit; als Himmelsbewohner is er allmächtig, dagegen sind die Bilder der heidnischen Tempel tot und nichtig. Und wenn dem frommen Juden bange wird, sagt er sich: Jahve ist in seinem heiligen Palast und blickt von seinem Himmelsthron auf die Erde herab Ps $11: 4$ vgl. Ps 2:4" (Duhm, Das Buch Habakuk, 69).

${ }^{3}$ See the investigation of this passage below. 
As discussed in the previous paragraphs, the possibility remains that Hab 2:20 may contain an allusion to the heavenly temple. The following arguments seem to substantiate this view.

1. As Davidson pointed out, the text implies a contrast between YHWH in his

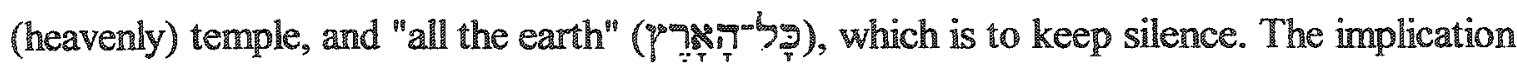
of this assertion is that the temple is outside the earth, and is not a part of it."

2. In the broad context of the book it is implied that "it is from heaven that YHWH looks' $(1: 3,13)$ at events in the world, ${ }^{12}$ thus it would be logical that $2: 20$ would point to the heavenly temple of YHWH.

3. The diction of $2: 20$ is very close to Zech $2: 13,{ }^{3}$ which clearly locates the temple in heaven.

4. Due to the overall conception that the earthly temple was patterned after a heavenly antitype, one must reckon with the possibility, suggested by some scholars, ${ }^{4}$ that

'Davidson, "The Heavenly Sanctuary in the Old Testament," 23.

${ }^{2}$ Francis I. Andersen, Habakkuk: A New Translation with hintroduction and Commentary, Anchor Bible 25 (New York: Doubleday, 2001), 256.

${ }^{3} \mathrm{Cf} . \mathrm{Ps} 11: 4$.

"Note the following statements: "If this composition dates prior to $587 / 6$, when the Jerusalem temple was completely destroyed, one may doubt whether the prophet made such a distinction between the earthly temple and its heavenly prototype" (J. J. M. Roberts, Nahum, Habakku, and Zephaniah: A Commentary [Louisville, KY: Westminster John Knox, 1991], 128). "The two identifications of the temple are not incompatible. There was a nexus between the heavenly shrine and its earthly replica. The construction of the latter according to the plan or model of the former was intended to symbolize and to facilitate this combination. Both loci are recognized in Solomon's great prayer toward the Jerusalem Temple and God hears in heaven" (Andersen, Habakkuk, 256). Cf. Also "His holy temple" [Hab 2:20], SDABC, 4:1055; Barker and Bailey, 349. 
even if there is an immediate reference heavenly temple, the Jerusalem temple may also be in view.

Granting that Hab 2:20 contains an allusion to the heavenly temple, one should inquire about the function of this temple and its relationship with the earthly counterpart. The thematic elements of the book of Habakkuk with their cry for justice, together with the view that Hab 2:20 reflects a "call to worship from the temple liturgy," allows two inferences to be drawn. First, the idea of YHWH in the heavenly temple appearing at the end of a series of woes in 2:5-20 may connote the idea of judgment. ${ }^{2}$ The mention of the temple at the conclusion of the section seems to imply that despite the arrogance of the wicked, the judgment will come. YHWH is in the heavenly temple, he is in control of earthly events, and will eventually bring judgment upon the wicked. ${ }^{3}$

Second, the liturgical setting just mentioned implies that the congregation has gathered to worship YHWH at the Jerusalem temple. According to Roberts, this communal worship in the temple suggests that "the prophet included the earthly temple in Jerusalem in his conception of Yahweh's holy temple." It seems reasonable to infer, then, that the probable allusion to both the heavenly temple and the Jerusalem temple in this passage suggests a irurgical correspondence between the heavenly temple and its earthly

${ }^{1}$ McComiskey, The Minor Prophets, 2:876.

${ }^{2}$ The Pesher of Habakkuk makes a connection between 2:19-20 and the Day of Judgment when "God will eradicate all the idolaters and the wicked from the face of the earth" (William Hugh Brownlee, The Midrash Pesher of Habakk [Missoula, MT: Scholars Press for the Society of Biblical Literature, 1979], 212 [1QpHab 13:2-4]).

${ }^{3} \mathrm{Cf}$. Roberts, Nahum, Habakkuk, and Zephaniah, 128.

${ }^{4}$ Ibid., emphasis supplied. 
counterpart. Davidson expressed this idea as he referred to "a link between cosmic judgment and (earthly sanctuary) liturgy." This linkage between heavenly and earthly temples resembles the one portrayed by Solomon's prayer ( 1 Kgs 8), where a dymamic interaction between the heavenly and earthly temples is delineated. ${ }^{2}$

Finally is should be noted that Hab $2: 20$ indicates a functional correspondence between the earthly temple and its earthly counterpart, as seen in the judgment and worship functions of both heavenly and earthly temples. A structural correspondence is also observed, inasmuch as the ל997 indicates a place in heaven. Finally, the text also implies a dynamic interaction between the heavenly temple and its earthly counterpart along the lines of Solomon's prayer in $1 \mathrm{Kgs} 8$ and Ps $1500^{3}$

\section{Zech 2:17 [13]}

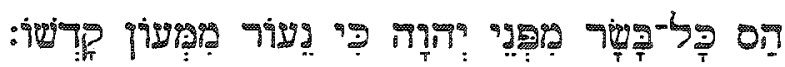

Be silent, all flesh, before YHWH; for he is aroused from his holy habitation.

Despite a few dissenting voices who suggest that the passage refers to the Jerusalem temple, ${ }^{4}$ most commentators favor a heavenly referent for the expression "his holy habitation" (706? 9ivg) in Zech 2:17 [13]. The passage under consideration occurs

'Davidson, "The Heavenly Sanctuary in the Old Testament," 23.

${ }^{2}$ See the discussion of $1 \mathrm{Kgs} 8$ earlier in this chapter.

${ }^{3} 1 \mathrm{Kgs} 8$ is discussed above in the present chapter, and Psa 150 is treated in chapter 5.

${ }^{4}$ Conrad, 85-86; Karl Elliger, Das Buch der Zwölf Kleinen Propheten II: Die Propheten Nahum, Habakuk, Zephania, Haggai, Sacharja, Maleachi, 5th ed., ATD 25 (Göttingen: Vandenhoeck and Ruprecht, 1964), 119; David L. Petersen, Haggai and Zechariah 1-8, 185; Sweeney, 2: 592.

${ }^{5}$ Baldwin, 112; Kenneth L. Barker, "Zechariah," The Expositor's Bible Commentary, ed. 
in the transition between the third and fourth night visions (2:5-17) reported in the first part of Zechariah. 'This pericope brings a message of assurance that Jerusalem would be rebuilt and that YHWH himself would dwell in it again. In 2:14-15 [10-11], as aptly noted by $\mathrm{Kim}$, the occurrence of the verb $92 \mathrm{~g} T$ ("dwell") in the context of YHWH's promise to dwell among his people evokes sanctuary/temple imagery, ${ }^{2}$ and contains the implication that YHWH would restore the temple. ${ }^{3}$

The context thus indicates that Jerusalem had been abandoned. Therefore if YHWH "is aroused from his holy habitation," this must be a reference to his heavenly

Frank E. Gaebelein (Grand Rapids: Zondervan, 1985), 7:621; Cohen, 279; James H. Gailey, Jr., Micah, Nahum, Habakkuk, Zephaniah, Haggai, Zechariah, Malachi, The Layman's Bible Commentary (Atlanta: John Knox, 1982), 106-107; Merrill, Haggai, Zechariah, Malachi, 128; Meyers and Meyers, 171-72; Hinckley Gilbert Thomas Mitchell, J. M. Powis Smith, and Julius August Bewer, A Critical and Exegetical Commentary on Haggai, Zechariah, Malachi, and Jonah, ICC (Edinburgh: T. and T. Clark, 1951), 145; Petitjean, 154; Paul L. Reddit, Haggai, Zechariah and Malachi: Based on the Revised Standard Version, NCBC (London: M. Pickering, 1995), 62; D. Winton Thomas, "Exegesis of the Book of Zechariah," The Interpreter's Bible, ed. George Arthur Buttrick (New York: Abingdon, 1956), 6:1067; Brian Tidiman, Le livre de Zacharie, Commentaire Évangélique de la Bible, vol. 18 (Vaux-sur-Seine, France: Edifac, 1996), 107; John D. Watts, "Zechariah," The Broadman Bible Commentary, ed. Clifton J. Allen (Nashville: Broadman, 1972), 319; Kim, 256.

${ }^{1}$ The book of Zachariah divides itself into two major parts (chaps. 1-8 and 9-14), of which the first part consists mainly of eight night visions $(1: 8-17 ; 2: 1-4[1: 18-21] ; 2: 5-17[2: 1-13] ; 3: 1-$ $10 ; 4: 1-14 ; 5: 1-4 ; 5: 5-11 ; 6: 1-15)$. Cf. Sweeney, 2:574-634.

According to Petersen, these visions share three essential themes: "They depict activity between heaven and earth, they present a world in which things are on the move, and they provide a perspective that is universal" (David L. Petersen, "Zechariah," The HarperCollins Bible Commentory, ed. James Luther Mays [San Francisco: HarperSanFrancisco, 2000], 677). Petersen has also pointed out that these themes emphasize that YHWH's imminent action is truly universal (note the phrase "all the earth" in 1:11, and 4:14) and will result in the restoration of Judah. Cf. Ibid., 677.

${ }^{2} \mathrm{Cf}$. the several occurrences of the root 9 gei to express the concept of YHWH's dwelling among his people (Exod 24:16;25:8; 29:45f.; 40:35; Lev 16:16; Deut 12:5; 1 Kgs 6:13; 8:12; Ps

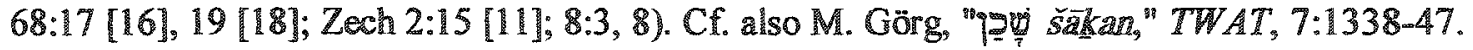

${ }^{3} \operatorname{Kim}, 256$. 
temple, as has been perceived by several scholars. "The overall picture then is that of YHWH coming from his heavenly temple to dwell again in the Jerusalem temple.

After these brief considerations about the presence of the heavenly sanctuary/temple motif in Zech 2:17 [13], one needs to consider the function and relationship of the heavenly temple with its earthly counterpart. Again, it is instructive to note YHWH's promise to "dwell" (ggei) in the Jerusalem temple. This implies that the temple would be restored with its corresponding cultic functions. Therefore, it may be inferred that this movement of YHWH from his heavenly temple to dwell in the Jerusalem temple implies some functional and structural correspondences between the latter and its heavenly counterpart. Thus, it is reasonable to suppose that certain functions of the heavenly temple would be operative in the heavenly temple and vice versa. Since YHWH is portrayed as coming from his heavenly temple to dwell in the Jerusalem temple, the implication is that both loci share some basic functional and structural similarities.

\section{Summary}

The investigation undertaken above has revealed that the heavenly sanctuary/temple motif is not a marginal theme in the prophetic section of the Hebrew Bible. The presence of this motif in the various passages investigated indicates the relevance of heavenly sanctuary/temple to the theology of the Hebrew Bible. As an object of an attack by the king of Babylon and profanation by the king of Tyre, the heavenly

'Ibid., 257-58; Baldwin, 112; Merrill, Haggai, Zechariah, Malachi, 128; H. G. T. Mitchell and others, A Critical and Exegetical Commentary on Haggai, Zechariah, Malachi, and Jonah, 145; Petitjean, 154; Reddit, Haggai, Zechariah and Malachi, 62; Tidiman, 107; Watts, "Zechariah," 319. 
sanctuary/temple emerges as the pivot center of the cosmic battle, that is, the great controversy, between good and evil.

The texts investigated above also conceive of the heavenly sanctuary/temple to function in a number of different, but complementary, ways. Apart from being conceived as the dwelling of YHWH or his center of command as King of the Universe, the heavenly sanctuary/temple functions as locus of judgment or tribunal, whence YHWH exerts his judicial functions by vindicating the righteous and punishing impenitent sinners. The judgment is sometimes conceived as a two-stage process, namely, an investigative phase preceding the actual execution of the sentence. In close connection to this judicial function, the heavenly sanctuary/temple is also understood as the meeting place of the council of YHWH. The heavenly sanctuary is also depicted as a place of worship where heavenly beings adore YHWH, source of help, and place of atonement, where cleansing and forgiveness are granted.

An interesting feature of the heavenly temple/sanctuary that emerged from the texts investigated above is its functional and structural correspondences with its earthly counterpart. For example, the function of the heavenly sanctuary/temple as a place of judgment, forgiveness, atonement-functions that are also in the domain of the earthly sanctuary temple--suggests that the heavenly temple operated in functional correspondence to its earthly counterpart. In addition, a structural correspondence was also observed. In addition to terminological indications that point to such structural similarities, one should note that the heavenly sanctuary/temple would contain an altar (Isa 6:1-8) and cherubim who correspond to the golden cherubim of the earthly temple. If so, it 
may be argued that the correspondence between the heavenly sanctuary/temple and its earthly counterpart was understood as extending beyond functional aspects to include some formal dimensions.

Finally, this vertical correspondence goes beyond mere static terms, or in terms of two entities operating side by side without mutual interaction. Rather, as inferred from the texts, there was a dynamic interaction between the heavenly temple/sanctuary and its earthly counterpart. That is, the heavenly temple was understood as providing legitimacy to the activities of the earthly temple and was capable of affecting and interacting with the activities of its earthly counterpart. Table 3 below provided a summary of the heavenly sanctuary/temple motif in the prophets. 
TABLE 3

THE HEAVENLY SANCTUARY/TEMPLE MOTIF IN THE PROPHETS

\begin{tabular}{|c|c|c|c|c|c|}
\hline \multirow[t]{3}{*}{ Passage } & \multirow[t]{3}{*}{ Vocabulary } & \multirow[t]{3}{*}{ Function } & \multicolumn{3}{|c|}{ Relationship to Earthly Counterpart } \\
\hline & & & \multicolumn{2}{|c|}{$\begin{array}{c}\text { Vertical } \\
\text { Correspondence }\end{array}$} & \multirow[t]{2}{*}{$\begin{array}{c}\text { Dynamic } \\
\text { Interaction }\end{array}$} \\
\hline & & & Functional & Structural & \\
\hline $2 \operatorname{Sam} 22: 1-51$ & hêkăl & $\begin{array}{l}\text { Source of help, judgment, } \\
\text { vindication of the } \\
\text { righteous, other cultic } \\
\text { aspects }\end{array}$ & 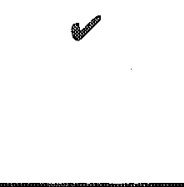 & 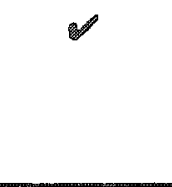 & \\
\hline 1 Kgs 8:12-66 & $\begin{array}{l}\text { mëkôn šibtkā } \\
\text { meqôm } \\
\text { sibtkã }\end{array}$ & $\begin{array}{l}\text { Answering prayer, } \\
\text { judgment, forgiveness, } \\
\text { kingship }\end{array}$ & 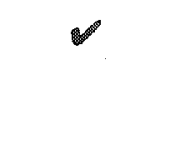 & 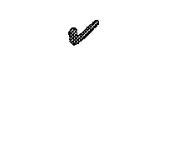 & 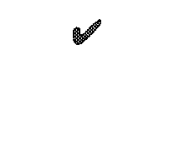 \\
\hline $1 \mathrm{Kgs} 22: 19-23$ & $\begin{array}{l}\text { [yšb, Risse', } \\
\text { șéba' } \\
\text { hašsăamayim] }\end{array}$ & $\begin{array}{l}\text { Judgment, meeting place } \\
\text { of the heavenly assembly, } \\
\text { kingship, worship }\end{array}$ & 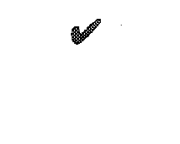 & & \\
\hline Isa $6: 1-8$ & hekall & $\begin{array}{l}\text { Kingship; place of } \\
\text { cleansing, forgiveness, } \\
\text { judgment }\end{array}$ & 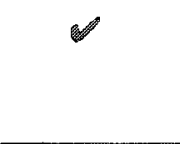 & 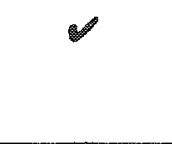 & 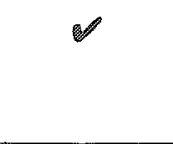 \\
\hline Isa $14: 12-15$ & har mốed & $\begin{array}{l}\text { Object of attack in the } \\
\text { cosmic battle; place of } \\
\text { worship, meeting place of } \\
\text { the heavenly assembly }\end{array}$ & $\mathscr{2}$ & & \\
\hline Isa 18:4 & mâkôn & Supervision, judgment & $\mathscr{2}$ & $\mathscr{Q}$ & \\
\hline Isa 63:15 & 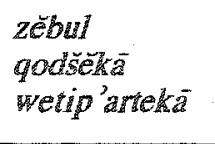 & $\begin{array}{l}\text { Supervision, } \\
\text { intervention, source of } \\
\text { help }\end{array}$ & $\mathscr{O}$ & 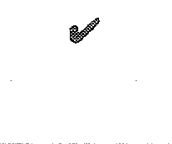 & \\
\hline Jer $17: 12$ & 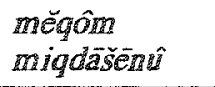 & Kingship, judgment & 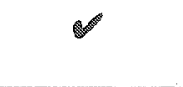 & 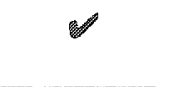 & \\
\hline $\operatorname{Jer} 25: 30$ & mé ôn godšô & Judgment & $\infty$ & 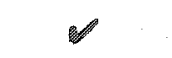 & \\
\hline Ezek 1 & $\begin{array}{l}\text { [niptahu } \\
\text { haššmayim, } \\
\text { sapon, } \\
\text { mar'ên' } \\
\text { eben sappir, } \\
\text { kabod } \\
\text { YHWH] }\end{array}$ & Kingship & 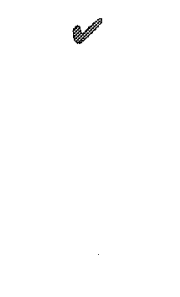 & & \\
\hline
\end{tabular}


TABLE 3-Continued.

\begin{tabular}{|c|c|c|c|c|c|}
\hline \multirow[t]{3}{*}{ Passage } & \multirow[t]{3}{*}{ Vocabulary } & \multirow[t]{3}{*}{ Function } & \multicolumn{3}{|c|}{ Relationship to Earthly Counterparts } \\
\hline & & & \multicolumn{2}{|c|}{$\begin{array}{c}\text { Vertical } \\
\text { Correspondence }\end{array}$} & \multirow[t]{2}{*}{$\begin{array}{l}\text { Dynamic } \\
\text { Interaction }\end{array}$} \\
\hline & & & Functional & Structural & \\
\hline Ezek 10 & $\begin{array}{l}\text { kabod } \\
\text { YHWH } \\
\text { kërûbim }\end{array}$ & Judgment & 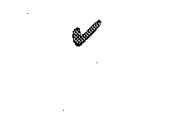 & 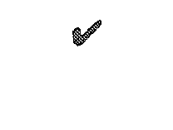 & $\mathscr{2}$ \\
\hline Ezek 28:11-19 & $\begin{array}{l}\text { 'eden gan } \\
\text { êlohim } \\
\text { har godeš } \\
\text { 'ëlohim } \\
\text { miqdās }\end{array}$ & $\begin{array}{l}\text { Object of improper } \\
\text { actions in the cosmic } \\
\text { battle, cultic aspects }\end{array}$ & 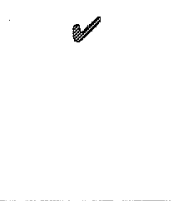 & $\mathscr{O}$ & \\
\hline Hos $5: 15$ & màqôm & Dwelling & & & \\
\hline $\begin{array}{l}\text { Jonah } 2: 5[4] \\
8[7]\end{array}$ & hêkăl & Source of help, salvation & $\mathscr{2}$ & 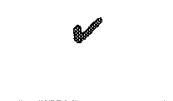 & $\mathscr{V}$ \\
\hline Mic $1: 2-3$ & hêkàl qodšô & $\begin{array}{l}\text { Judgment (covenant } \\
\text { lawsuit): investigative }+ \\
\text { executive }\end{array}$ & 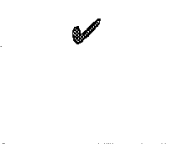 & 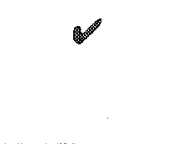 & \\
\hline $\mathrm{Hab} 2: 20$ & hêkal & Worship, judgment & $\mathscr{V}$ & $\mathscr{2}$ & $\mathscr{U}$ \\
\hline Zech 2:17 & mé ôn qodšô & Dwelling & 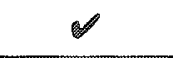 & $\mathscr{\theta}$ & \\
\hline Zech $3: 1-10$ & $\begin{array}{l}\text { Implied in } \\
\text { the heavenly } \\
\text { council }\end{array}$ & $\begin{array}{l}\text { Judgment, cultic aspects: } \\
\text { atonement }\end{array}$ & 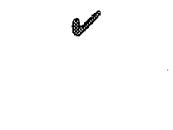 & & 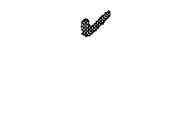 \\
\hline
\end{tabular}




\section{CHAPTER 5}

\section{THE HEAVENLY SANCTUARY/TEMPLE MOTIF \\ IN THE WRITINGS}

The present chapter provides an investigation of the following passages containing the heavenly sanctuary/temple motif in the writings: Pss $11: 1-7 ; 20: 1-10[9] ; 29: 1-11$; $33: 1-22 ; 60: 1-14[12] ; 68: 1-36[35] ; 96: 1-13 ; 102: 20-21[19-20] ; 150: 1-6 ;$ Dan $7: 9-14 ;$ 8:9-14; and 9:24. In order to provide a broader data base for this investigation, a more cursory treatment is reserved for shorter passages at the end of this chapter: Pss 14:1-6; $73: 17 ; 76: 8-9 ; 82: 1-8 ;$ Job $1: 6$ and $2: 1$; and 2 Chr $30: 27$.

Although these texts are not claimed to be an exhaustive inventory of heavenly sanctuary/temple passages in the Writings, they do claim to represent a fairly comprehensive overview of the theme under study in this section of the Hebrew Bible. Consequently, it is hoped that even if future research claims that other passages contain the heavenly sanctuary/temple motif, their investigation will not change the basic picture suggested by this study.

\section{P\$ 11:1-7}

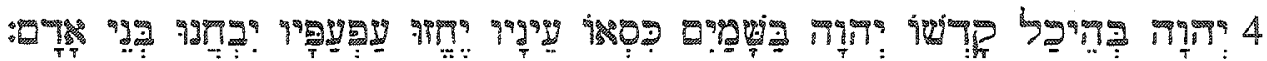
4 YHWH is in his holy temple; as for YHWH, in heaven is his throne; his eyes behold, his eyelids test the sons of men. 


\section{Preliminary Observations}

Despite being fraught with textual and exegetical difficulties, ${ }^{1}$ Ps 11 contains a clear message of trust in YHWH amid the most dire circumstances faced by the psalmist. For that reason, this psalm has appropriately been counted among the so-called "psalms of trust." ${ }^{12}$ Most commentators agree that the text divides itself into two parts: vss. 1-3 and 47. ${ }^{3}$ This demarcation is clearly indicated by a spatial and conceptual shift in vss. 4-7. As noted by Limburg, "the first words of this second part of the psalm take the focus away from the enemies and the psalmist and portray a scene in heaven. ${ }^{n 4}$ Interestingly enough, this change of focus occurs precisely in the middle point of the psalm's structural arrangement, as seen in the following outline: ${ }^{5}$

'These have been summarized as follows: (1) Whether the first direct speech ends with vs. 1 or continues through vs. 3. (2) Whether the "righteous" in vs. 3 is a human being or YHWH. (3) Whether 7og? (vs. 6) should be interpreted as a jussive or an indicative. (4) Whether the speaker of the psalm is a pious person harassed by enemies, or an individual who by virtue of misconduct had to seek asylum in the temple to seek for a decision from YHWH, or even a cultic prophet who utters judgment against the enemies of Israel. Cf. Frank-Lothar Hossfeld and Erich Zenger, Die Psalmen I, Psalm 1-50, NEBKAE (Würzburg: Echter Verlag, 1993), 88-89.

${ }^{2}$ Pss 11, 16, 23, 27, 62, 63, 131. Cf. James Limburg, Psalms, Westminster Bible Companion (Louisville, KY: Westminister John Knox, 2000), 33. Cf. also J. L. Mays, who has opted for the designation "song of trust" (James Luther Mays, Psalms, Interpretation [Louisville: John Knox, 19941, 75), and H. J. Kraus, who preferred to classify it as a "prayer song" (Hans Joachim Kraus, Psalms 1-59: A Commentary [Minneapolis: Fortress, 1993], 201).

${ }^{3}$ Cf., e.g., Robert Davidson, The Vitality of Worship: A Commentary on the Book of Psalms (Grand Rapids: Eerdmans, 1998), 47-48; Louis Jacquet, Les Psaumes et le cour de Ihomme: Étude textuelle, littéraire et doctrinale: Introduction et premier Livre du Psautier (Gembloux, Belgien: Duculot, 1975), 350-52; Limburg, Psolms, 33-34; Konrad Schaefer, Psalms, Berit Olam (Collegeville, MN: Liturgical, 2001), 28.

${ }^{4}$ Limburg, Psalms, 34.

${ }^{5}$ This structure was suggested by Samuel Terrien, The Psalms: Strophic Structure and Theological Commentary, ECC (Grand Rapids: Eerdmans, 2003), 147. 
I. Refuge and Refusal (vs. 1bcd)

11. The Evildoers (vs. 2)

III. Foundations Overturned (vs. 3)

IV. The Temple of the Lord (vs. 4)

IV. The Just God (vs. 5)

VI. The Evildoers (vs.6)

VII. Refuge and Presence (vs. 7).

Although other structures have been proposed by Alden ${ }^{1}$ and Auffret, ${ }^{2}$ they agree on the pivotal role of vs. 4 . This verse is the structural center of the pericope and corresponds to the spatial turning point where the focus of the psalm shifts from earth to heaven and proceeds to describe YHWH's activities in/from his [heavenly] ${ }^{3}$ temple.

The ensuing discussion undertakes an investigation of semantic and other exegetical aspects of the text under study. Special attention is given to the referent of

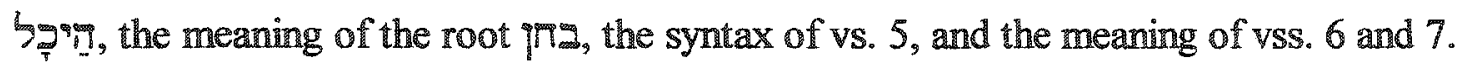
On the basis these exegetical procedures, a delineation of the heavenly sanctuary/temple motif is set forth.

\footnotetext{
"1 A The Lord is my refuge 2-3a B Wicked punished $3 b \quad C$ Righteous suffer

$4 a$ D Lord in Temple in heaven

$4 b \quad D$ Lord adjudicates everywhere

5a C Righteous vindicated

5b-6 B Wicked punished

7 A Lord the righteous"
}

(Robert L. Alden, "Chiastic Psalms: A Study in the Mechanics of Semitic Poetry in Psalms 1-50," JETS 17 [1974]: 16-17).

${ }^{2}$ Pierte Auffret suggests an envelopment of vs. 4 by vss. $2-3$ and 5-6, then by vss. 1 and 7 ("Essai sur la structure littéraire du Psaume 11," ZAW 93, no. 3 [1981]: 401-18).

${ }^{3}$ The arguments to support this suggestion will be presented in due course. 
Semantic and Other Exegetical Considerations

\section{Referent or}

The task now is to determine whether bgon ("temple") refers to the earthly or heavenly temple. Although some commentators argue in favor of an earthly referent, there are compelling arguments pointing to a heavenly setting, as noted in the following discussion.

At the outset it must be emphasized that the parallelism between לפด? 9eg? ("YHWH is in his holy temple") and ixt? heaven") indicates that the ל⿻ ("I." ("temple") of the first line must be located in heaven, as expressed by the parallel expression e"geg ("heaven") in the second line. It should be noted that vs. 4 marks a shift of perspective in the structure of the psalm. As noted by Kim, "the change of mood between vv. 1-3 and vv. 4-7 demands that לפg in v. $4 a \alpha$ should be beyond the earthly dimension. It is not that v. 4ao describes the earthly and v. $4 a \beta$ the 'heavenly', but that vss. 1-3 describes the 'earthly' and vss. 4-7 the heavenly." The

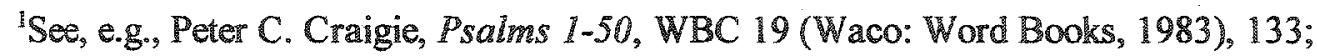
Kraus, Psalms 1-59, 201; Oswald Loretz, "Gottes Thron in Tempel und Himmel nach Psalm 11: Von der altorientalischen zur biblischen Theologie," UF 26 (1994): 245-70.

${ }^{2}$ The syntactic structure of each line differs markedly. While the first line consists of a straightforward nominal clause in which "YHWH" functions as the subject, the second line contains an extra clausal constiment "YHWH," which anticipates the referent of the pronominal suffix in the noun phrase iso which is the syntactic subject of the clause. Thus, from a syntactic point of view the parallelism is not so precise as it seems to be at first glance. However, from a functional perspective it must be stressed that "YHWH" is the topic of both clauses. Additionally it must be noted that both lines are composed by the same types and sequence of morphological units, i.e., noun, prepositional phrase, and noun phrase respectively. To sum up, although each line contains a different syntactic structure, both are headed by the same topic (YWWH), and display the same sequence of morphological units.

${ }^{3} \mathrm{Kim}, 139$. 
major thrust of the argument presented by the psalmist is that despite the dire

circumstances of his personal life, and the destruction of the foundations of society,

"YHWH is in his holy [heavenly] temple." This view is supported by the context. As vs. 5

makes clear, it is from heaven that YHWH "tests/investigates/looks" at the wicked and the

righteous; and vs. 6 says that YHWH "will rain fiery coals and burning sulfur," thus

implying a judgment from above, that is, from the heavenly realm. Thus if the judgment is

portrayed as coming from heaven, it is reasonable to suppose that it comes from the

heavenly temple, the locus of YHWH's presence according to vs. $4 .^{2}$

\section{Meaning of गुก}

Irg is one of the terms used to express the divine activities performed by YHWH

in/from the temple in heaven, hence its significance for the present study. ${ }^{3}$ Having the basic

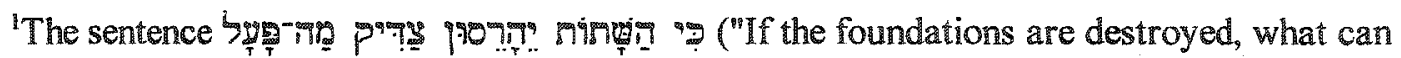

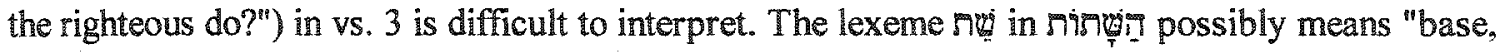
foundation" (HALOT, S.v. "ger"). This may suggest a metaphoric connotation as in the phrase 970im-ל disfuption of law and order seems to be presupposed in PS 11:3, which is the backdrop for the anguished cry: "If the foundations are destroyed, what can the righteous do?" Cf. Kraus, Psalms 159, 202; H. C. Leupold, Exposition of the Psalms (Columbus, OH: Wartburg, 1959), 126.

${ }^{2}$ As stated by Limburg, "The first words of this second part of the psalm take the focus away from the enemies and the psalmist and portray a scene in heaven" (Psalms, 34). Cf. Davidson, The Vitaliny of Worship, 48; Erhard Gerstenberger, Psalms Part 1 with an Introduction to Cuttic Poetry, FOTL 14 (Grand Rapids, MI: Eerdmans, 1988), 78; Derek Kidner, Psalms 1-72 (London: Inter-Varsity, 1973), 73; Mays, 76.

${ }^{3}$ For the motif of YHWH "looking down" from his heavenly dwelling/temple, see the discussion of Isa 18:4 and 63:15 in chapter 4 of this dissertation. 
meaning of "test, ${ }^{n 1}$ "examine, scrutinize," the root 1 ra appears thirty-one times in the Hebrew Bible, mostly in the books of Jeremiah, Psalms, and Job. ${ }^{3}$ An inspection of its occurrences discloses, on the one hand, that its paradigmatic field contains lexemes such

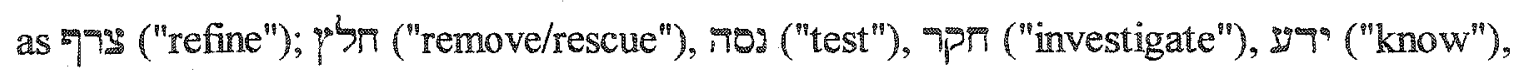

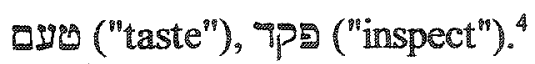

On the other hand, an examination of its syntagmatic field reveals that בח may

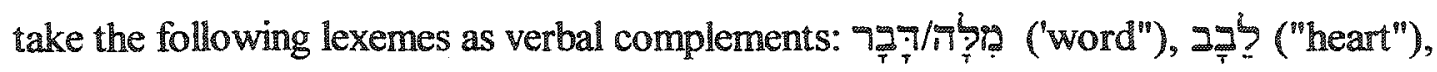

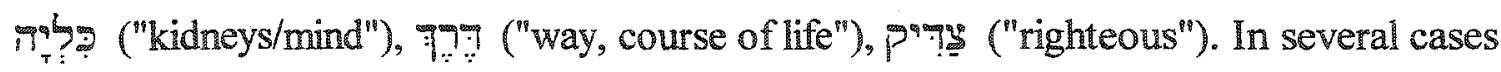
פI is complemented by a pronominal suffix pointing back to the speaker, or to the people of YHWH in general. Furthermore it can be observed that generally בחץ describes a positive activity of YHWH in "proving/investigating" the righteous. ${ }^{5}$ In some cases this

$$
\begin{aligned}
& \text { 1HALOT, s.v. "בחן." } \\
& { }^{2} B D B \text {, s.v. "בחק." }
\end{aligned}
$$

${ }^{3}$ Cf. Gen 42:15, 16; 1 ; Isa 28:16; Jer 6:27; 9:6; $11: 20 ; 12: 3 ; 17: 10 ; 20: 12$; Ezek 21:18; Zech 13:9; Mal 3:10, 15; Pss 7:10; 11:4, 5; 17:3; 26:2; 66:10; 81:8 [7]; 95:9; 139:23; Job 7:18; $12: 11 ; 23: 10 ; 34: 3,36$; Prov 17:3; 32:14; Chr 29:17.

${ }^{4}$ See the passages referred to in the previous note.

$$
\text { isee, e.g.: }
$$

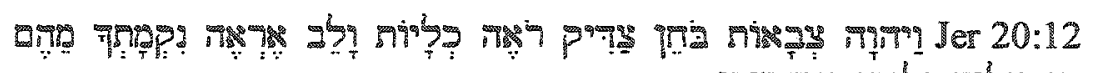

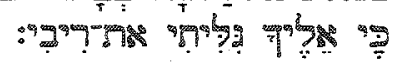
Jer 20:12 O YHWH of hosts, you who test the righteous, who see the mind and the heart; let me see your vengeance on them; for to you I have set forth my cause.

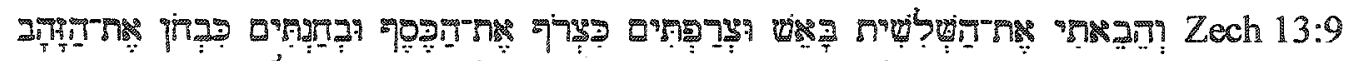

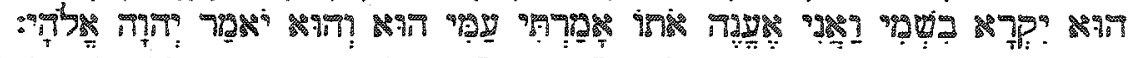
Zech 13:9 And I will bring the third part through the fire, Refine them as silver is refined, and test them as gold is tested. They will call on my name, and I will answer them; I will say, "They are my people," and they will say, "YHWH is my God." 
activity seems to be connected to judicial procedures, as deduced from terms such as ?ign and $29 \%$, which also inform the syntagmatic field of 9 m.'

Thus from this brief survey of the paradigmatic and syntagmatic fields of In following observations may be advanced: First, concerning the paradigmatic field, which displays an interesting variety of lexemes, Jenni provides an apt summary by saying that "par[allel] verbs and usages of $b h n$ point to a rather general meaning 'to test $=$ to investigate (critically). ${ }^{.12}$ Interestingly enough, the two occurrences of nominal derivatives of pry convey the idea of "observation" and "testing," as in Isa 28:16: 999 9m" (tested stone"), and 32:14: 1ng ("watchtower"). Second, as for the syntagmatic field, it should be observed that most of the theological usages of also govern an unspecified or generic object, ${ }^{3}$ in most of its occurrences the object denotes

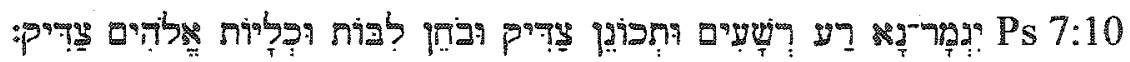
Ps 7:9 O let the evil of the wicked come to an end, but establish the righteous; for the righteous God tries the hearts and minds.

${ }^{1}$ See Jer 20:12 in the previous note.

'E. Jenni, "Ing bhn to test," Theological Lexicon of the Old Testament (Peabody, MA: Hendrickson, 1997), 1:208. Additionally, Terry L. Brensinger noted that in those passages where Irg lacks a clear theological connotation, "the key concern involves evaluating the dependability of something" " "Irn," NDOTTE, 1:623). In the context of Joseph's reunion with his brothers, Brensinger further observed that "the contrived scene-Joseph already knows their identity and therefore the truthfulness of what they say! - depicts him testing his brothers in order to discern the validity of their claims" [Gen 42:15-16]" (ibid.). Brensinger still points out that "both Job and Elihu suggest the need to test or evaluate the dependability of the spoken word. In both instances, to tesi [gra] a claim or word involves determining its truthfulness [Job 12:11;34:3]" (ibid.). It should also be kept in mind that in its theological usages, yra "expresses the concept of divine examination and divine knowledge" (M. Tsevat, "gra bhn," TDOT, 2:70).

3ob 7:17-18; Prov 17:3; 1 Chr 29:17. 
YHWH's own people, ${ }^{1}$ or an individual ${ }^{2}$ in relationship to him. ${ }^{3}$ That being said, attention is turned to the meaning of prit 2 in vss. 4 and 5.

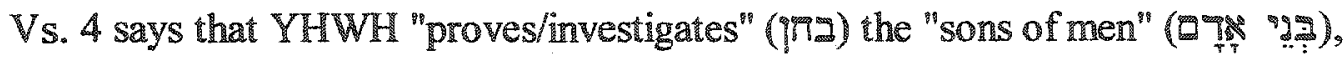
and vs. 5 reveals that YHWH "proves/investigates" (gnב) especially the "righteous" (P9-7y). Then it seems evident that the diction of the passage is that of judgment, as further corroborated by the reference to "fire" and "brimstone" in vs. 6. In this regard, the present study agrees with $\mathrm{Kim}$, who made clear that the major tenor of the pericope is that of judgment. ${ }^{5}$ Nonetheless there is an interesting aspect of this judgment as expressed by the term jra (vs. 5) that deserves further consideration. Richard Davidson advanced the suggestion that gra in Ps 11 may designate a specific aspect of the judgment (namely, the investigative judgment), ${ }^{6}$ and $\mathrm{E}$. Jenni pointed out that yrg means "investigate

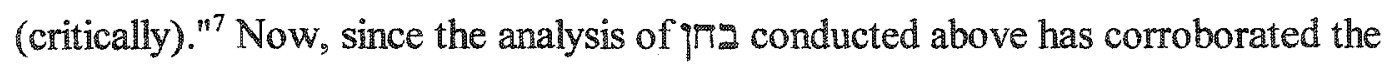
observations by Davidson and Jenni, attention is tumed to some syntactic and pragmatic aspects of vss. 5 and 6 . By means of this exegetical procedure, the insights gained from

Jer $6: 27 ; 9: 6 ; 11: 20 ; 12: 3 ; 17: 10 ; 20: 12 ;$ Ezek $21: 18 ;$ Zech 13:9; Pss 66:10;81:8.

${ }^{2}$ Sometimes the referent of an object in the singular may indicate a collective entity, and thus refer to the people as a whole. An examination of this aspect, however, is beyond the scope of this study.

${ }^{3} J o b 23: 10 ;$ PSS 7:10 [9]; 17:3; 26:2; $139: 23$.

The emphasis on "righteous" will become apparent in the discussion of the word order and the syntax of vs. 5 below.

${ }^{5} \mathrm{Cf} . \mathrm{Kim}, 140$.

"Davidson, "The Heavenly Sanctuary in the Old Testament," 6.

7Jenni, 208, emphasis supplied. 
the semantic study of prב in order to provide a more precise definition of the concept of judgment portrayed in the passage.

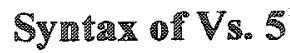

The discussion of vs. 5 focuses on two aspects: First, the difficulties regarding its clause divisions will be investigated, aiming at a clear delineation of the syntactic structure. Second, attention is devoted to the order of the constituents, particularly the first clause, in order to draw some implications for the understanding of the text in its pragmatic level. Commencing with the syntactic issues, one notes that there are at least three distinct ways to divide the clauses of this verse:

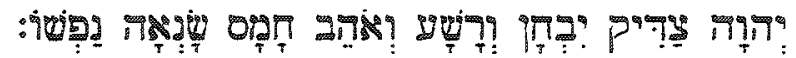
\#1. YHWH is righteous | he proves even the wicked / and those who love violence his soul hates. ${ }^{1}$

\#2. YHWH proves the righteous and the wicked/and those who love violence his soul hates. ${ }^{2}$

\#3. YHWH proves the righteous | but the wicked and those who love violence his soul hates. $^{3}$

The task now is to determine which option alines itself best with the grammar and context. Upon close examination it seems that the last option has some advantages on the basis of its syntax and context, and additionaly seems to be favored by the Masoretic pointing. Starting with the last, one notes that the verb irga? ("proves") is pointed with the

\footnotetext{
${ }^{1}$ Cf. Auffret, "Essai sur la structure hittéraire du Psaume $11,403$.

${ }^{2} \mathrm{Cf} . \mathrm{LXX}, \mathrm{NASB}, \mathrm{NAB}, \mathrm{NJB}, \mathrm{NLT}$.

${ }^{3} \mathrm{Cf} . \mathrm{ASV}, \mathrm{DBY}, \mathrm{ESV}, \mathrm{JPS}, \mathrm{KJV}, \mathrm{NKJV}, \mathrm{NIV}, \mathrm{NET}, \mathrm{RWB}, \mathrm{TNK}$.
} 
strong disjunctive accent 'ôlê wĕyôred (equivalent to 'ätnäh in the other books)' thus indicating a major pause at this point. Second, the phrase घỵT? ("and the wicked") is more naturally connected to what follows since it pairs up with violence"). Third, the vaw conjunction in มซึ่า ? seems to establish a contrast with the

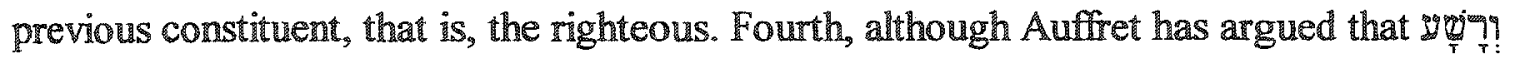
is dislocated for emphasis with the so-called emphatic waw, ${ }^{2}$ the text does not indicate any

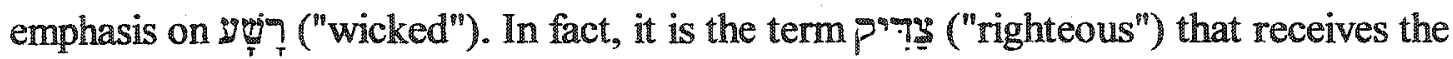
emphasis, as will be noted below. When these factors are taken into consideration, it seems more reasonable to understand the vaw in YHWH's contrasting attitudes toward the righteous and the wicked. That is to say, YHWH "proves/investigates" the righteous, but (I) "hates" the wicked. Thus, the cumulative effect of the arguments just mentioned favors the syntactic arrangement of vs. 5 suggested in option \#3, above: "YHWH proves the righteous; but the wicked and those who love violence his soul hates."

Turning to the pragmatic dimensions of the text, attention is focused on the order of its constituents. A close inspection of the first clause of vs. 5 reveals the significant fact

${ }^{1} \mathrm{Cf}$. James D. Price, The Syntax of Masoretic Accents in the Hebrew Bible (Lewiston, NY: Mellen, 1990), 183; William Wickes and Aron Dotan, Two Treatises on the Accentuation of

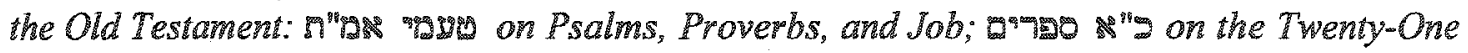
Prose Books (New York: KTAV, 1970), 54; Israel Yeivin, Introduction to the Tiberian Masorah, Masoretic Studies 5 (Missoula, MT: Society of Biblical Literature and International Organization for Masoretic Studies, 1980), 265-66. It should be remembered that the the Masoretic accentuation used in Psalms, Job, and Proverbs differs from that used in the other books of the Hebrew Bible.

${ }^{2} \mathrm{Cf}$. "Essai sur la structure littéraire du Psaume 11," 404-05. Cf. also Bruce K. Waltke and M. O'Connor, An Introduction to Biblical Hebrew Syntax (Winona Lake, IN: Eisenbrauns, 1990), 649; Ronald James Williams, Hebrew Syntax: An Outline, 2nd ed. (Toronto: University of Toronto Press, 1976), 71. 
that the direct object p"is? ("righteous") is placed before the verb, a salient position according to a pragmatic perspective. 'Since the first constituent of the clause, YHWH, is clearly the topic of the clause, the term "righteous" is the marked focus. If so, the following understanding of vs. 5a emerges: "It is the righteous [not the wicked] whom YHWH proves/investigates." This contrasts with vs. 5b: "But the wicked and those who love violence his soul hates." Consequently, on the basis of the pragmatic arrangement of the text, manifested in the focal position of 799 , the implication may be drawn that the work of "proving/investigating" relates in a special way to the activity that YHWH performs in favor of the "righteous". (i.e., his people).

Summing up, vs. 5 conveys the idea that YHWH's work of "proving/investigating" (१ก) in/from his heavenly temple is especially related to the pays ("righteous"). This is not to deny that "his eyes behold, his eyelids test ( $($ m) the sons of men" (vs. 4). The picture suggested by the text is that although in a general way YHWH

\footnotetext{
'As Buth argued, "the natural order of pragmatic marking (as a linguistic universal) when two elements are fronted is Topic/CC followed by Focus" (Randall Buth, "Word Order in the Verbless Clause: A Generative Functional Approach," in The Verbless Clause in Biblical Hebrew: Linguistic Approaches, ed. Cynthia L. Miller, Linguistic Studies in Ancient West Semitic 1 [Winona Lake, N: Eisenbrauns, 1999], 88). For a detailed discussion of the concepts of focus, topic, and word order, cf. Randall Buth, "Topic and Focus in Hebrew Poetry-Psalm 51," in Language in Context: Essays for Robert E. Longacre, ed. Shin Ja J. Hwang and William R. Merrifield (Dallas: Summer Institute of Linguistics/University of Texas at Arlington, 1992), 8396; idem, "Functional Grammar, Hebrew and Aramaic: An Integrated, Texilinguistic Approach to Syntax," in Discourse Analysis of Biblical Literature: What It Is and What It Offers, ed. Walter Ray Bodine (Atlanta, GA: Scholars Press, 1995), 77-102; Jean-Marc Heimerdinger, Topic, Focus and Foreground in Ancient Hebrew Narratives, JSOTSup 295 (Sheffield: Sheffield Academic, 1999); C. H. J. van der Merwe, J. A. Naudé, and Jan H. Kroeze, Biblical Hebrew Reference Grommar (Sheffield: Sheffield Academic, 1999); C.H.J. van der Merwe, "Review Article: Towards a Better Understanding of Biblical Hebrew Word Order," INSL 25, no. 1 (1999): 277 300; idem, "The Function of Word Order in Old Hebrew-With Special Reference to Cases Where a Syntagmeme Precedes a Verb in Joshua," JNSL 17 (1991): $129-44$.
} 


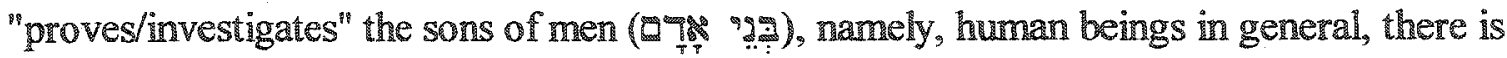
an emphasis/focus on the fact that "it is the righteous" whom he "proves/investigates."

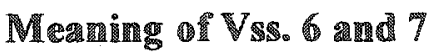

As noted by several commentators, vs. 6 evokes the "fire" and "brimstone" that YHWH rained over Sodom and Gomorrah ${ }^{\prime}$ and the prophetic passage describing the eschatological judgment of Gog and Magog in Ezek 38. A comparison between these passages and vss. 6-7 may prove useful.

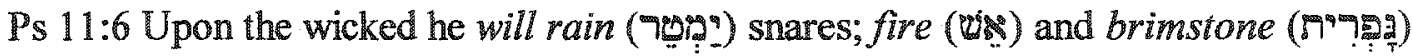
and burning wind will be the portion of their cup.

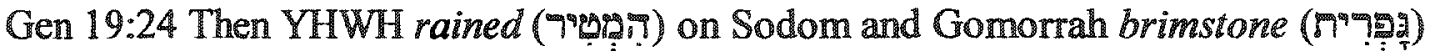
and fire (trom YHWH out of heaven.

Ezek 38:22 With pestilence and with blood I will enter into judgment with him; and I will rain (7?ers) on him and on his troops, and on the many peoples who are with him, a torrential rain, with hailstones, fire (שึ) and brimstone (n?

It should be noted that these are the only places in the Hebrew Bible where all

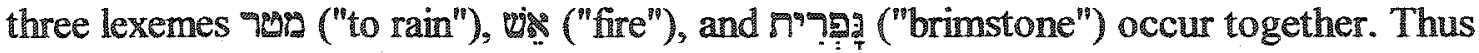
PS. 11:5 contains intertextual linkages with two other passages where the motif of judgment plays a major role. Gen 19:24 reports the judgment upon Sodom and Gomorrah, an executive judgment portrayed as the ultimate action of $Y H W H$ to eradicate the wicked. In the words of Schaefer, "Both the story of Sodom and Gomorrah and Psalm 11 have in common a cosmic punishment for a moral imbalance. ${ }^{n 2}$ The same can be argued in relation Schaefer, 29.

${ }^{1}$ Cf., e.g., Hossfeld and Zenger, Die Psalmen 1, 91-92; Kraus, Psalms 1-59, 203-04;

\footnotetext{
${ }^{2}$ Schaefer, 29.
} 
to Ezek $38: 22$, regarding the judgment of Gog. This passage provides a prophetic glimpse of the eschatological judgment upon the enemies of YHWH's people. Thus, on the basis of the intertextual connections just pointed out, it seems evident that the imagery portrayed in Ps 11:6 intends to depict YHWH's executive judgment against the wicked.

Tuming to vs. 7 , one is informed that the righteous will be vindicated, as expressed in the last clause of the psalm: "The upright will see his [YHWH] face" ("97" Attempts to interpret this statement as a reflection of the pagan cults where the worshipers could behold the image of the god ${ }^{1}$ seem to be farfetched. The view of Dahood that the text contains the idea of "an afterlife in the presence of Yahweh" may be accepted with some qualifications. Since vs. 6 portrays an image of the ultimate annihilation of the wicked, it is reasonable to infer that vs. 7 points to the ultimate reward of the righteous conveyed by the idiom of "behold[ing] the face of YHWH." The implication is that while the wicked are utterly destroyed, the upright are introduced in the presence of YHWH" as trusted courtiers to the presence of [the] sovereign. ${ }^{133}$

Summing up, the work of "proving/investigating" carried out by YHWH in/from his heavenly temple (vss. 4-5) eventuates in the final judgment which results in the

\footnotetext{
"Kraus, Psalms 1-59, 204.
}

2Dahood, Psalms I, 71. Dahood does not elaborate on what he means by "afterlife." Nonetheless, on the basis of the anthropological conceptions underlying the Hebrew Bible, the idea of a disembodied soul ascending to heaven after death should be excluded. $\mathrm{C}$. Hans Walter Wolff, Anthropology of the Old Testament, trans. Margaret Kohl (London: S.C.M. Press, 1974), 7-80. 60.

${ }^{3}$ A. F. Kirkpatrick, The Book of Psalms (Cambridge, England: University Press, 1939), 
amihilation of the wicked (vs. 6) and the acceptance of the righteous into the very presence of YHWH (Vs. 7).

\section{Heavenly Sanctuary/Temple Motif}

\section{Function}

The foregoing discussion has confirmed that a conspicuous function of the heavenly temple is that of judgment. In this regard, this investigation agrees with $\mathrm{Kim}$, who also postulated the same idea in his discussion of Ps 11:4. Nonetheless, a closer examination of the text uncovered some interesting aspects of this work of judgment. As observed above, the semantic connotations of 9 na convey the idea of an investigative judgment, which is conducted by YHWH in/from the heavenly temple, and the syntactic and pragmatic investigation of vs. 5 has revealed that the "righteous" are the special object of the investigative judgment. On the other hand, one should note that vss. 6 and 7 depict the executive aspect of the judgment, as underscored by the allusion to the judgment of Sodom and Gomorrah, and Gog. Thus by means of these allusions, the psalmist provides a portrayal of the executive judgment when YHWH will annihilate the wicked and bestow his salvation on the "upright." Thus, the heavenly sanctuary/temple motif emerges in PS 11 as a place where YHWH performs the activity of judgment, which manifests itself in two dimensions: an investigative aspect aimed specially at the righteous, and an executive aspect which consists in the final elimination of the wicked and the vindication of the upright. 


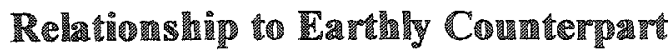

A vertical correspondence between the heavenly temple and its earthly counterpart may be inferred from PS 11 . The specific use of the term $y 99$, a term also used to designate the earthly temple, seems to indicate that the heavenly temple was understood as a place in heaven in a mamer similar to the earthly understood to exist in a structural correspondence to the earthly counterpart. Moreover, that the temple is understood as a place of judgment indicates functional correspondence between heavenly and earthly temples.

\section{Ps 20:1-10 [9]}

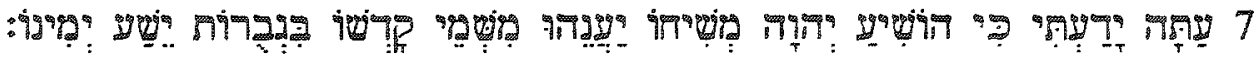
6 Now I know that YHWH saves his anointed; he will answer him from his holy heaven with the saving strength of his right hand.

\section{Preliminary Observations}

Ps 20 was probably "written in connection with an event in the life of the king," as suggested by the explicit mention of im "rope? ("his anointed" in vs. 7 [6]) and the ("king" in vs. 10 [9]). This psalm may have functioned as a prayer for the king before his going out to battle. ${ }^{2}$ This seems implied by the reference to the weakness of military appurtenances which is contrasted with the salvation provided by YHWH (vss. 8-10 [7 91). Therefore the designation of "royal prayer" seems fitting in view of its contents. In

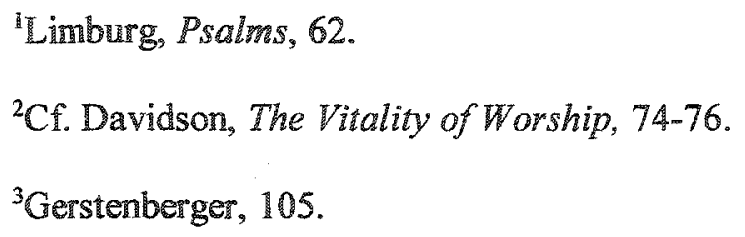


addition, the possibility should not be rejected that the text under study might also have had some liturgical usage in the context of worship in the Jerusalem temple.

From a literary point of view, this text is a closely integrated and coherent unit ${ }^{2}$ and divides itself naturally into two parts: vss. $1-6[5]$ and 7-10 [6-9]. The first part contains an intercession in which help is expected from the Zion sanctuary. The second section, introduced by the term 7 .ศก ("now") in vs. 7, contains an oracular response in which the salvation previously envisioned as coming from the Zion "sanctuary" is now depicted as already accomplished from heaven (i.e., the heavenly sanctuary). This can be portrayed as follows:
A. "May YHWH send help from the [earthly] sancuary" (wigp). Vs. 3a [2a]
B. "May [YHWH] remember" (79?"). Vs. 4a [3a])

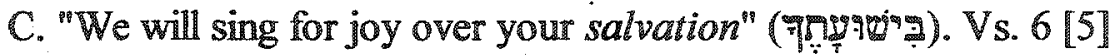
A" "YHWH will answer from the heavenly sanctuary (907? ?pepe $\mathrm{Vs}$. 7a [6a]
B." "We will remember" (7999). Vs. 8b [7b]

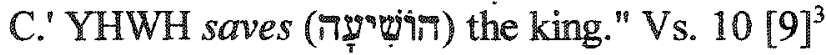

The ensuing discussion undertakes an analysis of porp (vs. 3 [2]) and 7007? (vs. $7[6]$ ) in order to ascertain the presence of the heavenly sanctuary/temple motif in this passage, as well as its function and relationship to its earthly counterpart.

${ }^{1} \mathrm{Cf}$. Kraus, Psalms 1-59, 279.

${ }^{2}$ This can be perceived in the repetition of key terms, such as ""Iม' ("answer") and gi" ("day") that occur in vss. 1 and 10, thus forming an inclusio. There are also three references to the

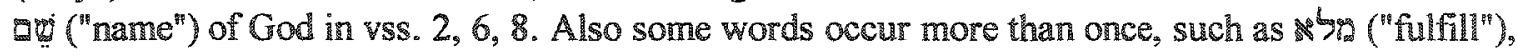

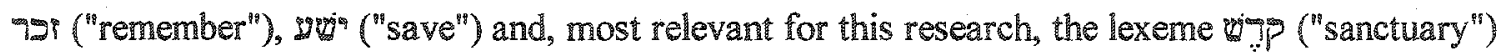
in vss. 3 [2] and 7 [6]. Cf. Craigie, Psalms $1-50,185$.

${ }^{3}$ With some modifications, this structure follows Marc Girard, Les Psaumes: Analyse Structurelle et Interpretation: 1-50, 3 vols., RNS 2 (Montréal: Editions Bellarmin and Paris: Éditions du Cerf, 1984), 181. 
Semantic and Other Exegetical Considerations

\section{Referent or ơ}

The inverted parallelism between the two halves of vs. 3 [2] indicates that wip refers to the earthly sanctuary on Mount Zion, as noted in the diagram below.

(B)

$$
\text { (A) } 7799.9 \text { (B) (B) }
$$

May he send you help (A) from the sanctuary (B)

And from Zion ( $\left.B^{\prime}\right)$ your support ( $\left.A^{\prime}\right)$

Therefore it is clear that if is the earthly temple that is here envisaged as a source of divine help for the king. After these brief considerations, attention needs to be turned to

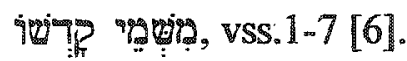

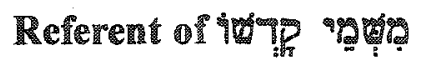

The expression ito :? heavens." At first glance this seems an appropriate rendering, and commentators usually do not elaborate on it. Yet three observations are in order. First, it should be noted that the genitival qualifier "ivg attached to "heavens" is the same word employed for "sanctuary" in vs. 3 [2] and thus seems to qualify not only "heaven" in a generic sense, but probably implies a reference to the heavenly sanctuary/dwelling of YHWH. ${ }^{1}$ Second, it instructive to note that very similar construction occurs in Obad 3 (ingar gimg "lofy

\footnotetext{
'Several scholars have recognized the presence of the heavenly sanctuary/temple motif in
}

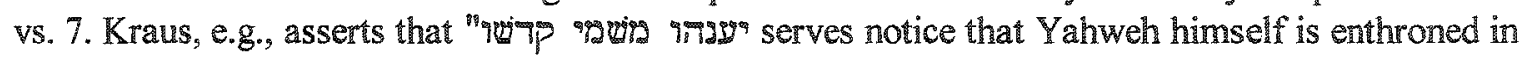
the heavenly sanctuary, hears the bidding prayer there, and finally carries out his saving interventions from on high" (Psalms 1-59,281). Cf. also Arnold Albert Anderson, The Book of Psalms, 2 vols., NCB (Grand Rapids, MI: Eerdmans, 1981), 1:178; Marc Girard, Les Psaumes: Analyse Structurelle et Interpretation: 1-50, 182; Hossfeld and Zenger, Die Psalmen 1, 138; J. W. Rogerson and J. W. McKay, Psalms 1 -50 (Cambridge: Cambridge University Press, 1977), 92. 
abode"). Here the element in construct functions adjectivally in relation to its genitival component. If the same grammatical logic is applied to iveng the translation "heavenly sanctuary" would emerge naturally. Third, the parallelism of wip in vs. 3 [2] with the locution 70 ?p understood in the sense of "sanctuary," namely the heavenly sanctuary."

\section{Heavenly Sanctuary/Temple Motif}

\section{Finetion}

The heavenly sanctuary emerges in the text as a source of royal help, since it is portrayed as the place whence YHWH answers prayers and sends help to his anointed king. As Kraus pointed out, "The statement 9097p "96? 97929 serves notice that Yahweh is enthroned in the heavenly sanctuary, hears the bidding prayer there, and finally carries out his saving intervention from on high."

\section{Relationship to Carhly Counderpartet}

One of the interesting perceptions of this passage is the implied interaction between the heavenly temple and its earthly counterpart, which can be delineated as follows. In the first section of the psalm, it is revealed that help is to come from the Zion

${ }^{1}$ Several scholars support the idea that the passage refers to the heavenly sanctuary. $\mathrm{Cf}$., e.g., Anderson, The Book of Psalms, 1:179; Anthony Lee Ash and Clyde M. Miller, Psalms (Austin, TX: Sweet Publishing Company, 1980), 88; Kraus, Psalms 1-59, 281; Rogerson and McKay, Psalms 1-50, 92; Schaefer, 49; Charles Briggs and Emilie G. Briggs, A Critical and Exegetical Commentary on the Book of Psalms, 2 vols., ICC (Edinburgh: T.and T. Clark, 19061907), 1:179-80.

${ }^{2}$ Kraus, Psalms 1-59, 281. 
sanctuary; in the second half, one learns that YHWH answered from the heavenly sanctuary.' Far from being contradictory, these two assertions complement each other. The underlying assumption is that the temple on Mount Zion corresponds to the temple in heaven and works in dynamic interaction with it. Thus it is not surprising that a petition made in the context of the earthly temple is answered from the heavenly sanctuary. Furthermore, the verbal and conceptual correlations between the sanctuary idea in vs. 3 [2] and vs. 7 [6] indicated the notion of a functional and structural correspondence between the heavenly sanctuary and its earthly counterpart.

\section{PS 29:1-11}

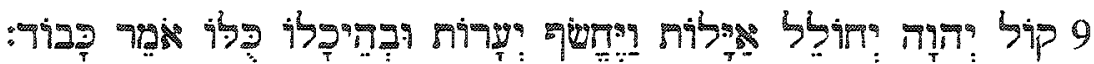
9 The voice of YHWH makes the deer to calve and strips the forests bare; And in his temple everything says, "Glory!"

\section{Preliminary Observations}

Ps 29 has been classified as a "hymn of victory" or "cosmic hymn" to YHWL, and, in view of similarities of themes and motifs, it has been considered by some scholars to be dependent upon Canaanite literature. Since this idea was first published by Ginsberg

${ }^{1}$ As Kidner puts it, "the dimensions of the scene are enlarged: the help sought from Zion . . is now sent from heaven itself" (Psalms $1-72,102$ ).

${ }^{2}$ Craigie, Psalms $1-50,245$.

${ }^{3}$ Alfons Deissler, "Zur Datierung und Situierung der 'kosmischen Hymnen' Pss 81920 , in Lex Tua Veritas: Festschrift für Hubert Junker zur Vollendung des siebzigsten Lebensjahres am 8. August 1961, dargeboten von Kollegen, Freunden und Schülern, ed. Heinrich Gross and Franz Mussner (Trier: Paulinus-Verlag, 1961), 47-58. 
in $1935,{ }^{1}$ a string of responses has come forth. ${ }^{2}$ Among these, the suggestion advanced by Peter Craigie should be noted. He contended that Ps 29 is a "song of victory" belonging to the oldest traditions of Israelite poetry, such as are represented, among others, by the "Song of the Sea" (Exod 15:1-18). ${ }^{4}$ This view has much to commend, since it is based on analogies with similar texts of the Hebrew Bible, rather than upon less objective and, rather frequently, speculative comparisons to alleged ANE parallels. It must be noted, however, that Craigie does not understand the psalm to be composed in a historical vacuum, inasmuch as he admits that "the poet has deliberately utilized Canaanite-type language and imagery in order to emphasize the Lord's strength and victory, in contrast to the weakness of the inimical Baal."

\footnotetext{
"H. Louis Ginsberg, "A Phoenician Hymn in the Psaiter," in XIX Congresso Internazionale degli Orientalisti (Rome: Tipografia del Senato, G. Bardi, 1936), 472-76.
}

${ }^{2}$ Cf. Michael L. Barré, "A Phoenician Parallel to Psalm 29," HAR 13 (1991): 25-32; P. C. Craigie, "Parallel Word Pairs in Ugaritic Poetry: A Critical Evaluation of Their Relevance for Psalm 29," UF 11 (1980): 135-40; Peter C. Craigie, "Psalm xxix in the Hebrew Poetic Tradition," VT 22 (1972): 143-51; F. M. Cross, "Notes on a Canaanite Psalm in the Old Testament," BASOR 117 (1950): 19-21; John Day, "Echoes of Baal's Seven Thunders and Lightnings in Psalm 29 and Habakkuk 3:9 and the Identity of the Seraphim in Isaiah 6," VT 29 (1979): 143-51; Herbert Domner, "Ugaritismen in der Psalmenforschung," ZAW 79 (1967): 322-50; A. Fitzgerald, "A Note on Psalm 29," BASOR 215 (1974): 61-63; T. H. Gaster, "Psalm 29," JQR 37 (1946-47): 55-65; Christian Macholz, "Psalm 29 und $1 \mathrm{Kön} 19, "$ in Werden und Wirken des Alten Testaments: Festschrifí fur Klaus Westerman zum 70. Geburtstog, ed. Rainer Albertz et al. (Göttingen: Vandenhoeck and Ruprecht, 1980), 325-33; B. Margulis, "The Canaanite Origin of Psaim 20 Reconsidered," Bib 51 (1970): 332-48; H. Strauss, "Zur Auslegung von Psalm 29 aus der Hintergrund seiner kanaanäischen Bezuge," ZAW 82 (1970): 91-102; Ernst Vogt, "Der Aufbau von Ps $29, " B i b 41$ (1960): 17-24.

\footnotetext{
${ }^{3}$ Craigie, "Psalm xxix in the Hebrew Poetic Tradition," 144; Craigie, Psalms 1-50, 246.

"Craigie, "Psalm xxix in the Hebrew Poetic Tradition," 144.

${ }^{5}$ Craigie, Psalms 1-50, 246.
} 
Structurally, PS 29 contains a central section with a sevenfold repetition of the phrase "voice of YHWH" (7ฺ̣T" Sip), framed by an introduction and conclusion. As shown in fig. 3 , this composition displays a well-crafted structure with parallelism and repetition of key words and expressions at regular intervals. For example, the phrase bip 1779? ("voice of YHWH") appears seven times across the poern, while the Tetragrammaton occurs eighteen times - ten times in the central section (vss. 3-9), four times in the introduction, and four times in the conclusion. Whether this numerical pattern is just a coincidence, or has some rhetorical purpose is difficult, if not impossible, to ascertain. What seems clear, nonetheless, is that such a numerical rhetoric contributes to the literary beauty of the composition.

All this contributes to provide a well-balanced structure in which the central section of the psalm is framed by heavenly scenes at the introduction and conclusion. The introduction portrays the "sons of God" as they are summoned to praise and glorify YHWH, while the final section frames the entire composition by depicting YHWH enthroned "over the flood" and bestowing blessing and peace upon his people. The central section portrays the theophanic thunderstorm traveling from north to south across the Promised Land and provoking the commotion of the elements of nature.

For the purpose of this research, special attention will be given to the terms 9. introduction. Thereafter, attention will be given to the expressions ib temple") and S9g9? ("since/over the flood"), followed by an excursus on the central 
1a Ascribe to YHWH, O sons of God, lb Ascribe to YHWH glory and strength.

2a Ascribe to YHWH the glory due to his name; $2 b$ Worship YHWH in the GLORIOUS SANCTUARY.

3a The voice of $Y H W H$ is upon the waters; $3 \mathrm{~b}$ The God of glory thunders, $3 c$ YHWH is over many waters. 4a The voice of $Y H W H$ is powerful, $5 \mathrm{~b}$ The voice of $Y H W H$ is majestic.

5a The voice of $Y H W H$ breaks the cedars; $5 \mathrm{~b}$ Yes, YHWH breaks in pieces the cedars of Lebanon.

6a He makes Lebanon skip like a calf, $6 \mathrm{~b}$ And Sirion like a young wild ox.

7 The voice of YHWH hews out flames of fire. 8a The voice of YHWH shakes the wilderness; $8 \mathrm{~b}$ YHWH shakes the wilderness of Kadesh.

9a The voice of $Y H W H$ makes the deer to calve $9 \mathrm{~b}$ And strips the forests bare;

9c And in HIS TEMPLE everything says, "Glory!"

10a YHWH sat as King above the flood;

$10 \mathrm{~b}$ Yes, YHWH sits as King forever.

10a YHWH will give strength to his people;

$10 \mathrm{~b}$ YHWH will bless his people with peace.

Fig. 3. Literary structure of Ps 29. Adapted from Marc Girard, Les Psaumes: Analyse Structurelle et Interpretation: 1-50 (Montreal: Bellarmin, 1984), 234. 
section of the psalm. After these exegetical procedures, a delineation of the heavenly sanctuary/temple motif as depicted in Ps 29 will be attempted.

\section{Semantic and Other Exegetical Considerations}

\section{Meaning or ary}

The locution "ge ("sons of God") most probably points to the heavenly beings who serve at YHWH's heavenly court, an idea found elsewhere in the Hebrew Bible, as already pointed out in this dissertation. 'Therefore no further elaboration of this concept is needed at this point. For the purpose of this study, it suffices to point out that the reference to the a'? contributes to setting the opening scene of Ps 29 in the heavenly realm, the implications of which will be noted in due course.

\section{Meaming and Referent of खึำ}

The genitival expression wopg connection with the cult either in the earthly or heavenly temple/sanctuary. The precise meaning of wim nom has remained elusive, as attested by different translations: "holy array, "holy attire/robes," "holy splendor, "beauty/splendor of [his] holiness, ${ }^{" 16}$

${ }^{1}$ See, e.g., Exod 15:11; Ps 86:8; et al.

${ }^{2}$ Pss 29:2; 96:9; 1 Chr 16:29;2 Chr 20:21.

${ }^{3} \mathrm{ASV}, \mathrm{NASB}, \mathrm{RSV}$.

${ }^{4} \mathrm{NET}, \mathrm{BBE}$.

${ }^{5} \mathrm{DBY}, \mathrm{NAB}, \mathrm{NRS}$.

${ }^{6} \mathrm{ESV}, \mathrm{JPS}, \mathrm{KJV}, \mathrm{NIV}, \mathrm{NIB}, \mathrm{NJB}, \mathrm{NKJ}, \mathrm{NLT}$. 
"majestic in holiness," "glorious sanctuary," "holy court. ${ }^{n 3}$ In order to decide which option fits better in the text, some semantic and syntactic issues need to be addressed,

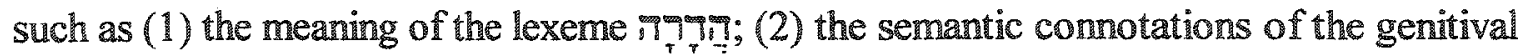

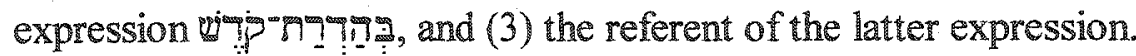

Concerning the meaning of "adornment, glory." Although some versions have הาרํา as "array" and "garments/attire," as mentioned above, it must be noted that this is an inference based on a presumed extended meaning of the word. Another possibility was raised by Cross, who argued that การกี means "appearance," a suggestion based on the alleged Ugaritic cognate hdrt which appears in parallel with hllm ("dream"). This suggestion, however, depends on an Ugaritic parallel which occurs only once, in a difficult text. ${ }^{6}$ Thus, in view of the difficulties of the options just mentioned, it seems that "adornment, glory" remains the most likely meaning

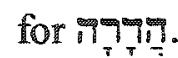

${ }^{1}$ TNK.

${ }^{2} \mathrm{GNV}, \mathrm{SRV}$.

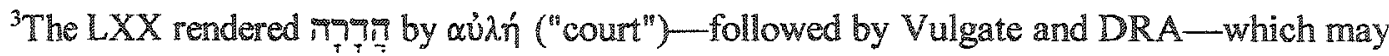
indicate the presence of the lexeme also exists that the LXX translator was simply attempting to interpret the passage in the light of the Jerusalem temple, where worshipers and singers would be positioned in the court.

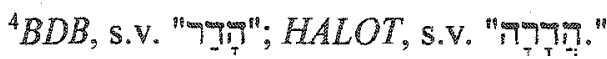

${ }^{5}$ Cross, "Notes in a Canaanite Psalm in the Old Testament," 21.

${ }^{6} \mathrm{Cf}$. Craigie, Psalms 1-50, 248; H. Domner and W. Röllig, Kanaanäische und Aramäische Inschriften (Wiesbaden: Otto Harrassowitz, 1966), 331-32. 
The task now is to ascertain the meaning of the genitival expression wip-97? ?7? In this regard, at least four options are available:

1. The nomen rectum may function adjectivally in relation to gn? 1 . This would result in the translation "holy splendor" or, if the nomen regens is understood adjectivally,

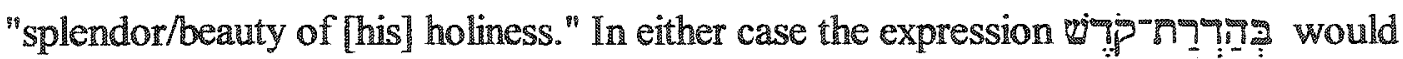
function syntactically as an adjunct to, and semantically as an attribute of, YHWH.

2. The phrase may be translated as "holy attire/robes" or "array" in reference to the garments or disposition of the temple singers, respectively. In this case, the expression under study would qualify not YHWL, but the outfit of those who are summoned to "praise" him.

3. If Ugaritic is followed, mogring would refer to the "holy appearance" or, in other words, to the theophany of YHWH. ${ }^{1}$ However, for the reasons expressed above, this option is untenable.

4. A more likely option would be to interpret viph translate it as "glorious sanctuary." In this case, $777 \rightarrow$ is taken in its natural lexical meaning and wip is understood as "parallel or complementary to hykl [S As can be deduced from Hab 2:20, ${ }^{4}$,

'Kraus, Psalms 1-59, 344. Cf. F. C. Fensham, "Psalm 29 and Ugarit," in Studies on the Psalms: Papers Read at 6th Meeting Held at the Potchefstroom University for C.H.E., 29-31 Jan. 1963 (Potchefstroom: Pro Rege, 1963), 89.

${ }^{2} \mathrm{Cf}$. GNV: "glorious Sanctuarie (sic)"; SRV: "glorioso santuario."

'David Noel Freedman and C. Franke Hyland, "Psalm 29: A Structural Analysis," HAR 66 (1973): 244.

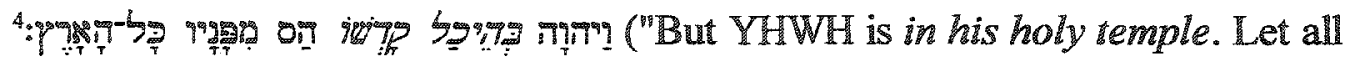




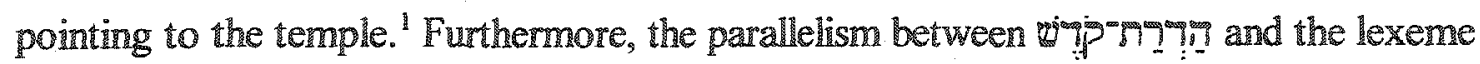
("court") in Ps 96:8-92 corroborates the view that the former points to the temple. ${ }^{3}$

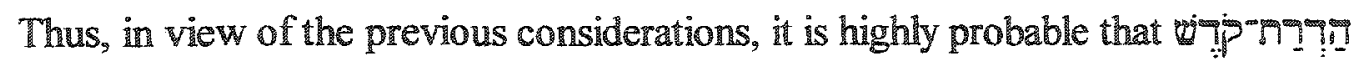
connotes the idea of "sanctuary/temple," a literal translation of which may be "glorious sanctuary" as suggested above.

As for the referent of this "glorious sanctuary," in view of the heavenly imagery evoked by the context in which the "sons of God" are summoned to worship YHWH, this sanctuary must be located in heaven. Therefore, Ps. $29: 2$ not only portrays a heavenly scene, as admitted by the vast majority of scholars, ${ }^{4}$ but relates this heavenly scene to the "glorious [heavenly] sanctuary."

\section{Storm Imagery}

The central verses of the psalm portray a storm that comes to hit Canaanite territory. As William Shea pointed out, from the heavenly sanctuary YHWH sends the

the earth be silent before him").

'See the discussion of this passage in chapter 4 of this dissertation.

${ }^{2}$ Ps 96:8-9:

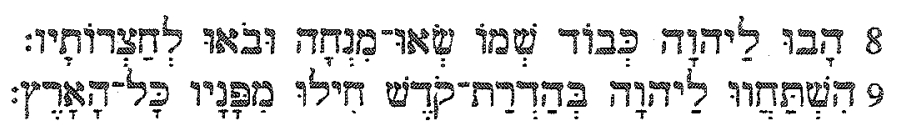

8 "Ascribe to YHWH the glory of his name; bring an offering and come into his courts.

9 Worship YHWH in holy attire; tremble before him, all the earth." 8

${ }^{3}$ Freedman and Hyland, 244.

${ }^{4}$ Cf., e.g., Fensham, 89, 92; Kidner, Psalms 1-72, 124; Kraus, Psalms 1-59, 348; Macholz, 325-26; Schaefer, 71-72. 
storm and flames of fire (Vss. 5-9) to strike the Canaanites. ${ }^{1}$ It is instructive to note that all the place names mentioned in the text belong to Canaanite territory. ${ }^{2}$ As Shea expressed, "the description tells how the storm was ordered by God from His heavenly temple as the angelic host stood by (vs $1-2,9 b$ ). In response to this demonstration of His power all the host in Yahweh's heavenly temple ascribe glory to him as they were exorted to do at the begining of the psalm." It thus becomes apparent that the heavenly temple functions as the place from where YHWH sends judgment upon the enemies of his people.

\section{Relerent of Sy9g}

At the outset it must be pointed out that the injunction to give oigs to YHWH in vs. 2 is matched by vs. 9c, in which everything says 7ig. As noted by Limburg, "what is called for in vs. 2 is executed in vs. $9 \mathrm{c}$ as all in the temple sing glory!"4 Furthermore, both verses evoke the notion of YHWH being worshiped in the "sanctuary/temple." In this

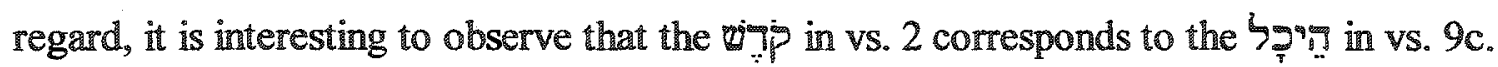
Furthermore, there seems to be a structural linkage between vs. $9 \mathrm{c}$ and the opening scene.

\footnotetext{
${ }^{1}$ William H. Shea, Selected Studies on Prophetic Interpretation, 7 vols., Daniel and Revelation Committee Series 1 (General Conference of Seventh-day Adventists, 1982), 6.

${ }^{2}$ The reference to Kadesh (Ps 29:8), which might be at first glance identifies a location in the in the south, most probably refers to a location in Syria, as argued by the following scholars: Ginsberg, 472-76; Oswald Loret, Psalm 29: Kanaunäische El- und Baalroditionen in jüdischer Sicht, Ugaritisch-Bibische Literatur 2 (Altenberg: CIS-Verlag, 1984), 91-92. However, the view that Kadesh should be identified with the location on the way from Egypt to Palestine (see Deut 1:19) was argued by Deissler on the basis that "the average Israelite could not understand it otherwise" ("Zur Datierung und Situierung der "kosmischen Hymnen' Pss 819 20," 54). Cf. also Kidner, Psalms 1-72, 126; Weiser, 264.

${ }^{3}$ Shea, Selected Studies on Prophetic Interpretation, 6.

4imburg, Psalms, 94.
} 
In this regard it must be remembered that the position of vs. $9 \mathrm{c}$ in the structure of the psalm has been debated. At first glance, it appears that vs. $9 \mathrm{c}$ is a piece of material loosely related to its immediate context, since there is no parallel to it, and its connection with either the preceding or following material is not apparent. This has led some scholars to hypothesize that vs. 9 c does not belong originally to the psalm. However, there is no textcritical basis for this conjecture, and this dissertation is concerned with the final form of the text. So Ps 29 must be treated as a unified composition. That having been said, two options remain: vs. $9 \mathrm{c}$ belongs either to the previous section or to the final one.

The verse divisions of the Masoretic text support the former possibility. Also, the

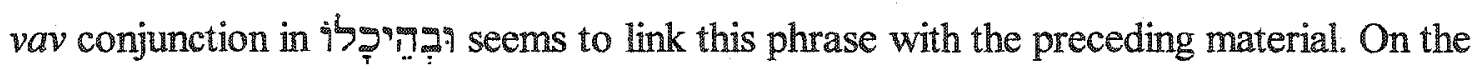
other hand, the content of the entire clause- "And in his temple everything (ibs) says, "Glory!"- seems more related to what follows, inasmuch as the entire participial clause seems to function as a formula to introduce not only the liturgical shout 7ig?, but also the contents of vss. 10 and 11 . Therefore, it is more likely that vs. $9 \mathrm{c}$ belongs to the final section. However, one should not rule out the possibility that it may have been intentionally placed at that position as a transitional marker ${ }^{2}$ in order to signal the point where the scene moves from earth to heaven. The importance of vs. $9 \mathrm{c} \mathrm{has} \mathrm{been}$ recognized by Von Rad, who argued that this "is the key-verse of the whole psalm-it leads us away from the commotions on the earth up to the heavenly sanctuary where the

${ }^{1} \mathrm{Cf} .$, e.g., Briggs and Briggs, $1: 254$.

${ }^{2}$ Freedman and Hyland hold that " $9 \mathrm{c}$ while belonging to the main section of the poem, nevertheless serves as the transition from the Introduction to the Conclusion, which constitutes the utterance referred to in vs. $9 \mathrm{c}^{\prime \prime}(241)$. 
company of the heavenly beings recognizes and glorifies these very occurrences on the earth as revelation of the glory of Jahweh."

It can also be suggested that although $y$ gुy primarily points to the heavenly temple, it may include the earthly temple. In this regard one should note that the phrase its might also encompass the earthly temple. ${ }^{2}$ Although the antecedent of the pronominal suffix 9 is understood as referring primarily to $\$ \frac{7}{9}$, the possibility remains that it may also refer to YHWH, who is the topic of the clause. In this case, th would include "everything that belongs to YHWH," thus encompassing the earthly temple and the worship offered therein. Such an idea seems corroborated by Ps 148 , where the earthly congregation joins the heavenly beings to praise YHWH. ${ }^{3}$ As James L. Mays put it, "The doxology that is offered in the heavenly temple is a model and motif for what must occur in the corresponding earthly temple; the congregation in its praise is led by and joins in the doxology sung by the 'sons of God. ${ }^{\text {np4 }}$

Summing up, although the term 597 in vs. $9 \mathrm{c}$ refers primarily to the heavenly temple, its structurally ambivalent position, coupled with the syntax and semantics of the phrase 69 , leaves open the possibility that the earthly temple may also be in view.

${ }^{1} G$ erhard von Rad, Old Testament Theology, trans. D. M. G. Stalker, 2 vols. New York: Harper and Row, 1962), 1:360.

${ }^{2}$ As pointed out by Hossfeld and Zenger, "Das Lob des himmlischen Hofstaates wird hier durch den Hinweis 'ein jeder, alle' [ 9 ' $\$$ ] auf die Menschen im irdischen Tempel ausgeweitet" ("In the allusion to 'every, all [15y] the praise of the heavenly court broadens to include the human beings in the earthly temple") (Die Psalmen 1, 185).

${ }^{3} \mathrm{Cf}$. Deissler, "Zur Datierung und Situierung der 'kosmischen Hymnen' Pss $81920,05$.

"James Luther Mays, "Psalm 29,"Int 39 (1985): 61. 


\section{Meaning of ไรฐฏ?}

Although etymology of $7 \pm 2$ camot be established with absolute certainty, ${ }^{1}$ the fact outside Ps 29 , Sqge occurs only in Gen 6-9, indicates that S992 in Ps 29:10 most probably refers to the Genesis Flood, ${ }^{2}$ and not to the heavenly ocean as suggested by some scholars. ${ }^{3}$ Thus, granting that 999 refers to the Genesis Flood, attention must now be given to the elusive prepositional phrase bag? The question arises whether the preposition connotes a temporal or locative idea. In the former case it should be translated "since the Flood"; in the latter, "on/over/above the flood."

In this connection, Dahood has proposed that Sym may connote the idea of "from the flood" on the basis of the Ugaritic meaning of $ל$ as "from/since." However, such a position is difficult sustain in view of D. Pardee's observation that Ugaritic $y t b /$ is not attested as meaning "to be seated since." An additional objection is that the locution

'This situation is reflected in the several suggestions for the etymology of ל192: Akkadian abübu ("llood"); bubbülu, biblu, bibbulu ("high tide"); napalu/ napälu I ("destroy"); general Semitic bIl ("to mix, mingle"); a maqtul form from ybI II ("to rain strongly"; cf. Arabic wabil ["cloudburst"]); Egyptian wbn("to overflow"). Cf. P Stenmans, "לุgag mabbûl," TWAT, 4:634-38.

${ }^{2}$ Alfons Deissler, Die Psalmen, 6th ed. (Düsseldorf: Patmos, 1989), 121; Kidner, Psalms 1-72, 127; Edward Joseph Kissane, The Book of Psalms (Dublin: Browne and Nolan Richvie, 1964), 128; Artur Weiser, The Psalms: A Commentary, The Old Testament Library (Philadelphia: Westminster, 1962), 265; Michael Wilcock, The Message of Psalms 1-72: Songs for the People of God, The Bible Speaks Today (Downers Grove, IL: InterVarsity, 2001), 101.

${ }^{3}$ So Anderson, The Book of Psalms, 1:196; Joachim Begrich, "Mabbul: Eine exegetischlexicalische Studie," ZS 6 (1928): 135-53; Carola Kloos, Thwh's Combat with the Sea: A Canaanite Tradition in the Religion of Ancient Israel (Amsterdam/Leiden: G.A. van Oorschot/Brill, 1986), 62-92.

Dahood, Psalms I, 184

5. Pardee, "On Psalm 29: Structure and Meaning," in The Book of Psalms: Composition and Reception, ed. Peter W. Flint et al. (Leiden: Brill, 2005), 171. 
? It" is a standard expression to convey locative meaning in biblical Hebrew. "Therefore it seems more natural, from a linguistic point of view, to construe 7992 ? a locative expression (i.e. "over the Flood"). This locative idea receives contextual support from vs.

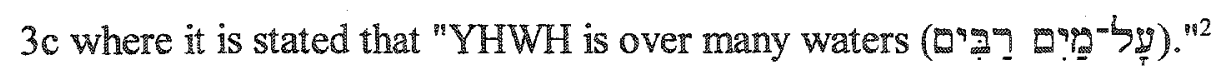

Assuming the validity of the previous suggestion that 992 conveys a locative connotation, one has a semantic problem the locative view seems to conceptualize byge as a "throne," an idea incongruent with semantic common sense. In this regard, Pardee seems to clarify the issue by pointing to an Ugaritic text in which appears the expression $b k m y t b$ b $1 /$ bhth ("with $\mathrm{Ba}$ lu enthroned at his house"). Since it is unlikely that $y t b 1+$ house means to seat upon the house, as if it were a chair (as with the Flood), the suggestion may be advanced that that $y t b /+$ house means to "seat in regards to the house," that is, to seat upon a throne in order to rule over the house. ${ }^{4}$ Turning to Ps 29:10, Pardee summarized by saying that the Hebrew idiom b9ges a "does not indicate that YHWH sat upon the Flood, treating it like a chair, but that he sat upon his kingly throne with respect to the Flood, i.e. acted as sovereign towards it. ${ }^{195}$

${ }^{1}$ See Judg 5:17; 1 Kgs 2:19; Isa 47:1; Pss 9:5 [4]; 110:1; 132:12; Prov 9:14; Lam 2:10.

${ }^{2} \mathrm{Cf}$. Gen 1:7: "God made the expanse, and separated the waters which were below the expanse from the waters which were above the expanse; and it was so."

${ }^{3}$ D. Pardee, "On Psalm 29: Structure and Meaning," in The Book of Psalms: Composition and Reception, ed. Peter W. Flint et al. (Leiden: Brill, 2005), 171, 174 (RS 2.008 +VII 42).

${ }^{4}$ See ibid., 171-72.

5Ibid., 172. 
Summing up, the expression 9 s? contributes to reafirm the heavenly setting of the ${ }_{T} 99$ mentioned in vs. $9 b$, and implicitly points to the heavenly temple as the place wherein YHWH has performed his activities as cosmic king ruling over the Flood and bestowing blessings upon his people.

\section{Heavenly Sanctuary/Temple Motif}

\section{Wunction}

The above investigation allows the following delineation concerning the function of the heavenly sanctuary/temple. The presence of the heavenly sanctuary/temple in Ps 29 is made evident by the heavenly imagery depicted in the opening and closing scenes. In the opening scene the "glorious sanctuary" functions as the locus of worship and praise, as deduced from the injunction to the heavenly beings to worship YHWH (vs. 2). The closing scene portrays YHWH receiving the adoration called for in the opening section (vs. 9c). It should be kept in mind, however, that the praise expressed in the psalm come as a result of YHWH's judgment upon the Canaanites, as represented by the storm that strikes Canaanite teritory. Thus, the heavenly sanctuary/temple also emerges as the place from where YHWH sends judgment upon the enemies of his people. The heavenly temple is portrayed as the place where $Y H W H$ exerts his kingship, as implied in the afrmation that he is enthroned "above the flood" (vs. 10a), and explicitly noted in the utterance that "YHWH sits as King forever" (vs. 10b). Furthermore, in vs. 11 the heavenly temple functions as the place whence YHWH grants blessing and peace upon his people. 
Summing up, the heavenly sanctuary/temple functions as a liturgical/cultic place where worship and praises are given to $\mathrm{YHWH}$, from where he sends judgment upon the enemies of his people, exerts his kingship over the cosmos, and bestows blessing and peace upon his people on earth.

\section{Relationship to Earthly Counterparter}

The portrayal of the heavenly sanctuary/temple as a place of worship, judgment, kingship, source of help, and blessings places it in functional correspondence with its earthly counterpart. In addition, the reference heavenly correspondence, as already noted.

\section{Ps 33:1-22}

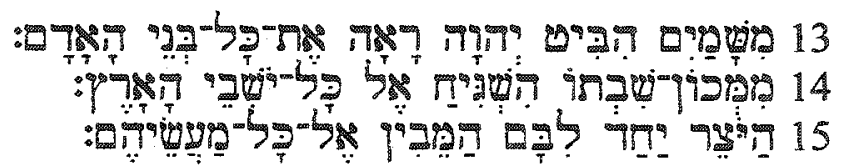

13 From heaven YHWH looks; he sees all the sons of men;

14 From his dwelling place he gazes at all the inhabitants of the earth,

$15 \mathrm{He}$ who fashions the hearts of them all, he who understands all their works.

\section{Preliminary Observations}

PS 33 consists of a "song of praise" alluding to the nature of $\mathrm{YHWH}$ and the creative power of his word. ${ }^{2}$ It is structurally arranged with an introductory call to praise (vss. 1-3) followed by the main section spelling out the reasons for the rejoicing (4-19). The following investigation deals mainly with the subunit of vss. 13-15, which alludes to

${ }^{1}$ Kraus, Psalms 1-59,374.

${ }^{2}$ Anderson, The Book of Psalms, 1:260. 


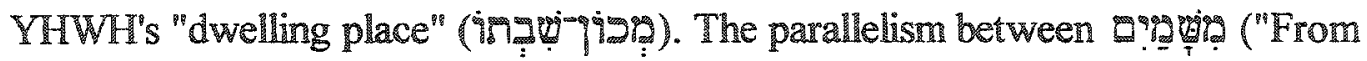

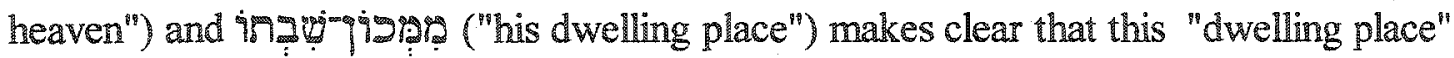
should be located in heaven. Thus the ensuing discussion deals with the connotation of

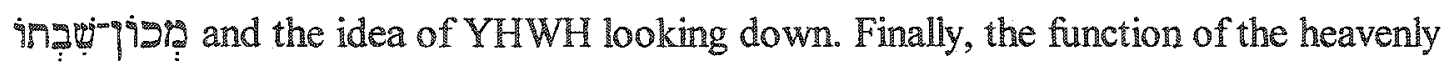
sanctuary/temple motif is delineated.

Semantic and Other Exegetical Considerations

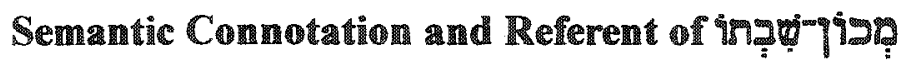

The main goal of this section is to determine the semantic contours of the locution

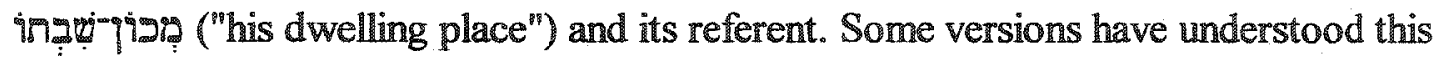
expression as connoting the idea of "throne." Dahood has suggested that the locution ที่ metonymy. ${ }^{2}$ He seems to have drawn this idea from the occurrence of gisp in connection with the idea of "throne" may be part of the overall complex of ideas connoting temple/sanctuary, one has to determine more specifically whether connotation of "throne" or "dwelling" (that is, temple/sanctuary). If the latter is the case, then this passage should be included in the present study.

"Cf. e.g.: "royal throne" (NAB); "where he sits enthroned" (ESV, NRS); "the place where he sits" (NJB); "throne" (NLT).

2Dahood, Psalms 1, 202. Cf. Anderson, The Book of Psalms, $1: 265$.

${ }^{3}$ Cf. Pss 89:15 [14]; 97:2. 
It is important to note that when pisp ("place, site") ${ }^{1}$ is comnected to the lexeme Ievi", as in the text under examination, it most probably carries the connotation of "dwelling" (i.e., temple/sanctuary). As already noted, the term jiş̧ derives from the root १19, which connotes the idea of firmness. ${ }^{3}$ It is used seventeen times in the Hebrew Bible, ${ }^{4}$ fourteen of which are in connection with the sanctuary, as pointed out by Rodriguez. ${ }^{5}$ Seven times it designates YHWH's "dwelling place" in heaven (i.e., the heavenly

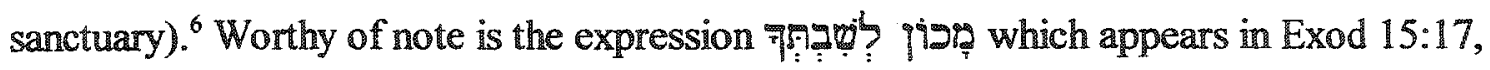

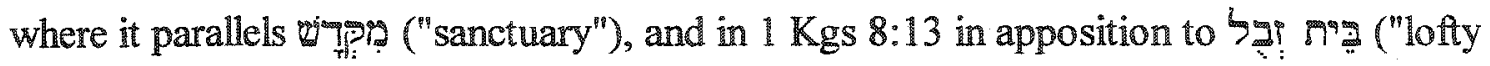

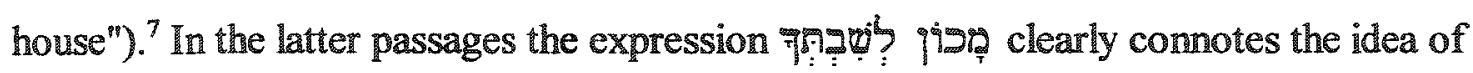

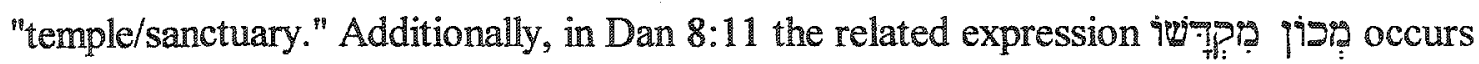
with the connotation of sanctuary/temple. In view of the usage of this expression in other

'HALOT, 2:579, s.v. מוֹ

${ }^{2}$ The form inge is the infinitive construct of

${ }^{3}$ Cf. HALOT, s.v. פפ.

${ }^{4}$ Exod 15:17; 1 Kgs 8:13, 39, 43, 49; 2 Chr 6:2, 30, 33, 39; Ezra 2:68; Pss 33:14; 89:15 [14]; 97:2; 104:5; Isa 4:5; 18:4; Dan 8:11.

${ }^{5}$ Angel Rodriguez, "Significance of the Cultic Language in Daniel 8:9-14," in Symposium on Daniel, ed. Frank B. Holbrook, DARCOM 2 (Washington, DC: Biblical Research Institute, 1986), 530-31.

${ }^{6} 1 \mathrm{Kgs} 8: 39,43,49 ; 2$ Chr 6:30, 33, 39; Ps 33:14. Cf. Gerhard F. Hasel, "The 'Little Hom, the Heavenly Sanctuary and the Time of the End: A Study of Daniel 8:9-14," in Symposium on Daniel, ed. Frank B. Holbrook, Daniel and Revelation Committee Series (Washington, DC: Biblical Research Institute, 1986), 413.

${ }^{7}$ See the study of Exod $15: 17$ and $1 \mathrm{Kgs} 8: 13$ in chapters 3 and 4 of this dissertation, respectively. 
passages of the Hebrew Bible, one can safely assume that the idea behind inapo pigag is most probably that of "dwelling" (i.e., temple/sanctuary, rather than throne).

Finally, some brief considerations should be devoted to the referent of the locution

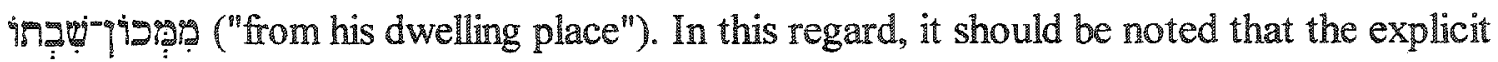

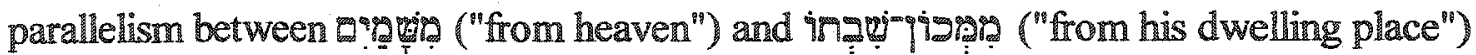
points undoubtedly to the heavenly sanctuary as the referent of the latter. So it may argued

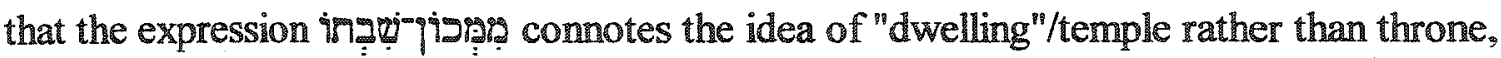
and thus most indicates the heavenly sanctuary/temple of YHWH.

\section{Idem of YHWIT Looking Down}

The idea of YHWH looking down is expressed by three different verbs: 892

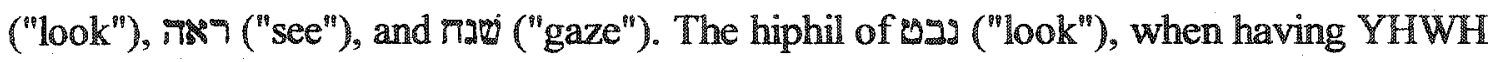
as its grammatical subject, is used to express the idea of his looking down from heaven to earth to hear grievances and free prisoners. "The verb $17 x$ ("see"), among several other usages, has connection with the conceptual realm of the courtroom, whence comes the notion that YHWH sees injustice, oppression, and idolatry. ${ }^{2}$ According to Fuhs this "seeing means God's intervention as judge, with judicial examination preceding execution

\footnotetext{
"Ps. 102:20f. [19f.]. Cf. H. Ringgren, "שs

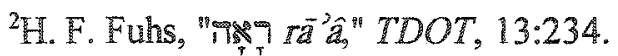


of the judgment." As for nae ("gaze"), is means "more precisely to look at closely and to examine critically."2

Thus, by using these three distinct verbal roots the psalmist seems to emphasize three basic ideas. First, everything in the world is under the scrutiny and supervision of YHWH. Second, the notion of supervision may entail the idea of judgment, or, as Kraus puts it, "universal judgment."13 This may also be implied in vs. 5 where YHWH is referred to as One who "loves righteousness and justice." This seems to be corroborated by vs. 10 , which says that "YHWH nullifies the counsel of the nations; he frustrates the plans of the peoples." Third, the concept of help/salvation also seems to be implied, as suggested by vss. 18 and 19: "But the eyes of YHWH are on those who fear him, on those whose hope is in his unfailing love, to deliver their soul from death and to keep them alive in famine."

Summing up, the picture of "looking down" connotes the notion of supervision, judgment, and help/salvation exerted by YHWH from his heavenly "dwelling place" (i.e., the heavenly sanctuary).

\section{Heavenly Sanctuary/Temple Motif}

\section{Function}

As noted above, the locution ingergy? ("his dwelling place") points to the sanctuary/temple of YHWH located in heaven. The task now is to delineate the function

Thid.

${ }^{2}$ HALOT, s.v. "กมขอ."

${ }^{3}$ Kraus, Psalms 1-59, 378. 
of this heavenly temple. As the text says: "From heaven YHWH looks; he sees all the sons of men; from his dwelling place he gazes at all the inhabitants of the earth" (vss. 13-14). Since idea of YHWH looking down from his heavenly "dwelling place" indicates that the latter would functions as place of dwelling, supervision, judgment, and help/salvation. It is from his heavenly temple that YHWH examines and evaluates the affairs of humankind, and bestows help and salvation on those who seek him.

\section{Relationship to Earthly Counterpart}

The heavenly sanctuary temple seems to have been understood in structural

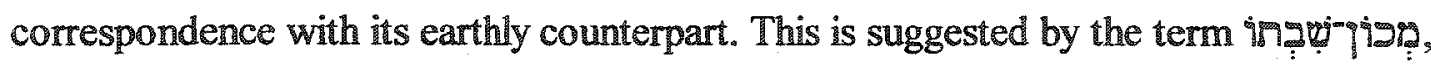

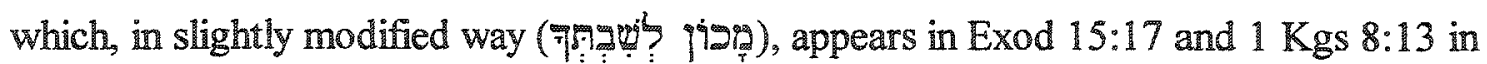
reference to the earthly temple. Additional some functional correspondence may also be inferred, inasmuch as the earthly temple may also function as a place of dwelling, supervision, and judgment.

\section{P\$ 61:1-14:12!}

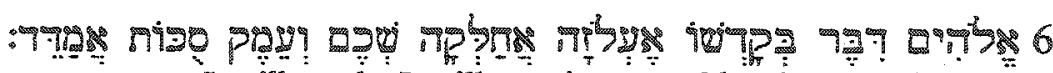
8 God has spoken in ${ }^{2}$ his sanctuary: I will exult, I will portion out Shechem and measure out the valley of Succoth.

\footnotetext{
${ }^{2}$ Par. Ps 108:8 [7].
}

"Dahood translates the preposition as "from" on the basis of context as well as Ugaritic parallels. Cf. Psalms II (51-100): Introduction, Translation, and Notes, AB 16 (Garden City, NY: Doubleday, 1968), 75, 79. Cf. also F. Charles Fensham, "Ugaritic and the Translation of the Old Testament, $"$ BT 18 (1967): 73-74. 


\section{Preliminary Observations}

Scholars have classified Ps 60 as lamentation, ${ }^{1}$ corporate prayer for help, ${ }^{2}$ or national complaint ${ }^{3}$ recited in a time of national crisis. ${ }^{4}$ The superscription ascribes this poem to David ${ }^{5}$ and relates it to the times of his wars against the Arameans ${ }^{6}$ and Edomites. ${ }^{7}$ Structurally the psalm divides itself into three sections: ${ }^{8} 3-7[1-5] ; 8-11$ [6-9]; 12-14 [10-12]. The word "ibs ("God") in the first line of each section provides a verbal marker for these divisions, which also tallies with the thematic divisions. In the first and

${ }^{1}$ Anderson, The Book of Psalms, 1:41; Frank-Lothar Hossfeld and Erich Zenger, Psalmen 51-100, HTKAT (Freiburg im Breisgau: Herder, 2000), 154; Graham S. Ogden, "Psalm 60: Its Rhetoric, Form, and Function," JSOT (1985): 83; Marvin E. Tate, Psalm 51-100, WBC 20 (Dallas: Word Books, 1990), 103.

${ }^{2}$ Mays, Psalms, 213.

${ }^{3}$ Schaefer, 146.

${ }^{4}$ It is not clear what specific crisis the poet has in mind. The context seems to imply a situation in which the nation had suffered a defeat at the hands of an enemy army. Cf. Anderson, The Book of Psalms, 1:441; Heinrich Gross and Heinz Reinelt, Das Buch der Psalmen: Teil I (Ps 1-72), 3rd ed., Geistliche Schriftlesung, Erläuterungen zum Alten Testament für die Geistliche Lesung 9 (Düsseldorf: Patmos Verlag, 1989), 322.

${ }^{5}$ Although the superscriptions of the Psalms have been considered inconclusive by most scholars (cf., e.g., Anderson, The Book of Psalms, 1:43-46; H. H. Rowley, Worship in Ancient Israel: Its Forms and Meaning [Philadelphia: Fortress, 1967], 205-12), Dahood expressed confidence that "the superscription, language and contenss permit a tentative dating in the Davidic period" (Psalms II, 76). Nonetheless, whatever opinion one may entertain about the actual date of composition of this psalm, it should be borne in mind that since the superscription is part of the final canonical form of the text, it should be taken into any interpretation that aims at understanding the composition in its final form.

${ }^{6}$ The wars of David against the Aramean kingdoms are describod in 2 Sam 8:3-8; 10:6-18; 1 Char 18:3-11; 19:6-19.

${ }^{7}$ See 2 Sam 8:13; 1 Chr 18:12.

${ }^{8} \mathrm{C}$. Tate, 103. 
third sections, which develop the same theme of the abandonment of the nation by God, ${ }^{1}$ the worshipers address the deity as "you" and identify themselves by means of the plural "us." Furthermore, the second section ends with a plea for salvation-"Save with your right hand, and answer us!" (vss. 7 [5])-which is then responded to in the central section. Here God addresses the people in the first person, assuring them of his relationship and reaffirming his lordship over Canaan, Edom, Moab, and Philistia (vss. 8-11 [6-9]).2

For the purpose of this study, it is important to note that the reference to God "in his sanctuary" (9ש? psalm as part of a formula introducing God's direct speech. Interestingly enough, when God utters his word of assurance in the midst of a crisis, he does so "in his sanctuary"

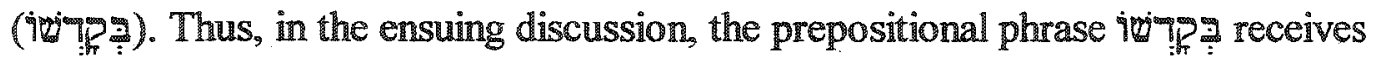
attention in order to ascertain the semantic connotation and referent of witp, followed by considerations on the function of the heavenly sanctuary and its relationship to the earthly counterpart.

\section{Semantic and Other Exegetical Considerations}

As already observed, this section attempts to ascertain the referent and connotation of the lexeme ogop in the phrase fremp. Some translations have rendered this phrase as an the text.

The term God is used here instead of YHWH because the former is the term employed in

${ }^{2}$ According to Kraus this central section, the "oracle of salvation," was conveyed by a priest or cultic prophet in the sanctuary (Psalms 60-150,4). (1989): 13

${ }^{3}$ Raymond J. Tournay, "Psaumes 57, 60 et 108: Analyse et Interprétation," RB 96 
abstract expression "in his holiness" while others have opted for a locative meaning "in the sanctuary."2 Among scholars who have opted for the latter, some entertain the possibility that ip refers to the earthly sanctuary/temple, ${ }^{3}$ while others favor the heavenly sanctuary. In view of these differences of opinion, it will be instructive to ascertain the semantic connotations and the referent of torj, before turning to the delineation of the function of heavenly sanctuary/temple and its relationship to the earthly counterpart.

Conceming the semantic connotations of 6 , it was pointed out above that this word can denote either the abstract concept of "holiness," or the locative idea of "sanctuary." The following arguments can be advanced in favor of a locative meaning. First, the syntactic similarity between 9007 ? sanctuary") in Ps 60:8 [6], and 979 9 9 of cloud") in Ps $99: 7$ contributes to clarify this issue. ${ }^{7}$ As can be observed, the prepositional phrase 99: 999 in PS $99: 7$ has a clear locative meaning. This illuminates the syntactically similar construction 9 irges in $60: 8$ [6], which most probably should also be understood as comoting a locative meaning. Second, it should be remembered that the

${ }^{1} \mathrm{C} . \mathrm{NASB}, \mathrm{KJV}, \mathrm{ESV}, \mathrm{JPS}, \mathrm{NKJV}$.

${ }^{2} \mathrm{Cf}$. NIV, RSV, NET, NRSV, TNK.

${ }^{3} \mathrm{Kraus}$, Psalms 60-150, 5; Toumay, 18; Briggs and Briggs, $2: 59$.

${ }^{4}$ Dahood, Psalms II, 79; Davidson, "The Heavenly Sanctuary in the Old Testament," 9-10.

${ }^{5}$ See chapter 3 of this dissertation.

6ahood translates as "from" as already noted (Psalms II, 75, 79).

${ }^{7}$ Tbid., 79. 
prepositional phrase tone connotes a locative sense in the majority or its occurrences. And the passage under study seems to follow this trend, since the locative connotation "in his sanctuary" seems to fit better in the context: As noted in the text (Ps 60:8 [6]), the prepositional phrase exp clearly refers to the locale whence God utters his word. ${ }^{2}$ Third, although the testimony of ancient versions does not represent the final word on exegetical

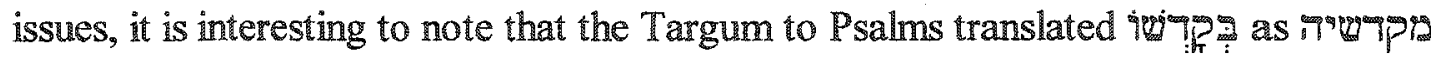
ת9 (lit. "in the house of his sanctuary"), ${ }^{3}$ thus corroborating the locative connotation of

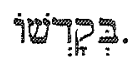

It must be noted, at this juncture, that the expression under study belongs to the central section of the psalm (8-10 [6-8]), which, as noted above, stands out from the text as an oracle in which YHWH addresses the people. As noted by Gerstenberger, the introductory expression " "God spoke") seems to be "an assertion of divine communication, a reference to well-known fact, almost like later reference to Scripture. If so, then it may be suggested that this well-known fact is the certainty that God/YHWH would intervene from "his sanctuary."

${ }^{1}$ See the discussion of Exod 15:11 in chapter 3 of this dissertation.

${ }^{2}$ On the basis of Amos 4:2 and Ps 89:36 [35] where God swears by his holiness, it has been suggested that in PS 60:8 [6] it means that God speaks in "his holiness" which is "equal to an oath 'by His holiness" (Franz Delitzsch, Biblical Commentary on the Psalms [Grand Rapids: Eerdmans, 1959], 2:198). Cf. Albert Barnes, Book of the Psalms (New York: Harper, 1868), 2:283. The problem with this view, as Richard M. Davidson pointed out, is that the text "uses $9 \mathrm{gm}$ and not specific words for swearing" ("The Heavenly Sanctuary in the Old Testament," 8).

${ }^{3}$ Miqrat of Gedolot, $10: 36$ (Ps 60:8 [6]).

${ }^{4}$ Gerstenberger, 240. 
As for the referent of wp in trif? it seems difficult to ascertain whether wion refers to the earthly or to the heavenly sanctuary. Nonetheless, a close examination of the text suggests that the kind of situation depicted in the text seems more appropriate to the heavenly sanctuary than to its earthly counterpart. The text reads:

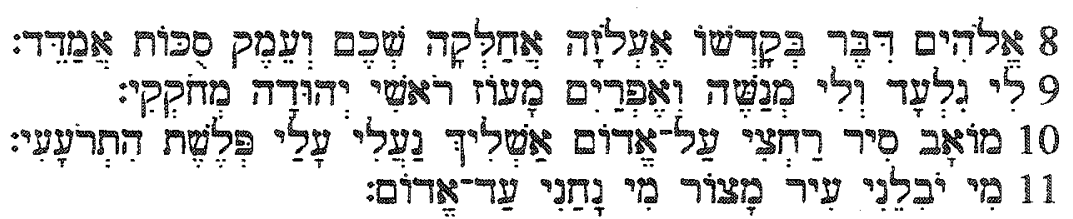

6 God has spoken in his sanctuary: "I will exult, I will portion out Shechem and measure out the valley of Succoth.

7 "Gilead is mine, and Manasseh is mine; Ephraim also is the helmet of my head; Judah is my scepter.

8 "Moab is my washbowl; over Edom I shall throw my shoe; shout loud, O Philistia, because of me!"

The passage speaks about subjugation of neighboring nations and partition of territory, and portrays the imagery of a gigantic God who considers Moab his "washbowl." This broad scope of activities and lofy picture of God seem more appropriate to a heavenly sanctuary context rather than a local earthly temple. Other passages of the Hebrew Bible when using such diction usually depict YHWH as located heaven. ${ }^{2}$ This view also seems to be corroborated by passages of the Hebrew Bible in which VHWH's response to the afflictions of his people is depicted as coming from the heavenly sanctuary/temple. ${ }^{3}$ Additionally, if one reads the psalm with the superscription in

\footnotetext{
${ }^{1}$ This may be an allusion to the Dead Sea according to Schaefer, 147.

${ }^{2} \mathrm{See}, \mathrm{e.g}$. Isa $6: 1 \mathrm{ff}$, and 63:1.

${ }^{3}$ Cf. Pss 11:4; 33:14.
} 
mind, thus placing it in the time of David when the Zion temple had not yet been built, the view that the text refers to the heavenly sanctuary may gain additional corroboration.

In addition to the above observations, further insights may be gained from the parallel passage of Ps $108 .{ }^{1}$ For the purposes of this research it suffices to note that Ps 108:7-14 [6-13] is a copy with very small alterations of Ps 60:7-14 [5-12]. Therefore it will be instructive to note what understanding of wp emerges from its placement in Ps 108.

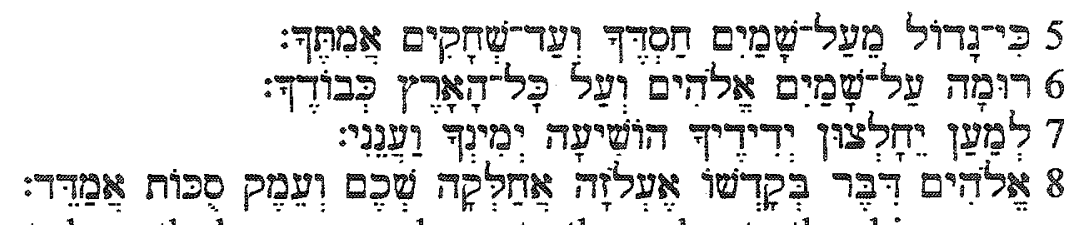

4 For your mercy is great above the heavens, and your truth reaches to the skies. $5 \mathrm{Be}$ exalted, $\mathrm{O}$ God, above the heavens, and your glory above all the earth. 6 That your beloved may be delivered, save with your right hand, and answer me! 7 God has spoken in his sanctuary: "I will exult, I will portion out Shechem and measure out the valley of Succoth.

As noted, vss. 5-7 [4-6] contain several expressions of exaltation in a heavenly context. As Davidson pointed out, "The psalmist longs for God to be exalted in a heavenly context, that he may answer his cry (v. 6), and in this progression, God answers 'from his sanctuary, indicating that he is indeed exalted, and the psalmist can be confident of deliverance." It thus seems reasonable to suppose that when the text says that "God has spoken in his sanctuary," it is the heavenly sanctuary that is in view. That being the case, the parallel occurrence of the text under study in Ps 108 corroborates the view that vip refers to the heavenly sanctuary.

${ }^{1}$ Ps 108 is a copy of Pss 57:8-11 [1-5] and 60:7-14 [5-12].

"Davidson, "The Heavenly Sanctuary in the Old Testament," 9. 


\section{Finction}

Granting the plausibility of the above suggestion that the term wig refers to the heavenly sanctuary, one needs to inquire about the function of the heavenly sanctuary. It is important to note that it is "in his [heavenly] sanctuary" that God issues the word of assurance for his people. This places the heavenly sanctuary in a salient position in the context of the passage, since it is portrayed as the locus whence divine help is bestowed. In other words, the heavenly sanctuary/temple functions as the place where God takes decisions in response to prayers, in other words, the heavenly sanctuary is the headquarters or command center from where YHWH governs the earth.

\section{Relationship to Earthly Counterpart}

Although Ps 60 does not provide a clear reference or allusion to earthlytemple/sanctuary imagery, the parallel passage of PS 108 may provide some hint of a vertical relationship. In Ps 108:12 [11), the reference to God not marching with the armies of Israel may well point to an earthly context, since $\mathrm{in}_{\mathrm{i}}$ evokes the imagery of the ark accompanying the Israelite army to battle. If such is the case, it may be suggested that the parallel text of PS 108:12 [11] might imply some vertical correspondence between the heavenly sanctuary and its earthy counterpart as represented by the ark of the covenant. ${ }^{2}$

\footnotetext{
'This situation fits the period of David, before the ark found its permanent resting place in Solomon's temple.

2Davidson, "The Heavenly Sanctuary in the Old Testament," 9.
} 


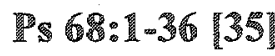

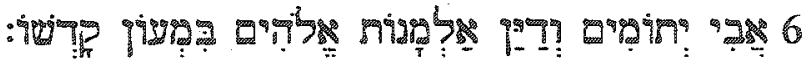
$5 \mathrm{~A}$ father of the fatherless and a judge for the widows, is God in his holy habitation. : $350 \mathrm{God}$, you are awesome from your sanctuary. The God of Israel himself gives strength and power to the people. Blessed be God!

\section{Preliminary Observations}

Ps 68 is comprised of a mix of various styles such as hymn, prayer, and summons to praise God. ${ }^{1}$ Containing a disproportionate amount of rare expressions and syntactic constructions, ${ }^{2}$ this psalm has been regarded as one of the most difficult passages of the Psalter. ${ }^{3}$ Another difficulty lies in the alleged lack of a thread holding together the composition as a whole. In the face of these problems, Kraus asserted that "there is hardly another song in the psalter which in its corrupt text and its lack of coherence precipitates Such serious problems for the interpreter as Psalm 68." advanced. Albright suggested that one should see Ps 68 as a list of opening lines of early Hebrew poems. ${ }^{6}$ Other scholars have hypothesized that the composition reflects a long

${ }^{1} \mathrm{Cf}$. Schaefer, 163.

${ }^{2}$ Hossfeld and Zenger, Psalmen 51-100, 246.

${ }^{3} \mathrm{Cf}$. Robert, The Vitality of Worship, 210.

4Tid.

5Kraus, Psalms 60-150, 47

${ }^{6} \mathrm{C}$. W. F. Albright, "A Catalogue of Early Hebrew Poems-PS 68," Hebrew Union College Annual 23, no. 1 (1950-51): 1-39; W. F. Albright, "Notes on Psalm 68 and 134," in Interpretationes ad Vetus Testamentum Pertinentes Sigmundo Mowinckel Septuagenario Missae (Oslo: Land og kirke, 1955), 1-12. 
process of growth in which it was supplemented by the addition of new material in order to attune it from the alleged previous setting of a northern sanctuary, probably on Mount Tabor, to the Jerusalem tradition." However, in spite of these negative assessments, some scholars have argued for the coherence of the pericope as it now stands in the Psalter. ${ }^{2}$ Schaefer, for example, discemed the following structure which, with slight modifications, is adopted in the ensuing discussion.

$\mathrm{X}$. Introduction (1-4 [1-3])

A. Hymnic invocation (vss. 5-7 [4-6])

B. From Sinai to Zion (vss. 8-19 [7-18])

C. Acclamation and Oracle (vss. 20-24 [19-23])

B' Procession toward the temple (25-32 [24-31])

$A^{\prime}$ Hymnic invocation-conclusion (vss. $\left.33-36[32-35]\right]^{3}$

${ }^{1} \mathrm{C}$. Jörg Jeremias, Das Königtum Gottes in den Psalmen: Israels Begegnung mit dem kanaanäischen Mythos in den Jahwe-König-Psalmen, Forschungen zur Religion und Literatur des Alten und Neuen Testaments 141 (Göttingen: Vandenhoeck und Ruprecht, 1987), 80; Othmar Keel and Urs Winter, Vögel als Boten: Studien zu Ps 68, 12-14, Gen 8, 6-12, Koh 10, 20 und dem Aussenden von Botenvögeln in Ägypten (Freiburg: Universitätsverlag, 1977), 17-23; Kraus, Psalms 60-150, 50-51; Sigmund Mowinckel, Der achtundsechzigste Psalm (Oslo: I kommisjon hos J.Dybwad, 1953), 44; Weiser, 489.

${ }^{2}$ Girard, for example, makes a strong case for the "perfect and impressive coherence of the psalm in its entirety" (Marc Girard, Les Psaumes: Analyse Structurelle et Interpretation: 51-100 [Montreal: Bellarmin, 1984], 229). He divides the text into two major sections: vss. 1-24 [1-23] and vss. 25-36 [24-35], which are further subdivided into "mini structures" (ibid, 221f.). Hossfeld and Zenger have identified nine strophes: vss. 2-4 [1-3]; 5-7 [4-6]; 8-11 [7-10]; 12-15 [11-14]; $16-$ 19 [15-18]; 20-24 [19-23]; 25-28 [24-27]; 29-32 [28-31]; 33-36 [32-35] (Psalmen 51-100, 68). Terrien suggested ten concentric strophes with an extra "core strophe" in vss. 17-19 [16-18] (The Psalms, 485-97). And Fokkelman divided the text into three sections (1-11; 12-24; 25-36) subdivided into eight stanzas and sixteen strophes (J. P. Fokkelman, "The Structure of Psalm 68," in In Quest of the Past: Sudies on Israelite Religion, Literature and Prophetism: Papers Read at the Joint British-Dutch Old Testament Conference, Held at Elspeet, 1988, ed. A.S. van der Woude [Leiden: E J Brill, 1990], 72-83). Despite the disagreements, there scems to be some consensus that the opening and closing sections correspond. Furthermore, vs. 24 [23] functions as a major divider in the flow of the composition.

${ }^{3}$ Schaefer, 163. 
This structure reveals that explicit references and allusions to the sanctuary/temple occur in $A$ (vs.6 [5]) and $A^{\prime}\left[v s .36[35]\right.$, and also in $B$ (vss. 17, 18, 19 [16, 17, 18]) and $B^{\prime}$ (vs. $25,30[24,29])$. The sanctuary/temple idea thus seems to function as an element of cohesion across the various sections. ${ }^{1}$

In view of the prominent presence of the temple idea in PS 68 , the following discussion attempts to ascertain whether the heavenly sanctuary/temple motif can be deduced from this text. In order to accomplish this, an examination of the several occurrences of the temple/sanctuary concept in this text will be undertaken. Finally a delineation of the function of the heavenly temple as well as its relationship to the earthly counterpart will be provided.

\section{Semantic and Other Exegetical Considerations}

References and allusions to the temple/sanctuary motif pervade the text, as can be

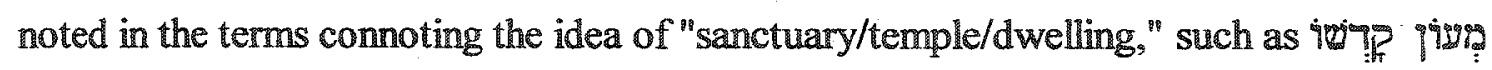

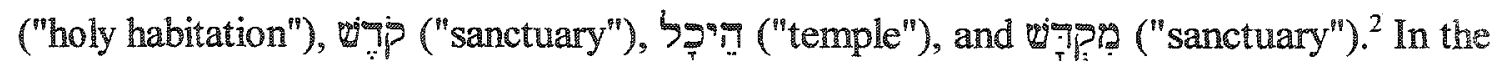
following discussion, attention is devoted to these terms in order to accomplish the purpose expressed above of ascertaining the function of the heavenly sanctuary/temple and its relationship to the earthly counterpart.

${ }^{1}$ The repeated mention of the sanctuary/temple motif in this psalm, especially the reference to the Jerusalem temple (vss. 17, 30 [16, 29], the choral singers and the players of stringed music (vs. 26f. [25f.]), the repetitive prayer style, and the call to the community to sing praises to YHWH have led Weiser to suggest that "the psalm presupposes a communal act of worship in the course of which it was recited" (482).

"Note also other terms such as "9I ("mountain") and aiา? ("height"). 


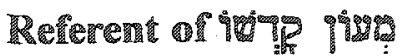

Although the expression in vs. 6 [5] is clear enough, scholars are divided as to its

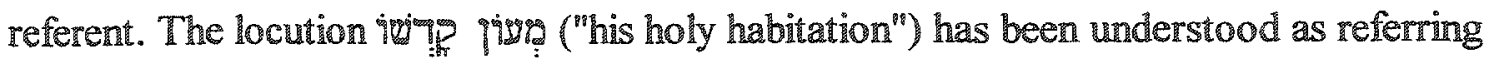
to the heavenly sanctuary, ${ }^{1}$ to the earthly sanctuary, ${ }^{2}$ to both heavenly and earthly sanctuaries, ${ }^{3}$ or to an unspecified referent.

A contextual examination of the locution 9wong (") the impression that it refers to the heavenly temple. The following arguments support this view: First, the expression ivigg giget pertains to the hymnic invocation (vss. 5-7 [4-6]), which addresses YHWH/God as the giv ㄱำ 290 ("rider upon the clouds"). Since the

'Anderson, The Book of Psalms, 1:485; Friedrich Baethgen, Die Psalmen, 2nd ed. (Göttingen: Vandenhoeck and Ruprecht, 1897), 199; Briggs and Briggs, 2:97; A. Cohen, The Psalms: Hebrew Text, English Translation and Commentary (Hindhead, Surrey: Soncino, 1945), 210; Hermann Hupfeld and Wilhelm Nowack, Die Psalmen, 3rd ed. (Gotha: F.A. Perthes, 1888), 145; Tate, 176. Kirkpatrick also agrees that the passage depicts a heavenly setting; however, he understands "his holy habitation" as connoting "not the temple [i.e., the earthly temple] but heaven" (A. F. Kirkpatrick, The Book of Psalms [Cambridge, England: The University Press, 1939], 381).

${ }^{2}$ Ash and Miller, 224; André Caquot, "Le Psaume 68," RHR 177 (1970): 153; Solomon B. Freehof, The Book of Psalms, A Commentary, The Jewish Commentary for Bible Readers (Cincinnati: Union of American Hebrew Congregations, 1938), 181; Mowinckel, 28-29.

3J. W. Rogerson and J. W. McKay, Psalms 51-100 (Cambridge: Cambridge University Press, 1977), 86.

${ }^{4}$ Anderson, The Book of Psalms, 1:485; Hossfeld and Zenger, Psalmen 51-100, 252.

"Despite some scholars' understanding of the phrase migny 297 as "rider on the steppe" (so, e.g., Hossfeld and Zenger, Psclmen 51-100, 242), one should note that nowhere else in the Hebrew Bible is the lexeme gag associated with "steppe" or "wilderness." Rather, as can be deduced from the functional equivalent vs. 34 [33], this expression most probably means "rider on the clouds." This is further corroborated by other references in the Hebrew Bible which portray YHWH/God as riding on a "cherub" (2 Sam 22:11, par. PS 18:11 [10]), or "cloud" (Isa 19:1). In addition, the occurrence of the expression $r k b$ ' $r p t$ (KTU 1.2 IV 8) in Ugaritic indicates that "rider of the clouds" was an epithet used for Baal. This being so, it should come as no surprise that the psalmist employed a stock ANE expression to manifest fear and reverence for the One true God YHWH. 


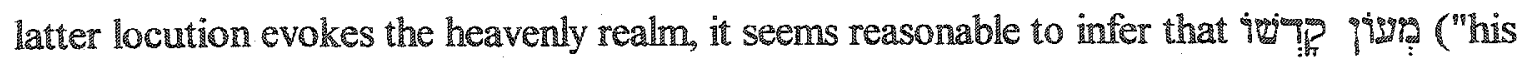
holy habitation") refers to the heavenly temple/sanctuary. ${ }^{3}$ Second, it should also be noted that this expression always refers to the heavenly sanctuary in its other four occurrences in the Hebrew Bible. ${ }^{2}$ Third, this seems further corroborated by the fact that the heavenly sanctuary/temple motif recurs in the final section of the poem where again God is depicted

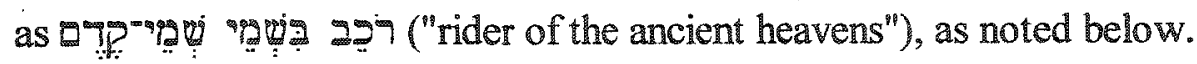

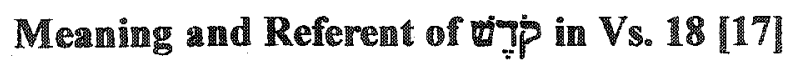

The lexeme exp in Ps 68:18 [17] deserves attention at this point. For the purpose of this research, it is instructive to determine whether vop means "holiness" or "sanctuary/holy place." If the latter proves to be the case, further inspection will be done in order to ascertain whether wip refers to the heavenly or earthly temple. The text reads as follows:

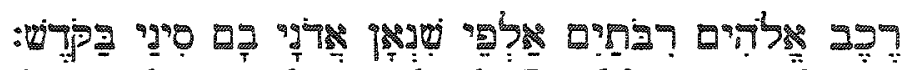
The chariots of God are myriads, thousands upon thousands; the Lord is among them [as at] Sinai, in holiness/the sanctuary.

Note that although $B D B$ renders niz HALOT notices that this lexeme can be related to the Ugaritic lexeme "Fpt meaning "clouds" (s.v. "II Taר:" (cf. Dahood, Psalms II, 136). As for the Hebrew $p$ instead of the Ugaritic $b$, it should be noted that it is a mere nonphonemic mutation of consonants (since these two letters are labials, they can easily interchange). Cf. Anderson, The Book of Psalms, 1:484.

"The following scholars favor a heavenly setting for iwi? pixp ("his holy habitation"): Anderson, The Book of Psalms, 1:485; Briggs and Briggs, 2:97; Tate, 176.

${ }^{2}$ Deut $26: 15 ;$ Jer $25: 30 ;$ Zech $2: 17 ; 2 \mathrm{Ch} 30: 27$. These passages are discussed elsewhere in this dissertation.

${ }^{3}$ So NASB, JPS, TNK.

${ }^{4}$ So ASV, KJV, NAB, NBB, NKJV, NRSV, RSV. Cf. Hossfeld, 245. 
Several readings and emendations have been proposed for this difficult verse; however, no compelling manuscript evidence has been produced against the text as it stands. So the ensuing discussion assumes the reliability of the MT and attempts to interpret it as such. Starting with the semantic contours of wigp, a locative meaning "sanctuary" seems more appropriate in view of the context, namely vss. 17-19 [16-18]. In these latter verses one finds the lexemes 9200\%, gev9, and s979, which evoke sanctuary/temple imagery. Thus, in a context where YHWH is extolled for choosing Mount Zion to establish his dwelling thereon, it is fitting that wip connotes "sanctuary."

As for the referent of wion, a more complex picture emerges. Although the mention of the mountain that "God chose" in vs. $17 \mathrm{~b}[16 \mathrm{~b}]$ favors an earthly referent (i.e., Mount Zion), the affirmation that "the chariots of God are myriads, thousands upon thousands ${ }^{n 2}$ in vs. $18 \mathrm{a}$ [17a] conveys an imagery more appropriate for the heavenly realm. This ambivalence may also affect the understanding of the clause 4 iา ascended on high") in vs. 19 [18]. Although at first glance one gets the impression that this clause must refer to Mount Zion-the place where YHWH is eventually

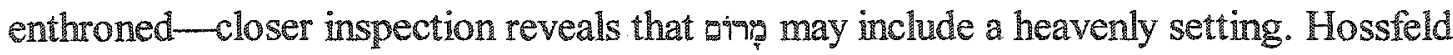
and Zenger have referred to gings as "den hohen, emporragenden Ort, an dem Himmel und Erde ineinander ubergehen, ${ }^{33}$ while Kraus has conjectured that behind vs. 17f. [16f.] lies a

\footnotetext{
"Terrien considers vss. 17-19 the "core strophe" of Ps 68 with its "focus on the holy place" (The Psalms, 486, 494).

${ }^{2}$ See, e.g., Ezek 1:1; PS 18:10-14; Dan 7:9-14.

${ }^{3}$ The German reads: "The high and lofty place where heaven and earth merge" (Hossfeld and Zenger, Psalmen 51-100, 253).
} 
"mythological fragment which told of a heavenly rebellion." Although such statements may be speculative, they do reflect the awareness that the temple imagery conveyed by the text goes beyond the earthly temple to encompass its heavenly counterpart. Thus, instead of postulating a "merging" of heaven and earth, or suggesting that behind the text lies a "mythological fragment of a heavenly rebellion," it seems more plausible to speak of a dynamic interaction between the earthly temple and its heavenly counterpart. ${ }^{2}$

\section{Referent of wiT in vS. 25 [24]}

The term op in vs. 25 [24] refers to the earthly temple, as indicated by vss. 25-26 [24-25]:

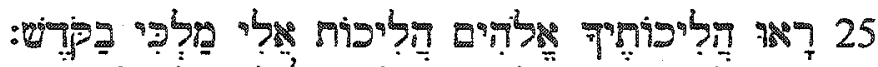

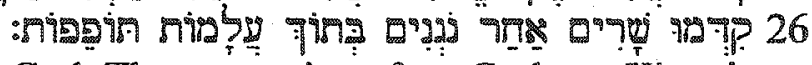

24 They have seen your procession, 0 God, The procession of my God, my King, into the sanctuary.

25 The singers went first, the musicians after them, in the midst of the maidens beating tambourines.

The mention of the "procession" into the sanctuary seems to clearly evoke the service of the earthly temple. Furthermore, the reference to "musicians" and "maidens" beating tambourines certainly connotes a Jerusalem-temple setting.

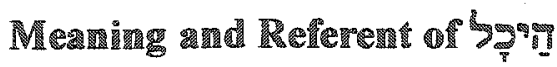

The term $Y$ T. in vs. 30 [29] seems at first glance to refer to the Jerusalem temple, since the immediate context talks about the kings of the earth bringing gits to God (vs.

${ }^{1}$ Kraus, Psalms 60-150,54.

${ }^{2}$ According to Terrien, vss. 17-19 are the "core strophe" with a focus on the holy place (The Psalms, 486, 494). 
30b). However, upon close examination, the entire syntagma an ambivalence that calls for further inspection. The preposition beverning gove connote that the temple stands either "at or by Jerusalem" or "above Jerusalem." For a temple located "in Jerusalem," one would expect the preposition sa, not לפg, as attested elsewhere in the Hebrew Bible." The use of לyg in the sense of "located in" Jerusalem appears to be unique to Ps 68:30 [29]. The impression then arises that the preposition לy in the present text may convey an ambivalent meaning "in/above." In addition, it must be noted that the gifts are brought not "to the temple," but "because of the temple."2 If the Jerusalem temple were the only referent in view, one would expect it to be the destination of the gifts. This is not the case, however, since the temple is clearly portrayed as the cause that motivates or impels the kings to bring gifts to God. The concept behind the expression seems to be that the kings of the earth would bring gifts to God (i.e., to the earthly temple), because of the temple above Jerusalem (i.e. the temple that granted legitimacy to the earthly temple).

The possibility that the expression "above Jerusalem" seems to be tacitly recognized by Tate as he asserts that this text reflects a "synergistic merger of thought in which there is no absolute difference between the two [i.e. heavenly and earthly temples]. Although to speak of a "synergistic merger"

${ }^{1}$ See 1 Kgs $2: 36 ; 12: 27 ; 2 \operatorname{Kgs} 23: 9 ; 1$ Chr $5: 36 ; 6: 17 ; 2$ Chr $1: 4 ; 3: 1 ; 28: 27 ; 30: 1,14 ;$ $33: 15 ; 36: 23$; Ezra $1: 2,5 ; 2: 68 ; 7: 27$.

${ }^{2}$ Note causal meaning of the preposition 99 in 7 spons. Cf. Williams, Hebrew Syntax, 54. ${ }^{3}$ Tate, 183. 
may be somewhat exaggerated, it seems reasonable to suppose that this ambivalent language may indicates a dynamic interaction between the earthly temple and its earthly

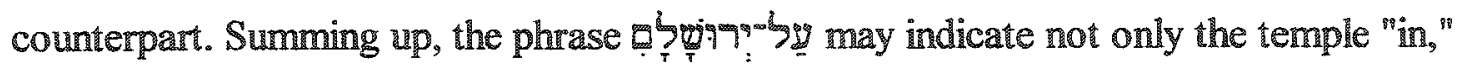
but also the temple "above" Jerusalem" in dynamic interaction.

\section{Referent of}

As for ${ }_{T} T p$ ? ("sanctuary") in vs. 36 [35], some scholars favor a heavenly referent, ${ }^{2}$ while others contend for an earthly referent, that is, the Jerusalem temple. ${ }^{3}$ In view of this situation, a reassessment of the referent of to examine vs. 36 [35] in its immediate context (vss. 33-36 [32-35]).

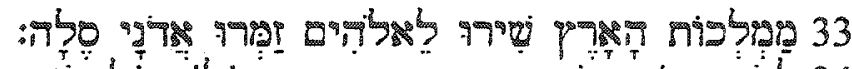

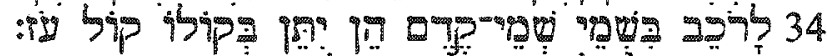
: : 32 Sing to God, O kingdoms of the earth, sing praises to God, Selah

33 To him who rides upon the ancient heavens, behold, he speaks forth with his voice, a mighty voice.

34 Ascribe strength to God; his majesty is over Israel and his strength is in the skies. $350 \mathrm{God}$, you are awesome from your sanctuary. The God of Israel himself gives strength and power to the people. Blessed be God!

Interestingly, the similar expression bagn ("above Israel") occurs in parallel with arprigig ("in the skies") in vs. $35 \mathrm{bc}$ [34bc]. See the discussion of this verse below.

${ }^{2}$ E.g., Dahood, Psalms 11, 152; Richard M. Davidson, "The Heavenly Sanctuary in the Old Testament," 11-12; Metzger, 140.

3E.g., Anderson, The Book of Psalms, 1:499; Louis Jacquet, Les psaumes et le coeur de Ihomme: Eude textuelle, littéraipe et doctrinale: Psaumes 42 à 100 (Gembloux, Belgium: Duculot, 1977), 367; Kim, 157-59; John Philip LePeau, "Psalm 68: An Exegetical and Theological Study" (Ph.D. diss., University of lowa, 1981), 230. 
This entire unit consists of a hymnic invocation closing the poem. ${ }^{1}$ The presence of heavenly imagery in this unit is relevant for ascertaining the referent of wiplpa ("sanctuary") in vs. 36 [35]. Here, God (avibs) is portrayed as the one who "rides upon the ancient heavens" (vS. 34 [33]), and whose "strength is in the skies" (vs. 35c [34c]). This heavenly imagery strengthens the probability that $v_{7 p ?}$ refers to the heavenly sanctuary. In fact, the

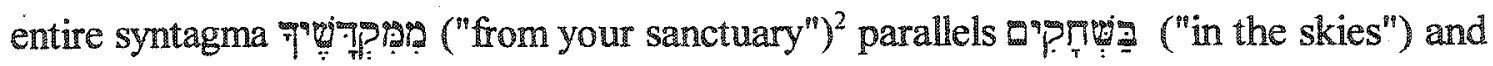
לูר it seems reasonable to suggest that the sanctuary referred to in vs. 36 [35] is the heavenly one. ${ }^{4}$ Additional corroboration comes from the fact that the other hymnic invocation of

${ }^{1}$ This corresponds to $\mathrm{A}^{\prime}$ in the structure displayed above. In the following chart the correspondences between vss. 5-6 [4-5] and 33-36 [32-35] are summarized by Kim:

Vss 5-6 in the prologue

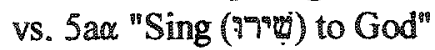
vs. 5 aß "Sing praises (979: to his name" vs. $5 b$ "to him who rides (2হ̄7? vs. $6 \mathrm{~b}$ "God in holy habitation"
Vss. 33-36 in the Epilogue

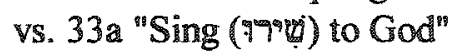
vs. $33 \mathrm{~b}$ "Sing praises (7)ge? ) to the Lord" vs. 34 a "to him who rides (999?) in the heavens" vs. $36 \mathrm{a}$ "God in his sanctuary" (158).

${ }^{2}$ The form tresper is translated in the singular (and with $3 \mathrm{~ms}$ suffix) by most scholars. The plural form most probably is a plural of amplification, as noted by Anderson (The Book of Psalms, 1:499) following GK 124e. Dahood has also contended for a plural meaning "on the ground that names for fortifications, like names for dwellings, are sometimes plural in form, though singular in meaning" (Psalms I, 128.) Cf. also idem, Psalms II, 152. Along these lines, Davidson has put forth the plausible suggestion that "possibly what is in view here is the plurality of the heavenly sanctuary (Holy Place and Most Holy Place) as in the earthly type" ("The Heavenly Sanctuary in the Old Testament, 11 ).

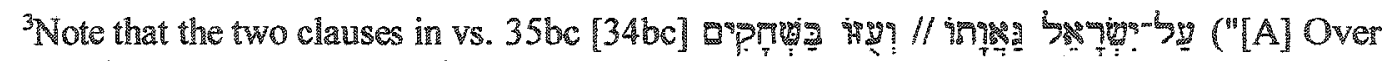
Israel is $[B]$ his majesty $\left./ / B^{\prime}\right]$ and his strength is $\left[A^{\prime}\right]$ in the skies") are organized in an inverted parallelism. Thus, it seems clear that $\mathrm{A}$ and $\mathrm{A}$ ' parallel each other in expressing a locative idea.

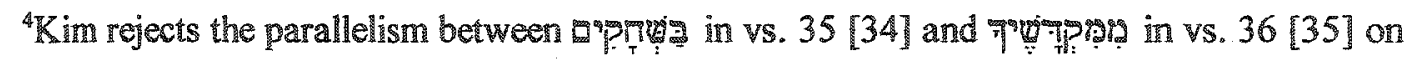
the grounds that the word "sanctuary" contains a pronominal suffix in the second person. This, he argues, makes vs. 36 [35] a petition, not a description. Therefore each phrase belongs to different "poetic sense units and so are not to be paired" (Kim, 156). Regarding Kim's position, two criticisms are in order. First, the disjunction between vss. 35 [34] and 36 [35] seems rather farfetched, since fluctuations of grammatical person in pronominal suffixes and verbs are a natural 
wss. 5-7 [4-6] - which correspond to vss. 33-36 [32-35] in the structure of the psalm - also contains heavenly imagery and an explicit reference to the heavenly temple. ${ }^{2}$

\section{Heavenly Sanctuary/Temple Motif}

Having determined the presence of the heavenly sanctuary/temple motif in Ps 68 , the task now is to delineate the function of the heavenly sanctuary/temple and its relationship to the earthly counterpart.

\section{Functio眐}

Kim in his brief treatment of vs. 6 [5] -his main concern was vs. 36 [35]-refers

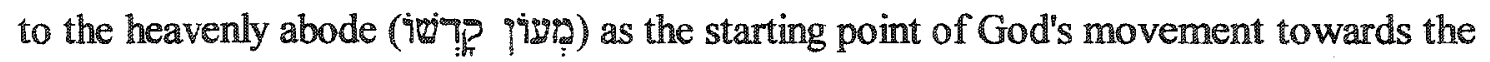
Jerusalem temple. ${ }^{3}$ Nonetheless it must be noted that "iemp also emerges as the place where God undertakes activities of judgment in favor of the weak and dispossessed. Thus the main point of vs. 6 [5] is not that God departs from the heavenly sanctuary, but that he acts as "a judge (99:9) for the widows in his holy

feature of Hebrew literature and do not necessarily mark transitions of theme, topic, or "poetic sense unit" (cf., e.g., the switch from second to third person in vss. 8 and 9). Second, the argument that the second person pronominal suffix turns vs. 36 [35] into a petition cannot be sustained upon closer examination of the text, since the latter contains no jussive or imperative verbal forms, which would be expected in a petition. Rather, there are only participial forms which continue and conclude the hymnic invocation commenced at vs. 33 [32].

${ }^{1}$ See the structural arrangement of Ps 68 and the discussion of 9 wing gives ("his holy habitation") in vs. 6 [5] undertaken above.

${ }^{2} \mathrm{Kim}$, although accepting the parallel between sections 5-6 [4-5] and 33-36 [32-35], denies that the "holy habitation" mentioned in vs. 6 [5] and the "sanctuary" referred to in vs. 36 [35] are the same place, on the grounds that "the former refers to the starting point of God's coming, whereas the latter designates his destination.

${ }^{3} \mathrm{Cf} . \mathrm{Kim}, 158$. 


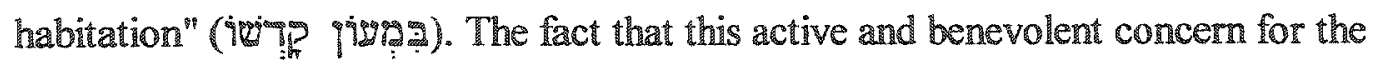
"widows" and dispossessed is ascribed to "God in his holy habitation" (vs. 6 [5]) reveals that the heavenly sanctuary plays a significant role as the locus of God's judicial and saving activities. In like manner, vs. 36 [35] also reveals that the heavenly sanctuary functions as the place of divine activities inasmuch as God "gives strength and power to the people" from his "sanctuary."

Summing up, the heavenly sanctuary/temple as portrayed in Ps 68 functions as the place wherein God performs activities of judgment that result in salvation and protection for, and bestowal of power upon, his people.

\section{Relationship to Earthly Counterpart}

The investigation conducted above has revealed a vertical correspondence between the heavenly sanctuary/temple and its earthly counterpart. Two major indicators of this relationship may be mentioned. First, it was noted that the perspective on the sanctuary/temple shifts from the heavenly sanctuary in vs. 6 [5] to its earthly counterpart in vss. 18 [17], 25 [24], 30 [29], and again to the heavenly sanctuary at the end of the psalm in vs. 36 [35]. The implication may be drawn that both the heavenly sanctuary/temple and its earthly counterpart function in dynamic interaction. This is reinforced by ambivalent grammatical constructions and imagery. The description of God's chariots in vs. 18 [17] seems to be contextually related to the earthly temple, but at the same time, this imagery seems to evoke a heavenly setting, as noted. The reader is left with the impression that both heavenly and earthly temples/sanctuaries work in close 
connection and what happens in one affects the other. Likewise, the reference to the temple "in/above" Jerusalem in vs. 30 [29], though pointing primarily to the earthly temple, may also evoke the temple above Jerusalem (i.e. the heavenly temple). This being the case, the expression "because of your temple 'above' Jerusalem" (vs. 30 [29]) might imply that the temple "above Jerusalem" (i.e., the heavenly temple) would provide legitimacy to its earthly counterpart. Thus the fluctuation of temple imagery between heavenly and earthly temple/sanctuary imagery and by employing ambivalent language, Ps 68 seems to indicate that the heavenly sanctuary and its earthly counterpart would function in dynamic interaction.

It is also to be noted that this vertical correspondence seems to indicate structural and functional correlations. Terms such as FשุT designate the earthly sanctuary/temple, seem to point to the heavenly sanctuary/temple as place in heaven, rather than a mere metaphor for YHWH's presence, and suggest a structural correspondence between the earthly sanctuary/hemple and its earthly counterpart. The text also suggests a functional correspondence, inasmuch as the judgment performed by YHWH in the heavenly temple corresponds to the same function in the earthly counterpart.

\section{P\$ $96: 1-13$}

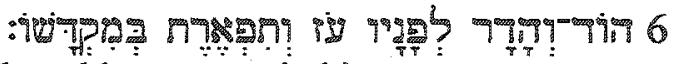
6 Splendor and majesty are before him, strength and beauty are in his sanctuary. 


\section{Preliminary Observations}

In a slightly modified form this psalm appears in $1 \mathrm{Chr} 16$, a composite hymn sung by the choir in connection with the bringing of the Ark of the Covenant to Jerusalem. On the basis of language and content Ps 96 may be categorized as a hymn celebrating the kingship of YHWH.' The composition divides itself into four sections: (1) Vss. 1-3 contain a summons to praise and lead into (2) the hymnic celebration of the greatness of

\footnotetext{
${ }^{1}$ Mowinckel included this psalm among the so-called "psalms of the enthronement of Yahweh," i.e., Pss 47;81, 93;95, 96;97;98; 99, which were allegedly recited at the time of a hypothetical New Year's festival (Sigmund Mowinckel, The Psalms in Israel's Worship, trans. D. R. Ap-Thomas [Sheffield: JSOT Press, 1992], 106). According to this hypothesis the Israelites, like their ANE neighbors, carried out an enthronement ceremony in which YHWH was again proclaimed as king over the world. Mowinckel's idea has faced many criticisms, the most devastating of which is that there is no mention of such a festival in the calendar of feasts in the Pentateuch (Kidner, Psalms 1-72, 8ff.), or in other parts of the Hebrew Bible (cf. Kraus, Psalms 159, 86-9; Roland de Vaux, Ancient Israel [New York: McGraw-HIIl, 1965], 502-06). As B. Anderson and S. Bishop have observed, "it is exceedingly doubtful whether the Israelite faith, even in the cosmopolitan atmosphere of Jerusalem, adopted wholesale the ancient mythical views. The notion that Yahweh is involved in the cycles of the cosmos and must fight to win kingship anew at the turn of the year is completely alien to Israel's faith" (Bernard W. Anderson and Steven Bishop, Out of the Depths: The Psalms Speak for Us Today, 3rd rev. and expand ed. (Louisville, KY: Westminster; John Knox, 2000), 158).

To circumvent these objections, other hypotheses have been formulated to explain the setting and origin of these psalms. Weiser has suggested cultic situations in which a renewal of the Sinai covenant was celebrated $(29,35-52)$, and Kraus advanced the idea of an annual covenant festival to celebrate the election of Zion and David (Psalms 60-150,86-89). However, this alternative view also faces objection, inasmuch as the Hebrew Bible does not seem to contain any description of an annual covenant-renewal festival. Although it is highly probable that these were hymnic compositions used in connection with the worship at the temple, it must be admitted that a precise determination of their Sitz im Leben remains elusive.

The possibility also exists that the so-called "enthronement psalms" may contain an eschatological outlook referring to a future time when YHWH will establish his universal sovereignty upon the earth. Cf. Davidson, The Vitality of Worszip, 319; J. H. Eaton, "The Psalms and Israelite Worship," in Tradition and Interpretation, ed. George W. Anderson (Oxford: Clarendon; New York: Oxford University Press, 1979), 243; Hermann Gunkel, Die Psalmen, 5th ed. (Göttingen: Vandenhoeck and Ruprecht, 1968), 421; David C. Mitchell, The Message of the Psalter: An Eschatological Programme in the Books of Psalms, ISOTSup 252 (Sheffield: Sheffield Academic, 1997), 288.
} 
YHWH in vss. 4-6; and (3) the summons in vss. $7-10^{1}$ leads into (4) the hymmic celebration in vss. 11-13. Each of these divisions is marked by specific linguistic features. For example, all the clauses of section 1 (vss. 1-3) commence with imperative verbs. Section 2 (vss. $4-6$ ) is formed almost exclusively by nominal clauses extolling the greatness of YHWH. Section 3 again contains mainly imperative verbs; and section 4 (vss. 10-13) contains mainly jussive verbs exhorting the created order to celebrate the kingship of YHWH.

\section{Semantic and Other Exegetical Considerations}

This section deals with the referent of wip? (vs. 6) and the phrase vigh-n?71? (vs. 9) in order to ascertain the presence of the heavenly sanctuary/temple and its relationship to its earthly counterpart.

\section{Referent of TP:}

The term wpes ("sanctuary") in the phrase 9w"7p? ("in his sanctuary") needs attention at this point. Although most scholars regard it as a reference to the Temple in

${ }^{1}$ Contrary to Robert Davidson, who considers vs. 10 as commencing the next section (The Vitality of Worship, 318). My reasons are the following: First, vs. 10 linguistically parallels the previous verses, since it starts with an imperative. Second, thematically, vs. 10 fits better as a continuation of the previous verses in which animate beings, i.e., peoples and nations, are summoned to worship YHWH. Third, it should be noted that vs. 11 starts a series of several clauses beginning with jussives, being therefore linguistically distinct from the previous section. Fourth, vs. 11 begins a series of injunctions to the elements of nature, i.e., the heavens, the earth, and the sea, to rejoice before YHWH. 
Jerusalem, ${ }^{1}$ a close examination of the context seems to indicate otherwise. In fact, some scholars have admitted that the wp? ("sanctuary") may refer to the heavenly sanctuary. ${ }^{2}$

A perusal of the context of the passage reveals that the previous verses depict cosmic imagery. ${ }^{3}$ YHWH is presented as creator of the heavens in contrast with the

${ }^{1}$ Cf., e.g., Hossfeld and Zenger, Psalmen 51-100, 669; Weiser, 629.

${ }^{2}$ E.g., Davidson has presented some cogent arguments in favor of a heavenly referent for T? ("sanctuary") in our passage ("The Heavenly Sanctuary in the Old Testament"). Anderson conjectured that 0 TP may designate either "God's heavenly dwelling or the restored temple," or "the reference may be simply to the temple in general" (The Book of Psalms, 2:683). Kissane also suggests a heavenly referent. However, he defines sanctuary as "heavens where he [YHWH] reigns as king over all the whole world" (The Book of Psalms, 446). Rogerson and McKay also seem to allow for a heavenly referent, as can be perceived in his comment on vs 6: "The probable meaning is that Majesty, splendour, might and beauty are personified, and seem to be God's royal attendants at his court, both in his heavenly sanctuary and in his temple which symbolizes his earthly dwelling" (Psalms 51-100,96). Kidner suggests that the reference is probably to both earthly and heavenly sanctuaries, for "the earthly one was a copy and shadow of the heavenly (Heb 8:5)" (Psalms 73-150 [London: Inter-Varsity Press, 1975], 348). Robert Davidson cautiously advances the idea that "his sanctuary' could mean either the temple in Jerusalem or his heavenly temple, or both" (The Vitality of Worship, 318).

${ }^{3}$ In vss, $4-6$, the cosmic imagery is reinforced by means of several nominal clauses describing YHWH's superiority above all gods and emphasizing the fact that YHWH created the heavens, stands above the gods of the nations, and is Creator of the heavens. A look at the structure of this section is instructive. One notes that vss. $4(A, B, C$,$) and 5\left(A^{\prime}, B^{\prime}, C^{\prime}\right)$ are arranged in a chiasm, as shown:

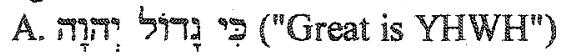

B.

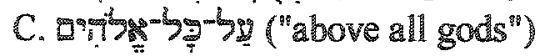

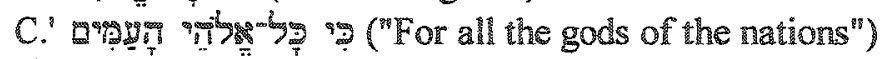

B.' dיל"? ("are idols")

A.' Tํำ

(Modified from Pierre Auffret, "Splendeur et majesté devant lui: čtude structurelle du Psaume 96," OTE 6 [1993]: 151). As suggested by the fulcrum of the structure ( $C$ and $C$ ), the main idea seems to be that YHWH is above all gods. The unit is framed by the claim that YHWH is great $(A)$, and (A) made the heavens. These two verses are then followed by vs. 6 , which presents a remarkable portrayal of YHWH: : : strength and beauty are in his sanctuary"). The universalistic and cosmic context of the preceding section seems to indicate that the sanctuary referred to here is located in heaven, as noted in due course. For now, it will suffice to mention that, in the sequence, the text presents an injunction for 


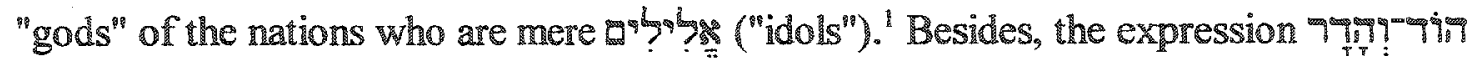
("splendor and majesty") seems to emphasize the royal splendor of $Y H W H$, who stands above the whole world. ${ }^{2}$ Although $7 T_{T \rightarrow}$ ? 7 in is used in other passages in reference to what clothes YHWH, here the text depicts "7TT! led some scholars to suggest that the locution $7 \mathrm{Tin}_{\mathrm{T}}$ ! 9 ?

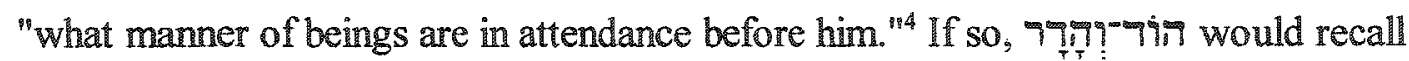
YHWH's heavenly assembly, ${ }^{5}$ thus adding further corroboration for a heavenly setting in the passage under study.

Splendor and majesty are before him, Strength and beauty are in his sanctuary.

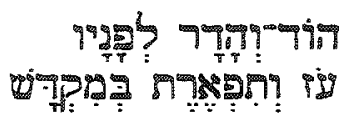

An important observation that may help to ascertain the referent of wip? can also be derived from the flow of the text itself. As pointed out by Tate, in vss. 7-13 YHWH is coming to judge the earth, ${ }^{6}$ which indicates that YHWH's point of departure must be some

the peoples of the earth to worship YHWH (vss. 7-9) in the "glorious sanctuary" (vs. 9). The referent of the latter expression seems to be the earthly sanctuary, as implied in the summons to bring offerings and come into "his courts."

${ }^{1}$ A derogatory expression to convey the notion that the gods of the nations are worthless, impotent, and therefore unworthy of any consideration. As a matter of fact, ang? ang $^{2}$ is translated as "worthless" (NASB, NIV) in Job 13:4, "futility" (NASB), and "delusion" (NIV) in Jer 14:14.

${ }^{2}$ Cr. Kraus, Psalms 60-150, 253

${ }^{3} \mathrm{Cf}$. Anderson, The Book of Psalms, 1:683; Kraus, Psalms 60-150, 253; Rogerson and McKay, Psalms 51-100, 96.

${ }^{4}$ Leupold, Exposition of the Psalms, 684.

${ }^{5} \mathrm{Cf}$, e.g., Isa 6:Iff.

${ }^{6}$ Tate, 514. 
place other than his earthly sanctuary. The implication can thus be drawn that the sanctuary (w?p: referred to in vs. 6 must be the heavenly sanctuary, whence $\mathrm{YHWH}$ comes forth to judge the earth.

\section{Qeferent and Mesming of}

The expression to "holy attire," "holy robe," "holy splendor," and "splendor of holiness." Some versions, however, read a locative idea in translate 07 "7า? nาง glorious Sanctuarie ${ }^{42}$ (sic). The possibility that this expression conveys a locative connotation of "sanctuary" seems to be favored by the injunction to praise YHWH in his courts, as noted below.

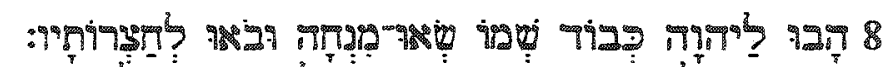

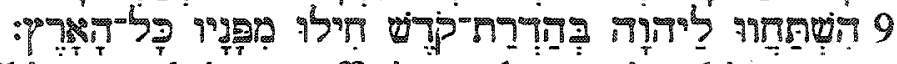
8 Ascribe to YHWH the glory of his name; bring an offering and come into his courts. 9 Worship YHWH in the glory of the sanctuary; tremble before him, all the earth.

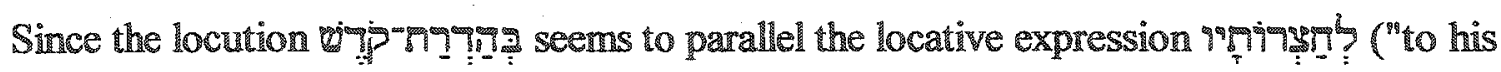
courts"), it seems reasonable to expect that w meaning of "glorious sanctuary" or "in the glory of the sanctuary," as in PS 29:2. Such a meaning seems more appropriate for the context than "in the beauty of holiness" or "in holy attire." There seems to be an escalation as the people are summoned to "bring an

\section{${ }^{1} \mathrm{Cf}$. SRV.}

${ }^{2}$ Cf. GNV. 
offering," "come into his [YHWH's] courts" (vs. 8), and "worship YHWH in the glory of the sanctuary" (vs. 9). In addition to the observation that ofp-mong has the locative meaning "sanctuary," it must be noted that the that injunction to "bring an offering and come into his [i.e., YHWH's] courts" (vs. 8) indicates that this sanctuary is the earthly one."

\section{Heavenly Sanctuary/Temple Motif}

The foregoing discussion indicated that the text refers to both heavenly (vs. 6) and earthly sanctuaries (vs. 9), as conveyed by the expressions iuำ respectively. In what follows, an attempt is made to delineate the function of the heavenly sanctuary and its relationship to the earthly counterpart.

\section{Function}

A prominent aspect of the heavenly sanctuary that seems to emerge from the text is that of a place of enthronement for YHWH, who is depicted as a king, an idea clearly

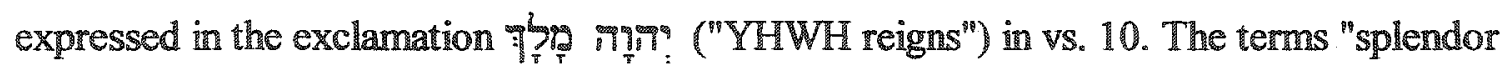
and majesty" reinforce notion, since they are descriptive of the glory of a king. Moreover, along with royal aspects, the concept of judgment also emerges from the text. As noted in vs. 13, YHWH "is coming to judge the earth," which presupposes that the verdict had already been reached in heavenly sanctuary. ${ }^{2}$ Additionally, this psalm contains several

\footnotetext{
"Nonetheless, the invitation for the "entire earth" to "worship YHWH" may also suggest

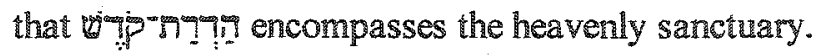

If the broad context of the Hebrew Bible may be used to illuminate this passage, it may be stated that when YHWH comes to execute judgment, he does so as a result of previous judicial
} 
injunctions to praise YHWH, which seems to indicate liturgical/cultic activities in the heavenly sanctuary. For example, statements such as YHWH is "greatly to be praised"

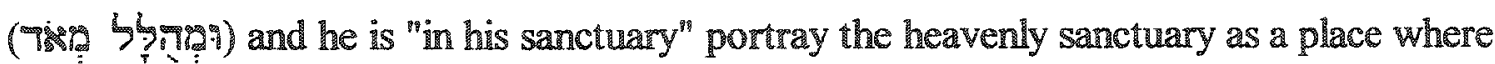
YHWH receives the praises and adoration of his creatures.

\section{Relationship to carthy Counterpart}

From the foregoing discussion, it may be suggested that heavenly sanctuary is understood as existing in functional correspondence to the earthly counterpart, as conveyed by the notions of kingship, worship, and judgment associated with the heavenly sanctuary. Furthermore, that the heavenly sanctuary is designated vop? may indicate a structural correspondence.

The fact that the text refers to both heavenly (vs. 6) and earthly (vS. 9) sanctuaries indicates a vertical relationship that goes beyond functional and structural correspondences. The description of YHWH majestically enthroned "in his [heavenly] sanctuary" (90?

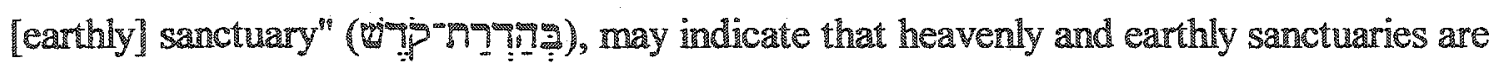
understood to work in dynamic interaction."

procedures undertaken in the heavenly sanctuary/temple (see, e.g., Gen 11: Mic 1:3.

${ }^{1}$ It should be remembered that a similar picture is more explicitly conveyed by Isa $6: 1 \mathrm{f}$, in its portrayal of heavenly and earthly sanctuaries functioning in close relationship, as delineated in chapter 4 , in the context of the discussion of Isa $6: 1 \mathrm{ff}$. 
Ps 102:20-21 [19-20]

$\begin{array}{rl} & \\ 0 & 0\end{array}$

19 For he has always looked down from the height of his sanctuary; $\mathrm{YHWH}$, from heaven he has always gazed upon the earth,

20 To hear the groaning of the prisoner, to set free those who are doomed to death. ${ }^{1}$

\section{Preliminary Observations}

A "bewildering multiplicity of interpretations have been offered for this complex psalm," especially in regard to its Sitz im Leben, unity, and time of composition. ${ }^{3}$

Fortunately for the purpose of this research, it is not necessary to delve into all these issues, since the concern of this study is with the final form of the text. According to its superscription, Ps 102 is categorized as a "prayer of an afflicted" (vs.1) individual who, as the text goes forward, turns out to be the community directing a plea towards YHWH in a time of affliction due to the devastation of Zion. ${ }^{4}$

${ }^{1} T h i s$ translation, especially the insertion of always, will be justified in due course.

${ }^{2}$ Leslie C. Allen, Psalms 101-150, WBC 21 (Waco: Word Books, 1983), 11.

${ }^{3}$ Sitz im Leben: The main issue here is whether or not the composition had the cult as its setting. Sigmund Mowinckel (Psalmenstudien, 2 vols. [Amsterdam: Verlag P. Schippers N.V., $1966], 1: 166)$ and Weiser (652-53) have understood this psalm as intended for cultic use, while Kraus (Psolms 60-150, 283) and Robert Davidson (The Vitality of Worship, 332), among others, believe it to be the lament of an individual.

Unity: Some critics believe that the abruptness of the thematic changes indicates that the psalm is a combination of two or more independent sources. See, e.g. Briggs and Briggs, 2:316ff. Moses Buttenweiser, The Psalms Chronologically Treated with a New Translation (Chicago: University of Chicago Press, 1938), 384-86.

Time of composition: The reference to the temple in ruins has led the majority of scholars to suggest that the psalm was composed in the exilic or early postexilic times. So Terrien, The Psalms, 699; Kraus, Psalms 60-150, 285-86; Robert Davidson, The Vilality of Worship, 332.

${ }^{4}$ This may be an indication that this psalm was composed during the time of the Babylonian exile when Zion was in ruins. See, e.g., Terrien, The Psalms, 699. 
From the point of view of its genre, this psalm consists of a blend of prayer and praise. Thematically, the first and last sections of the psalm have the impermanence of the suppliant as the main subject, thus framing the central section which deals with the permanence of YHWH. Thus, on a thematic basis, the following structure can be discerned: (1) The transitoriness of human existence $(1-11)$; (2) the permanence of YHWH (12-22); (3) the transitoriness of human existence (23-28). Consequently, the focus of the psalm is on the second/central section, where YHWH is extolled as the One who lives forever.

Attention now is turned to the structure of the small unit comprising vss. 21-22 [20-21]. This unit becomes important for this discussion because it is here that the heavenly sanctuary/temple motif emerges, as made clear by the expression Starting with vs. 20 [19], it may be noted that this verse contains two clauses arranged as an inverted parallelism, as shown below.

A. ๆ ๆ. ("For he has always looked down")

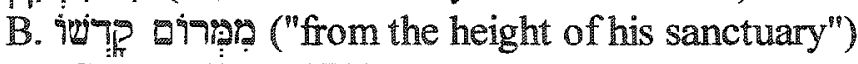
C. กIก?" ("YHWH")

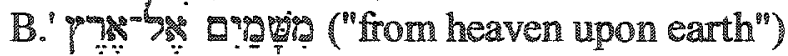

A.'

It should be observed that the Tetragrammaton is syntactically ambiguous in the sense that it may belong to either the first or the second clause. This may have a rhetorical purpose since "YHWH" functions not only as the logical grammatical subject of both clauses, but also as the structural center of the verse, functioning as a hinge between both clauses. 
As for vs. 21 [20], it expresses the purpose of the previous verse by means of two infinitive phrases expressing the activities of YHWH in his heavenly sanctuary.'

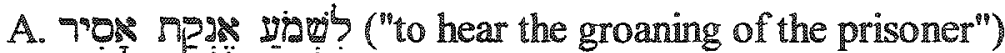

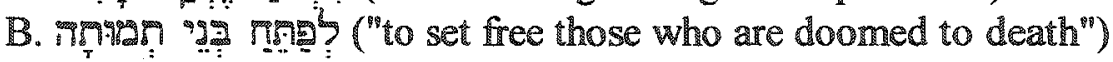

The text thus clearly discloses that the dynamic presence of YHWH in the heavenly

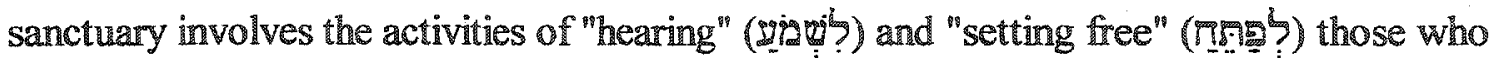
are oppressed.

\section{Semantic and Other Exegetical Considerations}

\section{Meaning of id}

The expression explicit reference to the heavenly sanctuary, as indicated by the synonymous parallelism

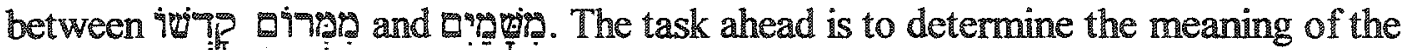
locution 1 was adjectively as in "his holy height." Others have preferred the concrete meaning of "sanctuary" as in "the height of his sanctuary," "his sanctuary above," "his sanctuary on

'The reasons for interpreting the locution iritip gquepa as the heavenly sanctuary will be spelled out below.

${ }^{2} \mathrm{NASB}, \mathrm{RSV}, \mathrm{ESV}, \mathrm{TNK}$.

3JPS, DBY, KJV.

${ }^{4} \mathrm{NET}$. 
high," "heights of his sanctuary," "his heavenly sanctuary." Some scholars seem to concur with this view, but use synonymous terms such as "dwelling place," or "heavenly abode" instead of "heavenly sanctuary. ${ }^{\circ 4}$

Although an abstract rendition of wip as "holiness" is semantically possible, the concrete meaning of "sanctuary" seems more probable. First, as Davidson pointed out, ${ }^{5}$ the poetic parallelism in the psalms and other passages of the Hebrew Bible usually would have "heavens" in parallelism with "sanctuary/temple," a construction in which one term enlarges the other. ${ }^{6}$ Second, when in construct relationship, อต่าม ("height") is usually followed by a concrete word specified by it. ${ }^{7}$ The following examples may help clarify this

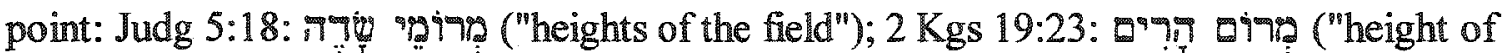

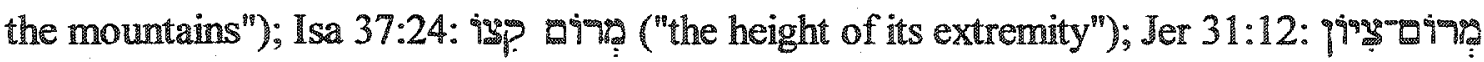

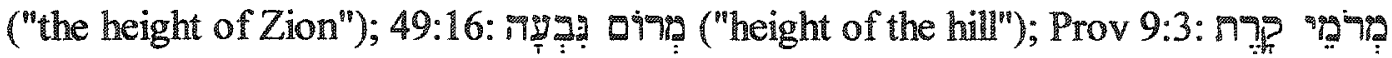

${ }^{1} \mathrm{NIB}$.

${ }^{2}$ NJB.

${ }^{3}$ NLT.

${ }^{4}$ Cf., e.g., Leupold, Exposition of the Psalms, 712; Erhard Gerstenberger, Psalms, Part 2, and Lamentations, FOTL 15 (Grand Rapids, Eerdmans, 2001), 213.

"Davidson, "The Heavenly Sanctuary in the Old Testament," 14.

${ }^{6} \mathrm{See}$, e.g., Deut 26:15; Isa 63:15; Ps 11:4. However, it should be noted that pine can also be used as a poetic term for "Heaven" or in parallelism to it. What makes the passage under scrutiny distinctive is the fact that the term wp appears only here in connection with

${ }^{7}$ An apparent exception to this occurs in Jer 51:3 where 9?\% however, the possibility remains that the expression iv ("strength") may have been used in the concrete sense of "fortress." Cf. HALOT, s.v. "II i2." 
("heights of the city"). As the examples mentioned make clear, an abstract term fits better as a qualification for a concrete noun than for another abstract term.'

Third, also relevant for the understanding of ewp is the statement in 13 [12] that

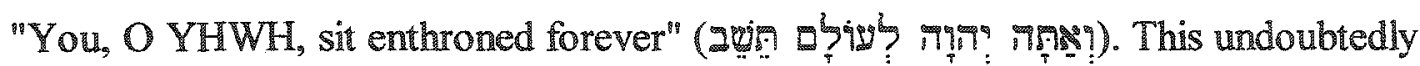
indicates a heavenly setting, since vss. 14-15 [13-14] presuppose that the earthly temple is in ruins. If such is the case, the allusion to YHWH being enthroned in heaven would reinforce the idea of a heavenly sanctuary/temple, since the Hebrew Bible conceives of the heavenly throne of $\mathrm{YHWH}$ as located in the heavenly sanctuary. ${ }^{2}$ A final consideration is

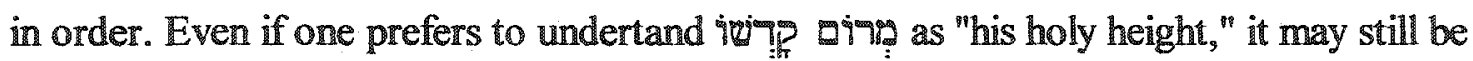
argued that this implies sanctuary imagery, inasmuch as it might evoke the heavenly "Mount of the Assembly." This idea is closely related to the heavenly sanctuary/temple motif, as shown in the discussion of Isa 14:12-15 in chapter 4 of this dissertation.

Summing up, in view of the foregoing, the term in the construction

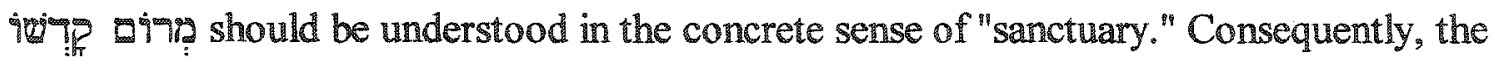
phrase ix"ip gim could be literally translated as "height of his sanctuary" or "his high/elevated sanctuary." Finally it should be noted that, as indicated by the context, this sanctuary is the heavenly one.

"Davidson, "The Heavenly Sanctuary in the Old Testament," 14.

${ }^{2}$ See, e.g., Isa 6:Iff; Ps 11:4. 


\section{Meaning of}

At this juncture, the semantic implications of the lexemes "por ("look") and $89 \mathrm{~g}$ ("gaze") need attention. As noted in the discussion of Isa $18: 4$, , the concept of YHWH "looking" down from heaven, or from his heavenly temple, upon the world is a common motif in the Hebrew Bible. ${ }^{2}$ In Ps 102: 20-21 [19-20], this imagery is employed to connote YHWH's attitude and actions in favor of the prisoner. The implication is that the action that YHWH undertakes to "set free the prisoner" is preceded by an examination or investigation. That is, YHWH "looks down" and "gazes" on the earth before "setting free those doomed to death." In other words, YHWH's actions in the heavenly sanctuary/temple seem to be performed in two steps, namely an investigation of the situation ("look/gaze") followed by the execution of his work of "setting free the prisoner, which contextually refers to the restoration of Zion/Jerusalem.

\section{Heavenly Sanctuary/Temple Motif}

\section{Function}

As delineated in Ps 102, the heavenly sanctuary functions as a source of help or salvation, which in this text refers to the restoration of Zion/Jerusalem ${ }^{3}$ and, by implication, the earthly temple. Therefore, it seems logical to assume that the heavenly sanctuary functions as a place where YHWH undertakes activities of supervision of world

${ }^{1}$ See chapter 4 of this dissertation.

${ }^{2} \mathrm{Cf}$, s.g., Deut 26:15; Ps 80:15 [14]; Isa 63:15.

${ }^{3}$ See Ps 102:17 [16], $22[21]$. 
affairs by "looking down" and "gazing from heaven to earth" in order to "hear" the prisoner, and to "set free those who are doomed to death." In this process, an investigative phase (looking down/gazing) is followed by an executive phase (setting free). In addition, it should be kept in mind that the reference to YHWH as the one who has sat forever emphasizes the royal functions of the heavenly sanctuary.

\section{Relationship to Earthly Counterpart}

Although the psalm presupposes a time during which the temple was in ruins, there appears to be some indication of a vertical relationship in the reference to Zion/Jerusalem in vs. 22 [21]. In its function as a place from where YHWH bestows help and salvation upon the suppliant points to a vertical correspondence between the earthly temple and its earthly counterpart. Moreover, the designation of the heavenly sanctuary by the lexeme ving may indicate that it is understood in structural correspondence with the earthly counterpart.

\section{P\$ 150:1-6}

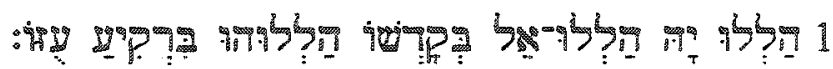
1 Praise YHWH! Praise God in his sanctuary; Praise him in his mighty expanse.

\section{Preliminary Observations}

Ps 150 is a hymn of praise fomed by ten imperative sentences ${ }^{1}$ and a concluding jussive, each of them a summons to praise YHWH. As such, it functions as a fitting

It has been suggested that the tenfold repetition of the imperative echoes "the ten words of creation in Gen 1 and the ten commandments (Ex 20)" (Deissler, Die Psalmen, 572). Cf. Anderson, The Book of Psalms, 2:955. 
conclusion for the entire book of Psalms. Commentators have observed that this psalm addresses some or all of the following aspects: $:^{1}$ who is to be praised (vs. Ia "YHWH/God"), where he is to be praised (vS. Ibc "in his sanctuary"), why is he to be praised (vs. 2 "for his mighty deeds" and "his excellent greatness"), how he is to be praised (vSs. $3-5$ with all kinds of musical instruments and dance), and finally who is to praise him (vs. 6 "everything that has breath").

The text displays a clear structure consisting of an introduction (vss. 1-2), main section (vss. 3-5), and a conclusion (vs. 6). ${ }^{2}$ A close look at the structural interconnections reveals that vss. 1-5 are tied together by the ninefold repetition of the preposition 7 , as well as the tenfold summons to praise. The psalm moves toward a climax as vs. 3 presents one pair of musical instruments, vs. 4 two pairs, while in vs. 5 the two fold reference to me ("cymbals"), the loudest instrument, takes it further. Eventually, vs. 6 with its inclusive summons, "Let everything that has breath praise YHWH," takes the psalm to its climatic conclusion, implying that heavenly and earthly sanctuaries are united in the praising of $\mathrm{YHWH}^{3}$ as argued below. Finally, it should be noted that $\mathrm{NT}$, and ${ }^{3}$ in vs. 1 , and the twofold 17 in vs. 6 create an inclusion that envelops the entire composition.

${ }^{1} \mathrm{Cf}$. Kidner, Psalms 73-150,490-92; Leupold, Exposition of the Psalms, 1006; Limburg, Psalms, 505; J. Clinton MacCam, Jr., "The Book of Psalms: Introduction, Commentary and Reflections," The Interpreter's Bible, ed. Leander E. Keck (Nashville: Abingdon, 1994), 4:1278; Mays, Psalms, 450.

${ }^{2}$ So Allen, Psalms 101-150, 323.

${ }^{3}$ Ibid., 323-24. 


\section{Semantic and Other Exegetical Considerations}

This section will focus on the meaning and referent of the phrase govep? Some scholars have suggested to translate this expression as "in his holiness/sanctity" while others opt for "in his sanctuary." The former alternative seems difficult to sustain in view of the parallelism of joip? with the locative phrase 197 ? reasonable to regard ive?p? as expressing the locative meaning "in his sanctuary."

The next step is to determine whether the referent of wip is the heavenly temple or its earthly counterpart. Although some scholars contend for an earthly referent, ${ }^{2}$ there are compelling reasons to understand toip ("sanctuary") as referring to the heavenly sanctuary, a view also supported by several commentators. ${ }^{3}$ First, it should be noted that

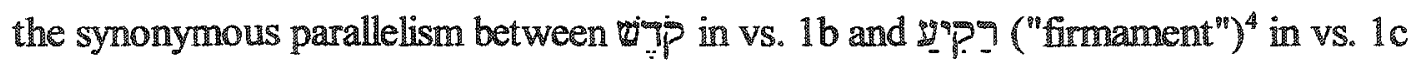
indicates that vig must be located in heaven. At this juncture it should be remembered that the view that the parallelism here is synonymous receives support from the fact that the entire hymn employs synonymous parallelism, as noted by Dahood. ${ }^{5} \mathrm{I}$ is illuminating that a similar parallelism is found in the closely related Ps 148:1. In this latter passage the

'E.g., Briggs and Briggs, 2:544.

${ }^{2}$ E.g., Terrien, The Psalms, 928; Baethgen, 435; Kidner, Psalms 73-150, 491.

${ }^{3}$ See Anderson, The Book of Psalms, 2:955; Cohen, 479; Limburg, Psalms, 505; Kissane, The Book of Psalms, 656; Kirkpatrick, 832; Delitzsch, 3:414-15; Mays, Psalms, 450; Leupold, Exposition of the Psalms, 1006; Carroll Stuhlmueller, "Psalms," The HorperCollins Bible Commentary, ed. James Luther Mays and Joseph Blenkinsopp (San Francisco: HarperSanFrancisco, 2000), 446.

"499" ("firmament") in this verse "is simply a synonym for "heavens" (Anderson, The Book of Psalms, 2:956).

'Dahood, Psalms III: 101-150, AB 17A (Garden City, NY: Doubleday, 1966), 359. 


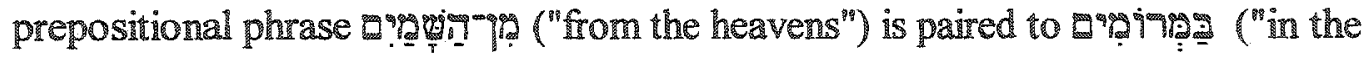
heights") as noted by Kim. ${ }^{1}$

Psalm 150

vs. 1b 'Praise God in his sanctuary'

vs. $1 \mathrm{c}$ "Praise him in his mighty firmament"

\section{Psalm 148}

vs. 1a Praise the Lord from the heavens vs. $1 \mathrm{~b}$ Praise him in the heights

Second, the use of 2 ("God") in connection with wp in the clause ("Praise God in his sanctuary") adds additional weight to the possibility of a heavenly referent. As noted by Allen, the term 4 ("God") "not infrequently has celestial associations in the Psalter."2

Third, further support for the heavenly setting of witp is provided by Kim's insightful critique of the earthly-sanctuary argument in this passage. Kim argued that those who argue that vs. $1 \mathrm{~b}$ refers to the earthly temple and vs. $1 \mathrm{c}$ to the heavenly sanctuary overlook the "significant point" that in the Hebrew Bible when "heaven" and "earth" are used side by side, heaven always precedes earth. ${ }^{3}$ Thus it would be very unusual that Ps 150:1 would be an exception to this rule. In view of the foregoing considerations it appears that gig in vs. $1 \mathrm{~b}$ refers to the heavenly sanctuary.

${ }^{1} \mathrm{Kim}, 164$.

${ }^{2}$ Allen, Psalms 101-150,322-23. See PSS 19:2 [1];29:3;82:1;89:8 [7]; cf. 90:2; 95:3).

${ }^{3} \mathrm{Kim}$, in a note, adds that "there is no exception throughout the Bible from Gen. 1:1 to Rev. 21:1" (162, n. 167). 
Heavenly Sanctuary/Temple Motif

The discussion undertaken above has made apparent that the term of refers to the heavenly sanctuary. The task now is to determine the function of the heavenly sanctuary and its relationship to the earthly counterpart.

\section{Function}

In order to delineate the function of the heavenly sanctuary, attention needs to be

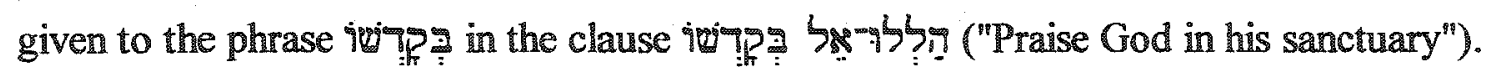
The question that arises concerns whether frompd modifies $3 x$ ("God") or the verb th? ("praise"). In other words, it must be determined whether it functions adnominally or adverbially. If $9 e^{2}$ is inderstood adnominally, it would function primarily to express that praise should be rendered to "God in his sanctuary," that is, the sanctuary is depicted primarily as the locus of God's presence, namely his dwelling place. Anderson favors this possibility when he asserts that "it seems that verse 1 describes not the place where God is to be praised but rather the 'place' where he dwells."

On the other hand, if ivom is understood adverbially-that is, as modifying the verb-the thrust of the verse is to "praise [God] in the sanctuary," that is, the sanctuary would function primarily as the "locus" wherein praise is rendered to God. This view has the support of Leupold, who argued that "the phrase 'in his sanctuary' does not modify the noun 'God' but the verb 'praise. "ri2 Leupold further argued that "the parallelism of the

\footnotetext{
'Anderson, The Book of Psalms, 2:955.

${ }^{2}$ Leupold, Exposition of the Psalms, 1006.
} 
second member of the verse supports this view. Those who are to be found in the heavenly sanctuary who are capable of singing God's praises are the holy angels."

Although the altemative between either an adnominal or adverbial function of iverp? may seem at first glance trivial, the argument of Leupold carries considerable weight. The parallelism between 960? $P$ ? and 299 ? ? suggests that the "sanctuary" functions primarily as the locus of worship to God, in that the heavenly beings are summoned to praise God "in the sanctuary." Consequently, the heavenly sanctuary emerges as a place of worship activities.

\section{Relationship to Earthly Cownterpart}

Although no explicit mention of the earthly temple is found in Ps 150 , the liturgy of the Jerusalem temple is most probably presupposed. In vss. $3-5$, the mention of several musical instruments ${ }^{2}$ and dance evokes the liturgical setting of the earthly temple. ${ }^{3}$ That being the case, the psalm would be a solemn invitation not only for the heavenly beings to praise God in the heavenly sanctuary (vs. 1), but also for his people on earth to join the heavenly chorus in the earthly temple. Such a connection between heavenly and earthly liturgies is reinforced by the concluding summons: "everything that has breath praise YHWH" (vs. 6).

I I pid.

${ }^{2}$ One is here reminded of the Chronicler's account of the temple worship, with its variety of musical instruments. See, e.g., 1 Chr 15:16; 2 Chr 5:13; 7:6.

${ }^{3}$ See W. T. Purkiser, "Psalms," Beacon Bible Commentary (Kansas City: Beacon Hill, 1967), 448. See the list of instruments depicted in vss. 3-5. 
The picture emerges of a correspondence between liturgical activities in the heavenly temple and their counterparts in the Jerusalem temple, which suggests a vertical a dynamic interaction between heavenly sanctuary and the earthly counterpart. That is to say, the worship of the heavenly sanctuary reverberates with the cultic activities of the earthly counterpart. As Davidson remarked, "the close connection between the worship in the heavenly sanctuary and the worship in the earthly is manifested, and the reality of the heavenly sanctuary is accentuated."

It is instructive to note that this connection between the heavenly temple and its earthly counterpart has been overtly or implicitly recognized by several other scholars. Schaefer, for example, argues that "the poet makes no distinctions between earth and heaven, and the temple liturgy imitates the heavenly. ${ }^{.2}$ Deissler talks about a "correspondence" (Übereinander) and "togetherness" (Zusammen) of the earthly and heavenly liturgy. ${ }^{3}$ Kidner says that "earth and heaven can be utterly at one in this.. According to Craig Broyles, "the liturgist is summoning both the earthly and heavenly congregations to worship. ${ }^{\text {.5 } 5}$ For Anderson, both heavenly and earthly temples are here "closely associated." In the opinion of Weiser, "all the voices on carth and in heaven unite

"Davidson, "The Heavenly Sanctuary in the Old Testament" 15.

${ }^{2}$ Schaefer, 345.

${ }^{3}$ Deissler, Die Psalmen, 572.

${ }^{4} \mathrm{Kidner}$, Palms 73-150, 491. 1999), 519 .

${ }^{5}$ Craig C. Broyles, Psalms, NIBC, Old Testament Series 11 (Peabody, MA: Hendrickson, ${ }^{6}$ Anderson, The Book of Psalms, 2:955. 
to the accompaniment of the triumphant strains of the entire orchestra of the temple music (v. 1a)." And Gross and Reinelt expressed the idea that the praise to God "effects a fusion of horizons (Horizontverschmelzung) between the heavenly and earthly world."2

Finally, it should be pointed out that the worship function of both heavenly and earthly temples indicates a functional correspondence, and the designation of the heavenly temple by the term opp probably presupposes a structural correspondence.

\section{Dan 7:9-14}

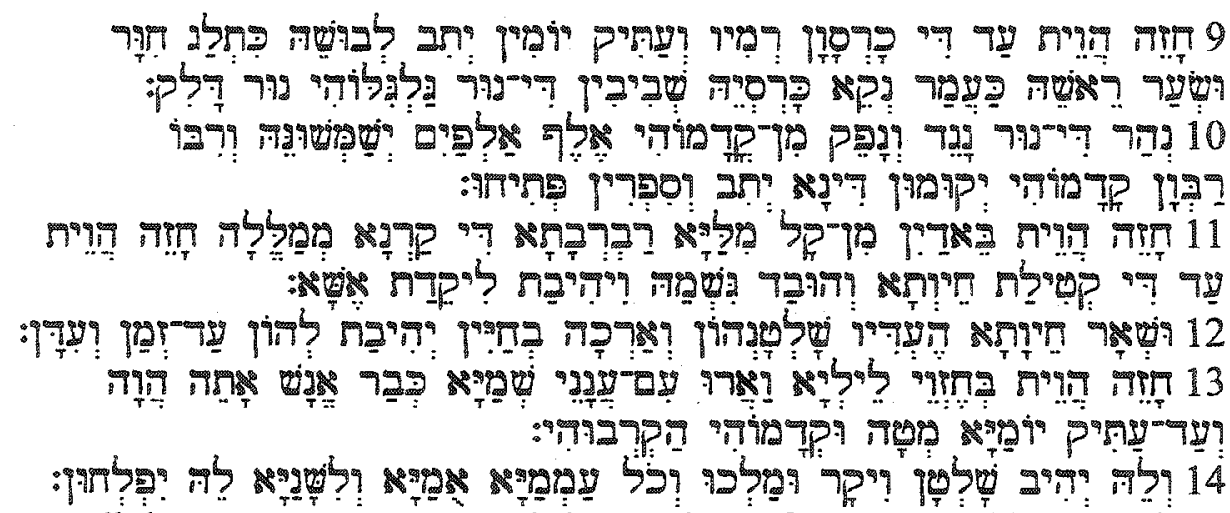

9 I kept looking until thrones were set up, and the Ancient of Days took his seat; his vesture was like white snow and the hair of his head like pure wool. His throne was ablaze with flames, its wheels were a burning fire.

10 A river of fire was flowing and coming out from before him; thousands upon thousands were attending him, and myriads upon myriads were standing before him; the court sat, and the books were opened.

11 Then I kept looking because of the sound of the boastful words which the horn was speaking; I kept looking until the beast was slain, and its body was destroyed and given to the burning fire.

12 As for the rest of the beasts, their dominion was taken away, but an extension of life was granted to them for an appointed period of time.

'Weiser, 841.

${ }^{2}$ Heinrich Gross and Heinz Reinelt, Das Buch der Palmen: Teil II (PS 73-150), 3rd ed. (Düsseldorf: Patmos Verlag, 1989), 442. 
13 I kept looking in the night visions, and behold, with the clouds of heaven One like a Son of Man was coming, and he came up to the Ancient of Days and was presented before him.

14 And to him was given dominion, glory and a kingdom, that all the peoples, nations and men of every language might serve him. his dominion is an everlasting dominion which will not pass away; and his kingdom is one which will not be destroyed.

\section{Preliminary Observations}

Before the analysis of Dan 7:9-14, it must be kept in mind that the interpretation of this pericope may be illuminated by its connection with Dan 8 . As has been demonstrated by William Shea, the apocalyptic ${ }^{1}$ visions of Dan 7 and 8 are closely linked by time elements, thematic, and verbal connections. ${ }^{2}$ For the discussion that follows, one should hold in mind, as other scholars ${ }^{3}$ have noted, that Dan 7 and 8 are parallel vision accounts

${ }^{1}$ For the characteristics of apocalyptic literature, cf. John Joseph Collins, Daniel: A Commentary on the Book of Daniel, Hermeneia-A Critical and Historical Commentary on the Bible (Minneapolis: Fortress, 1993), 54-58; Kenneth Albert Strand, Interpreting the Book of Revelation: Hermeneutical Guidelines, with Brief Introduction to Literary Analysis, 2nd ed. (Naples, FL: Ann Arbor Publishers, 1979). Roy Gane has cogently argued that the book of Daniel as a whole should be regarded as belonging to the apocalyptic genre. Even the narratives, although they may not contain some of the elements usually ascribed to the apocalyptic genre, "function within the book as an apocalyptic narrative framework" (Roy Gane, "Genre Awareness and Interpretation of the Book of Daniel," in To Understand the Scriptures: Essoys in Honor of William Shea, ed. David Merling [Berrien Springs, MI: Institute of Archaeology/Horn Archaeological Museum, 1997], 140).

${ }^{2}$ William H. Shea, "Unity of Daniel," in Symposizm on Daniel, ed. Frank B. Holbrook, DARCOM (Washington, DC: Biblical Research Institute, 1986), 183-255.

${ }^{3} \mathrm{Cf}$. Jacques Doukhan, Daniel: The Vision of the End (Berrien Springs, MI: Andrews University Press, 1987), 23-31; A. Feuillet, "Le fils de l'homme de Daniel et la tradition biblique," Revue Biblique 60 (1953): 196; John Goldingay, Daniel, WBC 30 (Dallas, TX: Word Books, 1989), 206-07; F. B. Huey, Jr, Ezekiel, Daniel, Layman's Bible Book Commentary 12 (Nashville, TN: Broadman, 1978), 141; D. S. Russell, Daniel (Philadelphia: Westminster, 1981), 137-39; William H. Shea, "Unity of Daniel," 183-219. Doukhan pointed out that "[t]he vision of chapter 8 shares a lot of common themes with chapter 7 . We are alert to this connection from the first words. 'A vision appeared to me-to me, Daniel-after the one that appeared to me the first time' (Daniel 8:1)" (Doukhan, Daniel: The Vision of the End, 23). 
outlining roughly the same sequence of events and displaying several common themes and motifs, as demonstrated by table 4

TABLE 4

\section{PARALLELS BETWEEN DAN 7 AND 8}

\begin{tabular}{ll}
\hline Daniel 7 & Daniel 8 \\
\hline The lion: Babylon & Not attested \\
The bear: Medo-Persia & The ram: Medo-Persia \\
The leopard: Greece & The goat: Greece \\
Leopard's four heads & Goat's four horns: \\
Unidentified beast & Horizontal work of the little hom \\
$4^{\text {th beast's little horm }}$ & Vertical work of the little horn \\
\hline Heavenly Judgment & Heavenly Sanctuary \\
Burning of the little horn & Breaking of the little hom \\
Son of man receives kingdom & Not attested \\
Saints enter his kingdom & Not attested \\
\hline
\end{tabular}

Source: Adapted from William H. Shea, "Unity of Daniel," in Symposium on Daniel, ed. Frank B. Holbrook, 165-255 (Washington, DC: Biblical Research Institute, 1986), 209.

Thus, a study of the heavenly sanctuary/temple needs to take Dan 7:9-14 and 8:914 into consideration. The former provides a graphic depiction of the heavenly sanctuary in activity, the vindication of the "saints of the Most High," and the anninilation of the power that attacks the sanctuary. The latter reports the anti-YHWH activities of the little hom, its attack on the sanctuary, and ammounces that the "[heavenly] sanctuary" would be cleansed. ${ }^{1}$

'The consensus among critical scholars is that Dan 8:9-14 refers to the desecration of the Jerusalem temple perpetrated by the Seleucid King, Antiochus IV Epiphanes. Louis Francis Hartman and Alexander A. Di Lella, for example, dogmatically assert that "there is not the 
Turning to the pericope of Dan $7: 9-14$, a brief examination of the literary structure of Dan 7, with attention to the thematic elements is in order. Arthur Ferch identified three panels in Dan 7, ${ }^{1}$ as shown in table 5.

TABLE 5

\section{PANEL STRUCTURE OF DAN 7}

Vss. 2-14

A. Oppression

(vss. 7-8)

B. Judgment (court and execution; vss. 9-12)

C. Kingship

(vss. 13-14)
Vss. 15-22

A. Oppression

(vs. 22a)

B. Judgment

(vs. 22a)

C. Kingship

(vs. 22b)
Vss. 23-27

A. Oppression

(vss. 23-25)

B. Judgment

(vs. 26)

C. Kingship

(vs. 27)

Source: Adapted from Arthur J. Ferch, The Son of Man in Daniel 7, AUSDDS 6 (Berrien Springs, MI: Andrews University Press, 1979), 142.

slightest doubt that he [Antiochus IV Epiphanes] is the one meant in the description of the 'small horn" ( The Book of Daniel, AB 23 [Garden City, NY: Doubleday, 1978], 335). A close look at the text and its broad context, however, indicates that the sanctuary referred to in vs. 14 most probably is the heavenly sanctuary, as noted by several scholars: Jacques Doukhan, Secrets of Daniel: Wisdom and Dreams of a Jewish Prince in Exile (Hagerstown, MD: Review and Herald, 2000), 121-33; Hasel, "The 'Little Horn,' the Heavenly Sanctuary and the Time of the End: A Study of Daniel 8:9-14," 378-461; idem, "Establishing a Date for the Book of Daniel," in Symposizm on Daniel, 84-164; Rodriguez, "Significance of the Cultic Language in Daniel 8:9$14, " 527-49$; William H. Shea, "Spatial Dimensions in the Vision of Daniel 8," in Symposium on Daniel, ed. Frank B. Holbrook, DARCOM (Washington, DC: Biblical Research Institute, 1986), 497-526; idem, "Unity of Daniel," 165-255.

1 The following structure has been suggested for the entire chapter:

A. Prologue (vss. 1-2a)

B. Vision (vss. 2b-14)

C. Seer's reaction to the vision (vss. 15-16)

D. Brief interpretation (center of chapter [vss. 17-18])

C.' Seer's reaction to and elaboration of vision (vss. 19-22)

B.' Lengthy interpretation (vss. 23-27)

A. Epilogue (vs. 28) (Arthur J. Ferch, The Son of Man in Daniel 7, AUSDDS 6 [Berrien Springs, MI: Andrews University Press, 1979], 142). 
As noted, the theme of "judgment forms the very center of the structure [B] and becomes the apex of a pattem that finds its broadest base in the vision of heavenly judgment (vss. 9. 14). ${ }^{n ! 1}$

Since the discussion that follows is especially concemed with the heavenly judgment scene portrayed in vss. $9-14$, it is instructive to keep in mind that this pericope belongs to the second half of the entire vision reported in vss. $2 \mathrm{~b}-14$, as shown below:

\section{$2 b-13$ four creatures appear}

4-6 the first three creatures

7 the fourth creature with its ten homs

8 a small horn on the fourth

9-10 a throne scene

11 a the small hom

$11 \mathrm{~b}$ the fourth creature

12 the first three creatures

13-14 a manlike figure appears ${ }^{2}$

As the above structure indicates, the scene of the heavenly judgment appears at the structural center of the entire vision and occupies the entirety of its second half. And, as indicated in 7:26-26, this judgment aims at the annihilation of the little horn and the consequent rendering of a favorable verdict for the saints of the Most High, granting them the kingdom.

\section{Semantic and Other Exegetical Considerations}

As noted, the pericope portrays a judgment setting in which the heavenly tribunal convenes to decide matters related to the activities of the little horn and vindication of the

'Arthur J. Ferch, "The Judgment Scene in Daniel 7," in The Sanctuary and the Atonement, ed. Arnold Wallenkampf and Richard Lesher (Washington DC: Review and Herald, 1981), 162.

${ }^{2}$ Goldingay, Daniel, 153. 
saints of the Most High. The discussion below undertakes a brief examination of the vertical dimension of the text, followed by an examination of judicial and cultic terms contained in the pericope.

\section{Vertical Dimension}

Dan 7:9-14 presents a correlation between earthly events and heavenly procedures, as noted in the following outline: vss. $9-10$ : heaven; vss. 11-12: earth; vss. 13-14: heaven.' The vision presents a clear vertical dimension, as the seer's glance shifts from earthly events to the heavenly tribunal, where the Ancient of Days presides over the judgment. One perceives that heaven and earth are interconnected, as the heavenly assembly convenes to deal with issues affecting the earthy realm. This judgment intends to "reach a decision about the final disposition of the little horn," and to vindicate the saints of the Most High. The picture thus emerges of the heavenly sanctuary interacting with earthly affairs, an interaction that culminates with the heavenly tribunal bringing the little horn to its demise and granting the everlasting kingdom to the saints of the Most High.

\section{Judicial and Cullitic Motifs}

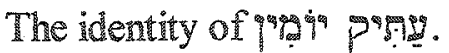

The figure introduced in Dan 7:9 as 9999 p"rig ("Ancient of Days") must be identified with $\mathrm{YHWH}$, as is obvious from the context. The expression probably indicates

${ }^{1}$ A detailed diagram portraying the vertical dimension in Dan 7 and 8 is found in Shea, "Unity of Daniel," 201.

${ }^{2}$ Shea, "Unity of Daniel," 202. 
YHWH's "longevity and eternal existence."1 Thus, it seems entirely appropriate that in the context of the heavenly tribunal YHWH is depicted as an "Ancient of Days." As the eternal one, YHWH holds the credentials to preside over the judgment session of the heavenly tribunal.

Implications of

An interesting connection with sanctuary imagery emerges in the term רצ' ("fire") in the expression "rivers of fire" and also in the reference to the "fire" in connection with the wheels of the throne, an imagery that reminds one of the vision reported in Ezek 1.2 Another expression evoking sanctuary imagery is pointed out that "[t]he clouds and fire draw upon the imagery and phenomena connected with the manifestation of the divine presence over the earthly sanctuary. These manifestations of God are seen in the heavenly sanctuary. ${ }^{13}$ Fletcher-Louis suggested that the fire and clouds evoke sanctuary imagery $4^{4}$ and the Son of Man in Dan 7:13 is a "priestly figure." ${ }^{\text {Th }}$ This priestly figure, Fletcher-Louis suggests, is portrayed as undertaking his

"Ferch, "The Judgment Scene in Daniel 7," 164. See PS. 9:7; 29:10; 90:2; Isa 9:6. A similar expression appears in Ugaritic, in reference to $\mathrm{El}$ as "father of years." Interestingly, the Ugaritic expression is applied to $\mathrm{El}$ in contexts of judgment, when $\mathrm{El}$ is sought to make a decision See the survey of Ugaritic texts in chapter 2 of this dissertation.

${ }^{2}$ On Ezek 1 , see chapter 4 of this dissertation.

${ }^{3}$ Shea, "Unity of Daniel," 217.

${ }^{4}$ Cf. Crispin H. T. Fletcher-Louis, "The High Priest as Divine Mediator in the Hebrew Bible: Dan 7:13 as a Test Case, "Society of Biblical Literature Seminar Papers 36 (1997): 16193; André Lacocque, The Book of Daniel (Atlanta: John Knox, 1979), 125.

${ }^{5}$ Fletcher-Louis, $169 \mathrm{ff}$. 
activities on the Day of Atonement "when the true high priest will come to the Ancient of Days surrounded by clouds of incense ${ }^{11}$ in order to "remove the impurity which has contaminated sacred space." Although Fletcher-Louis based his arguments on different presuppositions than those adopted in the present work, ${ }^{3}$ his suggestions imply that Dan 7:9-14 may portray Day-of-Atonement imagery and, therefore, correspond to the parallel passage of Dan 8:9-14, as argued below.

Implications of ๆ?ר? :?

The idea of heavenly "7 Hebrew Bible. There are references to "book of the living" (Ps 69:28), "book of remembrance" (Mal 3:16), and "books" (Exod 32:32; Ps 56:9 [8]; Dan 12:1). Some texts indicate that YHWH keeps records of good (Neh 5:19; 13:14) and bad deeds (Isa 65:6; Ps 109:14). The general idea seems to be that of heavenly records being kept by $\mathrm{YHWH}$ for purposes of judgment. In a study, mentioned earlier in this dissertation, Angel Rodriguez undertook a detailed study of heavenly books, categorized as books of life and books of human deeds. ${ }^{5}$ According to Rodriguez, the books mentioned in Dan 7:10 are books of

1bid., 186.

${ }^{2}$ Ibid., 181 .

${ }^{3} \mathbb{E} . g .$, Fletcher-Louis assumes the similarities of the passage with extracanonical literature, ANE mythological background of Dan 7, and the assumption that the temple of Jerusalem is the referent of the passage. Cf. Fletcher-Louis, 161-93. dissertation.

${ }^{4}$ For books related to the ANE concept of heavenly temple/sanctuary, see chapter 2 of this

5Rodriguez, "The Heavenly Books of Life and of Human Deeds," 10-16. 
human deeds, the primary function of which is "judiciary," since they "preserve evidence that will be used in the divine tribunal to determine the nature of the commitment of the individual" to YHWH. ${ }^{1}$ As Ferch pointed out, "the books are somehow related to the verdict that divides good and evil." 2

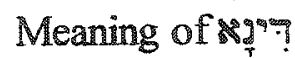

The term

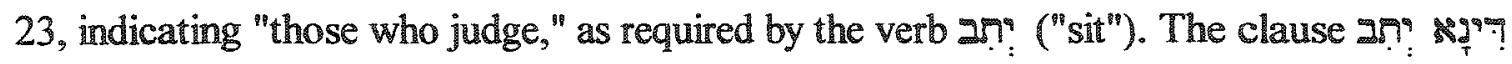
must be translated as "the judgment [i.e. those who judge] sat," implying heavenly beings, who possibly act as "associate judges." It is possible that the plurality of thrones referred to in vs. 10 was intended to be occupied by these celestial beings. It is instructive to note that apart from its occurrence in vs. 10 , where

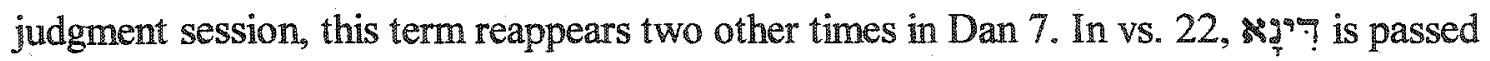
in favor of the saints of the most High, while in vs. 26, will wit to take away the dominion of the little horn and to destroy it. From this it follows that the activities of the heavenly tribunal have a double purpose: to vindicate people of YHWH depicted as "saints

Ibid., 21.

${ }^{2}$ Ferch, "The Judgment Scene in Daniel 7," 164.

${ }^{3}$ HALOT, $1: 220$, S.V. "P?T?"

${ }^{4}$ In vs. 22 however,

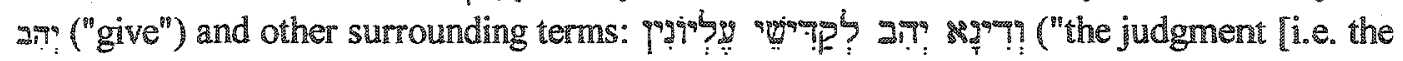
verdict] was given to the saints of the Most High"). C. . Arthur J. Ferch, "The Judgment Scene in Daniel $7, " 164$.

${ }^{5}$ Hartman and Di Lella, 218. 
of the Most High" and to annihilate the power that persecutes them, represented by the "little horn."

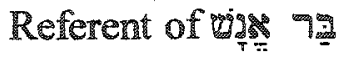

Although some scholars apply the expression of the Most High," Arthur Ferch has presented solid evidence for interpreting this figure as an individual eschatological heavenly being. The correlation between Dan 7 and 8 identifies the one like the host") referred to in $8: 11$ (see below). Furthermore, Shea observed that "the references to clouds in comnection with the person of God elsewhere in the OT indicate that the Son of Man possesses divine attributes."2

Summing up, the pericope of Dan 7:9-14 contains mainly judicial language, with some indications of a cultic setting. ${ }^{3}$ The activities of the heavenly tribunal are tantamount to the activities of the heavenly sanctuary, as noted in the discussion that follows.

\section{Heavenly Sanctuary Temple/Motif}

\section{F}

Although Dan 7:9-14 does not contain explicit references to the sanctuary/temple, its language, imagery, and comnection with Dan 8 make it apparent that the notion of a

'Ferch, The Son of Man in Daniel 7, 145-92.

${ }^{2}$ Shea, "Unity of Daniel," 216. Cf. e.g., Job 22:14; Ps 18:12-13 [11-12]).

${ }^{3}$ See the discussion of Zech 3:1-10, above, where it was pointed out that judicial and cultic procedures consist of integrated components of sanctuary activities and, therefore, cannot be separated. 
temple/sanctuary underlies the pericope. Having said that, it becomes apparent that the heavenly tribunal portrayed in Dan 7:9-14 is related to the heavenly sanctuary/temple. As such, it becomes clear that the most prominent function of the sanctuary/temple presupposed by the pericope is conceived as a place of judgment and in the context of the heavenly council of YHWH.

\section{Relationship to Earthly Counterpart}

Although Dan 7:9-14 does not contain an explicit reference to a sanctuary/temple, the cultic motifs found in the pericope seem to evoke sanctuary/temple overtones, which may indicate a vertical correspondence. Such a correspondence may be perceived in the Son of Man, who evokes a priestly figure in the Day of Atonement. This may indicate a functional correspondence between the heavenly sanctuary/temple and its earthly counterpart.

\section{Dan 8:9-14}

9 10 11 : 12 13 :

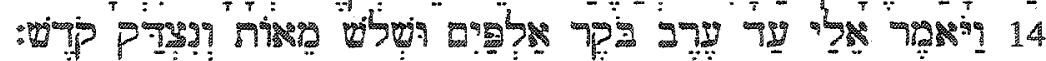

9 Out of one of them came forth a little horn which grew exceedingly great toward the south, toward the east, and toward the Beautiful Land.

10 It grew up to the host of heaven and caused some of the host and some of the stars to fall to the earth, and trampled them down.

11 He even magnified himself to be equal with the Prince of the host; and the regularity was removed from him, and the place of his sanctuary was thrown down. 
12 And a host will be given upon/with the regularity by means of transgression; and it will cast truth to the ground and will perform and will prosper. ${ }^{1}$

13 Then I heard a holy one speaking, and another holy one said to that particular one who was speaking, "Until when is the vision, the regularity, and the establishing of the transgression that causes horror, and the trampling of the host and the sanctuary?" 14 He said to me, "Until 2,300 evenings and mornings; then the sanctuary will be justified."

\section{Preliminary Observations}

The following thematic structure has been identified in Dan 8: vss. 1-2,

introduction; vss. 3-12, general vision; vss. 13-14, heavenly audition; vss. 15-26, first part of Gabriel's explanation of the revelation; vs. 27: conclusion. ${ }^{2}$ The investigation that follows will focus on vss. 9-14, which comprises the part of the general vision dealing with the little horn, its anti-YHWH activities, and the audition. This section, as Gerhard Hasel asserted, "lies at the thematic heart of chapter 8 in the book of Daniel."

"The understandings of "host" in vs. 12 depends on the interpretation of the ambiguous syntactic structure of the passage. Two main suggestions have been advanced: (1) The "host" in vs. 12 (as distinguished from the "host of heaven" in vs. 10 [cf. "prince of the host" in vs. 11]) is an evil power, somehow related to, or identified with, the little horn (So Roy Gane, "The Syntax of Tet $V^{2}$. . in Daniel 8:13," in Creation, Life, and Hope: Essays in Honor of Jacques B. Doukhan, ed. Jiri Moscala (Berrien Springs, MI: Old Testament Department, Seventh-day Adventist Theological Seminary, Andrews University, 2000), 367-82; and William H. Shea, "Spatial Dimensions in the Vision of Daniel $8, " 497-526,516$. (2) Another possibility is to understand the "host" referred to vs. 12 as the same entity mentioned in vss. 10, 11 and 13 , as negatively affected by the activities of the little horn. For a detailed defense of this view, see Martin T. Pröbstle, "A Linguistic Analysis of Daniel 8:11, 12,"JATS 7, no. 1 (1996): 86-93; Paul Birch Petersen, "The Theology and the Function of the Prayers in the Book of Daniel" (Ph.D. diss., Andrews University Theological Seminary, 1998), 204-08; Richard M. Davidson, "The Meaning of Nisdaq in Daniel 8:14," JATS 7, no. 1 (1996): 114-17.

${ }^{2}$ Hasel, "The 'Little Horn, the Heavenly Sanctuary and the Time of the End: A Study of Daniel 8:9-14," 378 .

${ }^{3}$ bid. 
Semantic and Other Exegetical Considerations

The ensuing discussion deals with the cultic language, the vertical dimension, and some key words and expressions occurring in Dan 8:9-14 and its immediate context. It is hoped that this will contribute to delineating the heavenly sanctuary/temple motif contained in this pericope.

\section{Vertical Dimension}

Like the parallel vision of Dan 7, Dan 8 contains indications of both a horizontal and a vertical dimension (earth-heaven). In vs. 9 the horizontal movement of the little hom is described. The text says that it "came forth" ( the south, toward the east, and toward the Beautiful Land." As noted by Hasel, the verb

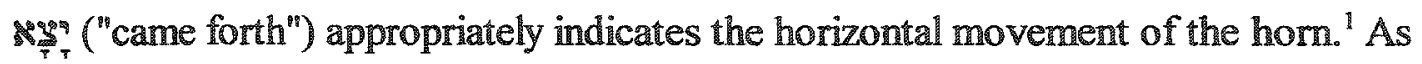
portrayed in vss. 10-11, however, the expansion of the little horn's power also occurs by means of two vertical actions. ${ }^{2}$ In the first action (vs. 10), the little horn attacked the host of heaven and threw down some of the stars. In the second (vs. 11), "he ${ }^{3}$ even magnified himself to be equal with the Prince of the Host (

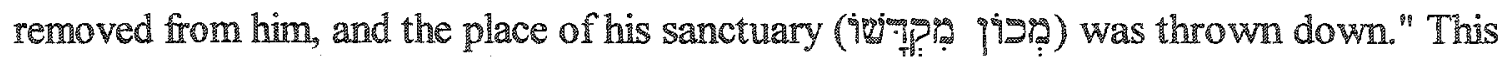
vertical movement is shown in fig. 4.

\footnotetext{
'Hasel, "The 'Little Horn,' the Heavenly Sanctuary and the Time of the End: A Study of Daniel 8:9-14," 392-93.

${ }^{2} \mathrm{Cf}$. Shea, "Spatial Dimensions in the Vision of Daniel 8," 512-19.

3In ws. 11 the grammatical gender of the verbs referring to the horn changes to masculine (in the previous verse they are feminine, thus agreeing with the feminine subject "hom"). This may imply that now the text is referring to the reality behind the symbol, as suggested by Hasel, "The 'Little Horn,' the Heavenly Sanctuary and the Time of the End: A Study of Daniel 8:9-14," 392-93.
} 


\begin{tabular}{cc}
\hline First Vertical Action $(8: 10)$ & Second Vertical Action $(8: 11)$ \\
\hline & Foundation place of the Princes"s Sanctuary \\
"the host of heaven" & $\wedge$ \\
$\wedge$ & $\wedge$ \\
"unto, even to" & $\wedge$ "The Prince" \\
"exalted" & $\wedge$ \\
$\wedge$ & "as high as" \\
The little horn & $\wedge$ \\
\hline
\end{tabular}

Fig. 4. Vertical movement of the little horn. Adapted from William H. Shea, "Spatial Dimensions in the Vision of Daniel 8," in Symposium on Daniel, ed. Frank B. Holbrook, DARCOM (Washington, DC: Biblical Research Institute, 1986), 512, 19.

It seems clear then that the actions of the little horn aim at the heavenly sanctuary. In the first action, the target is the host of heaven, probably a metaphorical expression for the people of YHWH. ${ }^{1}$ The second action is even more defiant. The little horn exalts himself as high as the Prince, and dares to throw down the "place of his [i.e., the prince's] sanctuary" ("ซึ? keep in mind that the "sanctuary" (ogepta) referred to in the passage must be other than the Jerusalem temple, since the actions of the little hom are depicted as moving in a vertical direction. The presence of words such as "heaven," "stars," and "host of heaven" in the context indicates that the "sanctuary" (of PP? ) must be located in heaven."

\section{${ }^{1} \mathrm{C}$. Dan 12:13, where the "stars" feature as a symbol of the saints.}

${ }^{2}$ It interesting to note that the idea that Dan 8:14 refers to the heavenly temple was suggested by John Everard (ca. 1575 to ca. 1650; also called Ebrard). According to Keil, Ebrard understood vs. 11 as referring "to heavenly events, to a putting away of the sacrifice from before 


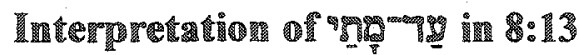

The examination of the interrogative phrase "Trp -79 ("Until when?") of 8:13

provides an interesting indication that contributes to clarify the referent of sanctuary in vs.

14. After all, the "cleansing" of the sanctuary mentioned in vs. 14 comes as a response to the question introduced by "Mng "थ (Until when") in vs. 13. This verse reads as follows:

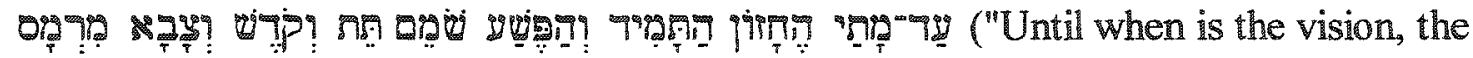
regularity, and the transgression..."). Some syntactic and semantic issues in the interpretation of this verse need to be noted.

The interrogative phrase "nู? " is not to be translated "how long?" as many versions ${ }^{1}$ and commentators ${ }^{2}$ usually do, but "Until when?" The emphasis, as Hasel demonstrated, is not upon the duration of a period of time, but upon its cumination. ${ }^{3}$ This leads to the next point. The syntactical relationship between girñ ("the vision") and 7ทตกา ("the regularity") has usually been overlooked. These two words are not in construct relationship - as the article in the first word clearly shows-but in apposition."

the throne of God and a destruction of the heavenly sanctuary" (C. F. Keil, Biblical Commentory on the Book of Doniel, trans. M. G. Easton [Grand Rapids: Eerdmans, 1959], 297). Cf. Hasel, "The 'Little Horn," the Heavenly Sanctuary and the Time of the End: A Study of Daniel 8:9-14," 454 , n. 126.

${ }^{1}$ E.g., NASB, NJB, NKJV, RSV, TNK.

${ }^{2}$ E.g., John Joseph Collins, Daniel: A Cammentary on the Book of Daniel, Hermeneia (Minneapolis: Fortress, 1993), 335; Mark Mangano, Esther and Daniel, The College Press NIV Commentary (Joplin, MO: College Press, 2001), 261; James A. Montgomery, A Critical and Exegetical Commentary on the Book of Daniel, ICC (Edinburgh: T. and T. Clark, 1950), 341.

${ }^{3}$ Hasel, "The 'Little Horn, the Heavenly Sanctuary and the Time of the End: A Study of Daniel 8:9-14," 433-34.

${ }^{4}$ Ibid. 
The expression does not concern the "vision of the regularity," but the "the vision, the regularity." This has significant implications for the interpretation of the passage since the word "vision" (9irn)- used in 8:1 to refer to the totality of the visionary description of Dan 8-implies that the scope of time involved in the question reaches back to the period of the Persian ram. "Therefore, the period of "2,300 evenings and momings" referred to in 8:14 cannot be restricted to a literal three and a half years, or 1150 days, as suggested by some scholars. ${ }^{2}$ Rather, the "2,300 evenings and mornings" must be a long period of time stretching back to the world power represented by the ram. ${ }^{3}$ Furthermore, this period cannot be interpreted as referring merely to the duration of the actions against the sanctuary, since it includes the time spanning the entire "vision" (giทฺฺ).

\section{${ }^{1} \mathrm{Cf}$. Dan 8:20.}

${ }^{2}$ Collins, 336; Arthur Jeffery, "Exegesis of the Book of Daniel," The Interpreter's Bible, ed. George Arthur Buttrick (New York: Abingdon, 1956), 6:476-77; W. Sibley Towner, Daniel, Intepretation (Atlanta: John Knox, 1984), 122.

${ }^{3}$ According to Historicist interpreters these "2,300 evenings and mornings" should be understood according to the so-called "year-day principle," which is also claimed to be consistent with other time periods in the apocalyptic prophecies of Daniel. $\mathrm{Cf}$. William H. Shea, "Poetic Relations of the Time Periods in Daniel 9:25," in The Sanctuary and the Atonement, ed. Arnold Wallenkampf and Richard Lesher (Washington, DC: Review and Herald, 1981), 277-82; idem, Selected Sudies on Prophetic Interpretation, 7 vols., DARCOM 1 (Washington, DC: General Conference of Seventh-day Adventists, 1982), 56-93; Alberto Timm, "Miniature Symbolization and the Year-Day Principle of Prophetic Interpretation," AUSS 42 (2004): 149-67.

It is instructive to note that Dan 8 contains two different Hebrew words for vision. The word girm refers to the events encompassing the entire time span of the vision from the Persian ram until the "cleansing of the sanctuary." The term ist? refers to the appearance of the two angelic figures talking about the "2,300 evenings and mornings" (vss. 13-14), hence it is called "the vision (TI\%) of the evenings and momings" (vs. 26). It was the "7xat thoubled Daniel (8:27) and is the object of explanation by Gabriel in 9:23: "At the beginning of your supplications the command was issued, and I have come to tell you, for you are highly esteemed; so give heed to the message and gain understanding of the vision (7x?m)." Cf. Shea, Selected Studies on Prophefic Interpretation, $241-46$. 
The context, therefore, indicates that the "cleansing of the sanctuary" was to occur after a period " of 2,300 evenings and mornings" had elapsed. This seems corroborated by the preposition 729 ("Until") in "Until 2,300 evenings and mornings; then the sanctuary will be justified." In the explanation of the vision by Gabriel, it becomes apparent that the vision covers a large period of time, starting with the Persian ram and culminating with the "cleansing" of the sanctuary.

\section{Cultic Language}

From the above considerations it has become apparent that the "sanctuary" referred to in the text must be the heavenly sanctuary. That being the case, further investigation is needed in order to determine the function of the heavenly sanctuary and its relationship to the earthly counterparts. As Rodriguez pointed out, Dan 8:9-14 is packed with cultic terminology. ${ }^{1}$ For the purposes of this research it suffices to review the following words and expressions:

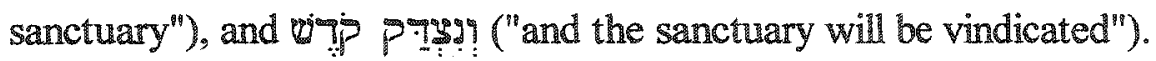

\section{Meaning of דงหุรุ}

The word ๆฯฺฺฺ ("regularity") $)^{2}$ appears several times in the Hebrew Bible in cultic contexts. This word is frequently used in adjectival genitive constructions with rלț for the

'Rodriguez, "Significance of the Cultic Languge in Daniel 8:9-14," 527-49.

${ }^{2}$ As adverb, "lasting, continually" (HALOT, s.v. "T"ִr)). Because of its connection with the regular burnt of fering ( $(7$ bis), i.e., the morning and evening sacrifices, several versions have translated Tagt: to connote regular or daily sacrifice/burnt offering, thus supplying the term "sacrifice" as if 7 rg̣: was restricted to only this aspect of the cult (cf., e.g., KJV, NASB, NIV, RSV, TNK). This interpretation faces major difficulties, as argued below. 
whole burnt offering, ${ }^{1}$ with N70?, the continual incense, ${ }^{2}$ with ant?, the continual bread, ${ }^{3}$ with 79 , the continual lamp, ${ }^{4}$ and 7 Trges, the continual grain offering. ${ }^{5}$ It is used as an

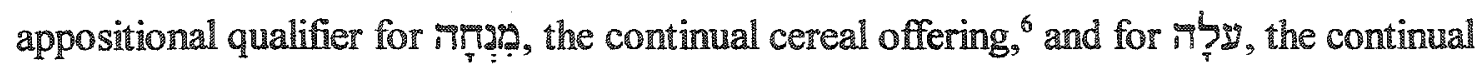
bumt offering. ${ }^{7}$ it is also used adverbially to denote regularity in some cultic duties. It refers to the "bread of presence" set regularly (once per week) before YHWH, the lamp that should burn continually, ${ }^{9}$ the continuous carrying by Aaron of the names of the sons of Israel, ${ }^{10}$ the Urim and Thummim, ${ }^{11}$ and the plate of pure gold; ${ }^{12}$ and it also indicates the fire that should burn continually on the altar. ${ }^{13}$

In view of these observations, it becomes apparent that Trap should not be restricted to one specific aspect of the sanctuary service, namely, the daily sacrifice.

${ }^{1}$ Exod 29:42; Num 28:6, 10, 15, 23; Ezra 3:5; Neh 10:34; cf. Ezek 46:15.

${ }^{2}$ Exod 30:8.

${ }^{3}$ Num 4:7.

${ }^{4}$ Exod 27:20.

${ }^{5}$ Num 4:16.

${ }^{6}$ Lev 6:13.

Num 28:3.

${ }^{8}$ Exod 25:30; Lev 24:8.

Lev $24: 2-4$

${ }^{10}$ Exod 28:29.

${ }^{11}$ Exod 28:36-38

${ }^{12}$ Exod 28:36.

${ }^{13} \operatorname{Lev} 6: 6$. 
Rather, as Rodriguez pointed out, "wa "was used in connection with the many activities the priest was commanded to perform continually in the sanctuary. ${ }^{11}$ Rodriguez also observed that these activities are related "with the ministry of the priests in the first apartment of the sanctuary." The absolute usage of $9997 \%$ in the text may have been intended to point to the daily service related to the first apartment of the sanctuary, with its focus on the continual intercession by the priest on behalf of the people. Assuming that the referent of wip in the passage is the heavenly sanctuary, one may infer a priestly ministry being carried out in the heavenly sanctuary along the lines of the earthly sanctuary/temple.

Meaning of iverops? 9is?

Although its component terms occur several times elsewhere in the Hebrew Bible, the exact locution iverper 9isp occurs only in Dan 8:11. This locution can be translated as "foundation/place of his sanctuary," according to the well-established meaning of 915\%? ("foundation/place") and wpt ("sanctuary"). The antecedent of the pronominal suffix $\dot{9}$ ["his"] in irif? ("his sanctuary") is most probably the "Prince of the Host" referred to in vs. 11. That the "sanctuary" is qualified by his pronominal suffix may indicate that the actions undertaken by the ittle horn against the sanctuary are ultimately directed against the "prince."

\footnotetext{
${ }^{1}$ Rodriguez, "Significance of the Cultic Language in Daniel 8:9-14," 533.

${ }^{2}$ Ibid., 528 .
} 
Moreover, if the sanctuary referred to in the passage is the heavenly sanctuary, it seems more reasonable to understand the 9igs" ("foundation") not in terms of a physical/material foundation, but in metaphorical or theological terms. This sense of pisp? is corroborated by the occurrence of this term in PSS 89:15 [14] and 97:2, where one learns that "righteousness and justice" are the "foundation" (9ìg) of WHWH's throne. "If the same metaphorical/theological usage obtains for Dan 8:11, it becomes apparent that the little hom does not attack a physical structure, but the theological foundation of the heavenly sanctuary, that is, YHWH's righteousness and justice.

If the connection between Dan 7 and 8 has any bearing upon the interpretation of the present pericope, the suggestion may be advanced that the attack on the foundation of the sanctuary in Dan 8:11 is related to the change of "times and law" referred to in Dan 7:25. It may also be said that the little hom, or the entity or institution represented by it, diverts human attention from the "righteousness and justice of YHWH" to "righteousness and justice" achieved by human efforts. Thus, it is not the "sanctuary" which is thrown down, but its "foundation/place." Hence it seems reasonable to suppose that the removal of the "7p? ("regularity") indicates that this attack is related to the little horn's taking over prerogatives that belonged to the "prince" of the sanctuary.

${ }^{1}$ Pss 89:15 [14]; $97: 2$.

'Hasel, "The 'Little Horn,' the Heavenly Sanctuary and the Time of the End: A Study of Daniel 8:9-14," 409-16. 
Meaning of vig? PTy?

Since the semantic contours of wip ("sanctuary") have been dealt with in chapter 3 , the following discussion focuses on the verbal form p 79 ? and the noun wip ("sanctuary"), which functions as the semantic object of the verb. Starting with pry, it must be remembered that the verbal derivatives of this root appear forty-one times ${ }^{2}$ in the Hebrew Bible. The Niphal stem pTyg occurs only in Dan 8:14 and most probably has a passive meaning. Several studies have pointed out that the root $p 7 s$ contains a broad semantic range. ${ }^{3}$

Jerome Justesen ${ }^{4}$ noted a parallelism between $p 9 y$ and derivatives of roots such as 7770 ("be clean, pure"), ${ }^{5} 1799$ ("be pure") ${ }^{6}$ and 799 ("purge out"). Although this by no means establishes an absolute definition, it certainly reveals some overlap between pres and the roots just mentioned. Worthy of note is the parallelism between $p 7 y$ and 7906 ("be

'Qal: "be in the right, be right"; Niphal: "brought to its justice, justified"; Piel: "make someone to appear righteous," "prove oneself upright," "declare as in the right"; Hiphil: "obtain rights for," "admit as right," treat as inocent"; Hithpael: "prove oneself innocent" (HALOT, s.v. "pqy"). C.. $B D B$, s.v. "Pqg."

${ }^{2} \mathrm{Cf}$. Hasel, "The 'Little Horm, "the Heavenly Sanctuary and the Time of the End: A Study of Daniel $8: 9-14, " 449$.

${ }^{3} \mathrm{Cf}$. Niels-Erik Andreasen, "Translation of Nisdaq/Katharisthesetaj in Daniel 8:14," in Symposium on Doniel, 475-96; Justesen, 53-61; Rodriguez, "Significance of the Cultic Language in Daniel 8:9-14," 543-49; Walter E. Read, "Further Observations on sädaq," AUSS 4 (1966): 2936.

\footnotetext{
4Justesen, 53-61.

${ }^{5}$ HALOT, s.v. " "ogตeger."

"Ibid., s.v. "กรi."

7bid., 1:163, s.y. "999" (a by-form of 799).
} 
clean, pure") in Job 4:17. This latter verb (7760) is a "typical term for the cultic-ritual cleanness," ${ }^{\text {"2 }}$ and is used of the cleansing of the sanctuary on the Day of Atonement. ${ }^{3}$ Consequently, it may be suggested that the use of pay in relation to the sanctuary most probably depicts Day-of-Atonement imagery.

The above suggestion is reinforced by the use of the term ("sanctuary") in

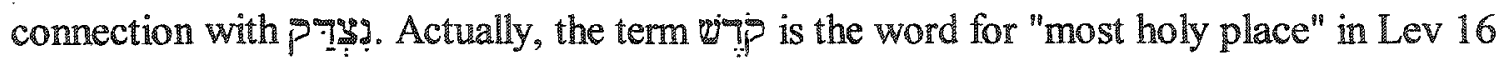
in the context of the cleansing of the sanctuary, namely, on the Day of Atonement. Hence, it is instructive to note that the terminological shift from שุ

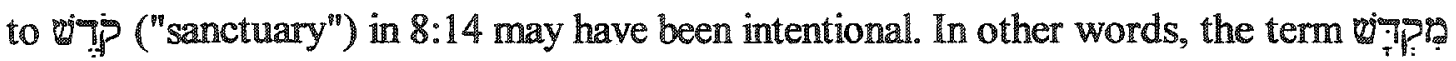
("sanctuary") is used in connection with the جงฺุ ("regularity"), that is, priestly activities related to the first apartment of the sanctuary (Dan 8:11), while the term wip appears in connection with "cleansing" of the "sanctuary" (wom) in Dan 8:14. As noted, wip ("sanctuary") is the very term used in Lev 16 to designate the "most holy place" in the Day of Atonement. ${ }^{4}$

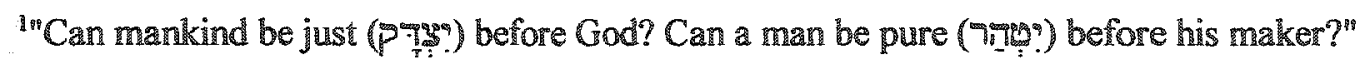

${ }^{2}$ Hasel, "The 'Little Hom, the Heavenly Sanctuary and the Time of the End: A Study of Daniel 8:9-14," 451. Cf. Hans-Jürgen Hermisson, Sprache und Ritus im altisraelitischen Kult; Zur "Spiritualisierang" der Kultbegriffe im Alten Testament, Wissenschaftliche Monographien zum Alten und Neuen Testament 19 (Neukirchen-Vluyn: Neukirchener Verlag des Erziehungsvereins, 1965), 84-99.

${ }^{3} \mathrm{Cf}$. Lev 16:9-30. Angel Rodriguez has convincingly shown that "the usage of $s d q$, especially in the Psalms, indicates that it expressed in the cultus the same idea expressed by taher in Leviticus." He further suggested that "Daniel was aware of this fact and felt free to use sdq to refer to the priestly work in the most holy place during the Day of Atonement" (Rodriguez, "Significance of the Cultic Languge in Daniel 8:9-14," 549).

${ }^{4}$ Another connection with the day of atonement can be perceived in the term swivi: "transgression" ("offence concerning propery," "crime," also "used for violation of cultic law" 
At this juncture the question emerges as to why a derivative of porg (and not $7 m$ or another) is used in connection with the sanctuary, and what kind of activities pors intends to communicate. This issue was addressed by Hasel, who suggested that pay was used because of its broad connotations. Thus, in Hasel's words:

It appears that Daniel chose the term nisdaq-a word from a root with rich and broad connotations, widely employed in judgment settings and legal procedures-in order to communicate effectively the interrelated aspects of the "cleansing" of the heavenly sanctuary in the cosmic setting of the end-time judgment. The narrow and limited aspects of other available terms did not seem to do justice to the far-reaching implications of the divine activity in the heavenly court."

At this juncture, one needs to recall the connection of Dan 8:9-14 with Dan 7:914. As noted, the heavenly judgment scene depicted in Dan 7 parallels the "cleansing" of the heavenly sanctuary in Dan 8:14. In this regard, it should be pointed out that the connection between p 79 and Davidson, ${ }^{2}$ further corroborates the idea that the heavenly sanctuary scene in Dan 8:9-14 corresponds to the heavenly judgment scene depicted in Dan 7:9-14.

Hence, the impression emerges that the "cleansing" of the heavenly sanctuary referred to in Dan $8: 14$ corresponds to the judgment undertaken by the Son of $\mathrm{Man}^{3}$ on

[HALOT, s.y. "gwe" in Dan 8:12. This is a strong word which is used in comection with the Day of Atonement in Lev 16:16,21.

'Hasel, "The 'Little Hom, the Heavenly Sanctuary and the Time of the End: A Study of Daniel 8:9-14," 453-54.

${ }^{2}$ Davidson, "The Meaning of Nisclag in Daniel 8:14," 112-15. The following passages are

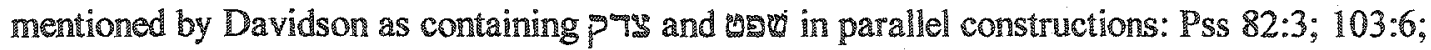
$97: 2 ;$ Isa $32: 1 ; 43: 9 ; 45: 25 ; 50: 8 ; 59: 14 ;$ Jer $22: 13 ; 22: 15 ; 23 ; 5$; Ezek $45: 9 ;$ Amos $5: 24 ; 6: 12$; Prov $21: 3$ (ibid.).

${ }^{3}$ Although some scholars may regard him as a collective designation for the "saints of the Most High" (Dan 7:18), Arthur J. Ferch has demonstrated that the Son of Man is "an individual, 
behalf of the saints as portrayed in Dan 7-a cultic/judicial activity that recalls Day-ofAtonement procedures described mainly in Lev 16. Thus the implication may be drawn

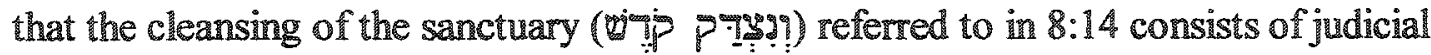
procedures undertaken by the Son of Man in the heavenly court, namely, the heavenly sanctuary.

Referent and function of sas?

Some critical scholars have sought the referent of Host" $^{\prime \prime}$ in the High Priest Onias III, assassinated in 171 by order of Antiochus IV. ${ }^{2}$ However, if the sanctuary referred to in the passage is the heavenly temple, as indicated above, one needs to look for the referent and function of the "the Prince of the Host" in the context of the passage itself, instead of reading some historical figure/event into the text.

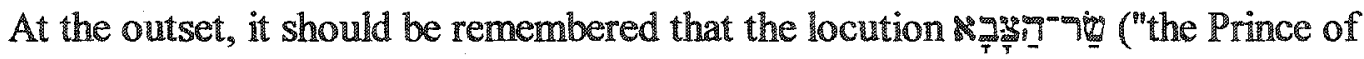
the Host $t^{\prime \prime}$ is a common expression in the Hebrew Bible for a human military commander. ${ }^{3}$

eschatological, celestial being with messianic characteristics, distinct from the saints, yet maintaining an intimate relationship with them in the endtime" (The Son of Man in Doniel 7, 192).

1J. Doukhan has pointed out that the ram and the goat, mentioned previously in Dan 8 , in addition to representing Persia and Javan [i.e., Greece] respectively, also evoke Day-of Atonement imagery since the dual offering on the Yom Kippur consisted of a goat and a ram (Lev 16:5) (Secrets of Daniel, 125-26).

${ }^{2}$ R. H. Charles, A Critical and Exegetical Commentary on the Book of Daniel (Oxford: Clarendon, 1929), 204; James A. Montgomery, A Critical and Exegetical Commentary on the Book of Daniel, ICC (Edimburgh: T. and T. Clark, 1950), 335.

${ }^{3}$ As exemplified in Josh 5:14-15 where it refers to a heavenly being who identifies himself as "the Prince of the Host of YHWH." See also Gen 21:22, 32; 26:26; Deut 20:9; Judg 4:2, 7; 1 Sam 12:9; et al. 
Jacques Doukhan pointed out that the term "ig ("prince") is used as a technical term for "high priest" 1 and "in the context of the book of Daniel the word [ๆ who is dressed with linen clothes like the high priest in the Day of Kippur." Additionally, the connections of the "prince" with the "sanctuary" and the "regularity" suggest that the "prince" is a priestly figure, a notion that can also be substantiated by the parallel passage of Dan 7:9-14.

Summing up, the "Prince of the Host" should be identified as a heavenly figure who is related to the sanctuary by means of his priestly duties. The parallel passage of Dan 7:9-14, which designates this figure as the Son of Man, implies that he is a priestly figure performing his duties in the heavenly sanctuary in a Day-of-Atonement setting. Finally, it should be pointed out that other passages of Daniel favor the identification of the "Prince of the Host" with Michael.

\section{Heavenly Sanctuary/Temple Motif}

\section{Fuanction}

The heavenly sanctuary is perceived as the locus of priestly/cultic activities. As noted, Dan 8:9-14 conceive of a priestly ministry in the heavenly sanctuary. The figure of

'Doukhan, Dariel: The Vision of the End, 37-38; cf. Ezra 8:24; 1 Chr.15:22; $24: 5$.

${ }^{2} \mathrm{Cf}$. Dan 10:5, 13, 21; 12:1. Lacocque also identifies the "Prince of the Host" with Michael; however, his view that Onias III is also included finds no support in the text. Cf. Lacocque, 162. For cogent arguments identifying the "Prince of the Host" with Michael, see Lewis Anderson, "The Michael Figure in the Book of Daniel" (Ph.D. diss., Andrews University, 1997), 296-317.

${ }^{3}$ Doukhan, Secrets of Daniel, 126. 
the "Prince of the Host," which on linguistic and contextual grounds was found to indicate a priestly, heavenly individual, corroborates this view.

Moreover, as the connection of Dan 8:9-14 with 7:9-14 makes apparent, the Day of Atonement reflected in the Dan 8 corresponds to the judgment scene depicted in Dan 7. The heavenly sanctuary thus functions as a locus of judgment in which the heavenly books were opened in order to pass judgment "in favor of the saints of the Most High."

Finally, it becomes apparent that according to Dan 8:9-14, the heavenly sanctuary plays a significant role in the context of the "great controversy" or "cosmic battle" between good and evil, inasmuch as the "foundation of the sanctuary" is attacked by the little horn. Thus, along with Isa 14:12-15 and Ezek 28:11-19, the heavenly sanctuary emerges in Dan 8:9-14 as a pivotal issue in the cosmic war between good and evil.

\section{Relationship to Earthly Counterpart}

A vertical correspondence between the heavenly sanctuary and its earthly counterpart may be perceived in the cultic language and the priestly activities in Day-ofAtonement activities portrayed in Dan 8:9-14. It seems apparent that the activities of the heavenly sanctuary are in line with those of its earthly counterpart, and therefore a functional correspondence between heavenly and earthly sanctuaries may be established.

Furthermore, the priestly/cultic activities performed in the heavenly sanctuary seem to follow a two-apartment ministration along the lines of the earthly sanctuary/temple. This suggestion is favored by the usage of wopp versus wp. It was observed that wip? occurs in connection with the ج"มุร ("regularity") activities-activities connected to the 
daily ministration of the tabernacle cultus, and thus related to its first-apartment ministry-that were removed from the "Prince of the Host." Interestingly enough, when the text shifts the focus from the attack of the little horn to the "cleansing" of the sanctuary, the terminology shifts to wigp, the word used to designate the sanctuary on the Day of Atonement in Lev 16. The text thus seems to envisage a heavenly temple with holy-place and most-holy-place activities, which indicates both functional and structural correspondences with the earthly sanctuary/temple.

\section{Dan 9:24}

\section{ת ח

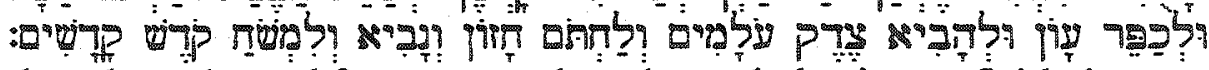
Seventy weeks have been decreed for your people and your holy city, to finish the transgression, to make an end of sin, to make atonement for iniquity, to bring in everlasting righteousness, to seal up vision and prophecy and to anoint the holy of holies.

Dan 9:24 also calls for some consideration, since, as argued below, it contains an explicit reference to the heavenly sanctuary that may contribute to this discussion. Furthermore, its connection with Dan 7 and $8^{1}$ justifies its inclusion here. Thus this brief discussion intends to ascertain the meaning and referent of the holies") mentioned in Dan 9:24, and draw implications for the present study of the heavenly sanctuary/temple motif. On the basis of $1 \mathrm{Chr} 23: 13$, which seems to apply the

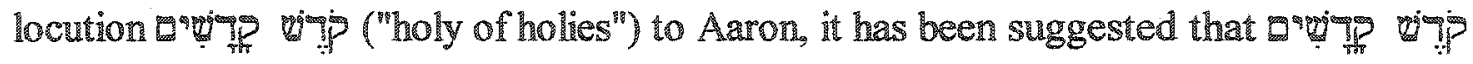

"See Shea, "Unity of Daniel," 183-219. Shea also demonstrated that in the prophecies of Dan 7, 8 and 9, "successive steps in the ministry of Christ are brought to view [i.e. Dan 9: sacrifice; Dan 8: priest; Dan 7: king]" (William H. Shea, Daniel 7-12: Prophecies of the End Time, The Abundant Life Bible Amplifier [Boise, D: Pacific Press, 1996], 155). 
("holy of holies") must also have a personal referent in Dan 9:24." This interpretation, however, has been rejected on the basis of the syntactic uncertainties surrounding the Chronicler's passage. ${ }^{2}$ As Th. Chary asserted: "It is in fact the temple that should be understood as the 'holy of holies,' which will be anointed. The expression qôdeš qodâšim is never applied to human beings. The only exception, 1 Chr $23: 13$, rests on an uncertain

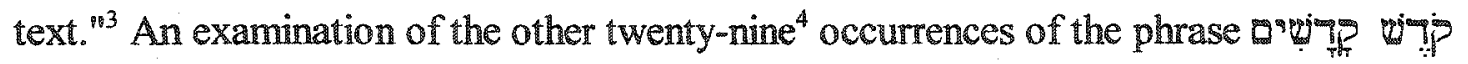
("holy of holies"), apart from Dan 9:24 and $2 \mathrm{Chr} 23: 13$, indicates that this phrase always refers to locations or objects (the tabemacle, temple, most holy place, incense, sacrifice, and objects pertaining to the sanctuary/temple). Thus, it has been rightly argued that "9ug ving carries the meaning of sanctuary/temple. As Delcor aptly summarized, "the

\section{"Lacocque, 193-94.}

${ }^{2}$ The text of 1 Chr 23:13, םำ of two ways. First, the third pronominal suffix i ("him/his") in ive"?s? may be interpreted subjectively, as referring to Aaron as the one performing the act of consecrating (miv? the

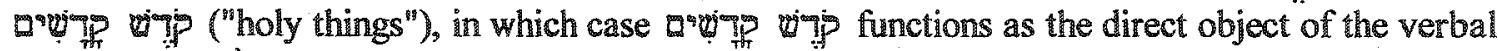
phrase ixi? "T?: "Aaron was set apart to consecrate the most holy things (lit. 'to his consecrating of the most holy things')" (ASV, KJV, NIV, NJB, NJV, NLT, NRSV, RSV). Another possibility is

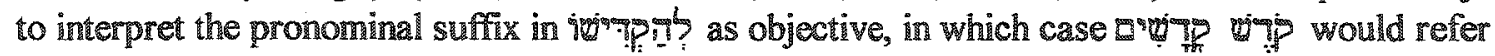
to Aaron as the object of the act of consecrating (tomp): "Aaron was set apart to consecrate him as most holy" (cf. NASB, JPS, TNK). Thus, due to this uncertain syntactic situation, a particular reading of 1 Chr 23:13 should determine the interpretation of aryong wo in Dan 9:24.

${ }^{3}$ The French reads: "C'est en effect le temple qu'il faut entendre par le 'Saint des Saints' qui recevra une onction. L'expression qôdeš qodâs̆ìm ne s'aplique jamais à de personnages humains. La seule exception éventuelle: 1 Chron., 23, 13 repose sur une texte incertain" (Théophane Chary, Les Prophètes et le Culțe à partir de l'Exil [Paris: Desclée et Cie, 1955], 43).

${ }^{4}$ Exod $26: 33 ; 29: 37 ; 30: 10,29,36 ; 40: 10 ;$ Lev $2: 3,10 ; 6: 10,18,22 ; 7: 1,6 ; 10: 12,17 ;$ $14: 13 ; 24: 9 ; 27: 28 ; \operatorname{Num} 4: 4,19 ; 18: 9 ; 1 \mathrm{Kgs} 8: 6 ;$ Ezek $41: 4 ; 43: 12 ; 45: 3 ; 48: 12 ; 1 \mathrm{Chr} 6: 34 ; 2$ Chr $3: 8,10 ; 5: 7$.

${ }^{5}$ Cf. M. Delcor, Le Livre de Doniel (Paris,: J. Gabalda, 1971), 196; Goldingay, Daniel, 229; Hartman and Di Lella, 244. 
simple explanation is to recognize here the consecration of a sanctuary. "In the same vein,

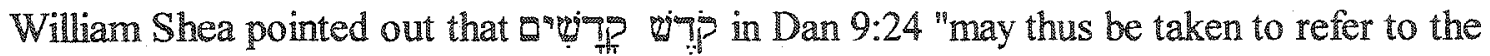
sanctuary, and to the sanctuary as a whole rather than to any part of it."

Additional corroboration for the idea that Qerep points to the sanctuary can be found in the literary structure of Dan 9:24, as shown in table 6.

TABLE 6

\section{LITERARY STRUCTURE OF DAN 9:24}

\begin{tabular}{|c|c|}
\hline \multicolumn{2}{|c|}{ 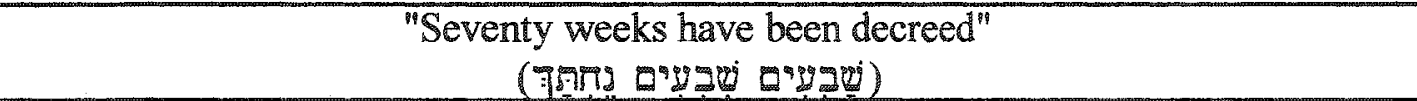 } \\
\hline A. "For your people" & B. "And your holy city" \\
\hline$(79 y-5)$ & 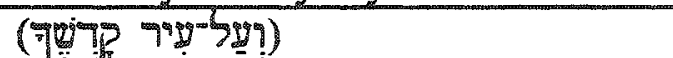 \\
\hline (1) to finish the transgression, & (1) to bring in everlasting righteousness \\
\hline (2) to make an end of $\sin$ & (2) to seal up vision and prophecy \\
\hline 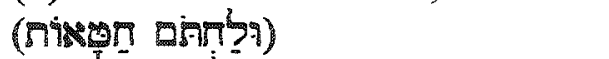 & 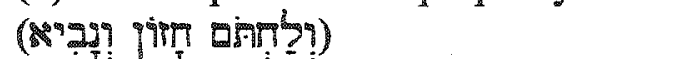 \\
\hline $\begin{array}{l}\text { (3) to make atonement for iniquity, } \\
\text { (9igs } 7 \text { as? }\end{array}$ & 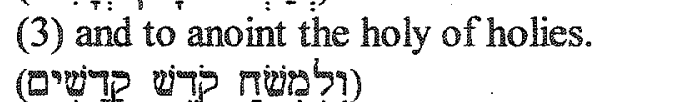 \\
\hline
\end{tabular}

Source: Adapted from Jacques Doukhan, "The Seventy Weeks of Daniel 9: An Exegetical Study," AUSS 17 (1979): 10.

As the structure shows, the two themes of the pericope are clearly stated: For your people "And your holy city." The fact that the expression "wang lies in the second column on the side of "holy city" seems to define ogrop as anctuary. ${ }^{3}$

\footnotetext{
'Delcor, 196.

${ }^{2}$ Shea, "Unity of Daniel," 233.

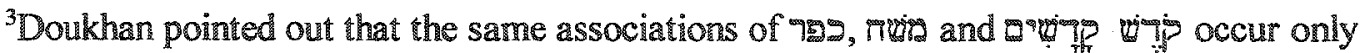


As for the referent of earthly or heavenly sanctuary. Because of their views and presuppositions on issues such as predictive prophecy, prophetic inspiration, and the date of the book of Daniel, most scholars argue for an earthly referent, that is, the Jerusalem temple during Maccabean times. Assuming, however, that Daniel 9:24-27 is predictive prophecy-not vaticinum ex eventu - and interpreting this prophecy within an historicist framework, ${ }^{1}$ a more plausible view emerges. At the outset, one notes that the prophecy foretold the rebuilding of the temple; the same prophecy also informed that the temple would be destroyed (vs. 26). Thus, ruling out an earthly referent, one is left with the heavenly sanctuary as the most probable referent for the a'ws mentioned in Dn $9: 24 .^{2}$

A final issue to be addressed in this brief discussion concerns the implications of the anointing of the heavenly sanctuary. An examination of the earthly counterparts indicates that a sanctuary/temple was anointed to inaugurate the ministrations to be carried out within it. ${ }^{3}$ Thus, in connection with the inauguration of the tabernacle, one learns that "on the day that Moses had finished setting up the tabernacle, he anointed it and consecrated it with all its furnishings and the altar and all its utensils; he anointed them and

in Exod 29:36-37. This passage deals with the consecration of Aaron and his sons to the priesthood and also involved the anointing of a arperp ("holy of holies"), namely, the altar of holocaust (ibid., 11).

\footnotetext{
${ }^{1}$ See the discussion of Dan 8:9-14, above.

${ }^{2} \mathrm{C}$. Shea, "Unity of Daniel," 233.

${ }^{3}$ Shea, "Unity of Daniel," 232.
} 
consecrated them also" (Num 7:1).' As one turns from the type to the antitype, it becomes apparent that this anointing of the heavenly sanctuary must be correlated with the commencement of the priestly ministry of the Messiah in the heavenly sanctuary after his death and resurrection. ${ }^{2}$

To conclude, Dan 9:24 indicates that the heavenly sanctuary may be understood in vertical relationship with its earthly counterpart. Thus, while the inauguration of its ministrations presupposes cultic aspects and point to a functional correspondence, the designation

\section{Other Prasages}

To broaden the basis of this investigation, a few more passages are included below. Although some of these passages may not contain explicit references to the heavenly sanctuary/temple, they are contextually and functionally related to sanctuary/temple activities and therefore contribute to complement the previous discussion.

\section{Ps 14:1-6}

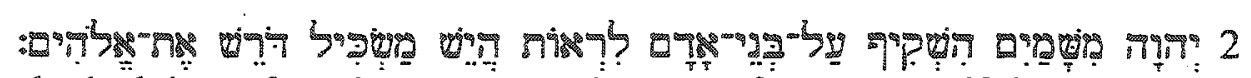
2 YHWH has looked down from heaven upon the sons of men to see if there are any who understand, who seek afier God.

Although the text contains no specific term for "sanctuary/temple," the reference to Zion (vs. 7), which evokes the Jerusalem temple, indicates that the temple motif underlies the passage. If so, the term "heaven" implies the idea of YHWH's heavenly

${ }^{1}$ Cf. Exod 40:9; Lev 8:10.

${ }^{2} \mathrm{Cf}$. Heb 8 and 9. 
abode, namely his temple in heaven, and the concept of YHWH looking down recalls other biblical texts where YHWH is portrayed as looking down from the heavenly temple/sanctuary. 'This idea, as already observed, indicates YHWH's supervision and judgment in the context of his interactions with earthly affairs. As connoted by the infinitive phrase nx? the execution of the judgment. ${ }^{2}$

The text also seems to reveal that a dynamic interaction would exist between the heavenly sanctuary/temple and its earthly counterpart. Thus, while vs. 2 reports that "YHWH has looked down from heaven," vs. 7 expresses the desire "that the salvation of Israel would come out of Zion!" The parallelism between "heaven" and "Zion" indicates that heaven (namely, the heavenly sanctuary/temple) and Zion were understood to work in close connection. Besides, the concept of judgment implied in the concept of YHWH "looking" down may indicated a functional correspondence.

\section{Ps $73: 17$ and 25}

:

17 Until I came into the sanctuary of God; then I perceived their end.

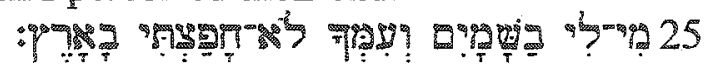

25 Whom have 1 in heaven but you? And besides you, I desire nothing on earth.

Ps 73 contains some interesting insights about the function of the sanctuary. As spelled out in vs. 17 , it is in the sanctuary that the psalmist found the decisive explanation

See Deut 26:15 (discussed in chapter 3); Isa 18:14; $23: 15$ (discussed in chapter 4); PSs 11:4; 33:13-14 and 102:20 [19] elsewhere in this chapter.

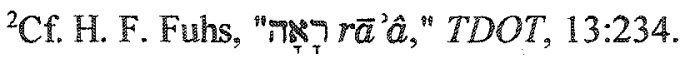


for the vexing problems of the prosperity of the wicked and the suffering of the righteous. The context implies that the sanctuary was the locus of some kind of judgment, ${ }^{2}$ which allowed the psalmist to perceive the "end" of the wicked (vs. 17). As Margaret Barker suggested, "the psalmist hints that the judgment took place in the temple; when he was overwhelmed by the wickedness of his enemies and their apparent prosperity, he admitted that he could make no sense of it. 'But when I thought how to understand this, it seemed to me a wearisome task, until I went into the sanctuary of God; then I perceived their end' $($ Psalm 73:16-17)."12

At this point one must address the issue of whether the ser the earthly or heavenly sanctuary. Although at first glance the impression arises that the sanctuary is the earthly temple, the term bs in Sx-" "sanctuaries of God") (" may indicate that the heavenly sanctuary is also in view. ${ }^{4}$ Additionally, the reference to "heaven" in vs. 25a ("Whom have I in heaven but you?") suggests that the heavenly sanctuary was somehow involved in the experience of the psalmist. Unfortunately, the text does not provide information about the kind of experience the psalmist underwent in the sanctuary. A reasonable suggestion would be that the psalmist, while in the earthly sanctuary, had a wision (cf. Isa 6:1-8) by means of which he was allowed to see the

'See vss. $18 \mathrm{ff}$.

2Barker, On Earth as It Is in Heaven, 50-51.

"The plural "sanctuaries" also occurs in Ezek 28:18. See the study of this passage, above.

${ }^{4}$ As noted by Allen, the term ("God") "not infrequently has celestial associations in the Psalter (19:2 [1]29:3; 82:1; 89:8 [7]); cf. 90:2; 95:3)" (Psalms 101-150, 322-23).

${ }^{5}$ See chapter 4 for a discussion of this passage. 
activities of the heavenly sanctuary. If so, it may be advanced that the text portrays the heavenly and earthly sanctuaries as working in dynamic interaction. Finally, as noted, the heavenly sanctuary functions as a place of judgment, and consequently the place where answers for the ultimate questions of life are provided. Such a concept indicates a functional relationship between the earthy temple and its earthly counterpart.

\section{Ps 76:8-9}

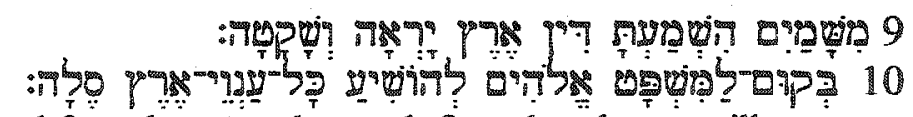

8 You caused judgment to be heard from heaven; the earth feared and was still,

9 When God arose to judgment, to save all the humble of the earth. Selah.

Ps 76 contains an interesting indication of the connection between the earthly temple and its heavenly counterpart. As Shea aptly noted, vss. 1-2 refer to the Jerusalem temple as the place where YHWH defeated the enemies of his people:" "His tabernacle is in Salem; his dwelling place also is in Zion. There he broke the flaming arrows, the shield and the sword and the weapons of war. Selah." Yet, one learns that the judgment also came down from heaven, as clearly stated in vss. 9-10 [8-9]: "You caused judgment to be heard from heaven; the earth feared and was still, when God arose to judgment, to save all the humble of the earth. Selah." If the term "heaven" presupposes the heavenly temple/sanctuary, as implied in the parallelism with "tabemacle/Zion," then it may be argued that this text depicts a close relationship between the heavenly temple/sanctuary and its earthly counterpart. That is to say, the judgment in the "tabernacle" in Zion was a reverberation of the judgment executed in the heavenly sanctuary/temple. Summing up,

\footnotetext{
${ }^{1}$ Shea, Selected Studies on Prophetic Interpretation, 1:6.
} 
the text reveals a dynamic interaction and a functional correspondence between the heavenly temple and its earthly counterpart.

PS 82:1-8

:80ำ. 1 A Psalm of Asaph. God takes his stand in the divine congregation; he judges in the midst of the heavenly beings.

For the purpose of this research, it is not necessary to dwell on the several interpretative issues raised by this psalm. It suffices to point out that the although the Ps 82 refers explicitly only to the heavenly assembly or heavenly council of $\mathrm{YHWH}^{2}$, the large context of the Hebrew Scriptures indicate that such an assembly would convene in the heavenly sanctuary/temple. The heavenly sanctuary is here portrayed as the locus of

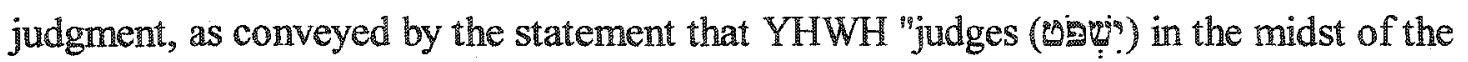
heavenly beings." It may then be suggested that PS 82 provides an interesting glimpse of the judicial activities performed in the heavenly sanctuary/temple, which indicates a functional correspondence to the earthly counterpart.

Job $1: 6$ and $2: 1$

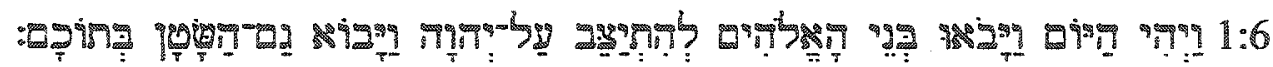
6 Now there was a day when the sons of God came to present themselves before YHWH and Satan also came among them. 73.

${ }^{1}$ For a summary of the main questions, cf. Robert Davidson, The Vitality of Worship, 270 -

${ }^{2}$ For a detailed study of this motif in the Hebrew Bible, see Mullen, 44.

${ }^{3}$ See, for example, Isa 6:1-13; Zech 3:1-10. See also 2 Kgs 22:19-23; Job 1:6; 2:1. 
The prologue of the book of Job (Job 1 and 2) depicts Satan going along with the other "sons of God" to present himself before YHWH (1:6 and 2:1). Satan's statement that he had come "from roaming about on the earth and walking around on it" $(1: 7)$ indicates that this meeting occurred not on earth, but somewhere in heaven. This is corroborated by the notion of a heavenly assembly/council session, as implied in the statement that the "sons of God came to present themselves before YHWH." Moreover, that this meeting was to happen on a specific day ( $\square$ is: setting, but seems also to suggest that the locus of this meeting was the 7g979-90 (Mount of the Assembly), ${ }^{2}$ where the heavenly beings convened under the headship of YHWH. ${ }^{3}$

That being the case, the suggestion may be advanced that although the prologue of Job does not contain specific terminological indications of the heavenly sanctuary/temple motif, it certainly presupposes this idea, as noted by James McCaffrey. ${ }^{4}$ This being so, it is instructive to note that Satan comes to the heavenly sanctuary/temple to bring accusations against YHWH, ${ }^{5}$ an idea that underscores not only the judicial function of the heavenly

'David J. A. Clines, Job, ed. David Hubbard, Glenn W. Barker, and James W. Watts, Word Biblical Commentary 17 (Waco, TX: Word Books, 1982), 17; Noman C. Habel, The Book of Job: A Commentary (Philadelphia: Westminster, 1985), 80.

${ }^{2}$ See Isa 14:13 (cf. Ezek 28:14, 16). It should be remembered that since the component

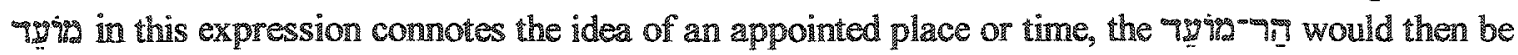
the appointed place/time where/when a cultic meeting would occur.

${ }^{3}$ This suggestion was put forth by Davidson, "Cosmic Metanarrative for the Coming Millennium, ${ }^{n} 113$.

"James McCaffrey, The House with Mony Rooms: The Temple Theme of Jn. 14,2-3 (Rome: Editrice Pontificio Istituto Biblico, 1988), 33, n. 17; 73.

${ }^{5} \mathrm{~A}$ similar situation is also reflected in Zech 3:1-10, which reports Satan's accusations against the high priest Joshua and his eventual vindication by YHWH. For an exegetical discussion 
sanctuary/temple, but, by portraying Satan's opposition to YHWH, also echoes the motif of the cosmic battle between good and evil. Thus Job 1:6 and 2:1 provide additional support for the idea that the heavenly sanctuary/temple functions as a pivotal spot in the context of the great cosmic battle between good and evil. ${ }^{1}$ As such, it functions as the place where not only YHWH, but also his people, are vindicated from Satan's accusations. Finally, it may be suggested that the judicial function implied Job $1: 6$ and $2: 1$ suggests a functional correspondence between the heavenly temple/sanctuary and its earthly counterpart.

2 Chr 30:27

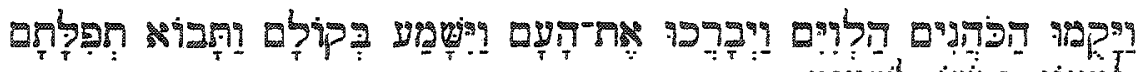

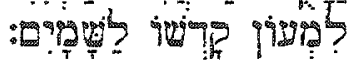

Then the Levitical priests arose and blessed the people; and their voice was heard and their prayer came to his holy dwelling place, to heaven.

The books of Chronicles display at least two allusions to the heavenly sanctuary/temple motif: one in commection with Solomon's prayer at the inauguration of the temple, and the other in the context of the Passover celebration promoted by King Hezekiah. Since the former passage was discussed in connection with the parallel text of $2 \mathrm{Kgs} 8$, in chapter 4 of this dissertation, the present consideration will be restricted to 2 Chr 30:27.

of Zech $3: 1-10$, see chapter 4 of this dissertation.

${ }^{1}$ For the connection of the heavenly sanctuary/temple motif with the concept of the great controversy or cosmic battle between good and evil, see the discussion on 1 sa 14:13 and Ezek $28: 14,16$ in chapter 4 of this dissertation. For a discussion of the cosmic battle in Job 1 and 2 , see Boyd, 143-49. 
It should be remembered that some major concems of the book of Chronicles are the Jerusalem temple, its cultic procedures, and other activities related to the proper functioning of the Temple. The theological centrality of the temple in the books of Chronicles is borne by the fact that, in large measure, the kings of Judah are evaluated on the basis of their relationship to the Temple. Therefore, it is against this backdrop that the allusions to the heavenly temple in this passage should be understood.

Two important observations should be made at this point: First, the "dwelling

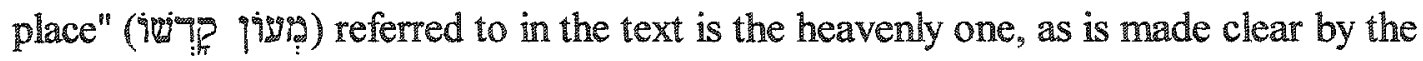
appositional phrase a located in heaven. Second, this dwelling place, since it is related to $\mathrm{YHWH}$, that is "his [YHWH's] holy dwelling place," should be understood as a sanctuary/temple. ${ }^{3}$ This idea is corroborated by the fact that the term 9igrs ("habitation") is also applied to the Jerusalem temple in $2 \mathrm{Chr} 36: 15$. It become apparent that idea conveyed by ferq? sanctuary/temple.

For the purpose of this study, inquiry should be made about the function of the heavenly sanctuary/temple referred to in $2 \mathrm{Chr} 30: 27$ as well as its relationship to the

'Cf. Peter R. Ackroyd, "Theology of the Chronicler," LTQ 8 (1973): 101-16; Roddy L. Braun, "Message of Chronicles: Rally Round the Temple, ${ }^{\text {si }}$ Concordia Theological Monthly 42 (1971): 502-14; Jonathan E. Dyck, The Theocratic Ideology of the Chronicler, BIS 33 (Leiden: Brill, 1998), 203-12; Sara Japhet, I and II Chronicles: A Commentary, OTL (Louisville, KY: Westminster/John Knox, 1993), 48; I. A. Thompson, 1, 2 Chronicles, NAB 9 (Nashville, TN: Broadman and Holman, 1994), 35-36.

${ }^{2} \mathrm{Cf}$. William Riley, King and Cullus in Chronicles: Worship and the Reinterpretation of History, ISOTSup 160 (Sheffield: ISOT Press, 1993), 37-156.

${ }^{3}$ See the definition of sanctuary/temple in chapter 1 of this dissertation. 
earthly counterpart. The statement that "their prayer came to his holy dwelling place, to heaven" suggests that the heavenly temple functions as the place where YHWH hears (and answers) prayer, an idea that appears in several other places of the Hebrew Bible!

As for the relationship between the earthly temple and its heavenly counterpart, the text indicates a vertical correspondence and a dynamic interaction. The notion that prayers offered in the earthy temple came to the heavenly temple indicates a functional relationship, and the designation of the heavenly temple as ivi? gis? indicates a structural correspondence. A dynamic interaction emerges in the fact that the heavenly and earthly temples appear to function in close connection. So, when the Levites prayed in the earthly temple, their "prayer came to his holy dwelling place, to heaven," which reveals a dynamic interaction between earthly temple and heavenly counterpart. That is, the prayers offered in the earthly temple resonate with the heavenly one from which YHWH responded. ${ }^{2}$

\section{Summary}

The investigation undertaken above has revealed that the heavenly sanctuary/temple motif is not a marginal theme in the third section of the Hebrew Bible. As a matter of fact, the presence of this motif in the various passages of the Writings has

IJacob Martin Myers, II Chronicles, The Anchor Bible 13 (Garden Ciry, NY: Doubleday, 1965), 179; Richard L. Pratt, I and 2 Chronicles (Fearm, Ross-shire, Great Britain: Mentor, 1998), 439.

${ }^{2}$ This idea is also reflected in the prayer of Solomon (see chapter 4), and several other places in the Hebrew Bible. Cf. Isa 6ff.; Ps 150:1-6. 
revealed its relevance for this section of the Hebrew Bible. The investigation undertaken in the present chapter further corroborates the basic picture delineated in chapters 3 and 4 .

The texts investigated above also conceive of the heavenly sanctuary/temple to function in a number of different, but complementary, ways. Apart from being conceived as the dwelling of YHWH or his center of command as King of the Universe, the heavenly sanctuary/temple functions as locus of judgment or tribunal, whence YHWH exerts his judicial functions by vindicating the righteous and punishing impenitent sinners. The judgment is sometimes conceived as a two-stage process, namely, an investigative phase preceding the actual execution of the sentence. In close connection to this judicial function, the heavenly sanctuary/temple is also understood as the meeting place of the council of YHWH. Moreover, the heavenly sanctuary/temple emerged as a place of worship where heavenly beings adore YHWH, source of help, and place of atonement, where cleansing and forgiveness are granted. It was also noted that as object of attack by anti-YWHW forces, the heavenly sanctuary/temple emerges an important element in the context of the cosmic battle between good and evil.

As for the relationship between the heavenly sanctuary/temple and its earthly counterpart, some functional and structural correspondences have become apparent. For example, the function of the heavenly sanctuary/temple as a place of judgment, forgiveness, atonement-functions that are also in the domain of the earthly sanctuary/temple-suggests that the heavenly temple operated in functional correspondence to its earthly counterpart. In addition, structural correspondences were 
also observed. In addition, terminological indicators point to structural similarities between the heavenly and earthly sanctuaries/temples.

Finally, this vertical correspondence goes beyond what would be expected of mere analogical entities. Some texts portray a dynamic interaction between the heavenly temple/sanctuary and its earthly counterpart. That is, the heavenly temple seem to function in connection and interaction with the earthly temple, or conversely, activities of the earthly temple would reverberate in the heavenly counterpart.

Table 7 below provides a summary of the heavenly sanctuary/temple motif in the Writings. 
TABLE 7

\section{THE HEAVENLY SANCTUARY/TEMPLE MOTIF NN THE WRITINGS}

\begin{tabular}{|c|c|c|c|c|c|}
\hline \multirow[t]{3}{*}{ Passage } & \multirow[t]{3}{*}{ Vocabulary } & \multirow[t]{3}{*}{ Function } & \multicolumn{3}{|c|}{ Relationship to Earthly Counterparts } \\
\hline & & & \multicolumn{2}{|c|}{$\begin{array}{c}\text { Vertical } \\
\text { Correspondence }\end{array}$} & \multirow[t]{2}{*}{$\begin{array}{l}\text { Dynamic } \\
\text { Connection }\end{array}$} \\
\hline & & & Functional & Structural & \\
\hline Ps $11: 1-7$ & hekat & $\begin{array}{l}\text { Judgment (two phases): } \\
\text { Investigative + executive }\end{array}$ & 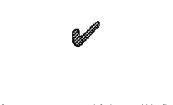 & 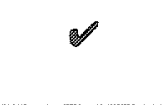 & \\
\hline $\operatorname{Ps} 14: 1-6$ & [sämayim $]$ & Judgment & 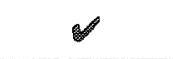 & & 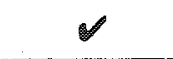 \\
\hline $\begin{array}{l}\text { Ps 20:1-19 } \\
{[20]}\end{array}$ & šĕmê qodšô & Source of help & 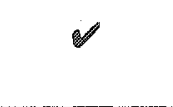 & & $\mathscr{Q}$ \\
\hline $\operatorname{Ps} 29: 1-11$ & $\begin{array}{l}\text { hadrat qōděs, } \\
\text { hêal }\end{array}$ & $\begin{array}{l}\text { Worship, praise, } \\
\text { judgment, kingship, } \\
\text { source of blessings }\end{array}$ & 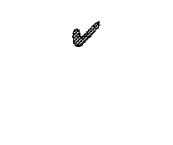 & $\mathscr{2}$ & \\
\hline Ps $33: 1-22$ & mekôn siotô & $\begin{array}{l}\text { Dwelling, supervision, } \\
\text { judgment, salvation }\end{array}$ & 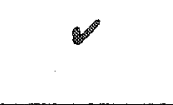 & 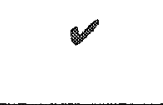 & \\
\hline $\begin{array}{l}\text { Ps } 60: 1-14 \\
{[12]}\end{array}$ & goder & Source of help & 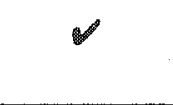 & 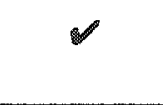 & 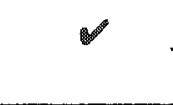 \\
\hline $\begin{array}{l}\text { Ps 68:1-36 } \\
{[35]}\end{array}$ & $\begin{array}{l}\text { mérôn qodsô } \\
\text { miqdaś }\end{array}$ & Judgment & 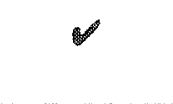 & 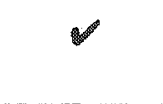 & 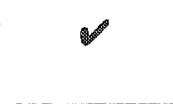 \\
\hline Ps 73:17, 25 & migdšé è & Judgment & 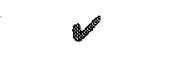 & & 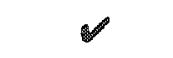 \\
\hline Ps 76:8-9 & [šămayim] & Judgment & 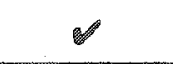 & & $\mathscr{H}$ \\
\hline Ps 82:1-8 & ['ădar 'ê] & Judgment & $\mathscr{H}$ & & \\
\hline Ps 96:1-13 & migdās & $\begin{array}{l}\text { Kingship, worship, } \\
\text { Judgment }\end{array}$ & 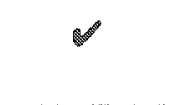 & 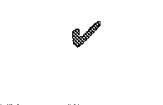 & 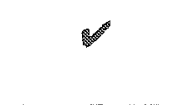 \\
\hline $\begin{array}{l}\text { Ps } 102: 20-21 \\
{[19-20]}\end{array}$ & $\begin{array}{l}\text { mĕrôm } \\
\text { qodšô }\end{array}$ & $\begin{array}{l}\text { Source of help, judgment } \\
\text { (investigative }+ \\
\text { executive), kingship }\end{array}$ & 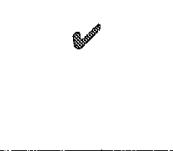 & 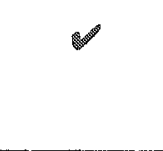 & \\
\hline PS 150:1-6 & godes & Worship & $\mathscr{H}$ & $\mathscr{O}$ & $\mathscr{H}$ \\
\hline $\operatorname{Job} 1: 6 ; 2: 1$ & Implied & $\begin{array}{l}\text { Heaveniy council, cosmic } \\
\text { bathle, judicial aspects }\end{array}$ & 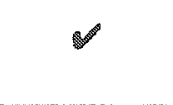 & & \\
\hline
\end{tabular}


TABLE 7-continued.

\begin{tabular}{|c|c|c|c|c|c|}
\hline \multirow[t]{3}{*}{ Passage } & \multirow[t]{3}{*}{ Vocabulary } & \multirow[t]{3}{*}{ Function } & \multicolumn{3}{|c|}{ Relationship to Earthly Counterpart } \\
\hline & & & \multicolumn{2}{|c|}{$\begin{array}{c}\text { Vertical } \\
\text { Correspondence }\end{array}$} & \multirow[t]{2}{*}{$\begin{array}{l}\text { Dynamic } \\
\text { Connection }\end{array}$} \\
\hline & & & Functional & Structural & \\
\hline Dan 7:9-14 & Implied & $\begin{array}{l}\text { Judgment, heavenly } \\
\text { council }\end{array}$ & 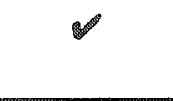 & & \\
\hline Dan $8: 9-14$ & $\begin{array}{l}\text { qodeřs, } \\
\text { miquăšs }\end{array}$ & $\begin{array}{l}\text { Judgment, cultic } \\
\text { functions, cosmic battle }\end{array}$ & 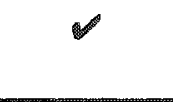 & 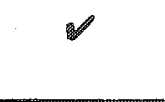 & \\
\hline Dan 9:24 & $\begin{array}{l}\text { qodeš } \\
\text { qodāsim }\end{array}$ & $\begin{array}{l}\text { Cultic functions: } \\
\text { inauguration/consecration }\end{array}$ & $\mathscr{V}$ & $\mathscr{V}$ & \\
\hline $2 \mathrm{Chr} 30: 27$ & mě ôn qodšô & Worship & 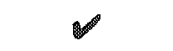 & 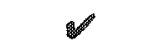 & 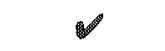 \\
\hline
\end{tabular}




\section{CHAPTER 6}

\section{THEOLOGICAL SYNTHESIS}

In the first chapter of this dissertation, it was found that the idea of a heavenly sanctuary/temple was a significant motif in the ANE literature. In like manner, as the forty-three biblical passages investigated in the subsequent chapters have demonstrated, this idea is by no means marginal to the Hebrew Scriptures. In this last chapter, the insights from the previous chapters are synthesized and summarized so that a theological synthesis of the heavenly sanctuary/temple motif in the Hebrew Bible may be delineated.

At first the heavenly sanctuary/temple motif is placed against the background of ANE literature so that the biblical usage of this motif may be brought into a sharper focus. Next, attention is given to the function and role of the heavenly temple/sanctuary in relation to the theological themes of judgment, cosmic battle, covenant, and the experience of the individual. Finally, the theological implications of the connection between the heavenly sanctuary/temple and its earthly counterparts will be delineated; the focus will be on the dynamic, functional relationship, and structural correspondence between the heavenly sanctuary and its earthly counterpart. 


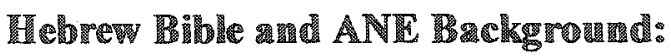 Simillarities and Differeaces}

The study conducted in the first chapter of this research allowed some instructive glimpses into the ANE perception of the heavenly sanctuary/temple motif. It was found that the ANE understanding of the heavenly temple/sanctuary resembles closely that of the Hebrew Bible in some aspects. Overall the heavenly temple/sanctuary is understood not only as the dwelling place for the deity/ies, but also as a place of divine activities whence the deity/ies would issue decrees and commands to deal with the created order. In other words, the heavenly sanctuary/temple would function as a place where judicial activities toward the created order are executed. In this regard it is worth noting that the heavenly temple/sanctuary functions as the meeting place for the heavenly council of the gods, which should also be understood within the general idea of judgment, since the divine council convenes to take part in a process of decision or judgment. According to ANE texts, the heavenly sanctuary/temple was also understood as a place of cultic/ritual activities wherein prayers and offerings could be presented to the deity.

Nonetheless, in spite of the similarities between the Hebrew Bible and the ANE literature in the portrayal of the heavenly sanctuary/temple motif, some significant differences emerge. The most conspicuous and obvious distinction emanates from the fact that the ANE literature is rooted in polytheistic and mythical conceptions, while the Hebrew Bible presupposes the reality of One God, YHWH. Thus while ANE texts conceive of several heavenly or mythical dwellings for a plurality of deities, the Hebrew Bible conceives of a single heavenly sanctuary/temple of YHWH. It may be conjectured 
that because of this, the heavenly sanctuary/temple plays a more prominent role in the sphere of individual piety, than it seems the case with its ANE counterparts. Thus, for example, the prayers of the psalmist with a plea for YHWH to answer from the heavenly sanctuary/temple are conspicuously absent from ANE literature. ${ }^{1}$ The impression thus emerges that the idea of a heavenly temple was significantly more practical and relevant for the Israelites than it was for their neighbors. Interestingly enough, in the ANE literature the heavenly sanctuary/temple motif was mostly confined to mythical accounts describing interactions among the gods, whereas in the Hebrew Bible this motif occurs in a variety of literary types such as, for example, historical, poetic, and prophetic texts.

To conclude, it was found that, despite some dissimilarities, both the ANE literature and the Hebrew Bible share some basic aspects of the heavenly sanctuary/temple motif. These commonalities, however, by no means suggest that the biblical authors borrowed the idea of a heavenly sanctuary/temple from their ANE counterparts. The differences in theological outlook between the monotheism of biblical literature and the polytheism reflected in ANE texts make any theory of literary dependance extremely unlikely. What may explain the similarities and differences, however, is that both the Hebrew Bible and the ANE literature shared some common traditions regarding the heavenly sanctuary/temple. Thus, for example, the notion that the heavenly sanctuary/temple would function as a place of judgment, or was attacked by an enemy of

\footnotetext{
A seeming exception occurs in an Egyptian text in which the heavenly sanctuary/temple is portrayed as a source of help. See the chapter 2 of this dissertation.
} 
the deity most likely reaches back to a common tradition that preceded in time the formation of both ANE literature and the Hebrew Bible.

\section{Heavenly Sanctuary/Temple and Judgment}

As noted, a prominent function of the heavenly sanctuary/temple is that of being a locus of judgment. Indeed, it is from the heavenly sanctuary/temple that YHWH evaluates and judges humankind, taking crucial decisions concerning the punishment of the wicked and the salvation/deliverance of the righteous. The frequent reference to prayers being directed to YHWH in the heavenly sanctuary/temple further corroborates the notion that the heavenly sanctuary/temple functions as the place where YHWH takes decisions and actions concerning the lives of those living upon the earth. The fact that several texts explicitly mention the heavenly sanctuary/temple (or some other analogous term) as the place where YHWH issues judgments seems to emphasize the importance of the sanctuary/temple as the locus of YHWH's activities.

The examination of several passages conveying the idea of judgment from the heavenly sanctuary/temple reveals that this judgment, in some cases, occurs in a two-stage process. Thus, as implied in Gen 11:1-9 and made more explicit in passages such as Mic 1:2-3, Pss 11:4, 102:19-20, the actual execution of the judgment is preceded by an investigative phase in which the facts of the matter are weighed and evaluated. The same idea can also be discerned in Dan 8:9-14 which, as suggested by the contextual indications of Dan 7, portrays the purification/vindication of the heavenly sanctuary in the context of the judicial activities of the Day of Atonement. In this regard, the connection of the 
heavenly council of YHWH in conjunction with the heavenly sanctuary/temple allows one to infer that the heavenly beings were also involved as assistants or witnesses in this process of judgment, an inference that can be made on the basis of texts such as $1 \mathrm{Kgs}$ 22:19-23, Zech 3:1-10, Dan 7:9-14.

\section{Heavenly Samctuary T Temple amd the Cosmic Battle}

The heavenly sanctuary/temple emerges in the Hebrew Scriptures as the "cosmic battleground"1 of the great controversy between good and evil. It becomes apparent, as noted in Isa 14:12-15 and Ezek 28:11-19, that the heavenly temple was the object of an attack and profanation caused by a figure identified as the King of Babylon and the King of Tyre, respectively. From Isa 14:12-15, the picture emerges of an attack on the Mount of Assembly by the King of Babylon. Granting that the Mount of Assembly refers to the heavenly sanctuary/temple, as cogently argued by Davidson, ${ }^{2}$ and further corroborated by the investigation conducted previously in this dissertation, the picture emerges of the heavenly sanctuary/temple as a crucial spot which the forces of evil, personified by the King of Babylon, attempted to take over. The crucial issue seems to be that of worship. The "Son of the Moming" coveted to receive the adoration due only to YHWH. It is

"Davidson, "Cosmic Metanarrative," 104; C1. also Alberto Timm "Desenvolvimento da Doutrina do Santuário no Contexto do Conflito Cósmico," Material de Classe para o Programa de Doutorado em Teologia, Seminário Adventista Latino-Americano de Teologia, Universidade Adventista del Plata Argentina, 1997, 1-27; idem, "The Sanctuary Motif within the Framework of the Great Controversy," in The Cosmic Battle for Planet Earth: Essoys in Honor of Norman $\mathbb{R}$. Gulley, ed. Ronald A. G. Du Preez and Jiri Moskala (Berrien Springs, MI: Andrews University, 2003), 69-84.

$$
{ }^{2} \text { bid., } 102-19
$$


observed that, in order to accomplish his sinful intention, that rebellious creature made an attempt to take over the Mount of Assembly, namely the heavenly sanctuary/temple, or place of worship in the heavenly realm.

In the passage of Ezek $28: 11-19$, it was noted that the King of Tyre, also designated as "the anointed cherub who covers, profaned the heavenly sanctuary. The implication thus emerged that the heavenly sanctuary/temple was the object of an improper action by the one who was supposed to "cover." It must be remembered that in the earthly sanctuary/temple, the covering cherubim were located in the most holy place as coverers of the Ark of the Covenant, in the holiest compartment of the sanctuary/temple wherein YHWH would manifest his presence in the most concrete way. Thus, assuming a structural parallel with the heavenly counterpart, it is reasonable to suppose that the "covering cherub" of Ezek 28:14 was a creature with access to, and entitled to special functions in, the most holy place of the heavenly sanctuary/temple. That being the case, the rebellious action of that creature represented the ultimate transgression, since it affected the most sacred spot of the heavenly realm.

Along the lines of the previous passages, one should note that Dan 8:9-14 also depicts the heavenly sanctuary as an object of attack by the little hom, which represents an anti-YHWH power. So, again the heavenly sanctuary is placed in the center of the controversy between good and evil; or, in other words, the cosmic war between YHWH and the forces of evil. 


\section{Heavenly Sanctuary/Temple Covenant}

The heavenly sanctuary/temple motif also intersects with covenant theology. As noted in the study of Gen 28:1-11, when YHWH ratifies the promises of the covenant with Abraham (and Isaac) to Jacob, the picture emerges of a ladder uniting the heavenly sanctuary/temple (the gate of heaven) with the earthly spot which in that precise moment was operating in the capacity of the earthly sanctuary, namely Beth-el. In that situation the heavenly sanctuary/temple was functioning to validate the procedures being taken in the earthly one.

Another connection between heavenly sanctuary temple and covenant can be perceived in the narrative of the Sinaitic covenant. In the context of the instructions to build the tabernacle, Moses was shown a תַ ("model") of what should be built on earth. This ת התבְנית, as argued before, most probably involved a vision of the heavenly sanctuary/temple, as implied in the appearance of the throne of YHWH and the sapphire pavement (cf. Exod 24:10). Also, it was noted that the covenant meal celebrated by the seventy elders of Israel at a certain distance from the top of the mount happened in the context of a heavenly sanctuary/temple vision. The implication can be drawn that the Sinaitic covenant occurred in the context of a heavenly sanctuary/temple experience. This indicates that the establishment of the covenant between YHWH and the people of Israel at Sinai was an event ratified and legitimated by actions of YHWH in the heavenly sanctuary/temple.

An interesting correlation between heavenly sanctuary/temple and covenant is found also in Exod 32-34. In the episode of the golden calf, the covenant transgression 
was atoned for by YHWH's action in the heavenly temple/sanctuary, as implied in the context. Thus the notion emerges of a heavenly sanctuary/temple as the locus of actions bearing upon the covenant between YHWH and Israel. In this case, the focus is on the atonement and forgiveness executed by YHWH in the heavenly temple/sanctuary. In Mic 1:2-3 one finds a connection of the heavenly sanctuary/temple motif with the covenant. In this passage, the heavenly sanctuary/temple activities are described as a covenant lawsuit, whereby YHWH in the heavenly temple judges his people for their breaking of the covenant.

From the foregoing observations, the impression emerges of a heavenly sanctuary/temple fully active in the covenantal experience of ancient Israel. These covenantal activities may be thus classified in three categories. First, the heavenly sanctuary/temple functioned as a surety for the covenant, as implied in Gen 28:1-11 and Exod 24:9-11. Second, the heavenly sanctuary functioned as a place where YHWH granted atonement and forgiveness to his people in the context of covenant transgression. Third, the heavenly sanctuary/temple relates with the covenant inasmuch as it is depicted as the place wherein YHWH undertakes a covenant lawsuit against his people because of their breaking of the covenant.

Summing up, it may be concluded that the heavenly sanctuary/temple was a significant element in the context of the covenant relationship between YHWH and Israel, and as such, the heavenly sanctuary does not belong exclusively to the "New" Covenant, 
but was fully operative during the establishment and enforcement of the "Old" Covenant as well. ${ }^{1}$

\section{Reldionship to Earthly Counterparts}

In this section attention is given to three aspects that were perceived in the relationship and correspondence between the heavenly temple/sanctuary and its earthly counterparts. First, it was noted that there is a dynamic relationship, namely, the heavenly sanctuary/temple interacts with, and affects the proceedings of, the earthly temple.

Second, there is a functional correspondence between both sanctuaries, in that both execute corresponding functions. Third, some passages imply a structural correspondence between the heavenly sanctuary/temple and its earthly counterparts, as elaborated below.

\section{Dymamic Interaction}

As noted previously, the heavenly sanctuary was understood to be in dynamic interaction to its earthly counterparts. The first explicit indication of this relationship occurs in Gen 28:11-22. In this passage, the ladder shown to Jacob in the dream effected not only a connection between heaven and earth, but a linkage between the heavenly sanctuary/temple and its earthly counterparts. This seems to be a natural inference considering the terminological and conceptual links with sanctuary language present in the pericope. Thus, the incipient sanctuary built by Jacob is linked up to its heavenly counterpart. Whatever the function of this linkage in the immediate context of the dream,

'This is further corroborated by the dynamic relationship between the heavenly sanctuary and its earthly counterpart, as will be noted below. 
it seems apparent that a principle is established that henceforward the subsequent sanctuaries would be characterized by the connection with the heavenly one.

In Solomon's prayer ( $1 \mathrm{Kgs} 8: 22 \mathrm{ff}$ ), the motion emerged that the petitions offered toward the earthly temple would be answered from the heavenly one. Moreover, activities of atonement and forgiveness, along with judicial procedures, performed in the earthly temple would ultimately be validated in the heavenly counterparts. Also, in $1 \mathrm{Kgs} 22: 19$ 23 , it was noted that procedures taken in the heavenly court/temple affected earthly circumstances. In Isa $6: 1-7$, one learned how closely connected heavenly and earthly temples could be. Here the heavenly temple was shown to interact with and affect the earthly temple. Thus it was perceived that, as Isaiah came into the Jerusalem Temple, he saw a vision of the heavenly temple. As the vision proceeded, actions undertaken in the heavenly temple effected the purification of the prophet.

Significant passages in this connection are Ezek 1 and 10. The prophet receives a vision in which heavenly realities come down to interact with the realities of the earthly temple. The implication is that the Glory of YHWH left the heavenly temple in order to occupy its corresponding place in the earthly temple. Another passage indicating this dynamic relationship is Zech $3: 1-10$. Here it was perceived that ritual actions performed in the earthly temple caused the purification of the high priest Joshua, thus making him fit for the ministry of the Jerusalem temple. This passage is important in that it demonstrates how actions in the heavenly temple could affect the performance of its earthly counterparts.

A close interaction between the heavenly temple and its earthly counterpart is also evident in $2 \mathrm{Chr} 30: 27$. Here one learns that as the Levitical priests arose and blessed the 
people, "their voice was heard and their prayer came to his holy dwelling place, to heaven." This passage is significant inasmuch as it depicts the liturgical activities of the earthly temple interacting with the heavenly counterpart. Not only was the heavenly temple able to affect the earthly counterpart, but the reverse was also possible, as is clearly demonstrated by the last passage.

Other passages, by means of rhetorical devices and ambivalent expressions, seem to imply a relationship between the heavenly temple/sanctuary and its earthly counterpart. Ps 68:1ff. seems to alternate references to the heavenly temple with allusions to the earthly temple, thus implying that both were operating together. And Ps 150 implies a close connection between the heavenly temple and its earthly counterpart in that the appeal to praise YHWH in his heavenly sanctuary (vs. 1) includes the worship to be offered in the earthly temple.

Summing up, in may be stated that the heavenly sanctuary/temple was understood to function in close connection to its earthly counterpart. It was found that the vertical movement of this dynamic relationship could operate either from heaven to earth, from earth to heaven, or in both directions simultaneously. That is to say, the heavenly sanctuary could affect the earthly counterpart; be affected by it, or work in close connection with mutual cooperation.

\section{Structural Correspondence}

The injunction that Moses should build a tabernacle according to the Mgy? ("model") shown on the mount (Exod 25:9) seems to indicate that the correspondence 
between the earthly sanctuary and its Vorbild reflected not merely functional aspects, but included structural similarities. As observed in chapter 3 , it is very probable that the concept of n9y ("model") included a vision of the heavenly temple/sanctuary. That being so, the notion of a structural correspondence between the heavenly sanctuary and its earthly counterpart is further underscored. After all, a visual representation of the heavenly sanctuary would not only function as a major guideline for the different rituals and functions of the sanctuary ministry, but would indicate a structural correspondence insofar as the structure of the earthly sanctuary would somehow mirror that of the n9g. ("model") or heavenly temple.

Indeed, this structural correspondence between the heavenly temple and its earthly counterpart is corroborated by subsequent passages of the Hebrew Bible. In Isa 6:6 one learns of an altar (of incense) in the heavenly temple, which seems to correspond to the altar of incense located in the earthly temple. In Ezek 1 and 10 one can perceive a corresponding relationship between the heavenly cherubim and their earthly counterparts, namely, the golden cherubim of the earthly temple. Another important indication of a structural correspondence is found in Ezek 28:16. The reference to the "covering" cherub in the heavenly sanctuary seems to indicate that the heavenly sanctuary/temple would be served by a "covering" cherub corresponding to the golden cherubim in the holy of holies of the sanctuary/temple, and the cherubim stationed at the entrance of the Garden of Eden (Gen $3: 24)$. That being the case, one can reasonably infer a structural correspondence between the heavenly temple and its earthly counterparts. One should note, however, that while the earthly sanctuary temple would contain a golden cherubim, the heavenly 
counterparts were living beings. Thus it becomes apparent that an intensification or escalation from the type to its antitype obtains in regards to this vertical typology.

In addition to the particular structural elements noted above, it should be observed that the vocabulary used throughout the Hebrew Bible to designate the heavenly temple/sanctuary corroborates the basic notion of a structural correspondence indicated by

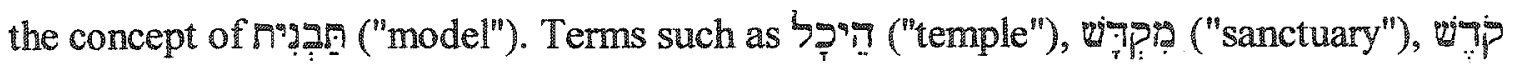
("sanctuary") and others ${ }^{1}$ may designate either the heavenly sanctuary/temple or its earthly counterparts suggest that the heavenly referent of these terms should be understood in structural correspondence to the earthly counterpart. Nonetheless, it must be noted the Hebrew words לำ ("tent"), ก" ("house"), and applied to the earthly sanctuary/temple, do not seem to be applied to the heavenly temple/sanctuary. It is probable that the notion of contingency and temporariness connoted by bys ("tent") and pove ("tabernacle"), and the common word for human habitation 7 ("house") are not fit to designate the permanent heavenly sanctuary/temple of YHWH. It may thus be concluded that although the heavenly sanctuary/temple corresponds structurally to the earthly counterpart, it is far greater than the earthly counterpart. An intensification from type to antitype is thus indicated.

\section{Functional Correspondence}

By functional correspondence is meant that the functions executed by YHWH in his heavenly temple are closely related to the functions being executed by the priests in the

${ }^{1}$ For a list of the sanctuary/temple terms, see the summary charts at the end of chapters 3 , 4 , and 5 . 
earthly temple. Thus one may note the function of judgment, which is a major function of the heavenly temple, as already pointed out. Also, along the lines of its earthly counterpart, the heavenly temple is depicted as a place of worship wherein the heavenly assembly worships YHWH. Cultic activities such as atonement, forgiveness, and cleansing have also been clearly ascribed to the heavenly temple (Exod $32-34$, Isa 6:1-8; Zech $3: 1-$ 10). The passage of Dan 8:9-14, which depicts Day-of-Atonement activities in the heavenly sanctuary, also provides some compelling evidence for the functional correspondence between the heavenly temple and its earthly counterpart. It should be noted that this functional correspondence reveals an intensification from type to antitype. Thus, for example, the limited scope of the activities performed in the earthly temple is a reflex of the cosmic actions undertaken by YHWH in the heavenly temple.

In addition, it should be remembered that the allusion to the heavenly sanctuary as "Eden, the garden of God" (Ezek 28:13), along with the evidence that the Garden of Eden described in Gen 2 functioned as a sanctuary/temple, suggests a functional correspondence between the heavenly sanctuary and the Carden of Eden.

Summing up, it may be stated that a dynamic interaction, structural and functional correspondences with an intensification from type to antitype was identified to exist between the heavenly sanctuary/temple and its earthly counterpart.

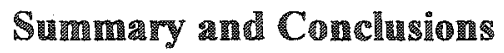

After surveying forty-three passages dealing with the heavenly sanctuary/temple motif in the Hebrew Bible, the following conclusions may be drawn (see table 8 , at the end 
of this chapter for a summary of the heavenly sanctuary/temple passages investigated in chapter 3,4 , and 5 of this dissertation):

1. The Hebrew Bible conceives of the heavenly sanctuary/temple as a place of divine activities, from which YHWH performs actions of judgment and government of the cosmos, grants help to the afflicted, and executes actions of atonement and forgiveness.

2. The heavenly sanctuary/temple was understood as existing in structural and vertical correspondence to the earthly counterpart, and an intensification from type to antitype was observed. In addition, the notion also emerged of a dynamic interaction between the heavenly sanctuary/temple and its earthly counterpart.

3. The heavenly sanctuary/temple seems to play a prominent role in the cosmic controversy between good and evil, inasmuch as it is portrayed as an object of attack by anti-YHWH forces.

4. The heavenly sanctuary/temple also emerges in connection with the covenant idea, since it is presented as a place where YHWH ratifies the covenant.

5. The investigation conducted above claims to have provided a broad exegetical and theological basis for the concept of a vertical typology of the heavenly sanctuary/temple motif in the Hebrew Bible.

6. A further implication of this research is that the heavenly sanctuary/temple is a place in heaven and, therefore, should not be interpreted as a metaphor for YHWH's presence or as a reality coextensive with heaven.

In contrast to Greek philosophy and its notion of a timeless God, the biblical idea of YHWH's involvement with creation and his temporal actions in history suggests that the concept of YHWH's heavenly sanctuary/temple should be interpreted at face value. See Fernando Luis 


\section{Suggestions for Further Stady}

It would be instructive to investigate the heavenly sanctuary temple motif in later texts such as the Dead Sea Scrolls and later Jewish literature in order to ascertain how the heavenly sanctuary/temple motif in was understood in different contexts. In addition, a detailed study of this motif in the New Testament might be illuminating. Such a study might help clarify to what extent the New Testament writers used the Hebrew Bible in their formulating of the heavenly sanctuary/temple idea.

Canale, "Philosophical Foundations and the Biblical Sanctuary," Andrews University Seminary Studies 36 (1998): 183-206. 
TABLE 8

THE HEAVENLY SANCTUARY/TEMPLE MOTIF IN THE HEBREW BIBLE

\begin{tabular}{|c|c|c|c|c|c|}
\hline \multicolumn{6}{|c|}{ TORAH } \\
\hline & & & \multicolumn{2}{|c|}{$\begin{array}{l}\text { Vertical } \\
\text { Correspondence }\end{array}$} & $\begin{array}{l}\text { Dynamic } \\
\text { Interaction }\end{array}$ \\
\hline & & & Functional & Structural & \\
\hline Gen $11: 1-9$ & $\begin{array}{l}\text { [yrd, } \\
\text { šämayim] }\end{array}$ & $\begin{array}{l}\text { Judgment (investigative } \\
+ \text { executive) }\end{array}$ & & & \\
\hline Gen $28: 10-22$ & $\begin{array}{l}\text { ša 'ar } \\
\text { haššămayim }\end{array}$ & Ratification of covenant & $\bullet$ & & 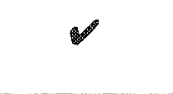 \\
\hline Exod 15:1-18 & qōdeš & $\begin{array}{l}\text { Heavenly assembly, } \\
\text { worship, kingship }\end{array}$ & $\mathscr{V}$ & $\vartheta$ & \\
\hline Exod 24:9-11 & $\begin{array}{l}\text { [libnat } \\
\text { hassappî, } \\
\text { haššamayim] }\end{array}$ & Kingship, covenant & 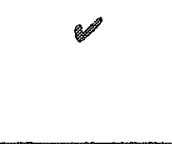 & & $\mathscr{\theta}$ \\
\hline Exod 25:9, 40 & tabañt & $\begin{array}{l}\text { Model for the } \\
\text { construction the earthly } \\
\text { sanctuary }\end{array}$ & & 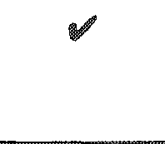 & \\
\hline Exod 32-34 & [implied] & Place of atonement & 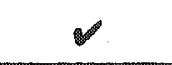 & & \\
\hline Deut 26:15 & $\begin{array}{l}\text { méóñ } \\
\text { qodšêkà }\end{array}$ & $\begin{array}{l}\text { Prayers, blessings, } \\
\text { fertility }\end{array}$ & $\mathscr{U}$ & $v$ & \\
\hline \multicolumn{6}{|c|}{ PROPHETS } \\
\hline & & & \multicolumn{2}{|c|}{$\begin{array}{l}\text { Vertical } \\
\text { Correspondence }\end{array}$} & $\begin{array}{l}\text { Dynamic } \\
\text { Interaction }\end{array}$ \\
\hline & & & Functional & Structural & \\
\hline $2 \operatorname{Sam} 22: 1-51$ & hêka & $\begin{array}{l}\text { Source of help, } \\
\text { judgment, vindication of } \\
\text { the righteous, other } \\
\text { cultic aspects }\end{array}$ & $\mathscr{U}$ & 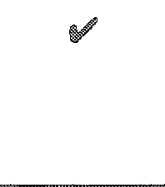 & \\
\hline $1 \mathrm{Kgs} 8: 12-66$ & $\begin{array}{l}\text { mékôn šibtkā } \\
\text { mëgôm šiblkat }\end{array}$ & $\begin{array}{l}\text { Answering prayer, } \\
\text { judgment, forgiveness, } \\
\text { kingship }\end{array}$ & 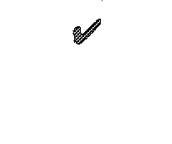 & 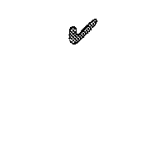 & $\mathscr{U}$ \\
\hline $1 \mathrm{Kgs} 22: 19-23$ & $\begin{array}{l}\text { [yšb, hisse', } \\
\text { șëba" } \\
\text { hašs̆amayim] }\end{array}$ & $\begin{array}{l}\text { Judgment, meeting } \\
\text { place of the heavenly } \\
\text { assembly, kingship, } \\
\text { worship }\end{array}$ & 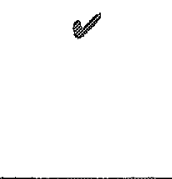 & & \\
\hline
\end{tabular}


Table 8-Continued.

\begin{tabular}{|c|c|c|c|c|c|}
\hline \multicolumn{6}{|c|}{ PROPHETS } \\
\hline & & & \multicolumn{2}{|c|}{$\begin{array}{c}\text { Vertical } \\
\text { Correspondence }\end{array}$} & $\begin{array}{l}\text { Dynamic } \\
\text { Interaction }\end{array}$ \\
\hline & & & Functional & Structural & \\
\hline Isa $6: 1-8$ & hêkä & $\begin{array}{l}\text { Kingship; place of } \\
\text { cleansing, forgiveness, } \\
\text { judgment }\end{array}$ & $\mathscr{2}$ & $\mathscr{U}$ & 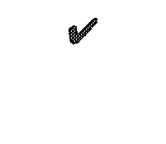 \\
\hline Isa 14:12-15 & har mốed & $\begin{array}{l}\text { Object of attack in the } \\
\text { cosmic battle; place of } \\
\text { worship, meeting place } \\
\text { of the heavenly } \\
\text { assembly }\end{array}$ & 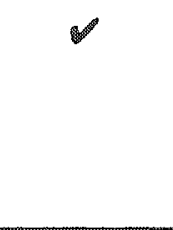 & & \\
\hline Isa 18:4 & mäkôn & Supervision, judgment & 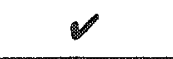 & 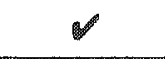 & \\
\hline Isa $63: 15$ & $\begin{array}{l}\text { zébul qodšè } \bar{a} \\
\text { wetip' artekāa }\end{array}$ & $\begin{array}{l}\text { Supervision, } \\
\text { intervention, source of } \\
\text { help }\end{array}$ & 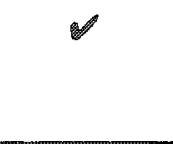 & $\mathscr{V}$ & \\
\hline Jer $17: 12$ & $\begin{array}{l}\text { mĕgôm } \\
\text { miqdâšemû }\end{array}$ & Kingship, judgment & 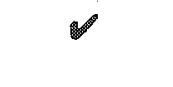 & 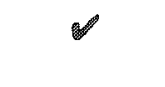 & \\
\hline Jer $25: 30$ & $m e^{c} \hat{o} \hat{n}$ qodšô & Judgment & 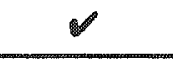 & 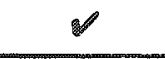 & \\
\hline Ezek 1 & $\begin{array}{l}\text { Iniptahu } \\
\text { hašsamayim, } \\
\text { sapon, } \\
\text { mar'én' eben } \\
\text { sappir, } \\
\text { kabod } \\
\text { YHWHI }\end{array}$ & Kingship & 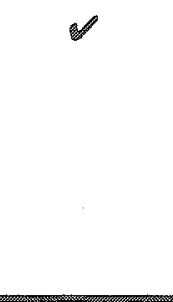 & & \\
\hline Ezek 10 & $\begin{array}{l}\text { kabod } \\
\text { YHWH, } \\
\text { kertibium }\end{array}$ & Judgment & 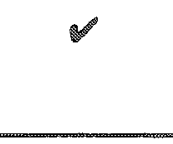 & $\forall$ & $\checkmark$ \\
\hline Ezek 28:11-19 & $\begin{array}{l}\text { 'edengan } \\
\text { elohim } \\
\text { har qodes } \\
\text { 'êtohn } \\
\text { migdas } \\
\end{array}$ & $\begin{array}{l}\text { Object of improper } \\
\text { actions in the cosmic } \\
\text { battle, cultic aspects }\end{array}$ & $\mathscr{\ddots}$ & 2 & \\
\hline Hos 5:15 & màqôm & Dwelling & & & \\
\hline $\begin{array}{l}\text { Jonah } 2: 5[4], 8 \\
{[7]}\end{array}$ & hêkal & Source of help, salvation & 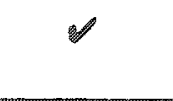 & 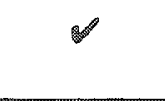 & $\mathscr{V}$ \\
\hline
\end{tabular}


Table 8-Continued.

\begin{tabular}{|c|c|c|c|c|c|}
\hline \multicolumn{6}{|c|}{ PROPHETS } \\
\hline & & & \multicolumn{2}{|c|}{$\begin{array}{l}\text { Vertical } \\
\text { Correspondence }\end{array}$} & $\begin{array}{l}\text { Dynamic } \\
\text { Interaction }\end{array}$ \\
\hline & & & Functional & Structural & \\
\hline Mic 1:2-3 & hêkāl godsố & $\begin{array}{l}\text { Judgment (covenani } \\
\text { lawsuit): investigative + } \\
\text { executive }\end{array}$ & $\mathscr{U}$ & 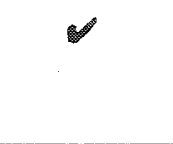 & \\
\hline Hab 2:20 & hêkàl & Worship, judgment & 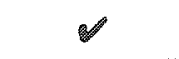 & $\mathscr{\vartheta}$ & 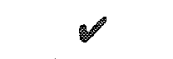 \\
\hline Zech 2:17 & mě ôn qodšô & Dwelling & 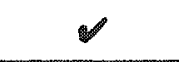 & 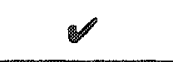 & \\
\hline Zech 3:1-10 & $\begin{array}{l}\text { Implied in the } \\
\text { heavenly } \\
\text { council }\end{array}$ & $\begin{array}{l}\text { Judgment, cultic } \\
\text { aspects: atonement }\end{array}$ & 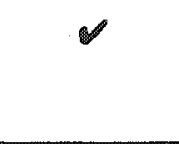 & & 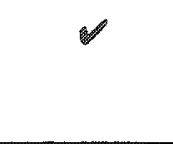 \\
\hline \multicolumn{6}{|c|}{ WRITINGS } \\
\hline & & & \multicolumn{2}{|c|}{$\begin{array}{l}\text { Vertical } \\
\text { Correspondence }\end{array}$} & $\begin{array}{l}\text { Dynamic } \\
\text { Interaction }\end{array}$ \\
\hline & & & Functional & Structural & \\
\hline Ps 11:1-7 & hêkal & $\begin{array}{l}\text { Judgment (two phases): } \\
\text { Investigative }+ \\
\text { executive }\end{array}$ & 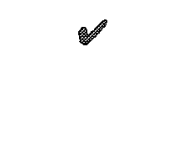 & $\mathscr{V}$ & \\
\hline Ps 14:1-6 & [sämayim] & Judgment & 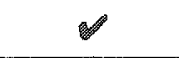 & & $\vartheta$ \\
\hline Ps 20:1-19 [20] & šĕmê qodšô & Source of help & $\bullet$ & & 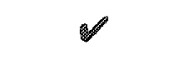 \\
\hline $\operatorname{Ps} 29: 1-11$ & $\begin{array}{l}\text { hadrat qōdeš, } \\
\text { hêkal }\end{array}$ & $\begin{array}{l}\text { Worship, praise, } \\
\text { judgment, kingship, } \\
\text { source of blessings }\end{array}$ & 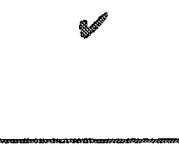 & $\mathscr{H}$ & \\
\hline Ps $33: 1-22$ & mekôn šibtô & $\begin{array}{l}\text { Dwelling, supervision, } \\
\text { judgment, salvation }\end{array}$ & 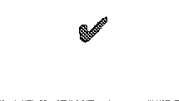 & $\mathscr{U}$ & \\
\hline Ps 60:1-14 [12】 & godes & Source of help & 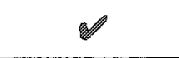 & 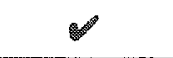 & 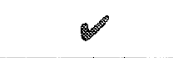 \\
\hline Ps 68:1-36 [35] & 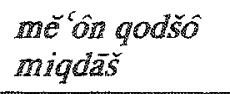 & Judgment & 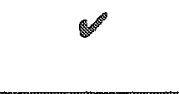 & 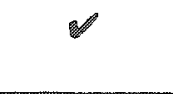 & 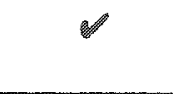 \\
\hline Ps 73:17,25 & miqdšê & Judgment & $\mathscr{H}$ & & $\mathscr{V}$ \\
\hline Ps 76:8.9 & [šămayim] & Judgment & $\mathscr{N}$ & & 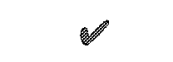 \\
\hline PS $82: 1-8$ & ['̌̃dat'êt] & Judgment & 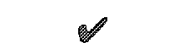 & & \\
\hline
\end{tabular}


Table 8-Continued.

\begin{tabular}{|c|c|c|c|c|c|}
\hline \multicolumn{6}{|c|}{ WRITINGS } \\
\hline & & & \multicolumn{2}{|c|}{$\begin{array}{l}\text { Vertical } \\
\text { Correspondence }\end{array}$} & $\begin{array}{l}\text { Dynamic } \\
\text { Interaction }\end{array}$ \\
\hline & & & Functional & Structural & \\
\hline PS 96:1-13 & miqdāšs & $\begin{array}{l}\text { Kingship, worship, } \\
\text { Judgment }\end{array}$ & $\mathscr{O}$ & 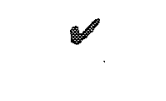 & 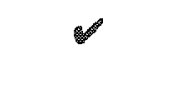 \\
\hline $\begin{array}{l}\text { Ps 102:20-21 } \\
{[19-20]}\end{array}$ & měrôm qodšô & $\begin{array}{l}\text { Source of help, } \\
\text { judgment (investigative } \\
+ \text { executive), kingship }\end{array}$ & $\vartheta$ & 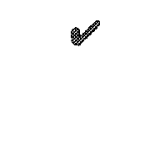 & \\
\hline Ps $150: 1-6$ & godeš & Worship & $\leadsto$ & $\mathscr{V}$ & 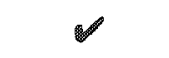 \\
\hline Job 1:6;2:1 & Implied & $\begin{array}{l}\text { Heavenly council, } \\
\text { cosmic battle, judicial } \\
\text { aspects }\end{array}$ & 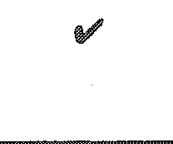 & & \\
\hline Dan $7: 9-14$ & Implied & $\begin{array}{l}\text { Judgment, heavenly } \\
\text { council }\end{array}$ & $\mathscr{O}$ & & \\
\hline $\operatorname{Dan} 8: 9.14$ & qodeš, miqdāš & $\begin{array}{l}\text { Judgment, cultic } \\
\text { functions, cosmic battle }\end{array}$ & 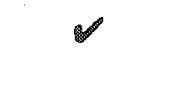 & $\mathscr{U}$ & \\
\hline Dan $9: 24$ & $\begin{array}{l}\text { qodešs } \\
\text { qodās̆lim }\end{array}$ & $\begin{array}{l}\text { Cultic functions: } \\
\text { inauguration/consecratio } \\
\mathrm{n}\end{array}$ & 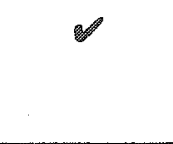 & 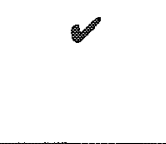 & \\
\hline 2 Chr $30: 27$ & mé ôn qqodš̂̀ & Worship & 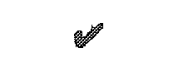 & $\mathscr{V}$ & $\mathscr{\nu}$ \\
\hline
\end{tabular}




\section{BIBLIOGRAPHY}

Aalders, G. Ch. Genesis. Translated by William Heynen. Bible Student's Commentary. Grand Rapids: Zondervan, 1981.

Achtemeier, Elizabeth Rice. Minor Prophets I. Peabody, MA: Hendrickson, 1996.

Achtmeier, Elizabeth. Nahum-Malachi. Interpretation. Atlanta: John Knox, 1986.

Ackerman, Susan. "The Deception of Isaac, Jacob's Dream at Bethel and Incubation on an Animal Skin." In Priesthood and Cult in Ancient Israel, ed. David J.A. Clines and Philip R. Davies, 92-120. Sheffield: JSOT, 1991.

Adams, Roy. "The Doctrine of the Sanctuary in the Seventh-day Adventist Church: Three Approaches." Ph.D. diss., Andrews University Theological Seminary, 1980.

Ahlström, G. W. "Heaven on Earth—Hazor and Arad." In Religious Syncretism in Antiquity: Essays in Conversation with Geo Widengren, ed. Birger A. Pearson, 67-83. Missoula, MT: Scholars Press, 1975.

Aistleitner, Joseph. Wörterbuch der Ugaritischen Sprache. 2nd ed. Berlin: AkademieVerlag, 1965.

Albenda, Pauline. "Mesopotamian Art and Architecture." The Anchor Bible Dictionary. Edited by David Noel Freedman. New York: Doubleday, 1992. 1:419-28.

Albright, William Foxwell. Archaeology and the Religion of Israel. Baltimore: Johns Hopkins Press, 1942.

. "The Furniture of El." Bulletin of the American Schools of Oriental Research 93 (1943): 20-25.

. "The Furniture of El." Bulletin of the American Schools of Oriental Research 91 (1943): 39-44.

. "A Catalogue of Early Hebrew Poems-Ps 68." Hebrew Union College Annual 23 , no. $1(1950-51): 1-39$. 
. "Notes on Psalm 68 and 134." In Interpretationes ad Vetus Testamentum Pertinentes Sigmundo Mowinckel Septuagenario Missae, 1-12. Oslo: Land og kirke, 1955.

- Yahweh and the Gods of Canaan: A Historical Analysis of Two Contrasting Faith. London: Athlone Press, 1968.

Alden, Robert L. "Chiastic Psalms: A Study in the Mechanics of Semitic Poetry in Psalms 1-50." Journal of the Evangelical Theological Society 17 (1974): 11-28.

- "Chiastic Psalms (II): A Study in the Mechanics of Semitic Poetry in Psalms 51-100." Journal of the Evangelical Theological Society 19 (1976): 191-200.

. "Chiastic Psalms (III): A Study in the Mechanics of Semitic Poetry in Psalms 101-150." Journal of the Evangelical Theological Society 21 (1978): 199-210.

Alexander, Ralph H. "Ezekiel." The Expositor's Bible Commentary. Edited by Frank E. Gaebelein. Grand Rapids: Zondervan, 1976. 6:735-996.

Alexander, T. D. "The Composition of the Sinai Narrative in Exodus XIX 1-XXIV 11." Vetus Testamentum 49 (1999): 2-20.

Allen, Leslie C. The Books of Joel, Obadiah, Jonah and Micah. The New International Commentary on the Old Testament. Grand Rapids: Eerdmans, 1976. . Ezekiel 20-48. Dallas, TX: Word Books, 1990.

. "The First and Second Books of Chronicles." The New Interpreter's Bible. Edited by Leander E. Keck. Nashville: Abingdon Press, 1994. 3:297-659. . "Talm 73: An Analysis." Tyndale Bulletin 33 (1982): 93-118. - Psalms 101-150. Word Biblical Commentary 21. Waco: Word Books, 1983. "The Structure and Intention of Ezekiel I." Vetus Testamentum 43 (1993): $145-61$.

Allen, Thomas George. The Book of the Dead or Going Forth by Day: Ideas of the Ancient Egyptians Concerning the Hereafter as Expressed in Their Own Terms. Studies in Ancient Oriental Civilization 37. Chicago: Oriental Institute of the University of Chicago, 1974.

Alonso-Schökel, Luis. "Nota estilistica sobre la particula mมๆ." Biblica 37 (1956): 74-80. 
"The altar" [Isa 6:6]. Seventh-day Adventist Bible Commentary. Rev. ed. Edited by Francis D. Nichol. Washington, DC: Review and Herald, 1976-80. 4:128-29.

Althnan, Robert. "Approaches to Prepositions in Northwest Semitic Studies." Journal of Northwest Semitic Languages 20, no. 2 (1994): 179-91.

. "The Psalms of Vengeance Against Their Ancient Near Eastern Background." Journal of Northwest Semitic Languages 18 (1992): 1-11.

Amit, Yaira. Reading Biblical Narratives: Literary Criticism and the Hebrew Bible. Minneapolis: Fortress, 2001.

Andersen, Francis 1. Habakkuk: A New Translation with Introduction and Commentary. The Anchor Bible, vol. 25. New York: Doubleday, 2001.

Andersen, Francis I., and David Noel Freedman. Micah: A New Translation with Introduction and Commentary. New York: Doubleday, 2000.

. "The Orthography of the Aramaic Portion of the Tell Fekherye Bilingual." In Text and Context: Old Testament and Semitic Studies for F.C. Fensham, ed. W. Claassen, 9-49. Sheffield: JSOT, 1988.

Anderson, Arnold Albert. A. The Book of Psalms. 2 vols. New Century Bible Commentary. Grand Rapids: Eerdmans, 1981. . 2 Samuel. Dallas, TX: Word Books, 1989.

Anderson, Bernhard W., and Steven Bishop. Contours of Old Testament Theology. Minneapolis, MN: Fortress, 1999.

- Ont of the Depths: The Psalms Speak for Us Todoy. 3rd rev. and expand ed. Louisville: Westminster John Knox, 2000.

Anderson, Lewis. "The Michael Figure in the Book of Daniel." Ph.D. diss., Andrews University, 1997.

Andreasen, M. L. The Sanctuary Service. Washington, DC: Review and Herald, 1937.

Andreasen, Niels-Erik. "The Heavenly Sanctuary in the Old Testament." In The Sanctuary and the Atonement, ed. Amold Wallenkampf and Richard Lesher, 67-86.

Washington, DC: Biblical Research Institute, 1981. 
"Translation of Nisdaq/Katharisthesetai in Daniel 8:14." In Symposium on Daniel, ed. Frank B. Holbrook, 475-96. Washington, DC: Biblical Research Institute, 1986.

Anthes, Rudolf. "Mythology in Ancient Egypt." In Mythologies of the Ancient world, ed. Samuel Noah Kramer, 15-90. Garden City, NY: Doubleday and Company, 1961.

Aptowitzer, Victor. The Celestial Temple as Viewed in the Aggadah. (Adapted by Aryeh Rubinstein.) Jerusalem: Intemational Center for University Teaching of Jewish Civilization, 1931.

Archer, Gleason Leonard. A Survey of Old Testament Introduction. $3 \mathrm{rd}$ updated and rev. ed. Chicago: Moody, 1994.

Arichea, Daniel C., Jr. "The Ups and Downs of Moses: Locating Moses in Exodus 1933." Bible Translator 40, no. 2 (1989): 244-46.

Armistead, David B. "The Images of Daniel 2 and 7: A Literary Approach." Stulos Theological Journal 6 (1998): 63-66.

Amold, Bill T., and John T. Choi. A Guide to Biblical Hebrew Syntax. Cambridge: Cambridge University Press, 2003.

Ash, Anthony Lee, and Clyde M. Miller. Psalms. Austin, TX: Sweet Publishing Company, 1980.

Assman, J. Agyptische Hymnen und Gebete. Zürich: Artemis Verlag, 1975.

Auffret, Pierre. "Essai sur la structure littéraire du Psaume 11." Zeischriff für die altestamentliche Wissenschaft 93, no. 3 (1981): 401-18.

.Hymnes d'Égypte et disrael. Orbis Biblicus et Orientalis 34. Götingen: Vanderhoeck und Ruprecht, 1981.

- "Notes complémentaires sur la structure litteraire des Psaumes 3 et 29." Zeitschrift furr die altestamentliche Wissenschaft 99 (1987): 90-93.

- "Notes conjointes sur la structure littéraire des psaumes 114 et $29 .{ }^{\text {" Estudios }}$ Büblicos 37 (1978): 103-13.

. "Splendeur et majesté devant lui: étude structurelle du Psaume 96." Old Testament Essays 6 (1993): 150-62. 
Auvray, Paul. Isaïe. Sources Bibliques. Paris: J. Gabalda, 1972.

Averbeck, Richard E. "Ritual Formula, Textual Frame, and Thematic Echoes in the Cylinders of Gudea." In Crossing Boundaries and Linking Horizons: Studies in Honor of Michael C. Astour in His 80th Birthday, ed. Mark W. Chavalas Gordon D. Young and Richard E. Averbeck, 37-93. Bethesda, MD: CDL Press, 1997. . "Sumer, the Bible, and Comparative Method: Historiography and Temple Building." In Mesopotamia and the Bible: Comparative Explorations, ed. Mark W. Chavalas and K. Lawson Younger Jr., 88-125. Grand Rapids: Baker, 2002.

Averbeck, Richard E., Mark W. Chavalas, and David B. Weisberg. Life and Culture in the Ancient Near East. Potomac, MD: CDL Press, 2003.

Avishur, Yitshak. "The Structure of the Narrative of the Revelation at Sinai (Exodus 19. 24)." In Studies in Biblical Narrative: Style, Structure, and the Ancient Near Eastern Literary Background, 375. Tel Aviv-Jaffa, Israel: Archaeological Center Publication, 1999.

. Stylistic Studies of Word-Pairs in Biblical and Ancient Semitic Literatures. Alter Orient und Altes Testament 210. Kevelaer: Butzon and Bercker, 1984.

Azevedo, Joaquim. "At the Door of Paradise: A Contextual Interpretation of Gen 4:7." Biblische Notizen, no. 100 (1999): 45-59.

Baaren, Theodorus Petrus van. "The Mythical Origin of the Egyptian Temple-Book Review." Nederlands Theologisch Tijdschrift 24D (1969): 122.

Baethgen, Friedrich. Die Psalmen. 2nd ed. Göttingen: Vandenhoeck und Ruprecht, 1897.

Bailey, Nicholas A. "What's Wrong with My Word Order? Topic, Focus, Information Flow, and Other Pragmatic Aspects of Some Biblical Genealogies." Joumal of Translation and Textlinguistics 10 (1998): 1-29.

Bailey, Nicholas A., and Stephen H. Levinsohn. "The Function of Preverbal Elements in Independent Clauses in the Hebrew Narrative of Genesis." Journal of Translation and Textlinguistics 5, no. 3 (1992): 179-207.

Baker, David W., T. Desmond Alexander, and Bruce K. Waltke. Obadiah, Jonah, Micah. The Tyndale Old Testament Commentaries. Leicester, England: Inter-Varsity Press, 1998. 
Bakon, Shimon. "Creation, Tabemacle and Sabbath." Jewish Bible Quarterly 25 (1997): 79.85 .

Baldwin, Joyce G. Haggai, Zechariah, Malachi: An Introduction and Commentary. Downers Grove, $\mathbb{I L}$ : Inter-Varsity Press, 1972.

Ballard, Harold Wayne. The Divine Warrior Motif in the Psalms. BIBAL Dissertation Series. North Richland Hills, TX: BIBAL Press, 1999.

Banning, E. B. "Towers." The Anchor Bible Dictionary. Edited by David Noel Freedman. New York: Doubleday, 1992. 6:622-24.

Baranowski, Shelley. The Confessing Church, Conservative Elites, and the Nazi State. Texts and Studies in Religion 28. Lewiston, NY: Mellen, 1986.

Barker, Kenneth L. "Zechariah." The Expositor's Bible Commentary. Edited by Frank E. Gaebelein. Zondervan: Grand Rapids, 1985. 7:593-697.

Barker, Kenneth L., and Waylon Bailey. Micah, Nahum, Habakkuk, Zephaniah. The New American Bible Commentary 20. Nashville: Broadman and Holman, 1998.

Barker, Margaret. "Beyond the Veil of the Temple: The High Priestly Origins of the Apocalypses." Scottish Journal of Theology 51 (1998): 1-21.

. On Earth as It Is in Heaven: Temple Symbolism in the New Testament. Edinburgh: T. and T. Clark, 1995.

. The Gate of Heaven: The History and Symbolism of the Temple in Jerusalem. London: SPCK, 1991.

Barnes, Albert. Book of the Psalms. New York: Harper, 1868.

Barnes, W. Emery. "Ezekiel's Denunciation of Tyre." Journal of Theological Studies 34 (1934): 50-54.

Barr, James. The Semantics of Biblical Language. Glasgow: Oxford University Press, 1961.

Barré, Michael L. "A Phoenician Parallel to Psalm 29." Hebrew Anmal Review 13 (1991): 25-32. 
Bartelmus, Rüdiger. "šamajim-Himmel: Semantische und traditiongeschichtliche Aspekt." In Das biblische Weltbild und seine altorientalischen Kontexte, ed. Bernd Janowski and Beate Ego, 87-124. Tübingen: Mohr Siebeck, 2001.

Bartelt, Andrew H. The Book around Immanuel: Style and Structure in Isaiah 2-12. Biblical and Judaic Studies 4. Winona Lake: Eisenbrauns, 1996.

Barth, Christoph, and Geoffrey William Bromiley. God with Us: A Theological Introduction to the Old Testament. Grand Rapids: Eerdmans, 1991.

Barton, George A. The Royal Inscriptions of Sumer and Akkad, vol. 1. New Haven: Yale University Press, 1929.

Barton, John. Isaiah 1-39. Old Testament Guides 19. Sheffield, England: Sheffield, 1995.

Batto, Bernard F. "Paradise Reexamined." In The Biblical Canon in Comparative Perspective: Scripture in Context IV, ed. K. Lawsson, William W. Hallo, and Bernard F. Batto, 33-66. Lewiston, NY: Mellen, 1991.

. Sloying the Dragon: Mythmaking in the Biblical Tradition. Louisville, KY: Westminster/John Knox, 1992.

Bauks, Michaela. "Chaos' als Metapher fur die Gefärdung der Welt Ordnung." In Das biblische Weltbild und seine altorientalischen Kontexte, ed. Bernd Janowski and Beate Ego, 431-64. Tübingen: Mohr Siebeck, 2001.

Baumann, Eberhard. "Die Hauptvisionen Hesekiels in ihrem zeitlichen und sachlichen Zusammenhang untersucht." Zeitschrift für die alttestamentliche Wissenschaft 67 , no. $1-2(1955): 56-67$.

Baumgarten, Joseph M. "The Heavenly Tribunal and the Personification of Sedeq in Jewish Apocalyptic." In Aufstieg und Niedergang der Römischen Welt, II.19.1, 219-239. Berlin-New York: Walter de Gruyter, 1979.

Beale, Gregory $\mathrm{K}$. "Garden Temple." Xerux: The Joumal of Northwest Theological Seminary 18, no. $2(2003): 3-50$.

. The Temple and the Church's Mission: A Biblical Theology of the Dwelling Place of God. New Studies in Biblical Theology 17. Downers Grove, IL: InterVarsity, 2004.

Beckman, Gary. "The Hittite Assembly." Journal of the American Oriental Society 102 $(1982): 435-442$. 
Beckwith, Roger. "Early Traces of the Book of Daniel." Tyndale Bulletin 53, no. 1 (2002): $75-82$.

Beer, Georg. Exodus. Handbuch zum Alten Testament, vol. 3. Tubingen: Mohr, 1939.

Begrich, Joachim. "Mabbul: Eine exegetisch-lexicalische Studie." Zeitschrift für Semitish und verwandte Gebiete 6 (1928): 135-153.

Bellinger, W. H., Jr. "The Interpretation of Psalm 11." Evangelical Quarterly 56 (1984): 95-101.

Bergen, Robert D. 1, 2 Samuel. The New American Commentary, vol. 7. Nashville: Broadman and Holman, 1996.

Berges, Ulrich. Das Buch Jesaja: Komposition und Endgestalt. Freiburg: Herder, 1998.

Berlin, Adele. "Parallel Word Pairs: A Linguistics Explanation." Ugarit-Forschungen 15 (1983): 7-16.

. The Dynamics of Biblical Parallelism. Bloomington: Indiana University Press, 1985.

Bertolucci, José M. "The Son of the Morning and the Guardian Cherub in the Context of the Controversy between Good and Evil." Th.D. dissertation, Andrews University, 1985.

Beuken, Willem A.M. Jesaja 1-12. Herders Theologischer Kommentar zum Alten Testament. Freiburg: Herder, 2003.

Beuken, Wim. Haggai-Sacharja 1-8. Studien zur Überlieferungsgeschichte der frïhnachexilischen Prophetie. Studia Semitica Neerlandica 10. Assen: Van Gorcum, 1967.

Bic, Miloš. Das Buch Sacharja. Berlin: Evangelische Verlagsanstalt, 1962.

Bienkowski, Piotr, and A. R. Millard, eds. Dictionary of the Ancient Near East. Philadelphia: University of Pennsylvania Press, 2000.

Bietenhard, Hans. Die himmlische Welt im Urchristentum and Spätiudentum. Wissenschafliche Untersuchungen zum Neuen Testament 2. Tübingen: Mohr, 1951. 
Black, Jeremy, Andrew George, and J. N. Postgate, eds. A Concise Dictionary of Akkadian. Wiesbaden: Harrassowitz, 2000. S.v. "simmiltu(m)."

Blenkinsopp, Joseph. Ezekiel. Interpretation. Louisville: John Knox, 1990.

. Isaiah 40-55: A New Translation with Introduction and Commentary. The Anchor Bible, vol. 19B. New York: Doubleday, 2002.

Isaiah 1-39: A New Translation with Introduction and Commentary. The Anchor Bible, vol. 19A. New York: Doubleday, 2000.

"Structure and Meaning in the Sinai-Horeb Narrative (Exodus 19-34)." In $A$ Biblical Itinerary: In Search of Method, Form and Content: Essays in Honor of George W. Coats, ed. Eugene E. Carpenter, 109-25. Sheffield: Sheffield Academic, 1997.

Bliese, Loren F. "The Poetics of Habakkuk." Journal of Translation and Textlinguistics 12 (1999): 47-75.

Blocher, Henri. "Zacharie 3: Josué et le grand jour des expiations." Études Théologiques et Religieuses 54 (1979): 264-70.

Bloch-Smith, Elizabeth. "Solomon's Temple: The Politics of Ritual Space." In Sacred Time, Sacred Place: Archaeology and the Religion of Israel, ed. Barry M. Gittlen, 83-94. Winona Lake: Eisenbrauns, 2002.

Block, Daniel I. The Book of Ezekiel: Chapters 1-24. New International Commentary on the Old Testament. Grand Rapids: Eerdmans, 1997.

The Book of Ezekiel: Chapters 25-48. New International Commentary on the Old Testament. Grand Rapids: Eerdmans, 1998.

. The Gods of the Nations: Sudies in Ancient Near Eastern National Theology. 2nd ed. Grand Rapids: Baker, 2000.

. "Text and Emotion: A Study in the "Corruptions" in Ezekiel's Inaugural Vision (Ezekiel 1:4-28)." Catholic Biblical Quorterly 50 (1988): 418-42.

Blum, Erhard. "Noch einmal: Jakobs Traum in Bethel-Genesis 28, 10-22." In Rethinking the Foundations: Historiography in the Ancient World and in the Bible, Essays in Honour of John Van Seters, ed. Steven L. McKenzie and Thomas Römer, 33-54. Berlin: Walter de Gruyter, 2000. 
- Studien zur Komposition des Pentateuch. Berlin: Walter de Gruyter, 1990.

Blumenthal, Fred. "The Prophetic Visions of God's Abode." Jewish Bible Quarterly 32 , no. 3 (2004): 162-66.

Bogaert, Pierre-Maurice. "Montagne Sainte, Jardin d'Éden et Sanctuaire (Hiérosolymitain) dans un Oracle d'Ézéchiel contre le Prince de Tyr (Ez 28,11-19)." In Mythe, Son Langage et Son Message, 131-53. Louvain-la-Neuve, Belgium: Centre dHistoire des Religions, 1983.

Bolger, Eric W. "The Compositional Role of the Eden Narrative in the Pentateuch." Ph.D. diss., Trinity Evangelical Divinity School, 1993.

Boman, Thorleif. Hebrew Thought Compared with Greek. New York: W.W. Norton, 1970.

Borgman, Paul Carlton. Genesis: The Story We Haven't Heard. Downers Grove, IL: InterVarsity Press, 2001.

Bost, Hubert. Babel: Du texte au symbole. Le Monde de la Bible. Genève: Labor et Fides, 1985.

Boutflower, Charles. The Book of Isaiah, Chapters [1-XXXIX], in the Light of the Assyrian Monuments. New York: Society for Promoting Christian Knowledge; Macmillan, 1930.

Boyd, Gregory A. God at War: The Bible and Spiritual Conflict. Downers Grove, IL: Inter-Varsity, 1997.

Bracke, John M. Jeremiah 1-29. Westminster Bible Companion. Louisville: Westminister John Knox, 2000.

Bratcher, Margaret Dee. "The Pattem of Sin and Judgment in Genesis 1-11." Ph.D. diss., The Southern Baptist Theological Seminary, 1984.

Braun, Roddy. 1 Chronicles. Word Biblical Commentary, vol. 14. Waco: Word Books, 1986.

Braun, Roddy L. "Message of Chronicles: Rally "Round the Temple." Concordia Theological Monthly 42 (1971): 502-14. 
Breasted, James Henry. Ancient Records of Egypt: Historical Documents from the Earliest Times to the Persian Conquest. 5 vols. Chicago: University of Chicago Press, 1906.

Brenner, Martin Leon. The Song of the Sea: Ex. 15:1-21. Berlin: W. de Gruyter, 1991.

Brensinger, Terry L. "Ing." New International Dictionary of Old Testament Theology and Exegesis. Edited by Willem A. VanGemeren. Grand Rapids: Zondervan, 1997. 1:636-38.

Briggs, Charles, and Emilie G. Briggs. A Critical and Exegetical Commentary on the Book of Psalms. 2 vols. The International Critical Commentary. Edinburgh: $T$. and T. Clark, 1906-1907.

Briggs, Robert A. Jewish Temple Imagery in the Book of Revelation. Studies in Biblical Literature 10. Edited by Hemchand Gossai. New York: Peter Lang, 1999.

Bright, John. Jeremiah. 2nd ed. The Anchor Bible, vol. 21. Garden City, NY: Doubleday, 1973.

Briley, Terry R. Isaiah. The College Press NIV Commentary: Old Testament Series. Joplin, MO: College Press, 2000.

Brinkman, Johan. The Perception of Space in the Old Testament. Kampen: Kok Pharos, 1992.

Briscoe, D. Stuart. Genesis. The Communicator's Commentary Series. Old Testament, vol. 4. Edited by Lloyd G. Ogilvie. Waco, TX: Word Books, 1987.

Brooke, George J., Adrian Curtis, and John F. Healey. Ugarit and the Bible: Proceedings of the International Symposium on Ugarit and the Bible, Manchester, September 1992. Münster: Ugarit-Verlag, 1994.

Brovarski, Edward. "The Doors of Heaven." Orientalia 46 (1977): 107-15.

Brown, Francis, Edward Robinson, S. R. Driver, Charles A. Briggs, and Wilhelm Gesenius. A Hebrew and English Lexicon of the Old Testament, with an Appendix Containing the Biblical Aramaic. Based on the lexicon of William Gesenius.

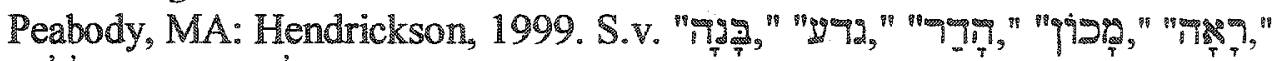

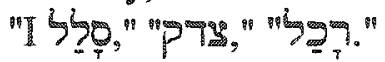

Brownlee, William Hugh. Ezekiel 1-19. Waco, TX: Word Books, 1986. 
.The Midrash Pesher of Habakkuk Missoula, MT: Published by Scholars Press for the Society of Biblical Literature, 1979.

Broyles, Craig C. Psalms. New International Biblical Commentary. Old Testament Series 11. Peabody, MA: Hendrickson, 1999.

Brueggemann, Walter. A Commentary on Jeremiah: Exile and Homecoming. Grand Rapids: Eerdmans, 1998.

"The Book of Exodus: Introduction, Commentary and Reflections." The New Interpreter's Bible. Edited by Leander E. Keck. Nashville: Abingdon, 1994. 1:675981.

. Deuteronomy. Abingdon Old Testament Commentaries. Nashville: Abingdon, 2001 .

. Isaiah 1-39. Westminster Bible Companion. Louisville: Westminster John Knox, 1998.

To Pluck Up, to Tear Down: A Commentary on the Book of Jeremiah 1-25. Grand Rapids: Eerdmans; Edinburgh: Handsel, 1988.

Bullock, C. Hassell. An Introduction to the Old Testament Prophetic Books. Chicago: Moody, 1986.

Burden, Jasper J. "A Stylistic Anaysis of Exodus 15:1-21: Theory and Practice." In Exodus 1-15: Text and Context: Proceedings of the 29th Annual Congress of the old Testoment Society of South Africa, ed. J. J. Burden, P. J. Botha and H. F. Van Rooy, 34-72. Pretoria: University of South Africa, 1987.

Burns, Rita J. Exodus, Leviticus, Numbers, vol. 3. Old Testament Message: A BiblicalTheological Commentary. Wilmington, DE: Michael Glazier, 1983.

Burrows, Eric. "Some Cosmological Patterns in Babylonian Religion." In The Labyrinth: Further Studies in the Relation between Myth and Ritual in the Ancient World, 45-70. London: Macmillan, 1935.

Bush, Newton Lee. "A Critical and Exegetical Study of Psalm 68." Th.D. diss, Dallas Theological Seminary, 1980.

Buth, Randall. "Contextualizing Constituent as Topic: Non-Sequential Background and Dramatic Pause: Hebrew and Aramaic Evidence." In Function and Expression in 
Functional Grammar, ed. Elisabeth Engberg-Pedersen, Lisbeth Falster Jakobsen, and Lone Schack Rasmussen, 215-31. Berlin: Mouton de Gruyter, 1994.

. "Functional Grammar, Hebrew and Aramaic: An Integrated, Textlinguistic

Approach to Syntax." In Discourse Analysis of Biblical Literature: What It Is and What It Offers, ed. Walter Ray Bodine, 77-102. Atlanta, GA: Scholars Press, 1995.

."The Hebrew Verb in Current Discussions." Jommal of Translation and Textlinguistics 5, no. 2 (1992): 91-105.

"Topic and Focus in Hebrew Poetry-Psalm 51." In Language in Context: Essoys for Robert E. Longacre, ed. Shin Ja J. Hwang and William R. Merrifield, 83-96. Dallas: Summer Institute of Linguistics/University of Texas at Arlington, 1992.

"Word Order Differences Between Narrative and Non-Narrative Material in Biblical Hebrew." In Proceedings of the 10th World Congress of Jewish Studies, ed. David Assaf, 9-16. Jerusalem: Magnes, 1990.

"Word Order in the Verbless Clause: A Generative Functional Approach." In The Verbless Clause in Biblical Hebrew: Linguistic Approaches, ed. Cynthia L. Miller, 79-108. Winona Lake: Eisenbrauns, 1999.

Butler, Trent C. Isaiah. Layman's Bible Book Commentary 10. Nashville, TN: Broadman, 1978.

Butler, Trent Craver. "The Song of the Sea': Exodus 15:1-18: A Study in the Exegesis of Hebrew Poetry." Ph.D. diss., Vanderbilt University, 1971.

Buttenweiser, Moses. The Psalms Chronologically Treated with a New Translation. Chicago: University of Chicago Press, 1938.

Campbell, Antony F. Of Prophets and Kings: A Late Ninth Century Document (1 Samuel 1-2 Kings 10). Washington, DC: Catholic Biblical Association of America, 1986.

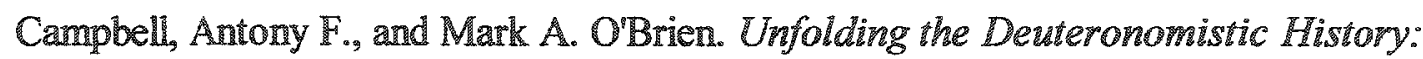
Origins, Upgrades, Present Text. Minneapolis: Fortress, 2000.

Canale, Femando Luis. "Philosophical Foundations and the Biblical Sanctuary." Andrews University Seminary Studies 36 (1998): 183-206.

Caquot, André. "Le Psaume 68." Revue de l'Thistoire des religions 177 (1970): 147-182. 
Caragounis, C. C. "The Interpretation of the Ten Horns of Daniel 7." Ephemerides Theologicae Lovaniensis 63 (1987): 106-11.

Caragounis, Chrys $\mathbb{C}$. The Son of Man: Vision and Interpretation. Tübingen: Mohr (Paul Siebeck), 1986.

Carley, Keith W. The Book of the Prophet Ezekiel. Cambridge University Press, 1974.

Carmichael, Calum. "Law and Narrative in the Pentateuch." In The Blackwell Companion to the Hebrew Bible, ed. Leo G. Perdue, 321-34. Oxford: Blackwell, 2001.

Carroll, Robert P. Jeremiah: A Commentary. The Old Testament Library. Philadelphia: Westminster, 1986.

Casey, Maurice. "Corporate Interpetation of 'One Like a Son of Man' (Dan 7:13) at the Time of Jesus." Novum Testamentum 18 (1976): 167-180.

Cassuto, Umberto. A Commentary on the Book of Exodus. Jerusalem: Magnes, 1967. . A Commentary on the Book of Genesis. Jerusalem: Magnes, 1989. . "The Palace of Baal in Tablet IIAB of Ras Shamra." In Biblical and Oriental Studies, 113-139. Jerusalem: Magnes, 1975.

. "The Sequence and Arrangement of the Biblical Sections." In Biblical and Oriental Studies, 1 Bible, 1-6. Jerusalem: Magnes, 1973.

Cerny, Jaroslav. "Note on (3wy-pt." Journal of Egyptian Archaeology 34 (1948): 120.

Charles, R. H. A Critical and Exegetical Commentary on the Book of Daniel. Oxford: Clarendon, 1929.

Chary, Théophane. Les Prophètes et le Culte à partir de l'Exil. Paris: Desclée et Cie, 1955.

Chavalas, Mark W., and K. Lawson Younger. Mesopotamia and the Bible: Comparative Explorations. Grand Rapids: Baker Academic, 2002.

Cheyne, T. K. The Book of Psalms. 2 vols. New York: T. Whittaker, 1904. . The Two Religions of Israel, with a Re-examination of the Prophetic Narratives and Utterances. London: A. and C. Black, 1911. 
Childs, Brevard S. The Book of Exodus: A Critical, Theological Commentary. The Old Testament Library. Philadelphia: Westminster, 1974. . Introduction to the Old Testament as Scripture. Philadelphia: Fortress, 1979. . Isaiah. The Old Testament Library. Louisville: Westminster John Knox, 2001. . Old Testament Theology in a Canonical Context. Philadelphia: Fortress, 1986.

Chilton, Bruce. "Temple Restored, Temple in Heaven: Isaiah and the Prophets in the Targumim." In Restoration: Old Testament, Jewish and Christian Perspectives, ed. James M. Scott, 335-62. Leiden: Brill, 2001.

Chirichigno, Gregory C. "The Narrative Structure of Exod 19-24." Biblica 68, no. 4 (1987): 457-79.

Christensen, Duane L. Deuteronomy. Word Biblical Commentary, vol. 6b. Waco, TX: Word Books, 2002.

, ed. A Song of Power and the Power of Song: Essays on the Book of Deuteronomy. Winona Lake: Eisenbrauns, 1993.

Churgin, Pinkhos. Targum Jonathan to the Prophets. New York: AMS, 1980.

Clark, David J., and Howard Hatton. A Handbook on Haggai, Zechariah, and Malachi. UBS Handbook Series. New York: United Bible Societies, 2002.

Clements, Ronald E. The Book of Deuteronomy: A Preacher's Commentary. Peterborough: Epworth, 2001.

"The Book of Deuteronomy: Introduction, Commentary, and Reflections." In The New Interpreter's Bible. Eited by Leander E. Keck. Nashville: Abingdon, 1998. 2:269-538.

- Exodus. Cambridge: Cambridge University Press, 1972.

. Ezekiel. Louisville: Westminster John Knox, 1996.

. God and Temple. Oxford: Basil Blackwell, 1965.

Isaiah 1-39. New Century Bible Commentary. Grand Rapids: Eerdmans, 1980. 
- Old Testamen Prophecy: From Oracles to Canon. Louisville: Westminster John Knox, 1996.

Clifford, Richard J. The Cosmic Mountain in Canaan and the Old Testament. Harvard Semitic Monographs 4. Cambridge, MA: Harvard University Press, 1972.

. Cosmogonies in Ugaritic Texts and in the Bible." Orientalia 53 (1984): 183201.

Deuteronomy. Old Testament Message: A Biblical-Theological Commentary, vol. 4. Wilmington, DE: Michael Glazier, 1982.

Psalms 1-72. Abingdon Old Testament Commentaries. Nashville, TN:

Abingdon, 2002.

Psalms 73-150. Abingdon Old Testament commentaries. Nashville: Abingdon, 2003.

"The Temple and the Holy Mountain." In The Temple in Antiquity: Ancient Records and Ancient Perspectives, ed. Truman G. Madsen, 107-24. Provo, UT: Brigham Young University, 1984.

"The Temple in the Ugaritic Myth of Baal." In Symposia, ed. F. M. Cross, 137-145. Boston: American Schools of Oriental Research, 1975.

" "The Tent of El and the Israelite Tent of Meeting." Catholic Biblical Quarterly 33 (1971): 221-27.

Clines, David J. A., ed. The Dictionary of Classical Hebrew, vol. 3. Sheffield: Sheffield Academic, 1993. S.v. "Wgi? I."

.Job. Word Biblical Commentary, vol. 17. Edited by David Hubbard, Glenn W. Barker and James W. Watts. Waco, TX: Word Books, 1982.

"Psalm Research Since 1955:1. The Psalms and the Cult." Tyndale Bulletin 18 $(1967): 103-126$

"Psalm Research since 1955: 1 . The Literary Genres." Tyndale Bulletin 20 (1969): 105-25.

Coats, George Wesley. "Song of the Sea." Catholic Biblical Quarterly 31 (1969): 1 -17.

Cobb, W. H. "The Ode in Isaiah XIV." Journal of Biblical Language 15 (1896): 18-35. 
Cody, Aelred. Heavenly Sanctuary and Liturgy in the Epistle to the Hebrews. St. Meinrad, IN: Grail Publications, St. Meinrad Archabbey, 1960.

. Ezekiel, with an Excursus on Old Testoment Priesthood. Wilmington, DE: Glazier, 1984.

Cogan, Mordechai. I Kings: A New Translation with Introduction and Commentary. The Anchor Bible, vol. 10. New York: Doubleday, 2001.

Coggins, R. I. The First and Second Books of the Chronicles. The Cambridge Bible Commentary: Cambridge: Cambridge University Press, 1976.

Cohen, A. The Psalms: Hebrew Text, English Translation and Commentary. Hindhead, Surrey: Soncino, 1945.

. The Twelve Prophets, Hebrew Text, English Translation and Commentary. Boumemouth, Hants.: Soncino, 1948.

Cohen, Chaim. "Studies in Early Israelite Poetry I: An Unrecognized Case of Three-Line Staircase Parallelism in the Song of the Sea." Journal of the Ancient Near Eastern Society 7 (1975): 13-17.

Cohen, Mark E., ed. Sumerian Hymnology: The Ersemma. Hebrew Union College Annual Supplements 2. Cincinnati: Hebrew Union College Press, 1981.

Cole, H. Ross. "The Sacred Times Prescribed in the Pentateuch: Old Testament Indicators of the Extent of Their Applicability." Ph.D. diss., Andrews University Theological Seminary, 1996.

Cole, R. Alan. Exodus: An Introduction and Commentary. Downers Grove, IL: InterVarsity, 1973.

Collins, John Joseph. Daniel: A Commentary on the Book of Daniel. Hemeneia-A Critical and Historical Commentary on the Bible. Minneapolis: Fortress, 1993. . "Introduction: Towards the Morphology of a Genre." Semeia (1979): 1-20. "Stirring up the Great Sea: The Religio-Historical Background of Daniel 7." In The Book of Daniel in the Light of New Findings, ed. A. S. van der Woude, 121 36. Leuven-Louvain (Belgium): Leuven University Press, 1993.

Coloe, Mary L. God Dwells with Us: Temple Symbolism in the Fourth Gospel. Collegeville, MN: Liturgical, 2001. 
Conrad, Edgar W. Zechariah. Readings, a New Biblical Commentary. She Pheld: Sheffield Academic, 1999.

Conroy, Charles. 1-2 Samuel, 1-2 Kings. Old Testament Message: A Biblical-Theological Commentary, vol. 6. Wimington, DE: Michael Glazier, 1983.

Coogan, Michael David, ed. Stories from Ancient Canaan. Philadelphia: Westminster, 1978.

Cooke, G. A. A Critical and Exegetical Commentary on the Book of Ezekiel. The International Critical Commentary. Edinburgh: T. and T. Clark, 1951.

Cooper, Allan M. "The Life and Times of King David According to the Book of Psalms." In The Poet and the Historian: Essays in Literary and Historical Biblical Criticism, ed. Richard Elliott Friedman, 117-31. Chico, CA: Scholars Press, 1983.

Cooper, Jerrold S. Presargonic Inscriptions (Sumerian Royal Inscriptions, v. 1). AOS Translation Series 1. New Haven, CT: American Oriental Society. Winona Lake: Eisenbrauns, 1986.

Cooper, Jerrold S., and E. Bergmann. The Return of Ninurta to Nippur. Analecta Orientalia 52. Rome: Pontificium Institutum Biblicum, 1978.

Cooper, Lamar Eugene. Ezekiel. The New American Bible Commentary, vol. 17. Nashville, TN: Broadman and Holman, 1994.

Comelius, Isak. "The Visual Representation of the World in the Ancient Near East and the Hebrew Bible." Joumal of Northwest Semitic Languages 20, no. 2 (1994): 193218.

Couffignal, Robert. "Le Songe de Jacob: Approches nouvelles de Genèse 28, 10-22." Biblica $58(1977): 342-60$.

Craigie, Peter Campbell. The Book of Deuteronomy. The New Intemational Commentary on the Old Testament. Grand Rapids: Eerdmans, 1976.

"Earliest Israelite Religion: A Study of the Song of the Sea

(Exodus 15:1-18)." Ph.D. diss., McMaster University, 1971.

. Ezekiel. The Daily Study Bible. Philadelphia: Westminster, 1983.

"Helel, Athtar and Phaethon, Jes 14:12-15." Zeitschriff firs die

altestamentliche Wissenschaft 85, no. 2(1973): 223-25. 
. "Parallel Word Pairs in Ugaritic Poetry: A Critical Evaluation of Their

Relevance for Psalm 29." Ugarit-Forschungen 11 (1980): 135-40.

.Psalms 1-50. Word Biblical Commentary, vol. 19. Waco: Word Books, 1983.

. "Psalm xxix in the Hebrew Poetic Tradition." Vetus Testamentum 22 (1972):

$143-51$.

.The Twelve Prophets. 2 vols. The Daily Study Bible. Philadelphia:

Westminster, 1984.

. "Ugarit and the Bible: Progress and Regess in 50 Years." In Ugarit in

Retrospect: 50 Years of Ugarit and Ugaritic, ed. Gordon Douglas Young, 99-111.

Winona Lake: Eisenbrauns, 1981.

. Ugarit and the Old Testament. Grand Rapids: Eerdmans, 1983.

Craigie, Peter C., Page H. Kelley, and Joel F. Drinkard. Jeremiah 1-25. Word Biblical Commentary, vol. 26. Dallas, TX: Word Books, 1991.

Crenshaw, James L. The Psalms: An Introduction. Grand Rapids: Eerdmans, 2001.

Cross, Frank Moore, Jr. Canaanite Myth and Hebrew Epic: Essays in the History of the Religion of Israel. Cambridge, MA: Harvard University Press, 1973.

.From Epic to Canon: History and Literature in Ancient Israel. Baltimore: Johns Hopkins University Press, 1998.

. "Notes in a Canaanite Psalm in the Old Testament." Bulletin of the American Schools of Oriental Research 117 (1950): 19-21.

. "The Tabernacle: A Study from an Archaeological and Historical Approach." Biblical Archaeologist 10 (1947): 45-68.

. "The Priestly Tabernacle in the Light of Recent Research." In Temples and High Places in Biblical Times, 169-80. Jerusalem: Nelson Glueck School of Biblical Archaeology of Hebrew Union College, 1977.

Cross, Frank Moore, Jr., and David Noel Freedman. Early Hebrew Orthography: A Study of the Epigraphic Evidence. American Oriental Series 36. New Haven: American Oriental Society, 1952. 
. "A Royal Song of Thanksgiving: II Samuel 22=Psalm 18." Journal of Biblical Literature 72 (1953): 15-34.

. "The Song of Miriam." Journal of Near Eastern Studies 14 (1955): 237-50.

Curtis, Edward Lewis. A Critical and Exegetical Commentary on the Book of Chronicles. The International Critical Commentary. Edinburgh: T. and T. Clark, 1910.

Da Silva, Andrew. "A Comparison between the Three-Levelled World of the Old Testament Temple Building Narratives and the Three-Levelled World of the House Building Motif in the Ugaritic Texts KTU 1.3 and 1.4." In Ugarit and the Bible: Proceedings of the International Symposium on Ugarit and the Bible, ed. Adrian H. W. Curtis, John F. Healey, and George J. Brooke, 11-23. Munster: UgaritVerlag, 1994.

Dahood, Mitchell J. Psalms I (1-50): Introduction, Translation, and Notes. The Anchor Bible, vol. 16. Garden City, NY: Doubleday, 1966.

- Psalms III (101-150). The Anchor Bible, vol. 16. Garden City, NY:

Doubleday, 1966.

. Psalms II (51-100): Introduction, Translation, and Notes. The Anchor Bible, vol. 16. Garden City, NY: Doubleday, 1968.

. "The Temple and Other Sacred Places in the Ebla Tablets." In The Temple in Antiquity: Ancient Records and Ancient Perspectives, ed. Truman G. Madsen, 77 89. Provo, UT: Brigham Young University, 1984.

Dahood, M., and T. Penar. "Ugaritic-Hebrew Parallel Pairs." In Ras Shamra Parallels: The texts from Ugarit and the Hebrew Bible, ed. Loren R. Fisher, F. Brent Knutson, Donn F. Morgan and Stan Rummel, 1:158. Rome: Pontificium institutum biblicum, 1972.

Davidson, Richard M. "The Chiastic Literary Structure of the Book of Ezekiel." In To Understand the Scriptures: Essays in Honor of William Shea, ed. David Merling, 71-94. Berrien Springs, MI: Institute of Archaeology and Horn Archacological Museum, 1997.

"Cosmic Metanarrative for the Coming Millennium." Joumal of the Adventist Theological Society 11 (2000): 102-19.

. "The Heavenly Sanctuary in the Old Testament." TMs, 1976. Adventist Heritage Center, Berrien Springs, MI. 
. "The Meaning of Nisdaq in Daniel 8:14." Journal of the Adventist Theological Society 7, no. $1(1996)$ : $107-19$.

. "Sanctuary Typology." In Symposium on Revelation, ed. Frank B. Holbrook, 6, 99-130. Silver Spring, MD: Biblical Research Institute, General Conference of Seventh-day Adventists, 1992.

. "Satan's Celestial Slander." Perspective Digest 1, no. 1(1996): 31-34.

. "Typology in the Book of Hebrews." In Issues in the Book of Hebrews, ed.

Frank B. Holbrook, 121-86. Silver Spring, MD: Biblical Research Institute, 1989.

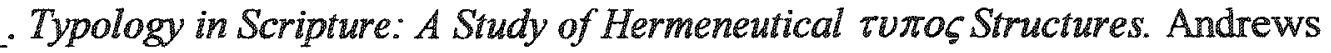
University Seminary: Doctoral Dissertation Series 2. Berrien Springs, MI: Andrews University Press, 1981.

Davidson, Robert. Genesis 12-50. Cambridge: Cambridge University Press, 1979.

. The Vitality of Worship: A Commentary on the Book of Psalms. Grand Rapids: Eerdmans, 1998.

Davies, G. Henton. "Genesis." The Broadman Bible Commentary. Edited by Clifton J. Allen. Nashville: Broadman, 1969. 1:99-304.

Davies, Graham I. Hosea: Based on the Revised Standard Version. New Century Bible Commentary. London: Marshall Pickering, 1992.

Davies, Graham I., Markus N. A. Bockmuehl, D. R. De Lacey, and A. J. Poulter. Ancient Hebrew Inscriptions: Corpus and Concordance. Cambridge: Cambridge University Press, 1991.

Davila, James R. "Shinar." The Anchor Pible Dictionary. Edited by David Noel Freedman. New York: Doubleday, 1992. 5:1220.

Davis, Dale R "Rebellon, Presence, and Covenant: A Study in Exodus 32-34." Westminster Theological Joumal 44 (1982): $71-87$.

Dawson, David Allan. Text-Linguistics and Biblical Hebrew. JSOTSup 177. Sheffield: She Prield Academic, 1994.

Day, John. "Echoes of Baal's Seven Thunders and Lightnings in Psalm 29 and Habakkuk 3:9 and the Identity of the Seraphim in Isaiah 6." Vetus Testamentum 29 (1979): $143-51$. 
- "Ugarit and the Bible: Do They Presuppose the Same Canaanite Mythology and Religion?" In Ugarit and the Bible: Proceedings of the International Symposium on Ugarit and the Bible, ed. Adrian H. W. Curtis, John F. Healey, and George J. Brooke, 35-52. Muinster: Ugarit-Verlag, 1994.

Day, Peggy. An Adversary in Heaven: Satan in the Hebrew Bible. Harvard Semitic Monographs 43. Atlanta, GA: Scholars Press, 1988.

De Vaux, Roland. "Le lieu que Yahvé a choisi pour y établir son nom." In Das Ferne und Nahe Wort, ed. Fritz Maass, 219-28. Berlin: Verlag Alfred Töpelmann, 1967.

De Vries, Simon J. "Moses and David as Cult Founders in Chronicles." Journal of Biblical Literature 107 (1988): 619-639.

De Vries, Simon John. Prophet Against Prophet: The Role of the Micaiah Narrative (I Kings 22) in the Development of Early Prophetic Tradition. Grand Rapids: Eerdmans, 1978.

Dearman, John Andrew. Jeremiah and Lamentations. Grand Rapids: Zondervan, 2002.

Deissler, Alfons. "Zur Datierung und Situierung der 'kosmischen Hymnen' Pss $81929 . "$ In Lex Tua Veritas: Festschrift für Hubert Junker zur Vollendung des siebzigsten Lebensjahres am 8. August 1961, dargeboten von Kollegen, Freunden und Schulern, ed. Heinrich Gross and Franz Mussner, 47-58. Trier: Paulinus-Verlag, 1961. . Die Psalmen. 6th ed. Düsseldorf: Patmos, 1989.

Deist, Ferdinand E. "On 'Synchronic' and 'Diachronic': Wie es Eigentlich Gewesen." Joumal of Northwest Semitic Languages 21, no. 1 (1995): $37-48$.

Delcor, M. Le Livre de Daniel. Paris,: J. Gabalda, 1971.

Delitzsch, Franz. Biblical Commentary on the Prophecies of Isaiah. Grand Rapids: Eerdmans, 1949. . Biblical Commentary on the Psalms. Grand Rapids: Eerdmans, 1959.

Dequeker, L. "The "Saints of the Most High" in Qumran and Daniel." In Syntax and Meaning, 108-87. Leiden: Brill, 1973.

Derchain, Ph. "Du temple cosmique au temple ludique." In Ritual and Sacrifice in the Ancient Near East, ed. J. Quagebeur, 93-97. Leuven: Uitgeverij Peeters, 1993. 
DeRoche, Michael. "Yahweh's Rib against Israel: A Reassessment of the So-called 'Prophetic Lawsuit' in the Preexilic Prophets." Journal of Biblical Literature 102 (1983): $563-74$.

DeVries, Simon J. 1 Kings. Word Biblical Commentary. Vol 12. Waco: Word Books, 1985.

Dietrich, Manfred. "Das biblische Paradies und der babylonische Tempelgarten." In Das biblische Weltbild und seine altorientalischen Kontexte, ed. Bernd Janowski and Beate Ego, 281-323. Tübingen: Mohr Siebeck, 2001.

Dietrich, Manfred, Oswald Loretz, and Joaquin Sanmartin. The Cuneiform Alphabetic Texts from Ugarit, ras Ibn Hani and Other Places (KTU: second, enlarged edition). Münster: Ugarit-Verlag, 1995.

Dietrich, Walter. Prophetie und Geschichte: Eine redaktionsgeschichtliche Untersuchung zum deuteronomistischen Geschichtswerk. Forschungen zur Religion und Literatur des Alten und Neuen Testaments 108. Göttingen: Vandenhoeck und Ruprecht, 1972.

Dijkstra, Meindert. "The Glosses in Ezekiel Reconsidered: Aspects of Textual Transmission in Ezekiel 10." In Ezekiel and His Book, ed. J. Lust, 55-77. Leuven: Leuven University Press, 1986.

Donner, H., and W. Röllig. Kanaanäische und Aramäische Inschriften. Wiesbaden: Otto Harrassowitz, 1966.

Donner, Herbert. "Ugaritismen in der Psalmenforschung." Zeitschrift für die altestamentliche Wissenschaft 79 (1967): 322-50.

Doukhan, Jacques. "The Seventy Weeks of Daniel 9: An Exegetical Study." AUSS 17 (1979): 1-22.

- Daniel: The Vision of the End. Berrien Springs, MI: Andrews University Press, 1987.

- Le Soupir de la Terre: Etude Prophétique du Livre de Daniel. Dammarie les Lys, France: Editions Vie et Santé, 1993.

- Secrets of Daniel: Wisdom and Dreams of a Jewish Prince in Exile.

Hagerstown, MD: Review and Herald, 2000. 
Downing, Fred L. "Theological Concepts Conceming Jerusalem in Isaiah 1-39." Th.D. diss., New Orleans Baptist Theological Seminary, 1976.

Doyle, Brian. "Heaven, Earth, Sea, Field and Forest: Unnatural Nature in Ps 96." Journal of Northwest Semitic Languages 27, no. 2 (2001): $23-44$.

Dozeman, Thomas B. God on the Mountain: A Study of Redaction, Theology, and Canon in Exodus 19-24. Atlanta, GA: Scholars Press, 1989.

"The Song of the Sea and Salvation History." In On the Woy to Nineveh: Studies in Honor of George M. Landes, ed. Stephen L. Cook and S. C. Winter, 94-113. Atlanta, GA: Scholars Press, 1999.

Driver, G. R. "Ezekiel: Linguistic and Textual Problems." Biblica 35 (1954): 145-59.

Driver, S. R. A Critical and Exegetical Comentary on Deuteronomy. The International Critical Commentary. Edinburgh: T. and T. Clark, 1902. . The Book of Genesis. Westminster Commentaries. London: Methuen, 1943.

Duhm, Bernhard. Das Buch Habakuk. Tübingen: Mohr, 1906.

. Das Buch Jesaia. 5th ed. Göttingen: Vandenhoeck und Ruprecht, 1968. . Die Psalmen. Freiburg: Mohr, 1899.

Durham, John I. Exodus. Word Biblical Commentary, vol. 3. Waco: Word Books, 1987. -Hosea-Micah: A Call to Radical Reform. The Abundant Life Bible Amplifier. Edited by George R. Knight. Boise, ID: Pacific Press, 1996.

Eaton, J. H. "The Psalms and Israelite Worship." In Tradition and Interpretation, ed. George W. Anderson, 238-73. Oxford: Clarendon, 1979.

Edzard, Dietz Otto. Gudea and Dynasty, vol. 3/1. The Royal Inscriptions of Mesopotamia Early Periods. Toronto: University of Toronto, 1997.

Eggler, Jurg. Influences and Traditions Underlying the Vision of Daniel 7:2-14: The Research History from the End of the 19th Century to the Present. Orbis Biblicus et Orientalis 177. Fribourg, Switzerland; Gottingen: University Press: Vandenhoeck und Ruprecht, 2000. 
Ego, Beate. Im Himmel wie auf Erden: Studien zum Verhältnis von himmlischer und irdischer Welt im rabbinischen Judentum. Tübingen: Mohr, 1989.

Ehrlich, Arnold Bogumil. Randglossen zur hebräischen Bible: Textkritisches, Sprachliches und Sachliches. 7 vols. Hildesheim: G. Olms, 1968.

Eichrodt, Walther. Der Herr der Geschichte. Jesaja 13-23 und 28-39. Stuttgart: Calwer Verlag, 1967.

. Ezekiel: A Commentary. Translated by Cosslet Quin. Philadelphia:

Westminster, 1970.

Eiler, David Lemoine. "The Origin of Zion as a Theological Symbol in Ancient Israel." Ph.D. diss., Princeton Theological Seminary, 1968.

Eising, Hermann. Das Buch Jesaja. 2nd ed. Düsseldorf: Patmos-Verlag, 1987.

Elgavish, D. "The Encounter of Abram and Melchizedek King of Salem: A Covenant Establishing Ceremony." In Studies in the Book of Genesis: Literature, Redaction and History, ed. André Wénin, 495-508. Leuven: Uitgeverij Peeters, 2001.

Elliger, Karl. Das Buch der Zwölf Kleinen Propheten II: Die Propheten Nahum, Habakuk, Zephania, Haggai, Sacharja, Maleachi. 5th ed. Alte Testament Deutsch 25. Göttingen: Vandenhoeck und Ruprecht, 1964.

Ellison, H. L. Ezekiel: The Man and His Message. Grand Rapids: Eerdmans, 1956.

Emerton, J. A. "The 'Mountain of God' in Psaim 68:16." In History and Traditions of Early Israel, ed. André Lemaire and Benedikt Otzen, 24-37. Leiden: Brill, 1993.

Engstrom, Paul Lee. "Deliverance at the Sea: A Reading of Exodus 15 in Light of Ancient Near Eastern Literature and Its Implications for the Assemblies of God." Th.D. diss., Luther Seminary, 1996.

Erlandsson, Seth. The Burden of Babylon: A Study of Isaiah 13:2-14:23. Lund: Gleerup, 1970.

Ewald, Heinrich. The Prophet Isaiah: Chapters I-XXXIII. Cambridge: Deighton Bell and Co., 1869.

Falkenstein, Adam. The Sumerian Temple City. Los Angeles: Undena Publications, 1974. 
Falkenstein, Adam, and Wolfram von Soden. Sumerische und Akkadische Hymnen und Gebete. Zürich: Artemis-Verlag, 1953.

Faulkner, Raymond Oliver. The Ancient Egyptian Pyramid Texts. Oxford: Clarendon, 1969. 1973.

.The Ancient Egyptian Coffin Texts. Warminster, England: Aris and Phillips,

Feinberg, Charles L. The Prophecy of Ezekiel: The Glory of the Lord. Chicago: Moody, 1969.

Fensham, F. Charles. "Psalm 29 and Ugarit." In Studies on the Psalms: Papers Read at 6th Meeting Held at the Potchefstroom University for C.H.E., 29-31 Jan. 1963, 84-99. Potchefstroom: Pro Rege, 1963.

. "Ugaritic and the Translation of the Old Testament." Bible Translator 18 (1967): $71-74$.

Ferch, Arthur J. "The Judgment Scene in Daniel 7." In The Sanctuary and the Atonement. Edited by Arnold Wallenkampf and Richard Lesher, 157-76. Washington, DC: Review and Herald, 1981.

. The Son of Man in Daniel 7. Andrews University Seminary Doctoral

Dissertation Series 6. Berrien Springs, MI: Andrews University Press, 1979.

Feuillet, A. "Le fils de lhomme de Daniel et la tradition biblique." Revue Biblique 60 (1953): 170-202; 321-46.

Fischer, Georg. "Das Schilfmeerlied Exodus 15 in seinem Kontext." Biblica 77, no. 1 (1996): $32-47$.

Fishbane, Michael A. Biblical Interpretation in Ancient Israel. Oxford: Clarendon; New York: Oxford University Press, 1988.

. Text and Texture: Close Readings of Selected Biblical Texts. New York: Schocken Books, 1979.

Fisher, Loren R. F. "Creation at Ugarit and in the Old Testament." Vetus Testamentum 15 (1965): 313-24.

. "The Temple Quarter." Journal of Semitic Studies 8 (1963): 34-41. 
Fittzgerald, A. "A Note on Psalm 29." Bulletin of the American Schools of Oriental Research 215 (1974): 61-63.

Fletcher-Louis, Crispin H T. "The High Priest as Divine Mediator in the Hebrew Bible: Dan 7:13 as a Test Case." Society of Biblical Literature Seminar Papers 36 (1997): $161-93$.

Floor, S. "From Word Order to Theme in Biblical Hebrew Narrative: Some Perspectives from Information Structure." Journal for Semitics 12, no. 2 (2003): 197-236.

Fohrer, Georg. Ezekiel. Handbuch zum Alten Testament, 13. Tübingen: Mohr, 1955.

. "Die Glossen im Buche Ezechiel." In Studien zur alttestamentliche Prophetie (1949-1965), 204-21. Berlin: de Gruyter, 1967.

Fokkelman, J. P. Major Poems of the Hebrew Bible: At the Interface of Hermeneutics and Structural Analysis. 2 vols. Studia Semitica Neerlandica 37. Assen, The Netherlands: Van Gorcum, 1998.

- Narrative Art and Poetry in the Books of Samuel: A Full Interpretation Based on Stylistic and Structural Analyses, vol. 3 of 4 vols. Assen, Netherlands: Van Gorcum, 1981.

. Narrative Art in Genesis: Specimens of Stylistic and Structural Analysis. 2nd ed. Sheffield, England: JSOT, 1991.

- Reading Biblical Poetry: An Introductory Guide. Louisville: Westminster John Knox, 2001.

"The Structure of Psalm 68." In In Quest of the Past: Studies on Israelite Religion, Literature and Prophetism: Papers Read at the Joint British-Dutch Old Testament Conference, Held at Elspeet, 1988, ed. A.S. van der Woude, 72-83. Leiden: Brill, 1990.

Forsyth, Neil. The Old Enemy: Satan and the Combat Myth. Princeton, NJ: Princeton University Press, 1987.

Fox, Andrew. "Topic Continuity in Biblical Hebrew Narrative." In Topic Continuity in Discourse: A Quantitative Cross-Language Study, ed. T. Givón, 215-54. Amsterdam/Philadelphia: John Benjamins Publishing Company, 1983.

Fox, Michael V. The Temple in Society. Winona Lake: Eisenbrauns, 1988. 
Fredericks, Daniel C. "Diglossia, Revelation, and Ezekiel's Inaugural Rite." Journal of the Evangelical Theological Society 41 (1998): 189-99.

Freedman, David Noel. "A Letter to the Readers." Biblical Archaeologist 40 (1977): 4648.

"Strophe and Meter in Exodus 15." In A Light unto My Path: Old Testament Studies in Honor of Jacob M. Myers, ed. Howard N. Bream, Ralph Daniel Heim, and Carey A. Moore, 163-203. Philadelphia: Temple University Press, 1974.

"Temple Without Hands." In Temples and High Places in Biblical Times, 21 30. Jerusalem: The Nelson Glueck School of Biblical Archaeology of Hebrew Union College, 1977.

Freedman, David Noel, and C. Franke Hyland. "Psalm 29: A Structural Analysis." Hanvard Theological Review 66 (1973): 237-56.

Freedy, Kenneth S. "Glosses in Ezekiel 1-24." Vetus Testamentum 20 (1970): 129-52.

Freehof, Solomon B. Book of Isaiah: A Commentary. New York: Union of American Hebrew Congregations, 1972.

. The Book of Psalms, A Commentary. The Jewish Commentary for Bible Readers. Cincinnati: Union of American Hebrew Congregations, 1938.

Fretheim, Terence E. "Because the Whole Earth Is Mine": Theme and Narrative in Exodus." Interpretation 50, no. 3 (1996): 229-39.

"The Book of Genesis: Introduction, Commentary, and Reflections." The New Interpreter's Bible. Edited by Leander E. Keck. Nashville: Abingdon, 1994. 1:319674.

- Exoduss. Interpretation: A Bible Commentary for Teaching and Preaching. Lousville: John Knox, 1991.

Friedman, Richard Elliot. "The Tabernacle in the Temple." Biblical Archaeologist 43 $(1980): 241-48$.

Fritz, Volkmar. Dos erste Buch der Könige. Zürcher Bibelkommentare. Zürich: Theologischer Verlag, 1996.

- "Temple Architecture: What Can Archaeology Tell Us about Solomon's Temple?" Biblical Archaeology Review 13, no. 4 (1987): 39-49. 


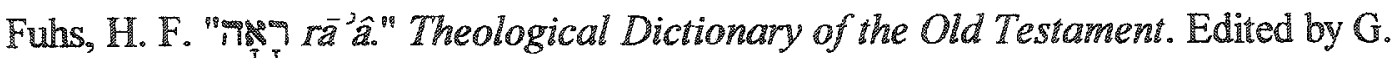
Johannes Botterweck and Helmer Ringgren. Grand Rapids: Eerdmans, 1974-2004. $13: 208-42$.

Fujita, Shozo. "The Temple Theology of the Qumran Sect and the Book of Ezekiel: Their Relationship to Jewish Literature of the Last Two Centuries B.C." Th.D. diss., Princeton Theological Seminary, 1970.

Futato, Mark D. "291, בפ9." New International Dictionary of Old Testament Theology and Exegesis. Edited by Willem A. VanGemeren. Grand Rapids: Eerdmans, 1997. $3: 333$.

Gailey, James H., Jr. Micah, Nahum, Habakkuk, Zephaniah, Haggai, Zechariah, Malachi. The Layman's Bible Commentary. Atlanta: John Knox, 1982.

Galambush, Julie. Jerusalem in the Book of Ezekiel: The City as Yahweh's Wife. SBL Dissertation Series 130. Edited by David L. Petersen. Atlanta: Scholars Press, 1992.

Gamberoni, J. "aipe mäqom." Theological Dictionary of the Old Testament. Edited by G. Johannes Botterweck and Helmer Ringgren. Grand Rapids: Eerdmans, 19742004 . 8:532-44.

Gamper, Amold. "Die Heilsgeshichte Bedeuteung des Solomonischen Tempelweihgebets." Zeitschriff fü katholische Theologie 85 (1963): 55-61.

Gane, Roy. Cult and Character: Purification Offerings, Day of Atonement, and Theodicy. Winnona Lake: Eisenbrauns, 2005. Forthcoming.

"Genre Awareness and Interpretation of the Book of Daniel." In To Understand the Scriptures: Essays in Honor of William Shea, ed. David Mering, 138-48. Berrien Springs, MI: Institute of Archaeology/Horn Archaeological Museum, 1997.

"Hurrian Ullikummi and Daniel's 'Little Hom'." In Shalom Paul Festschrift. Forthcoming.

The NIV Application Commentary: Leviticus, Numbers. Grand Rapids: Zondervan, 2004.

Ritual Dynamic Structure. Gorgias Dissertations 14, Religion 2. Piscataway, NJ: Gorgias, 2004. 
. The Syntax of Tet $V^{P} .$. in Daniel 8:13." In Creation, Life, and Hope: Essays in Honor of Jacques B. Doukhan, ed. Jiri Moscala, 367-82. Berrien Springs, MI: Old Testament Department, Seventh-day Adventist Theological Seminary, Andrews University, 2000.

Garcia-Treto, Francisco O. "Jacob's 'Oath-Covenant' in Genesis 28." In Trinity University Studies in Religion, 10, 1-10. San Antonio: Trinity University Dept. of Religion, 1975.

Gardner, Anne E. "The Great Sea of Dan VII 2." Vetus Testomentum 49 (1999): $412-15$.

Garelli, P., ed. Le Temple et la Culte. Istanbul: Uitgaven van Het Netherlands Historischarchaeologisch Institute te Istanbul XXXVII, 1975.

Garland, D. David. "Habakkuk." The Broadman Bible Commentary. Edited by Clifton J. Allen. Nashville: Broadman, 1972. 7:245-69.

Garrett, Duane A. Hosea, Joel. The New American Commentary, vol. 19A. Nashville: Broadman and Holman, 1997.

Garscha, Jörg. Studien zum Ezechielbuch: Eine redaktionkwitische Untersuchung von Ez 1-39. Bern: Herbert Lang, 1974.

Gaster, T. H. "Psalm 29." Jewish Quarterly Review 37 (1946-47): 55-65.

George, A. R. House Most High: The Temples of Ancient Mesopotamia. Mesopotamian Civilizations 5. Winona Lake: Eisenbrauns, 1993.

Geraty, Lawrence T. "The Jerusalem Temple and Its Near Eastern Context." In The Sanctuary and the Atonement: Biblical, Theological, and Historical Studies, ed. Amold Valentin Wallenkampf, W. Richard Lesher and Frank B. Holbrook, 37-62. Silver Spring, MD: Biblical Research Institute, 1989.

Gerstenberger, Erhard. Leviticus: A Commentary. Louisville: Westminster John Knox, 1996.

. Psalms, Part 2, and Lamentations. Forms of the Old Testament Literature 15. Grand Rapids: Eerdmans, 2001.

- Psalms Part 1 with an Introduction to Cultic Poetry. Forms of the Old Testament Literature 14. Grand Rapids: Eerdmans, 1988.

Gesenius, Wilhelm, E. Kautzsch, and A. E. Cowley. Gesenius' Hebrew Grammar. 2nd English ed. Oxford: Clarendon, 1910. 
Gevirtz, Stanley. "Evidence of Conjugational Variation in the Parallelization of Selfsame Verbs in the Amarna Letters." Journal of Near Eastern Studies 23 (1973): 99-104.

Gibson, J. L. Davidson's Introductory Grammar Syntox. Edinburgh: T. and T Clark, 1994. . "The Theology of the Ugaritic Baal Cycle." Orientalia 53 (1984): 202-19.

Gileadi, Avraham. The Literary Message of Isaiah. New York: Hebraeus, 1994.

Gillingham, S. E. The Poems and Psalms of the Hebrew Bible. Oxford Bible Series. Oxford: Oxford University Press, 1994.

Ginsberg, H. Louis. "A Phoenician Hymn in the Psalter." In XIX Congresso Internazionale degli Orientalisti, 472-76. Rome: Tipografia del Senato, G. Bardi, 1936.

. "Introduction [to Isaiah]." In The Book of Isaiah, 7-21. Philadelphia: J ewish Publication Society of America, 1973.

. "Reflexes of Sargon in Isaiah after 715 B.C.E." In Essoys in Memory of E. A. Speiser, 47-53. New Haven, CT: American Oriental Society, 1968.

Girard, Marc. Les Psaumes: Analyse Structurelle et Interpretation: 1-50. 3 vols. Recherches Nouvelle Série-2. Montréal; Éditions Bellarmin, 1984.

. Les Psaumes: Analyse Structurelle et Interpretation: 51-100. Montréal: Éditions Bellarmin, 1984.

Glatt, David A. Chronological Displacement in Biblical and Related Literatures. Atlanta, GA: Scholars Press, 1993.

Goldingay, John. "Holy Ones on High' in Daniel 7:18." Journal of Biblical Literature 107 (1988): $495-97$.

. Daniel. Word Biblical Commentary 30. Dallas, TX: Word Books, 1989.

Görg, M. "awịn? yăăab." Theological Dictionary of the Old Testament. Edited by G. Johannes Botterweck and Helmer Ringgren. Grand Rapids: Eerdmans, 1974-2004. $6: 436$. 


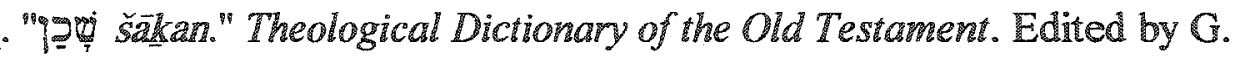
Johannes Botterweck and Helmer Ringgren. Grand Rapids: Eerdmans, 1974-2004. $7: 1338-47$.

Goppelt, Leonhard. "זutos." Theological Dictionary of the New Testament. Grand Rapids: Eerdmans, 1964-1976. 8, 246-59.

. Typos: The Typological Interpretation of the Old Testament in the New. Translated by Donald H. Madvig. Grand Rapids: Eerdmans; 1982.

Görg, M. "Die Gattung des sogenannten Tempelweihespruchs (1 $\mathrm{Kg} \mathrm{8,121)."} \mathrm{Ugarit-}$ Forschungen 6 (1974): 55-63.

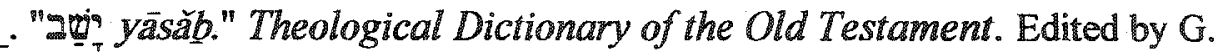
Johannes Botterweck and Helmer Ringgren. Grand Rapids: Eerdmans, 1974-2004. 6:420-38.

. "Y๊ơ šakan." Theologisches Wörterbuch zum alten Testament. Stuttgart, W. Kohlhammer, 1973-1997. 1338-47.

Goulder, M. D. The Prayers of David (Psalms 51-72): Studies in the Psalter, II. Joumal for the Study of the Old Testament, Supplement Series 102. Sheffield, England: 1990.

.The Psalms of the Return: (BookV, Psalms 107-150). Journal for the Study of the Old Testament, Supplement Series 258. Edited by M. D. Goulder. Sheffield: Sheffield Academic, 1998.

Gowan, Donald E. "Isaiah 6:1-8." Interpretation 45 (1991): 172-76.

. Theology of the Prophetic Books: The Death and Resurrection of Israel. Louisville: Westminster John Knox, 1998.

. The Triumph of Faith in Habarksk. Atlanta: John Knox, 1976.

When Man Becomes God: Humanism and Hybris in the Old Testament. Pittsburgh: Pickwick, 1975.

Graham, Wiliam Creighton. "Some Suggestions toward the Interpretation of Micah 1:1016." The American Joumal of Semitic Languages and Literature 47, no. 4 (1931): $237-58$. 
Graupner, Axel. Der Elohist: Gegenwart und Wirksamkeit des transzendenten Gottes in der Geschichte. Wissenschaftiche Monographien zum Alten und Neuen Testament 97. Neukirchen-Vluyn: Neukirchener Verlag, 2002.

Gray, George Buchanan. A Critical and Exegetical Commentary on the Book of Isaiah I39. The International Critical Commentary, vol.19, part I. Edinburgh: $T$. and $T$. Clark, 1912.

"The Heavenly Temple and the Heavenly Altar." The Expositor 5 (1908): 385 $402 ; 531-46$.

Gray, John. I and II Kings: A Commentary. Philadelphia: Westminster, 1963.

Grayson, A. K. Assyrian and Babylonian Chronicles. Texts from Cuneiform Sources 5. Locust Valley, NY: J.J. Augustin Publisher, 1975.

Green, Alberto R. W. The Storm-God in the Ancient Near East. Biblical and Judaic Studies 8. Winona Lake: Eisenbrauns, 2003.

Greenberg, Moshe. Ezekiel 1-20. The Anchor Bible, vol. 22. New York: Doubleday, 1983.

Ezekiel 21-37. The Anchor Bible, vol. 22A. New York: Doubleday, 1997.

Greenstein, Edward L. "One More Step on the Staircase." Ugarit-Forschungen (1977): 77-86.

Greimas, Algirdas Julien, and Joseph Courtés. Semiotics and Language: An Analytical Dictionary. Bloomington: Indiana University Press, 1982.

Grelot, Pierre. "Isaì 14:12-15 et son arrière-plan mythologique." Revue de l'Histoire des Religions 149 (1956): 18-48.

Griffiths, J. G. "The Celestial Ladder and the Gate of Heaven (Gen 28:12 and 17)." Expository Times 76 (1964-65): 229-30.

Gross, Heirrich. "Weltherrschaft als Gottesherrschaft nach Genesis 11,1-9 und Daniel 7: Bibeltheologische Überlegungen." In Gottesherrschaft, Weltherrschaft, 15-22. Regensburg: Friedrich Pustet Verlag, 1980.

Gross, Heinrich, and Heinz Reinelt. Dos Buch der Psalmen: Teil I (PS L-72). 3rd ed. Geistliche Schriftlesung. Erläuterungen zum Alten Testament für die Geistliche Lesung 9. Düsseldorf: Patmos Verlag, 1989. 
- Das Buch der Psalmen: Teil II (PS 73-150). 3rd ed. Geistliche Schriftlesung. Erläuterungen zum Alten Testament fur die Geistliche Lesung 9. Düsseldorf: Patmos Verlag, 1989.

Gunkel, Hermann. Genesis. Translated by Mark E. Biddle. Mercer Library of Biblical Studies. Macon, GA: Mercer University Press, 1997.

. Die Psalmen. 5. Auf. Gottingen: Vandenhoeck und Ruprecht, 1968.

. Schöpfung und Chaos. Göttingen: Vandenhoeck und Ruprecht, 1895.

Gumey, O. R. "Hittite Prayers of Mursili II." Annals of Archaeology and Anthropology 27 (1940): 3-163.

. Some Aspects of Hittite Religion. Oxford University Press, 1977.

Güterbock, Hans Gustav, ed. The Song of Ullikummi: Revised Text of the Hittite Version of a Hurrian Myth. New Haven, CT: The American Schools of Oriental Research, 1952.

Gütterbock, Hans G. "Hittite Mythology." In Mythologies of the Ancient World, ed. Samuel Noah Kramer, 139-79. Garden City, NY: Doubleday, 1961.

"The Hittite Palace." In Le Palais et la Royauté (Archéologie et Civilization), ed. P. Garelli, 305-14. Paris: Geuthner, 1974.

Haag, Ernst. Das Bach Jeremia. 2nd ed. Geistliche Schriflesung: Erläuterungen zum Alten Testament fir die geistliche Schriftlesung 5. Düsseldorf: Patmos-Verlag, 1990.

- Das Buch Jeremia. 3rd ed. Geistliche Schriftlesung: Erläuterungen zum Aiten Testament uirr die geistliche Schriflesung 5. Düsseldorf: Patmos-Verlag, 1988.

Haas, Volkert. Geschichte der Hethitischen Religion. Leiden: Brill, 1994.

Habel, Noman. The Book of Job: A Commentary. Philadelphia: Westminster, 1985.

. "The Form and Significance of the Call Narratives." Zeitschrift für die altestamentliche Wissenschaft 77 (1965): $297-323$.

Hagelia, Hallvard. "Meal on Mount Zion-Does Isa 25:6-8 Describe a Covenant Meal?" Svensk Exegetish Arsbok 68 (2003): 73-95. 
Hailey, Homer. A Commentary on the Minor Prophets. Grand Rapids: Baker, 1972.

Hallo, William W. "Toward a History of Sumerian Literarture." In Sumerological Studies in Honor of Thorkild Jacobsen on His Seventieth Birthday, June 7, 1974, 181203. Chicago: University of Chicago Press, 1976.

Hallo, William W., and K. Lawson Younger, eds. The Context of Scripture: Canonical Compositions from the Biblical World, vol. 1. Leiden: Brill, 1997. , eds. The Context of Scripture: Monumental Inscriptions from the Biblical World, vol. 2. New York: Brill, 1997.

Halpern, Baruch. "Ritual Background of Zechariah's Temple Song." Catholic Biblical Quarterly 40 (1978): 167-90.

Hals, Ronald M. Ezekiel. Grand Rapids: Eerdmans, 1989.

Hamerton-Kelly, R. G. "The Temple and the Origins of Jewish Apocaliptic." Vetus Testamentum 20 (1970): 1-15.

Hamilton, Victor P. The Book of Genesis: Chapters 1-17. Grand Rapids: Eerdmans, 1990. - Handbook on the Pentateuch: Genesis, Exodus, Leviticus, Numbers, Deuteronomy. Grand Rapids: Baker, 1982.

Haney, Randy G. Text and Concept Analysis in Royal Psalms. Studies in Biblical Literature 30. New York: Lang, 2002.

Hanson, Paul D. Isaiah 40-66. Interpretation: A Bible Commentary for Teaching and Preaching. Louisville: John Knox, 1995.

. "Rebellion in Heaven, Azazel, and Euhemeristic Heroes in 1 Enoch 6-11." Joumal of Biblical Literature 96, no. $2(1977): 195-233$.

Haran, Menahem "The Ark and the Cherubim: Their Symbolic Significance in Biblical Ritual" Israel Exploration Journal 9 (1959): 30-38; 89-98.

."The Divine Presence in the Israelite Cult and Cultic Institutions." Biblica 50 $(1969): 251-67$.

"Temple and Community in Ancient Israel." In Temple in Society, ed. Michael V. Fox, 17-25. Winona Lake: Eisenbrauns, 1988. 
Temple and Temple Service in Ancient Israel: An Inquiry into Biblical Cult Phenomena and the Historical Setting of the Priestly School. Winona Lake: Eisenbrauns, 1985.

Harbach, Robert C. Studies in the Book of Genesis. Grandville, MI: Reformed Free Pub. Association, 2001.

Harrington, Daniel J. "The Ideology of Rule in Daniel 7-2." In Society of Biblical Literature Seminar Papers 1999, 540-51. Atlanta: Society of Biblical Literature, 1999.

Harrington, Daniel J., and Anthony J. Saldarini. Targum Jonathan of the Former Prophets. Collegeville, MN: Liturgical, 1990.

Harris, R. L. "rp;K'." Theological Wordbook of the Old Testament. Chicago: Moody, 1981. 2:452-453.

Harrison, R. K. Jeremiah and Lamentations: An Introduction and Commentary. Downers Grove, IL: Inter-Varsity, 1973.

Hart, George. A Dictionary of Egyptian Gods and Goddesses. London: Routledge and Kegan Paul, 1986.

Hartenstein, Friedhelm. "Wolkendunkel und Himmelfeste: Zur Genese und Kosmologie der Vorstellung des himmlischen Heiligtums JHWHs." In Das biblische Weltbild und seine altorientalischen Kontexte, ed. Bernd Janowski and Beate Ego, 125 179. Tübingen: Mohr Siebeck, 2001.

Hartman, Louis Francis, and Alexander A. Di Lella. The Book of Doniel. The Anchor Bible, vol. 23. Garden City, NY: Doubleday, 1978.

Hasel, Gerhard F. "The Book of Daniel and Matters of Language: Evidences Relating to Names, Words, and the Aramaic Language." Andrews University Seminary Studies $19(1981): 211-25$.

. "Establishing a Date for the Book of Daniel." In Symposium on Daniel, ed.

Frank B. Holbrook, 84-164. Washington, DC: Biblical Research Institute, 1986.

. "The 'Little Hom," the Heavenly Sanctuary and the Time of the End: A Study of Daniel 8:9-14." In Symposium on Daniel, ed. Frank B. Holbrook, $378-461$. Washington, DC: Biblical Research Institute, 1986. 
. "The Little Horn,' Saints, and the Sanctuary in Daniel 8." In The Sanctuary and the Atonement. Edited by Amold Wallenkampf and Richard Lesher, 177-227. Washington, DC: Review and Herald Publishing Association, 1981.

Hasel, Gerhard "The Meaning of "Let Us' in Gn 1:26." Andrews University Seminary Studies 13 (1975): 58-66.

Hauge, Martin Ravndal. Between Sheol and Temple: Motif Structure and Function in the I-Psalms. Joumal for the Study of the Old Testament 178. Sheffield: Sheffield, 1995.

. The Descent from the Mountain: Narrative Patterns in Exodus 19-40.

JSOTSup 323. Sheffield: Sheffield Academic, 2001.

Haul, Michael. Das Etana-Epos: Ein Mythos von der Himmelfahrt des Königs von Kiš. Göttinger Arbeitsheft zur Altorientalischen Literatur. Göttingen: Seminar für Keilschrifforschung, 2000.

Hayman, Peter. "Some Observations on Sefer Yesira: (2) The Temple at the Centre of the Universe." Journal of Jewish Studies 37 (1986): 176-82.

Hays, J. Daniel. From Every People and Nation: A Biblical Theology of Race. Downers Grove, IL: Inter-Varsity, 2003.

Hayward, Robert. The Jewish Temple: A Non-Biblical Sourcebook London: Routledge, 1996.

"He Dreamed" [Gen 28:12]. Seventh-doy Adventist Bible Commentary. Rev. ed. Edited by Francis D. Nichol. Washington, DC: Review and Herald, 1976-80. 1:382.

Heidel, Alexander. The Babylonian Genesis: The Story of the Creation. 2 d ed. Chicago: University of Chicago Press, 1951.

Heimerdinger, Jean-Marc. Topic, Focus and Foreground in Ancient Hebrew Narratives. Joumal for the Study of the Old Testament, Supplement Series 295. Sheffield: Sheffield Academic, 1999.

Henderson, E. The Book of the Prophet Isaiah. 2nd ed. London: Hamilton Adams, 1857.

Hendrix, Ralph E. "A Literary Structural Overview of Exod 25-40."Andrews University Seminary Studies 30, no. 2(1992): 123-38. 
"The Use of Miškān and 'Ōhel Mốéd in Exodus 25-40." Andrews University Seminary Studies 30, no. 1 (1992): 3-13.

Herbert, Arthur S. The Book of the Prophet Isaiah: Chapters 1-39. Cambridge: Cambridge University Press, 1973.

Hermisson, Hans-Jürgen. Sprache und Ritus im altisraelitischen Kult: Zur "Spiritualisierung" der Kultbegriffe im Alten Testament. Wissenschaftliche Monographien zum Alten und Neuen Testament 19. Neukirchen-Vluyn: Neukirchener Verlag des Erziehungsvereins, 1965.

Hertzberg, Hans Wilhelm. I and II Samuel: A Commentary. Philladelphia: Westminster, 1964.

Hilde, Reuben L. "An Exegesis of the Little Hom of Daniel." MA thesis, Seventh-day Adventist Theological Seminary, 1953.

Hillers, Delbert R. Micah. Hermeneia. Philadelphia: Fortress, 1984.

Himmelfarb, Martha. "Apocalyptic Ascent and the Heavenly Temple." SBL Seminar Papers 26 (1987): 210-17.

"The Temple and the Garden of Eden in Ezekiel, the Book of the Watchers, and the Wisdom of Ben Sira." In Sacred Places and Profane Spaces: Essays in the Geographics of Judaism, Christianity, and Islam, ed. Jamie S. Scott and Paul Simpson-Housley, 63-78. New York: Greenwood, 1991.

."Torah, Testimony, and the Heavenly Tablets: The Claim to Authority of the Book of Jubilees." In A Multiform Heritage: Studies on Early Judaism and Christianity in Honor of Robert A. Kraft, ed. Benjamin G. Wright, 19-29. Atlanta, GA: Scholars Press, 1999.

"His holy temple" [Hab 2:201. Seventh-day Adventist Bible Commentary. Rev. ed. Edited by Francis D. Nichol. Washington, DC: Review and Herald, 1976-80.4:1055.

Hitzig, Ferdinand, and Heinrich Steiner. Die Zwölf Kleinen Propheten. 4th ed. Leipzig: S. Hirzel, 1881.

Hoffner, Harry A., Jr. Hittite Myths. Atlanta: Scholars Press, 1998.

"Second Millennium Antecedents to the Hebrew 'ob." "Journal of Biblical Literaiure 86 (1967): 385-401. 
Holbrook, Frank B. "The Israelite Sanctuary." In The Sanctuary and the Atonement:

Biblical, Theological, and Historical Studies, ed. Frank B. Holbrook, 3-36. Silver Spring, MD: Biblical Research Institute, 1989.

Holladay, William Lee. Jeremiah 1: A Commentary on the Book of the Prophet Jeremiah, Chapters 1-25. Hermeneia-A Critical and Historical Commentary on the Bible. Philadelphia: Fortress, 1986.

Honeycut, Roy L., Jr. "Exodus." The Broadman Bible Commentary. Edited by Clifton J. Allen. Nashville: Broadman, 1969. 1:305-472.

"Hosea." The Broadman Bible Commentary. Edited by Clifon J. Allen.

Nashville: Broadman, 1972. 7:1-60

Hooke, S. H. Myth and Ritual. London: Oxford University Press, 1933.

Hoonacker, Albin van. Les Douze Petits Prophètes. Paris: J. Gabalda, 1908.

Homung, Erik. Conceptions of God in Ancient Egypt: The One and the Many. Translated by John Baines. Ithaca: Comell University Press, 1982.

Horowitz, Wayne. Mesopotomian Cosmic Geography. Mesopotamian Civilizations 8. Winona Lake: Eisenbrauns, 1998.

Hossfeld, Frank-Lothar, and Erich Zenger. Die Psalmen I: 1-50. Neue Echter Bibel. Altes Testament 29, 40. Wurzburg: Echter Verlag, 1993.

. Psalmen 51-100. Herders theologischer Kommentar zum Alten Testament. Freiburg im Breisgau: Herder, 2000.

Houk, Comelius B. "Final Redaction of Ezekiel 10." Journal of Biblical Literature 90 , no. I (1971): 42-54.

- "A Statistical Linguistic Study of Ezekiel 1:4-3:11." Zeitschrift für die Altestamentliche Wissenschaft 93 (1981): 76-85.

Houtman, Comelis. Exodus. Translated by Sierd Woudstra. Historical Commentary on the OId Testament. Leuven, Belgium: Peeters, 2000.

Der Himmel im Alten Testament: Israels Weltbild und Weltanschanung.

Oudtestamentische Studiën 30. Leiden: Brill, 1993. 
. "Tempel und Schöpfung: Schöpfungstheologische Aspekte der priesterschriflichen Heiligtumskonzeption." In Schöpfung und Neuschöpfung, ed. Ingo Baldermann et al., 37-69. Neukirchen-Vluyn: Neukirchener Verlag, 1990.

Jansen, Waldemar. Mouming Cry and Woe Oracle. Beihefte zur Zeitschrift fur die Alttestamentliche Wissenschaft 125. New York: de Gruyter, 1972.

Japhet, Sara. I and II Chronicles: A Commentary. The Old Testament Library. Louisville: Westminster John Knox, 1993.

Jeffery, Arthur. "Exegesis of the Book of Daniel." The Interpreter's Bible. Edited by George Arthur Buttrick. New York: Abingdon, 1956. 6:339-549.

Jenni, Emst. "gnב bhn." Theological Lexicon of the Old Testament. Peabody, MA: Hendrickson, 1997. 1:207-09.

Jensen, Hans Jørgen Lundager. "Reden, Zeit und Raum in Genesis 28, 10-15." Linguistica Biblica 49 (1981): 54-70.

Jensen, Joseph. Isaiah 1-39. Old Testament Message: A Biblical-Theological Commentary 8. Wilmington, DE: Michael Glazier, 1984.

Jenson, Philip Peter. Graded Holiness: A Key to the Priestly Conception of the World. Journal for the Study of the Old Testament, Supplement Series 106. Sheffield: JSOT, 1992.

Jepsen, A. "דin chàzâh." Theological Dictionary of the Old Testament. Edited by G. Johannes Botterweck and Helmer Ringgren. Grand Rapids: Eerdmans, 1974-2004. $4: 280-90$.

Jeppesen, Knud. "You Are a Cherub, but No God." Scandinavian Joumal of the Old Testament 5 (1991): 83-94.

Jeremias, Alfred. Das Alte Testament im Lichte des Alten Orient. Leipzig: J. C. Hinrichs, 1930.

. The Babylonion Conception of Hecven and Hell. Translated by Jane Hutchison. London: D. Nutt, 1902.

Babylonisches im Neuen Testament. Leipzig: J. C. Hinrichs'sche Buchhandhung, 1905.

"Das Orientalische Heiligtum." Angelos 4 (1932): 56-69. 
Jeremias, Jörg. Das Königtum Gottes in den Psalmen: Israels Begegnung mit dem kanaanäischen Mythos in den Jahwe-König-Psalmen. Forschungen zur Religion und Literatur des Aiten und Neuen Testaments 141. Göttingen: Vandenhoeck und Ruprecht, 1987.

-Theophanie: Die Geschichte einer alttestamentichen Gattong. 2 nd ed. Wissenschaftiche Monographien zum Alten und Neuen Testament 10. Neukirchen-Vluyn: Neukirchener Verlag, 1977.

Jirku, A. "Zur magischen Bedeitung der Kleidung in Israel." Zeitschrift für Alttestamentliche Wissenschaft 37 (1917/18): 109-25.

Jones, Douglas Rawlinson. Jeremiah. New Century Bible Commentary. Grand Rapids: Eerdmans, 1992.

Jones, Gwilym H. 1 and 2 Kings. Grand Rapids: Eerdmans, 1984.

Jonker, Louis C. "Hope Beyond the Pre-Exilic Period: The Interrelationship of the Creation and Temple/Zion Traditions during the Monarchical and Exilic Periods." Scriptura 66 (1998): 199-215.

Jordan-Smith, Paul. "The Gate of Heaven." Parabola 7, no. 2 (1982): 6-12.

Joüon, Paul, and T. Muraoka. A Grammar of Biblical Hebrew. Subsidia Biblica 14/114/2. Rome: Editrice Pontificio Istituto Biblio, 1996.

Justesen, Jerome P. "On the Meaning of SADAQ." Andrews University Seminary Studies 2 (1964): $53-61$

Kaiser, Otto. Isaiah 13-39: A Commentary. Philadelphia: Westminster, 1974. - Isaiah 1-12. Translated by John Bowden. The Old Testament Library. Philadelphia: Westminster, 1983.

Kapelrud, Arvid S. "Temple Building, a Task for Gods and Kings." Orientalia 32 (1963): $56-62$.

Kaplan, Mordecai M. "Isaiah 6:1-11." Journal of Biblical Literature 45 (1926): 251-259.

Keamey, Peter J. "Creation and Liturgy: The P Redaction of Ex 25-40." Zeitschriff fur die alttestamentliche Wissenschaft 89 (1977): $375-87$. 
. Jahwe-Visionen und Siegelkunst: eine neue Deutung der

Majestätsschilderungen in Jes 6, Ez 1 und 10 und Sach 4. Stuttgart: Verlag

Katholisches Bibelwerk, 1977.

. Die Welt der altorientalischen Bildsymbolik und das Alte Testament. Am

Beispiel der Psalmen. Zürich: Beziger, 1972.

Keel, Othmar, and Christoph Uehlinger. Gods, Goddesses, and Images of God in Arcient Israel. Minneapolis, MN: Fortress, 1998.

Keel, Othmar, and Urs Winter. Vögel als Boten: Sudien zu Ps 68, 12-14, Gen 8, 6-12, Koh 10, 20 und dem Aussenden von Botenvögeln in Agypten. Freiburg: Universitätsverlag, 1977.

Keil, C. F. Biblical Commentary on the Book of Daniel. Translated by M. G. Easton. Grand Rapids: Eerdmans, 1959.

. Biblical Commentary on the Books of Samuel. Translated by James Martin. Grand Rapids: Eerdmans, 1950.

- Biblical Commentary on the Old Testament. The Pentateuch. Vol 2 of 3.

Translated by James Martin. Grand Rapids: Eerdmans, 1952.

. Biblical Commentaries on the Prophecies of Ezekiel, vol. 1 of 2. Translated by James Martin. Grand Rapids: Eerdmans, n.d.

. The Twelve Minor Prophets. Vol. 1 of 2. Translated by James Martin. Biblical Commentary on the Old Testament. Grand Rapids: Eerdmans, 1949.

Kelley, Page H. "Isaiah." Broadman Bible Commentary. Nashville: Broadman, 1969. $5: 149-474$.

Kempf, Stephen. "Introducing the Garden of Eden: The Structure and Function of Genesis 2:4b-7." Journal of Translation and Textlinguistics 7, no. 4 (1996): 33-53.

Keown, G. "A History of Interpretation of Isaiah 14:12-15." Ph.D. diss., Southern Baptist Theological Seminary, 1979.

Ker, Alan R. The Temple of Jesus' Body: The Temple Theme in the Gospel of John. Journal for the Study of the New Testament Supplement Series 220. London: Sheffield Academic, 2002. 
Kessler, Rainer. Micha. Herders theologischer Kommentar zum Alten Testament. Freiburg im Breisgau: Herder, 1999.

Khoo, Jeffrey. "Isaiah 14:12-14 and Satan: A Canonical Approach." Stulos Theological Journal 2(1994): 67-77.

Kidner, Derek. The Book of Genesis: An Introduction and Commentary. Chicago: InterVarsity, 1967.

- Psalms 1-72. London: Inter-Varsity, 1973.

. Psalms 73-150. London: Inter-Varsity, 1975.

Kikawada, Isaak M. "The Shape of Genesis 11:1-9." In Rhetorical Criticism: Essays in Honor of James Muilenburg, ed. Jared J. Jackson and Martin Kessler, 19-32.

Pittsburgh: Pickwick, 1974.

Kim, Sanglae. "The Heavenly Sanctuary/Temple in the Hebrew Bible." Ph.D. diss., University of Sheffield, 2002.

Kinet, Dirk. "Theologische Reflexion im Ugaritischen Ba'al-Zyklus." Biblische Zeitschrift 22 (1978): $236-44$.

King, L. W. The Seven Tablets of Creation or the Babylonian and Assyrian Legends Concerning the Creation of the World and of Mankind, vol. 1. London, Luzac, 1902.

Kingsbury, Edwin C. "The Prophets and Council of Yahweh." Journal of Biblical Literature $83(1964)$ : 279-86.

Kirkpatrick, A. F. The Book of Psalms. Cambridge, England: University Press, 1939.

Kissane, Edward J. The Book of Isaiah, Translated from a Critically Revised Hebrew Text with Commentory. Dublin: Browne and Nolan, 1941.

Kissane, Edward Joseph. The Book of Psams: Translated from a Critically Revised Hebrew Text: With a Commentary. Dublin: Browne and Nolan, Richview, 1964.

Kistemaker, Simon J. "The Temple in the Apocalypse." Journal of the Evangelical Theological Society 43 (2000): 433-41.

Klein, George L. "The "Prophetic Perfect"." Journal of Northwest Semitic Languages 16 $(1990): 45-60$. 
Klein, Jacob. Three Sulgi Hymns: Sumerian Royal Hymns Glorifying King Sulgi of Ur. Bar-Ilan Studies in Near Eastem Languages and Culture. Ramat-Gan, Israel: Barllan University Press, 1981.

Klein, Ralph W. "Back to the Future: The Tabernacle in the Book of Exodus." Interpretation 50, no. 3 (1996): 264-76.

Kleinert, P., and Johann Peter Lange. Obadiah, Jonah, Micha, Nahum, Habakuk, Zephanjah. Theologish-homiletish Bibel Werk 5. Edited by J. P. Lange. Bielefeld und Leipzig: Velhagen und Klasing, 1868.

Kline, Meredith G. "The Structure of the Book of Zechariah." Journal of the Evangelical Theological Society 34 (1991): 179-93.

Kloos, Carola. Yhwh's Combat with the Sea: A Canaanite Tradition in the Religion of Ancient Israel. Amsterdam/Leiden: G.A. van Oorschot/Brill, 1986.

Knierim, Rolf. "The Vocation of Isaiah." Vetus Testamentum 10 (1968): 47-68.

Knight, George Angus Fulton. Psalms. 2 vols. Philadelphia: Westminister, 1982.

Knoppers, Gary N. "Prayer and Propaganda: Solomon's Dedication of the Temple and the Deuteronomist's Program." Catholic Biblical Quarterly 57 (1995): 229-54.

Koch, Klaus. "qgiva mó 'éd." Theological Dictionary of the Old Testament. Edited by G. Johannes Botterweck and Helmer Ringgren. Grand Rapids: Eerdmans, 1974-2004. 8:167-73.

Köhler, Ludwig, Walter Baumgartner, M. E. J. Richardson, and Johann Jakob Stamm. The Hebrew and Aramaic Lexicon of the Old Testament. Translated and edited under the

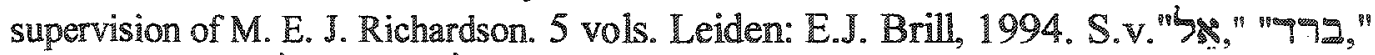

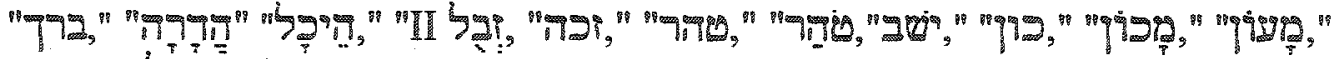

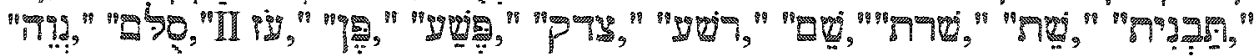

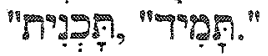

Koenen, Klaus. Jahwe wird hommen, zu herschen über die Erde: PS 90-110 als Komposition. Bonner Biblisch Beitråge 101. Weinheim: Beltz Athenåum, 1995.

Koester, Craig R., ed. The Dwelling of God: The Tabernacle in the Old Testament, Intertestamental Jewish Literature, and the New Testament. Edited by Robert J. Karris. The Catholic Biblical Quarterly Monograph Series, 22. Washington, DC: The Catholic Biblical Association of America, 1989. 
Kornfeld, K. "wionp gds." Theologisches Wörterbuch zum Alten Testament. Stuttgart: Verlag W. Kohlkhammer, 1973-1997. 6:1179-87.

Korpel, Marjo C. A. "The Poetic Structure of the Priestly Blessing." Journal for the Study of the Old Testament $45(1989): 3-13$.

Korpel, Marjo Christina Amete. A Rift in the Clouds: Ugaritic and Hebrew Descriptions of the Divine. Muinster: Ugarit-Verlag, 1990.

Kovacs, Maureen Gallery. The Epic of Gilgamesh. Stanford, CA: Stanford University Press, 1989.

Kraeling, Emil Gottlieb Heinrich. Commentary on the Prophets. Camden, NJ: T. Nelson, 1966.

Kraetzschmar, Richard. Das Buch Ezechiel, übersetzt und erklärt. Göttingen: Vandenhoeck und Ruprecht; 1900.

Kramer, Samuel Noah. History Begins at Sumer: Thirty-Nine Firsts in Man's Recorded History. 3rd rev. ed. Philadelphia: University of Pennsylvania Press, 1981.

"Poets and Psalmists: Goddesses and Theologians." In The Legacy of Sumer: Invited Lectures on the Middle East at the University of Texas at Austin, ed. Denise Schmandt-Besserat, 3-21. Malibu: Undena Publications, 1976. . Sumerian Mythology: A Study of Spiritual and Literary Achievement in the Third Millennium B.C. Philadelphia: American Philosophical Society, 1944.

"The Temple in the Sumerian Literature." In Temple in Society, ed. Michael V. Fox, 1-16. Winona Lake: Eisenbrauns, 1988.

Kraus, Hans-Joachim. Psalmen. 2 vols. 2 nd ed. Biblischer Kommentar Altes Testament. Neukirchen Kreis Moers: Neukirchener Verlag der Buchhandlung des Erziehungsvereins, 1961. . Psalms 60-150. Minneapolis: Augusburg, 1989. . Psalms 1-59. Mimneapolis: Fortress, 1993. .Theology of the Psalms. Translated by Keith Crim. Minneapolis: Augsburg Publishing House, 1986. - Worship in Israel. Richmond: John Knox, 1965. 
Krispen,, Jutta. "Grammatik und Theologie in der Botenformel." Zeitschriff für Althebraistik 11, no. 2(1998): 133-39.

Krüger, Annette. "Himmel-Erde-Unterwelt." In Das biblische Weltbild und seine altorientalischen Kontexte, ed. Bernd Janowski and Beate Ego, 65-83. Tübingen: Mohr Siebeck, 2001.

Kruger, Paul A. "The Hem of the Garment in Marriage: The Meaning of the Symbolic Gesture in Ruth 3:9 and Ezek 16:8." Joumal of Northwest Semitic Languages 12 (1984): $79-86$.

Kselman, John S. "Recovery of Poetic Fragments from the Pentateuchal Priestly Source." Journal of Biblical Literature 97, no. 2 (1978): 161-173.

Kumaki, F Kenro. "The Deuteronomistic Theology of the Temple: As Crystallized in 2 Sam 7, 1 Kgs 8." Annual of the Japanese Biblical Institute 7 (1981): 16-52.

Kuntz, J. Kenneth. "Psalm 18: A Rhetorical-Critical Analysis." Journal for the Study of the Old Testament (1983): 3-31.

Kvanvig, H. S. "An Akkadian Vision as Background for Daniel 7?" Studia Theologica 35 $(1981): 85-89$.

Laberge, Léo. "Le lieu que YHWH a choisi pour y mettre son Nom (TM, LXX, Vg et Targums): Critique textuelle d'une formule deutéronomiste." Estadios Biblicos, no. 3-4 (1985): 209-236.

Labuschagne, C. J. The Incomparability of Yahweh in the Old Testament. Leiden: Brill, 1966.

Lacocque, André. The Book of Daniel. Atlanta: John Knox, 1979.

Lambdin, Thomas Oden. Introduction to Biblical Hebrew. New York: Scribner, 1971.

Lambrecht, Knud. Information Structure and Sentence Form: Topic, Focus, and the Mental Representations of Discourse Referents. Cambridge: Cambridge University Press, 1996.

Landes, George $M$. "The Kerygma of the Book of Jonah: The Contextual Interpretation of the Jonah Psalm." Interpretation 21 (1967): 3-31.

Landsberger, B., and J.V. Kinnier Wilson. "The Fith Tablet of Enuma Elis." Journal of Near Eastern Studies 20 (1961): 154-79. 
Langdon, Stephen. Babylonian Penitential Psalms to Which Are Added Fragments of the Epic of Creation from Kish in the Weld Collection of the Ashmolean Museum. Paris: P. Geuthner, 1927.

Lang, B. "q2. kipper." Theological Dictionary of the Old Testament. Edited by G. Johannes Botterweck and Helmer Ringgren. Grand Rapids: Eercmans, 1974-2004. $7: 382-88$

Lange, Johann Peter, and Philip Schaff. A Commentary on the Holy Scriptures: Critical, Doctrinal, and Homilectical, with Special Reference to Ministers and Siudents. New York: C. Scribner, 1912.

LaRondelle, Hans K. Deliverance in the Psalms. Berrien Springs, MI: First Impressions, 1983.

Lau, Susan Carol Walter. "Garden as a Symbol of Sacred Space." Ph.D. diss., University of Pittsburgh, 1981.

Laubach, Fritz. Der Prophet Sacharja. Wuppertaler Studienbibel. Reihe Altes Testament. Wuppertal: Brockhaus, 1984.

Lauderville, Dale. "Ezekiel's Cherub: A Promising Symbol or a Dangerous Idol?" Catholic Biblical Quarterly 65 (2003): 165-183.

Lee, Pilchan. The New Jerusalem in the Book of Revelation: A Study of Revelation 21-22 in the Light of Its Background in Jewish Tradition. Wissenschaftliche Untersuchungen zum Neuen Testament, 2 Series, 129. Tübingen: Mohr Siebeck, 2001.

Lefevre, A. "The Power of Evil in the Old Testament." In Satan: Essays Collected and Translated from 'Etudes Carmelitaines, ed. Bruno de Jésus-Marie, 55-56. New York: Sheed and Ward, 1951.

Leick, Gwendolyn. A Dictionary of Ancient Near Eastern Mythology. London: Routledge, 1991.

Lenglet, A. "La Structure Littéraire de Daniel 2-7." Biblica 53 (1972): 169-90.

LePear, John Philip. "Psalm 68: An Exegetical and Theological Study." Ph.D. diss., University of lowa, 1981. 
Lesko, Leonard H. "Death and the Afterlife in Ancient Egyptian Thought." In

Civilizations of the Ancient Near East. Edited by Jack M. Sasson. 3:1763-74. New York: Scribner, 1995.

Leslie, Elmer Archibald. Isaiah, Chronologically Arranged, Translated and Interpreted. New York: Abingdon, 1963.

. The Psalms: Translated and Interpreted in the light of Hebrew Life and Worship. New York: Abingdon-Cokesbury, 1949.

Lete, G. del Olmo. Interpretación de la Mitología Cananea: Estudios de Semántica Ugarítica. Valencia, Spain: Institución San Jerónimo, 1984.

. Canaanite Religion According to the Liturgical Texts of Ugarit. Translated by Wilfred G. E. Watson. Bethesda, MD: CDL, 1999.

"Let Us Build a City" [Gen 11:4]. Seventh-day Adventist Bible Commentary. Rev. ed. Edited by Francis D. Nichol. Washington, DC: Review and Herald, 1976-80. $1: 284$.

"Let Us Go Down" [Gen 11:7]. Seventh-day Adventist Bible Commentary. Rev. ed. Edited by Francis D. Nichol. Washington, DC: Review and Herald, 1976-80. 1:285.

Leupold, H. C. Exposition of Genesis. Columbus, OH: The Wartburg, 1942. - Exposition of Isaiah. Grand Rapids: Baker, 1977. Exposition of the Psalms. Columbus, OH: Wartburg, 1959. - Exposition of Zechariah. Grand Rapids: Baker, 1971.

Levenson, Jon D. Theology of the Program of Restoration of Ezekiel 40-48. Harvard Semitic Monograph Series, vol. 10. Missoula, MT: Scholars Press, 1976. . "From Temple to Synagogue." In Traditions in Transformation: Turning Points in Biblical Faith, ed. Baruch Halpem and J. on Douglas Levenson, 143-66. Winona Lake: Eisenbrauns, 1981. . "The Temple and the World." The Journal of Religion 64 (1984): 275-97. - Sinci and Zion. New York: Harper and Row, 1985. 
Levine, Baruch A. "The Descriptive Tabemacle Texts of the Pentateuch." Journal of the American Oriental Society 85 (1965): 307-18.

L'Heureux, Conrad E. Rank among the Gods El, Ba'al, and the Repha'im. Harvard Semitic Monographs 21. Edited by Frank M. Cross. Missoula, MT: Scholars Press, 1979.

Limburg, James. Hosea-Micah. Atlanta: John Knox, 1988. 993.

Jonah: A Commentary. The Old Testament Library. Louisville: Iohn Knox,

Psalms. Westminster Bible Companion. Louisville: Westminister John Knox, 2000.

Lind, Millard. Ezekiel. Believers Church Bible Commentary. Scottdale, PA: Herald, 1996.

Lipinski, E. "GI' 'am." Theological Dictionary of the Old Testament. Edited by G. Johannes Botterweck and Helmer Ringgren. Grand Rapids: Eerdmans, 1974-2004. 11:163-177.

Lipton, Diana. Revisions of the Night: Politics and Promises in the Patriarchal Dreams of Genesis. JSOTSup 288. Sheffield: Sheffield, 1999.

Livingston, George Herbert. "Genesis." Beacon Bible Commentary. Kansas City: Beacon Hill, 1969.

Loewenstamm, Samuel E. "On the Theology of the Keret Epic." In From Babylon to Canaan, 185-200. Jerusalem: Magnes, 1992.

Lohfink, Norber. The Christian Meaning of the Old Testament. Translated by $\mathbb{R}$. A. Wilson. Milwaukee: Bruce, 1968.

Lokkegaard, F. "The House of Baal." Acta Orientalia 22 (1955): 10-27.

Long, Burke O. "Reports of Vision among the Prophets." Joumal of Biblical Literature $95(1976): 353-65$.

I Kings: With an Introduction to Historical Literature. Grand Rapids: Eeromans, 1984.

Longman, Tremper, and Daniel G. Reid. God Is a Warrior. Studies in Old Testament Biblical Theology. Grand Rapids: Zondervan, 1995. 
Loretz, D. "Der Kanaanaische-Bibilsche Mythos vom Sturz des Šahar-Sohnes Hêlel." Ugarit-Forschungen (1976): 133-36.

. "Der Sturz des Fursten von Tyrus (Ez. 28:1-19)." Ugarit-Forschungen 8 (1976): $455-58$.

Loretz, Oswald. Die Psalmen Teil II: Beitrag der Ugarit Texte zum Verständnis von Kolometrie und Textologie der Psalmen. Germany: Neukirchener Verlag, 1979.

- Psalm 29: Kanaanäische El- und Baalraditionen in jüdischer Sicht.

Ugaritisch-Biblische Literatur 2. Altenberg: CIS-Verlag, 1984.

. "Der Wohnort Els nach ugaritischen Texten und Ez 28,1-2.6-10." UgaritForschungen 21 (1990): $259-67$.

. Ugarit und die Bible. Darmstadt: Wissenschaftiche Buchgesellschaft, 1990.

. "Gottes Thron in Tempel und Himmel nach Psalm 11: Von der altorientalischen zur biblischen Theologie." Ugarit-Forschungen 26 (1994): 24570.

Low, Alvin A. K. "Interpretive Problems in Ezekiel 1." Ph.D. diss., Dallas Theological Seminary, 1985.

Lüddeckens, Erich. "The Mythical Origin of the Egyptian Temple - Book Review." Zeitschrift fur Religions- und Geistesgeschichte, no. 25 (1973): $261-66$.

Lundquist, John M. "The Common Temple Ideology of the Ancient Near East." In The Temple in Antiquity: Ancient Records and Ancient Perspectives, ed. Truman G. Madsen, 53-76. Provo, UT: Brigham Young University, 1984.

"The Legitimizing Role of the Temple in the Origins of the State." In Society of Piblical Literature Seminor Papers, 21, 271-97. Missoula, MT: Scholars Press, 1982.

"Temple, Covenant, and Law in the Ancient Near East and in the Old Testament." In Isprael's Apostasy and Restoration: Esscys in Honor of Rolond $K$. Harrison, ed. Avraham Gileadi, 293-305. Grand Rapids: Baker, 1988.

"Temple Symbolism in Isaiah." In Iswah and the Prophets, ed. Monte S. Nyman, 205-219. Provo, UT: Religious Studies Center, Brigham Young University, 1984. 
The Temple: Meeting Place of Heaven and Earth. London: Thames and Hudson, 1993.

. "Studies in the Temple in the Ancient Near East." Ph.D. diss., University of Michigan, 1983.

"What Is a Temple? A Preliminary Typology." In Qnest for the Kingdom of God: Studies in Honor of George E. Mendenhall, ed. E. A. Spina, H. B. Huffmon, and A. R. W. Green, 205-219. Winona Lake: Eisenbrauns, 1983.

Lurker, Manfred. Dictionary of Gods and Goddesses, Devils and Demons. London: Routledge and K. Paul, 1988.

. Wörterbuch biblischer Bilder und Symbole. Munich: Kösel-Verlag, 1987. S.v. "Kleid, Kleidung."

Lust, Johan. "Cult and Sacrifice in Daniel. The Tamid and the Abomination of Desolation." In The Book of Daniel: Composition and Reception, ed. John Collins and Peter Flint, 671-688. Leiden: Brill, 2001.

Luzarraga, J. Las Tradiciones de la Nube en la Biblia y en el Judaismo Primitivo. Rome: Biblical Institute Press, 1973.

Lyons, John. Linguistic Semantics. Cambridge: Cambridge University Press, 1995.

Lyons, William John. Canon and Exegesis: Canonical Praxis and the Sodom Narrative. Journal for the Study of the Old Testament, Supplement Series 352. London: Sheffield Academic, 2002.

MacCann, J. Clinton, Jr. "The Book of Psalms: Introduction, Commentary and Reflections." The Interpreter's Bible. Edited by George Arthur Buttrick. Nashville: Abingdon, 1994. 4:640-1280.

Macholz, Christian. "Psalm 29 und 1 Kön 19." In Werden und Wirken des Alten Testaments: Festschrift für Klaus Westerman zum 70. Geburtstag, ed. Rainer Albertz, Hans Peter Müller, Hans Walter Wolf, and Walther Zimmerli, 325-33. Göttingen: Vandenhoeck und Ruprecht, 1980.

Mackay, Cameron. "The King of Tyre." Church Quarterly Review 117 (1934): 239-58.

MacRae, George W. "Heavenly Temple and Eschatology in the Letter to the Hebrews." Semeia 12 (1978): 179-99. 
"What Is a Temple?" In The Temple as a House of Revelation, ed. Truman G. Madsen, 175-190. Provo, UT: Brigham Young University, 1984.

Magonet, Jonathan. "The Structure of Isaial 6." In Proceedings of the 9th World Congress of Jewish Studies, Jerusalem, Aug. 1985, 91-97. Jerusalem: World Union of Jewish Studies, 1986.

Maher, Michael. Genesis, vol. 2. Old Testament Message: A Biblical-Theological Commentary. Wilmington, DE: Michael Glazier, 1982.

Maier, Gerhard. Der Prophet Ezekiel: Kapitel 25-48. Wuppertal: R. Brockhaus, 2000.

Mangan, Céline. 1-2 Chronicles, Ezra, Nehemiah. Old Testament Message: A BiblicalTheological Commentary, vol. 13. Wilmington, DE: Michael Glazier, 1982.

Mangano, Mark. Esther and Daniel. The College Press NIV Commentary. Joplin, MO: College Press, 2001.

Mann, Thomas W. Divine Presence and Guidance in Israelite Traditions: The Typology of Exaltation. Baltimore: Johns Hopkins University Press, 1977.

Marbo̊ck, J. "Heilige Orte im Jakobszyklus. Einige Beobachtungen und Aspekte." In Die Väter Israels: Beiträge zur Theologie der Patriarchenüberlieferung im Alten Testament, ed. Manfred Görg, 211-24. Stuttgart: Katholisches Bibelwerk, 1989.

Margueron, Jean-Claude. "Babylon." The Anchor Bible Dictionary. Edited by David Noel Freedman. New York: Doubleday, 1992. 1:563-65.

Margulis, B. "The Canaanite Origin of Psalm 20 Reconsidered." Biblica 51 (1970): 33248.

Marsh, John. Amos and Micah. London: S.C.M., 1979.

Martens, E. A. Jeremiah. Scotdale, PA: Herald, 1986.

Marti, Karl. Das Dodekapropheton erklürt. Tübingen: Mohr, 1902.

Martin, Ralph P. 2 Corinthians. Waco, TX: Word Books, 1986.

Martínez, Florentino Garcia. "The Heavenly Tablets in the Book of Jubilees." In Studies in the Book of Jubilees, ed. Jörg Frey Matthias Albani and Armin Lange, 243-60. Tubingen: Mohr (Paul Siebeck), 1997. 
Mason, Rex. The Books of Haggai, Zechariah, and Malachi. Cambridge: Cambridge University Press, 1977.

"The Prophets of the Restoration." In Israel's Prophetic Tradition: Essays in Honour of Peter R. Ackroyd, ed. R. J. Coggins, Anthony Phillips and Michael A. Knibb, 137-54. Cambridge: Cambridge University Press, 1982.

Mathews, K. A. Genesis 1-11:26, vol. 1A. The New American Commentary. Nashville: Broadman and Holman, 1996.

Matthes, J. C. "Die Psalmen und der Tempeldienst." Zeitschrift für die alttestamentliche Wissenschaft 22 (1902): 65-82.

Mauchline, John. Isaiah 1-39: Introduction and Commentary. Torch Bible Commentaries. London: S.C.M., 1962.

Maxwell-Mahon, W D. "Jacob's Ladder": A Structural Analysis of Scripture." Semitics 7 (1980): 118-30.

May, Herbert G. "The King in the Garden of Eden: A Study of Ezekiel 28:12-19." In Israel's Prophetic Heritage: Essays in Honor of James Muilenburg, ed. Bernhard W. Anderson and Walter J. Harrelson, 166-76. New York: Harper and Brothers, 1962.

Mayes, A. D. H. Deuteronomy. New Century Bible. London: Oliphants, 1979.

Mays, James L. "The Centre of the Psalms." In Language, Theology, and the Bible:

Essoys in Honour of James Barr, ed. Samuel E. Balentine and John Barton, 23046. Oxford: Clarendon, 1994.

Mays, James Luther. Micak: A Commentary. Philadelphia: Westminster, 1976. - Psalms. Interpretation. Louisville: John Knox, 1994. - "Psalm 29."Interpretation 39 (1985): 60-64.

Mazar, Benjamin. "Jerusalem: From Isaiah to Jeremiah." In Congress Volume, ed. J. A. Emerton, 1-6. Leiden: E J Brill, 1988.

McBride, S. Dean, Ir. "The Deuteronomic Name Theology." Ph.D. diss., Harvard University, 1969. 
. "Divine Protocol: Genesis 1:1-2:3 as Prologue to the Pentateuch." In God

Who Creates: Essays in Fonor of W. Sibley Towner, ed. William P. Brown and S. Dean McBride, 3-41. Grand Rapids, M: Eerdmans, 2000.

McCaffrey, James. The House with Mony Rooms: The Temple Theme of In. 14,2-3.

Rome: Editrice Pontificio Istituto Biblico, 1988.

McCarter, P. Kyle. II Samuel: A New Translation with Introduction, Notes, and Commentary. Garden City, NY: Doubleday, 1984.

McCarthy, D. J. "The Uses of whinnè in Biblical Hebrew." Biblica 61 (1980): 330-42.

McComiskey, Thomas Edward. "wive 'ysh." Theological Wordbook of the Old Testament. Chicago: Moody, 1981. 1:38-39.

- The Minor Prophets: An Exegetical and Expository Commentary. Grand Rapids: Baker, 1992.

McCrory, Jeff H., Jr. "Up, Up, and Up': Exodus 24:9-18 as the Narrative Context for the Tabernacle Instructions of Exodus 25-31." Society of Biblical Literature Seminar Papers 29 (1990): 570-82.

McCurley, Foster R. Ancient Myths and Biblical Faith: Scriptural Transformations. Philadelphia: Fortress, 1983.

McEvenue, Sean. "A Return to Sources in Genesis 28,10-22." Zeitschrift für die alttestamentliche Wissenschaft 106 (1994): $375-89$.

McGee, J. Vemon. Malachi, vol. 33. Thru the Bible Commentary Series. Nashville: Thomas Nelson, 1991.

Mclver, Robert K. Ezekiel: Through Crisis to Glory. Abundant Life Bible Amplifier. Boise, ID: Pacific Press, 1997.

McKane, William. The Book of Micah: Introduction and Commentary. Edinburgh: T. and T. Clark, 1998.

McKay, J. W. "Helel and the Dawn-goddess: A Re-examination of the Myth in Isaiah 14:12-15." Vetus Testamentum 20 (1970): 451-64.

McKeating, Henry. The Books of Amos, Hosea, and Micah. The Cambridge Bible Commentary: Cambridge University Press, 1971. 
McKeating, Henry. The Book of Jeremiah. Epworth Commentaries. London: Epworth, 1999.

McKenna, David L. Isaiah 1-39. The Communicator's Commentary, vol. 16a. Dallas: Word Books, 1986.

McKenzie, John L. Second Isaiah. The Anchor Bible, vol. 20. Garden City, NY: Doubleday, 1968.

McNeile, A. H. The Book of Exodus. 3rd ed. London: Methuen, 1931.

McNicol, Allan James. "The Heavenly Sanctuary in Judaism: A Model for Tracing the Origin of an Apocalypse." Journal of Religious Studies 13, no. 2 (1987): 66-94.

"The Relationship of the Image of the Highest Angel to the High Priest Concept in Hebrews." Ph.D. diss., Vanderbilt University, 1974.

Meissner, Bruno. Babylonien und Assyrien, vol. 2. Heidelberg: C. Winter, 1925.

Mercer, Samuel A. B. "Heaven, and How to Get There in the Pyramid Texis." In The Pyramid Texts, ed. Samuel A. B. Mercer, 1-6. New York: Longmans Green, 1952.

Merrill, Eugene H. An Exegetical Commentary: Haggai, Zechariah, Malachi. Chicago: Moody, 1994.

. Deuteronomy. The New American Bible Commentary, vol. 4. Dallas: Broadman and Holman, 1994.

Merwe, C. H. J. van der, and Eep Talstra. "Biblical Hebrew Word Order: The Interface of Information Structure and Formal Features." Zeitschrift für Athebraistik 15-16 $(2002-2003): 68-107$.

Merwe, C.H.J. van der. "Explaining Fronting in Biblical Hebrew." Journal of Northwest Semitic Languages 25 (1999): $173-86$.

. "The Function of Word Order in Old Hebrew--With Special Reference to Cases Where a Syntagmeme Precedes a Verb in Joshua." Joumal of Northwest Semitic Languages 17 (1991): 129-44.

"Review Article: Towards a Better Understanding of Biblical Hebrew Word Order." Journal of Northwest Semitic Languages 25, no. 1 (1999): 277-300. 
Meshullan, Margaliot. "The Theology of Exodus 32-34." In Proceedings of the Eleventh World Congress of Jewish Studies, Div A, 43-50. Jerusalem: World Union of Jewish Studies, 1994.

Messner, Reinhard, and Martin Lang. "Gott erbaut sein himmlisches Heiligtum: zur

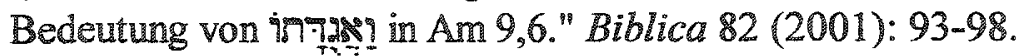

Mettinger, Tryggve N. D. The Dethronement of Sabaot. Coniectanea Biblica, Old Testament Series 18. Uppsala, Sweden: CWK Gleerup, 1982.

. "YHWH SABAOTH-The Heavenly King on the Cherubim Throne." In Studies in the Period of David and Solomon and Other Essays, ed. Tomoo Ishida, 109-38. Winona Lake: Eisenbrauns, 1982.

Metzger, M. "Himmliche und Irdische Wohnstatt Jahwes." Ugarit-Forschungen 2 (1970): 139-158.

Meyer, Sibylle, ed. Egypt Temple of the Whole World: Leiden: Brill, 2003.

Meyers, Carol. "The Elusive Temple." Biblical Archaeologist 45 (1981): 33-41.

. "Temple, Jerusalem." The Anchor Bible Dictionary. Edited by David Noel Freedman. New York: Doubleday, 1992. 6:350-69.

Meyers, Carol L., and Eric M. Meyers. Haggai, Zechariah 1-8: A New Translation with Introduction and Commentary. Garden City, NY: Doubleday, 1987.

Michaeli, Frank. Le Livre de la Genèse. Neuchâtel, Paris: Delachaux et Niestlé, 1957.

Michalowski, Piotr. The Lamentation over the Destruction of Sumer and Ur. Winona Lake, IN: Eisenbrauns, 1989.

Millard, A. R. "The Celestial Ladder and the Gate of Heaven (Gen xxvii. 12, 17)." Expository Times 78 (1966-67): 86-87.

Millard, A. R. James Karl Hoffmeier, and David W. Baker. Faith, Tradition, and History: Old Testament Historiography in Its Near Eastern context. Winona Lake, $\mathbb{N}$ : Eisenbrauns, 1994.

Miller, Patrick D., Jr. Genesis 1-11: Studies in Structure and Theme. Journal for the Study of the Old Testament, Supplement Series. Sheffield, England: University of Sheffield Dept. of Biblical Studies, 1978. 
. Deuteronomy. Interpretation: A Bible Commentary for Teaching and Preaching. Louisville: John Knox, 1990.

. "Prayer and Sacrifice in Ugarit and Israel." In Text and Context: Old Testament and Semitic Studies for F. C. Fensham, ed. W. Claassen, 139-55. Sheffield: JSOT, 1988.

. "Two Critical Notes on Psalm 68 and Deuteronomy 33." Harvard Theological Review 57 (1964): 240-43.

Miqra'ot Gedolot. New York: Pardes, 1951.

Miscall, Peter D. Isaiah. Readings: A New Biblical Commentary. Sheffield: JSOT, 1993.

Mitchell, David C. The Message of the Psalter: An Eschatological Programme in the Books of Psalms. Journal for the Study of the Old Testament, Supplement Series 252. Sheffield: Sheffield Academic, 1997.

Mitchell, H. G. A Critical and Exegetical Commentary on Haggai and Zechariah. The International Critical Commentary. Edinburgh: T. and T. Clark, 1912.

Mitchell, Hinckley Gilbert Thomas, J. M. Powis Smith, and Julius August Bewer. A Critical and Exegetical Commentary on Haggai, Zechariah, Malachi, and Jonah. The International Critical Commentary. Edinburgh: T. and T. Clark, 1951.

Mittmann, Siegfried. "Komposition und Redaktion von Psalm 29." Vetus Testamentum 28 (1978): 172-94.

Moberly, R. W. L. At the Mountain of God: Story and Theology in Exodus 32-34. Journal for the Study of the Old Testament. Supplement Series 22. Sheffield: JSOT, 1983.

Monson, John M. "The Temple of Jerusalem: A Case Study in the Integration of Text and Artifact." Ph.D. diss., Harvard University, 1998.

Montgomery, James. A Critical and Exegetical Commentary on the Book of Kings. The International Critical Commentary. Edinburgh: T. and T. Clark, 1951.

Montgomery, James A. A Critical and Exegetical Commentary on the Book of Daniel. International Critical Commentary. Edinburgh: T. and T. Clark, 1950.

Moor, Johannes Cornelis de. The Seasonal Patterns in the Ugaritic Myth of Ba'lu. Alter Orient und Altes Testament 16, ed. Kurt Berghof, Manfred Dietrich and Oswald Loretz. Vluyn: Verlag Butzon and Bercker Kevalaer, 1971. 
Moor, Johannes C. de. "East of Eden." Zeitschriff für die alttestamentliche Wissenschaft 100, no. 1 (1988): 105-11.

. "Narrative Poetry in Canaan." Ugarit-Forschungen 20 (1988): 149-71.

Morenz, Siegfried. Egyptian Religion. Ithaca, NY: Cornell University Press, 1973.

Morgenstern, Julian. "The Book of the Covenant." Hebrew Union College Anmul 5

(1928): 1-151.

. "Psalm 11." Journal of Biblical Literature 69 (1950): 221-31.

Motyer, J. Alec. The Prophecy of Isaiah. Downers Grove, IL: Inter-Varsity, 1993.

Mowinckel, Sigmund. Der achtundsechzigste Psalm. Oslo: I kommisjon hos J.Dybwad, 1953.

. Psalmenstudien. 2 vols. Amsterdam: Verlag P. Schippers N.V., 1966.

.The Psalms in Israel's Worship. Translated by D. R. Ap-Thomas. Sheffield: JSOT, 1992.

. Religion and Cult: A Translation of Sigmund Mowinckel's Religion og Kultus. Translated by John F. X. Sheehan. Milwaukee: Marquette University, 1981.

Muilenburg, James. "Exegesis of the Book of Isaiah 40-66." The Interpreter's Bible. Edited by George Arthur Buttrick. New York: Abingdon, 1956. 5:419-773.

. "A Liturgy on the Triumphs of Yahweh." In Studia Biblica et Semitica, 23351. Wageningen: $H$. Veenman, 1966.

Mullen, E. Theodore, Jr. The Assembly of the Gods. Harvard Semitic Monographs 24. Edited by Frank M. Cross. Chico, CA: Scholars Press, 1980.

Naccache, Alberte. "El's Abode in His Land." In Ugarit, Religion and Culture: Proceedings of the Internotional Colloquium on Ugarit, Religion and Culture, Edinburgh, July 1994, ed. W.G.E. Watson, J. B. Lloyd, and N. Wyatt, 249-271. Münster: Ugarit-Verlag, 1996.

Nam, Daegeuk. "The Biblical Meanings of Heaven." In To Understand the Scriptures: Essays in Honor of William Shea, ed. David Merling, 291-300. Berrien Springs, MI: Institute of Archaeology/Horn Archaeological Museum, 1997. 
. "The "Throne of God" Motif in the Hebrew Bible." Th.D. diss., Andrews University, 1989.

Naudé, Jackie A., and R. K. Harrison, "grgan." New International Dictionary of Old Testament Theology and Exegesis. Edited by Willem A. VanGemeren. Grand Rapids: Eerdmans, 1997. 3:1201.

Nel, P. J. "The Conception of Evil and Satan in Jewish Traditions in the Pre-Christian Period." In Like a Roaring Lion, 1-21. Pretoria: University of South Africa, 1987.

. "Juxtaposition and Logic in the Wisdom Saying." Joumal of Northwest Semitic Languages 24, no. 1 (1999): 115-27.

"Parallelism and Recurrence in Biblical Hebrew Poetry: A Theoretical

Proposal." Journal of Northwest Semitic Languages 18 (1992): 135-43.

Nelson, Harold H. "The Egyptian Temple." In The Biblical Archaeologist Reader, ed. G. Emest Wright and David Noel Freedman, 147-58: American Schools of Oriental Research and Scholars Press, 1975.

Nelson, Richard D. The Double Redaction of the Deuteronomistic History. JSOTSup 18. Sheffield: JSOT, 1981.

. "God and the Heroic Prophet: Preaching the Stories of Elijah and Elisha." Quarterly Review, Summer 1989, 93-105.

- First and Second Kings. Interpretation: A Bible Commentary for Teaching and Preaching. Atlanta: John Knox, 1987.

. The Historical Books. Nashville: Abingdon, 1998.

Newing, Edward G. "Up and Down-In and Out: Moses on Mount Sinai: The Literary Unity of Exodus 32-34." Australian Biblical Review 41 (1993): 18-34.

Newsom, Carol. Songs of the Sabbath Sacrifice: A Critical Edition. Harvard Semitic Studies 27. Atlanta, GA: Scholars Press, 1985.

Nibley, Hugh W. "What Is a Temple?" In The Temple in Antiquity: Ancient Records and Ancient Perspectives, ed. Truman G. Madsen, 19-37. Provo, UT: Brigham Young University, 1984.

Nicholson, Emst W. "The Interpretation of Exodus XXIV 9-11." Vetus Testamentum 24 (1974): $77-97$. 
Nicholson, Wallace B. The Hebrew Sanchary: A Study in Typology. Grand Rapids: Baker, 1951.

Niehr, Herbert. Der höchste Gott: alttestamentlicher JHWH-Glaube im Kontext syrischkanaanäischer Religion des 1. Jahrtausends v. Chr. Berlin: W. de Gruyter, 1990. 419-26.

. "Überlegungen zum El-Temple in Ugarit." Ugarit-Forschungen 26 (1994):

Nielsen, Kirsten. Yahweh as Prosecutor and Judge: An Investigation of the Prophetic Lawsuit (Rîb-pattern). Journal for the Study of the Old Testament. Supplement Series 9. Sheffield: Dept. of Biblical Studies, University of Sheffield, 1978.

Ninow, Friedbert. "Indicators of Typology within the Old Testament: The Exodus Motif." Ph.D. diss., Andrews University, 1999.

Noth, Martin. The Deuteronomistic History. Translated by Jane Doull. Journal for the Study of the Old Testament, Supplement Series 15. Sheffield: University of Sheffield, Dept. of Biblical Studies, 1981.

Nötscher, Friedrich. Die Gerechtigkeit Gottes bei den vorexilischen Propheten: Ein Beitrag zur Alttestamentische Theologie. Münster: Aschendorff, 1915.

Oblath, Michael. "To Sleep, Perchance to Dream . . .: What Jacob Saw at Bethel (Genesis 28.10-22)." Journal for the Study of the Old Testament 95 (2001): 117-26.

Oesterley, W. O. E. The Psalms, vol. 2. New York: Macmillan, 1939.

Ogden, Graham S. "Psalm 60: Its Rhetoric, Form, and Function." Journal for the Study of the Old Testament (1985): 83-94.

Ogilvie, Lloyd John. The Communicator's Commentary: Old Testament. Dallas: Word Books, 1986.

O'Kennedy, D. F. "Zechariah 3-4: Core of Proto-Zechariah." Old Testament Essays 16, no. $3(2003): 635-53$.

Oldenburg, U1f. "Above the Stars of El: El in Ancient South Arabic Religion." Zeitschrift fur die alttestamentiche Wissenschaft 82, no. 2 (1970): 187-208.

Oliva, Manuel. "Visión y Voto de Jacob en Bethel." Estudios Bzblicos 33 (1974): 117-55. 
Ollenburger, Ben C. Zion, City of the Great King. Journal for the Study of the Old Testament, Supplement Series. Sheffield: JSOT, 1987.

Olson, Dennis T. Deuteronomy and the Death of Moses: A Theological Reading. Overtures to Biblical Theology. Minneapolis: Fortress, 1994.

Oppenheim, A. Leo. The Interpretation of Dreams in the Ancient Near East, With a Translation of an Assyrian Dream-Book. Transactions of the American Philosophical Society, New Series-Volume 46, Part 3. Philadelphia: American Philosophical Society, 1956.

Oppenheim, Leo A. "The Mesopotamian Temple." In The Biblical Archaeologist Reader, ed. G. Ernest Wright and David Noel Freedman, 158-69. Missoula: MT: American Schools of Oriental Research and Scholars Press, 1975.

Orelli, C. v. The Prophecies of Isaiah. Edinburgh: T. and T. Clark, 1895.

. The Twelve Minor Prophets. Translated by J. S. Banks. Edinburgh: T. and T. Clark, 1893.

Ornan, Uzzi. "The Mysteries of Wow Connective." Zeitschrift für die alttestamentliche Wissenschaft 115 (2003): 241-55.

Oswald, Wolfgang. Israel am Gottesberg: Eine Untersuchung zur Literargeschichte der vorderen Sinaiperikope Ex 19-24 und deren historischen Hintergrund. Orbis Biblicus et Orientalis159. Freiburg, Switzerland: Universitâtsverlag; Göttingen: Vandenhoeck und Ruprecht, 1998.

Oswalt, John N. The Book of Isaioh: Chapters 1-39. Grand Rapids: Eerdmans, 1986.

- "Golden Calves and the 'Bull of Jacob: The Impact on Israel of Its Religious Environment." In Israel's apostasy and restoration: Essays in Honor of Rolond $K$. Horrison, ed. Avraham Gileadi, 19-37. Grand Rapids: Baker, 1988. Isaich. The NIV Application Commentary. Grand Rapids: Zondervan, 2003.

Otten, Heinrich. Die Überlieferungen des Telipinu-Mythus. Leipzig: J. C. Hinrichs, 1942.

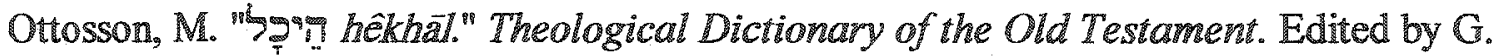
Johannes Botterweck and Helmer Ringgren. Grand Rapids: Eerdmans, 1974-2004. 3:382-88. 
Otzen, Benedikt. "Heavenly Visions in Early Judaism: Origin and Function." In In the Shelter of Elyon: Essays on Ancient Palestinian Life and Literature in Honor of G. W. Ahlström, ed. W. Boyd Barrick and John R. Spencer, 199-215. Sheffield: JSOT, 1984.

Ouellette, Jean. "The Solomonic $D^{e}$ bir according to the Hebrew Text of 1 Kings 6." Journal of Biblical Literature 89 (1970): 338-43.

Owusu-Antwi, Brempong. "An Investigation of the Chronology of Daniel 9:24-27." Ph.D. diss., Andrews University, 1993.

Page, Hugh Rowland, Jr. The Myth of Cosmic Rebelion: A Study of Its Reflexes in Ugaritic and Biblical Literature. Leiden: Brill, 1996.

Page, Sydney H. T. Powers of Evil: A Biblical Study of Satan and Demons. Grand Rapids: Baker, 1995.

Pagels, Elaine H. The Origin of Satan. New York: Vintage Books, 1996.

Pardee, D. "On Psalm 29: Structure and Meaning." In The Book of Psalms: Composition and Reception, ed. Peter W. Flint, Patrick D. Miller, Aaron Brunell and Ryan Roberts, 153-83. Leiden: Brill, 2005. . Ritual and Cult at Ugarit. Atlanta: Society of Biblical Literature, 2002.

Parker, Simon B., ed.. Ugaritic Narrative Poetry. Writings from the Ancient World 9. Atlanta: Society of Biblical Literature, 1997.

Parrot, André. The Tower of Babel. New York: Philosophical Library, 1955.

Parry, Donald W. "Garden of Eden: Prototype Sanctuary." In Temples of the Ancient World: Ritual and Symbolism, ed. Donald W. Parry, 126-151. Salt Lake City, UT: Deseret, 1994.

Parunak, Henry V. D. "The Literary Architecture of Ezekiel's Mar'ôt 'Elohim." Journal of Biblical Literature 99 (1980): 61-74.

Patai, R. Man and Temple in Ancient Jewish Myth and Ritual. London: T. Nelson, 1947.

Patterson, Richard D. "The Key Role of Daniel 7." Grace Theological Journal 12 (1991): $245-61$. 
. "Victory at Sea: Prose and Poetry in Exodus 14-15." Bibliotheca Sacra 161, no. 641 (2004): $42-54$.

Patterson, Richard D., and Hermann J. Austel. "1, 2 Kings." The Expositor's Bible Commentary. Edited by Frank E. Gaebelein. Grand Rapids: Zondervan, 1988. 4:1300 .

Patterson, Richard Duane. Nahum, Habakkuk, Zephaniah. The Wycliffe Exegetical Commentary. Chicago: Moody, 1991.

Patton, John Hastings. Canaanite Parallels in the Book of Psalms. Baltimore: Johns Hopkins, 1944.

Paul, Shalom M. "Heavenly Tablets and the Book of Life." The Journal of the Ancient Near Eastern Society of Columbia University 5 (1973): 345-53.

Paul, Shalom M., and Frank Moore Cross. Amos: A Commentary on the Book of Amos. Hermeneia-A Critical and Historical Commentary on the Bible. Minneapolis: Fortress, 1991.

Paulien, Jon. "The Song of Miriam: A Poetic Analysis." TMs. 1981.

. "The Role of the Hebrew Cultus, Sanctuary, and Temple in the Plot and Structure of the Book of Revelation." Andrews University Seminary Studies 33 (1995): 245-64.

Payne, David F. Deuteronomy. Philadelphia: Westminster, 1985.

Peleg, Itzhak (Itzik). "Going Up and Down: A Key to Interpreting Jacob's Dream (Gen 28,10-22)." Zeitschrift für die alttestamentliche Wissenschaft 116 (2004): 1-11.

Perdue, Leo G. The Collapse of History: Reconstructing Old Testament Theology. Overtures to Biblical Theology. Minneapolis: Fortress, 1994.

Perowne, J. J. Stewart. The Book of Psalms: A New Translation with Introductions and Notes Explanatory and Critical. 2 vols. Grand Rapids: Zondervan, 1976.

Petersen, David L. Haggai and Zechariah 1-8: A Commentary. Philadelphia: Westminster, 1984.

. "Zechariah." The HarperCollins Bible Commentary. Edited by James Luther Mays. San Francisco: HarperSanFrancisco, 2000. 677-86. 
Petersen, David L., and Mark Woodward. "Northwest Semitic Religion: A Study of Relational Structures." Ugarit-Forschungen 9 (1977): 233-48.

Petersen, Paul Birch. "The Theology and the Function of the Prayers in the Book of Daniel." Ph.D. diss., Andrews University Theological Seminary, 1998.

Petitjean, Albert. Les Oracles du Proto-Zacharie: Un programe de restauration pour la communauté juive après l'exil. Paris: J. Gabalda et Cie, 1969.

Pfeiffer, Robert Henry. Introduction to the Old Testament. New York: Harper and Brothers, 1941.

Pieper, August, and Erwin E. Kowalke. Isaiah II: An Exposition of Isaiah 40-66. Milwaukee, WI: Northwestern Pub. House, 1979.

Plöger, Otto. Das Buch Daniel. Kommentar zum Alten Testament 18. Gütersloh: G. Mohn, 1965.

Plyler, Lorenzo Pierce. "The Concept of "God in Heaven" in Israel." Ph.D. diss., Boston University Graduate School, 1961.

Pope, Marvin H. El in the Ugaritic Texts. Supplements to Vetus Testamentum 2. Leiden: Brill, 1955.

Porter, Paul A. Metaphors and Monsters: A Literary-Critical Study of Daniel 7 and 8. Lund: CWK Gleerup, 1983.

Pratt, Richard L. 1 and 2 Chronicles. Fearn, Ross-shire, Great Britain: Mentor, 1998.

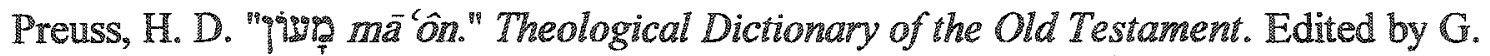
Johannes Botterweck and Helmer Ringgren. Grand Rapids: Eerdmans, 1974-2004. 8:449-52.

Price, Ross E. "Isaiah." Beacon Commentary. Kansas City: Beacon Hill, 1966. 4:19-300.

Prinsloo, Willem S. "Isaiah 14:12-15-Humiliation, Hubris, Humiliation." Zeitschrift für die alttestamentliche Wissenschaft 93, no. 3 (1981): 432-38.

Pritchard, James B., ed. Ancient Near Eastern Texts Relating to the Old Testament. 3rd ed. Princeton, NJ: Princeton University Press, 1969.

Pröbstle, Martin T. "A Linguistic Analysis of Daniel 8:11, 12." Journal of the Adventist Theological Society 7, no. 1 (1996): 81-106. 
Prokurat, Michael. "Haggai and Zechariah 1-8: A Form Critical Analysis." Ph.D. diss., Graduate Theological Union, 1988.

- Exodus 1-18: A New Translation with Introduction and Commentary. The Anchor Bible, vol. 2. New York: Doubleday, 1999.

Propp, William Henry. "Eden Sketches." In The Hebrew Bible and Its Interpreters, ed. William Henry Propp, Baruch Halpern, and David Noel Freedman, 189-203. Winona Lake, IN: Eisenbrauns, 1990.

Puley, Steven R. "The Qinah Concerning the King of Tyre." M.Div. thesis, Grace Theological Seminary, 1982.

Purkiser, W. T. "Psalms." Beacon Bible Commentary. Kansas City: Beacon Hill, 1967. $3: 125-452$.

Quirke, Stephen. "Judgment of the Dead." The Oxford Encyclopedia of Ancient Egypt. Oxford: Oxford University Press, 2001. 2:211-214.

, ed. The Temple in Ancient Egypt: New Discoveries and Recent Research. London: British Museum Press, 1997.

Raabe, P. R. "Daniel 7: Its Structure and Role in the Book." Hebrew Annual Review 9 $(1985): 267-75$.

Read, Walter E. "Further Observations on sädaq." Andrews University Seminary Studies 4 (1966): 29-36.

Redditt, Paul L. "Daniel 9: Its Structure and Meaning." The Catholic Biblical Quarterly 62 (2000): $236-49$.

-Haggai, Zechariah and Malachi: Based on the Revised Standard Version. New Century Bible Commentary. London: M. Pickering, 1995.

. "Zerubbabel, Joshua, and the Night Visions of Zechariah." Catholic Biblical Quarterly 54 (1992): 249-59.

Redpath, Henry A. The Book of the Prophet Ezekiel. Westminster Commentaries 19. New York: Edwin S. Gorham, 1907.

Reid, George. "Salvation and the Sanctuary." Journal of the Adventist Theological Society 3, no. 1 (1992): 97-104. 
Reimer, David. "pryg." New International Dictionary of Old Testament Theology and Exegesis. Edited by Willem A. VanGemeren. Grand Rapids: Zondervan, 1997. 3:744-69.

Reimer, Steve. "The Tower of Babel: An Archaeologically Informed Reinterpretation." Direction 25 (1996): 64-72.

Reisman, Daniel David. "Two Neo-Sumerian Royal Hymus." Ph.D. diss., University of Pennsylvania, 1969.

Reiterer, F. W. "geø sēm." Theologisches Wöterbuch zum alten Testament. Stuttgart: W. Kohlhammer, 1973-1997. 10:122-74.

Renaud, B. La Formation du Livre de Michée: Tradition et Actualisation. Paris: J. Gabalda, 1977. . La Théophanie du Sinaï: Ex 19-24: Exégèse et Théologie. Cahiers de la Revue Biblique 30. Paris: J. Gabalda, 1991.

Rendtorff, Rolf. "Leviticus 16 als Mitte der Torah." Biblical Interpretation 11 (2003): 252-58.

Reymond, E. A. E. The Mythical Origin of the Egyptian Temple. Manchester: Manchester University Press, 1969.

Richter, Sandra L. The Deuteronomistic History and the Name Theology: l'šakken šmô sam in the Bible. Beihet zur Zeitschrift fur die alttestamentliche Wissenschaft 318. Berlin: De Gruyter, 2002.

Ridderbos, J. Deuteronomy. Bible Student's Commentary. Grand Rapids: Zondervan, 1984. Isaiah. Grand Rapids: Regency Reference Library, 1985.

Ringgren, H. "Qip? mầôm." Theological Dictionary of the Old Testament. Edited by G. Johannes Botterweck and Helmer Ringgren. Grand Rapids: Eerdmans, 1994-2004. 8:532-44. " "Bga nb." Theological Dictionary of the Old Testament. Edited by G.

Johannes Botterweck and Helmer Ringgren. Grand Rapids: Eerdmans, 1974-2004. 9:12628. 
"Trs: 'amad" Theological Dictionary of the Old Testament. Edited by G. Johannes Botterweck and Helmer Ringgren. Grand Rapids: Eerdmans, 1994-2004. $11: 179-80$.

Roberts, J. J. M. Nahum, Habakkuk, and Zephaniah: A Commentary. The Old Testament Library. Louisville, KY: Westminster John Knox, 1991.

Robertson, O. Palmer. The Books of Nahum, Habakku, and Zephaniah. Grand Rapids: Eerdmans, 1990.

Robinson, Bernard P. "Jeremiah's New Covenant: Jer 31,31-34." Scandinavian Journal of the Old Testament 15 (2001): 181-204.

Robinson, H. Wheeler. "The Council of Yahveh." Journal of Theological Studies 45 (1944): 151-56.

Robinson, J. The First Book of Kings. The Cambridge Bible Commentary. Cambridge University Press, 1972.

Rodriguez, Angel Manuel. "The Heavenly Books of Life and of Human Deeds." Journal of the Adventist Theological Society 13, no. 1 (2002): 10-26.

. "Sanctuary Theology in the Book of Exodus." Andrews University Seminary Studies 24 (1986): 127-145.

. "Significance of the Cultic Language in Daniel 8:9-14." In Symposium on Daniel, ed. Frank B. Holbrook, 527-49. Washington, DC: Biblical Research Institute, 1986.

Roeder, Gunther. "Zwei Hieroglyphische Inschriften aus Hermopolis." Amnales du Service des Antiquites de l'Egypte 52 (1954): $315-442$.

Rofé, Alexander. Deuteronomy: Issues and Interpretation. London: T and T Clark, 2002.

Rogerson, J. W., and J. W. McKay. Psalms 1-50. Cambridge: Cambridge University Press, 1977. . Psalms 51-100. Cambridge: Cambridge University Press, 1977.

Rogland, M. F. Alleged Non-Past Uses of Qatal in Classical Hebrew. Assen: Van Gorcum, 2003. 
Rose, Christian. "Nochmals: Der Tumbau zu Babel." Vetus Testamentum 54 (2004): 221 38.

Rose, Martin. Der Ausschliesslichkeitsanspruch Jahwes: Deuteronomische Schultheologie und die Volksfrömmigkeit in der späten Königszeit. BWA(N)T 106. Stuttgart: W. Kohlhammer, 1975.

Rosenberg, A. J. Shemoth: A New English Translation. 2 vols. Judaica Press Books of the Bible. New York: Judaica, 1995.

Ross, Allen P. "Jacob's Vision: The Founding of Bethel." Bibliotheca Sacra 142 (1985): 224-37.

"gev." New International Dictionary of Old Testament Theology and Exegesis. Edited by Willem A. VanGemeren. Grand Rapids: Eerdmans, 1997. 4:147-51.

Roth, Martha T. Law Collections from Mesopotamia and Asia Minor. Atlanta, GA: Scholars Press, 1997.

Rowe, Robert D. "Is Daniel's 'Son of Man' Messianic?" In Christ the Lord: Studies in Christology Presented to Donald Guthrie, ed. Harold H. Rowdon, 71-96. Downers Grove, IL: Inter-Varsity, 1982.

Rowley, H. H. Worship in Ancient Israel: Its Forms and Meaning. Philadelphia: Fortress, 1967.

Russell, Brian Douglas. "The Song of the Sea: The Date and Theological Significance of Exodus 15:1--21." Ph.D. diss., Union Theological Seminary and Presbyterian School of Christian Education, 2002.

Russell, D. S. Daniel. Philadelphia: Westminster, 1981.

Rust, E. C. "Theology of the Prophets." Review and Expositor 74 (1977): 337-52.

Ryken, Leland, Jim Wilhoit, and Tremper Longman, eds. Dictionary of Biblical Imagery. Downers Grove, IL: Inter-Varsity, 1998. S.v. "Garments."

Sabourin, Léopold. "Biblical Cloud: Terminology and Traditions." Biblical Theology Bulletin 4 (1974): 290-311.

Sadka, Yitshak. "Hinne in Biblical Hebrew." Ugarit-Forschugen 33 (2001): 479-93. 
Sailhamer, John. "Creation, Genesis 1-11, and the Canon." Bulletin for Biblical Research 10, no. 1 (2000): 89-106.

Sailhamer, John $\mathrm{H}$. The Pentateuch as Narrative: $A$ Biblical-Theological Commentary. Library of Biblical Interpretation. Grand Rapids: Zondervan, 1992.

. Introduction to Old Testament Theology: A Canonical Approach. Grand Rapids: Zondervan, 1995.

Saleh, Abdel-Aziz. "The So-called 'Primeval Hill' and other Related Elevations in Ancient Egyptian Mythology." Mitteilungen des Deutschen Archäologischen Instituts Abteilung Kairo 25 (1969): 110-30.

Sarna, Nahum M. Exodus. The JPS Torah Commentary. Philadelphia: Jewish Publication Society, 1991.

. Genesis. The JPS Torah Commentary. Philadelphia: Jewish Publication Society, 1989.

Sasson, Jack M. Civilizations of the Ancient Near East. New York: Scribner, 1995. . Jonah: A New Translation with Introduction, Commentary, and Interpretations. The Anchor Bible, vol. 24B. New York: Doubleday, 1990.

. "The "Tower of Babel" as a Clue to the Redactional Structuring of the Primeval History (Genesis 1:1-11:9)." In The Bible World: Essays in Honor of Cyrus Gordon, ed. Gary A. Rendsburg, R. Adler, M. Arfa and N. H. Winter, 211-19. New York: KTAV and the Institute of Hebrew Culture and Education of New York University, 1980.

Savignac, J. de. "Note sur le Sens du Terme sâphôn dans Quelques Passages de la Bible." Vetus Testamentum 3 (1953): 95-96.

Sawyer, John F. A. Isaidh. 2 vols. Philadelphia: Westminster, 1984.

Schaefer, Konrad. Psalms. Berit Olam. Collegeville, MN: Liturgical, 2001.

Schaeffer, Claude F. A. The Cuneiform Texts of Ras Shamra-Ugarit. London: Oxford University Press, 1939.

Schafran, Philip Matthew. "The Form and Function of Exodus 15:1-18." Th.D diss., Dallas Theological Seminary, 1988. 
Schibler, Daniel. Der Prophet Micha. Wuppertaler Studienbibel. Reihe Altes Testament. Wuppertal: R. Brockhaus, 1991.

Schmid, Hartmut. Das erste Buch der Könige. Wuppertaler Studienbibel. Reihe Altes Testament. Wuppertal: R. Brockhaus, 2000.

Schmidt, Francis. How the Temple Thinks: Identity and Social Cohesion in Ancient Judaism. The Biblical Seminar 78. Sheffield: Sheffield Academic, 2001.

Schmidt, Hans. "Das vierte Nachtgesicht des Propheten Sacharja." Zeitschrift für die altestamentliche Wissenschaft 54 (1936): 48-60.

. Die Psalmen. Handbuch zum Alten Testament 15. Tübingen: Mohr, 1934.

Schmid, Werner H. Königtum Gottes in Ugarit and Israel. Beihefte zur Zeitschrift für die Alttestamentliche Wissenschaft 80. Berlin: Verlag Alfred Töpelmann, 1966.

Schneider, Dieter. Der Prophet Jesaja. Wuppertaler Studienbibel: Reihe Altes Testament. Wuppertal: R. Brockhaus, 1988.

Schreiner, Josef. Jeremia. Leipzig: St. Benno, 1987.

Schult, H. "Der Debir im Salomonischen Tempel." Zeitschrift für Deutschen Palästina Vereins 80 (1964): 45-54.

Schwantes, Siegfried J. "Ereb Bōger of Daniel 8:14 Re-Examined." In Symposium on Daniel, ed. Frank B. Holbrook, 462-74. Washington, DC: Biblical Research Institute, 1986.

Schwarz, Baruch. "The Bearing of Sin in the Priestly Literature." In Pomegranates and Golden Bells: Studies in Biblical, Jewish, and Near Eastern Ritual, Law, and Literature in Honor of Jacob Milgrom, ed. David P. Wright, David Noel Freedman and Avi Hurvitz, 3-21. Winona Lake, $\mathbb{N}$ : Eisenbrauns, 1995.

Schwarz, J. "Jubilees, Bethel and the Temple of Jacob." Hebrew Union College Anmual 56 (1985): 63-85.

Scoggin, B. Elmo. "Micah." The Broudman Commentary. Nashville: Broadman, 1972. $7: 183-229$.

Scott, J. "The Pattern of the Tabernacle." Ph.D. diss., University of Pennsylvania, 1965. 
Scott, R.B.Y. "The Book of Isaiah: Chapters 1-39." Interpreter's Bible Commentary. New York: Abingdon, 1956. 5:149-381.

Scullion, John. Isaiah 40-66. Wilmington, DE: Michael Glazier, 1982.

Seely, Paul H. "The Date of the Tower of Babel and Some Theological Implications." Westminster Theological Journal 63 (2001): 15-38.

Segert, S. A Basic Grammar of the Ugaritic Language with Selected Texts and Glossary. Berkeley: University of California Press, 1997.

Seitz, Christopher R. "The Book of Isaiah 40-66." The New Interpreter's Bible. Edited by Leander E. Keck. Nashville: Abingdon, 1994. 6:309-552.

Selman, Martin J. 1 Cronicles. Tyndale Old Testament Commentaries. Leicester, England: Inter-Varsity, 1994.

"7in." New Dictionary of Old Testament Theology and Exegesis. Grand Rapids: Zondervan, 1997. 1:1051-55.

Seow, Choon-Leong. "The First and Second Books of Kings." The New Interpreter's Bible. Edited by Leander E. Keck. Nashville: Abingdon, 1994. 3:3-295.

Seybold, K. "Sg: gamal" Theological Dictionary of the Old Testament. Edited by G. Johannes Botterweck and Helmer Ringgren. Grand Rapids: Eerdmans, 1974-2004. 3:23-33.

. "לbn hll." Theological Dictionary of the Old Testament. Edited by G. Johannes Botterweck and Helmer Ringgren. Grand Rapids: Eerdmans, 1974-2004. $4: 409-17$.

Seybold, Klaus. Die Psalmen. Handbuch zum Alten Testament 15. Tübingen: Mohr (Paul Siebeck), 1996.

Šanda, Albert. Die Bücher der Könige übersetzt und erklärt. Munster i. Westf.: Aschendorff, 1911.

Shank, Harold. Minor Prophets. The College Press NIV Commentary. Old Testament Series. Joplin, MO: College Press, 2001.

Sharon, Diane M. "A Biblical Parallel to a Sumerian Temple Hymn? Ezekiel $40-48$ and Gudea." Joumal of the Ancient Near Eastern Society 24 (1996): 99-109. 
Sharp, Carolyn J. Prophecy and Ideology in Jeremiah: Struggles for Authority in Deatero-Jeremianic Prose. London: T. and T. Clark, 2003.

Shea, William H. Daniel 7-12: Prophecies of the End Time. The Abundant Life Bible Amplifier. Boise, ID: Pacific Press, 1996.

. "Further Literary Structures in Daniel 2-7: An Analysis of Daniel 4." Andrews University Seminary Studies 23 (1985): 193-202.

. "Further Literary Structures in Daniel 2-7: An Analysis of Daniel 5 and the Broader Relationships within Chapters 2-7." Andrews University Seminary Studies 23 (1985): 277-95.

. "The Investigative Judgment of Judah." In The Sanctuary and the Atonement, ed. Amold Wallenkampf and Richard Lesher, 283-91. Washington, DC: Biblical Research Institute, 1981.

. "The Literary Structure of Zechariah 1-6." In Creation, Life, and Hope: Essays in Honor of Jacques B. Doukhan, ed. Jiri Moscala, 83-100. Berrien Springs, M: Old Testament Department, Seventh-day Adventist Theological Seminary, Andrews University, 2000.

"Poetic Relations of the Time Periods in Daniel 9,25." In The Sanctuary and the Atonement, ed. Amold Wallenkampf and Richard Lesher, 277-82. Washington, DC: Review and Herald, 1981.

. "Sabbath Hymns for the Heavenly Sanctuary." In Symposium on Revelation-Book 1, ed. Frank B. Holbrook, 391-407. Silver Spring, MD: Biblical Research Institute, 1992.

- Selected Studies on Prophetic Interpretation. 7 vols. Daniel and Revelation Committee Series 1. Washington, DC: General Conference of Seventh-day Adventists, 1982.

. "Spatial Dimensions in the Vision of Daniel 8." In Symposium on Daniel, ed. Frank B. Holbrook, 497-526. Washington, DC: Biblical Research Institute, 1986.

. "Unity of Daniel." In Symposium on Daniel, ed. Frank B. Holbrook, 165-255. Washington, DC: Biblical Research Institute, 1986.

Sheely, Steve. Small Group Ice-Breakers and Heart-Warmers: 101 Ways to Kick off and End Meetings. Serendipity Small Group Resources. Littleton, CO: Serendipity, 1996. 
Shemesh, Yael. "Lies by Prophets and Other Lies in the Hebrew Bible." The Joumal of the Ancient Near Eastern Society 29 (2002): 49-70.

Shorter, Alan W. The Egyptian Gods: A Hondbook. London: K. Paul, Trench, Trubner and Company and Co., 1937.

Silva, Moisés. Biblical Words and Their Meaning: An Introduction to Lexical Semantics. Rev. and expanded ed. Grand Rapids, MI: Zondervan, 1994.

Simon, Uriel. Jonah: The Traditional Hebrew Text with the New JPS Translation. Translated by Lenn J. Schramm JPS Bible Commentary. Philadelphia: Jewish Publication Society, 1999.

Simpson, Cuthbert A. "The Book of Genesis." The Interpreter's Bible. Edited by George Arthur Buttrick. Nashville: Abingdon, 1952. 1:437-829.

Simundson, Daniel J. "The Book of Micah." The New Interpreter's Bible. Edited by Leander E. Keck. Nashville: Abingdon, 1994. 7.531-89.

Singer, Itamar. Hittite Proyers. Writings from the Ancient World 11. Atlanta, GA: Society of Biblical Literature, 2002.

Sjöberg, Åke W. Der Mondgott Nanna-Suen in der Sumerischen Überlieferung, vol. 1. Stockholm: Almquist and Wiksell, 1960.

. "Nungal in the Ekur." Archiv für Orientforschung 24 (1973): 19-46.

Sjöberg, Åke W., and E. Bergmann. The Collection of the Sumerion Temple Hymns. Texts from Cuneiform Sources 3. Locust Valley, NY: J. J. Augustin, 1969.

Ska, Jean Louis. "Le repas de Ex 24,11." Biblica 74 (1993): 305-27.

. "La structure du pentateuque dans sa forme canonique." Zeitschrift fuir die altestamentiche Wissenschaft 113 (2001): 331-352.

Skinner, John. The Book of Ezekiel. The Expositor's Bible, vol. 13. New York: Armstrong and Son, 1908.

. A Critical and Exegetical Commentary on Genesis. 2nd ed. The Intemational Critical Commentary. Edinburgh: T. and T. Clark, 1930.

Slotki, 1. W. Isaiah: Hebrew Text and English Translation. London: Soncino, 1949. 
Smidt, K.-L. "Jerusalem als Urbild and Abbild." Eranos-Jahrbuch 18 (1950): 207-48.

Smith, Gary V. Amos. [Rev. and expanded]. Fearn: Mentor, 1998.

-Hosea, Amos, Micah: The NIV Application Commentary from Biblical Text ... to Contemporary Life. Grand Rapids: Zondervan, 2001.

Smith, George Adam. The Book of Isaiah. The Expositor's Bible. New York: Funk and Wagnalls, 1900.

Smith, John M. P., William H. Ward, and Julius A. Bewer. A Critical and Exegetical Commentary on Micah, Zephaniah, Nahum, Habakkuk, Obadiah and Joel. The International Critical Commentary. New York: Charles Scribner's Sons, 1911.

Smith, Mark S. "Interpreting the Baal Cycle." Ugarit-Forschungen 18 (1986): 313-39.

. "Mythology and Myth-making in Ugaritic and Israelite Literatures." In Ugarit and the Bible: Proceedings of the International Symposium on Ugarit and the Bible, ed. Adrian H. W. Curtis and John F. Healey George J. Brooke, 293-341. Muinster: Ugarit-Verlag, 1994.

. "The Baal Cycle." In Ugaritic Narrative Poetry, ed. Simon B. Parker, 81-180: Atlanta: GA: Society of Biblical Literature, 1997.

. The Pilgrimage Pattern in Exodus, with Contributions of Elizabeth M. Bloch Smith. Journal for the Study of the Old Testament, Supplement Series 239. Sheffield: Sheffield Academic, 1997.

.The Early History of God: Yahweh and the Other Deities in Ancient Israel. 2nd ed. The Biblical Resource Series. Grand Rapids: Eerdmans, 2002.

Smith, Morton. "The Common Theology of the Ancient Near East." Journal of Biblical Literature 71 (1952): 135-47.

Snyder, Barbara Wootten. "Combat Myth in the Apocalypse: the Liturgy of the Day of the Lord and the Dedication of the Heavenly Temple (Revelation)." Ph.D. diss., University of California Berkeley, 1991.

Soden, Wolfram von. The Ancient Orient: An Introduction to the Study of the Ancient Near East. Grand Rapids: Eerdmans, 1994.

Soggin, J. Alberto. Dos Buch Genesis: Kommentar. Darmstadt, Germany: Wissenschafliche Buchgesellschaft, 1997. 
Speiser, Ephraim Avigdor. Genesis. Garden City, NY: Doubleday, 1964.

Spencer, Patricia. The Egyptian Temple: A Lexicographical Study. Boston: Kegan Paul International, 1984.

Spicckermann, Hermann. Heilsgegenwart: Eine Theologie der Psalmen. Forschungen zur Religion und Literatur des Alten und Neuen Testaments 148. Göttingen: Vandenhoeck und Ruprecht, 1989.

Spiegelberg, W. "Die Auffassung des Temples als Himmel." Zeitschrift für Äguptische Sprache und Altertumskunde 53 (1917): 98-101.

Spina, Frank Anthony. "Babel." The Anchor Bible Dictionary. Edited by David Noel Freedman. New York: Doubleday, 1992. 1:561-63.

Spoer, Hans H. "Versuch einer Erklärung von Psalm 18." Zeitschrift für die alttestamentiche Wissenschaft 27 (1907): 145-61.

Sprinkle, Joe M. The Book of the Covenant: A Literary Approach. Joumal for the Study of the Old Testament, Supplement Series 174. Sheffield: JSOT, 1994.

Stade, B. "Streiflichter auf die Entstehung der jetzigen Gestalt der alttestamentlichen Prophetenschriften." Zeitschrift für die alttestamentliche Wissenschaft 23 (1903): 153-71.

Stager, Lawrence. "Jerusalem and the Garden of Eden." In Eretz Israel, 26, 183-94. Jerusalem: Istael Exploration Society, 1998.

Stalker, D. M. G. Ezekiel. London: SCM, 1968.

Stenmans, P. "brges mabbuly" Theologisches Wöterbuch zum alten Testament. Stuttgart: W. Kohlhammer, 1973-1997.4:634-38, 1984.

Stevenson, G. S. "The Heavenly Sanctuary, 1952." Adventist Heritage Center, Andrews University, Berrien Springs, MI.

Stoltz, Fritz, ed. Funkionen und Bedeutungsbereiche des Ugaritischen Ba'alsmythus. Göttingen: Vandenhoeck und Ruprecht, 1982.

Stordalen, Terje. Echoes of Eden. Genesis 2-3 and Symbolism of the Eden Garden in Biblical Hebrew Literature. Contributions to Biblical Exegesis and Theology 25. Leuven, Belgium: Peeters, 2000. 
Strand, Kenneth A. "Apocalyptic Prophecy: A Brief Introduction to Its Nature and Interpretation (with Special Attention to Daniel and Revelation)." TMS, Prepared for Members of the Sanctuary Review Committee, Adventist Heritage Center, Andrews University, 1980.

Strauss, H. "Zur Auslegung von Psalm 29 aus der Hintergrund seiner kanaanäischen Bezüge." Zeitschrift fur die altestamentliche Wissenschaft 82 (1970): 91-102.

Struppe, Ursula. Die Bucher Obadja, Jona. NSKAT 24/1. Stuttgart: Katholisches Bibelwerk, 1996.

Stuart, Douglas. Hosea-Jonah. Word Biblical Commentary 31. Waco: Word Books, 1987.

Stuhlmueller, Carroll. "Psalms." The HarperCollins Bible Commentary. Edited by James Luther Mays. San Francisco: HarperSanFrancisco, 2000. 394-446.

. Psalms 1 (Psalms 1-72). Old Testament Message: A Biblical-Theological Commentary 21. Wilmington, DE: Michael Glazier, 1983.

. Psalms 2 (Psalms 73-150). Old Testament Message: A Biblical-Theological Commentary 22. Wilmington, DE: Michael Glazier, 1983.

Swartley, Willard M. Israel's Scripture Traditions and the Synoptic Gospels: Story Shaping Story. Peabody, MA: Hendrickson, 1994.

Sweeney, Marvin A. The Twelve Prophets. 2 vols. Berit Olam: Studies in Hebrew Narrative and Poetry. Collegeville, MN: Michael Glazier, 2000.

Swiggers, P. "Recent Developments in Linguistic Semantics and Theip Application to Biblical Hebrew." Zeitschrift fur Althebraistik 6 (1993): 21-25.

Tal, Abraham. The Samaritan Pentateuch. Tel Aviv: Tel Aviv University, 1994.

Talstra, Eep. "Reading Biblical Hebrew Poetry: Linguistic Structure or Rhetorical Device?" Journal of Northwest Semitic Languages 25 (1999): 101-26.

Talstra, Eep, and G. Runia-Deenick. Solomon's Proyer: Synchrony and Diachrony in the Composition of 1 Kings 8:14-61. Contributions to Biblical Exegesis and Theology 3. Kampen, Netherlands: Kok Pharos, 1993.

Tanner, J Paul. "The Literary Structure of the Book of Daniel." Bibliotheca Sacra 160 , no. 639 (2003): $269-82$. 
Tate, Marvin E. Psalm 51-100. Word Biblical Commentary, vol. 20. Dallas: Word Books, 1990.

Taylor, Charles L., Jr. "Exegesis of the Book of Habbakuk." The Interpreter's Bible. Edited by George Arthur Buttrick. New York: Abingdon, 1956. 6:971-1003.

Taylor, John B. Ezekiel: An Introduction and Commeniary. The Tyndale Old Testament Commentary. Downers Grove, IL: Inter-Varsity, 1969.

ten Cate, Houwink. "The Sun God of Heaven and the Hittite King." In Effigies Dei: Essays on the History of Religions, 13-34. Leiden: E J Brill, 1987.

Terrien, Samuel. The Elusive Presence. Religious Perspectives 26. Edited by Ruth Nanda Anshen. San Francisco: Harper and Row, 1978.

.The Psalms: Strophic Structure and Theological Commentary. Eerdmans Critical Commentary. Grand Rapids: Eerdmans, 2003.

Thomas, D. Winton. "Exegesis of the Book of Zechariah." The Interpreter's Bible. Edited by George Arthur Buttrick. New York: Abingdon, 1956. 6:1051-114.

Thompson, Alden L. Samuel: From the Danger of Chaos to the Danger of Power. The Abundant Life Bible Amplifier. Boise, ID: Pacific Press, 1995.

Thompson, J. A. The Book of Jeremiah. The New International Commentary on the Old Testament. Grand Rapids: Eerdmans, 1980.

1, 2 Chronicles. The New American Commentary, vol. 9. Nashville: Broadman and Holman, 1994.

Thompson, J.A. Deuteronomy: Introduction and Commentary. London: Inter-Varsity, 1974 .

Throntveit, Mark A. "The Significance of the Royal Speeches and Prayers for the Structure and Theology of the Chronicler." Ph.D. diss., Union Theological Seminary, 1982.

Tidiman, Brian. Le livre de Zacharie. Commentaire Évangélique de la Bible, vol. 18. Vaux-sur-Seine, France: Edifac, 1996.

Tidwell, N. L. A. "Wä'ömar (Zech 3.5) and the Genre of Zechariah's Fourth Vision." Journal of Biblical Literature 94 (1975): 343-55. 
Tigay, Jeffrey H. Deuteronomy. The JPS Torah Commentary. Philadelphia: Jewish Publication Society, 1996.

Timm, Alberto Ronald. "Desenvolvimento da Doutrina do Santuário no Contexto do Conflito Cósmico." Material de Classe para o Programa de Doutorado em Teologia, Seminário Adventista Latino-Americano de Teologia, Universidade Adventista del Plata Argentina, 1997, 1-27.

. "Miniature Symbolization and the Year-Day Principle of Prophetic

Interpretation." Andrews University Seminary Studies 42 (2004): 149-67.

"The Sanctuary and the Three Angels' Messages 1844-1863 Integrating Factors in the Development of Seventh-day Adventist Doctrines." Ph.D. diss., Andrews University Theological Seminary, 1995.

. "The Sanctuary Motif within the Framework of the Great Controversy." In The Cosmic Battle for Planet Earth: Essays in Honor of Norman R. Gulley, ed. Ronald A. G. Du Preez and Jiri Moskala, 69-84. Berrien Springs, MI: Andrews University, 2003.

Tischler, Johann. Hethitisch-Deutsches Wörterverzeichnis: Mit einem Semasiologischen Index. Innsbruck: Institut für Sprachwissenschaft der Universität Innsbruck, 1982. . Hethitisches Etymologisches Glossar. Innsbruck, 1983.

Tobin, Vincent Arieh. Theological Principles of Egyptian Religion. New York: P. Lang, 1989.

Tomes, Roger. "'Our Holy and Beautiful House': When and Why Was 1 Kings 6-8 Written?" Journal for the Study of the Old Testament 70 (1996): 33-50.

Tournay, Raymond J. "En marge d'une traduction des psaumes." Revue biblique 63 (1956): 161-81. $5-26$.

"Psaumes 57, 60 et 108: Analyse et Interprétation." Revue biblique 96 (1989):

. Seeing and Hearing God with the Psalms. Journal for the Study of Old Testament 118. Sheffield: JSOT, 1991.

Towner, W. Sibley. Daniel. Intepretation. Atlanta: John Knox, 1984. 
. Genesis. Westminster Bible Companion. Louisville, KY: Westminster John Knox, 2001.

Treiyer, Alberto R. The Day of Atonement and the Heavenly Judgement from Pentateuch to Revelation. Siloam Springs, AR: Enterprises International, 1992.

. "The Priest-King Role of the Messiah." Joumal of the Adventist Theological Society 7 , no. 1 (1996): 64-80.

Trible, Phyllis. Rhetorical Criticism: Context, Method, and the Book of Jonah. Minneapolis: Fortress, 1994.

Tsevat, M. "A Window for Baal's House." In Studies in the Bible and the Ancient Near East Presented to Samuel E. Loewenstamm on His 70 th Birthday, ed. Y. Avishtur and J. Blau, 151-161. Jerusalem: E. Rubenstein, 1978.

Tsumura, D. T. "The Deluge' (mabbuin) in Psalm 29:10." Ugarit-Forschungen 20 (1988): $351-355$.

Tucker, Gene M. T. "The Book of Isaiah 1-39." The New Interpreter's Bible. Edited by Leander E. Keck. Nashville: Abingdon, 2001. 6:27-305.

Tuell, Steven S. "7998." New International Dictionary of Old Testament Theology and Exegesis. Edited by Willem A. VanGemeren. Grand Rapids: Eerdmans, 1997. $2: 333-34$

Tuell, Steven Shawn. "The Rivers of Paradise." In God Who Creates: Essoys in Honor of W. Sibley Towner, ed. William P. Brown and S. Dean McBride, 171-89. Grand Rapids: Eerdmans, 2000.

Tumer, Laurence A. Genesis. Sheffield: Sheflield Academic, 1999.

Uehlinger, Christoph, and Susanne Muller Trufaut. "Ezekiel 1, Babylonian Cosmological Scholarship and and Iconography: Attempts at Further Refinement." Theologische Zeitschrift 57 (2001): 140-71.

Unger, Merrill Frederick. Zechariah: Prophet of Messiah's Glory. Grand Rapids: Zondervan, 1963.

Valentine, James. "Theological Aspects of the Temple Motif in the Old Testament and Revelation." Ph.D. diss., Boston University, 1987. 
Van Dijk, H. J. Ezekiel's Prophecy on Tyre (Ez. 26:1-28:19): A New Approach. Biblica et Orientalia, 20. Rome: Pontifical Biblical Institute, 1968.

Van Seters, John. "Comparing Scripture with Scripture': Some Observations on the Sinai Pericope of Exodus 19-24." In Canon, Theology, and old Testament Interpretation: Essays in Honor of Brevard S. Childs, ed. Gene M. T. Tucker, David L. Petersen and Robert R. Wilson, 111-30. Philadelphia: Fortress, 1988.

Van Winkle, D. W. "1 Kings 20-22 and True and False Prophecy." In Goldene Apfel in silbernen Schalen: collected communications to the XIITh Congress of the International Organization for the Study of the Old Testament, Leuven 1989, ed. Klaus-Dietrich Schunck and Matthias Augustin, 9-23. Frankfurt am Main: P. Lang, 1992.

VanderKam, James C. "Joshua the High Priest and the Interpretation of Zechariah 3." Catholic Biblical Quarterly 53 (1991): 553-570.

Vawter, Bruce, and Leslie J. Hoppe. A New Heart: A Commentary on the Book of Ezekiel. International Theological Commentary. Grand Rapids: Eerdmans, 1991.

Vermeylen, J. Du prophète Isaïe à l'apocalyptique: Isaïe, I-XXXV, miroìr d'un demimillénaire d'expérience religieuse en Israël. 2 vols. Paris: J. Gabalda, 1977.

Vine, W. E. Vine's Expository Commentary on Isaiah. Nashville: T. Nelson, 1997.

Vogel, Winfried. "Cultic Motifs and Themes in the Book of Daniel." Journal of the Adventist Theological Society 7, no. 1 (1996): 21-50.

"The Cultic Motif in Space and Time in the Book of Daniel." Th.D. diss., Andrews University, 1999.

Vogt, Emst: "Der Aubau von Ps 29." Biblica 41 (1960): 17-24.

Von Rad, Gerhard. Deuteronomy: A Commentory. The Old Testament Library. Philadelphia: Westminster, 1966.

. Genesis: A Commentary. The Old Testament Library. Philadelphia: The Westminster, 1972.

. Old Testament Theology. Translated by D. M. G. Stalker, vol. 1 of 2 vols. New York: Harper and Row, 1962.

- Studies in Deuteronomy. London: S.C.M., 1953. 
. "Typological Interpretation of the Old Testament." In Esscrys on Old

Testament Interpretation, ed. Claus Westerman, 17-39. London: SCM, 1963.

von Schuler, Einar. Kleinasien. Die Mythologie der Hethiter und Hurriter. Stuttgart: E. Klett, n.d.

Wade, G. Woosung. The Book of Habakkuk. Westminster Commentaries 31 . London: Methuen, 1928.

The Books of the Prophets Micah, Obadiah, Joel and Jonah. London: Methuen, 1925.

Walker-Jones, Arthur. Hebrew for Biblical Interpretation. Atlanta: Society of Biblical Literature, 2003.

Walle, B. van de. "L'Ennéade dHéliopolis dans les Textes des Pyramids--Excursus Ii." In The Pyramid Texts, ed. Samuel A. B. Mercer, 6-18. New York: Longmans Green, 1952.

Walsh, Jerome T. I Kings. Berit Olam: Studies in Hebrew Narrative and Poetry. Collegeville, MN: Michael Glazier, 1996.

Waltke, Bruce K., and Cathi J. Fredricks. Genesis: A Commentary. Grand Rapids: Zondervan, 2001.

Walke, Bruce K., and M. O'Connor. An Introduction to Biblical Hebrew Syntax. Winona Lake, IN: Eisenbrauns, 1990.

Walton, John H. Genesis: From Biblical Text . . to Contemporary Life. The NIV Application Commentary. Grand Rapids: Zondervan, 2001.

. "The Mesopotamian Background of the Tower of Babel Account and Its Implications." Bulletin for Biblical Research 5 (1995): 155-75.

"The Tower of Babel." Ph.D. diss., Hebrew Union College-Jewish Institute of Religion, 1981.

Wanke, Gunther. Jeremia. Zürcher Bibelkommentare. Zürich: Theologischer Verlag, 1995.

Watson, Wilfed G. E. Classical Hebrew Poetry: A Guide to Its Techniques, vol. 26 Journal for the Study of the Old Testament, Supplement Series. Sheffield: JSOT, 1984. 
Watson, Wilfred G. E., and N. Wyatt. Handbook of Ugaritic Studies. Handbuch der Orientalistik. Erste Abteilung, Nahe und der Mittlere Osten 39. Boston: Brill, 1999.

Watts, James W. Reading Law: The Rhetorical Shaping to the Pentateuch. The Biblical Seminar 59. Sheffield: Sheffield Academic, 1999.

Watts, John D. W. "Deuteronomy." The Broadman Bible Commentary. Edited by Clifton J. Allen. Nashville: Broadman, 1970. 2:175-296. .Isaiah 1-33. Word Biblical Commentary, vol. 24. Waco: Word Books, 1985. .Isaiah 34-66. Word Biblical Commentary, vol. 25. Waco: Word Books, 1987. . Joel, Obadiah, Jonah, Nahum, Habakkuk and Zephaniah. The Cambridge Bible Commentary: Cambridge University Press, 1975. . "Song of the Sea-Ex. xv." Vetus Testamentum 7, no. 4 (1957): 371-380. . "Zechariah." The Broadman Bible Commentary. Edited by Clifton J. Allen. Nashville: Broadman, 1972. 7:308-65.

Webb, Barry G. The Message of Isaiah: On Eagles' Wings. The Bible Speaks Today. Leicester, England: Inter-Varsity, 1996.

Wefing, Sabina. "Beobachtungen zum Ritual mit der roten Kuh (Num 19:1-10a)." Zeitschrift für die alttestamentliche Wissenschaft 93 (1981): 341-364.

Weinfeld, Moshe. Deuteronomy and the Deuteronomic School. Oxford: Clarendon, 1972.

Weiser, Artur. The Psalms: A Commentary. The Old Testament Library. Philadelphia: The Westminster, 1962.

Wellhausen, Julius. Die Kleinen Propheten. 4th ed. Berlin: De Gruyter, 1963. . Prolegomena to the History of Israel. Edinburgh: A. and C. Black, 1885.

Wenham, Gordon J. "Deuteronomy and the Central Sanctuary." Tyndale Bulletin 22 (1971): 103-18.

. "Sanctuary Symbolism in the Garden of Eden Story." In Proceedings of the Ninth World Congress of Jewish Studies, 19-25. Jerusalem: World Union of World Studies, 1986. 
1987.

Genesis 1-15. Word Biblical Commentary, vol. 1. Waco, TX: Word Books,

. Genesis 16-50. Word Biblical Commentary, vol.2. Waco: Word Books, 1994.

Westermann, Claus. Basic Forms of Prophetic Speech. Cambridge, England: Westminster, 1991.

. Genesis 1-11: A Commentary. Minneapolis: Augsburg Pub. House, 1984.

. Genesis 12-36: A Commentary. Minneapolis: Augsburg Pub. House, 1985.

. Genesis: A Practical Commentary. Translated by David Green. Grand Rapids:

Eerdmans, 1987.

. Isaiah 40-66: A Commentary. London: S.C.M., 1969.

Wevers, John W., ed. Ezekiel. The New Century Bible. London: Thomas Nelson, 1969.

Wheeler, Samuel Billings. "Prayer and Temple in the Dedication Speech of Solomon, I Kings 8:14-61." Ph.D. diss., Columbia University, 1977.

Whitelocke, L. T. "The RIB-Pattern and the Concept of Judgment in the Book of Psalms." Ph.D. diss., Boston University Graduate School, 1968.

Whybray, R.N. Isaiah 40-66. New Century Bible. London: Oliphants, 1975.

Wickes, William, and Aron Dotan. Two Treatises on the Accentuation of the Old

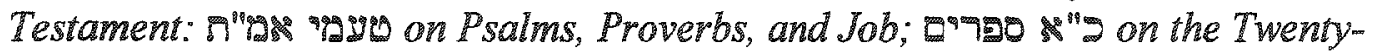
One Prose Books. New York: KTAV Pubiblishing House, 1970.

Widengren, Geo. The Ascension of the Apostle and the Heavenly Book (King and Saviour III). Uppsala: Lundequistska Bokhandeln, 1950.

"Aspetti Simbolici dei Templi e Luoghi di Culto del Vicino Oriente Antico." Numen 7 (1960): $1-25$.

"Myth and History in Israelite-Jewish Thought." In Philosophy, Religious Studies, and Myth, 379-407. New York: Garland Pub, 1996.

Widyapranawa, S. H. The Lord Is Savior: Faith in National Crisis: A Commentary on the Book of Isaiah 1-39. Grand Rapids: Eerdmans, 1990. 
Wilcock, Michael. The Message of Psalms 1-72: Songs for the People of God. The Bible Speaks Today. Downers Grove, IL: Inter-Varsity, 2001.

Wilcox, Max. "According to the Pattern (tbnyt) . . : Exodus 25,40 in the New

Testament and Early Jewish Thought." Revue de Qumran 13 (1988); $647-56$.

Wildberger, Hans. Isaiah 1-12: A Commentary. Translated by Thomas H. Trapp.

Continental Commentaries. Minneapolis: Fortress, 1991.

- Isaiah 13-27: A Commentary. Continental Commentaries. Minneapolis:

Fortress, 1991.

Williamson, H. G. M. Ezra, Nehemiah. Word Biblical Commentary 16. Waco, TX: Word Books, 1985.

"The Temple in the Books of Chronicles." In Templum Amicitiae: Essays on the Second Temple Presented to Ernst Bammel, ed. William Horbury, 15-31.

Sheffield: JSOT, 1991.

Willis, John T. "Some Suggestions on the Interpretation of Micah 1:2." Vetus Testamentum 18 (1968): 372-79.

Wilson, E. Jan. The Cylinders of Gudea: Transliteration, Translation and Index. Alter Orient und Altes Testament 244. Neukirchen-Vluyn: Neukirchener Verlag, 1996.

Wilson, Gerald H. "gogi". "New International Dictionary of Old Testament Theology and Exegesis. Edited by Willem A. VanGemeren. Grand Rapids: Eerdmans, 1997. 2:551.

"לซึ?. "New International Dictionary of old Testament Theology and Exegesis. Edited by Willem A. VanGemeren. Grand Rapids: Eerdmans, 1997. 2:1134-36.

Wilson, Gnanamutha Santhanam. "A Descriptive Analysis of Creation Concepts and Themes in the Book of Psalms." Ph.D. diss., Andrews University Theological Seminary, 1995.

Wilson, Ian Ont of the Midst of the Fire: Divine Presence in Deuteronomy. Atlanta, GA: Scholars Press, 1995.

Wilson, Robert R. "Prophecy in Crisis: The Call of Ezekiel." Interpretation 38 (1984):

117-30. 
Wiseman, Donald D. I and 2 Kings. The Tyndale Old Testament Comentaries. Leicester, England: Inter-Varsity, 1993.

Wiseman, Donald J. "Is It Peace?: Covenant and Diplomacy." Vetus Testamentum 32, no. 3 (1982): $311-26$.

Wohlstein, Herman. The Sky-God, An-Amu. Jericho, NY: P. A. Strook, 1976.

Wolde, Ellen van. "The Earth Story as Presented by the Tower of Babel Narrative." In The Earth Story in Genesis, ed. Norman C. Habel and Shirley Wurst, 236.

Sheffield: Sheffield Academic, 2000.

Wolf, Herbert M. Interpreting Isaiah: The Suffering and Glory of the Messiah. Grand Rapids: Zondervan, 1985.

Wolfe, Rolland E. "Exegesis of the Book of Micah." The Interpreter's Bible. Edited by George Arthur Buttrick. New York: Abingdon, 1956. 6:895-949.

Wolff, Hans Walter. Anthropology of the Old Testament. Translated by Margaret Kohl. London: S.C.M., 1974. Hosea: A Commentary on the Book of the Prophet Hosea. Hermeneia-A Critical and Historical Commentary on the Bible. Philadelphia: Fortress, 1974. - Micah the Prophet. Philadelphia: Fortress, 1981. . Obadiah and Jonah: A Commentary. Minneapolis: Augsburg, 1986.

Wright, Charles H. H. Zechariah and His Prophecies, Considered in Relation to Modern Criticism: With a Critical and Gramatical Commentary and New translation: Eight Lectures. 2nd ed. London: Hodder and Stoughton, 1879.

Wright, Christopher J. H. The Message of Ezekiel: A New Heart and a New Spirit. The Bible Speaks Today. Leicester, England: Inter-Varsity, 2001. "hygn." New International Dictionary of Old Testament Theology and Exegesis. Edited by Willem A. VanGemeren. Grand Rapids: Eerdmans, 1997. 4:272-73, 1997.

Wright, David P. Ritual in Narrative: The Dynamics of Feasting, Mourning, and Retaliation Rites in the Ugaritic Tale of Aqhat. Winona Lake: Eisenbrauns, 2001. 
Wright, G. Emest. "The Book of Deuteronomy." The Interpreter's Rible. Edited by George Arthur Buttrick. Nashville: Abingdon, 1953. 2:309.537.

. "The Significance of the Temple in the Ancient Near East III: The Temple in Syria Palestine." Biblical Archaeologist 7(1944): 65-77.

"The Temple in Palestine-Syria." In The Biblical Archaeologist Reader, ed. G. Ernest Wright and David Noel Freedman, 169-184: American Schools of Oriental Research and Scholars Press, 1975.

Wright, G. R. H. "Pre-Israelite Temples in the Land of Canaan." Palestine Exploration Quarterly 103 (1971): 17-32.

Wright, J. Edward. "Biblical versus Israelite Images of the Heavenly Realm." Journal for the Study of the Old Testament 93 (2001): 59-75.

Würthwein, Emst. "Die josianische Reform und das Deuteronomium." Zeitschrift für Theologie und Kirche 73, no. 4 (1976): 395-423.

. Das Erste Buch der Könige: Kapitel 1--16. Das Alte Testament Deutsch 11/1. Göttingen: Vandenhoeck und Ruprecht, 1977.

Wyat, N. "The Liturgical Context of Psalm 19 and its Mythical and Liturgical Origins." Ugarit-Forschungen 27 (1995): 559-96.

. "The Religion of Ugarit: An Overview." In Handbook of Ugaritic Studies, ed. Wilfried G. E. Watson and Nicolas Wyatt, 529-685. Leiden: Brill, 1999.

, trans. Religious Texts from Ugarit. 2nd ed. Biblical Seminar 53. London:

Sheffield Academic, 2002.

"The Source of the Ugaritic Myth of the Conflict of Ba'al and Yam." UgariForschungen 20 (1988): $375-85$.

. Space and Time in the Religious Life of the Near East. The Biblical Seminar 85. Sheffield: Sheffield Academic, 2001.

"Where Did Jacob Dream His Dream?" Scandinovian Journal of the Old Testament Theology 2, no. $2(1990): 44-57$.

Yaron, Kalman. "The Dirge over the King of Tyre." In Ammal of the Swedish Theological Institute, 3:28-56. Leiden: Brill, 1964. 
Yee, Gale A. "The Book of Hosea." The New Interpreter's Bible. Edited by Leander E. Keck. Nashville: Abingdon, 1994. 7:195-297.

Yeivin, Israel. Introduction to the Tiberian Masorah. Masoretic Studies 5. Missoula, MT: Society of Biblical Literature and Intemational Organization for Masoretic Studies, 1980.

Yon, Margerite. "Sanctuaires d'Ougarit." In Temples et Sanctuaires: Seminaire de Recherche sous la Direction de G. Roux, 37-50: Lyon: GIS-Maison de lOrient, 1984.

Young, Edward. The Book of Isaiah. 3 vols. The New International Commentary on the Old Testament 23. Grand Rapids: Eerdmans, 1965.

Youngblood, Ronald F. The Book of Genesis: An Introductory Commentary. 2nd ed. Grand Rapids: Baker, 1991.

Zevit, Ziony. "The Exegetical Implications of Daniel VIII 1, IX 21." Vetus Testamentum $28(1978): 488-91$.

Zimmer, Robert G. "The Temple of God." Journal of the Evangelical Theological Society 18 (1975): 41-46.

Zimmerli, Walther. Ezekiel 1: A Commentary on the Book of the Prophet Ezekiel. Translated by R. E. Clements. Hermeneia. Philadelphia: Fortress, 1979. . Ezekiel 2: A Commentary on the Book of the Prophet Ezekiel: Chapters 2548. Translated by James D. Martin. Hermeneia. Philadelphia: Fortress, 1983. 1. Mose 1:1-11:32: Die Urgeschichte. 3rd ed. Zuirich: Zwingli Verlag, 1967. 